UNIVERSIDADE DE SĀO PAULO
INSTITUTO DE GEOCIENCIAS

\title{
DEPÓSITOS CENOZÓICOS COSTEIROS E A MORFOLOGIA DO EXTREMO SUL DE SANTA CATARINA
}

Gerusa Maria Duarte

Orientador: Prof. Dr. Kenitiro Suguio

TESE DE DOUTORAMENTO

COMISSÃO JULGADORA

nome

ass.

Presidente:

Examinadores:

Kenitiro Suguio

José Maria Landim Domingues

Vicente José Fulfaro

Rodolfo José Angulo

Cláudio Riccomini

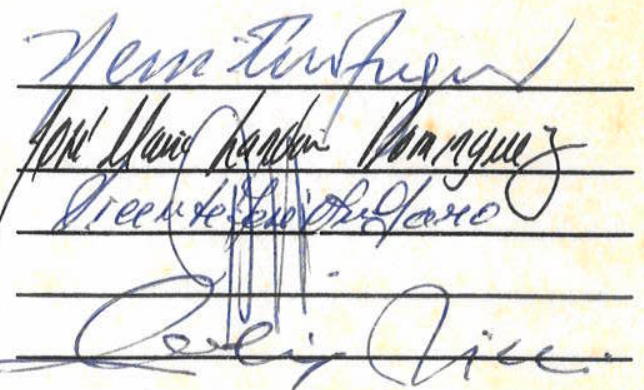

São Paulo 


\title{
DEPÓSITOS CENOZÓICOS COSTEIROS E A MORFOLOGIA DO EXTREMO SUL DE SANTA CATARINA
}

\author{
Gerusa Maria Duarte \\ Orientador: Prof. Dr. Kenitiro Suguio
}

TESE DE DOUTORAMENTO

Programa de Pós-Graduação em Geologia Sedimentar

VOLUME 1

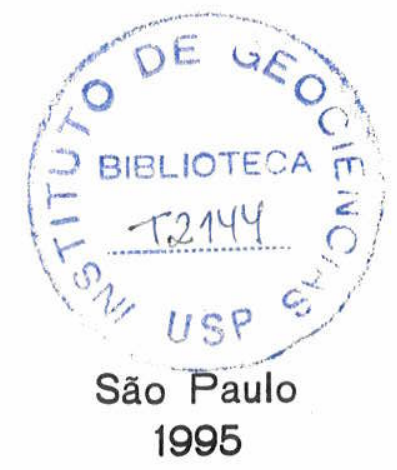




\section{AGRADECIMENTOS}

Os mais sinceros agradecimentos são aqui externados como reconhecimento aqueles que contribuiram de várias formas para a realização deste trabalho.

Ao Professor Dr. Kenitiro Suguio pela atenção em aceitar a orientação, paciência da espera, pela leitura do texto final e sugestões, e a oferta de material bibliográfico em vários momentos.

Ao Curso de Pós-Graduação em Geociências da Universidade de São Paulo, na pessoa de sua Coordenadora Professora Dra. Sonia Maria Barros de Oliveira, pelo papel social que seus integrantes executam com toda a dedicação e esforço e pela atenção a mim dispensada. Agradecimento especial à secretária do Curso, Maria Madalena B. M. Ventura.

Ao Professor Dr. Renato R. Andreis pelas discussões em campo e identificação mineralógica que subsidia este trabalho.

Aos geólogos Alberto Rolon, Alberto R. Luna e Rodi A. Medeiros pelo ânimo transmitido, a boa vontade, a presteza em campo e as discussões sobre o embasamento e as paleocorrentes.

Ao Professor Dr. Moisés $\mathrm{G}$. Tessler pelo apoio na identificação mineralógica sobre muitas e muitas lâminas, tendo toda a minha admiração e reconhecimento.

Ao Professor Dr. Antônio E. G. de Azevedo do Instituto de Física Nuclear- UFBa, por várias datações que fazem parte deste estudo.

Ao Professor Kay Saalfeld e a bióloga Cristiane Barretto pela identificação e classificação da malacofauna.

Ao Professor Dr. Breno Correia da Silva pelo tratamento em computador dos dados de paleocorrentes.

À Professora Roseli de Souza e ao Dr. João Carlos Coimbra pela busca de indicadores paleoambientais através da microfauna e microflora. 
Ao Professor Dr. Daniel Attencio pela identificação de argilo-minerais e aos laboratoristas dos IG e IAG pela preparação de amostras.

À Maria Lúcia Cicconi pelos "socorros" com as cópias de material bibliográfico e à Elaine A. da S. Sinfrônio pelo encaminhamento das amostras de argilas.

Ao Sr. Enor da Silva Pereira e ao Sr. Artur Gonçalves, operários que me acompanharam durante anos. Meu agradecimento profundo pela sua dedicação, presteza e companheirismo.

Agradecimentos também são devidos ao Anilson, Robson, Marcus Vinícius e Yayla pelas ajudas de emergência com o computador.

Outras pessoas ajudaram em momentos diversos como Maria José, Lúcia Herrmann, Magaly, Heitor, Eduardo e Valdemir, o meu agradecimento pela atenção e o tempo despendido.

À Márcia Janice, Eloi, Jefferson, Karlla que muitos seixos mediram, o meu reconhecimento.

São devidos agradecimentos à Prefeitura de Praia Grande, na pessoa do Prefeito Dr. João José de Mattos, e à Prefeitura de Araranguá que concederam licença aos operários em todas as atividades de campo.

À Professora Dra. Maria de Lourdes de Souza que na Pró-Reitoria de Extensão e Cultura possibilitou a redução de alguns mapas dentro da Imprensa Universitária.

Ao geólogo Dario Valiati pela gentileza em ceder as cartas do Plano do Carvão Nacional.

À Petrobrás pela doação de cópias de relatórios internos.

Ao CNPq pelos dois auxílios-pesquisa que possibilitaram as primeiras atividades.

À CAPES pela concessão de bolsa que favoreceu a permanência em São Paulo.

À minha família que sem entender muito o tipo e razão do esforço, acompanhava meu trabalho com o apoio possível. 


\section{DEPÓSITOS CENOZÓICOS COSTEIROS E A MORFOLOGIA \\ DO EXTREMO SUL DE SANTA CATARINA}

SUMÁRIO

VOLUME 1

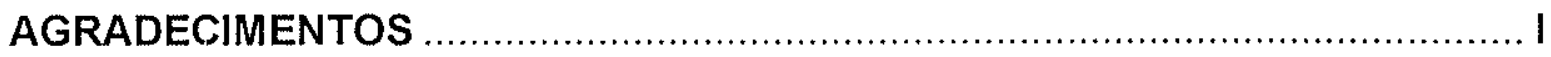

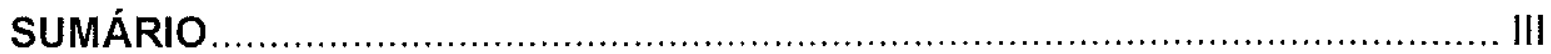

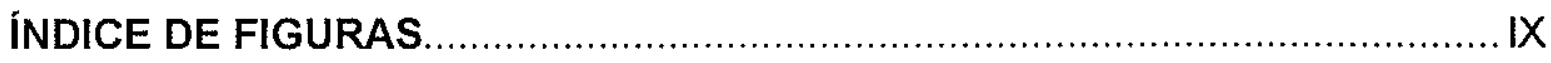

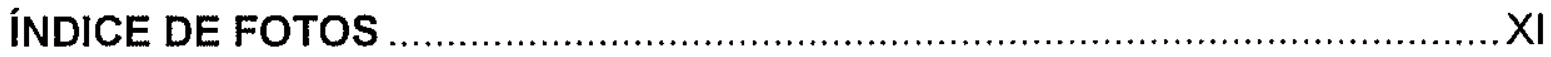

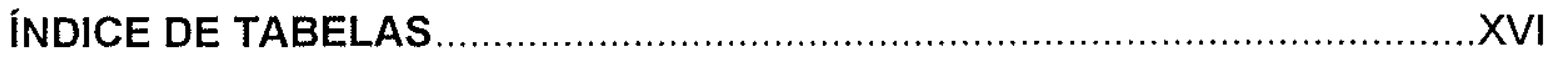

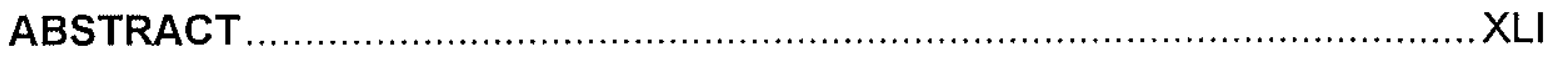

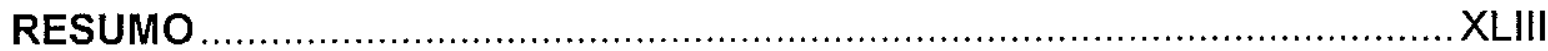

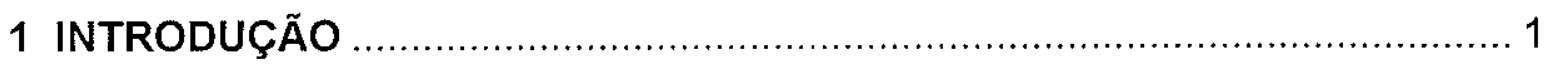

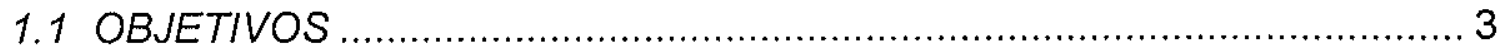

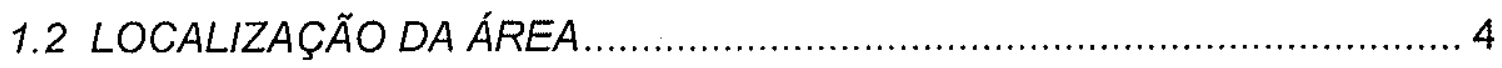

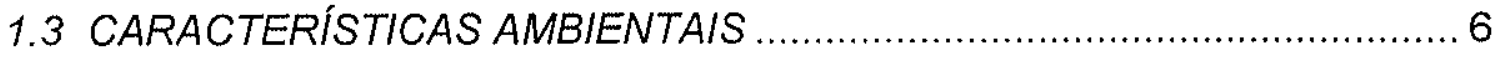

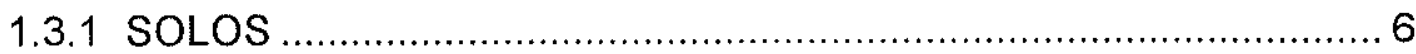

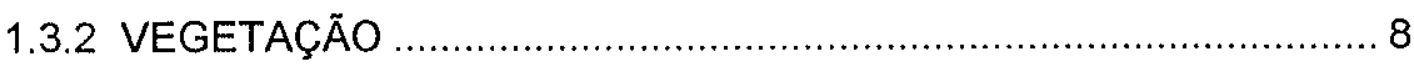

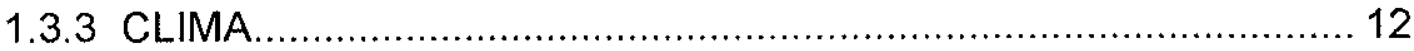

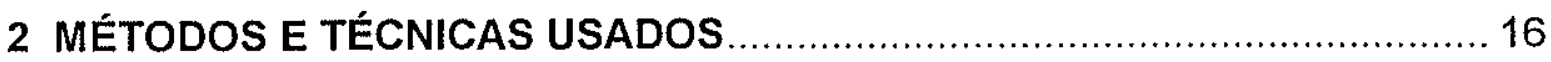

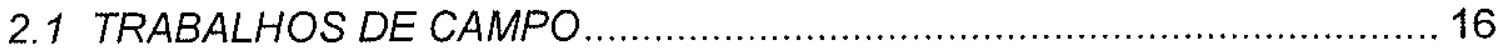

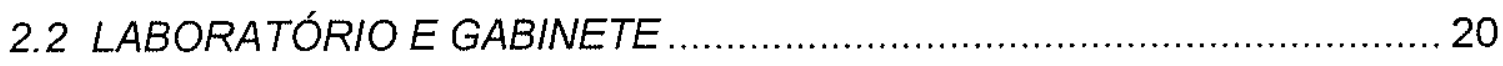


4 O EMBASAMENTO, SUA MORFOLOGIA E TECTÔNICA ......................... 32

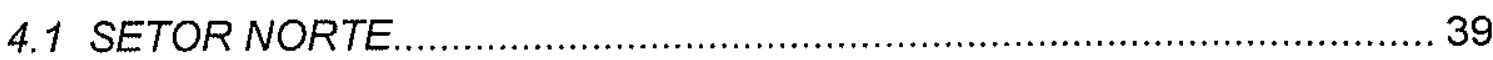

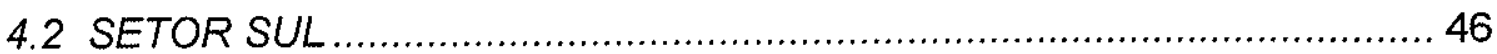

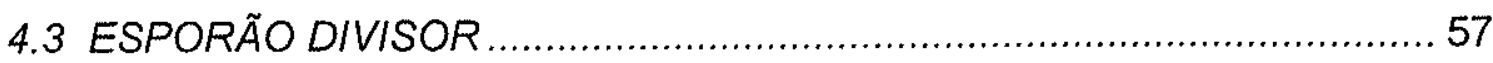

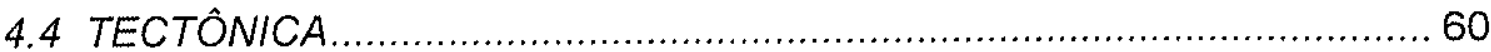

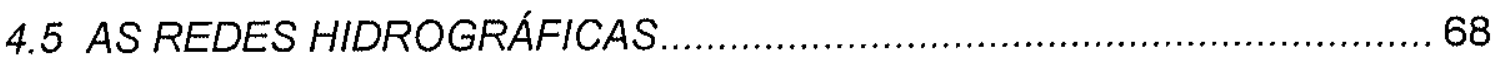

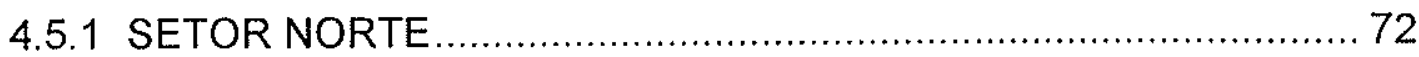

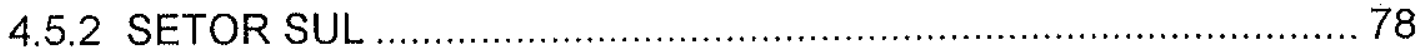

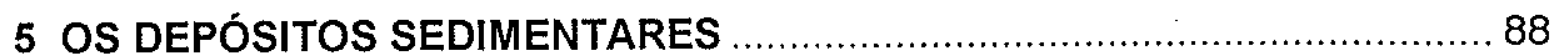

5.1 A MORFOLORGIA DOS DEPÓSITOS ........................................ 88

5.1 .1 LEQUES ALUVIAIS .................................................. 90

5.1.1.1 Morfologia dos Leques Aluviais no Setor Norte .......... 97

5.1.1.2 Morfologia dos Leques Aluviais no Setor Sul ........... 103

5.2 CARACTERIZAÇÃO SEDIMENTOLÓGICA ................................ 106

5.2.1 DEPÓSITOS DE LEQUES ALUVIAIS

E A ATIVIDADE FLUVIAL .......................................... 106

5.2.1.1 Depósitos das Áreas Proximais e Medianas.............. 107

5.2.1.2 Depósitos Distais ........................................ 123

5.2.1.3 Depósitos Fluviais dos Canais Atuais.................... 126

5.2.1.3.1 Formas dos Clastos ............................. 137

5.2.1.3.2 Achatamento e Esfericidade ................... 138

5.2.1.3.3 Relações entre Parâmetros ........................ 139

5.2.1.4 Margens dos Canais Atuais - Diques Marginais ......... 140

5.2.1.5 Mineralogia dos Depósitos de Leques Aluviais ........ 146 
5.2.1.5.1 Área Proximal e Mediana .............................. 148

5.2.1.5.2 Área Distal ................................................... 149

5.2.1.6 Processos Geradores dos Depósitos......................... 151

5.2.2 DEPÓSITOS PRAIAIS ANTIGOS E ATUAIS........................... 157

5.2.2.1 Depósitos Praiais Pleistocênicos Anteriores a

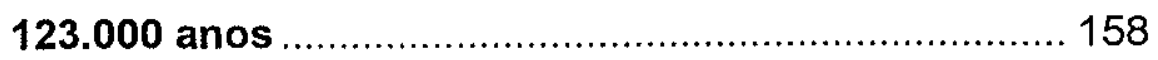

5.2.2.1.1 Caracteristicas Sedimentológicas ................. 165

A) Cristas Praiais de Maracajá-Barro Vermelho.

B) Cristas Praiais entre Araranguá e Sombrio 172

C) Cristas Praiais a Leste de Araranguá.......... 173

D) Cristas Praiais no Setor Sul ....................... 174

E) Mineralogia dos Depósitos ......................... 175

5.2.2.2 A Área a Leste das Maiores Lagoas …………............ 176

5.2.2.2.1 Depósitos Praiais Pleistocênicos de 123.000 anos .......................................... 176

A) Mineralogia ............................................. 179

5.2.2.2.2 Depósitos Praiais Holocênicos ................... 181

A) Mineralogia .............................................. 182

B) Praias Atuais ............................................. 183

C) Moluscos ................................................ 183

5.2.3. DEPÓSITOS EÓlICOS ANTIGOS E ATUAIS......................... 184

5.2.3.1 Depósitos Eólicos Pleistocênicos ................................. 184

5.2.3.1.1 Características Sedimentológicas ............. 191

A) A Duna Pleistocênica Mais Antiga............. 191

B) Outras Dunas Fixas................................ 192

C) Moluscos .............................................. 193 
5.2.3.2 Dunas Ativas 193

5.2.4 DEPÓSITOS DE LAGUNAS, ESTUÁRIOS

E LAGOAS PRETÉRITAS E ATUAIS ............................... 195

5.2.4.1 Características Sedimentológicas ......................... 196

5.2.4.2 Tanatocenoses de Moluscos ............................... 198

5.2.4.3 Margens das Lagoas Atuais ................................. 199

5.2.4.3.1 Mineralogia..................................... 201

5.2.4.3.2 Tanatocenoses de Moluscos................... 202

5.2.4.4 Depósitos Organógenos Carbonosos..................... 203

5.2.4.4.1 Localização dos Depósitos e Acesso..... 206

5.2.4.4.2 Turfeira Banhado do Sombrio .................. 209

A) Descrição da Turfa em Campo .................. 211

B)Descrição dos Testemunhos em Laboratório............................................ 214

5.2.4.4.3 Turfeira Banhado do Piritu ....................... 217

A) Descrição da Turfa em Campo ................... 217

B)Descrição dos Testemunhos em

Laboratório............................................. 218

5.2.4.4.4 Turfeira Caverá....................................... 221

A)Descrição da Turfa em Campo .................. 223

B)Descrição dos Testemunhos em

Laboratório............................................. 225

5.2.4.4.5 Turfeira Olvebra ................................ 228

A)Descrição da Turfa em Campo .................. 228

B) Descrição do Testemunho em

Laboratório............................................. 229

5.2.4.4.6 Turfeira Sanga dos Rodrigues................. 230

A)Descrição da Turfa em Campo ................... 230 
5.2.4.4.7 Turfeira Córrego Corrupiá

A)Descrição do Testemunho em

Laboratónio 231

5.2.4.4.8 Turfeira Rio do Sertão 231

5.2.4.4.9 Outras Turfas Soterradas 231

5.2.4.5 Solos das Turfeiras 232

5.2.4.6 A Vegetação das Turfeiras 237

5.2.4.7 Algumas Características Climatológicas 241

5.2.4.8 Características Físico-Químicas 243

5.2.4.8.1 Turfeira Banhado do Sombrio. 243

5.2.4.8.2 Turfeira Banhado Piritu 246

5.2.4.8.3 Turfeira Caverá 248

5.2.4.8.4 Turfeira Olvebra 250

5.2.4.8.5 Turfeira Sanga dos Rodrigues 252

5.2.4.8.6 Turfeira Corrupiá 253

5.2.4.8.7 Turfeira sob Crista Praial da Lagoa do Sombrio 253

5.2.4.8.8 Total das Amostras Analisadas 254

5.2.4.9 Características Agronômicas 255

5.2.4.9.1 Turfeira Banhado do Sombrio 260

5.2.4.9.2 Turfeira Banhado Piritu 261

5.2.4.9.3 Turfeira Caverá 262

5.2.4.9.4 Turfeira Olvebra. 262

5.2.4.9.5 Turfeira Sanga dos Rodrigues 263

5.2.4.9.6 Turfeira Corrupiá 263

5.2.4.9.7 Turfeira sob Crista Praial da Lagoa do Sombrio. 264

5.2.4.10 Idades, Espessuras e Taxas de Sedimentação 264 
5.2.4.11 O Embasamento dos Depósitos de Turfas 269

5.3 RELAÇÕES ESTRATIGRÁFICAS E IDADES DOS SEDIMENTOS... 271

5.4 RELAÇÃO COM OS NIVEIS MARINHOS QUATERNÁRIOS. 274

6 CONCLUUSÕES 277

BIBLIOGRAFIA 282 


\section{INDICE DE TABELAS, FOTOS E FIGURAS}

\section{ÍNDICE DE FIGURAS - Volume 1}

Figura 1 - Mapa de localização da área ......................................................... 5

Figura 2 - Mapa de localidades e estradas ................................................... 7

Figura 3 - Parte do "Mapa Geológico do Quaternário Costeiro de Santa Catarina..........26

Figura 4 - Trecho do "Mapa Geológico das Folhas Três Cachoeiras e Torres".............28

Figura 5 - Mapa Geológico do Setor Norte .................................................... encarte

Figura 6 - Mapa Geológico do Setor Sul......................................................encarte

Figura 7 - Perfil geológico NE-SW, ao longo da parte leste da área ........................33

Figura 8 - Mapa geológico do "Projeto Carvão em Araranguá” .................................. 34

Figura 9 - Coluna estratigráfica da área do Projeto Carvão Bonito Gaseificável...........35

Figura 10 - Características morfológicas da escarpa da Serra Geral

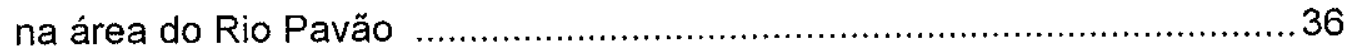

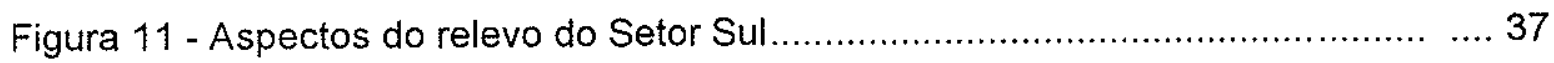

Figura 12 - Aspectos do relevo do Setor Norte - visão parcial .................................... 38

Figura 13 - Mapa hipsométrico mostrando a escarpa da

Serra Geral de ambos os setores ............................................... encarte

Figura 14 - Bloco de perfis topográficos da área estudada .....................................40

Figura 15 - Mapa da Rede Hidrográfica do Setor Norte .................................... encarte

Figura 16 - Mapa da Rede Hidrográfica do Setor Sul......................................... encarte

Figura 17 - Seção geológica no eixo escolhido para a barragem projetada pela SUDESUL no Rio Mampituba ........................... 52

Figura 18 - Seção geológica na altura do eixo A, um dos projetados para a barragem do Rio Mampituba 
Figura 19 - Seção geológica ao longo do eixo B

do projeto de barragem do Rio Mampituba

Figura 20 - Seção geológica do eixo D do projeto de barragem do Rio Mampituba 55

Figura 21 - Seção geológica longitudinal do fundo de vale do Rio Mampituba

Paralela I - perpendicular aos eixos projetados 56

Figura 22 - Seção geológica longitudinal - Paralela central - ao longo do fundo do vale do Rio Mampituba e perpendicular aos eixos projetados .56

Figura 23 - Mapa tectônico de Leinz, 1949 62

Figura 24 - Bloco diagrama de Leinz, 1949 62

Figura 25 - Mapa de contorno estrutural, delineando

falhamentos paralelos à linha de costa 63

Figura 26 - Mapa de contorno estrutural da parte NE da área estudada 64

Figura 27 - Mapa com as principais feições estruturais da Bacia de Pelotas. 69

Figura 28 - Curvas e dados hipsométricos de sub-bacias da Bacia do Rio Araranguá...75

Figura 29 - Curvas e dados hipsométricos da sub-bacia do

Rio Engenho Velho e da Bacia do Rio Araranguá 76

Figura 30 - Curvas e dados hipsométricos das sub-bacias

da Bacia do Rio Mampituba

Figura 31 - Curva e dados hipsométricos da Bacia do Rio Mampituba - parcial 84

Figura 32 - Variações de nível do Rio Mampituba, medidas em 5 estações,

devidas à influência da maré dentro deste rio, e comparação com variações de maré no Porto de Imbituba - SC 


\section{INDICE DE FIGURAS - Volume 2}

Figura 33 - Mapa Geomorfológico do Setor Norte............................................ encarte

Figura 34 - Mapa Geomorfológico do Setor Sul ............................................... encarte

Figura 35 - Mapa do comportamento altimétrico dos leques aluviais no

Setor Norte encarte

Figura 36 - Mapa do comportamento altimétrico dos depósitos do leque aluvial do Rio Pavão encarte

Figura 37 - Perfis de afloramentos da parte superior dos lobos de leques aluviais, em áreas proximais e medianas

Figura 38 - Diagramas de paleocorrentes em leques aluviais - quatro amostragens do Setor Norte

Figura 39 - Diagramas de paleocorrentes em leques aluviais - quatro amostragens do Setor Norte.

Figura 40 - Diagramas de paleocorrentes em leques aluviais - três amostragens do Setor Norte. 26

Figura 41 - Diagrama de paleocorrentes em leques aluviais - cinco amostragens do Setor Norte.

Figura 42 - Diagrama de paleocorrentes em leques aluviais - duas amostragens do Setor Norte

Figura 43 - Diagrama de paleocorrentes em leques aluviais - cinco amostragens do Setor Norte.

Figura 44 - Diagramas de paleocorrentes em leques aluviais - cinco amostragens do Setor Sul 30

Figura 45 - Diagrama de paleocorrentes em leques aluviais - quatro amostragens do Setor Sul 31

Figura 46 - Diagrama de paleocorrentes em leques aluviais - quatro amostragens 
do Setor Sul

Figura 47 - Diagramas de paleocorrentes em leques aluviais - duas amostragens

do Setor Sul

Figura 48 - Diagrama triangular de Shepard (1954), de amostras de leques aluviais proximais e medianos

Figura 49 - Diagrama C-M das amostras de depósitos de leques aluviais proximais e medianos dos setores Norte e Sul

Figura 50 - Histogramas representativos da distribuição granulométrica dos materiais mais finos dos leques aluviais, proximais e medianos 36

Figura 51 - Diagrama tridimensional mostrando a relação entre os parâmetros estatísticos: diâmetro médio, assimetria e desvio padrão de amostras dos materiais mais finos dos leques aluviais, proximais e medianos 44

Figura 52 - Diagrama tridimensional mostrando a relação entre os parâmetros diâmetro médio, assimetria e curtose das amostras dos materiais mais finos dos leques aluviais proximais e medianos

Figura 53 - Diagrama tridimensional relacionando diâmetro médio, desvio padrão e assimetria dos materiais mais finos de leques aluviais proximais e medianos 46

Figura 54 - Diagrama tridimensional relacionando diâmetro médio, assimetria e curtose dos materiais mais finos de leques aluviais, proximais e medianos .47

Figura 55 - Diagrama triangular de Shepard (1954), das classes de areia de amostras de leques aluviais proximais e medianos 48

Figura 56 - Diagrama tridimensional relacionando diâmetro médio, assimetria e curtose da fração areia dos materiais mais finos de leques aluviais, proximais e medianos 49

Figura 57 - Diagrama tridimensional mostrando a relação entre os parâmetros diâmetro médio, assimetria e desvio padrão, das classes de areia, 
de amostras dos materiais mais finos dos leques aluviais, proximais e medianos

Figura 58 - Diagrama tridimensional relacionando diâmetro médio, desvio padrão e assimetria dos materiais mais finos de leques aluviais, proximais e medianos apenas das classes de areia de amostra total recalculada 51

Figura 59 - Diagrama tridimensional relacionando diâmetro médio, desvio padrão e curtose' (KG') dos materiais mais finos de leques aluviais proximais e medianos, apenas das classes de areia de amostra total recalculada .....52

Figura 60 - Perfis de afloramentos de depósitos distais de leques aluviais 53

Figura 61 - Diagrama triangular de Shepard (1954), de amostras de leques distais.......59

Figura 62 - Histogramas representativos, da distribuição granulométrica dos depósitos distais de leques aluviais 60

Figura 63 - Diagrama C-M das amostras de depósitos de leques distais

- Setor Norte.

Figura 64 - Diagrama tridimensional mostrando a relação entre diâmetro médio, achatamento e forma, de seixos e matacões de canal do Rio Rocinha, Timbé do Sul, Setor Norte. .64

Figura 65 - Diagrama tridimensional mostrando a relação entre diâmetro médio, achatamento e forma, de seixos e matacões de barra lateral no Rio da Pedra, W de Jacinto Machado, Setor Norte .65

Figura 66 - Diagrama tridimensional mostrando a relação entre diâmetro médio, achatamento e forma, de seixos e matacões de barra longitudinal no Rio da Pedra, W de Jacinto Machado, Setor Norte. .66

Figura 67 - Diagrama tridimensional mostrando a relação entre diâmetro médio, achatamento e forma, de seixos e matacões de barra lateral no Rio da Pedra, em Jacinto Machado - W, Setor Norte.

Figura 68 - Diagrama tridimensional mostrando a relação entre diâmetro médio, achatamento e forma, de seixos de barra lateral, no Rio da Pedra a E 
de Jacinto Machado, Setor Norte.

Figura 69 - Diagrama tridimensional mostrando a relação entre diâmetro médio, achatamento e forma, de seixos de barra lateral no Rio Itoupava, na localidade de Santana, Setor Norte

Figura 70 - Diagrama tridimensional mostrando a relação entre diâmetro médio, achatamento e forma, de seixos de barra lateral no Rio Itoupava, a W de Ermo, Setor Norte .70

Figura 71 - Diagrama tridimensional mostrando a relação entre diâmetro médio, achatamento e forma, de seixos de barra lateral no Rio Itoupava, a E de Ermo, Setor Norte .71

Figura 72 - Diagrama tridimensional mostrando a relação entre diâmetro médio, achatamento e forma, de seixos de barra lateral no Rio Itoupava, em Taquarussu, Setor Norte

Figura 73 - Diagrama tridimensional mostrando a relação entre diâmetro médio, achatamento e forma, de seixos e matacões, de um dos canais do Rio Pavão, na localidade de Fundos do Rio do Boi, Setor Sul 73

Figura 74 - Diagrama tridimensional mostrando a relação entre diâmetro médio, achatamento e forma, de seixos e matacões de canal do Rio Seco, um dos canais do Rio Pavão, perto da ponte pencil, Setor Sul 74

Figura 75 - Diagrama tridimensional mostrando a relação entre diâmetro médio, achatamento e forma, de seixos e matacões de barra longitudinal em um dos canais do Rio Pavão, próxima à $1^{\text {a }}$ Escola Isolada, Setor Sul .75

Figura 76 - Diagrama tridimensional mostrando a relação entre diâmetro médio, achatamento e forma, de seixos e matacões de canal a montante da ponte de alvenaria sobre o Rio Pavão, Setor Sul

Figura 77 - Diagrama tridimensional mostrando a relação entre diâmetro médio, achatamento e forma, de seixos de canal a jusante da ponte de alvenaria 
sobre o Rio Pavão, Setor Sul

Figura 78 - Diagrama tridimensional mostrando a relação entre diâmetro médio, achatamento e forma, de seixos de um dos canais na parte distal do leque do Rio Pavão, já sobre o canal do Rio Mampituba, Setor Sul

Figura 79 - Diagrama tridimensional mostrando a relação entre diâmetro médio, achatamento e forma, de seixos de um dos canais na parte distal do leque do Rio Pavão, já sobre o canal do Rio Mampituba, Setor Sul

Figura 80 - Diagrama tridimensional mostrando a relação entre diâmetro médio, esfericidade e forma, de seixos e matacões de canal do Rio Rocinha, Timbé do Sul, Setor Norte. .80

Figura 81 - Diagrama tridimensional mostrando a relação entre diâmetro médio, esfericidade e forma, de seixos e matacões de barra lateral no Rio da Pedra, W de Jacinto Machado, Setor Norte

Figura 82 - Diagrama tridimensional mostrando a relação entre diâmetro médio, esfericidade e forma, de seixos e matacões de barra longitudinal no Rio da Pedra, a W de Jacinto Machado, Setor Norte

Figura 83 - Diagrama tridimensional mostrando a relação entre diâmetro médio, esfericidade e forma, de seixos de barra lateral no Rio da Pedra, em Jacinto Machado - W.- Atafona, Setor Norte

Figura 84 - Diagrama tridimensional mostrando a relação entre diâmetro médio, esfericidade e forma, de seixos de barra lateral, no Rio da Pedra a E de Jacinto Machado, Setor Norte .84

Figura 85 - Diagrama tridimensional mostrando a relação entre diâmetro médio, esfericidade e forma, de seixos de barra lateral, no Rio ltoupava, na localidade de Santana, Setor Norte .85

Figura 86 - Diagrama tridimensional mostrando a relação entre diâmetro médio, esfericidade e forma, de seixos de barra lateral no Rio Itoupava, a W de Ermo, Setor Norte .86 
Figura 87 - Diagrama tridimensional mostrando a relação entre diâmetro médio, esfericidade e forma, de seixos de barra lateral no Rio Itoupava a E de Ermo, Setor Norte.

Figura 88 - Diagrama tridimensional mostrando a relação entre diâmetro médio, esfericidade e forma, de seixos de barra lateral no Rio Itoupava, em Taquarussu, Setor Norte 88

Figura 89 - Diagrama tridimensional mostrando a relação entre diâmetro médio, esfericidade e forma, de seixos e matacões de barra, de um dos canais do Rio Pavão, na localidade de Fundos do Rio do Boi, Setor Sul 89

Figura 90 - Diagrama tridimensional mostrando a relação entre diâmetro médio, esfericidade e forma, de seixos e matacões do Rio Seco, um dos canais do leque do Rio Pavão, Setor Sul.

Figura 91 - Diagrama tridimensional mostrando a relação entre diâmetro médio, esfericidade e forma, de seixos e matacões de barra longitudinal/lateral em um dos canais do Rio Pavão, próximos à ła Escola Isolada, Setor Sul 91

Figura 92 - Diagrama tridimensional mostrando a relação entre diâmetro médio, esfericidade e forma, de seixos e matacões de canal a montante da ponte de alvenaria sobre o Rio Pavão, Setor Sul . .92

Figura 93 - Diagrama tridimensional mostrando a relação entre diâmetro médio, esfericidade e forma, de seixos de canal do Rio Pavão, a jusante da ponte de alvenaria, Setor Sul.

Figura 94 - Diagrama tridimensional mostrando a relação entre diâmetro médio, esfericidade e forma, de seixos de um dos canais na parte distal do leque do Rio Pavão, já sobre o Rio Mampituba, Setor Sul 94

Figura 95 - Diagrama tridimensional mostrando a relação entre diâmetro médio, esfericidade e forma, de seixos de um dos canais na área distal 
do leque do Rio Pavão, já sobre o canal do Rio Mampituba,

Setor Sul 95

Figura 96 - Diagrama triangular de Shepard (1954), modificado. Características de duas amostras de leito fluvial coletadas junto a cascalhos 96

Figura 97 - Histogramas de amostras de sedimentos mais finos de canal, na área dos leques medianos 97

Figura 98 - Diagrama triangular de Shepard (1954), de amostras de diques marginais 98

Figura 99 - Histogramas representativos da distribuição granulométrica dos depósitos de diques marginais. 99

Figura 100 -Perfis de afloramentos de depósitos de diques marginais. 101

Figura 101- Diagrama C-M de amostras de diques marginais 103

Figura 102 - Mapa do comportamento altimétrico dos depósitos pleistocênicos de itha-barreira entre Araranguá e Guarita (Sombrio) encarte

Figura 103 - Mapa da possivel linha de costa da paleobaía norte no

Pleistoceno encarte

Figura 104 - Mapa da possivel linha de costa da paleobaía sul no Pleistoceno ..... encarte

Figura 105 - Perfis de afloramentos e de poços em depósitos de cristas praiais pleistocênicas relativas a nivel de mar mais alto, anterior a 123.000 anos 104

Figura 106 - Diagrama triangular de Shepard (1954). Caracteristicas granulométricas de amostras de cristas praiais pleistocênicas a N do Rio Araranguá 128

Figura 107 - Diagrama triangular de Shepard (1954), modificado. Características granulométricas da fração areia, de amostras de cristas praiais pleistocênicas, a $\mathrm{N}$ do Rio Araranguá 129

Figura 108 - Histogramas representativos da distribuição granulométrica dos depósitos de cristas praiais pleistocênicas, relativas a nivel de mar 
mais alto, anterior a 123.000 anos

Figura 109 - Diagrama C-M de amostras de depósitos de cristas praiais

pleistocênicas a N do Rio Araranguá - Setor Norte.

Figura 110 - Diagrama triangular de Shepard (1954). Características

granulométricas de amostras de cristas praiais pleistocênicas

a $S$ do Rio Araranguá 150

Figura 111 - Diagrama triangular de Shepard (1954), modificado. Características

granulométricas da fração areia, de amostras de cristais praiais a

$S$ do Rio Araranguá

Figura 112 - Diagrama C-M de amostras de depósitos de cristas praiais pleistocênicas a S do Rio Araranguá, entre este e a cidade de Sombrio - Setor Norte

Figura 113 - Diagrama triangular de Shepard (1954), de amostras de cristas praiais pleistocênicas a E da cidade de Araranguá - Setor Norte 153

Figura 114 - Diagrama triangular de Shepard (1954), de amostras de cristas praiais pleistocências a $E$ da cidade de Araranguá - classes de areia - Setor Norte 154

Figura 115 - Diagrama C-M de amostras de depósitos de cristas praiais pleistocênicas a E de Araranguá - Setor Norte 155

Figura 116 - Diagrama triangular de Shepard (1954), de amostras de cristas praiais pleistocênicas a W do Rio Sertão - Setor Sul 156

Figura 117 - Diagrama triangular de Shepard (1954), de amostras de cristas praiais pleistocências a W do Rio Sertão - classes de areia - Setor Sul 157

Figura 118 - Diagrama triangular de Shepard (1954), de amostras de cristas praiais pleistocências a E do Rio Sertão - Setor Sul 158

Figura 119 - Diagrama triangular de Shepard (1954), de amostras de cristas praiais pleistocências a E do Rio Sertão - classes de areia 
- Setor Sul

Figura 120 - Diagrama C-M de amostras de depósitos de cristas praiais

pleistocênicas, a W do Rio Sertão - Setor Sul. 160

Figura 121 - Diagrama C-M de amostras de cristas praiais pleistocênicas,

a E do Rio Sertão - Setor Sul. 160

Figura 122 - Diagrama tridimensional relacionando diâmetro médio, assimetria e curtose das amostras de cristas praiais pleistocênicas, relativas a nivel de mar mais alto, anterior a 123.000 anos 161

Figura 123 - Diagrama tridimensional relacionando diâmetro médio, desvio padrão e assimetria das amostras de cristas praiais pleistocênicas, relativas a nivel de mar mais alto, anterior a 123.000 anos 162

Figura 124 - Diagrama tridimensional relacionando diâmetro médio, assimetria e curtose apenas das classes de areia de amostras de cristas praiais pleistocênicas, relativas a nível de mar mais alto, anterior a 123.000 anos 163

Figura 125 - Diagrama tridimensional relacionando diâmetro médio, desvio padrão e assimetria apenas das classes de areia das amostras de cristas praiais pleistocênicas, relativas a nivel de mar mais alto, anterior a 123.000 anos 164

Figura 126 - Perfis de afloramentos e de poços em depósitos de cristas praiais pleistocênicas, relativas a nível de mar alto, de 123.000 anos 165

Figura 127 - Diagrama triangular de Shepard (1954), modificado. Características granulométricas das cristas pleistocênicas, relativas a nível de mar mais alto, de 123.000 anos. 171

Figura 128 - Histogramas representativos da distribuição granulométrica de amostras de cristas praiais pleistocênicas, relativas a nivel de mar mais alto, de 123.000 anos.

Figura 129 - Diagrama C-M de amostras de cristas praiais pleistocências, 
relativas a nivel de mar mais alto, de 123.000 anos

Figura 130 - Diagrama triangular de Shepard (1954), modificado.

Características granulométricas de amostras de cristas praiais holocênicas.

Figura 131 - Histogramas representativos da distribuição granulométrica de amostras de cristas praiais holocênicas

Figura 132 - Perfis de afloramentos e poços em depósitos de cristas praiais holocênicas 182

Figura 133 - Diagrama C-M de amostras de cristas praiais holocênicas 185

Figura 134 - Diagrama triangular de Shepard (1954), modificado.

Características granulométricas de amostras de praia 186

Figura 135 - Histogramas representativos da distribuição granulométrica de amostras de praias atuais 187

Figura 136 - Perfis de afloramentos em depósitos eólicos pleistocênicos 188

Figura 137 - Diagrama triangular de Shepard (1954). Características granulométricas de amostras de dunas fixas 192

Figura 138 - Histogramas representativos da distribuição granulométrica de amostras de dunas fixas 193

Figura 139 - Diagrama C-M de amostras de dunas fixas e dunas ativas 197

Figura 140 - Diagrama triangular de Shepard (1954), modificado. Características granulométricas de amostras de dunas ativas, e da fração areia de amostras de dunas fixas 198

Figura 141 - Histogramas representativos da distribuição granulométrica de amostras de dunas ativas 199

Figura 142 - Perfis de afloramentos e testemunhagem em depósitos de paleolagunas, paleoestuários e paleolagoas 200

Figura 143 - Diagrama triangular de Shepard (1954). Características granulométricas de amostras de paleoestuário $(\Delta)$ e de 
paleolagunas.

Figura 144 - Histogramas representativos da distribuição granulométrica de amostras de depósitos de paleolagunas, paleoestuários e paleolagoas. 206

Figura 145 - Diagrama C-M de amostras de paleolagunas e paleoestuários. 209

Figura 146 - Perfis de poços em depósitos de cristas praiais relacionadas aos corpos de água das maiores lagoas

Figura 147 - Diagrama triangular de Shepard (1954), modificado. Características granulométricas de cristas praiais holocênicas relacionadas aos corpos das maiores lagoas 215

Figura 148 - Histogramas representativos da distribuição granulométrica de amostras de depósitos de cristas praiais relacionadas com as maiores lagoas 216

Figura 149 - Diagrama C-M de amostras de cristas praiais holocênicas em torno das lagoas de Sombrio e Caverá 220

Figura 150 - Mapa de localização das turfeiras do Sul de Santa Catarina .221

Figura 151 - Mapa de localização da Turfeira Banhado do Sombrio e Turfeira do Rio do Sertão

Figura 152 - Mapa de localização da Turfeira Banhado Piritu, Turfeira Piritu II, Turfeira Piritu III, Turfeira Três Coqueiros e Turfeira Sul da Lagoa de Sombrio. .223

Figura 153 - Mapa de localização e isópacas de parte da Turfeira Caverá 224

Figura 154 - Perfil topográfico de NW, no Morro do Soares, a SE, na Praia de Caçamba, atravessando a área turfosa do Córrego Corrupiá e Turfeira de Caverá

Figura 155 - Mapa de áreas de mata em 1979, nas turfeiras Banhado do Sombrio e Rio do Sertão. .226

Figura 156 - Diagrama de regressão linear simples entre Poder Calorífico 
Superior e Cinzas de amostra de turfa da Turfeira Banhado

de Sombrio

Figura 157 - Diagrama $X-Y$ mostrando a relação do Poder Calorífico Superior (PCS) com Poder Calorífico Inferior, $\mathrm{S}$ em base seca, $\mathrm{C}$ fixo, em base seca, Matérias Voláteis (MV), Cinzas, Umidade Livre, Umidade Higroscópica, de amostras de turfa da Turfeira Banhado de Sombrio 228

Figura 158 - Diagrama de regressão linear simples entre Poder Calorífico Superior e Matérias Voláteis de amostras de turfa da Turfeira Banhado de Sombrio 229

Figura 159 - Diagrama tridimensional relacionando o PCS com cinzas e umidade livre de turfas da Turfeira Banhado do Sombrio 230

Figura 160 - Diagrama de regressão linear simples em Poder Calorífico Superior e Cinzas de amostras de turfa da Turfeira Banhado Piritu

Figura 161 - Diagrama $X-Y$ mostrando a relação do Poder Calorífico Superior (PCS) com Poder Calorífico Inferior, $\mathrm{S}$ em base seca, $\mathrm{C}$ fixo, em base seca, Matérias Voláteis (MV), Cinzas, Umidade Livre, Umidade Higroscópica, de amostra de turfeira da Turfeira Banhado do Piritu 232

Figura 162 - Diagrama tridimensional relacionando o PCS com cinzas e umidade livre de turfas da Turfeira Banhado do Piritu

Figura 163 - Diagrama de regressão linear simples entre Poder Calorifico Superior e Cinzas de amostras de turfa da Turfeira Caverá .234

Figura 164 - Diagrama $X-Y$ mostrando a relação do Poder Calorifico Superior (PCS) com Poder Calorífico Inferior, $\mathrm{S}$ em base seca, $\mathrm{C}$ fixo, em base seca, Matérias Voláteis (MV), Cinzas, Umidade Livre, Umidade Higroscópica, de amostras de turfa da Turfeira Caverá .235

Figura 165 - Diagrama tridimensional relacionando o PCS com cinzas e umidade livre de turfas da Turfeira Caverá 236 
Figura 166 - Diagrama de regressão linear simples entre Poder Calorifico

Superior e Cinzas de amostras de turfa da Turfeira Olvebra

Figura 167 - Diagrama X-Y mostrando a relação do Poder Calorífico Superior

(PCS) com Poder Calorifico Inferior, $\mathrm{S}$ em base seca, $\mathrm{C}$ fixo, em

base seca, Matérias Voláteis (MV), Cinzas, Umidade Livre,

Umidade Higroscópica, de amostras de turfa da Turfeira Olvebra.

.238

Figura 168 - Diagrama tridimensional relacionando o PCS com cinzas e umidade livre de turfas de Turfeira Olvebra

Figura 169 - Diagrama de regressão linear simples entre Poder Calorífico

Superior e Cinzas de amostras de turfa da Turfeira Sanga dos

Rodrigues. 240

Figura 170 - Diagrama X-Y mostrando a relação do Poder Calorífico Superior (PCS) com Poder Calorifico Inferior, $\mathrm{S}$ em base seca, $\mathrm{C}$ fixo, em base seca, Matérias Voláteis (MV), Cinzas, Umidade Livre, Umidade Higroscópica, de amostras de turfa da Turfeira Sanga dos Rodrigues.

Figura 171 - Diagrama de Regressão Linear Simples entre Poder Calorífico

Superior e Cinzas de amostras de turfas do Sul de Santa Catarina 242

Figura 172 - Diagrama de Regressão Linear Simples entre Poder Calorifico

Superior e Matérias Voláteis de amostras de turfas do Sul de Santa

Catarina 243

Figura 173 - Diagrama de Regressão Linear Simples entre Matérias Voláteis

e Cinzas de amostras de turfas do Sul de Santa Catarina .244

Figura 174 - Diagrama tridimensional correlacionando Poder Calorifico

Superior, Umidade Livre e Cinzas de amostras de turfa do Sul de

Santa Catarina .245

Figura 175 - Diagrama tridimensional correlacionando Poder Calorifico Superior, Umidade Livre e Matérias Voláteis de amostras de turfa do Sul 
de Santa Catarina

Figura 176 - Diagrama tridimensional correlacionando Poder Calorífico Superior,

Cinzas e Matérias Voláteis de amostras de turfa do Sul de Santa Catarina

Figura 177 - Evolução de tipos de turfeiras até high moor ou turfeira alta 248 


\section{INDICE DE FOTOS - Volume 1}

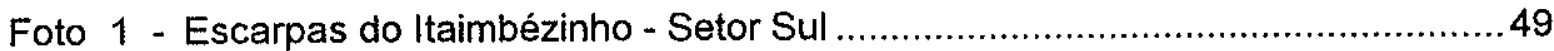

Foto 2 - Nascentes do Rio da Velha II - Setor Norte .........................................71

Foto 3 - Nascentes do Rio Malacara ou Macaco - Setor Sul ...................................71

Foto 4 - Aspecto da área da foz do Rio Araranguá, semelhante a do Rio

Mampituba, Setor Norte ............................................................... 77

Foto 5 - Aspecto da área da foz do Rio Mampituba com largo corpo de água com disposição N-S, Setor Sul

Foto 6 - Vista a partir da Serra da Rocinha - Serra Geral, para o fan-bay do Rio Rocinha - Setor Norte 98

Foto 7 - Escarpa da Serra Geral e formas do sopé no leque do Rio da Pedra - Setor Norte

Foto 8 - Escarpa da Serra Geral e formas convexas de leque aluvial, Setor Sul

Foto 9 - Forma de topo dos leques distais - Setor Norte 100

Foto 10 - Depósitos rudáceos intercalados e sobrepostos com material mais fino e sua morfologia em Praia Grande - Setor Sul

Foto 11 - Depósitos rudáceos pedogenizados, em Praia Grande - Setor

Sul

Foto 12 - Depósito de antiga barra-ilha, margem de um dos canais do

Rio Rocinha - Setor Norte

Foto 13 - Afloramento de depósito rudáceo na localidade de Barra do

Pinheirinho - Setor Norte

Foto 14 - Depósitos rudáceos intercalados com sedimentos mais finos

a W de Vila Progresso - Setor Norte 113

Foto 15 - Depósitos rudáceos em Cachoeira - Setor Sul .114 
Foto 16 - Depósito rudáceo de leque aluvial, com alteração, em Timbé do Sul -

Setor Norte.

Foto 17 - Depósito rudáceo de leque aluvial, com alteração, a W de Itoupava -

Setor Norte.

Foto 18 - Forma dos depósitos de leque mediano a NW da cidade de

Turvo - Setor Norte 116

Foto 19 - Detalhe da foto 18. Material rudáceo capeado com solo 116

Foto 20 - Depósito rudáceo, alterado, em Itoupava II - Setor Norte

Foto 21 - Depósito rudáceo de leque mediano, a W de Ermo - Setor

Norte

Foto 22 - Sedimentos mais finos de cor cinza quando secos, que constituem

o topo das áreas planas, entre as formas lobadas dos leques

aluviais - Setor Sul .

Foto 23 - Coloração e morfologia distinta entre as formas convexas lobadas

e as áreas planas intercaladas, entre as localidades de Favela e

Costa do Rio Canoas - Setor Sul 119

Foto 24 - Sedimentos mais finos de cor cinza, intercalando depósitos

rudáceos, próximo à localidade de Tenente, Jacinto Machado -

Setor Sul 120

Foto 25 - Depósito mais fino de leques distais, pedogenizado, a NW de

Araranguá - Setor Norte

Foto 26 - Barra lateral do Rio Amola Faca - Setor Norte

Foto 27 - Barra longitudinal no leito do Rio da Pedra - Setor Norte

Foto 28 - Aspecto do leito do Rio Itoupava, defronte à Igreja

do Morro do Ermo - Setor Norte

Foto 29 - Barra de cascalho, bifurcada a jusante, no Rio Itoupava, visada para montante - Setor Norte 129 
Foto 30 - Aspecto da barra de cascalho da foto 29 , visando para montante

Setor Norte

Foto 31 - Barra longitudinal em um dos canais do Rio Pavão,

no leque proximal - Setor Sul

Foto 32 - Aspecto da bifurcação do canal do Rio Pavão, leque proximal,

pelo entulhamento do canal à direita - Setor Sul

Foto 33 - Rio "Seco", um dos canais do Rio Pavão, a jusante das fotos

31 e 32 - Setor Sul

Foto 34 - Seixos imbricados no leque distal do Rio Pavão, sobre o Rio Mampituba - Setor Sul

Foto 35 - Detalhe de uma barra de cascalho, no mesmo canal da foto 34 , no extremo distal do leque aluvial do Rio Pavão - Setor Sul

Foto 36 - Depósitos de canal do Rio Pavão - Setor Sul

Foto 37 - Depósitos de canal e morfologia de depósitos mais antigos do Rio Pavão - Setor Sul

Foto 38 - Barra longitudinal de seixos e depósitos rudáceos de canal, erodidos na margem direita do Rio Canoas - Setor Sul

Foto 39 - Detalhe da foto 38 - Setor Sul

Foto 40 - Depósito rudáceo de canal sendo erodido, na margem esquerda do Rio Itoupava - Setor Norte

Foto 41 - Seqüência de fotos da margem esquerda do Rio Itoupava no local da barra das fotos 29 e 30 - Setor Norte 143

Foto 42 - Dique marginal da margem esquerda do Rio Itoupava a montante da confluência com o Rio Jundiá - Setor Norte 147

Foto 43 - Depósito praial pleistocênico pedogenizado, correspondente a um nivel de mar mais alto, anterior a 123.000 anos, em Mato Alto, Araranguá - Setor Norte 162

Foto 44 - Vista parcial da seqüência dos sedimentos praiais pleistocênicos, 
em Mato Alto, Araranguá - Setor Norte, visada para SE

Foto 45 - Vista parcial dos sedimentos praiais pleistocênicos, visados para

SW, em Mato Alto, Araranguá - Setor Norte

Foto 46 - Seqüência de níveis bioturbados, em Mato Alto, na base dos

sedimentos da foto 43 - Setor Norte

Foto 47 - Detalhe das estruturas geradas pelos crustáceos do gênero

Callichirus, em Mato Alto - Setor Norte

Foto 48 - Detalhe da bioturbação nos depósitos praiais, em Mato Alto -

Setor Norte

Foto 49 - Detalhe da seqüência vertical de "bancos" das estruturas de

Callichirus, em Mato Alto - Setor Norte

Foto 50 - Detalhe do afloramento em Mato Alto, com evidências de

Callichirus, na faixa situada entre a parte superior pedogenizada

e a da base sem esta caracteristica - Setor Norte 169

Foto 51 - Detalhe do afloramento em Mato Alto com as evidências de bioturbação - Setor Norte

Foto 52 - Área de depósitos de paleolaguna a W de Sanga Negra e W das mais altas e mais antigas cristas praiais pleistocênicas - Setor Norte 170

Foto 53 - Depósito de paleolaguna, detalhe da foto 52 - Setor Norte 171

Foto 54 - Seqüência de cristas praiais pleistocênicas, relativas a um nível de mar mais alto, de 123.000 anos, SE da Lagoa de Sombrio

- Setor Sul 177

Foto 55 - Detalhe morfológico da foto 54 - Setor Sul 177

Foto 56 - Depósito de crista praial, a E das maiores lagoas, remobilizado por ação eólica a $\mathrm{E}$ de Sombrio 179

Foto 57 - Aspecto dos sedimentos de cristas praiais a E da Lagoa de Sombrio, em Anita Garibaldi - Setor Sul 180 
Foto 58 - Vista parcial do afloramento dos depósitos eólicos pleistocênicos, mais antigos da área, a NW da Lagoa dos Esteves - Setor Norte 186

Foto 59 - Detalhe da foto 58 mostrando camadas com evidência de perfil pedogenisado, antigo, truncado - Setor Norte 186

Foto 60 - Detalhe da foto 58 mostrando crosta de óxidos de Fe - Setor Norte 187

Foto 61 - Detalhe da foto 58 , sob a crosta de precipitados de $\mathrm{Fe}$, onde as areias estão com estruturas onduladas horizontalizadas - Setor Norte 188

Foto 62 - Afloramento na mesma duna das fotos 58 a 61 , porém no seu extremo Sul - Setor Norte 188

Foto 63 - Afloramento de depósitos eólicos pleistocênicos, mais novos que os das fotos anteriores, a $E$ das maiores lagoas, a SE da Lagoa Mãe Luzia - Setor Norte 189

Foto 64 - Afloramento de depósitos eólicos pleistocênicos a $E$ das maiores lagoas, SE da Lagoa de Sombrio - Setor Sul 190

Foto 65 - Morfologia da área de cristas praiais holocênicas relacionadas às lagoas maiores, Lagoa de Sombrio - Setor Sul

Foto 66 - Depósitos na área de cristas praiais holocênicas na margem $\mathrm{W}$ da Lagoa de Sombrio - Setor Sul

Foto 67 - Área cultivada da turfeira do Banhado de Sombrio, área de paleolagoa - Setor Sul. 209

Foto 68 - Área desmatada e rebaixada da turfeira do Banhado de Sombrio -

Setor Sul 210

Foto 69 - Área de exploração das turfas da Turfeira Caverá - Setor Norte 222 
ÍNDICE DE TABELAS - Volume 1

TABELA 81 - Sugestões de identificação de graus de decomposição de turfas..........204

TABELA 82 - Sistema de VON POST (1925) de graus de humificação 205

TABELA 83 - Resultado das análises imediatas, PCS, PCS calculado, $\mathrm{PCi}$ sobre umidade higroscópica e livre, cor da turfa moída, Razão $\mathrm{C} / \mathrm{N}$

TABELA 84 - Resultado das análises imediatas PCS, PCS calculado PCi sobre umidade livre de amostras de turfa da Turfeira Banhado do Sombrio 245

TABELA 85 - Resultado das análises imediatas, PCS, PCS calculado, $\mathrm{PCi}$ sobre umidade livre de amostras de turfa da Turfeira Banhado Piritu

TABELA 86 - Resultado das análises imediatas PCS, PCS calculado

$\mathrm{PCi}$ sobre umidade livre de amostras de turfa da Turfeira Caverá .249

TABELA 87 - Resultado das análises imediatas PCS, PCS calculado

PCi sobre umidade livre de amostras de turfa da Turfeira Olvebra .251

TABELA 88 - Resultado das análises imediatas PCS, PCS calculado PCi sobre umidade livre de amostras de turfa da Turfeira Sanga dos Rodrigues 252

TABELA 89 - Resultado das análises imediatas PCS, PCS calculado

PCi sobre umidade livre de amostras de turfa da Turfeira Córrego Currupiá 253

TABELA 90 - Resultado das análises imediatas PCS, PCS calculado PCi sobre umidade livre de amostras de turfa da Turfeira 
soterrada sob crista praial da Lagoa de Sombrio

TABELA 91 - Resultado de análises agronômicas sobre as àmostras de turfas

TABELA 92 - Valores de densidade aparente (DBD, HDB),

redução em peso e em volume da turfa, índice de cor da

turfa e da água 
ÍNDICE DE TABELAS - Volume 2

TABELA 1 - Medida de dois eixos de seixos de afloramento em Timbé do Sul 249

TABELA 2 - Resumo da tabela 1. Valores distribuidos segundo as classes de tamanho de $1 \varnothing(103$ seixos e matacões).

TABELA 3 - Medida de dois eixos de seixos em corte de barra antiga no Rio Rocinha, Timbé do Sul

TABELA 3 - Medida de dois eixos de seixos em corte de barra antiga no rio Rocinha, Timbé do Sul (continuação).

TABELA 4 - Resumo da tabela 3. Valores distribuídos segundo as classes de tamanho de $1 \varnothing$ (195 seixos e matacões).

TABELA 5 - Medidas de dois eixos de seixos de afloramento em Timbé do Sul 254

TABELA 5 - Medidas de dois eixos de seixos de afloramento em Timbé do Sul (Continuação)

TABELA 6 - Resumo da tabela 5. Valores distribuídos segundo as classes de tamanho de $1 \varnothing$ (142 seixos)

TABELA 7 - Medidas de dois eixos de seixos em corte de barra antiga junto ao canal do Rio da Pedra, na localidade de Pedra, Jacinto Machado .257

TABELA 8 - Resumo da tabela 7. Valores distribuidos segundo as classes de tamanho de $1 \varnothing$ (111 seixos) 258

TABELA 9 - Medidas de dois eixos de seixos de afloramento na margem do Rio Itoupava, na localidade de Último Rio, E de Jacinto Machado. 259

TABELA 9 - Medidas de dois eixos de seixos de afloramento na margem do Rio Itoupava, na localidade de Último Rio, E de Jacinto Machado (Continuação) 260

TABELA 10 - Resumo da tabela 9. Valores distribuídos segundo as classes de tamanho de $1 \varnothing(137$ seixos $)$ 
TABELA 11 - Parâmetros estatísticos de amostras dos materiais mais finos dos leques aluviais, proximais e medianos, dos dois setores 262

TABELA 12 - Parâmetros estatísticos apenas das areias (percentagens recalculadas de amostra total) dos materiais mais finos dos leques aluviais, proximais e medianos, dos dois setores

TABELA 13 - Parâmetros estatísticos de amostras de leques distais .264

TABELA 14 - Valores de tamanho médio, achatamento, esfericidade e forma dos sedimentos de canal, no Rio Rocinha, Setor Norte

TABELA 15 - Resumo da tabela 14. Valores distribuídos segundo as classes de tamanho de $1 \varnothing$ (110 seixos e matacões)

TABELA 16 - Valores de tamanho médio, achatamento, esfericidade e forma dos sedimentos de peneiramento em um dos canais do Rio Rocinha, Setor Norte

TABELA 17 - Resumo da tabela 16. Valores distribuídos segundo as classes de tamanho de $1 \varnothing$ 268

TABELA 18 - Valores de tamanho médio, achatamento, esfericidade e forma dos sedimentos de canal, em barra lateral, no Rio da Pedra, na localidade de Pedra, Jacinto Machado, Setor Norte. 269

TABELA 19 - Resumo da tabela 18. Valores distribuídos segundo as classes de tamanho de $1 \varnothing$ (101 seixos e matacões)

TABELA 20 - Valores de tamanho médio, achatamento, esfericidade e forma dos sedimentos de canal em barra longitudinal, no Rio da Pedra, na localidade de Pedra, Jacinto Machado, Setor Norte

TABELA 21 - Resumo da tabela 20. Valores distribuídos segundo as classes de tamanho de $1 \varnothing(100$ seixos a matacões $)$

TABELA 22 - Valores de tamanho médio, achatamento, esfericidade e forma de seixos de barra lateral de um dos canais do Rio da Pedra em Jacinto Machado-W., Setor Norte 
TABELA 22 - Valores de tamanho médio, achatamento, esfericidade e forma de seixos de barra lateral de um dos canais do Rio da Pedra em Jacinto Machado -W ( Continuação).

TABELA 22 - Valores de tamanho médio, achatamento, esfericidade e forma de seixos de barra lateral de um dos canais do Rio da Pedra em Jacinto Machado -W (Continuação)

TABELA 23 - Resumo da tabela 22. Valores distribuídos segundo as classes de tamanho de $1 \phi$ (252 seixos e matacões). 276

TABELA 24 - Valores de tamanho médio, achatamento, esfericidade e forma de seixos de barra lateral, do canal do Rio da Pedra a $E$ de Jacinto Machado, Setor Norte

TABELA 24 - Valores de tamanho médio, achatamento, esfericidade e forma de seixos de barra lateral, do canal do Rio da Pedra a E de Jacinto Machado (Continuação) 278

TABELA 25 - Resumo da tabela 24. Valores distribuídos segundo as classes de tamanho de $1 \phi$ (230 seixos). 279

TABELA 26 - Valores de tamanho médio, achatamento, esfericidade e forma de seixos de barra lateral do canal do Rio Itoupava entre Jacinto Machado e Ermo, localidade de Santana, Setor Norte 280

TABELA 26 - Valores de tamanho médio, achatamento, esfericidade e forma de seixos de barra lateral do canal do Rio Itoupava entre Jacinto Machado e Ermo, localidade de Santana (Continuação) 281

TABELA 27 - Resumo da tabela 26. Valores distribuídos segundo as classes de tamanho de $1 \phi$ (210 seixos). 282

TABELA 28 - Valores de tamanho médio, achatamento, esfericidade e forma de seixos de barra lateral do canal do Rio Itoupava a W de Ermo, Setor Norte 283

TABELA 28 - Valores de tamanho médio, achatamento, esfericidade e forma 
de seixos de barra lateral do canal do Rio ltoupava a W de Ermo (Continuação) . .284

TABELA 29 - Resumo da tabela 28 Valores distribuidos segundo as classes de tamanho de $1 \phi$ (206 seixos)... .285

TABELA 30 - Valores de tamanho médio, achatamento, esfericidade e forma de seixos de barra lateral, do canal do Rio Itoupava a E de Ermo, Setor Norte 286

TABELA 30 - Valores de tamanho médio, achatamento, esfericidade e forma de seixos de barra lateral, do canal do Rio ltoupava a E de Ermo (Continuação) 287

TABELA 31 - Resumo da tabela 30. Valores distribuídos segundo as classes de tamanho de $1 \phi$ (158 seixos). 288

TABELA 32 - Valores de tamanho médio, achatamento, esfericidade e forma de seixos de barra lateral do canal do Rio Itoupava, na localidade de Taquarussu, Setor Norte 289

TABELA 32 - Valores de tamanho médio, achatamento, esfericidade e forma de seixos de barra lateral do canal do Rio Itoupava, na localidade de Taquarussu (Continuação) 290

TABELA 33 - Resumo da tabela 32. Valores distribuídos segundo as classes de tamanho de $1 \phi$ (167 seixos)

TABELA 34 - Valores de tamanho Médio, Achatamento, Esfericidade e Forma dos sedimentos de barra de canal do Rio Pavão, no leque mediano para proximal. Localidade de Fundos do Rio Boi. É a amostragem mais a montante neste leque, Setor Sul.

TABELA 35 - Resumo da tabela 34. Valores distribuidos segundo as classes de tamanho de $1 \varnothing$ (105 seixos e matacões). 293

TABELA 36 - Valores de tamanho médio, achatamento, esfericidade e forma dos sedimentos de canal atual do Rio Seco, um dos canais do 
leque do Rio Pavão, perto da ponte de arame, Setor Sul

TABELA 37 - Resumo da tabela 36. Valores distribuidos segundo as classes de tamanho de $1 \varnothing$ (83 seixos e matacões) 295

TABELA 38 - Valores de tamanho médio, achatamento, esfericidade e forma dos sedimentos de barra longitudinal/lateral, de um dos canais do Rio Pavão, próxima à $1^{a}$ Escola Isolada, Setor Sul 296

TABELA 39 - Resumo da tabela 38. Valores distribuidos segundo as classes de tamanho de $1 \varnothing$ (117 seixos e matacões).

TABELA 40 - Valores de tamanho médio, achatamento, esfericidade e formas de depósito de peneiramento em um dos canais atuais do leque do Rio Pavão, próximo à ła Escola Isolada e, à jusante da barra medida 298

TABELA 41 - Resumo da tabela 40. Valores distribuídos segundo as classes de tamanho de $1 \varnothing$ 299

TABELA 42 - Valores de tamanho médio, achatamento, esfericidade e formas de sedimentos de canal, a montante da ponte de alvenaria sobre o Rio Pavão, Setor Sul 300

TABELA 43 - Resumo da tabela 42. Valores distribuídos segundo as classes de tamanho de $1 \varnothing$ (101 seixos a matacões) 301

TABELA 44 - Valores de tamanho médio, achatamento, esfericidade e forma dos sedimentos de canal atual do Rio Pavão, tendendo para uma barra lateral, à jusante da ponte de alvenaria, Setor Sul 302

TABELA 45 - Resumo da tabela 44. Valores distribuídos segundo as classes de tamanho de $1 \varnothing$ (109 seixos) 303

TABELA 46 - Valores de tamanho médio, achatamento, esfericidade e forma dos sedimentos de peneiramento de canal tual, à jusante da ponte de alvenaria sobre o Rio Pavão, Setor Sul .304

TABELA 47 - Resumo da tabela 46. Valores distribuídos segundo as classes 
de tamanho de $1 \varnothing$ 305

TABELA 48 - Valores de tamanho médio, achatamento, esfericidade e formas dos sedimentos de barra de um dos canais atuais do leque do Rio Pavão, na área distal, sobre o canal do Rio Mampituba, Setor Sul. 306

TABELA 49 - Resumo da tabela 48. Valores distribuídos segundo as classes de tamanho de $1 \varnothing$ (102 seixos) 307

TABELA 50 - Valores de tamanho médio, achatamento, esferidade e forma dos seixos de um dos canais atuais do leque do Rio Pavão, na área distal, sobre o canal do Rio Mampituba, Setor Sul. 308

TABELA 50 - Valores de tamanho médio, achatamento, esferidade e forma dos seixos de um dos canais atuais do leque do Rio Pavão, na área distal, sobre o canal do Rio Mampituba (Continuação) 309

TABELA 51 - Resumo da tabela 50. Valores distribuídos segundo as classes de tamanho de $1 \varnothing$ (209 seixos)

TABELA 52 - Valores de tamanho médio, achatamento, esfericidade e forma dos sedimentos de peneiramento (sieve deposits) de um dos canais do leque do Rio Pavão, na área distal, sobre o canal do Rio Mampituba, Setor Sul

TABELA 53 - Resumo da tabela 52. Valores distribuídos segundo as classes de tamanho de $1 \varnothing$

TABELA 54 - Parâmetros estatísticos de amostra dos sedimentos mais finos encontrados entre os seixos, em canais atuais, na área de leques aluviais. 313

TABELA 55 - Parâmetros estatísticos de amostras de diques marginais. 314

TABELA 56 - Valores percentuais de minerais leves dos leques aluviais, áreas proximal e mediana 315

TABELA 57 - Valores absolutos totais e percentuais dos minerais pesados de leques aluviais, áreas proximais e medianas, dos dois setores 316 
TABELA 58 - Valores absolutos e percentuais dos minerais pesados de 13 amostras da área distal de leques aluviais

TABELA 59 - Valores percentuais de minerais leves de áreas distais dos leques aluviais 318

TABELA 60 - Valores absolutos e percentuais dos minerais pesados de duas amostras de canais atuais, área dos leques aluviais

TABELA 61 - Parâmetros estatísticos de amostras dos depósitos mais antigos de cristas praiais pleistocênicas, relativas a nivel de mar mais alto, anterior a 123.000 anos 320

TABELA 61 - Parâmetros estatísticos de amostras dos depósitos mais antigos de cristas praiais pleistocênicas, relativas a nível de mar mais alto, anterior a 123.000 anos (Continuação)

TABELA 61 - Parâmetros estatísticos de amostras dos depósitos mais antigos de cristas praiais pleistocênicas, relativas a nível de mar mais alto, anterior a 123.000 anos (Continuação) 322

TABELA 62 - Parâmetros estatísticos apenas das areias das amostras dos depósitos mais antigos de cristas praiais pleistocênicas, relativas a nivel de mar mais alto, anterior a 123.000 anos 323

TABELA 62 - Parâmetros estatísticos apenas das areias das amostras dos depósitos mais antigos de cristas praiais pleistocênicas, relativas a nivel de mar mais alto, anterior a 123.000 anos (Continuação) 324

TABELA 62 - Parâmetros estatísticos apenas das areias das amostras dos depósitos mais antigos de cristas praiais pleistocênicas, relativas a nivel de mar mais alto, anterior a 123.000 anos (Continuação) 325

TABELA 63 - Valores absolutos totais e percentuais dos minerais pesados dos depósitos pleistocênicos de cristas praiais, relativas a nível 
de mar mais alto, anterior a 123.000 anos 326

TABELA 64 - Valores percentuais de minerais leves das cristas praiais pleistocênicas, relativas a nivel de mar mais alto, anterior a 123.000 anos

TABELA 65 - Parâmetros estatísticos de amostras dos depósitos de cristas praiais pleistocênicas, relativas a nível de mar mais alto, de 123.000 anos

TABELA 66 - Valores absolutos totais e percentuais dos minerais pesados de amostras dos depósitos de cristas praiais pleistocênicas, relativas a nivel de mar mais alto, de 123.000 anos

TABELA 67 - Valores percentuais de minerais leves de cristas praiais, relativas a nivel de mar mais alto, de 123.000 anos ( 2 amostras) e de crista praial holocênica (1 amostra)

TABELA 68 - Parâmetros estatísticos de amostras dos depósitos de cristas praiais holocênicas

TABELA 69 - Parâmetros estatísticos de amostras de praias atuais

TABELA 70 - Valores absolutos totais e percentuais dos minerais pesados de 5 amostras de depósito de praias atuais

TABELA 71 - Valores percentuais de minerais leves de praias atuais 334

TABELA 72 - Parâmetros estatísticos de amostras dos depósitos eólicos pleistocênicos e de dunas ativas

TABELA 73 - Valores absolutos e percentuais dos minerais pesados de amostras de dunas fixas (6) e ativas (5) 336

TABELA 74 - Valores percentuais de minerais leves de dunas pleistocênicas e ativas

TABELA 75 - Parâmetros estatísticos de amostras dos depósitos de paleolagunas/paleoestuários e paleolagoas. 338

TABELA 76 - Valores absolutos e percentuais de minerais pesados de 
amostras (11) de depósitos paleolagunares, paleoestuarinos

e de paleolagoas

TABELA 77 - Valores percentuais de minerais leves de sedimentos de paleolagunas e paleoestuários.

TABELA 78 - Parâmetros estatísticos de amostras dos depósitos de cristas praiais no entorno das maiores lagoas.

TABELA 79 - Valores absolutos totais e percentuais dos minerais pesados de 11 amostras de cristas praiais das maiores lagoas

TABELA 80 - Valores percentuais de minerais leves decristas praiais relacionadas às maiores lagoas 


\section{ABSTRACT}

The southernmost region of the state of Santa Catarina, viewed geologically, is composed of sedimentary and igneous rock formations from the Paraná Basin and sedimentary deposits from the Cenozoic. The rock formations appear in the form of scarps and residual elevations and underlie the Cenozoic sediments that cover the greater part of the area under investigation.

These sediments consist of various deposits that originated under different conditions and environments and are distributed from the foot of the scarp of the "Serra Geral" (General Range) to the Atlantic Ocean.

In the west there are alluvial fan deposits covering a broad surface, larger in the Northern Sector than in the Southern Sector of the region, spreading out over an area that begins with an altitude of $200 \mathrm{~m}$ and goes down to one of $10 \mathrm{~m}$. The deposits are found mainly in the proximal and medial areas of the fans. They consist of rudaceous deposits, interspersed in some areas, and nearly always covered with finer-grained material. They have a lobe morphology with a convex top, separated by low flat areas. This morphology is due to deposit and erosion processes characteristic of alluvial fans. The distal deposits of the fans have a very slight representation. Rudaceous deposits are also found on the subsurface, covered over with coastal marine deposits, corresponding to the higher sea level of over 123,000 years ago. The deposits and processes generated in the alluvial fans began earlier than this older coastal deposits and therefore the subsurface rudaceous deposits show lower sea level than the present one.

Paleolagoonar and estuary deposits in certain stretches and situations are covered by lacustrine deposits, running parallel or perpendicular to beach ridges sandy bodies from various ages. Lacustrine deposits frequently appear as surface sediments, consisting of peat, ranging in thickness from 1 to $4.5 \mathrm{~m}$. 
Sandy beach deposits are from varying ages of the Pleistocene and Holocene and cover areas of two river basins. The oldest deposits, corresponding to the higher sea level prior to 123,000 years ago, are found in the Northern Sector, to the north of the Araranguá River in the areas of Maracajá-Barro Vermelho and Campo Mãe LuziaHercilio Luz, with altitudes of 14 to $16 \mathrm{~m}$ to the south of this river, between the towns of Araranguá and Sombrio, with altitudes as high as around $25 \mathrm{~m}$. One part of this deposit began as a barrier island during a period of marine transgression. The remainder was added in the regressive period that followed, giving rise to beach ridges varying in height from 14 to $16 \mathrm{~m}$. In the Southern Sector deposits with comparable ages and altitudes are found around Santa Rosa do Sul, Vila Santa Catarina, São João do Sul, as far as the Mampituba River. They belong to the Pleistocene, and correspond to Barrier II in the state of Rio Grande do Sul.

To the east of this assemblage, lakes can be found, partially filled with peat. They are bound on the east by another Pleistocene set of beach ridges and dunes (Barrier III), corresponding to a higher sea level of 123,000 years ago and followed by a third formation (Barrier IV) with an aeolic covering and containing active dunes from the Holocene.

A large part of this sequence is bound to the north and south by lagoonar and estuary deposits, which are cut through at present by the Ararangua River to the north, and the Mampituba to the south. These deposits have a flat top and are slightly inclined to the east.

There seem to have been two major periods of aeolic activity: that of the oldest Pleistocene in the area and the present epoch. Belonging to the Pleistocene is a large formation of aeolic origin that reaches an altitude of $100 \mathrm{~m}$ and is supported by rocks of the Palermo Formation. It is situated in the northeast of the area under investigation.

Some deposits, with samples of trunks, shells and peat, mainly lagoonar, estuary and lacustrine deposits, could be dated by $\mathrm{C}^{14}$.

The sequence of deposits makes it possible to define the recurrence of both the marine and continental processes. 
O extremo sul do Estado de Santa Catarina, área das bacias dos rios Araranguá e Mampituba, constitui-se do ponto de vista geológico, de rochas sedimentares e ígneas da Bacia do Paraná e depósitos sedimentares do Cenozóico. As rochas apresentam-se sob forma de escarpas e elevações residuais e embasam os sedimentos cenozóicos que cobrem a maior parte da área estudada.

Estes sedimentos constituem vários depósitos originados sob diferentes condições e ambientes que se distribuem do sopé da escarpa da Serra Geral até o Oceano Atlântico.

No oeste situam-se os depósitos de leques aluviais cobrindo superfície ampla, maior no Setor Norte que no Setor Sul da área, espraiando-se de aproximadamente $200 \mathrm{~m}$ até $10 \mathrm{~m}$ de altitude. São depósitos principalmente de áreas proximais e medianas dos leques. Constituem-se de depósitos rudáceos intercalados por vezes, e recobertos quase sempre, por materiais mais finos. A sua morfologia é de lobos com topo convexo, separados por áreas rebaixadas planas. Esta morfologia deve-se aos processos deposicionais e erosivos característicos da geração dos leques aluviais. Os depósitos distais de leque têm pequena representação. Os depósitos rudáceos são também encontrados em subsuperfície, recobertos por depósitos marinhos litorâneos correspondentes a um nível de mar mais alto, anterior a 123.000 anos. Os depósitos e processos geradores dos leques aluviais são, portanto, já anteriores aos depósitos praiais mais antigos da área e os depósitos em subsuperfície registram nível marinho mais baixo que $o$ atual.

Seguem-se depósitos paleolagunares e paleoestuarinos, recobertos em certos trechos e situações por depósitos de paleolagoas, que se dispõem paralelamente ou transversalmente a corpos arenosos de cristas praiais de várias idades. Freqüentemente os depósitos de paleolagoas apresentam turfas com espessuras de 1 a 4,5 m. 
Os depósitos arenosos praiais são de várias idades, do Pleistoceno e do Holoceno e cobrem áreas das duas bacias fluviais. Os depósitos mais antigos correspondentes a um nível de mar mais alto anterior a 123.000 anos, ocorrem no Setor Norte, ao norte do Rio Araranguá nas áreas de Maracajá- Barro Vermelho e no Campo Mãe Luzia-Hercílio Luz, com altitudes entre 14 e $16 \mathrm{~m}$ e ao sul deste rio entre as cidades de Araranguá e Sombrio,com altitudes até em torno de $25 \mathrm{~m}$. Uma parte deste depósito teve uma primeira etapa como ilha-barreira no período de transgressão marinha. O restante do depósito foi acrescentado no período regressivo que se seguiu, gerando cristas praiais com altitudes entre 14 e $16 \mathrm{~m}$. No Setor Sul estes depósitos de idades e altitudes similares ocorrem entre Santa Rosa do Sul, Vila Santa Catarina, São João do Sul até próximo ao Rio Mampituba. Eles são pleistocênicos, equiparados à Barreira ll do Estado do Rio Grande do Sul.

A leste deste conjunto de cristas praiais ocorrem lagoas parcialmente já colmatadas, contendo turfa, limitadas a leste por outro conjunto de cristas praiais e dunas, do Pleistoceno (Barreira III), correspondentes a um nível de mar mais alto de 123.000 anos, seguidas por um terceiro conjunto (Barreira IV) com bom recobrimento eólico, com dunas ativas, do Holoceno.

Grande parte desta seqüência limita-se ao Norte e Sul por depósitos lagunares e estuarinos, hoje cortados pelos rios Araranguá, no norte e Mampituba no sul, com topo plano, levemente inclinados para leste.

Os depósitos da atividade eólica parecem ter dois momentos maiores: aquele do Pleistoceno mais antigo da área, e o atual. Corresponde ao Pleistoceno uma grande forma de origem eólica que alcança $100 \mathrm{~m}$ de altitude, embasada por rochas da Formação Palermo. Situa-se no nordeste da área estudada.

Alguns depósitos puderam ser datados através do $\mathrm{C}^{14}$ através de amostras de troncos, conchas e turfas, principalmente os lagunares, estuarinos e lacustres.

A seqüência de depósitos permite definir recorrência de processos, tanto marinho como continental. 


\section{INTRODUÇÃO}

A área estudada compreende uma variada gama de depósitos que representa, possivelmente, o mais completo registro de seqüência deposicional cenozóica na área emersa do Estado de Santa Catarina, cujas características geológicas, geomorfológicas e altimétricas, aliadas ao relevo circundante expresso sobre as rochas da Bacia do Paraná, exigiam seu melhor conhecimento tanto por estas razões como por constituir uma superfície importante da zona costeira e abranger o espaço considerado economicamente um dos mais pobres deste Estado.

Para esta situação de pobreza contribuem algumas das características citadas, uma vez que esta área compreende terrenos escarpados da Serra Geral, solos arenosos e áreas inundáveis, com o nível do lençol freático muito alto, como os banhados do Sombrio, Piritu e Caverá. Os terrenos arenosos apresentam cotas altimétricas dominantemente abaixo de $25 \mathrm{~m}$ e os banhados, cotas menores que $15 \mathrm{~m}$, estando a maior parte dos últimos abaixo de $10 \mathrm{~m}$. Essas condições e sua relação com a rede fluvial possibilitam freqüentes inundações, por vezes avassaladoras como a de 1974. Por outro lado, situações como a do município de Araranguá, com cerca de $80 \%$ de sua superfície constituida de depósitos arenosos, e as dos municípios de Sombrio, Santa Rosa do Sul e São João do Sul em que mais de $90 \%$ de suas áreas estão constituídos por depósitos de vários tipos e pelas águas da Lagoa do Sombrio, 
apresentam problemas, entre outros, com o suprimento de água potável e com material para a construção civil, uma vez que as rochas disponíveis são basaltos e diabásios de difícil corte, e Arenito Botucatu, e os depósitos de argila apropriada são pequenos e disputados com ceramistas.

O interesse da autora pela área foi despertado no início da década de 70 , pelas razões acima expressas e pelo fato de ali existirem turfeiras em situações geográficas e geológicas diversas, e os terrenos arenosos serem conjuntos de cristas praiais, distintos de outros depósitos similares no restante da zona costeira catarinense, em vários aspectos como altimetria, área, situação geológica-geográfica e pedogênese. Por outro lado, as redes hidrográficas das duas bacias fluviais que fazem parte da drenagem da área - a do Rio Araranguá e a do Rio Mampituba - a distribuição espacial das mesmas e os efeitos das ações erosivo-deposicionais fluviais, gerando depósitos de leques aluviais, são muito diferentes das duas maiores bacias da vertente atlântica em Santa Catarina, isto é, as dos rios Tubarão e Itajaí-Açu, e possivelmente de quaisquer outras desse Estado.

Nas bacias fluviais da área ocorrem depósitos de leques aluviais, situados mais internamente na planície, a partir do sopé da escarpa da Serra Geral, e outros depósitos fluviais sob a forma de diques marginais. No seu espaço de drenagem ocorrem, ainda, depósitos lagunares, estuarinos e lacustres, depósitos arenosos de cristas praiais e eólicos de várias idades. Depósitos de valvas de moluscos estão relacionados aos depósitos lagunares e estuarinos, e aqueles de turfa, aos depósitos lacustres.

Trata-se de uma área do leste catarinense, constituindo, em grande parte, uma planície costeira. Nela intervêm rochas da Bacia do Paraná sob forma de elevações individualizadas, em meio aos depósitos cenozóicos e uma elevação contínua que se desenvolve a partir da escarpa, com disposição E-W, separando as duas bacias, que será referida como esporão-divisor. Os espaços abrangidos por ambas as bacias serão mencionados como Setor Norte e Setor Sul. 


\subsection{OBJETIVOS}

O objetivo primordial deste trabalho é determinar a extensão e as características dos depósitos sedimentares da área estudada, bem como a sucessão dos eventos deposicionais cenozóicos, relacionados com o recuo da escarpa da Serra Geral e com a variação do nível relativo de mar. A escarpa, além de constituir fonte de material terrígeno, é um front de planalto ou face rochosa com alta declividade, voltado para leste, dispersor de águas e sedimentos. A variação do nível marinho cenozóico por sua vez, ficou registrada em vários depósitos da planície costeira, bem como na seqüência sedimentar submersa da Bacia de Pelotas que apresenta um depocentro defronte à área estudada. Os eventos deposicionais, erosivos e tectônicos registrados nesta bacia fazem parte de um conjunto de eventos geológicos que explicam a posição geográfica, a altitude e a morfologia das rochas da Bacia do Paraná, que embasam e rodeiam os sedimentos na planície costeira.

Este trabalho possivelmente contribuirá para a ocupação mais racional da área, isto é, para o uso adequado de sua superfície e de seus recursos, uma vez que ali são patentes as questōes relacionadas com a mineração de turfas, de areia de dunas, de argila e de arenito, com a construção de estradas e pontes, com o saneamento, com a captação de água potável, com o uso agrícola de áreas de turfas. O mau uso de áreas com turfa tem levado à degradação desta e à perda de espaço agrícola; a construção de estradas e pontes na área de leques aluviais, sem levar em conta a sua dinâmica, aumenta os gastos de dinheiro e trabalho das prefeituras e comunidades; a construçã́o de estradas sobre terrenos arenosos eólicos e de cristas praiais, sem planejamento, gera muitos problemas para os cidadãos, causados pelo adensamento e movimentação das areias; a mineração de areia de dunas, proibida por lei e feita clandestinamente, deixa amplas cavas com águas estagnadas do que decorrem problemas que se opõem ao desejo das populações locais, de desenvolvimento turístico de seus municípios; a captação de água potável sempre foi realizada precariamente em cidades como Araranguá, Maracajá, Sombrio, Santa Rosa do Sul e 
São João do Sul, situadas sobre depósitos arenosos pleistocênicos e, especialmente, em todas as cidades balneárias como Morro dos Conventos, Arroio do Silva, Caçamba, Balneário da Lagoinha do Norte, Balneário Gaivotas, Balneário Rosa do Mar, situadas sobre depósitos arenosos holocênicos bem mais baixos que os pleistocênicos. As diversas empresas contratadas pelo Estado e pelos municípios, muitas delas sem técnicas adequadas para esses terrenos, produziram muitos gastos, pois freqüentemente poços são perdidos por colapso de suas paredes, penetração de areias muito finas e por contaminação. Naqueles municípios o saneamento das áreas urbanas é uma necessidade premente, tanto nas áreas situadas sobre depósitos de leques aluviais, pelas suas características granulométricas e sua dinâmica, como naquelas dos depósitos arenosos altamente permeáveis.

\subsection{LOCALIZAÇÃO DA ÁREA}

A área estudada cobre uma superfície de cerca de $3.200 \mathrm{~km}^{2}$ no sul do Estado de Santa Catarina. Abrange os municípios de Araranguá, Sombrio, Santa Rosa do Sul, Passo de Torres, São João do Sul, Praia Grande, Jacinto Machado, Turvo, Maracajá, a maior parte de Meleiro, além de partes dos municípios de Timbé do Sul, Içara, Forquilhinha e Morro Grande (Figura 1).

Situa-se entre os limites com o Estado do Rio Grande do Sul, a sul delimitado pelo Rio Mampituba e a oeste definido pela borda do Planalto Sul Brasileiro, tendo o Oceano Atlântico a leste, e o paralelo $28^{\circ} 45^{\prime}$ de Latitude Sul como limite norte.

O limite com o Oceano Atlântico traduz-se por uma linha de costa muito regular, com direção NE-SW, interrompida apenas pela foz do Rio Araranguá e limitada no extremo sul pela foz do Rio Mampituba.

O limite oeste da área é bastante irregular, sendo formado pela borda da escarpa conhecida como Serra Geral. As características das rochas que afloram nesta escarpa e os alinhamentos estruturais colaboram com essa irregularidade. 


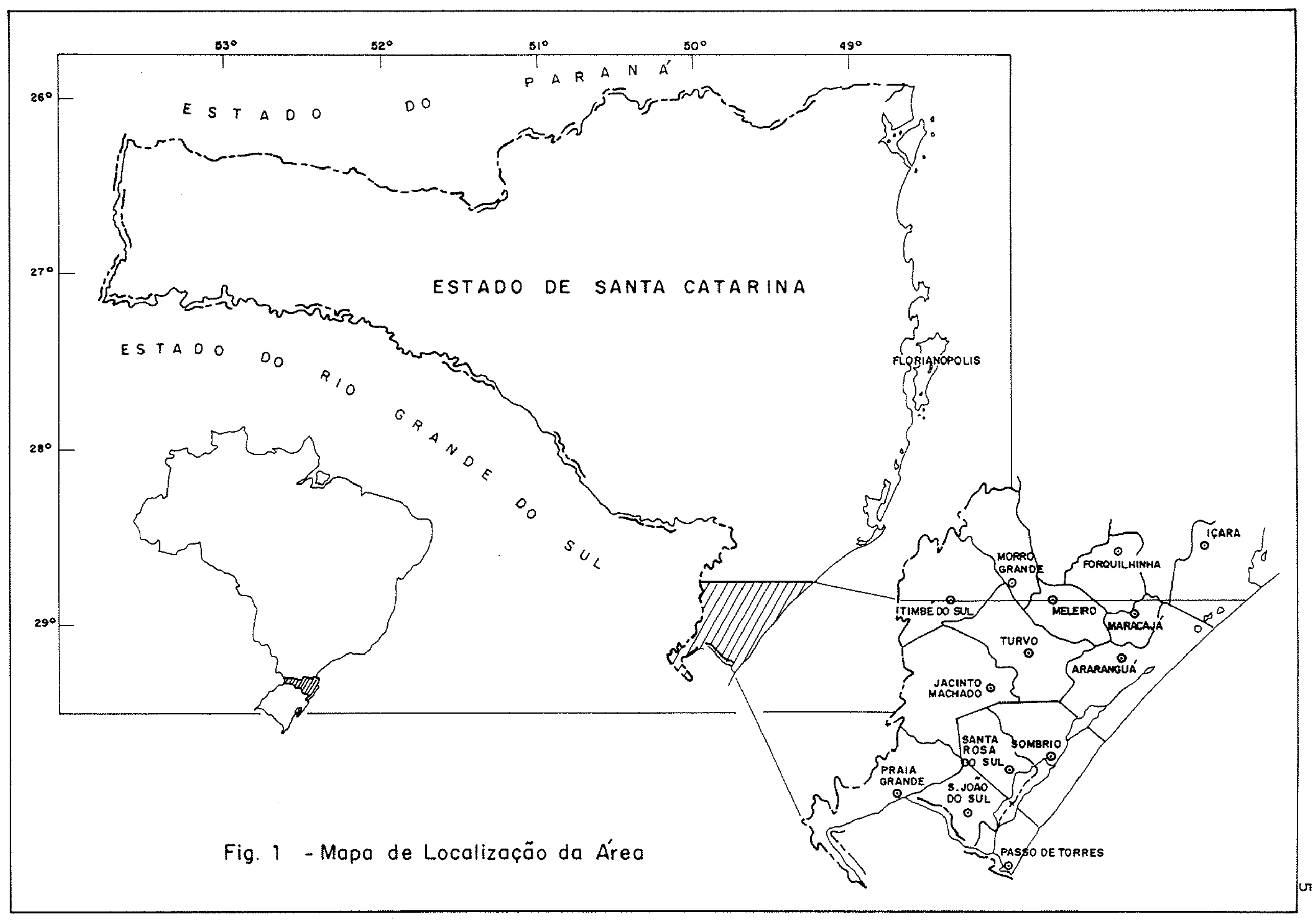


A fronteira natural sul entre os dois estados, representada pelo Rio Mampituba, no trecho sobre depósitos de leques aluviais, traduz-se por algumas dificuldades que serão explicitadas adiante.

A divisão administrativa, as localidades que serão referidas $e$ as estradas que dão acesso à área podem ser visualizadas na Figura 2.

\subsection{CARACTERISTICAS AMBIENTAIS}

\subsubsection{SOLOS}

Ocorre na área uma grande variedade de solos. Eles são importantes para este estudo, pois fornecem dados quanto ao seu grau de desenvolvimento que possibilitam sugerir idades relativas, outros que evidenciam a permanência de água devido às condições de declividade baixa e/ou condições climáticas e/ou materiais que retêm a umidade, além das características relativas a sua constituição granulométrica.

As unidades de mapeamento de solos levantadas nos trabalhos da SUDESUL (por Klamt et al. 1978; 1980 a,b) são: Molha Coco, Morro Chato, Araranguá, Jacinto Machado, Rio Leão, Poço da Lontra, Várzea da Areia, Espigão, Rio do Sertão, Tapera, Jundiaí, Juncal, Gravatal, Timbopeva e suas associações.

As unidades de solo que cobrem as maiores superfícies na área estudada são: Molha Côco, Morro Chato e Araranguá. A primeira é classificada como Terra Roxa estruturada e as outras duas são solos podzólicos vermelho-amarelo, com seqüência de horizontes $\mathrm{A}, \mathrm{B}$ e $\mathrm{C}$ contrastantes, perfil profundo, com horizonte $\mathrm{B}$ textural com estrutura em blocos e cerosidade.

O solo Molha Coco ocorre principalmente sobre as elevações; o Morro Chato em depósitos dos leques aluviais; e o Araranguá, em depósitos arenosos praiais e eólicos pleistocênicos. 


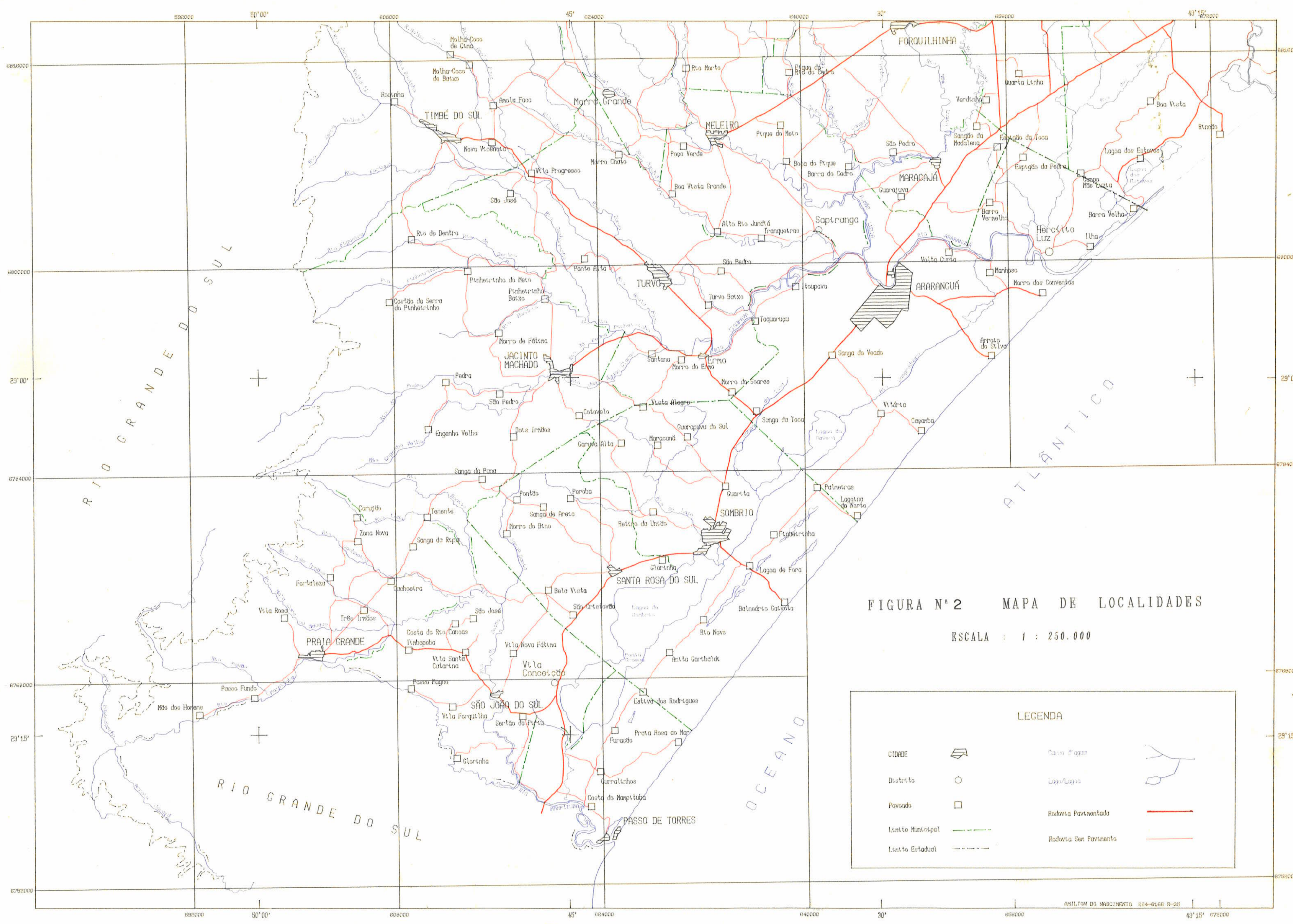


O solo Morro Chato ocorre nas formas lobadas típicas dos leques aluviais da área, intercalados com depressões mal drenadas, onde se situam os solos das unidades Várzea da Areia ou Poço da Lontra.

Quando os depósitos dos leques aluviais apresentam-se como áreas mais planas ou de lobos muito baixos, o solo Morro Chato dá lugar ao solo Jacinto Machado, transicionalmente.

Unidades de solo que apresentam horizonte-B incipiente são Jacinto Machado e Rio Leão. São cambissolos com substrato aluvial de basalto. Os cambissolos mais arenosos constituem o solo Rio Leão. Possuem também perfis profundos com horizontes $A, B$ e $C$, com cores bruna-escura a bruna. São solos mais novos que os anteriores, e suas características se devem, em parte, às adições que são realizadas no seu topo através das cheias. Os solos que não estão sujeitos a cheias freqüentes são Morro Chato, Molha Coco e Araranguá, devido as suas posições topográficas.

Outros solos são pouco desenvolvidos, hidromórficos, como os Poço da Lontra e Várzea da Areia, entre outros.

Uma quarta categoria a ser referida são os solos orgânicos hidromórficos que são encontrados nas turfeiras da área estudada. Recebem os nomes de Gravatal e Rio do Sertão.

\subsubsection{VEGETAÇÃO}

A zona costeira de Santa Catarina tem sido estudada, do ponto de vista botânico, desde 1803, segundo REITZ (1961), quando uma expedição russa, chefiada por Adão KRUSENSTEIN nela fez coletas de espécimes vegetais. Uma série de outros naturalistas ou botânicos tem estudado sua vegetação desde então até os dias atuais.

O litoral sul deste estado foi percorrido por Auguste de SAINT HILLAIRE e Friedrich SELLOW penetrou pelo Rio Mampituba, alcançando o planalto, em 1827 (REITZ, 1961). Porém, dentre estes, REITZ (1961) reconheceu como o maior contribuidor para a botânica catarinense Ernst Heinrich ULE que foi professor em vários 
municípios do litoral deste Estado. Ele estudou especialmente a vegetação litorânea. Mas, RAMBO (1949) afirma que o colecionador que dedicou mais atenção à vegetação do sul do estado foi Friedrich SELLOW.

B. RAMBO também estudou a área já em 1946, a convite de R.REITZ. Ambos, realizando coletas, estudaram a flora do então município de Araranguá. RAMBO (1949) dividiu a área em quatro faixas $\mathrm{N}-\mathrm{S}$ entre o oceano e a serra, examinando a flora do litoral, da região lacustre, da zona dos morros e do talude da Serra Geral.

Este autor considerou o extremo sul de Santa Catarina como o limite sul da flora costeira tropical que, para ele, deve-se mais à barreira geomorfológica dada pela presença do planalto até junto ao mar, do que ao clima, sendo um divisor florístico muito marcante, tanto para a planície como para o planalto.

De acordo com VELOSO et al. (1963), a composição florística da área varia de acordo com as condições edáficas e é formada por duas associações, a que recobre a planície e a dos terrenos mais altos com solos argilosos. Outras associações são observadas nos contrafortes da Serra Geral. Estas associações constituem a vegetação florestal pluvial do sul do Brasil ou floresta tropical da encosta atlântica que se estende pela planície.

$\mathrm{Na}$ unidade de mapeamento de solo Gravatal predomina a vegetação arbórea de porte relativamente baixo, com densa vegetação de ciperáceas. Sobre os solos hidromórficos fora das turfeiras, a vegetação apresenta-se com maior porte e variedade de espécies arbóreas, com grande número de epífitas e bromélias. Sobre o solo Jacinto Machado e Morro Chato, as árvores são mais altas sendo a mata mais exuberante. Nas elevações com o solo Molha Coco, a vegetação tem maior variedade de espécies (KLAMT et al. 1978).

A ocupação da área nos últimos 70 anos dizimou a vegetação sobre o solo Araranguá. Estes terrenos enxutos e relativamente planos têm sido ocupados preferencialmente pelas populações humanas, inclusive há mais tempo pelos índios Tupi-Guarani, contribuindo para a extinção da sua cobertura vegetal. 
Entretanto, a referência à vegetação neste trabalho se faz mais em função dos restos vegetais acumulados em depressões, constituindo as turfeiras que são numerosas na área.

REITZ (1961) cita uma série de gêneros e espécies de musgos, pteridófitas e fanerógamas que existem nas áreas de pântanos, brejos e banhados do extremo sul de Santa Catarina.

Entre os musgos, além daqueles citados por ULE (1900), é ainda referida por REITZ (1961) a presença da família Funariaceae, representada pela Funaria hygrométrica Hedw. Entre as pteridófitas o autor registra Regnelidium diplyllum Lindm.

Dentro das fanerógamas, foram registradas por REITZ (1961), as seguintes:

$\begin{array}{ll}\text { FAMÍLIA } & \text { GÊNERO/ESPÉCIE } \\ \text { Alismataceae } & \text { - Echinodorus grandiflorus (Cham. et Schl.) Mich. } \\ & - \text { Echinodorus telellus (Mart.) Buch. } \\ \text { Amaryllidaceae } & - \text { Alstroemeria isabelleana, terrícola nos banhados } \\ & \text { Como o da Sanga dos Rodrigues } \\ \text { Araceae } & \text { - Pistia stratiotes L., conhecida como repolhinho } \\ & \text { da água, também identificada na Sanga dos Rodrigues } \\ \text { Begoniaceae } & - \text { Begonia fisheri Otto \& Dietr. } \\ \text { Bromeliaceae } & - \text { Vriesia fribrurguensis Mez var. paludosa (L.B. Smith) L.B. } \\ & \text { Smith, terrícola nos banhados } \\ & - \text { Vriesia incurvata Gaud., epifita } \\ \text { Burmanniaceae } & - \text { Vriesia phillippocoburgii Wawra var. philippocoburgii, epifita. } \\ \text { Butomaceae } & - \text { Burmannia flava Mart. } \\ \text { Compositae } & - \text { Hidrocleis nymphaeoides (Willd.), erva flutuante } \\ & - \text { Achyrocline alata (HBK) DC., erva } \\ & - \text { Aster squamatus (Spr.) Hieron., erva } \\ & - \text { Eupatorium dendroides Spreng., arbusto de cerca de 2 m }\end{array}$


- Vernonia florida Gardn., arbusto de $3 \mathrm{~m}$, conhecido como vassoura

Eriocaulaceae - Eriocaulon magnificum Ruhl., erva

- Eriocaulon modestum Kunth

Gentianaceae - Schultesia australis Griseb.

Halorrhagaceae - Myriophyllum brasiliensi Camb., conhecido como pinheirinho de água

Leguminosae - Aeschynomene sensitiva Sw., arbusto com $2 \mathrm{~m}$

- Indigofera suffruticosa Mill., arbusto de $1 \mathrm{~m}$

- Sesbania punicea (Cav,.) Benth., arbusto de $1 \mathrm{~m}$

Mayaceae

Onagraceae

- Mayaca sellowiana Kunth, erva

- Fuchsia regia (Vand.) Munz var. affinis (Camb.) Munz, uma liana dos brejos conhecida como brinco de princesa

- Jussiae caparosa Camb., arbusto de $1 \mathrm{~m}$

- Jussiae leptocarpa Nutt., erva com 0,5 m

- Jussiae longifolia DC., var. major, erva de $1 \mathrm{~m}$

- Jussiae uruguayensis Camb.

Orchidaceae

- Habenaria parviflora Lindl., terrícola nos banhados

Palmae

- Bactris lindmaniana Drude, conhecido como tucum

- Geonoma schottiana Mart., com $1 \mathrm{~m}$ de altura

Pontederiaceae - Eichornia azurea (Sw.) Kunth, conhecida como aguapé de baraço, é flutuante com caule imerso

- Eichornia crassipes (Mart.) Solms. também um aguapé, flutuante

Rubiaceae

- Borreria valerianoides Cham \& Schl., erva de $1 \mathrm{~m}$

Umbelliferae

- Lilaeopis caroliniensis C.\&.R., erva

Xyridaceae

- Xyris caroliniana Walt. 
Estas são as famílias, gêneros e espécies citadas claramente por REITZ (1961) como sendo paludícolas, porém muitas outras ocorrem na área. A omissão da citação dáse pela incerteza de que tenham contribuído para a formação das turfas.

RAMBO (1949) registrou que em terreno brejoso existia uma vegetação muito rica, constituída de gramíneas, ciperáceas, eriocauláceas, xiridáceas e orquídeas terrestres, entre outras famílias.

Ele relatou a existência entre a Lagoa do Sombrio e a do Caverá de uma mata de brejo com Euterpe edulis Mart., isto é, o palmito, em abundância, e outras palmeiras como a Geonoma schottiana Mart., além de aráceas, euphorbiáceas, rosáceas, moráceas, rubiáceas, entre outras.

\subsubsection{CLIMA}

No extremo sul de Santa Catarina há insuficiência de estações meteorológicas e, em conseqüência, de dados que permitam entender todas as condições climáticas, tanto para explicar as cheias, como o desenvolvimento das turfas. Havia apenas duas estações, a de Torres e a de Araranguá, mantidas pelo Ministério da Agricultura, porém a de Araranguá encerrou as atividades em 1972. O DNAEE (Departamento Nacional de Águas e Energia Elétrica) mantém pequena estação em Praia Grande. Entretanto, a morfologia da região com elevações circundando parte da planície, constituindo, a oeste, escarpas com $1.000 \mathrm{~m}$ de altitude, exige estações no sopé dessas escarpas e outras estações no plano sedimentar mais interno.

Com interesse nos solos orgânicos e sabendo da importância dos dados climatológicos, a SUDESUL instalou, durante 7 a 8 meses, em 1977178, sete estações com pluviômetros e pluviógrafos, justamente na área de sopé da escarpa da Serra Geral e na área do plano sedimentar da Bacia do Rio Mampituba. Uma estação mais completa foi instalada no leste do Banhado do Sombrio.

Para o estudo climatológico, a mesma Instituição, em convênio com o IPH/UFRGS (SUDESUL 1978) reuniu os dados da estação de Torres, correspondentes ao periodo 
entre 1931 e 1978, aos seus próprios e os de outras estações do planalto e de Praia Grande, do DNAEE.

Neste estudo, foi verificado o significado dos dados de Torres em relação aos obtidos nas estações instaladas pelo IPH/UFRGS. Os testes de correlação mostram que os registros da estação de Torres podem ser usados para representação das condições climáticas na área.

Assim, a série de dados de Torres, coletados entre 1931 a 1978, mostrou que para a precipitação de chuvas, os meses de maiores índices pluviométricos médios são março, fevereiro, setembro, janeiro e agosto em ordem decrescente, indo de $147 \mathrm{~mm}$ de chuva no primeiro a $136 \mathrm{~mm}$ no último mês citado. Os menores índices são verificados, em ordem decrescente, nos meses de maio, junho, dezembro e julho com os valores de $93 \mathrm{~mm}$ a 87 $\mathrm{mm}$, respectivamente, em maio e julho. Haveria, então, dois períodos de mais altas precipitações: janeiro-fevereiro-março e agosto-setembro e dois períodos de menores precipitações pluviométricas: maio-junho-julho e novembro-dezembro (SUDESUL 1978).

A esses períodos de maior índice pluviométrico também correspondem maior número de dias de chuvas, sugerindo boa distribuição, sem chuvas muito concentradas.

A precipitação pluviométrica permite os cálculos do balanço hídrico que, por sua vez, permite caracterizar os períodos de deficiência e excedentes hídricos, que são importantes para as turfas.

Os dados das estações instaladas pelo IPH/UFRGS, em convênio com a SUDESUL, mostraram alguma discordância com os de Torres. Porém, deve ser salientado que os meses de instalação dessas estações corresponderam a um período de condições de seca para toda a região. A discrepância mais significativa relaciona-se aos meses de novembro-dezembro, quando os dados de Torres mostram médias mais baixas, ao passo que, na área interiorizada da bacia, o mês de dezembro apresentou o maior índice pluviométrico (SUDESUL 1978).

Os dados das estações da SUDESUL mostraram que a área do sopé da Serra Geral apresenta os maiores índices pluviométricos, evidenciando o papel da escarpa nas chuvas orográficas. 
Os valores médios anuais para a série de Torres mostram que a média desta série é de $1.336 \mathrm{~mm}$ anuais, porém, no período considerado, os valores anuais variaram de cerca de $700 \mathrm{~mm}$ até quase $2.000 \mathrm{~mm}$, constituindo-se de anos mais secos e de anos mais chuvosos.

Os valores de temperatura ficaram mais prejudicados, pois as estações instaladas não estavam aparelhadas para estas medidas, com exceção daquela situada a leste do Banhado do Sombrio. Os dados de Torres, correlacionados com os desta estação, mostram a mesma tendência geral de aumento da temperatura de julho como mês mais frio, para fevereiro como o mês mais quente, a partir do qual ela passa a decrescer.

A umidade relativa é bastante alta durante o ano, variando de $79,5 \%$ a $85 \%$ para Torres, dados estes comparáveis com os obtidos no Banhado do Sombrio. A amplitude de variação é muito pequena (SUDESUL 1978).

Os valores de Torres para a evaporação correspondem a uma série bem menor, de 1967 a 1974. Eles evidenciaram que junho, julho, agosto e setembro são os meses com menor evaporação. De setembro até dezembro, ela aumenta e depois fica estável nos demais meses. Estes períodos correspondem também à variação da insolação, isto é, os menores e os maiores valores de evaporação e insolação coincidem, ficando marcado o papel da insolação na transferência da água entre o solo e a atmosfera (SUDESUL, 1978).

Essa transferência de água dos solos para a atmosfera, somada à das plantas, é conhecida como evapotranspiração. Como os dados numéricos eram poucos, os pesquisadores do IPH optaram por uma fórmula mais antiga que é a equação empírica de THORNTHWAITE, que usa a temperatura média mensal do ar como elemento essencial para o cálculo deste índice.

Os dados obtidos mostram que há três períodos, durante o ano, em que a evapotranspiração é distinta. Os meses entre maio e setembro correspondem a um período de baixa evapotranspiração potencial, outubro-novembro e março-abril correspondem a períodos de valores médios, e os meses de dezembro a fevereiro constituem o período de alta evapotranspiração. Os valores extremos são $119 \mathrm{~mm}$ para janeiro e $35 \mathrm{~mm}$ para julho (SUDESUL, 1978). 
Com esses dados, verifica-se que as turfas estarão com maior disponibilidade de água nos meses de agosto e setembro. Estes constituem um dos períodos de mais alta pluviosidade e estão, também, entre os meses de menor evaporação e menor evapotranspiração. Essas condições de umidade deveriam favorecer o desenvolvimento de vegetação adaptada aos banhados, isto é, às condições de excessos de água e também ao acúmulo de material morto. Mas, na verdade, essas condiçőes existem o ano todo, quer por fatores climáticos de pluviosidade e umidade relativa do ar alta, quer por questões de relevo baixo com o nivel do freático alto. Este relevo baixo, com menos de $20 \mathrm{~m}$ de altitude, está na área de domínio da escarpa da Serra Geral, e é essa área baixa que capta também as águas das chuvas orográficas. 


\section{MÉTODOS E TÉCNICAS USADOS}

A caracterização dos distintos depósitos sedimentares e a determinação da sucessão dos eventos deposicionais foram feitas mediante mapeamento sistemático dos depósitos e do estudo dos aspectos paleo-ambientais e paleogeográficos, pela aplicação de técnicas sedimentológicas usuais e com os dados estratigráficos disponiveis.

\subsection{TRABALHOS DE CAMPO}

Para o mapeamento foram utilizadas folhas topográficas de várias origens como as do IBGE (Instituto Brasileiro de Geografia e Estatística), na escala 1:50.000, de nomes: Praia Grande, Sombrio, Jacinto Machado, Turvo, Araranguá, Rio Sangrador, e as de mesma escala do SGE (Serviço Geográfico do Exército),com as denominações de Torres, Três Cachoeiras, Aratinga, Cambará do Sul e Bom Jesus. Alguns trechos do sul da área foram cartografados em escalas 1:20.000, 1:5.000 e 1:2.000, para a SUDESUL (Superintendência do Desenvolvimento da Região Sul). A metade norte da área foi quase inteiramente coberta por folhas na escala $1: 10.000$, elaboradas pela GEOFOTO Ltda. para a Comissão Executiva do Plano do Carvão Nacional. 
As fotografias usadas em campo e para a elaboração dos mapas estão na escala 1:25.000, em preto e branco, obtidas em dois vôos: 1956/58 e 1978/79, contratados por vários órgãos estaduais e federais, e realizados pela Aerofoto Cruzeiro do Sul.

Quatro altímetros de dois tipos, OTA com precisão de $5 \mathrm{~m}$ e WALLACE \& TIERNAN com precisão de $1 \mathrm{~m}$, foram utilizados para verificação altimétrica de alguns depósitos. Foram também realizados quatro levantamentos planialtimétricos, partindose de pontos geodésicos, com teodolito KERN DKM-2AT cuja precisão é de 1", e distanciômetro KERN DM-504, com precisão de $3 \mathrm{~mm}-2 \mathrm{~mm} / \mathrm{km}$. Os perfis topográficos executados situam-se (1) entre as grutas no Arenito Botucatu e o nível da Lagoa do Sombrio, ao sul da cidade de Sombrio; (2) em trecho do terraço pleistocênico, a oeste da Lagoa de Caverá até o nível desta, a nordeste da localidade de Guarita; (3) em trecho de cristas praiais pleistocênicas, a sudeste da Lagoa do Sombrio e a leste da localidade de Curralinhos; (4) e entre a cidade de Sombrio e o oceano, passando por terraço lagunar-lacustre, situado entre as lagoas do Sombrio e Caverá. Como foram feitos nivelamentos a partir de pontos geodésicos até o início destes perfis, obteve-se a altimetria absoluta dos mesmos e conseqüentemente também os desníveis dos terraços e das grutas, e sua relação com os níveis das atuais lagoas e do oceano.

$\mathrm{Na}$ coleta de sedimentos subsuperficiais foram usados amostradores a pistão, a percussão e tipo Hiller, para testemunhar depósitos lacustres, lagunares e estuarinos. Os testemunhos de turfeiras obtidos com amostrador tipo pistão muitas vezes foram descritos em campo, observando-se a presença de troncos e fibras, a coloração, a maior ou menor quantidade de água e sua coloração de acordo com a técnica de VON POST, (1925, apud SHOTYK 1988; apud PELLETIER 1981). As turfas amostradas com testemunhador à percussão e tubos de PVC foram levadas para descrição detalhada em laboratório. Ambos os testemunhadores evidenciam que as amostras são compactadas pelos mesmos, com variações tanto de uma turfeira para outra quanto em relação a camadas mais ou menos espessas. A variação da compactação 
com a profundidade ou com as camadas é melhor percebida com o amostrador a pistão, pois este é enterrado e retirado em cada metro amostrado.

Além do material coletado com os testemunhadores, foram obtidas amostras de depósitos diversos (de leques aluviais, paleo-praiais e eólicos), em afloramentos naturais ou em exposições artificiais como cortes de estradas, minerações, retilinização de canais ou em paredes de valas de drenagem. Na ausência de afloramentos dos corpos sedimentares, foram abertos poços com 1 a $2 \mathrm{~m}^{2}$ de boca e profundidade limitada pelo nível do lençol freático ou pela possibilidade de manutenção da parede em posição vertical. Nos afloramentos a espessura variou de $1,20 \mathrm{~m}$ a $14 \mathrm{~m}$, e nos poços a profundidade ficou entre $0,60 \mathrm{~m}$ e 1,90 $\mathrm{m}$. Nas turfeiras a abertura de poços e trincheiras foi tentada, buscando-se a análise do perfil, mas em todos os casos houve problema de manutenção da parede. A turfa partia-se, rachava na parte superior e escorregava em níveis mais baixos, rotacionando por vezes. Estas tentativas foram realizadas em turfeiras parcialmente drenadas, pois naquelas sem drenagem ou com valas de drenagem obstruídas, a presença abundante de água impediu qualquer pequeno poço para exame da turfa in situ.

$\mathrm{Na}$ caracterização dos depósitos foram considerados aspectos cromáticos e texturais (granulometria, presença ou não de matriz), bem como as estruturas sedimentares (acamamento, outras estruturas primárias ou secundárias) e a presença ou não de raízes. A presença e o alcance das raízes serviram para delimitar a profundidade da pedogênese ou da destruição de estruturas. As amostragens foram feitas de acordo com as características de cada seqüência vertical e sua variação horizontal.

Os leques aluviais existentes na área foram estudados sob vários aspectos. Para a obtenção de dados de paleocorrentes foram realizadas medidas em um mínimo de 50 seixos em cada um dos 43 afloramentos escolhidos e dispersos na área. Foram escolhidos seixos com eixos longos e imbricados nos quais foram medidas a inclinação e a direção da inclinação. Para a comparação de tamanhos de fragmentos entre depósitos antigos e aqueles dos canais atuais, bem como para comparações entre 
situações montante-jusante, foram medidos os três eixos de seixos a matacões. Nas barras de canais atuais ora escolheu-se delimitar áreas de $1 \mathrm{~m}^{2}$ a $2 \mathrm{~m}^{2}$, onde foram medidos todos os seixos da superficie, ora escolheu-se apenas medir um mínimo de 100 individuos de cada local. SPIEGEL (1984) considera que para uma população infinita, o número igual ou superior a 30 é um valor grande de amostragem. Dentro da teoria avançada da probabilidade a precisão da aproximação melhora quando este número cresce. $\mathrm{CHURCH}$ et al. (1987) citam pesquisadores que, trabalhando com cascalhos fluviais, consideraram 40 seixos como uma amostra suficiente, entre eles HEY \& THORNE em 1983; ou amostras de 50 seixos como BRAY em 1972, e, em 1954, WOLMAN usou 60 seixos embora recomendando amostras com 100 seixos.

A amostragem com delimitação de área foi aplicada para que concomitantemente todos os seixos da superfície fossem medidos e quebrados, para determinar sua litologia e para ser observado sistematicamente o comportamento dos fragmentos situados sob esses seixos. Quando o critério foi o dos 100 seixos, a intenção foi se obter um número estatisticamente bem representativo. Os fragmentos com tamanhos menores que o seixo, isto é, grânulos e areias, foram também amostrados. Eles são raros nos leitos fluviais onde ocorrem os seixos. Nos depósitos rudáceos, com coesão maior ou com alteração intensa, os seixos imbricados expostos foram medidos segundo duas linhas perpendiculares entre si, isto é, o eixo maior e o seu perpendicular, para se ter um padrão que possibilitasse a comparação entre esses depósitos.

Identificou-se a competência dos cursos fluviais atuais através da observação visual e pela busca de seixos e matacões pintados antes de enchentes, com diversas cores e legendas, identificando-se sua movimentação em momentos meteorológicos diversos : antes da chuva, durante a chuva e após esta. Comprovou-se também o transporte dos fragmentos pela formação de barras ou sua modificação, seja em planta, seja em espessura, variação dos depósitos de peneiramento (sieve deposits), alargamento e/ou aprofundamento de leito e solapamento de margens com queda de blocos de material rudáceo cimentado ou de seixos e areias. 
Os depósitos arenosos praiais foram coletados, tentando se verificar diferenças entre os mais internos e mais antigos, examinando-os de crista a crista.

As praias atuais e dunas ativas foram amostradas nas suas superfícies. A coleta dos sedimentos praiais foi realizada em sete locais, ao longo do arco praial, paralelamente à linha de água, e os eólicos foram coletados paralelamente a estes.

\subsection{LABORATÓRIO E GABINETE}

Os sedimentos foram analisados quanto as suas granulometrias pelas técnicas convencionais de peneiramento e pipetagem, respectivamente, para as frações arenosas e para as pelíticas. As areias e grânulos foram separados em intervalos de $1 / 4$ de $\phi$ e as frações pelíticas em $1 \phi$. A conveniência do uso do intervalo de $1 / 4$ de $\phi$ para o peneiramento deve-se a razões apresentadas por MOIOLA \& WEISER (1968) e VISHER (1969).

Os minerais leves e pesados foram separados, usando-se a metodologia usual de líquido pesado, isto é, bromofórmio, sendo, a partir desta separação, preparadas lâminas dos grãos entre $0,088 \mathrm{~mm}$ e 0,105 $\mathrm{mm}$. A escolha deste tamanho deve-se ao fato de facilitar o estudo e identificação dos componentes que apresentam espessura mais regular e características óticas semelhantes às das lâminas delgadas.

A partir dos resultados da análise textural, foram construídas as curvas cumulativas e histogramas, obtidos os valores estatísticos e outros dados numéricos. Posteriormente, a partir dos resultados estatísticos, foi usado o programa Statigraphics para elaborar os diagramas binários e tridimensionais. Os dados estatísticos obtidos manualmente foram posteriormente controlados através do uso de programa de computador, a partir dos percentis obtidos das curvas cumulativas.

As medidas triaxiais dos seixos de afloramentos e dos canais fluviais atuais foram usadas para determinação de tamanho médio, esfericidade e forma segundo KRUMBEIN (1941); e CATACOSINOS (1965), além do achatamento de acordo com WENTWORTH (1922). 
Amostras de turfas foram datadas por radiocarbono, pelo laboratório BETA ANALYTIC Inc. de Miami, Flórida, USA. Outras amostras foram analisadas pela Fundação de Ciência e Tecnologia do Estado do Rio Grande do Sul - CIENTEC-RS, e pelo Laboratório de Análises e Ensaios de Carvão da SATC - Criciúma, para determinar características desses sedimentos organógenos e identificar as suas propriedades energéticas. Amostras estratigraficamente semelhantes a estas foram analisadas pelo Laboratório de Físico-Química e Biologia Agrícola da Companhia Integrada de Desenvolvimento Agrícola de Santa Catarina - CIDASC, obtendo-se outras qualificações desses sedimentos. Com os dados das análises desses dois últimos laboratórios obtiveram-se diagramas a partir do programa Statigraphics.

As 52 análises das turfas executadas pela Fundação CIENTEC - RS e pelo LAEC-SATC-Criciúma, foram realizadas segundo a metodologia indicada pelas normas da ABNT-NBR 8290 para poder calorífico superior (PCS) e matéria volátil, os elementos $\mathbf{C}, \mathbf{H}$ e $\mathbf{S}$ foram detectados por infravermelho, $\mathrm{O} \mathbf{N}$ por condutividade térmica, umidades livre e higroscópica e cinzas foram determinadas segundo as normas do Instituto de Tecnologia do Rio Grande do Sul, Boletim 12 e MB-15. Com as 42 análises de turfas realizadas pelo Laboratório da Companhia Integrada de Desenvolvimento Agrícola de Santa Catarina-CIDASC foram obtidos os parâmetros $\mathrm{pH}, \mathrm{P}, \mathrm{K}, \mathrm{Al}, \mathrm{Ca}+\mathrm{Mg}$, índice SMP, matéria orgânica e $\mathrm{C}$ orgânico. Os métodos e técnicas analíticas utilizadas são as de rotina para análises de solos. O poder calorífico superior calculado e o poder calorífico inferior foram determinados de acordo com LIMA (1974). As medidas de densidade aparente a seco (DBD) e a úmido (HBD) foram realizadas utilizando-se amostras cilíndricas obtidas dos testemunhos retirados com tubos de PVC de $75 \mathrm{~mm}$ de diâmetro. Cada amostra foi medida quanto ao diâmetro e à altura do cilindro para se obter o seu volume, e pesada em balança analítica, obtendo-se sua densidade, depois levada para secar em estufa fria com exaustor, para retirada da umidade, durante três dias. O cilindro de cada amostra foi novamente medido e pesado, obtendo-se a perda da umidade por volume, o valor do novo volume e sua densidade relativa. 
Amostras de conchas, de turfas e de troncos foram enviadas para datação pelo processo do radiocarbono, para o Laboratório de Física Nuclear Aplicada da Universidade Federal da Bahia, sob a responsabilidade do Dr. Antônio Expedito Gomes de AZEVEDO. Foram recebidas nove datações de conchas, duas de troncos e uma de turfa.

Uma amostra de tronco também foi datada pelo mesmo método no laboratório BETA ANALYTIC Inc., USA.

Conchas de bivalves e gastrópodes de vários depósitos foram classificadas pelo Professor Kay SAALFELD, do Centro de Biociências da UFSC e pela bióloga Cristiane BARRETO que, além da classificação dos espécimes, forneceram as características ambientais sugeridas pelas associações dos moluscos de cada local.

Amostras dos sedimentos das paleolagunas e paleolagoas foram examinadas pela Professora Roseli Maria de Souza MOSIMANN, do Horto Botânico da UFSC, para determinação de diatomáceas, com o intuito de obterem-se dados paleoecológicos. Amostras também foram analisadas pelo Professor Dr. João Carlos COIMBRA, do Instituto de Geociências da UFRGS, para identificação de microorganismos calcários ostracodes e foraminíferos - com interesse em resultados paleoambientais.

Algumas amostras de arenitos das formações Rio do Rasto e Botucatu foram analisadas granulométrica e mineralogicamente, buscando-se subsídios sobre a textura, composição e, portanto, rochas-fonte dos minerais encontrados nos depósitos. Foram ainda preparadas seções delgadas de alguns seixos coletados nos leitos dos principais rios, que não se enquadravam entre as rochas ígneas e sedimentares da área.

Complementarmente aos dados de campo, com a intenção de conhecer a espessura e distribuição dos depósitos em estudo e avaliar a bacia cenozóica, foram examinados os perfis de sondagens para carvão, para a construção civil, para a implantação da rodovia BR-101 e de poços de água. Foram obtidas informações a respeito das litologias dos embasamentos paleozóicos e mesozóicos, sobre a tectônica que as afetou, bem como sobre a espessura e identificação do material cenozóico não 
litificado. Colunas estratigráficas foram então construídas para mostrar a sucessão de fácies e localização de níveis de interesse paleoambiental.

Junto à SUDESUL foram obtidos alguns dados geológicos e estruturais provenientes de sondagens, com sondas a percussão e rotativa, e resultados de levantamentos eletrorresistivimétrico e eletromagnético no médio vale do Rio Mampituba. Outros dados relacionam-se às áreas das barragens dos rios Leão e Bonito, afluentes do Mampituba.

Vários perfis topográficos foram elaborados a partir das folhas topográficas, visando a caracterização morfológica da escarpa da Serra Geral e o contraste desta em relação à planície costeira adjacente. 


\section{TRABALHOS ANTERIORES}

Dentro dos objetivos do presente estudo, a publicação mais significativa que trata dos depósitos aqui abordados é a de MARTIN \& SUGUIO (1986). Nela são apresentados mapas em escala aproximada de 1:150.000. Trata-se do roteiro de excursão ao longo das planícies costeiras dos estados do Paraná e Santa Catarina, preparado para o "Simpósio Internacional sobre Mudanças do Nível do Mar e Linhas de Costa do Quaternário'"(1986), realizado em São Paulo. A segunda parte deste roteiro focaliza os depósitos costeiros do Quaternário dos dois estados. Nela, os autores discutem as características e a idade dos depósitos marinhos e lagunares, características e distribuição de terraços marinhos pleistocênicos e holocênicos, depósitos de cascalhos marinhos antigos e depósitos continentais. Sobre as variações do nivel relativo do mar nos últimos 7.000 anos, é apresentado um conjunto de elementos associados a datações de conchas de sambaquis, e datações de conchas e madeira de outros depósitos que permitiram àqueles autores elaborar curvas de flutuação do nível marinho para parte do Holoceno, para setores destes estados.

O extremo sul do Estado de Santa Catarina é quase coberto por quatro mapas do referido roteiro. Neles são registrados depósitos de fundo de baía e lagunar, flúvio-lagunar, dunas e terraços marinhos arenosos do Holoceno, além de depósitos do Pleistoceno, constituídos por dunas com idade maior que 6.000 a 7.000 anos A.P. e 
menor que 120.000 anos A.P., e terraços marinhos arenosos com idade inferida em 120.000 anos A.P. São ainda assinalados depósitos continentais indiferenciados do Quaternário.

Anexas à publicação encontram-se quatro tabelas que, entre outras informações sumariam as datações por radiocarbono, de conchas, madeira e carvão com respectivas localizações, idades e cotas em relação ao atual nível marinho, porém nenhuma refere-se à área aqui estudada.

Outra contribuição semelhante é o "Mapa Geológico do Quaternário Costeiro dos Estados do Paraná e Santa Catarina", na escala 1:200.000, de MARTIN et al. (1988) (Figura 3). Sua legenda distingue as características litológicas, aspectos morfológicos e idades pleistocênica ou holocênica dos depósitos. Os autores, no texto explicativo deste mapa, discutem as evidências dos niveis marinhos altos durante o Quaternário, as conseqüências das variações do nível relativo do mar sobre a sedimentação litorânea, bem como a evolução paleogeográfica e paleoclimática do litoral de ambos os Estados; apresentam a distribuição e características dos depósitos marinhos, lagunares e continentais e ocorrências minerais. Em apêndice apresentam longa lista de sambaquis, com sua localização, natureza do substrato e as datações disponíveis. Além destas, são apresentadas várias outras datações de conchas e madeira que possibilitaram a elaboração das curvas médias de variações do nível relativo do mar, durante os últimos 7.000 anos, para os estados do Paraná e Santa Catarina.

O Atlas de Santa Catarina (GAPLAN,1986) inclui mapas geológico e geomorfológico, na escala 1:1.000.000, elaborados por equipes do Projeto Radambrasil-IBGE. No mapa geológico, os autores além de apresentarem as rochas aflorantes da Bacia do Paraná, qualificam, nesta parte de Santa Catarina, os depósitos holocênicos como coluviais, aluviais, eólicos, marinhos e lacustres, e aplicam aos depósițos pleistocênicos as denominações Formação Chuí e Formação Itapoã devidas a DELANEY (1965), sem maiores explicações. Estas nomenclaturas são aplicadas a toda a zona costeira do Rio Grande do Sul e, como tal, são usadas para características 


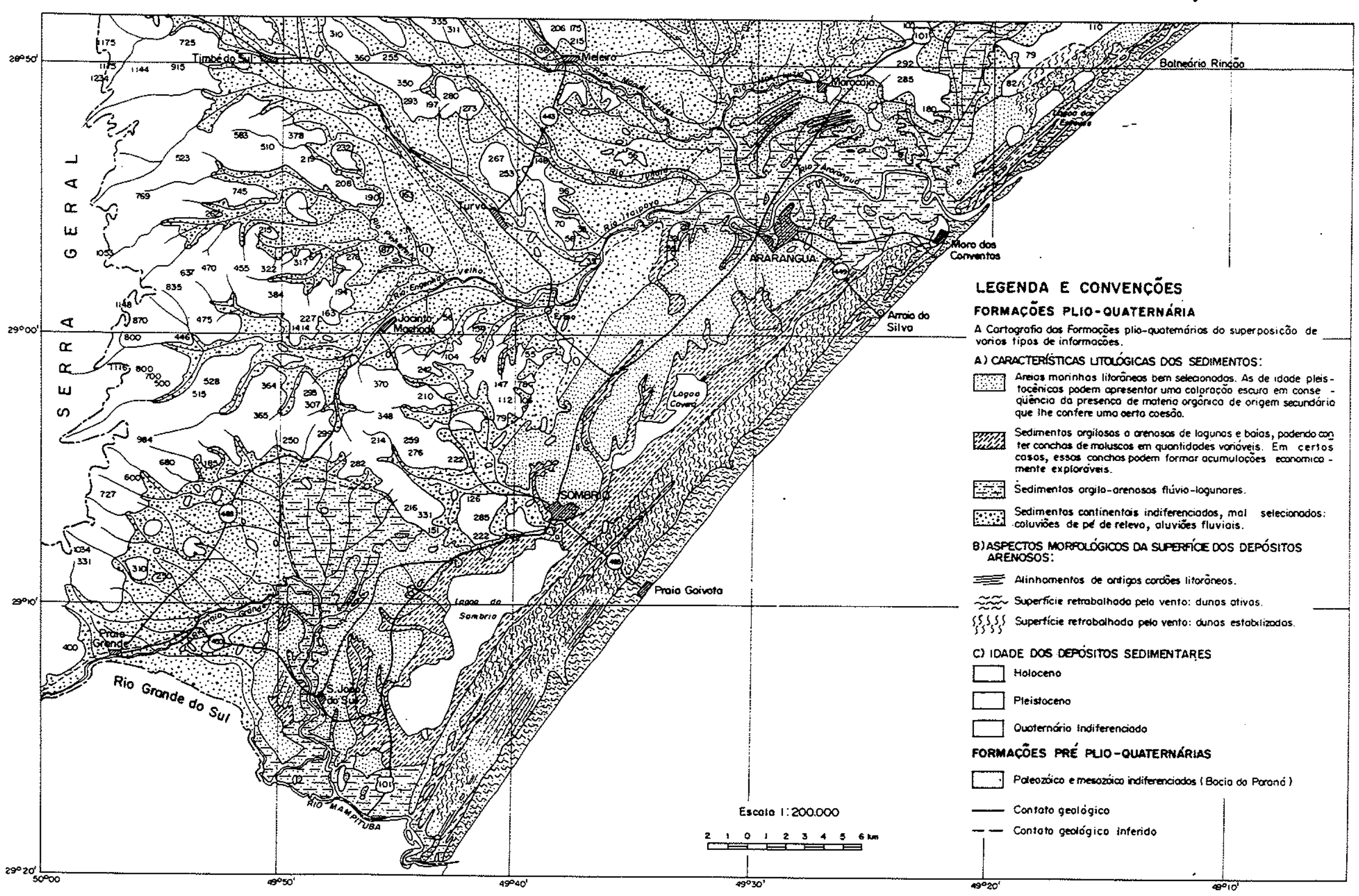

Fig. 3 - Parte do "Mapa Geológico do Quaternário Costeiro do Estado de Santa Catarina "escala I:200.000, que cobre a áreo estudada. (Martin et al , 1988). 
litológicas e não cronológicas. A Formação Chuí compreende os depósitos arenosos marinhos/litorâneos e a Formação Itapoã compreende os depósitos eólicos. O Mapa Geomorfológico deste Atlas apresenta as formas de relevo dentro de dois domínios: o dos Depósitos Sedimentares e o de Bacias e Coberturas Sedimentares, referindo-se neste caso, às rochas sedimentares da Bacia do Paraná. Dentro do primeiro domínio situa-se o que é considerada Região das Planícies Costeiras subdividida em Planícies Litorâneas e a Planície Colúvio-Aluvionar, sendo mapeados terraços (fluviais, marinhos, lacustres) e áreas planas ou embaciadas da planície colúvio-aluvial.

O Mapa Geológico do Estado de Santa Catarina, em escala 1:500.000, do Departamento Nacional da Produção Mineral-DNPM, e da Secretaria de Ciência, Tecnologia, Minas e Energia-SCTME (1987), apresenta a distribuição dos depósitos cenozóicos do estado sob duas legendas, uma referente ao Quaternário no sopé da escarpa, aplicada a depósitos aluviais atuais, e outra ao Terciário/Quaternário, aplicada a terraços marinhos. Portanto, os depósitos do sopé da escarpa são considerados atuais, sendo os depósitos a leste destes, considerados marinhos e mais antigos. Entretanto uma outra questão se coloca pela contradição com o texto explicativo. Neste, os depósitos são apresentados de duas outras maneiras: uma na redação e outra na Tabela Litoestratigráfica. No texto, o autor declara que considera todos os depósitos como quaternários, porém, no esquema litoestratigráfico, deixa suas idades indiferenciadas como do Terciário/Quaternário. Por outro lado, separa os sedimentos fluviais dos continentais, parecendo considerar ambientes distintos.

O "Mapa Geológico - Folhas Três Cachoeiras e Torres" de HORN FILHO et al. (1984) e o trabalho de HORN FILHO (1987), que trata da "Geologia das Folhas Torres, Três Cachoeiras, Arroio Teixeira e Maquiné, Nordeste do Rio Grande do Sul", abrangem em Santa Catarina um pequeno trecho da área aqui tratada, no sudeste da mesma, dentro das Folhas de Torres e Três Cachoeiras (Figura 4). Quanto às litologias, fácies e idades há coincidência, em ambos, com as conclusões de MARTIN \& SUGUIO (1986) e MARTIN et al. (1988), aplicando-se, porém, as designações dentro do esquema evolutivo usado para a Província Costeira do Rio Grande do Sul. Desta 


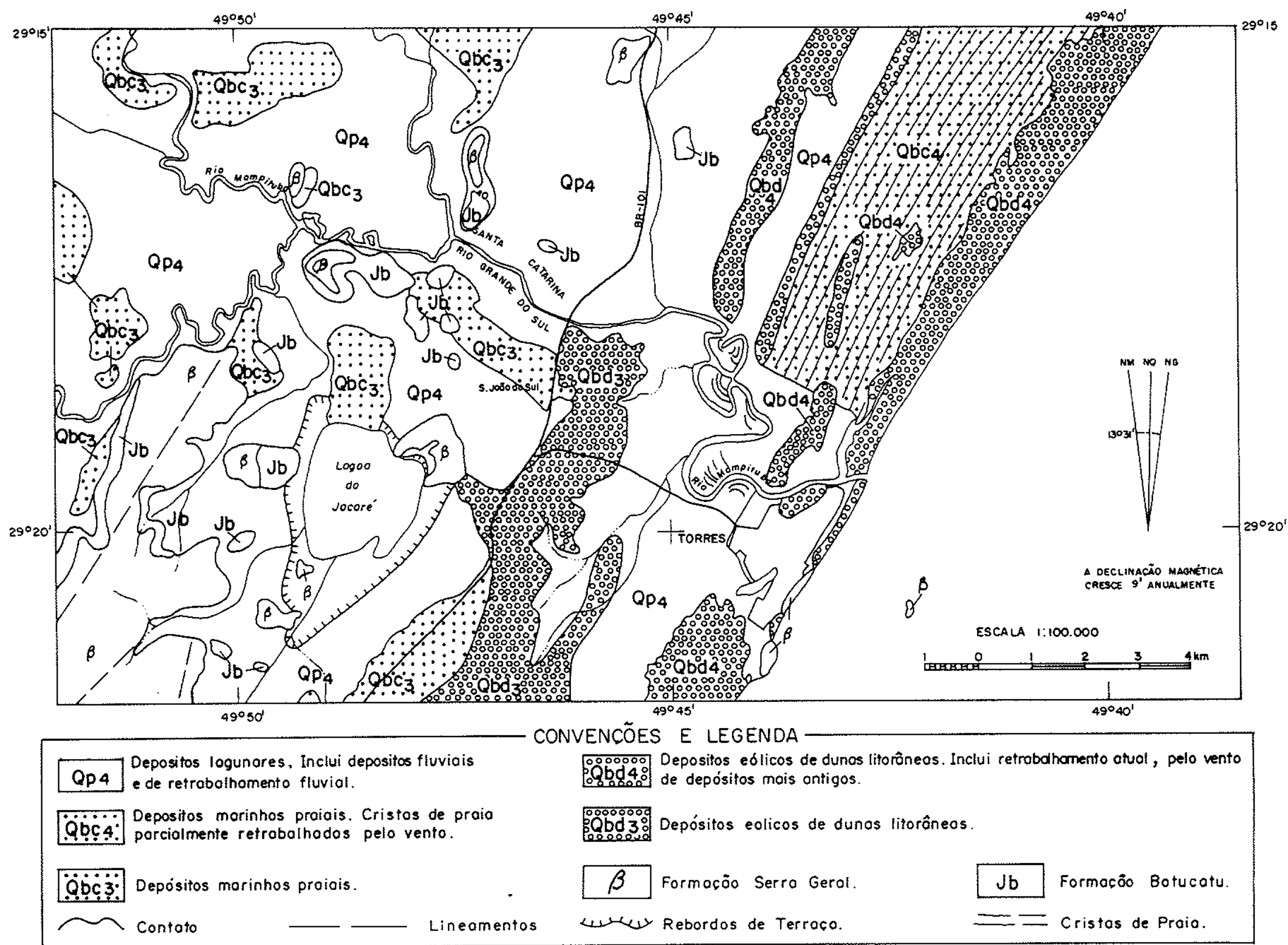

Fig. 4 - Trecho que abrange o SE da área do extremo Sul de Santa Catarina, do"Mapa Geológico das Folhas Três Cachoeiras e Torres"na escala I:100.000. (Horn Fo eł al., 1984). 
maneira, no trecho mapeado em Santa Catarina, ocorreriam depósitos relacionados sobretudo ao que é considerada Barreira IV, e aqueles da Barreira III estão representados por três pequenos corpos.

Dentro do "Projeto Litoral Sul de Santa Catarina", as atividades desenvolvidas pela SUDESUL (Superintendência do Desenvolvimento da Região Sul), quer mediante convênios com a Universidade Federal do Rio Grande do Sul, a Escola de Agronomia de Pelotas, a Fundação de Ciência e Tecnologia do Rio Grande do Sul quer por meio de empresas contratadas, resultaram em vários relatórios e mesmo em publicações apenas sobre o Setor Sul, como a de COULON (1983). Este último trabalho, centrado na área das barragens dos rios Leão e Bonito, da Bacia do Mampituba, embora se ocupe mais com questões geotécnicas, forneceu espessuras e outras características dos sedimentos junto ao sopé da escarpa.

Alguns relatórios dos resultados dos projetos provenientes destes convênios apresentam dados hidrológicos, climáticos, de solos, de tradagens e sondagens realizadas a percussão ou com sondas rotativas, abrangendo parte do Setor Sul. As tradagens e sondagens contribuem para a identificação dos sedimentos e suas espessuras em áreas de depósitos rudáceos ou áreas inundáveis.

Tratando de sedimentos ou da morfologia ainda da Bacia do Rio Mampituba, no Rio Grande do Sul, há os trabalhos de BIGARELLA \& BECKER (1975), GOMES (1976), ANDREIS \& BOSSI (1978). No primeiro trabalho é descrito sucintamente o depósito rudáceo que ocorre junto à BR-101, a uns $200 \mathrm{~m}$ ao sul da ponte sobre o Rio Mampituba, no limite do Rio Grande do Sul com Santa Catarina. DELANEY (1963, 1965 e 1966 apud BIGARELLA \& BECKER 1975; e ANDREIS \& BOSSI 1978), já havia feito referência ao depósito e descrito um afloramento a oeste da BR-101, ao passo que BIGARELLA \& BECKER (1975) descreveram um outro afloramento a leste da mesma estrada. Nestes trabalhos o depósito foi considerado como de origem marinha. BIGARELLA \& BECKER (1975) identificaram areias no meio dos seixos como marinhas ou eólicas e afirmaram que ele significa um nivel de mar pleistocênico cerca de $8 \mathrm{~m}$ acima do atual. 
ANDREIS \& BOSSI (1978) examinaram os dois afloramentos do "Conglomerado Mampituba", reestudando-os com descrição minuciosa de sua composição ("os clastos são de diabásio") e realizando uma série de medidas texturais e orientação dos clastos. Consideraram que há diferenças entre os dois afloramentos, tanto em idade relativa quanto em fábrica. Os depósitos estão sobre arenito da Formação Botucatu e diabásio da Formação Serra Geral que foi interpretado por BIGARELLA \& BECKER (1975) como basalto. $A$ altitude do afloramento $A$, a leste, situa-se entre $7 \mathrm{~m}$ e $11,50 \mathrm{~m}$, enquanto a cota máxima do afloramento $B$, a oeste, é $7 \mathrm{~m}$. Segundo os autores, os clastos de diabásio estão total ou parcialmente alterados e constituem $98 \%$ dos dois afloramentos. Por outro lado, foram medidos os rumos e os mergulhos dos eixos maiores dos clastos. Ambos os afloramentos tiveram origem em fluxos de lama incorporando detritos rochosos. No afloramento $A$, considerado o mais antigo pelos autores, os fragmentos são mais grossos, e a matriz é heterogênea (argila, silte e areia). Este depósito interpretado como marinho por BIGARELLA \& BECKER (1975) é então reinterpretado como devido a movimento de massa mediante fluxo laminar. Entretanto, no afloramento $\mathbf{B}$ os fragmentos de diabásio são menores, em média, que no $A, e$ apresentam imbricação que evidencia paleocorrentes vindas de oeste, provavelmente vinculada a retrabalhamento dos depósitos grossos pelo "paleo-rio Mampituba", cerca de $7 \mathrm{~m}$ acima do nível atual. Os autores reconhecem, portanto, dois processos geradores dos depósitos rudáceos na área.

No que concerne à geomorfologia, GOMES (1976) discorre sobre "Aspectos da Evolução Geomorfológica da Escarpa Oriental do Planalto Meridional durante o Quaternário". Este trabalho foi realizado sobre atividades de campo e fotografias aéreas obtidas logo após as chuvas e enchente de 1974. A autora concentra seu trabalho no Município de Torres e no vale do Rio Mampituba, a montante da cidade de Praia Grande. Usa a toponímia da população local para os rios, sem perceber a dinâmica fluvial dos leques aluviais com o entrelaçamento de canais, de tal maneira que denomina o Rio Mampituba ora de Rio Roça da Estância ora de Praia Grande. Refere-se aos aluviões heterométricos, às corridas de lama sobre as encostas, à ação 
de escoamento torrencial e aos cones de dejeção. Considera os cones como depósitos de encosta cujo material mais fino se espraia sobre os depósitos do assoalho do vale, desvinculando-os totalmente dos depósitos fluviais. 


\section{O EMBASAMENTO, SUA MORFOLOGIA E TECTÔNICA}

A área apresenta como embasamento dos depósitos estudados, as rochas sedimentares e ígneas da Bacia do Paraná, que constituem também a borda do Planalto Meridional, chamada de Serra Geral. Estas mesmas rochas formam os esporões e elevações isoladas, refletindo posições anteriores da "Serra" e seu recuo possivelmente durante o Cenozóico. Grandes áreas destas rochas, no sul do Estado, apresentam-se, portanto, dissecadas e recobertas por sedimentos mais jovens (Figuras 5 e 6 no encarte). Esta situação é confirmada nas sondagens para carvão (Figura 7) e em poços de água subterrânea.

O trabalho de GUAZELLI \& FEIJÓ (1970) apresenta mapa na escala 1:100.000, que fornece a base da geologia regional. Estes autores mapearam parte do Estado de Santa Catarina, isto é, o centro-leste e sudeste do estado, do paralelo $26^{\circ} 40^{\prime}$ de Latitude Sul até o norte do Rio Grande do Sul, englobando, portanto, a área aqui tratada. As rochas do flanco leste da Bacia do Paraná constituíram o foco deste trabalho.

O estudo de SÜFFERT (1976) focalizou apenas o extremo sul da área abrangida pelo trabalho dos autores acima citados, usando e modificando o mapa desse trabalho, ou definindo melhor alguns afloramentos e aceitando a mesma coluna estratigráfica (Figuras 8 e 9 ). 


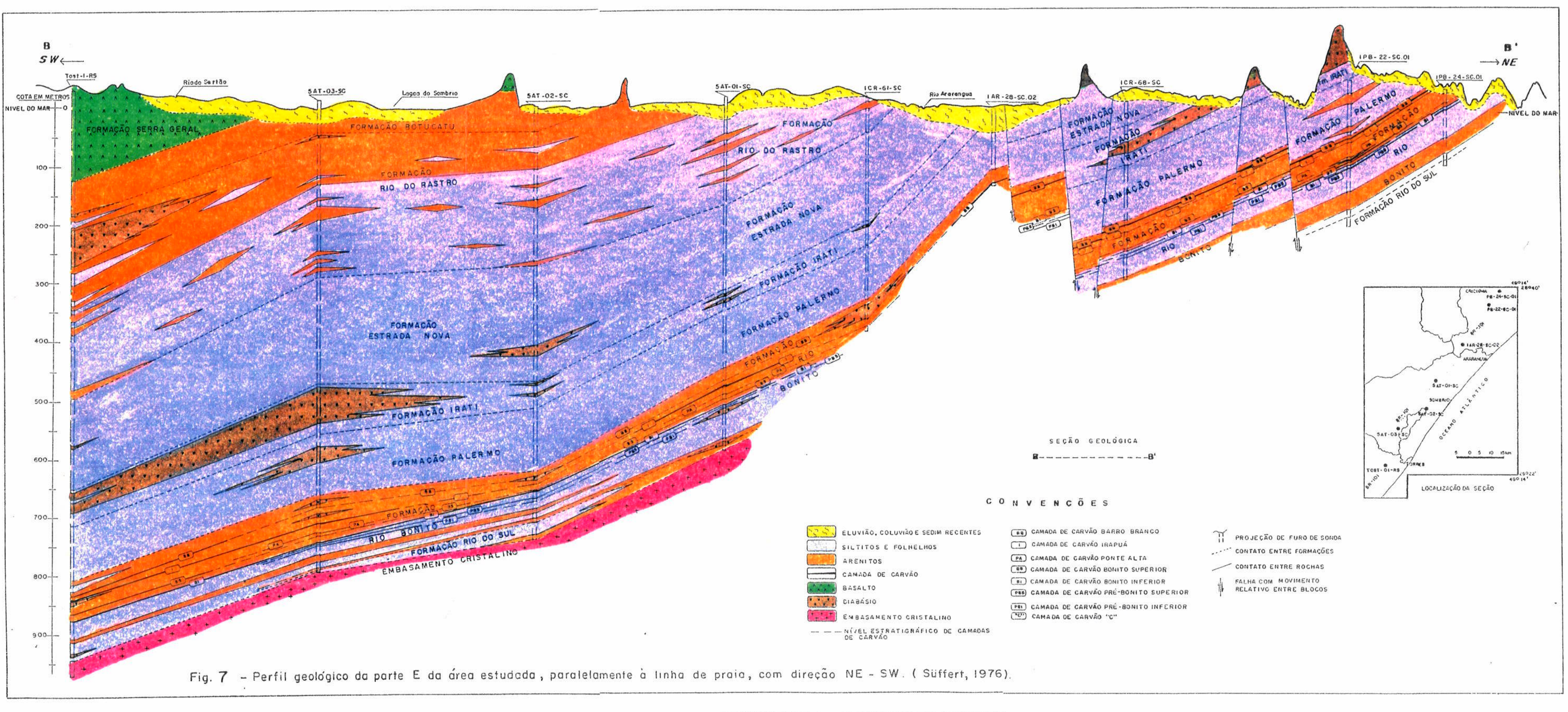




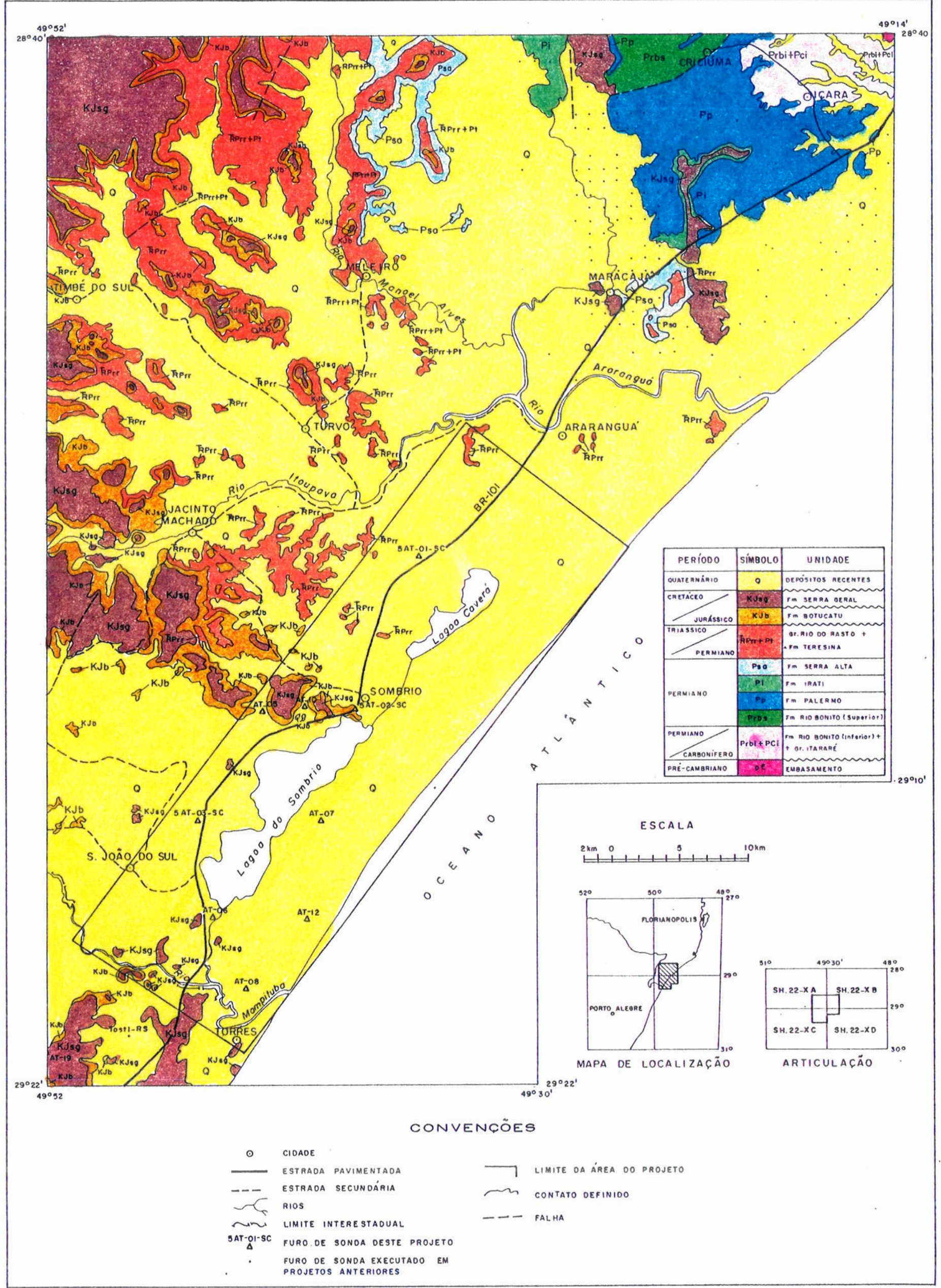

Fig. 8 - Mapa Geológico, Projeto Carvão em Araranguá - Torres, Süffert (1976). 


\begin{tabular}{|c|c|c|c|}
\hline \multirow{2}{*}{ Períado } & \multicolumn{2}{|c|}{ Unidode Liroeetratigrófico } & \multirow{2}{*}{ Litologiat } \\
\hline & Grupo & Formacäo & \\
\hline QUATERNÁRIO & \multirow{4}{*}{$\begin{array}{l}\text { ditcordäncio } \\
\text { dikcordöncio } \\
\text { diecordöncio } \\
\text { RIO OO RASTO }\end{array}$} & & Depósito de aluviōes e coluvî́tee. \\
\hline \multirow{2}{*}{ JURÁSSICO-CRETÁCEO } & & SERRA GERAL & $\begin{array}{l}\text { Derromes e intrusoes de lovas basólticon sob } \\
\text { forma de diques e soleciras. }\end{array}$ \\
\hline & & BOTUCATU & $\begin{array}{l}\text { Arenitot médiok e grosseiror com estrotificagáo } \\
\text { cruzodo. Arenito e siltito vermetho argibso. }\end{array}$ \\
\hline TRIÁSSICO-PERMIANO & & & $\begin{array}{l}\text { Arenito violeta-acinzentodo, siltitos e folhelho } \\
\text { morrom-overm ethados. }\end{array}$ \\
\hline \multirow{5}{*}{$\begin{array}{l}P \\
E \\
R \\
M \\
1 \\
A \\
N \\
O\end{array}$} & & TERESINA & $\begin{array}{l}\text { Siltitos cinzo-etcuros a pretos, laminados, cam } \\
\text { intercalocöes de orenito fino. }\end{array}$ \\
\hline & & SERRA AL.TA & folhethos pretos com discreto faminacoo. \\
\hline & & IRATI & $\begin{array}{l}\text { Folhethos e siltitos pretos com niveis betumino- } \\
30 s, \text { cotciferos. }\end{array}$ \\
\hline & & PALERMO & $\begin{array}{l}\text { Sittitos cinzo arenitos finos, finomente inter- } \\
\text { colodos. }\end{array}$ \\
\hline & & RIO 80 NITO & $\begin{array}{l}\text { Arenitos cinzo-cloros, siltitos, follhelhos e comodas } \\
\text { de corvo. }\end{array}$ \\
\hline PERMO-CARBONIFERO & $\begin{array}{l}\text { ITARARÉ } \\
\text { discordóncio }\end{array}$ & RIO DO SUL & Arenitos, siltifos, vorvitos e diomictitos. \\
\hline
\end{tabular}

Fig. 9 - Coluno Estrotigráfico do óreo do Projeto Carvõo Bonito Gaseificóvel (Süfert, el al. $\{98 \mid\}$.

O limite oeste desses trabalhos foi a borda do planalto. Ela é a forma que primeiro chama a atenção na área estudada, pois é parte de um escarpamento que se prolonga para o norte. É a feição geomorfológica mais impressionante e, talvez, a de maior significado, que se desenvolve desde o Rio Grande do Sul até o Espírito Santo. $\mathrm{Na}$ área este escarpamento além de Serra Geral tem nomes locais como: Aparados da Serra, Serra da Rocinha, Serra da Figueira, entre outros. Ele é o limite de dois outros compartimentos geomorfológicos que são o planalto, para oeste, e a planicie costeira, a leste (Figuras 10 a 12). Esta é área muito baixa que se desenvolve entre o oceano e o sopé da escarpa e que, no caso, é bastante ampla.

As características de escarpamento muito alto e longo, de sua situação geográfica e das rochas que o constituem e continuam para leste, servindo de embasamento aos depósitos da planicie, bem como formando colinas residuais mais ou menos isoladas, induzem a considerações sobre o volume erodido, o local de deposição do material retirado, o tempo para a erosão do mesmo e a época em que a escarpa adquiriu sua posição atual. Um outro lado da questão é a relação destes fatos, em áreas emersas, com eventos na área oceânica, como as variações do nivel 


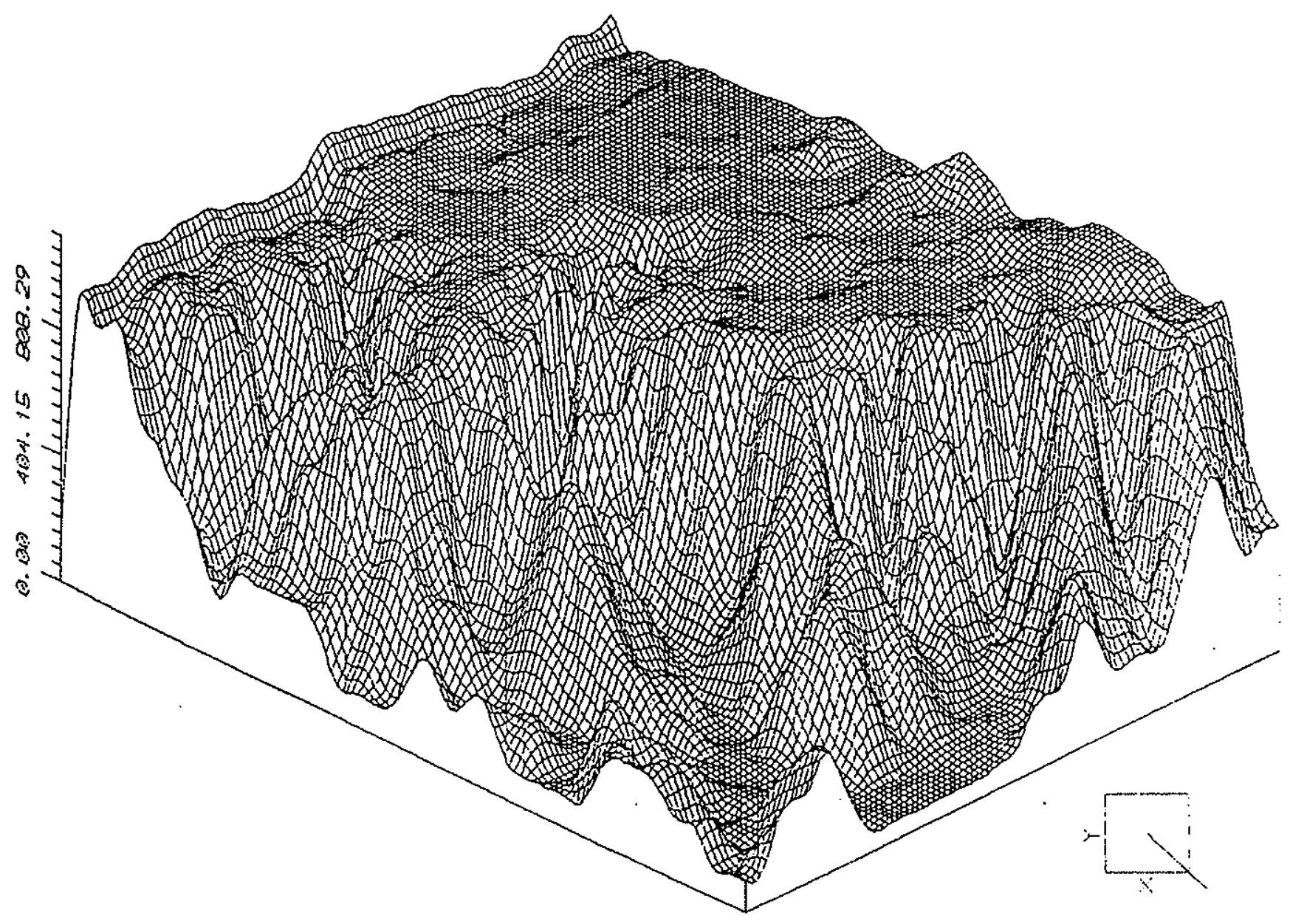

FIGURA 10 - Características morfológicas da escarpa da Serra Geral na área do Rio Pavão, vendo-se ondulado do planalto onde nasce este rio. 


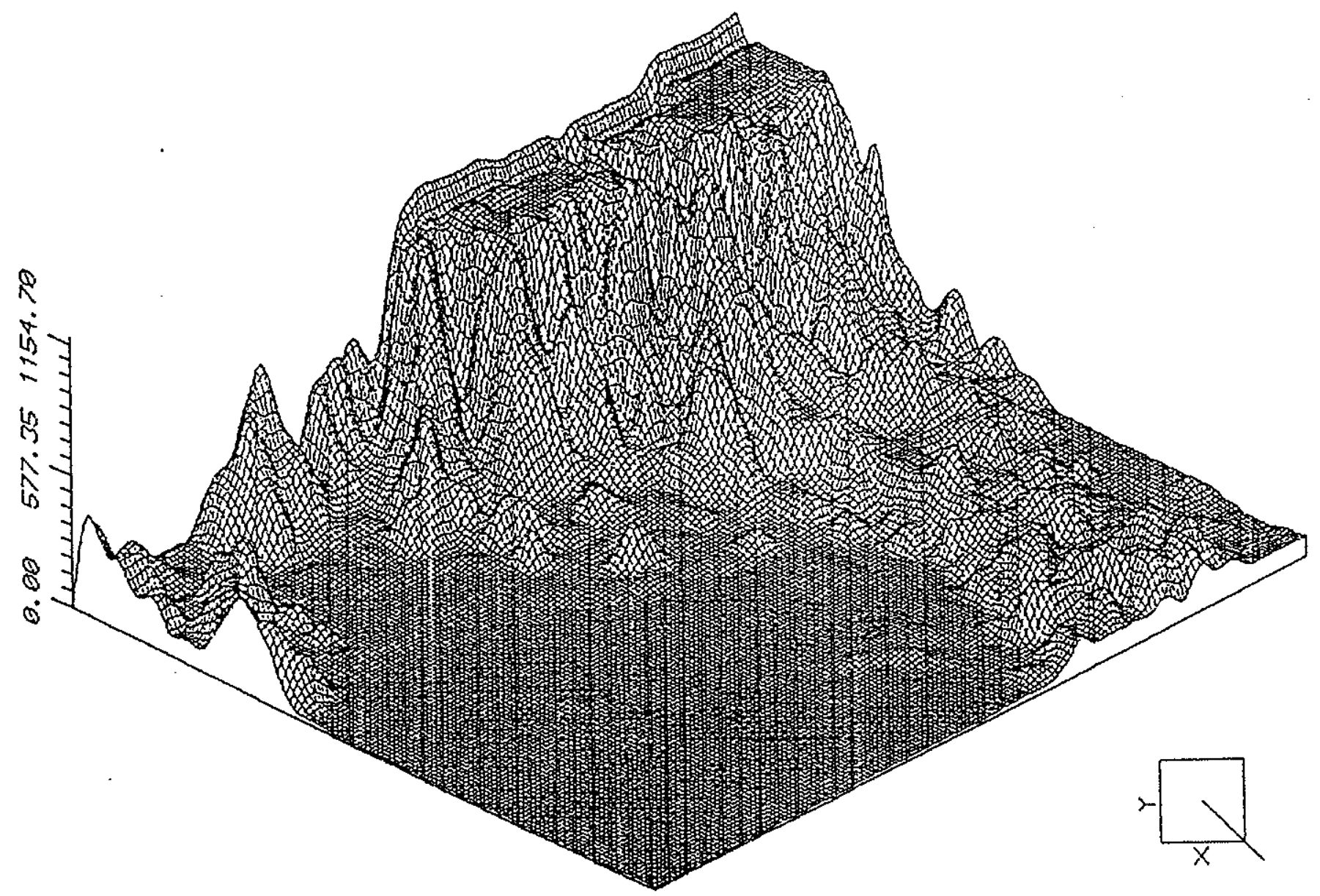

FIGURA 11 - Aspectos do relevo do Setor Sul: a planície, a escarpa da Serra Geral e o esporăo-interflúvio, vistos de SE. Folha de Praia Grande - IBGE, 1: 50.000 . 


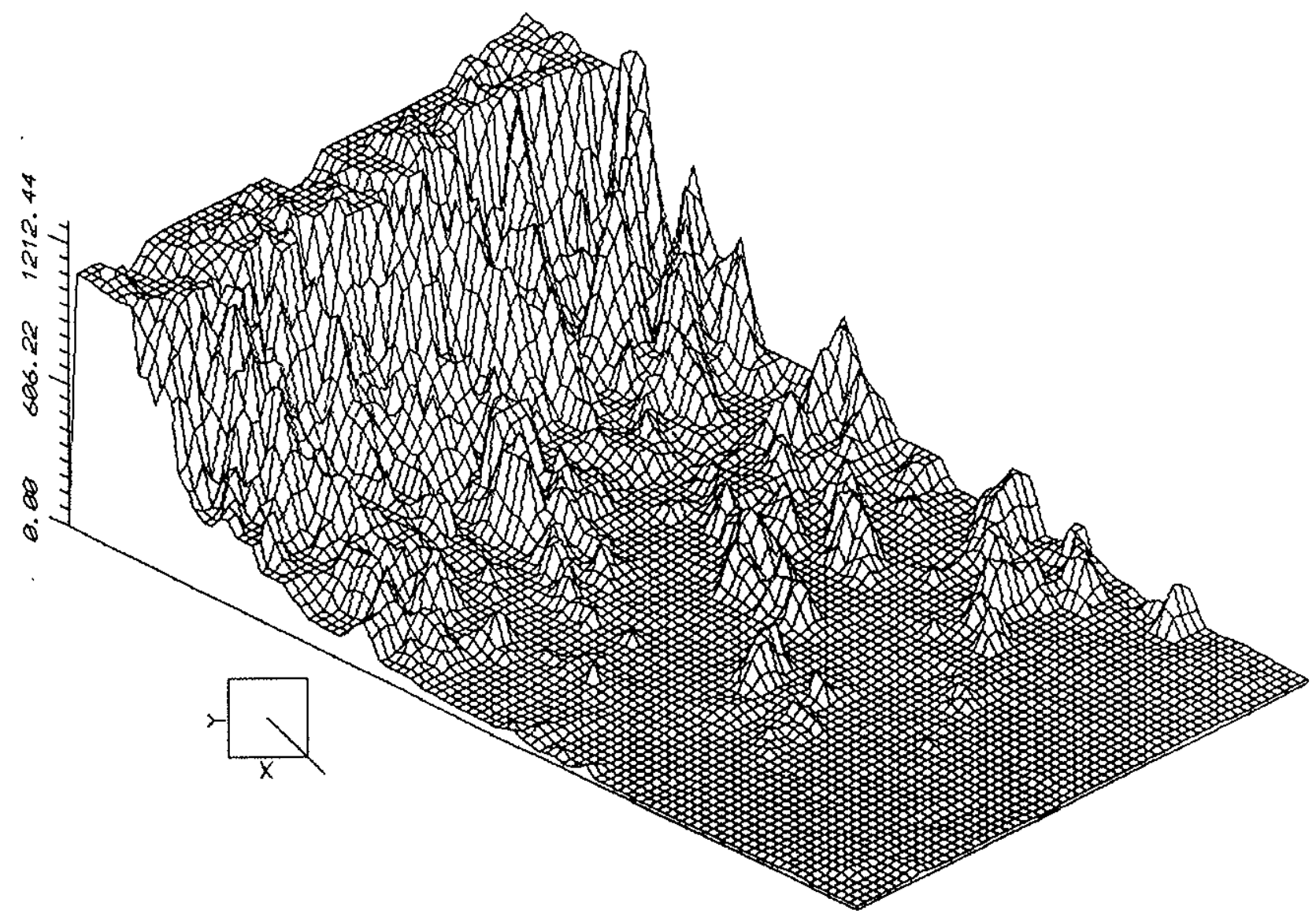

Figura 12 - Aspectos do relevo do Setor Norte. Vista parcial obtida a partir da Folha Jacinto Machado, 1:50.000 - IBGE. 
relativo do mar registradas na planície costeira e na margem continental submersa adjacente.

Este escarpamento, no trecho em questão, é bem visível em imagens de satélite, de radar ou fotografias aéreas. Em detalhe é sinuoso, porém sua borda superior tem um alinhamento geral $\mathrm{N}$-S, em quase toda sua extensão na área. Constitui exceção a este alinhamento, o trecho drenado pelos afluentes que alimentam o alto e médio curso do Rio Mampituba, isto é, da cidade de Praia Grande para o sul (Figura 13 no encarte).

A escarpa, ora não exibe características de controle estrutural nítido, ora este controle interfere, orientando preferencialmente alguns canais e mesmo sub-bacias fluviais e gargantas ocupadas por rios, como é o caso do Rio Pavão no cânion do Itaimbézinho (Figura 13 no encarte).

A borda do escarpamento apresenta altitudes que crescem de sul para norte. Desta maneira, defronte à cidade de Praia Grande tem $1.000 \mathrm{~m}$, chegando a $1.100 \mathrm{~m}$ defronte à cidade de Jacinto Machado e $1.200 \mathrm{~m}$ para mais, na área de Timbé do Sul, alcançando $1.300 \mathrm{~m}$ no limite norte da área (Figura 13 no encarte e Figura 14). Sabe-se que estas altitudes da borda da escarpa, mais a norte, chegam aos seus valores extremos em Santa Catarina, isto é, $1.822 \mathrm{~m}$ no Morro da lgreja e $1.828 \mathrm{~m}$ no Campo dos Padres.

\subsection{SETOR NORTE}

Neste setor a escarpa da "Serra" é composta dominantemente por rochas do Grupo São Bento, isto é, arenitos eólicos da Formação Botucatu e rochas ígneas da Formação Serra Geral, porém em sua base afloram ainda rochas do topo do Grupo Passa Dois. Estas últimas tornam-se freqüentes nas elevações residuais a leste.

A Formação Serra Geral está constituída predominantemente pelos basaltos e pelos diabásios. Os últimos ocorrem sob forma de diques de várias dimensões e soleiras, em ambos os setores. 


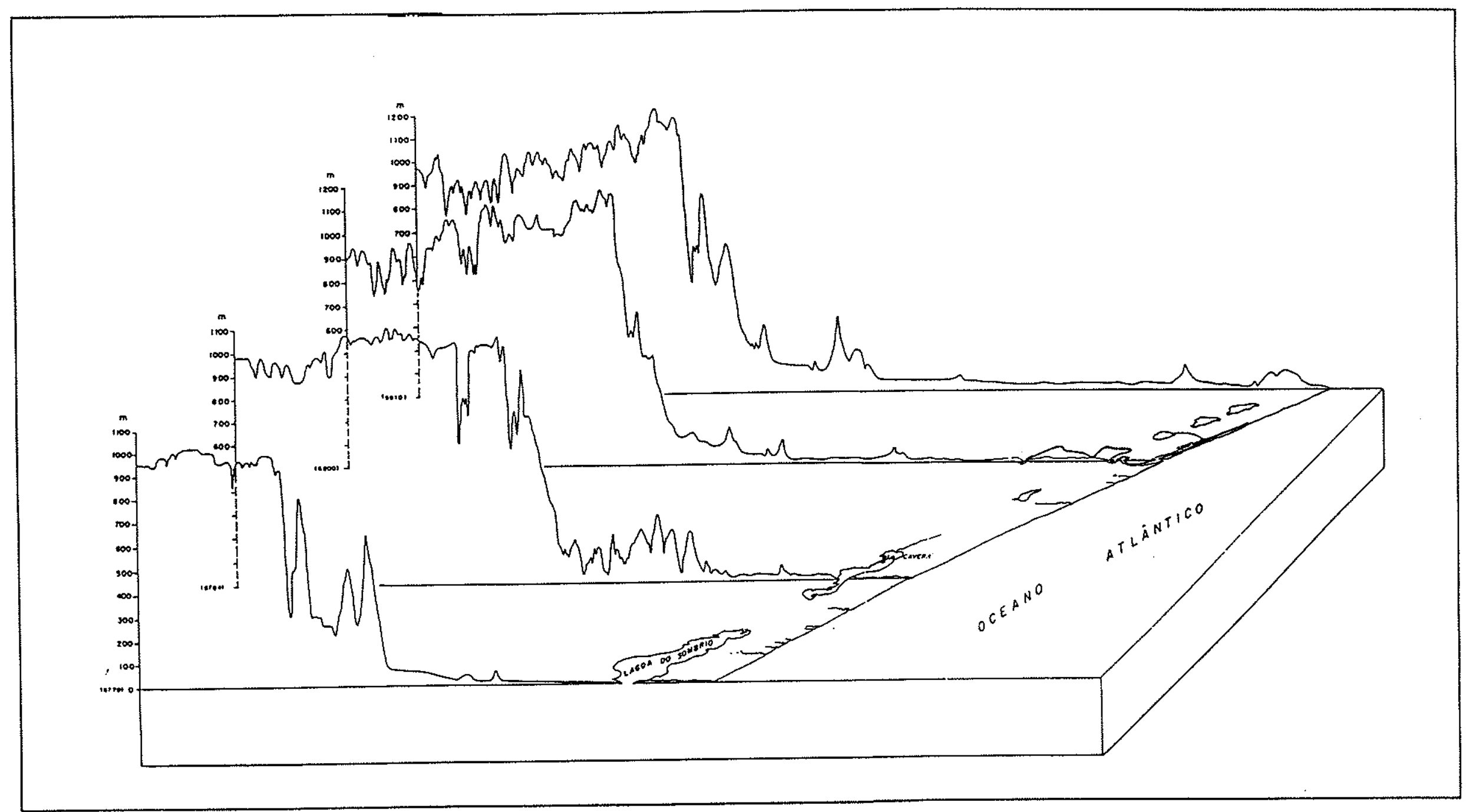

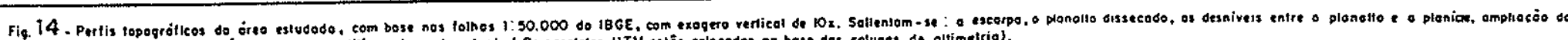

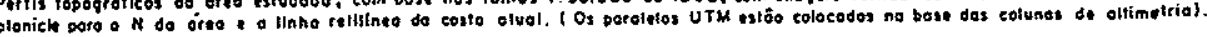


LEINZ (1949) registrou a espessura de $850 \mathrm{~m}$ para os derrames na localidade de Pedra, hoje pertencendo ao Municipio de Jacinto Machado.

As soleiras são numerosas, e o diabásio de várias delas é utilizado, depois de britado, em particular, para calçamento de ruas das cidades balneárias, ou mesmo das cidades como Araranguá, Sombrio e Praia Grande. A alta freqüência de soleiras de diabásio próximas ao mar, uma das quais ocupa grande superfície a leste de Maracajá e do Morro do Tigre, sugere a anterior presença de espessas seqüências de rochas sobre as mesmas e possivelmente uma posição inicial da borda escarpada da bacia muito a leste da atual, permitindo também estimar o volume erodido de rochas, do final do Mesozóico até hoje.

O Arenito Botucatu aflora no oeste, fazendo parte da escarpa, ora dando continuidade, para baixo, à verticalidade das rochas básicas ora com declividades menores, expandindo sua área de exposição. $\dot{E}$ bimodal, de cores rosada, avermelhada e amarelo-rosada. As exposições mostram camadas de espessura milimétrica, muito longas, cujos "sets" apresentam-se em estruturas cruzadas. As camadas muito longas são as mais freqüentes mas também ocorrem aquelas de 1,5 a 2,0 m de comprimento, como em Retiro da União.

Suas espessuras alcançam cerca de $200 \mathrm{~m}$, pelo menos o dobro daquelas citadas por GUAZELLI \& FEIJÓ (1970), e já referidas também por LEINZ (1949:35).

As exposições das rochas sedimentares do Grupo Passa Dois são bem maiores, mais freqüentes, com maiores espessuras e altitudes neste Setor Norte em relação ao Setor Sul. Arenitos deste Grupo são encontrados constituindo o leito de rios, como no caso do Rio Pinheirinho, em $30 \mathrm{~m}$ de altitude.

As litologias de topo do Grupo Passa Dois afloram tanto no sul como no norte deste Setor, ao passo que aquelas que constituem a base da Formação Estrada Nova e o topo da Formação Irati afloram apenas no norte do mesmo (Figura 8).

Dentro deste Grupo, os siltitos cinza, da Formação Serra Alta, afloram apenas no nordeste da área aqui estudada, a leste da cidade de Maracajá. Acham-se cortados por diques de diabásio, e para leste seu contato se faz com a maior soleira aflorante 
em toda a área, aquela a leste do Morro do Tigre. Estes siltitos são extraídos como matéria-prima para indústria cerâmica de Criciúma.

As rochas de topo deste Grupo afloram junto a Jacinto Machado, por exemplo, no Morro da Gávea, em contato com o Arenito Botucatu, em baixa altitude. Afloram também ao sul e sudeste daquela cidade, e mesmo mais para leste, constituindo uma série de elevações de até pouco mais de $100 \mathrm{~m}$ de altitude.

Os afloramentos situados entre Jacinto Machado e Guarita apresentam litologias com cores amarela, rosada, roxo-azulada, roxo-avermelhada e amarela bem clara, tendendo para branco-acinzentada. A área é a do Morro do Ermo, Santana, Vista Alegre, Garapuvu do Sul, Morro do Soares e Morro da Canoa.

Nesta área foi encontrada madeira silicificada que possuía cerca de $15 \mathrm{~m}$ de comprimento e diâmetro maior de cerca de $0,80 \mathrm{~m}$, hoje dividida em vários fragmentos de em torno de $1 \mathrm{~m}$ cada, encontrada a aproximadamente $40 \mathrm{~m}$ de altitude, em Vista Alegre.

As litologias da parte superior do Grupo Passa Dois ocorrem ainda em muitas elevações isoladas do Setor Norte, como o Morro do Pronto, a leste da localidade de Itoupava, o Morro do Centenário e Morro Agudo, junto à cidade de Araranguá e o Morro dos Conventos.

As exposições de rochas do Grupo Passa Dois são bem mais freqüentes, com maior superficie, maiores altitudes e chegam mais a leste, até junto ao mar, no Setor Norte que no Setor Sul, como no caso do Morro dos Conventos $(<80 \mathrm{~m})$, no Município de Araranguá.

As rochas aflorantes constituindo a escarpa apresentam formas que foram afeiçoadas por processos de alteração supérgena e erosivos agindo mais intensamente nas linhas de fragilidade, tanto devidas à tectônica quanto ao tipo de estrutura apresentada pelos derrames. Muitas outras formas constituem prolongamentos rebaixados das rochas da escarpa, como esporões, que ainda evidenciam o papel da tectônica, porém a erosão tem sido o processo mais importante para explicar a morfologia dos seus topos e encostas. Além destas há elevações de 
vários tamanhos, altitudes e conformações, que são formas erosivas isoladas em meio aos depósitos ( Figura 5 no encarte e Figura 12).

As elevações contínuas da escarpa das quais as maiores situam-se a oeste, apresentam-se com aspecto de um anfiteatro muito amplo e aberto. As elevações a sul fazem parte do divisor de águas entre a Bacia do Rio Mampituba e a Bacia do Rio Araranguá. As elevações que completam o anfiteatro a norte situam-se fora da área estudada. Há, entretanto, alguns testemunhos a nordeste da cidade de Araranguá como o Espigão da Toca (293 m), Espigão da Pedra (150 m), Espigão do Tigre (171 m) e Morro de Maracajá (171 m), e a elevação alongada, mais a norte, na área da Quarta Linha $\left(49^{\circ} 24^{\prime} \mathrm{LW},<150 \mathrm{~m}\right.$ de altitude). Esta tem sua continuidade espacial com aquelas situadas na área de Criciúma, a norte dos $28^{\circ} 45^{\prime} \mathrm{LS}$, limite estipulado neste estudo.

Os afloramentos nestas elevações e noutras de extensão e altura variáveis demonstram que se constituem de rochas do Grupo Passa Dois. Podem ser pequenas elevações isoladas como as de Guarita, Morro dos Conventos, Morro do Centenário, Morro Agudo e duas outras na cidade de Araranguá. Podem ser extensas como aquelas do Morro do Ermo, em direção à Vista Alegre e Garapuvu do Sul, a sudeste de Jacinto Machado. Estas se apresentam com relevo de formas convexas de baixa declividade. Algumas, entretanto, como aquelas junto à localidade de Guarita, Município de Sombrio, têm seus topos aguçados.

Em muitos afloramentos, os sedimentitos são encaixantes de corpos de rochas ígneas básicas.

Cabe salientar que as elevações isoladas, constituídas de rochas do Grupo Passa Dois, raramente apresentam arenitos da Formação Botucatu no seu topo, como ocorre no Morro da Boa Vista, a norte da cidade de Turvo, e no Morro da Gávea, junto a Jacinto Machado.

Os arenitos da Formação Botucatu são bem expostos no esporão interflúvio ao sul deste Setor, tanto com aspecto ruiniforme quanto em blocos contínuos. Igualmente são vistos no sopé das formas ainda unidas à escarpa da Serra Geral, como festões, 
formando interflúvios das sub-bacias afluentes do Rio Araranguá. Na estrada entre Turvo e Timbé do Sul vê-se que este arenito esteve sob a ação de esforços tectônicos, pois encontra-se tão fraturado que apresenta formas com aspecto colunar, às vezes colunas isoladas como grandes dedos apontando o céu. Não parece tratar-se dos prismas hexagonais de BJORNBERG et al. (1964), considerando as descrições, os desenhos $e$ as escalas apresentadas por estes autores. As colunas aqui referidas apresentam altura de 30 a $50 \mathrm{~m}$ ou mais, e largura de aproximadamente $10 \mathrm{~m}$. Arenito Botucatu, com as características apresentadas nas fotos do referido trabalho é encontrado a leste da cidade de Sombrio, em pequeno afloramento ao nível do terraço lagunar.

A maioria das elevações isoladas apresentam altitudes abaixo de $150 \mathrm{~m}$, porém o Morro da Boa Vista e aqueles situados a nordeste da cidade de Araranguá atingem até $285 \mathrm{~m}$.

O topo da escarpa vai apresentando, para o norte, altitudes maiores até $1.300 \mathrm{~m}$. No sopé, no mesmo sentido, vão aflorando maiores espessuras das rochas sedimentares do Grupo Passa Dois.

As declividades da escarpa entre o topo e os $300 \mathrm{~m}$ de altitude variam de $15^{\circ}$ a $23^{\circ}(27 \%$ a $43 \%)$ em alguns lugares, porém são freqüentes os valores entre $43^{\circ}$ a $45^{\circ}(80 \%$ a $100 \%)$. Mas as medidas tomadas entre os topos e os $200 \mathrm{~m}$ de altitude demonstram que a declividade varia de $10^{\circ}$ a $16^{\circ}(19 \%$ a $30 \%)$, o que demonstra que abaixo dos $300 \mathrm{~m}$ os valores são bem menores. As declividades ao longo de alguns canais, no trecho da escarpa, entre os topos e $200 \mathrm{~m}$ de altitude, são bem mais baixas, ficando entre $5^{\circ}$ e $9^{\circ}(10 \%$ a $16 \%)$. Esses valores são mais baixos do que aqueles do Setor Sul.

As elevações continuas do esporão interflúvio e da escarpa da borda do planalto acham-se profundamente dissecadas, pois os vales são freqüentemente mais profundos, mais longos e mais largos que no Setor Sul, formando festões no sopé da "Serra". Estas características explicam os valores mais baixos de declividade dos canais. 
Em razão destas características dos vales, os interflúvios que os ladeiam nada mais são que os resíduos da escarpa que está retrocedendo pelo efeito dos processos erosivos e de remoção do material instabilizado.

Os canais e seus vales na escarpa são efeito e causa de muitos processos. Os canais maiores apresentam situação de paralelismo entre si que, considerada juntamente com as direções tectônicas preferenciais levantadas por vários pesquisadores desde a década de 40 e evidências obtidas nas imagens de radar, lembram que há um forte controle estrutural sobre estas formas (Figura 13, no encarte).

Os vales dos rios nela estabelecidos, do esporão interflúvio para o norte, divergem da direção mais freqüente que apresentam no Setor Sul, isto é, de NW-SE. Passam, no Setor Norte, a ter direção preferencial NE-SW. Novamente a direção NW-SE se estabelece a partir do Rio Serra Velha II na qual se orientam os vales ao norte deste, a maioria já fora da área de estudo. Salienta-se que os rios com nascentes e alto curso neste trecho fora da área de estudo têm seus médios e baixos cursos dentro desta. Os vales e seus canais com esta última orientação são: Serra Velha I, Rocinha, Molha Coco, Amola Faca, Manoel Alves, Morto e Cedro.

Essas orientações que são nitidamente estruturais geraram e mantém um tipo de grande anfiteatro circundando a área de uma paleobaía e contribuem para a disposição assimétrica das sub-bacias fluviais componentes da Bacia do Rio Araranguá, em relação ao canal principal (Figura 15, no encarte).

A direção geral NE-SW do Rio da Pedra se prolonga nos trechos do curso com as toponímias Itoupava e Araranguá. Por outro lado, os rios que na escarpa apresentam esta direção, ao sair da maior influência deste relevo alto e íngreme, mudam-na para NW-SE, até alcançar o Rio Itoupava-Araranguá.

Por outro lado, o comportamento dos dois rios principais das duas bacias, 0 Mampituba e o Araranguá, também sugerem este controle. A disposição dos seus afluentes de forma radiada, a maioria com fluxo para sudeste, além da característica de assimetria de ambas as redes de canais, permitem supor que este controle continua 
fora da escarpa, ordenando a disposição dos leques e o fluxo das águas ( Figuras 15 e 16 , no encarte).

Dominam em subsuperfície, embasando os sedimentos neste Setor Norte, em ordem estratigráfica decrescente, as rochas da Formação Rio do Rasto, seguidas pelas da Formação Estrada Nova e da Formação Palermo, além de corpos de diabásio. As litologias da Formação Rio do Rasto são lamito, siltito, siltito argiloso e arenito. A Formação Estrada Nova está constituída de siltito argiloso e a Formação Palermo é composta de siltitos argilosos, siltitos arenosos e camadas de arenito fino de pequena espessura, intercaladas. As cores da formação inferior para a Formação Rio do Rasto mudam de cinzentas para avermelhadas.

A declividade deste embasamento entre o poço SW-02-SC, situado a $1 \mathrm{~km}$ a oeste de Meleiro, e os poços MA-16-SC e MA-13-SC, a sul de Maracajá, é de 13' e a entre o poço SW-01-SC, situado a $2 \mathrm{~km}$ ao sul da cidade de Turvo e o poço 5AT-01SC, em Sanga da Toca, Araranguá, é também de 13', inclinando para leste.

\subsection{SETOR SUL}

Este Setor também apresenta a Serra Geral como limite oeste, e seu limite norte é o esporão-divisor, rebaixado e bastante dissecado.

Na escarpa afloram rochas das duas formações do Grupo São Bento, com cerca de 800 a $980 \mathrm{~m}$ de espessura. Podem ser observadas também no Estado do Rio Grande do Sul, flanqueando descontinuamente a margem direita do Rio Mampituba, até junto ao oceano, em Torres.

Ao sul da cidade de Sombrio, a algumas dezenas de metros da lagoa homônima, os arenitos da Formação Botucatu apresentam-se em elevações, algumas das quais exibindo grandes grutas. Porém, a leste e a sul desta cidade, entre a rodovia BR-101 e a lagoa, vários afloramentos destas rochas, com poucas dezenas de $\mathrm{m}^{2}$, estão no nível do terraço lagunar-lacustre que margeia a referida lagoa, isto é, 
apresentam-se em altitudes entre $0,80 \mathrm{~m}$ e $5 \mathrm{~m}$, evidenciando a forte dissecação apresentada por essas rochas.

Neste Setor Sul, afloramentos de arenitos da Formação Botucatu e/ou rochas básicas sob forma de soleiras e diques, bem como arenitos, siltitos e argilitos de cores roxo-azulada e roxo-avermelhada, do Grupo Passa Dois, são reconhecidos em elevações isoladas, isto é, afastadas da escarpa e circundadas por sedimentos cenozóicos diversos. Estas rochas afloram ainda em leitos de rios, já na área de planície, porém, junto à escarpa.

Elevações isoladas, constituídas de rochas do Grupo Passa Dois, ocorrem somente ao norte da localidade de Timbopeba e a oeste do meridiano marcado pelo Rio Sertão. Constituem sete elevações isoladas, pequenas e interiorizadas na planície. A elevação do Morro do Bino, com $45 \mathrm{~m}$ de altitude, é a que está situada mais a leste (Figura 6, no encarte).

Chamam atenção três soleiras de rochas básicas, a leste da Lagoa do Sombrio, e outros corpos a oeste e sul da mesma, ao longo da BR-101.

Na parte oriental dos dois setores os afloramentos destas soleiras freqüentemente atingem altitudes em torno de $60 \mathrm{~m}$.

Por outro lado, neste Setor Sul vêem-se afloramentos de rochas sedimentares cortadas por intrusões de rochas básicas nem sempre tabulares; ao contrário, há algumas bastante irregulares, como as que acompanham um dique que ocorre na elevação em Vila Santa Catarina, a noroeste da cidade de São João do Sul, cortando arenito vermelho da Formação Botucatu.

A encaixante destes corpos de diabásio, na maioria das vezes, é o arenito da Formação Botucatu. Quando a elevação é de rocha ígnea básica, em geral é uma soleira que comumente constitui toda a elevação, isto é, não aflora a encaixante da sua base e já foi erodida a encaixante de topo. Apenas uma das soleiras apresenta-se ladeada a oeste por pequeno afloramento de arenito da Formação Botucatu.

Neste setor o embasamento foi erodido, ficando também suas elevações contínuas com a configuração de um anfiteatro que compreende parte do Rio Grande 
do Sul, limitando a área de uma paleobaía sul. As elevações contínuas do embasamento, que constituem o contorno desta paleobaía, apresentam-se muito dissecadas no Rio Grande do Sul, com vales profundos e relativamente abertos que deixam como resíduos mais altos, interflúvios estreitos. Estes raramente apresentam-se acima da cota $1.000 \mathrm{~m}$. Em Santa Catarina a expressão morfológica é distinta, uma vez que a escarpa está mais distante do oceano e é mais acentuada, tanto pela alta declividade quanto por ter vales menos profundos e menos abertos, relativamente curtos (com exceção do Rio Mampituba, a montante da cidade de Praia Grande), constituindo nitidamente a borda escarpada do planalto, com altitudes em geral acima de $1.000 \mathrm{~m}$. As declividades medidas em alguns perfis, entre o topo e a altitude de $100 \mathrm{~m}$, variaram de $11^{\circ}$ a $18^{\circ}(20 \%$ a $32 \%)$, ao passo que entre o topo es $200 \mathrm{~m}$, variaram de $14^{\circ}$ a $28^{\circ}(25 \%$ a $52 \%)$. Entretanto, esses valores são bem mais altos a partir dos $300 \mathrm{~m}$ de altitude e principalmente na parte superior da escarpa que chega a ser verticalizada (Foto 1). Medidas efetuadas nos intervalos de $300 \mathrm{~m}$ e os topos com $1.000 \mathrm{~m}$ a $1.100 \mathrm{~m}$ variaram de $35^{\circ}$ a $50^{\circ}(62 \%$ a $82 \%)$.

A parte superior da escarpa é composta pela seqüência de rochas basálticas de sucessivos derrames cuja morfologia na borda leste, freqüentemente se constitui pelas declividades mais altas. Porém, neste Setor Sul o Arenito Botucatu apresenta, muitas vezes, as mesmas declividades. Em alguns locais, no contato dessas duas litologias, há uma quebra da morfologia íngreme e da alta declividade, formando ressalto de extensão variável, após o quê retornam a morfologia e a declividade anteriores, agora em cotas mais baixas. Os ressaltos mais largos, devidos à mudança litológica de basalto para Arenito Botucatu, estão arredondados por causa de depósitos ali situados e que apresentam grande quantidade de material argiloso envolvendo fragmentos resistentes e angulosos ou subangulosos de basalto. Em alguns locais, estes depósitos acompanham, por sua vez, a morfologia geral da encosta com alta declividade, como pode ser observado na margem esquerda do vale do Rio Pavão. 


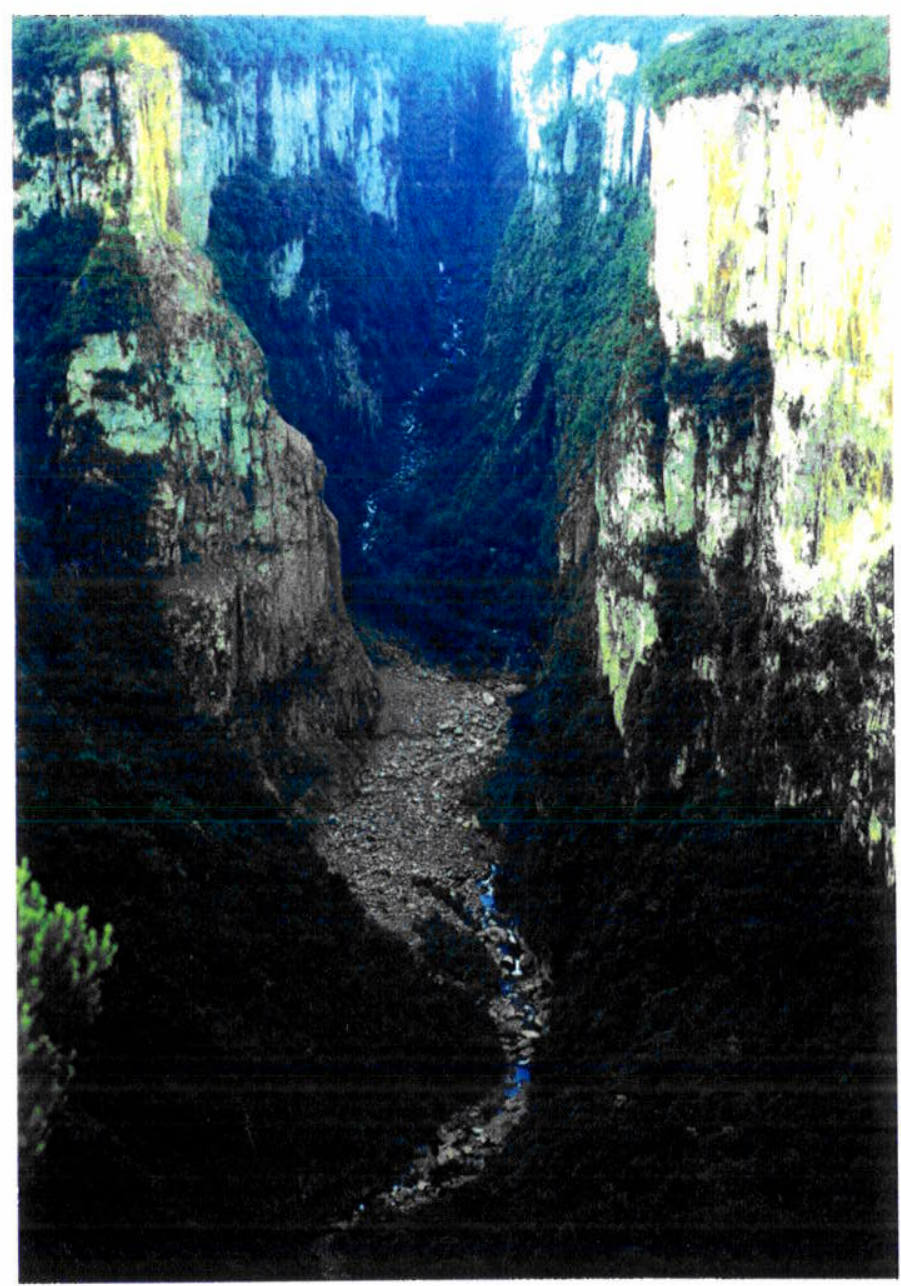

Foto 1 - Escarpas do Itaimbézinho. Declive praticamente de $90^{\circ}$. Evidências de desmoronamentos no alto da escarpa, à esquerda. Fragmentos de variados tamanhos no fundo, onde corre o Rio Pavão, no trecho acima do ápice do seu leque aluvial. A borda da escarpa marca o limite entre os estados de Santa Catarina e Rio Grande do Sul.

O amplo anfiteatro sul apresenta, no seu domínio, uma série de elevações isoladas, com altitudes de até 250 m, como o Morro dos Leffas, o Morro da Pedra e outros mais baixos, no Rio Grande do Sul. Em Santa Catarina, neste Setor Sul, as formas isoladas com mais de $200 \mathrm{~m}$ de altitude estão junto à escarpa e foram geradas sobre arenitos da Formação Botucatu, possuindo alta declividade. A maioria das elevações isoladas possuem altitude até quase $80 \mathrm{~m}$, como é o caso das modeladas sobre rochas do Grupo Passa Dois e soleiras de diabásio. 
A morfologia resultante da disposição dos vales e seus cursos de água, na área dominada pela escarpa, evidencia claramente o controle estrutural para o seu estabelecimento (Figuras 13 e 16, no encarte).

Uma série deles tem direção NW-SE como o Arroio Josafaz, um dos tributários do alto curso do Rio Mampituba, que também constitui o limite entre Santa Catarina e Rio Grande do Sul; o Faxinalzinho; o médio curso do Rio Pavão; os rios Molha Coco, Malacara ou Macaco, Fortaleza ou Três Irmãos, Cachoeira, Praia Seca e Leão. O Rio Mampituba e seu vale, no trecho a montante da cidade de Praia Grande e trecho do seu afluente Rio Pavão, não seguem esta direção e sim a de NE-SW (Figura 16, no encarte). Ao alcançar Praia Grande este rio se redireciona para NW-SE, mas em seguida o curso se bifurca. Seu maior volume continua dentro de um canal, na direção NE-SW, com o nome de Rio Canoas, até a área de um paleolago hoje transformado no Banhado do Sombrio (Figuras 6 e 16 no encarte). A outra parte de suas águas, no trecho entre as cidades de Praia Grande e Torres, nos $6 \mathrm{~km}$ a leste da primeira, se dispersam em vários canais estreitos que depois se reúnem em um canal reconhecido novamente como Rio Mampituba, com direção geral NW-SE.

A morfologia do embasamento coberto pelos sedimentos, neste Setor Sul, pode ser deduzida pelos afloramentos das distintas litologias ilhadas pelos depósitos, e pelas sondagens tanto para a barragem do Rio Mampituba (Figuras 17 a 22) como para aquelas dos rios Leão e Bonito. Além destes há as sondagens exploratórias para jazidas de carvão, já referidas, efetuadas no leste do setor, junto à BR-101 e também a leste da Lagoa do Sombrio.

Com estes dados, pode-se afirmar que o embasamento, à época da sedimentação dos depósitos ali instalados, apresentava uma superfície irregular. Os desniveis, hoje cobertos por sedimentos, até a área da Lagoa do Sombrio, chegavam acerca de $130 \mathrm{~m}$, entre as formas mais altas e as mais baixas. Por outro lado, vêem-se situações distintas no sopé da escarpa, pois enquanto o assoalho rochoso no vale do Mampituba, a montante da cidade de Praia Grande, na área dos eixos projetados para a barragem, varia de 70 a $100 \mathrm{~m}$ de altitude, e sobre ele ocorrem espessuras de 
sedimentos entre $20 \mathrm{~m}$ até pouco mais de $50 \mathrm{~m}$, mais para o norte, ainda no sopé da escarpa, vê-se rocha aflorando nos leitos dos rios Leão e Cachoeira, em altitudes de 20 e 32 m, respectivamente. Esta situação evidencia que as rochas antigas que embasam os sedimentos foram menos erodidas e estão cobertas por maior espessura de sedimentos cenozóicos na área do médio vale do Rio Mampituba, do que aquelas na situação ainda de sopé da escarpa, mais a norte, neste Setor. Salienta-se que a primeira situação está dentro do vale encaixado que se abre para NNE, ao passo que as outras já são de área de coalescência de leque, sem o constrangimento das paredes dos vales e voltadas para leste.

Entretanto, a superfície recoberta do embasamento inclina dominantemente para leste. As medidas de profundidade do mesmo, obtidas de perfis de sondagens próximas à rodovia BR-101, evidenciam que este assoalho situa-se a até $30 \mathrm{~m}$ abaixo do zero hidrográfico.

A área entre as localidades de São José, Vila Santa Catarina e Vila Forquilha, a oeste, e a Lagoa do Sombrio a leste, englobando o espaço entre Santa Rosa do Sul e São João do Sul, esteve em situação de plataforma rasa pelo menos durante um intervalo de tempo no Pleistoceno, com uma declividade de 21 ' $(0,4 \%$, se for aceita como constante e progressiva a inclinação do embasamento entre Cachoeira, onde ele aflora a $32 \mathrm{~m}$ de altitude e a situação do Arenito Botucatu no poço AT-03, na BR-101, em Três Coqueiros, situado a norte de Vila Conceição. No perfil desta perfuração este arenito está a $-24 \mathrm{~m}$ e no poço AT-10 está a $-18 \mathrm{~m}$.

Da Lagoa do Sombrio para leste, a situação é distinta, pois ali o embasamento constituído pelo Arenito Botucatu está a profundidades bem maiores. Os perfis dos poços AT-08, AT-12, AT-07 e uma perfuração para água na Fazenda do Dr. Pila, a leste da cidade de Sombrio registram a presença deste arenito em $-81,40 \mathrm{~m},-84 \mathrm{~m}$, $-105 \mathrm{~m},-115 \mathrm{~m}$ respectivamente, testemunhando a situação no lado leste daquela lagoa. A posição do embasamento entre os lados oeste e leste da Lagoa do Sombrio, portanto, estabelece uma diferença em torno de 60 a $90 \mathrm{~m}$. Esses poços do "Projeto 


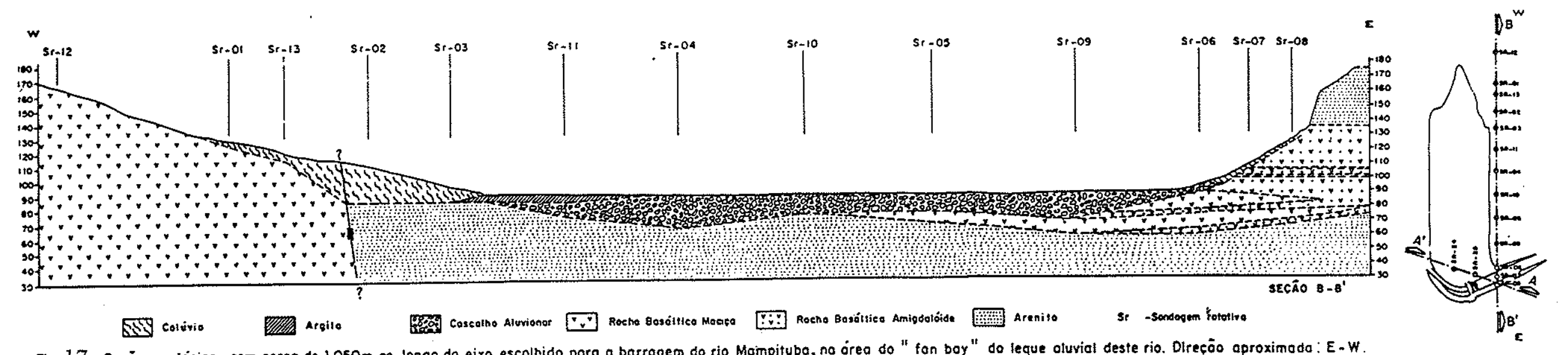

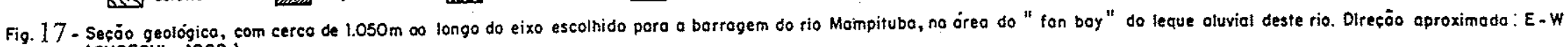
(SUDESUL, 1982). 


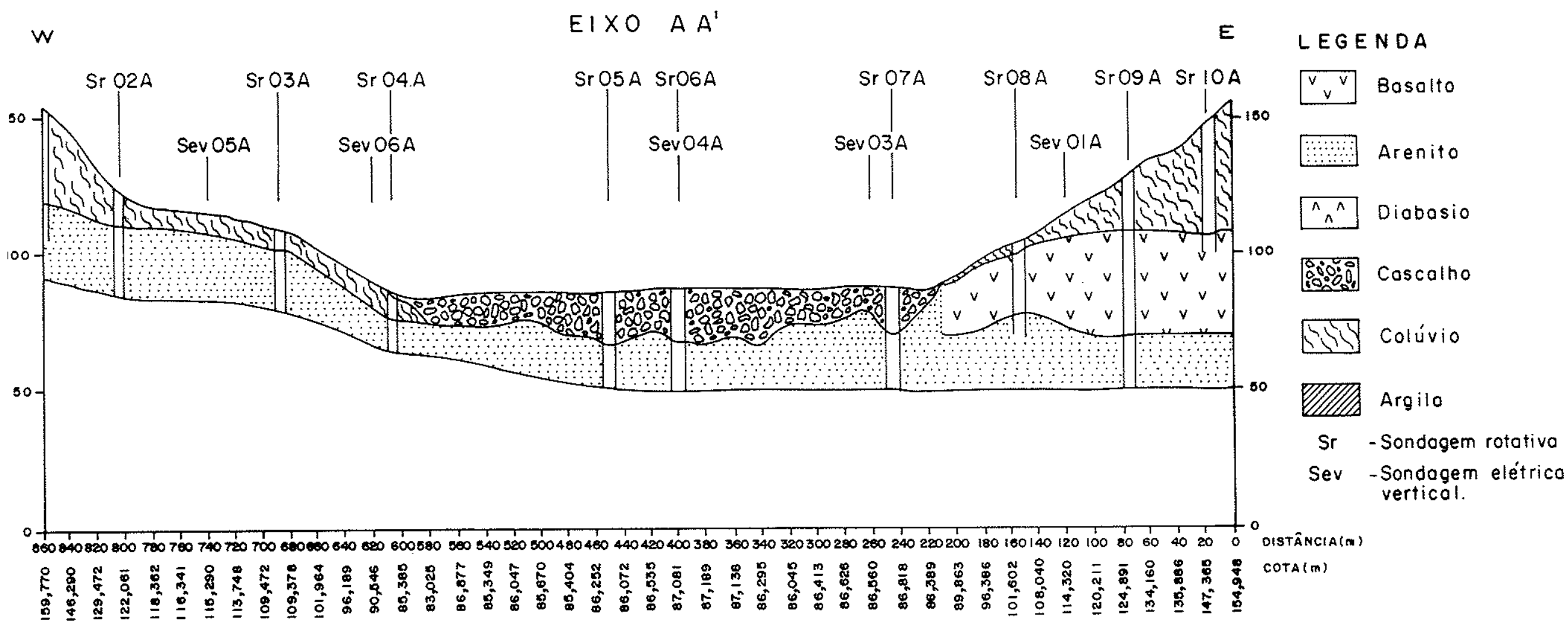

Fig.18 - Seção geológica no eixo A do projeto da barragem do rio Mampituba, vale médio, área do "fan bay" do seu leque, a montante do seu tributário rio Povão ou rio do Boi. (Vide seção geológica do paralela central). (SUDESUL, 1982). 
EIXO B B

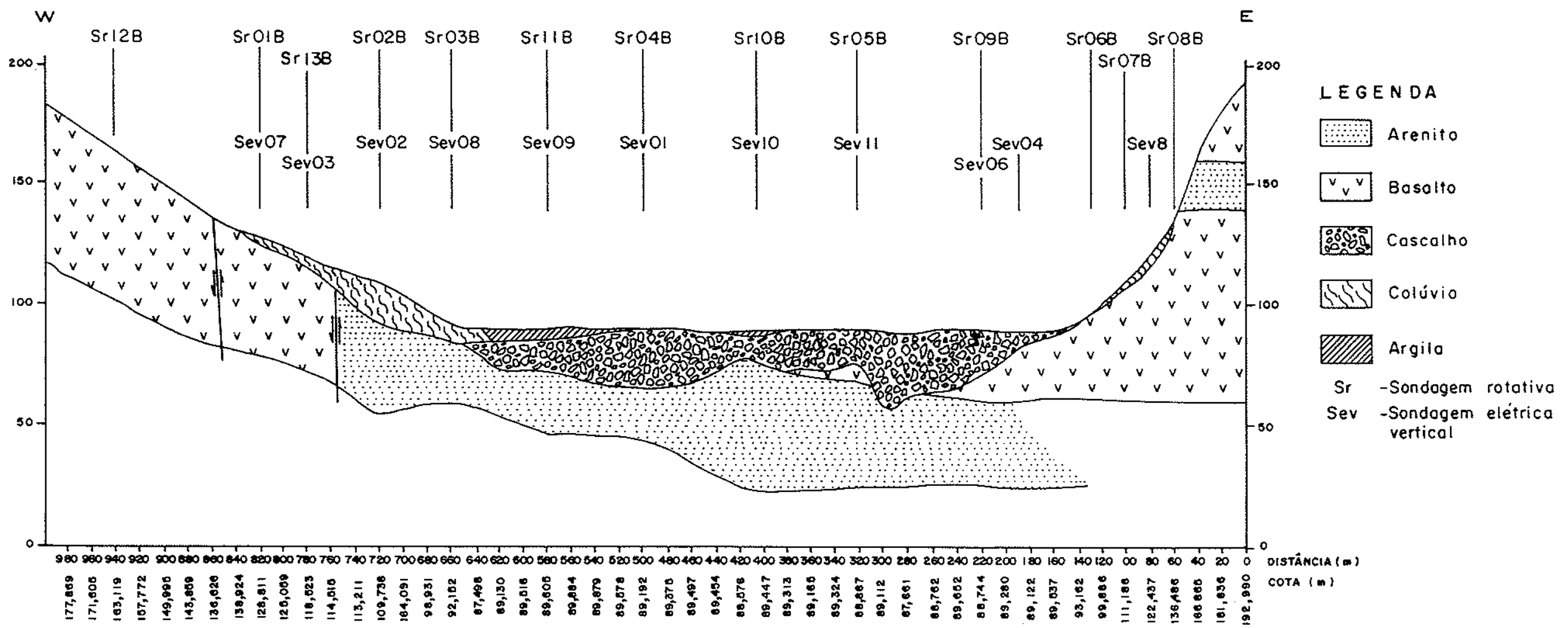

Fig. 19 - Seção geológica ao longo do eixo B, do projeto do borrogem do rio Mampiłuba a montante do eixo $A$. (Vide seção geológica da paralela central). Notam-se falhas à esquerda do vale e a variação da espessura dos depósitos rudáceos. (Levantamento SUDESUL, 1982) 


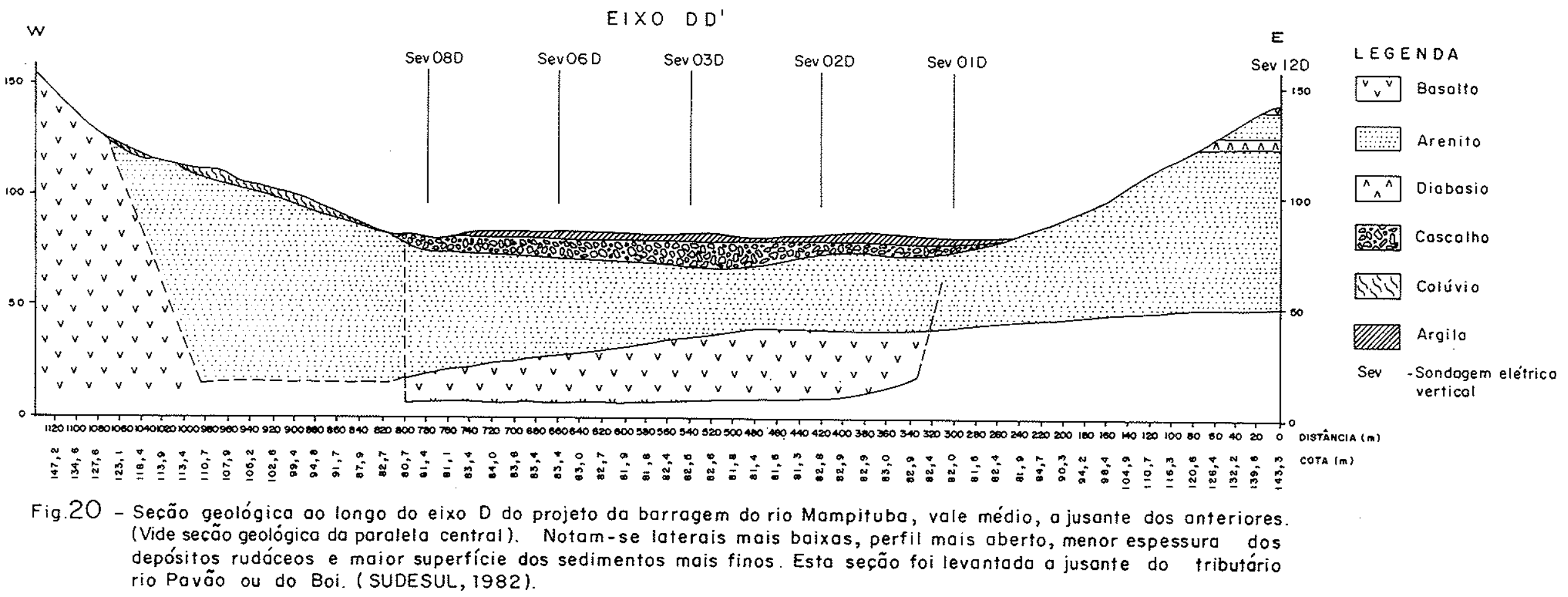




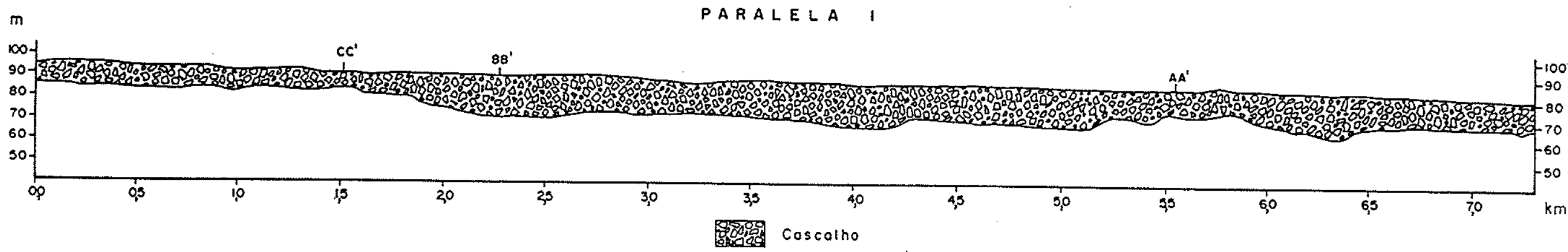

Fig. 21 - Seção geológica longitudinal do médio vale do rio Mompituba, margem esquerda, perpendicular aos diversos eixos possíveis, da barragem do mesmo rio, mos trando menor irregularidade do embosamento que na "paralela central "e evidenciando as diferentes espessuros dos depósitos rudáceos. (SUDESUL, 1982).

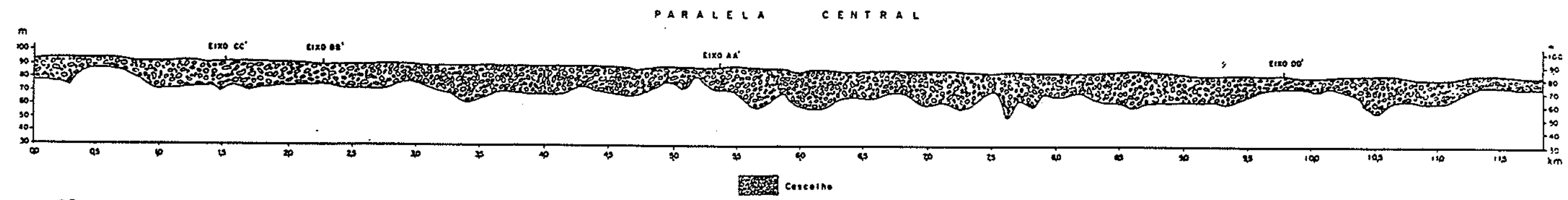

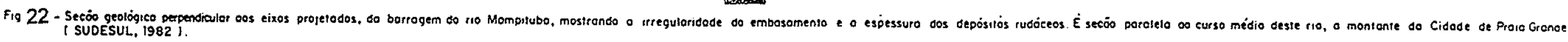


Carvão em Araranguá-Torres" do convênio CPRM-DNPM evidenciam pequenas escarpas ou degraus gerados pela tectônica referida por vários autores já mencionados e que está registrada na Figura 7.

Os perfis de grande número de sondagens concentradas na parte oriental, mais no Setor Norte do que no Setor Sul, registram o substrato dos sedimentos.

Embora não se tenham sondagens para a área inteira, há ainda algumas relacionadas à construção das barragens dos rios Mampituba, Leão e Bonito no Setor Sul.

Os testemunhos daquelas sondagens existentes junto à rodovia BR-101 e a leste da Lagoa do Sombrio, evidenciam que no Setor Sul o embasamento é representado pelos arenitos da Formação Botucatu e subordinadamente pelos basaltos (Figura 7). Situação semelhante foi encontrada onde está projetada a barragem do Rio Mampituba, a montante da cidade de Praia Grande (Figuras 17 a 19).

\subsection{ESPORÃO-DIVISOR}

Separando os dois setores, isto é, as áreas e as águas da bacia do Rio Mampituba e da bacia do Rio Itoupava-Araranguá, há um esporão aproximadamente entre os paralelos $29^{\circ} 02^{\prime}$ e $29^{\circ} 04^{\prime}$ de Latitude Sul, que se prolonga até junto à cidade de Sombrio ( $29^{\circ} 07^{\prime}$ LS e $49^{\circ} 38^{\prime}$ LW ) (Figura 11).

Exposiçőes de rochas sedimentares e ígneas da Bacia do Paraná nele ocorrem, pois trata-se de um expressivo testemunho da posição anterior da seqüência de rochas dessa bacia, hoje erodida.

Bons afloramentos dos arenitos da Formação Botucatu são encontrados especialmente nas elevações do extremo leste deste divisor, em torno da pequena bacia do Córrego da Peroba, afluente do Rio da Laje.

Neste esporão-divisor também são importantes os afloramentos de rochas ígneas básicas, tanto extrusivas ocorrendo em alguns topos de elevações, como intrusivas, sob forma de diques e soleiras de diabásio que se diferenciam uns dos 
outros pela suas variadas espessuras, cotas altimétricas, topografias, orientações, texturas e outros aspectos litológicos. Os diques mais espessos observados na área situam-se neste divisor; o maior apresenta algumas dezenas de metros de espessura. LEINZ (1949) cita a ocorrência de dique de $80 \mathrm{~m}$ de espessura no antigo Município de Araranguá. A orientação desses diques é sobretudo NE-SW. A maior soleira e o maior dique deste divisor estão sendo minerados.

Esses corpos tabulares são provavelmente os responsáveis pela manutenção deste divisor de águas, e a intrusão dos mesmos deve estar associada a uma tectônica que torna esta forma um referencial para as diferenças tanto das exposições das rochas do Grupo Passa Dois nos dois setores, como para a morfologia da escarpa da "Serra" e da configuração das duas bacias fluviais, a do Rio Mampituba e a do Rio Araranguá.

Rochas do Grupo Passa Dois ocorrem no sopé deste divisor, no lado sul, em um trecho mais a leste. Nota-se que ali há paredões íngremes e nus, quase verticais, de Arenito Botucatu, tendo na sua base formas de pequena altura, de declividade muito baixa e de curta extensão. Estas estão quase no nível dos banhados, dissecadas por ravinamentos de fundo plano, por onde é mais intensa a drenagem. Estes ravinamentos estão atapetados com vegetação de gramíneas ou mesmo vegetação arbustiva e arbórea. O comportamento da vegetação desenvolvida em área úmida é evidência desta drenagem, embora sem fluxo subaéreo permanente de água e distinta da que se desenvolve sobre o Arenito Botucatu ou depósitos dele provenientes. Tanto a morfologia como a textura das fotos atestam a presença das rochas do Grupo Passa Dois. Por outro lado, em Forquitha do Cedro, a nordeste de Santa Rosa do Sul, o poço AT-05 (CPRM-DNPM) alcançou rochas da Formação Rio do Rasto, com uma cobertura cenozóica de $27 \mathrm{~m}$ de sedimentos.

O esporão-divisor é bastante rebaixado em relação à borda do planalto, pois, em apenas alguns locais na parte oeste, apresenta altitudes de quase $550 \mathrm{~m}$, estando a sua maior área abaixo de $300 \mathrm{~m}$, enquanto as altitudes da "Serra" têm naquele paralelo mais de $1.100 \mathrm{~m}$, portanto, desnível mínimo de $550 \mathrm{~m}$. 
O seu lado sul apresenta encostas bastante íngremes, uma vez que em curto espaço as altitudes decrescem de $200 \mathrm{~m}$ para $10 \mathrm{~m}$ a $15 \mathrm{~m}$. As declividades medidas entre $20 \mathrm{~m}$ e $280 \mathrm{~m}$ podem ser apenas de $11^{\circ}(19 \%)$, entretanto, aquelas entre $40 \mathrm{~m}$ e topos de $200 \mathrm{~m}$ são de $23^{\circ}$ a $34^{\circ}$ (38\% a 58\%). As medidas em cotas mais altas, por exemplo, entre $200 \mathrm{~m}$ e $300 \mathrm{~m}$, chegam a $37^{\circ}(67 \%)$.

Esta situação é bem distinta daquela do seu lado norte, com dissecação mais pronunciada e declividades menores. Assim, as medições entre cotas de $20 \mathrm{~m}$ a 140 $m$, dão declividades em torno de $6^{\circ}(10 \%)$. Os fundos de vale, entretanto, estão na sua maior parte acima de $50 \mathrm{~m}$ de altitude e as declividades entre cotas acima de $60 \mathrm{~m}$ são de $13^{\circ}$ a $22^{\circ}(21 \%$ a $36 \%)$.

A única explicação para as declividades mais altas, aliadas a vales estreitos e mais curtos no flanco sul, é a presença de rochas básicas. Portanto, a morfologia das duas laterais deste divisor é distinta. No flanco norte ela se expressa em grande extensão sobre rochas sedimentares, entre as quais são freqüentes os arenitos da Formação Botucatu, porém, de Jacinto Machado para leste, os afloramentos de rochas do Grupo Passa Dois são os mais freqüentes. Grande extensão do Arenito Botucatu está exposta sob morfologia escarpada ou ruiniforme como a sudeste de Jacinto Machado, na localidade de Cotovelo. Esta litologia também possibilitou o alargamento de pequenos vales no flanco Norte, como aquele do Rio Dois Irmãos, a sudoeste da cidade de Jacinto Machado.

A frente leste deste divisor tem morfologia semelhante ao flanco norte do mesmo, uma vez que é dominada pelas rochas sedimentares. Entre estas o Arenito Botucatu é que se apresenta mais contínuo, mais espesso e mais íngreme, apresentando declividades em torno de $20^{\circ}(32 \%)$, valor este a partir de folhas topográficas 1:50.000, havendo na realidade paredões quase verticais.

No extremo leste do esporão-interflúvio e a sul-sudoeste da cidade de Sombrio, bem próximas desta, ocorrem as grandes grutas no Arenito Botucatu, já referidas. A elevação constituída com este arenito tem cerca de $60 \mathrm{~m}$ de altitude. As grutas estão no nivel da BR-101 e junto à Lagoa do Sombrio. A diferença entre a base das grutas e 
o nível da água da lagoa é de $4,70 \mathrm{~m}$, estando esta base a 5,50 $\mathrm{m}$ acima do zero hidrográfico.

\subsection{TECTÔNICA}

A tectônica que atingiu rochas da Bacia do Paraná, na área, foi discutida por LEINZ (1949), PUTZER $(1953,1955)$ e nos trabalhos visando a prospecção do carvão, executados para o DNPM e CPRM, por FABRÍClO et al. (1979, 1981a,b), SÜFFERT (1976), SÜFFERT et al. (1977, 1981), entre outros.

O trabalho de LEINZ (1949) está centrado em dados obtidos na área sul de Santa Catarina e norte do Rio Grande do Sul. O autor analisa as questões dos derrames, suas rochas e toda a atividade vulcânica, relacionando-as com problemas de tectônica regional.

Através das medidas de espessuras dos derrames, nivelamentos de precisão, a posição das "camadas" horizontais de ágata, e um estudo das texturas fluidais, paralelamente a outras considerações, LEINZ(1949) deduz que ali houve uma zona de intensa produção magmática, e que as corridas de lavas se afastaram a partir da linha tectônica Torres-Posadas, derramando-se sobre uma superfície praticamente horizontal que não teria sido muito modificada com os movimentos posteriores (Figura 23).

Este autor admite que os diques de diabásio cortando rochas sedimentares, estejam relacionados aos derrames, porém coloca em dúvida esta relação no que se refere aos diques "instalados" no Pré-Cambriano. Esta dúvida vem de situações encontradas no Estado de São Paulo, sugerindo que "o cristalino foi afetado por diques de diabásio-gabro, em épocas anteriores". Na área, entretanto, não se tem evidências, pelos mapeamentos até hoje realizados, de rochas aflorantes do Pré-Cambriano. Por outro lado, há afloramento de rocha gabróica no Setor Sul, junto ao sopé da escarpa que talvez tenha relação com a existência do esporão-interflúvio que separa os dois 
setores. Portanto, se houver esta relação, esta intrusão tem papel significativo se não no registro da tectônica antiga, pelo menos na morfologia da área.

Analisando os arenitos da Formação Botucatu como o embasamento dos basaltos, LEINZ (1949) afirma que há falhamento escalonado que posiciona estas litologias cada vez mais altas para o norte (Figura 24). Refere-se a dois tipos de movimentos, inferidos de situações observadas no Município de Araranguá (que em 1949 compreendia todos os municípios aqui estudados), registrando dois momentos da tectônica. Um tipo em que o Arenito Botucatu apresenta-se falhado e com ressalto, e com ambos os blocos cobertos com o basalto de um derrame, e outro tipo em que há o preenchimento da falha por dique de diabásio. No primeiro caso o movimento teria sido anterior ao derrame, seguido deste, e no segundo houve movimento concomitante ao derrame. Outro fato registrado são as zonas brechadas e milonitizadas nos derrames, evidenciando movimentos tectônicos posteriores à atividade magmática. Na sua Tabela $n^{\circ}$ 5, LEINZ (1949) apresenta treze falhas identificadas na área. Todas as falhas por ele observadas foram classificadas como normais.

Para este autor, os falhamentos formariam dois sistemas: um entre $\mathrm{N} 50^{\circ} \mathrm{W} \mathrm{e}$ $\mathrm{E}-\mathrm{W}$, considerado o mais importante para a região, e o outro sistema de $\mathrm{N} 10^{\circ}-40^{\circ} \mathrm{E}$. Ambos os sistemas atingem tanto os arenitos da Formação Botucatu quanto as efusivas. Falhamentos de direção geral N-S, segundo ele, seriam responsáveis por abatimento de blocos, com abaixamento do bloco oriental. Eles são comprovados no sul de Santa Catarina, nos estudos para carvão, na área das maiores lagoas e a leste das mesmas (Figuras 25 e 26).

Os afloramentos de rochas diversas e sua situação topográfica relativa também são evidências dessa tectônica. No Setor Sul, afloramentos de arenitos da Formação Botucatu, com 60 e $80 \mathrm{~m}$ de altitude, ocorrem a leste de outros afloramentos com cotas similares, de rochas do Grupo Passa Dois. Os últimos estão situados entre aqueles e a escarpa da Serra Geral. Ora, se as rochas da Bacia do Paraná inclinam para sul e oeste, com uma resultante sudoeste, os afloramentos de rochas do Grupo Passa Dois, em situação 


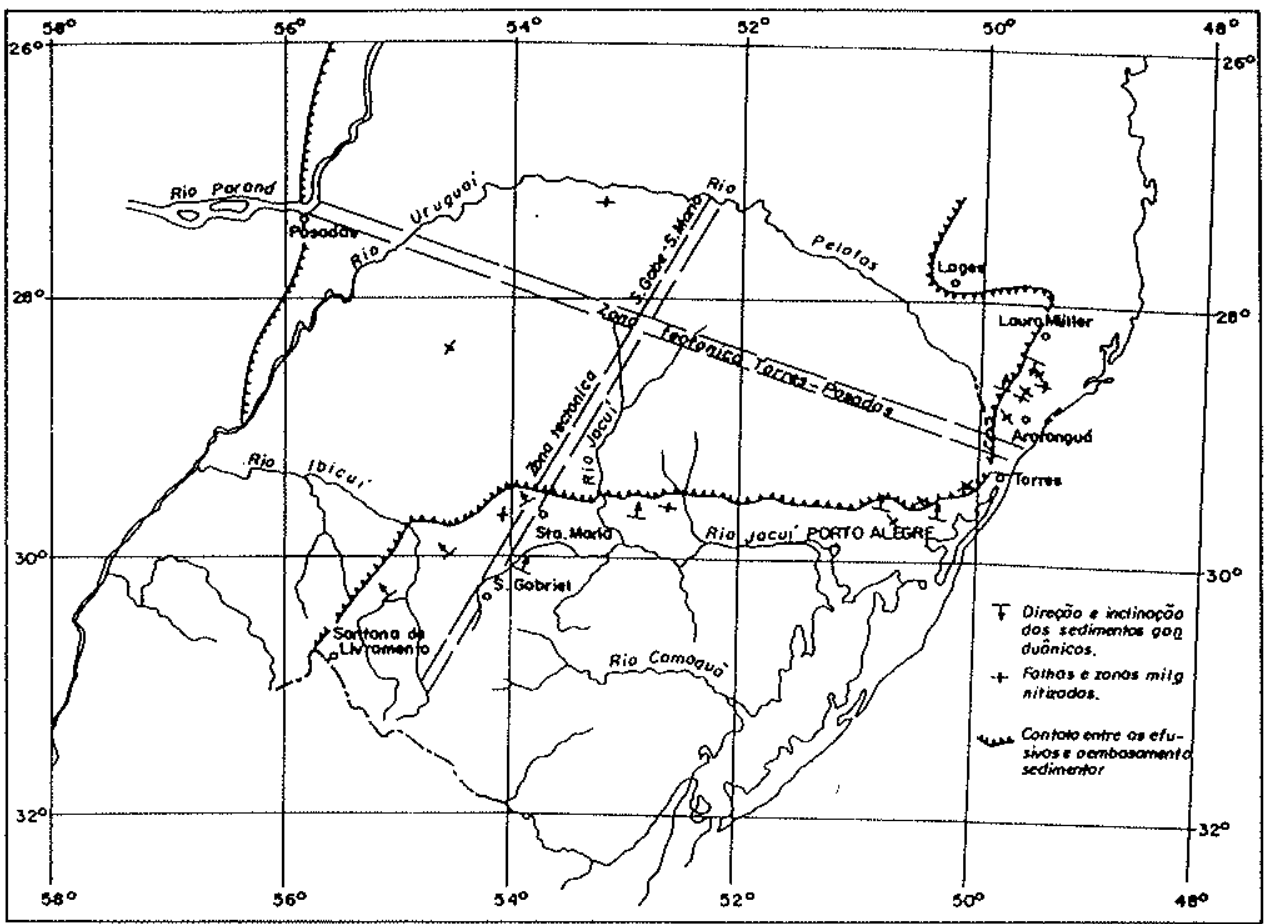

Fig. 23 - Mapa tectônico indicondo direçōes e inclinoçöes nos sedimentos gondwânicos, falhas e zonos de milonitizaçao ( Fig. 17 de Leinz, 1949)

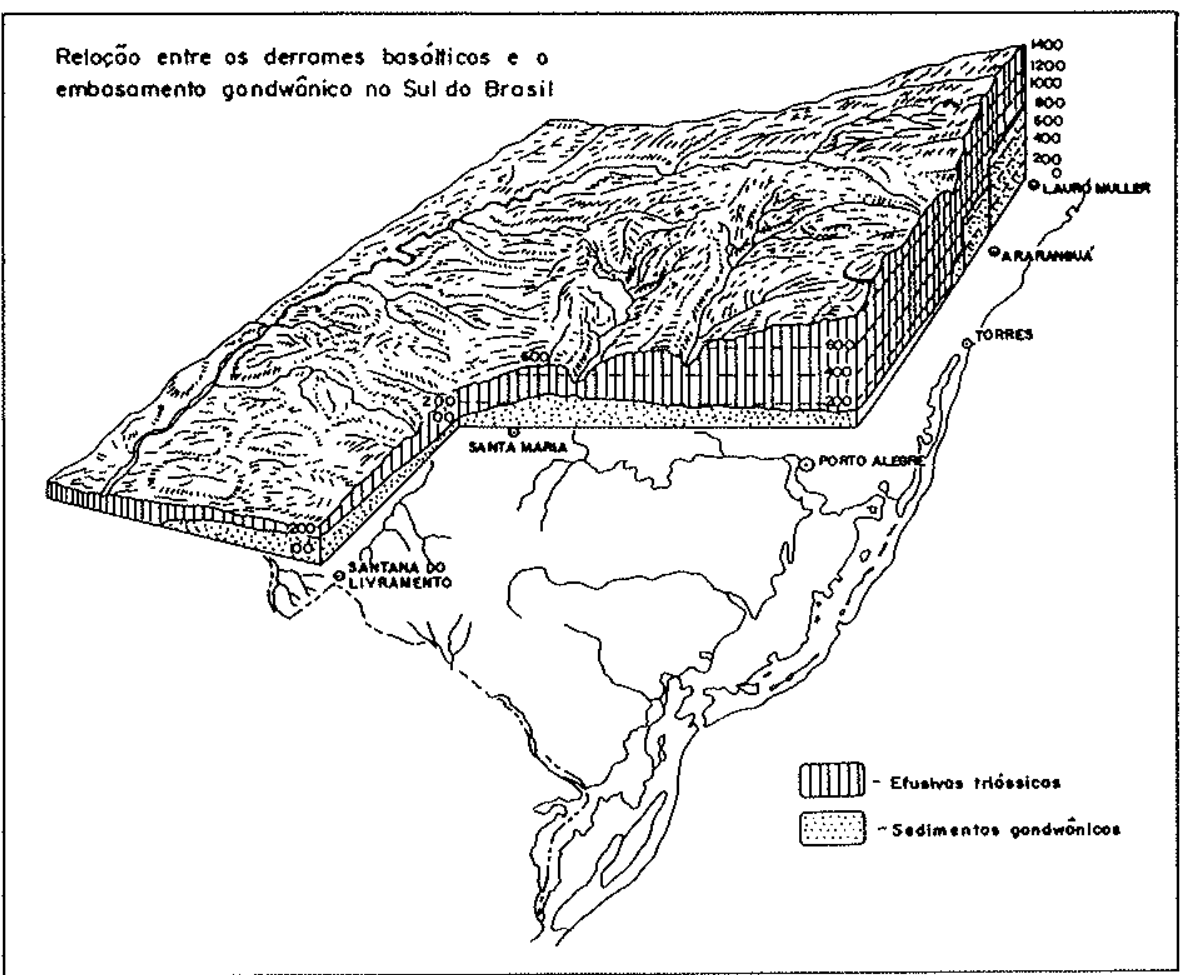

Fig. 24 - Bloco diagrama mostrando o óreo dos efusivas nos Estados do Rio Grande do Sul e Santa Cotarina, suas espessuras e a posiçáo do embosomento (Fig. 2 - Leinz, 1949). 


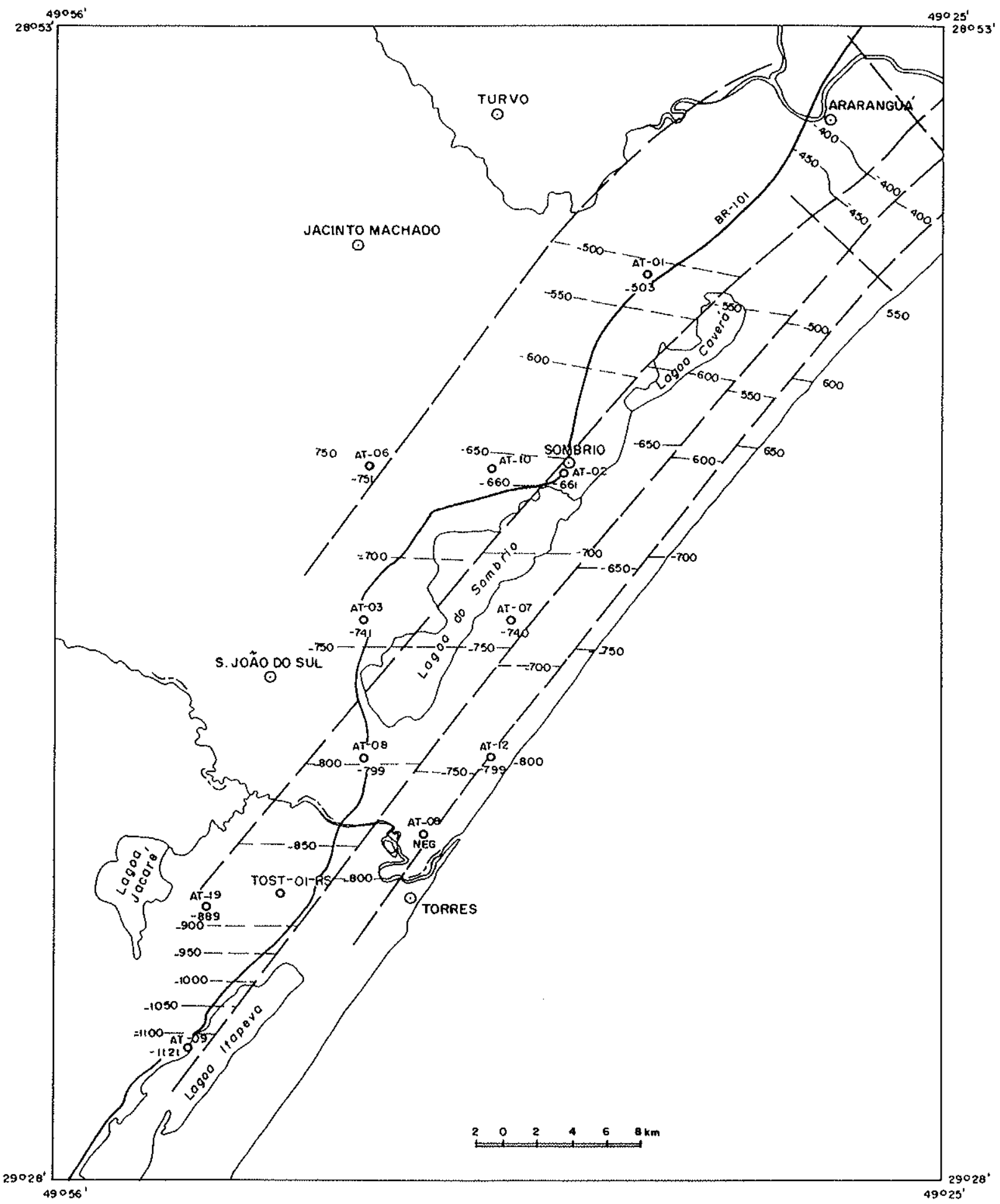

Fig.25 - Mapa de contorno estrutural da lapo da camada de carvão Bonito Inferior (Fabricio, et ol. 1981) 


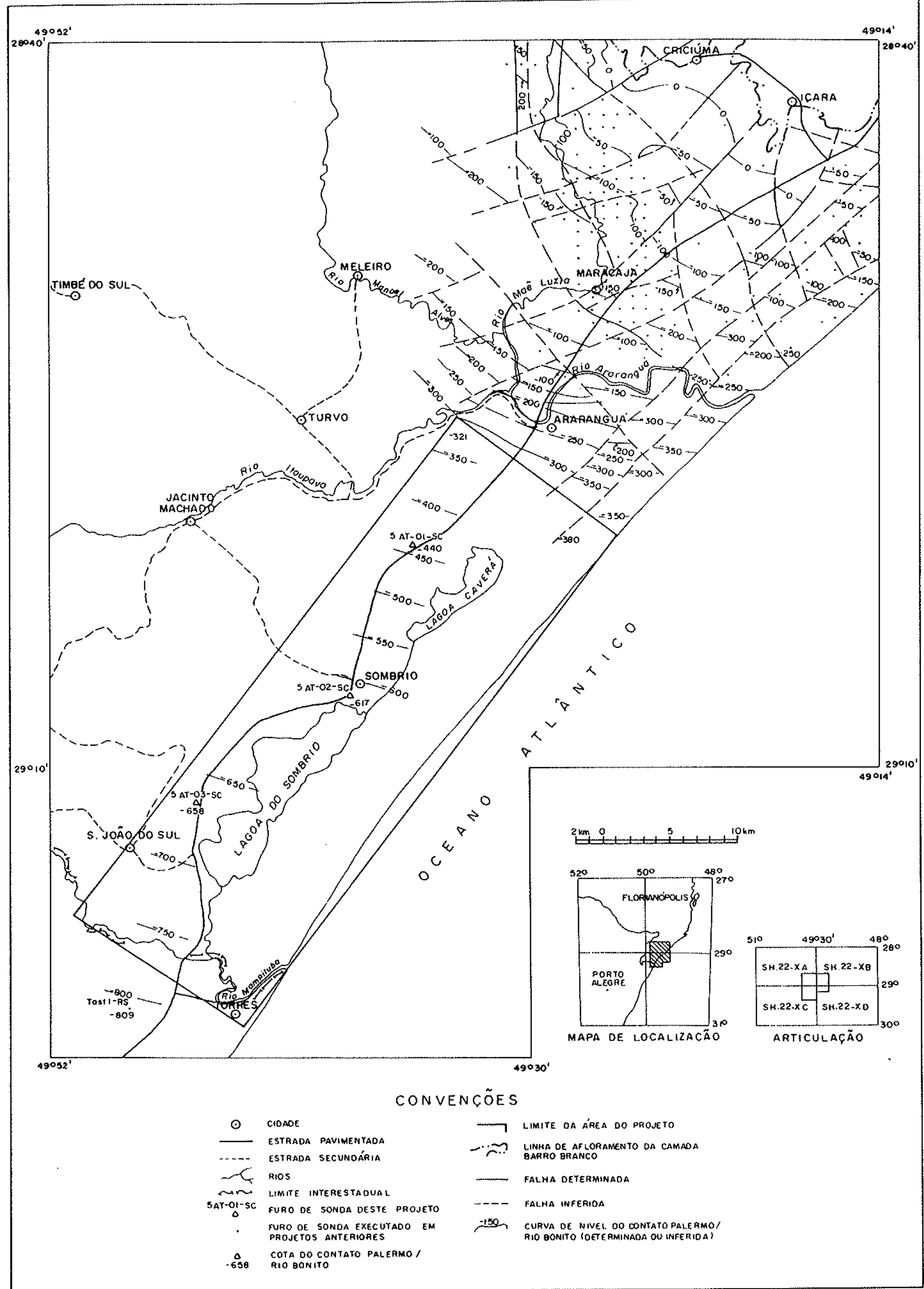

Fig. 26 - MAPA DE CONTORNO ESTRUTURAL DO CONTATO ENTRE AS FORMACÕES PALERMO E RIO BONITO (Siffert, 1976) 
topográfica igual ou mais alta, não poderiam situar-se a oeste de afloramentos do Arenito Botucatu que estratigraficamente lhes está sobreposto, a não ser por tectônica. Os afloramentos de Arenito Botucatu ocorrem em Timbopeba, Vila Santa Catarina e duas elevações a leste do Rio Sertão e próximos à Vila Nova de Fátima, na altura do paralelo $29^{\circ} 11^{\prime}$. A oeste destes, o afloramento mais alto de rochas da Formação Rio do Rasto, cujo topo está há pouco mais de $80 \mathrm{~m}$ de altitude, situa-se junto ao Rio Malacara ou Macaco, a nordeste de Praia Grande. O Arenito Botucatu volta a aflorar tanto a nordeste desta última elevação e nas mesmas condições altimétricas, no Morro da Cachoeira, como a oeste, na parte inferior da escarpa, em altitudes de $80 \mathrm{~m}$.

Junto à cidade de Sombrio, no seu quadrante sul, há afloramentos de Arenito Botucatu desde o nível da Lagoa do Sombrio, isto é, 0,80 m até pelo menos $100 \mathrm{~m}$ de altitude. Entretanto, em Guarita, $6 \mathrm{~km}$ a norte da cidade de Sombrio, há afloramentos de rochas da Formação Rio do Rasto, entre $20 \mathrm{~m}$ e $80 \mathrm{~m}$ de altitude. Portanto, os arenitos da Formação Botucatu, no mesmo nível da lagoa, estão quase $20 \mathrm{~m}$ mais baixos que a base do afloramento das rochas da Formação Rio do Rasto. Caso não seja este fato explicado por tectônica, a inclinação das rochas para o sul é no mínimo de $2^{\circ} 30^{\prime}$, sendo bem maior que a média atribuída aos mergulhos regionais, que é de 30'. Não está sendo considerada a erosão que atingiu as elevações do Grupo Passa Dois, nem a espessura que possa ter o Arenito Botucatu abaixo do nível referido. Dessa maneira está se usando apenas uma evidência topográfica, sem levar-se em conta os contatos, o que aumentaria este valor de inclinação.

PUTZER (1953) apresenta, para o sul de Santa Catarina, as "direções catarinenses" $\mathrm{N} 50^{\circ}-70^{\circ}$ e suas normais $\mathrm{N} 140^{\circ}-170^{\circ}$, e as "direções rio-grandenses" $\mathrm{N} 0^{\circ}-30^{\circ}$ e suas normais $\mathrm{N} 90^{\circ}-120^{\circ}$. O maior número de dados apresentados por este autor vem de áreas contíguas a esta estudada. Na área em questão ele fez sete estações de medidas de direções e delineou falhas. Considerou o tectonismo anterior aos derrames, mas posterior ao Arenito Botucatu, porém com os movimentos continuando menos intensamente, até o fim do vulcanismo. 
Entre as três principais falhas marcadas no seu mapa geral e explicitadas no texto, está a denominada "Falha Pedramararanguá", dentro da "direção catarinense", que é descrita como uma grande falha de rumo geral $N 70^{\circ}$, "que se inicia como um graben no topo da Serra Geral", passando por Araranguá até ao mar, perto da barra do Rio Urussanga. No mapa de seu trabalho de 1955 esta falha passa a ser desenhada como falha inferida. PUTZER (1953) descreve que o falhamento é detectado pela situação dos afloramentos da Formação Botucatu e arenitos e siltitos da Formação Rio do Rasto.

Neste último trabalho ele se refere também a pequenas falhas com direção geral N-S, em Torres, que, segundo os dados das sondagens Torres $I I$ e Torres III, realizadas em 1952, evidenciariam a "direção riograndense", com rejeitos de 120 a $150 \mathrm{~m}$ tendo o bloco oriental rebaixado.

Ele comenta a linha tectônica Torres-Posadas, de LEINZ (1949), dizendo que ela não é visível no campo a norte de Torres. Por outro lado afirma que "o curso do Rio Mampituba como também a grande planície costeira de Passo do Sertão-Glória-Praia Grande (...) permitem aceitar aí uma zona tectônica". Esta "zona" citada por PUTZER (1953) corresponde a um direcionamento NW-SE ao longo do baixo curso do Rio Mampituba.Passo do Sertão é hoje Passo de Torres.

Falhas inferidas por FABRíClO et al. (1981c), próximas e paralelas à costa, com direção NE-SW, apoiam-se em evidências de poços a norte, onde a malha das sondagens é mais densa, e nas atitudes das juntas que também evidenciam um conjunto normal à direção acima (Figuras 25 e 26). Os estratos, entretanto, dispõem-se como homoclinal, mergulhando para S-SW, como já registrava LEINZ (1949), e foram medidos ângulos pouco inferiores a 30'. Acrescentam estes autores que dados de sísmica, por sua vez, localizam o eixo da Sinclinal de Torres na altura do Balneário de Arroio do Sal, isto é, cerca de $28 \mathrm{~km}$ a sul de Torres.

O que se observa na área costeira de Santa Catarina, de sul para norte, é que as formas elaboradas inicialmente sobre rochas da Bacia do Paraná e depois, mais para norte, sobre as rochas do embasamento cristalino, do Pré-Cambriano, tornam-se 
cada vez mais elevadas e com exposições mais extensas. Há, portanto, neste mesmo sentido, uma descida na estratigrafia. Inicia-se com basaltos na altura de Torres e já na latitude de $28^{\circ} 40^{\prime}$, na altura de Morro da Fumaça, afloram rochas do Pré-Cambriano. A exposição destas tem seu limite oeste quase como uma linha $\mathrm{N}-\mathrm{S}$, no seu contato com as rochas sedimentares da Bacia do Paraná. Entretanto, a exposição das rochas do Pré-Cambriano se amplia para o norte, porque o limite oriental de Santa Catarina situa-se cada vez mais a leste, isto é, a partir do sul a linha de costa inflete para nordeste.

Salienta-se que algumas destas características correspondem à área ao norte da aqui estudada, porém nesta têm seus reflexos, uma vez que parte da drenagem analisada tem suas nascentes fora do limite dos $28^{\circ} 45^{\prime}$ de Latitude Sul. Alguns desses detalhes servem para explicar questões referentes à tectônica e à morfologia da área, pois, além dos esforços localizados, sabe-se que a parte mediana da faixa leste de Santa Catarina esteve sob um esforço maior que o restante, e que os efeitos declinaram para o sul. Como resultado, sobe-se estratigraficamente nesse sentido e se desce altimetricamente, chegando-se então à maior planície costeira do Estado. Diferentemente das demais situadas a norte, ela está embasada apenas por rochas da Bacia do Paraná.

Por outro lado, a área submersa no Oceano Atlântico, defronte aos setores Norte e Sul, constitui-se em um trecho significativo da Bacia de Pelotas por sua extensão e por conter um depocentro da mesma. CHANG et al. (1988), entre outros, consideram que esta bacia ocupa a planície costeira, a plataforma continental e o talude continental. Assim, a área estudada pertenceria à Bacia de Pelotas. $O$ comportamento tectônico da faixa mais próxima à atual linha de costa, referido por LEINZ (1949), PUTZER (1953) e FABRÍClO et al. (1981c), está coerente com aquele referido por GONÇALVES et al. $(1978,1979)$, na área submersa.

Os trabalhos da PETROBRÁS, na área desta bacia, registram também as evidências da tectônica através das linhas de charneira, da zona de ruptura, das 
seqüências deposicionais falhadas em blocos, e processos de subsidência (Figura 27). Estas estruturas têm, portanto, paralelismo com aquelas da Figura 25.

Segundo GONÇALVES et al. $(1978,1979)$, o registro mais antigo da tectônica na Bacia de Pelotas corresponde a falhas do embasamento subparalelas à costa, provavelmente resultantes de basculamentos da margem continental e não do processo de rifteamento. A cada episódio mais novo de basculamento, a zona de ruptura posicionava-se mais para oeste. Como os episódios se repetiram, o mais antigo detectado é de idade pré-albiana, e o mais recente é do Terciário. Como este autor refere-se às evidências da bacia submersa, fica aberta a discussão sobre a idade destes falhamentos na parte emersa da bacia.

\subsection{AS REDES HIDROGRÁFICAS}

As redes hidrográficas têm sido, freqüentemente, analisadas estaticamente $e$, assim, têm sido criados padrões. Além de não se explicar os principais aspectos de uma bacia de drenagem, seu funcionamento, formas, origem e evolução, esse tipo de estudo não mostra a dinâmica dentro da bacia, além do que um padrão não pode, comumente, ser aplicado a uma bacia inteira ou mesmo a uma sub-bacia.

A literatura nos campos da geomorfologia, da hidrologia e mesmo da geologia tem se preocupado com a geometria hidráulica, numa relação entre forma de canais e processos, e com padrões de canais. Estudos que se fixam apenas nos canais permitem apenas resultados parciais e não explanatórios. Muitas vezes quando se fazem referências a padrões de canais, é como se um único tipo ocorresse desde a nascente até a foz. Entretanto, desde a geomorfologia clássica de DAVIS (1899), há referência a três situações que no seu conceito ocorriam ao longo de um canal, e não apenas um padrão.

Entretanto, uma série de fatores numa relação complexa e dinâmica, específica para cada bacia, é que explicaria as formas de canais e suas redes. Estes fatores incluem estrutura geológica, tipo e distribuição de rochas e sedimentos, grau de permeabilidade, características altimétricas e de morfologia da área, intensidade da pluviosidade. 


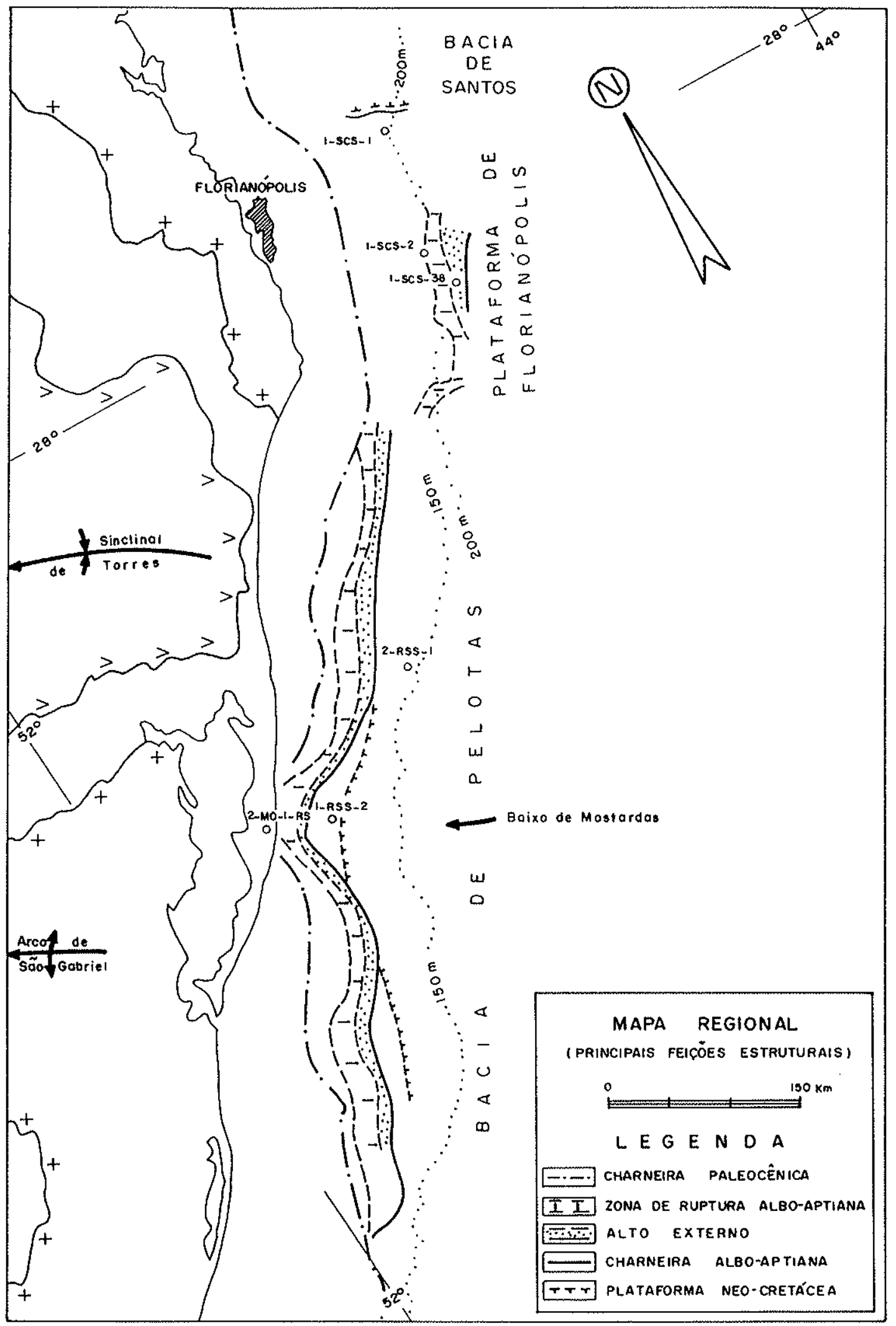

Fig. 27 -Mapa regional com as principais feições estruturais. (Figura 1 de Goncalves et al., 1979, modificado), da Bacia de Pelotas. 
Dessa maneira pode se afirmar para a área estudada que o relevo íngreme e muito alto, voltado para o mar, além de gerar chuvas orográficas e, portanto, aumento da pluviosidade na região, gera também um comportamento hidráulico na escarpa, muito diferente do que ocorreria se a área fosse plana ou sem aqueles desniveis da Serra Geral. Por outro lado, as condições altimétricas e de permeabilidade dos depósitos rudáceos e dos arenitos da Formação Botucatu, no sopé da escarpa, geram condições hidrodinâmicas diferentes de outras bacias como, por exemplo, da Bacia do Rio Tubarão ao norte.

Deve ser ressaltado que as condições hidrodinâmicas são diferentes não apenas entre a escarpa e seu sopé, mas também entre este e o mar, inclusive porque boa parte das duas bacias não é produto apenas da ação fluvial, uma vez que a área compreende depósitos praiais, lacustres e lagunares.

Sobre as condições distintas em vários trechos das bacias, há que se lembrar que na escarpa, nas várias sub-bacias, muitos canais tributários com alta declividade migram sobre rocha e se reúnem num único canal (Fotos 2 e 3). Este, ao chegar no sopé da escarpa, se abre em muitos distributários que são "permanentes", até que haja uma condição de caudal máximo ou suficientemente grande para mudar sua disposição ou traçado. Entre o sopé da escarpa e o oceano, outras situações se originam: a distância entre ambos, a declividade da planície, o controle efetuado pelo nível marinho, os diferentes depósitos (vide capítulo 5) e suas permeabilidades próprias vão contribuir para gerar condições distintas de drenagem e também hidráulicas que afetarão os canais, desenvolvendo-se maior ou menor sinuosidade em diferentes trechos. Mas a sinuosidade pode também ser explicada pela resistência maior das margens, seja por litificação de sedimentos, seja por afloramento de rochas do embasamento. É o que se verifica ao longo do Rio ltoupava onde a angulosidade da sua sinuosidade é, na maioria das vezes, devida ao impedimento do fluxo por depósitos rudáceos litificados que obrigam a mudança de direção do curso das águas.

As duas bacias da área estudada, embora tenham muitas características semelhantes, são distintas em superfície, tamanho das sub-bacias, distribuição dos 


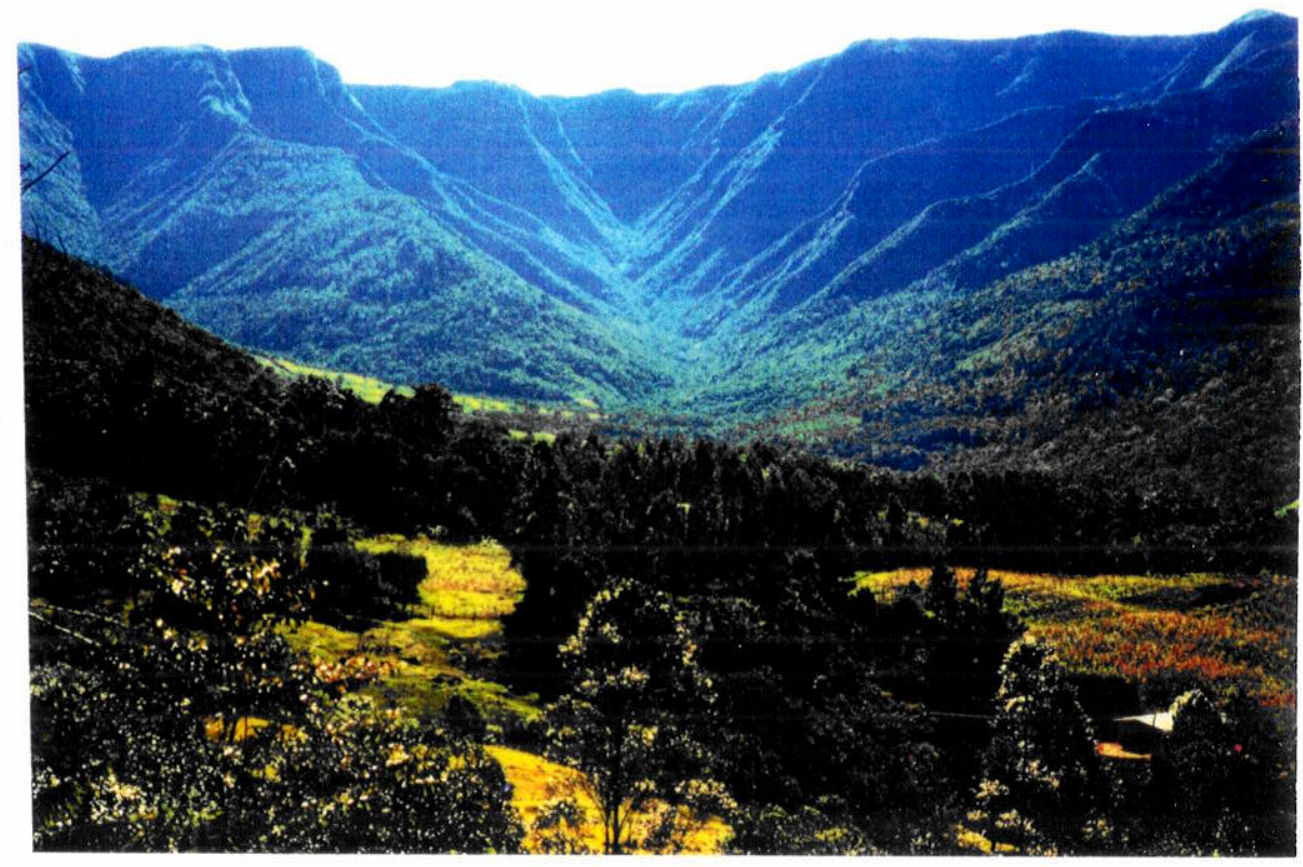

Foto 2 - Nascentes do Rio Serra Velha II, afluente do Rio Rocinha, na escarpa da Serra Geral, em Timbé do Sul, Setor Norte.

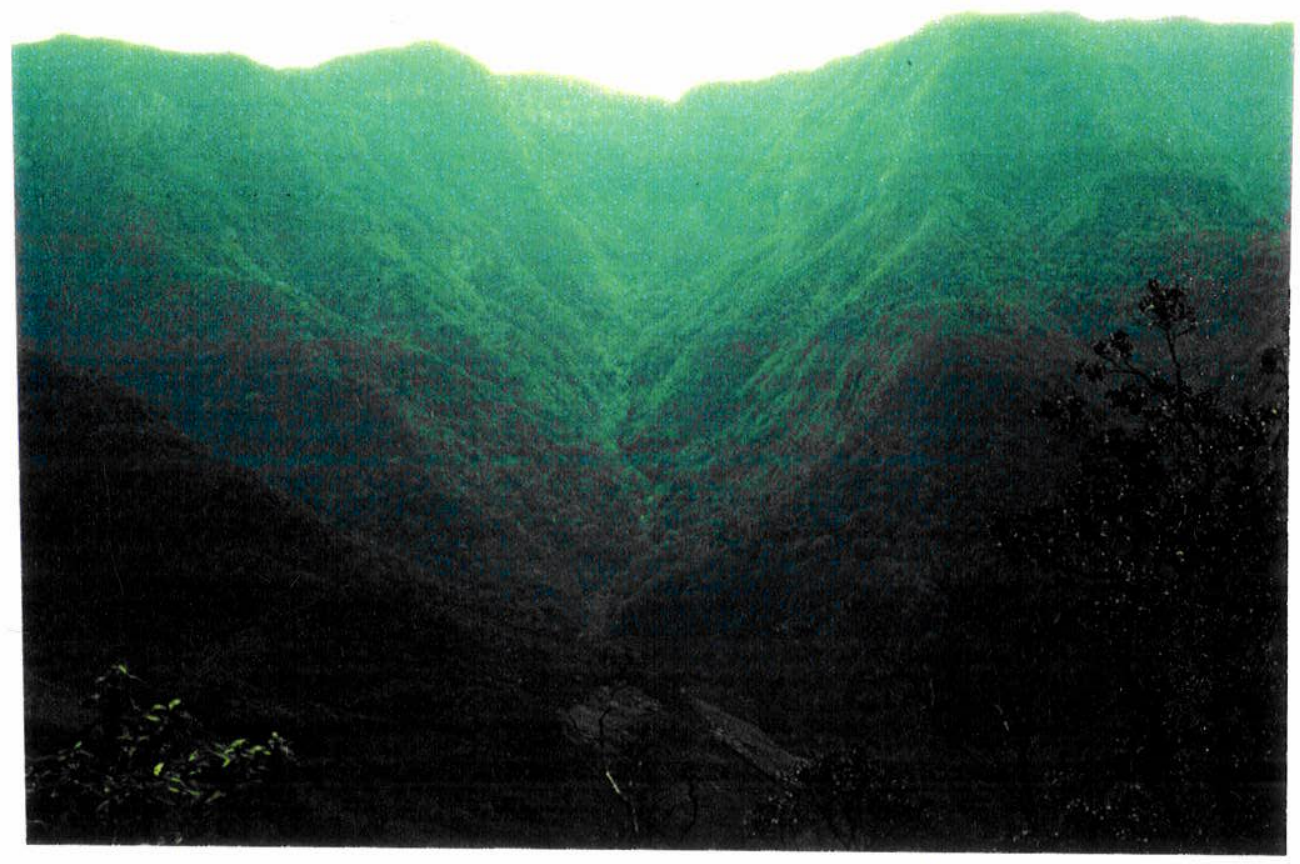

Foto 3 - Nascentes do Rio Malacara ou Macaco, na escarpa da Serra Geral, no Município de Praia Grande, Setor Sul, mostrando ser um vale mais fechado e mais inclinado que o da foto 2 . 
depósitos e suas altimetrias, tendo-se ainda a considerar a distância maior entre o sopé da escarpa e o oceano no Setor Norte.

O desenvolvimento deste item, entretanto, tem a função de descrição-apresentação, pois uma bacia de drenagem, como já foi referido, deve ser tratada em toda a sua dinâmica, o que não vai ser possível pela falta de elementos para tal.

\subsubsection{SETOR NORTE}

O canal fluvial com três toponímias, isto é, Rio da Pedra, Rio Itoupava e Rio Araranguá, é o que reúne as águas dos demais canais da rede hidrográfica deste setor, que está sendo referida como Bacia do Rio Araranguá e que possui área bem maior que a Bacia do Rio Mampituba (Figura 15, no encarte).

A Bacia do Rio Araranguá apresenta distribuição assimétrica de canais, isto é, os canais afluentes da margem esquerda são muito mais numerosos e muito mais longos do que os da margem direita. Os tributários da margem direita são desprezíveis, tanto pelas extensões como em áreas de drenagem. Entre estes, os mais significativos nascem no esporão-interflúvio e são afluentes do Rio da Pedra no trecho a oeste da cidade de Jacinto Machado.

O curso do Rio da Pedra/ltoupava/Araranguá segue uma direção geral NE-SW, notadamente entre a escarpa e a confluência com o Rio Mãe Luzia.

O Rio da Pedra tem na escarpa um vale bastante retilíneo, orientado NE-SW, que foi interpretado por PUTZER (1953) como um gráben. Este trecho situa-se justamente defronte à faixa de elevações rochosas dissecadas, isto é, o esporão-divisor. É a partir do Rio da Pedra que há uma mudança de direção dos vales fluviais sobre a escarpa (Figura 13 no encarte).

Os vales dos rios formadores da bacia do Rio Araranguá dispõem-se com duas orientações. Entre os vales dos rios da Pedra, ao sul, e da Serra da Velha II, ao norte, os vales sobre a escarpa estão orientados na direção NE-SW, mas os vales situados para o norte, após estes, dispõem-se segundo NW-SE. 
Em altitudes abaixo dos $200 \mathrm{~m}$, quando os leitos dos rios não estão mais sobre substrato rochoso e sim sobre os depósitos rudáceos dos leques aluviais, os canais com direção NE-SW, com exceção do Rio da Pedra, mudam também sua direção para NW-SE, ao passo que os outros mantém a sua direção original NW-SE. Todo o conjunto passa a ter a mesma direção até desaguar no rio principal da bacia. Este, o Rio da Pedra/ltoupava/Araranguá, mantém a direção inicial NE-SW, migrando para nordeste (Figura 15, no encarte).

Além do Rio da Pedra podem ser citados os rios Praia do Norte, formador do Pinheirinho; o Figueira, o Fortuna e um afluente do Rio Serra Velha II que exibem direção NE-SW. Algumas nascentes deste último, justamente ao sul da estrada da Serra da Rocinha, marcam a mudança para a outra direção. Com a direção NW-SE há os rios Serra Velha I, Rocinha, Molha Côco, Amola Faca, Jundiá, Morto e Manoel Alves. Os rios Amola Faca, Manoel Alves e Morto nascem fora da área estudada tendo, porém, a maior parte de seus cursos dentro dela (Figura 15 no encarte).

Algumas características geomórficas das principais sub-bacias integrantes da Bacia do Rio Pedra/ltoupava/Araranguá podem ser verificadas nas Figuras 28 e 29. As sub-bacias dos rios Manoel Alves, Cedro, Mãe Luzia e Porcos, com apenas parte de suas superfícies dentro da área estudada, não tiveram estas características medidas.

As curvas e os dados hipsométricos das sub-bacias do Setor Norte oferecem subsídios para sua comparação àquelas do Setor Sul, principalmente quanto à área das mesmas e suas alturas médias. Verifica-se que as sub-bacias do Rio Araranguá apresentam a média de suas alturas médias mais baixa que a daquelas do Rio Mampituba. Na Bacia do Rio Araranguá, a sub-bacia do Rio Jundiá é que apresenta menor altura média $(92,91 \mathrm{~m})$ e menor declividade $\left(8^{\circ} 04^{\prime}\right)$, com uma área de 131,27 $\mathrm{km}^{2}$. A sub-bacia do Rio Rocinha é que apresenta maior altura média $(726,80 \mathrm{~m})$ e declividade de $32^{\circ} 05^{\prime}$, com uma área de apenas $46,12 \mathrm{~km}^{2}$, enquanto na bacia do Rio Mampituba a sub-bacia do Rio Leão é que apresenta a menor altura média $(168,75 \mathrm{~m})$, tendo declividade de $8^{\circ} 31^{\prime}$ e área de $95,41 \mathrm{~km}^{2}$. A sub-bacia do Rio Pavão é que apresenta maior altura média $(716,67 \mathrm{~m})$ e declividade de $35^{\circ} 09^{\prime}$ dentro de uma área 
de $101,17 \mathrm{~km}^{2}$. Estes dados mostram que a amplitude entre as alturas médias é maior na bacia do Rio Araranguá e evidenciam a dissecação mais pronunciada desta bacia.

Os dados das figuras 28 e 29 mostram também que as sub-bacias do alto e médio curso do Rio da Pedra/ltoupava, como as dos rios Pinheirinho, Honório e Engenho Velho, apresentam alturas médias menores, sugerindo que o grande canal fluvial tem um papel maior que o de coleta das águas da bacia.

Um fator que adiciona erro nos trabalhos quantitativos, baseados apenas na rede cartografada das sub-bacias, é quando estas se desenvolvem também sobre leques aluviais lateralmente coalescentes. A rede não é totalmente desenhada, e os limites das sub-bacias são delineados subjetivamente, pois os canais são complexos, e a rede hidrográfica muito mais. Com estas condições os limites das sub-bacias, interpretados pelos "interflúvios", são deficientes. Além destes fatos, elas compreendem a parte sobre a escarpa rochosa com alta declividade, por vezes grande área sobre sedimentos incoerentes e com muito baixa declividade, e canais muito longos também devido às suas sinuosidades. Dessa maneira, os valores médios e homogeneizadores não explicam bem a realidade.

O Rio Mãe Luzia, situado a leste daqueles medidos, com nascentes no norte, fora da área estudada, tem direção geral N-S, migrando, pois, com sentido sul. Os rios Itoupava e Mãe Luzia unem-se e formam o Rio Araranguá que apresenta a direção geral E-W e sinuosidades do tipo meandrante, com barras em pontal e meandros abandonados.

O Rio dos Porcos é o tributário situado mais a leste na bacia e também apresenta a direção NE-SW, porém, com sentido distinto de todos os outros, isto é, flui para sudoeste (Figura 15, no encarte). Nasce sobre rochas sedimentares, em altitudes abaixo de $100 \mathrm{~m}$. Pela sua situação geográfica e seu baixo gradiente, ele tem mais da metade de seu perfil longitudinal sobre cotas menores que $20 \mathrm{~m}$, além de todo o seu baixo curso estar sobre depósitos lagunares e estuarinos, com o nível freático muito alto, que the assegurava forte sinuosidade e fluxo lento, hoje modificados pela retificação do seu canal. 


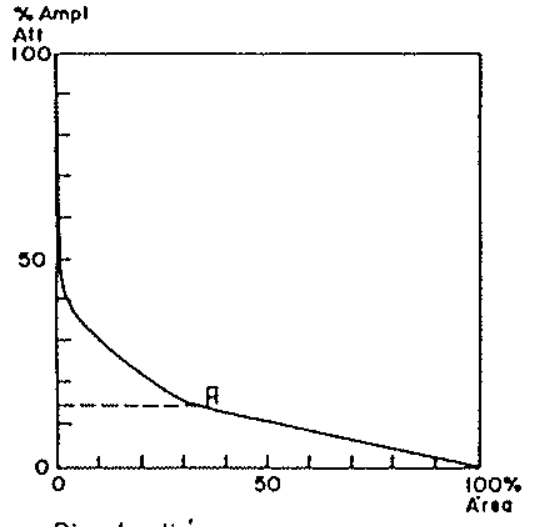

Rio Jundio

Aireo: $131,27 \mathrm{~km} 2$

Alturo Média: $92,91 \mathrm{~m}$

Coef. Massividade: $0,142\left(\alpha=8^{\circ} 04^{\prime} 55^{4}\right)$

Coet. Orogrólico : 13.19

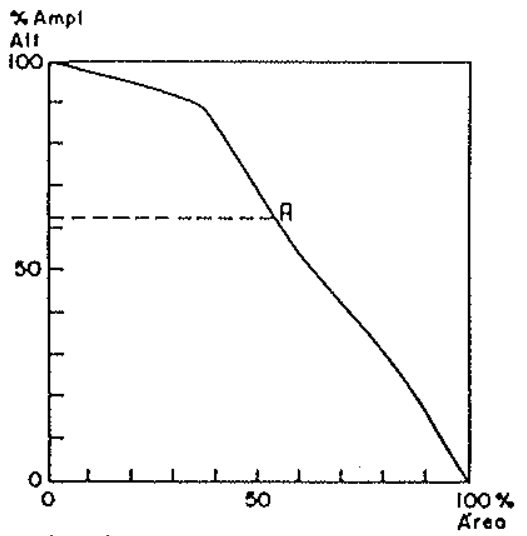

Rio Rocinho

Areo: $46.12 \mathrm{~km} 2$

Allura Média: $726,80 \mathrm{~m}$

Coet. Mossividode : 0.627 ( $\alpha=32^{\circ} 05^{\prime} 15^{\prime \prime}$ )

Coef. Orogrólico: 455,70

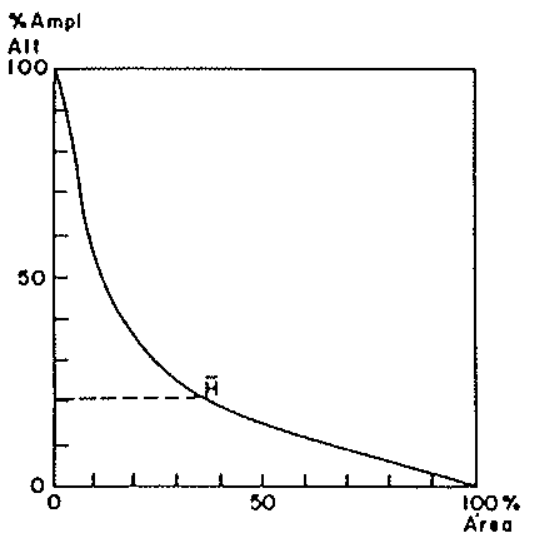

Rio Pinheirintio

Areo: $127,32 \mathrm{~km} 2$

Altura Médio : $240,98 \mathrm{~m}$

Coet. Mossividode: $\left.0,206(\alpha=1) \cdot 38^{\prime} 24^{\prime \prime}\right)$

Coef. Orogrófico: 49,64

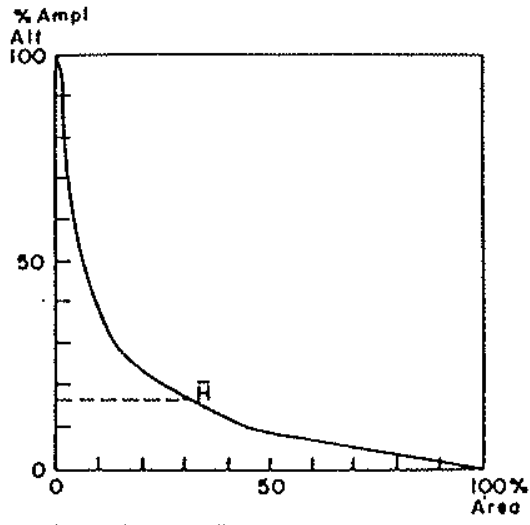

Rio Amola Foco

Aireo: $46,32 \mathrm{~km} 2$

Altura Médio: $194,39 \mathrm{~m}$

Coef. Mossividade: $0,162\left(\alpha=9^{*} 12^{\prime} 07 "\right)$

Coet. Orográlico: 31,49

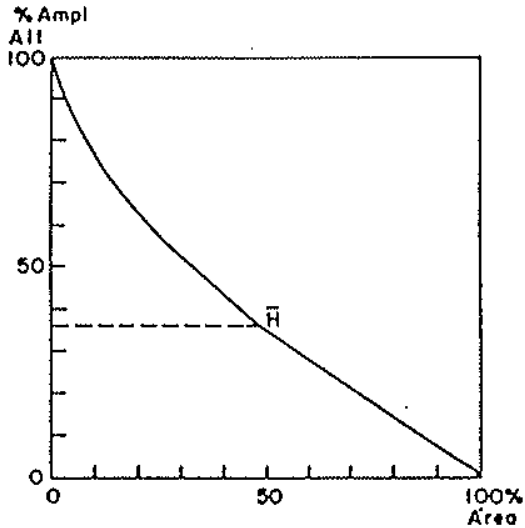

Rio Serra Velho II

Airea: $58,08 \mathrm{~km} 2$

Alturo Mèdio: $424,77 \mathrm{~m}$

Coef. Massividode: 0,366 ( $\alpha=20^{\circ} 06^{\prime} 09^{\prime \prime}$ )

Coef. Orográfico: $: 155,46$

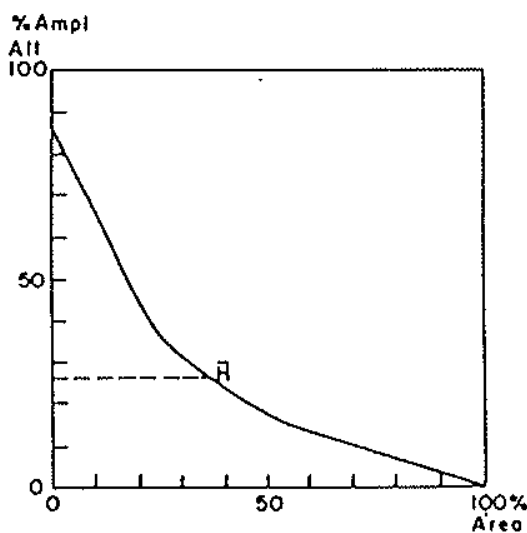

Rio Honório

Areo: $31,72 \mathrm{~km} 2$

Allura Media: $110,40 \mathrm{~m}$

Coef. Mossividade: 0,26$)\left(\alpha=14^{\circ} 37^{+} 40^{\prime \prime}\right)$

Coef. Orográlico: 28,81

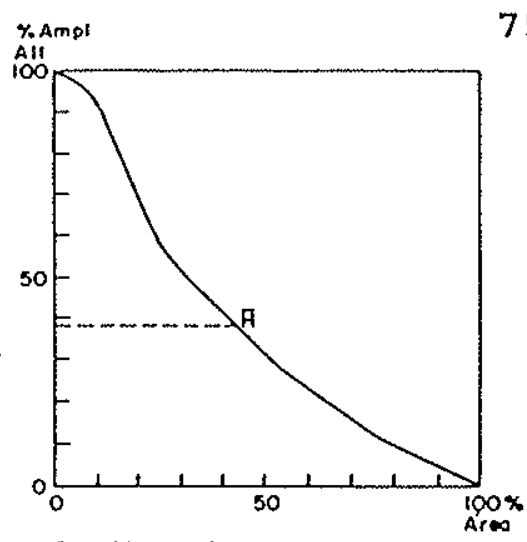

Rio Molno Coco

Areo: $58,88 \mathrm{~km} 2$

Alturo Médio: $455,24 \mathrm{~m}$

Coet. Massividade: $0,384\left(\alpha=21^{\circ} 04^{\prime} 24^{\prime \prime}\right)$

Coef. Orogrótico: 174,81

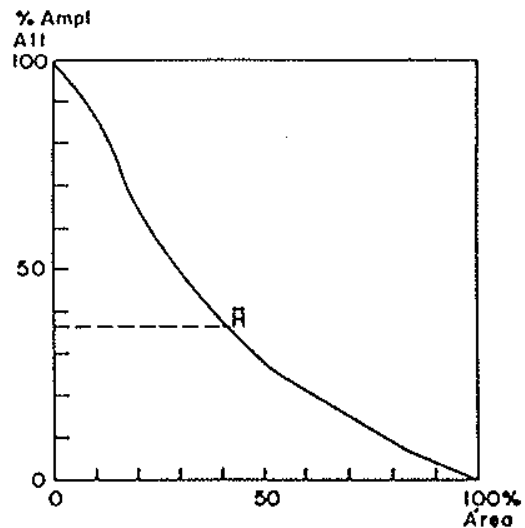

Rio Fiqueiro

Area: $71.79 \mathrm{~km} 2$

Altura Média: $389,45 \mathrm{~m}$

Coef. Mossividode: $0,365\left(\alpha=20^{\circ} 03^{\prime} 07^{* \prime}\right)$

Coef. Orogrófico: 142,15

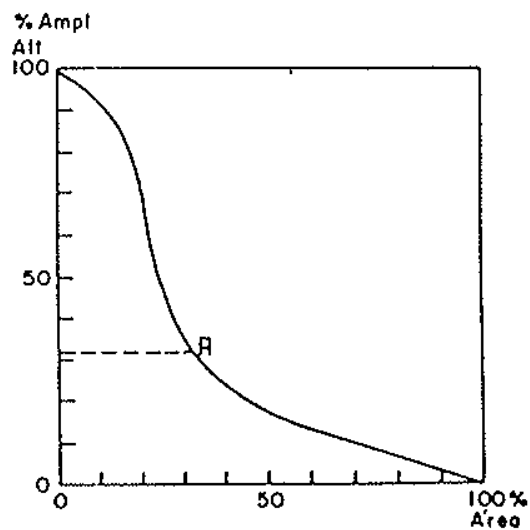

Rio do Pedra

Areo: $212,41 \mathrm{~km} 2$

Altura Médio: $354,71 \mathrm{~m}$

Coef. Mossividade: $0,315\left(\alpha=17^{\circ} 29^{\prime} 03^{* \prime}\right)$ Coet. Orogrático: 111,73

Fig.28 - Curvos - Dodos Hipsométricos da Bocia do Rlo Ararangua. 


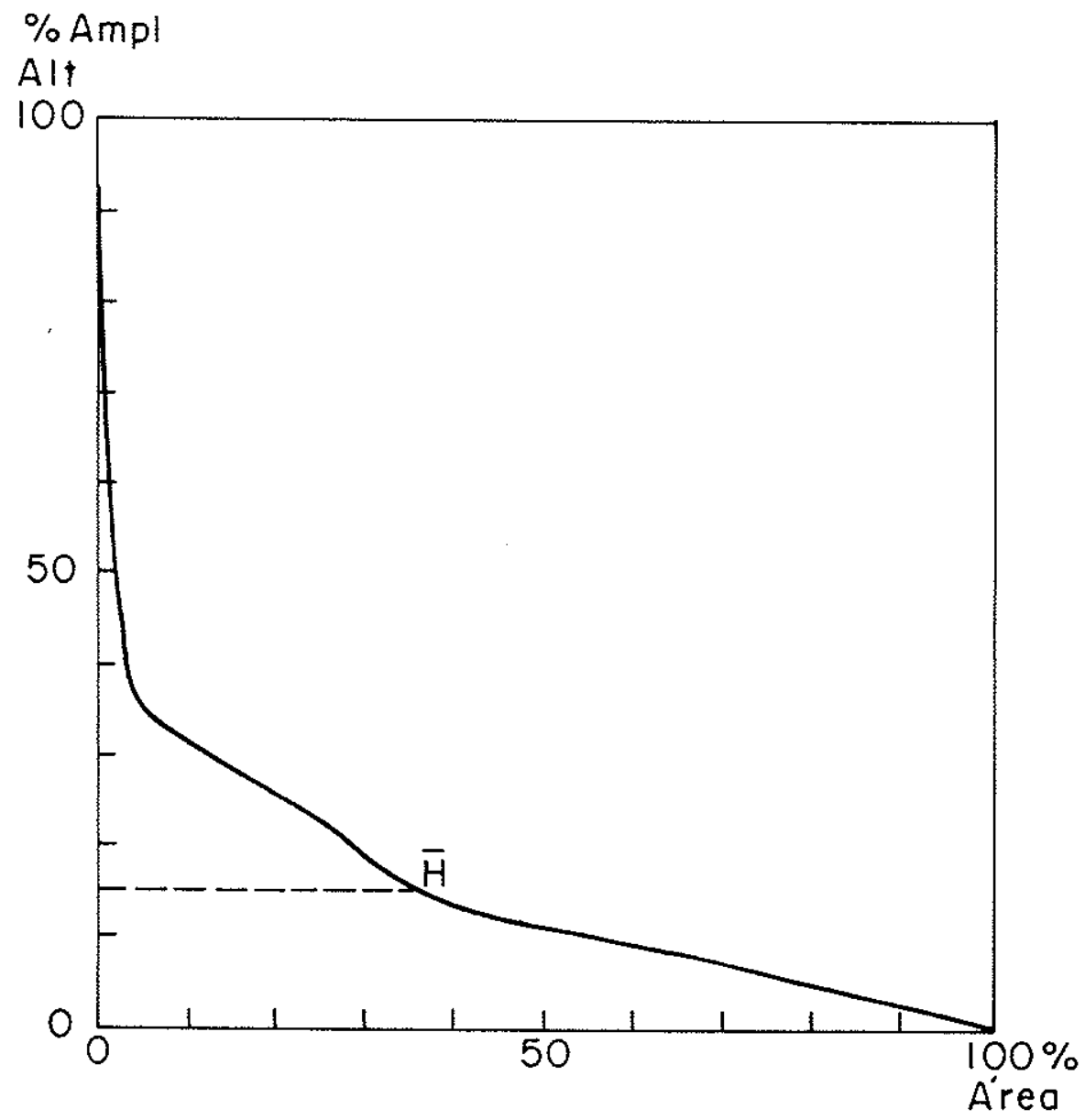

Rio Engenho Velho

Área: $61,94 \mathrm{~km} 2$

Altura Média: 140,28 m

Coef. Massividade: $0,151\left(\alpha=8^{\circ} 35^{\prime} 12^{\prime \prime}\right)$

Coef. Orográfico: 21,18
$\%$ Ampl

Alt

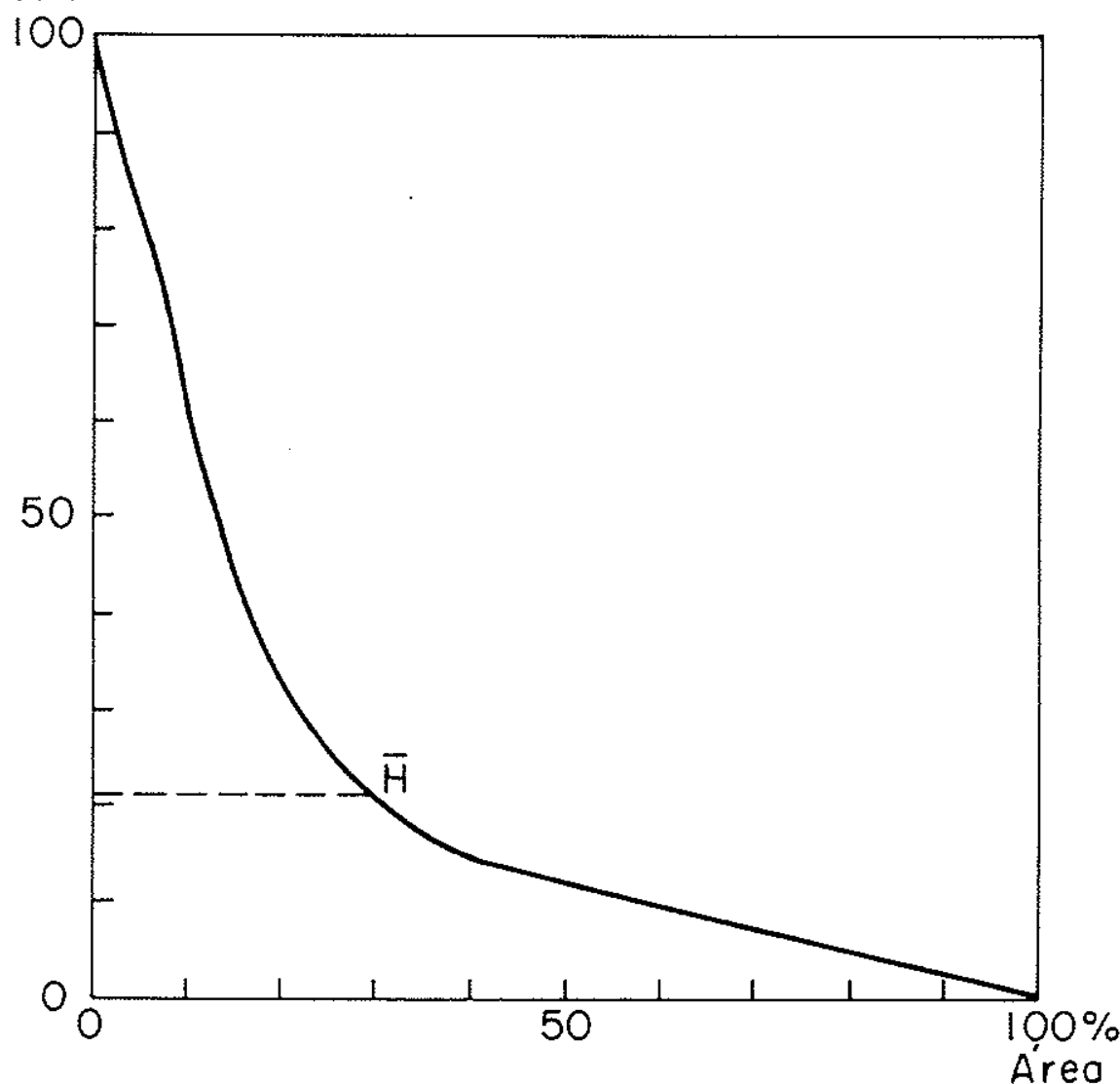

Rio da Pedra/Itoupava

Área: $1.113,60 \mathrm{~km} 2$

Altura Média: $285,27 \mathrm{~m}$

Coef. Massividade: $0,217\left(\propto=12^{\circ} 14^{\prime} 36^{\prime \prime}\right)$

Coef. Orográfico: 61,90

Fig. 29 - Curvas e Dados Hipsométricos da Bacia do Rio Araranguá. 
O último trecho do Rio Araranguá, junto à sua foz, desloca-se para nordeste, acompanhando a linha de costa por influência da deposição efetuada pela alta energia das ondas (Foto 4). Esta situação parece que vem se repetindo no decorrer do Holoceno, de oeste para leste, possibilitada pelo conjunto de fatores associados à progradação da zona costeira, tais como orientação das vagas e das correntes de

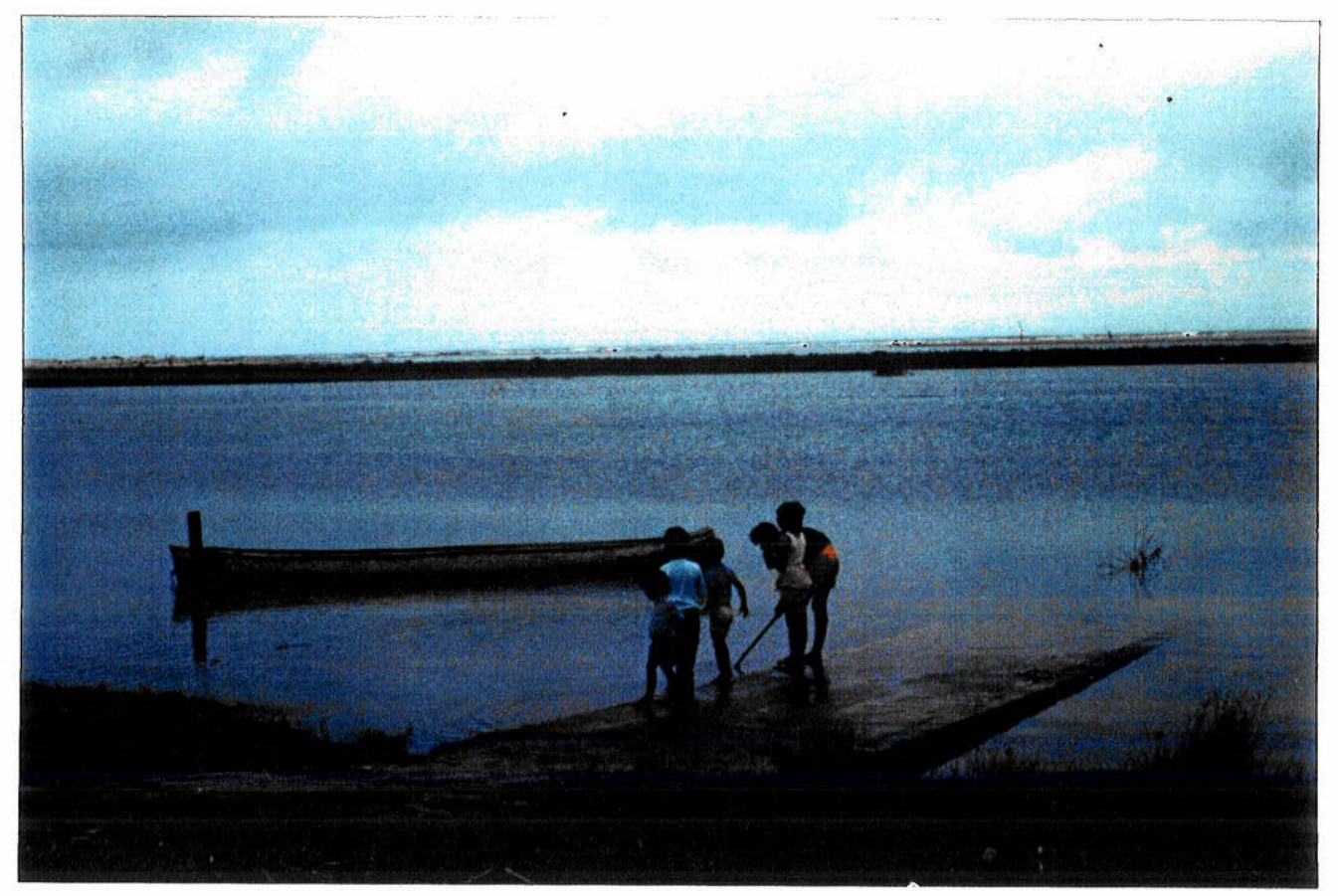

Foto 4 - Área da foz do Rio Araranguá, notando-se a largura da área estuarina, com o arco praial a este e o corpo de água paralelo à linha de costa. Visada para leste a partir da localidade de llhas, com a foz deste rio no centro da foto. A vegetação de taboa no centro do corpo do estuário mostra que a circulação cria bancos rasos. 
deriva litorânea, energia das ondas e fonte de material, acompanhadas pelas sucessivas posições da foz do rio. As evidências são as morfologias e os depósitos associados, provenientes de corpo de água alongado, com condições estuarinas e larguras semelhantes àquelas que o último trecho do rio tem hoje, e que se deslocou paralelamente à linha de costa de diferentes épocas.

O Rio Araranguá apresenta regime estuarino, com a cunha salina subindo até perto da localidade de Itoupava, isto é, a montante da confluência do Mãe Luzia com o Itoupava. O Rio Mãe Luzia também é influenciado por esta cunha que progride nas marés altas, até junto à foz do Rio Manoel Alves.

O comportamento dos canais ou da rede fluvial é bastante complexo e não apresenta um padrão único. Nos afluentes do canal considerado como principal, são notados trechos de canal retilíneo, entrelaçado e com sinuosidades fortes devidas a várias razões já mencionadas. Um rịo muito sinuoso é o Rio Jundiá. O rio principal também apresenta trecho retilineo, trecho entrelaçado e trecho meandrante.

\subsubsection{SETOR SUL}

A área hoje é drenada pela bacia hidrológica do Rio Mampituba cujos tributários, em grande parte, têm suas nascentes na escarpa, ou mesmo no planalto. Outros tributários nascem nos depósitos sedimentares, em altitudes abaixo dos $200 \mathrm{~m} \mathrm{e}$ mesmo abaixo dos $25 \mathrm{~m}$ (Figura 16, no encarte).

A área desta bacia compreende tanto os terrenos configurados pelo anfiteatro sul, bem como a área cuja drenagem está vinculada às lagoas da Serra, de Caverá e do Sombrio (Figura 16, no encarte).

Os canais fluviais que concentram a drenagem da área formam uma rede assimétrica, uma vez que os afluentes de maior expressão em comprimento, largura, volume de água e de área de suas bacias são aqueles da margem esquerda do tronco principal. Estas sub-bacias dispõem-se como em leque, abrindo-se de sudoeste para norte, em torno do canal principal (Figura 16, no encarte) e pertencem ao Estado de 
Santa Catarina, com exceção daqueles trechos de nascentes no planalto, pertencentes ao Rio Grande do Sul, dos quais são exemplos as áreas de nascentes do Rio Pavão, com aproximadamente $60 \mathrm{~km}^{2}$, e do Arroio Faxinalzinho, com cerca de $35 \mathrm{~km}^{2}$.

Os afluentes principais da margem esquerda do Rio Mampituba, de sudoeste para norte, são: Arroio Faxinalzinho, Arroio Facão, Pavão ou do Boi, Molha Coco, Malacara ou Macaco, Três Irmãos, Fortaleza, Leão - todos nascendo a oeste, na escarpa ou no planalto - e Rio Bonito com nascentes tanto na escarpa como no esporão-divisor, a norte. Neste também nascem a Sanga da Areia e a Sanga Barro Preto.

As lagoas dos Bichos, da Serra, do Caverá e do Sombrio, interligadas e desaguando nesta última, recebem águas de terrenos sedimentares, com baixas altitudes, e de pequenos rios como o da Laje, com seus principais afluentes, Córrego Garuva e Córrego Peroba que constituem drenagem da margem esquerda do Rio Mampituba, tornando esta bacia ainda mais assimétrica. A leste das lagoas há a Sanga dos Rodrigues que drena área de cristas praiais e dunas, emitindo as águas para o Rio Mampituba, já bem perto da foz deste.

O canal principal que recolhe as águas da bacia constitui um sistema complexo do qual o Rio Mampituba é parte importante. Esta complexidade é devida a vários fatores como: controle estrutural, a situação do seu trecho no sopé da escarpa sobre leques aluviais, seu percurso através de outros depósitos não fluviais, isto é, depósitos praiais e lagunares, e o pequeno desnível $(<20 \mathrm{~m})$ entre a posição terminal dos leques aluviais e o oceano.

Este canal tem as nascentes mais distantes, no extremo sudoeste da área, produto da confluência do Arroio Josafaz, Arroio Faxinalzinho e do próprio Mampituba que é o menor destes três, neste trecho. Entre esta posição e a cidade de Praia Grande, o Rio Mampituba tem a direção geral NE-SW e apresenta vários afluentes em ambas as margens, porém só a margem esquerda pertence à Santa Catarina. Os dois afluentes mais importantes neste trecho são o próprio Arroio Faxinalzinho e o Rio Pavão que apresentam nítido controle estrutural, segundo o padrão da área, 
visualizado pelas orientações de seus vales e as mudanças de orientação em cotovelo (Figura 16, no encarte).

Este trecho do Mampituba tem várias toponímias, tanto entre a população do Rio Grande do Sul como em mapas diversos. É chamado de Rio Roça da Estância (GOMES, 1976 e mapas 1:250.000, do IBGE), Mampituba, Rio Grande, Morto, Velho, Praia Grande, Grande, Preto, Verde e novamente Mampituba, no último trecho do baixo curso. Entretanto, o Rio Roça da Estância é um afluente da margem direita do Rio Mampituba.

A partir da cidade de Praia Grande, para jusante, é que o curso do rio se torna bastante complexo, acompanhado de toponímia também variada. Ele é chamado de Rio Grande, Rio Praia Grande e Rio Mampituba, para logo em seguida ganhar o nome de Canoas, dirigindo-se para nordeste.

Defronte à cidade de Praia Grande são visíveis cicatrizes das posições anteriores do canal maior ou, ainda, a sua divisão em canais menores que são retomados em épocas de cheias. Os paleocanais ainda apresentam água cujo influxo dá-se pelas cheias ou subterraneamente. A saída é feita subterraneamente. Assim as águas mantidas pelos antigos canais chamados de Rio Morto e Rio Velho, não são totalmente paradas. O lençol freático é muito alto e com muito fluxo nesta área de depósitos rudáceos dos leques aluviais. Há igualmente fuga de água do canal principal que alimenta também o lençol freático e vice-versa. Dessa maneira, águas fluem para leste, ora subaereamente ora subterraneamente, incorporadas ao lençol freático. Elas vão constituir estreitos riachos que vão desaguar num canal cada vez mais amplo que tem vários nomes como Preto, Verde e novamente Mampituba.

Entretanto, o curso principal proveniente de sudoeste, inicialmente com o nome de Mampituba, após a cidade de Praia Grande passa a se chamar Canoas, mantendo a mesma direção NE-SW até voltar-se para o sul, quando recebe o nome de Rio Sertão. Este, correndo para sul, vai confluir com as águas que se reuniram a leste de Praia Grande e formaram o Rio Verde. Após esta confluência o curso de água passa a 
chamar-se novamente Rio Mampituba. As águas reunidas vão formar um canal único a menos de $3 \mathrm{~km}$ a montante da ponte, na rodovia BR-101, no limite estadual.

Uma grande área onde se situam as localidades de Timbopeba, Vila Santa Catarina, São José, Passo Magno e Glória fica circundada pelas águas; assim divididas, do Rio Mampituba. Nesta área situam-se alguns afloramentos de Arenito Botucatu cortado por diques e soleiras de diabásio, em Timbopeba e Vila Santa Catarina. Afloram, ainda, siltitos roxos do Grupo Passa Dois, depósitos das áreas medianas dos leques aluviais e depósitos paleopraiais. A disposição deste canal maior do Setor Sul tem o controle estrutural como a principal explicação possível.

Os canais fluviais são complexos, assim como sua própria rede. Eles apresentam trechos relativamente retos na escarpa, com inclinações, entre as suas nascente e os $200 \mathrm{~m}$ de altitude, de cerca de $15^{\circ}$ a $17^{\circ}(27 \%$ a $30 \%)$, e entre os topos da escarpa até os $100 \mathrm{~m}$ de altitude, as inclinações variam de $8^{\circ}$ a $12^{\circ}(15 \%$ a $22 \%)$. 0 canal do Arroio Josafaz, nas nascentes do Mampituba, entretanto, tem inclinação muito baixa, de pouco mais de $3^{\circ}(6 \%)$. Outros trechos são bastante sinuosos como o que apresenta o Rio Canoas, entre a localidade de Costa do Rio Canoas e a confluência com o Rio Leão; o próprio Mampituba, entre a localidade de Glorinha e a confluência com o Rio Sertão; trechos do Rio Cachoeira; do Leão e do Bonito. Mas, o meandramento propriamente dito ocorre nos últimos $4 \mathrm{~km}$ do curso inferior do Mampituba, entre a localidade de Costa do Mampituba e a sua foz que, desde 1973, encontra-se mantida por molhes. Neste trecho encontram-se lagos em crescente, formados por meandros abandonados. Entretanto, o padrão de canal dominante na bacia é o entrelaçado (braided), principalmente entre a faixa de $100 \mathrm{~m}$ de altitude até cotas em torno de $10 \mathrm{~m}$.

O padrão entrelaçado é o característico desta área dos leques aluviais, no sopé da escarpa da Serra Geral. Este padrão constitui-se ali por sistemas de canais múltiplos, complexos. Tanto os canais principais das sub-bacias como os menores, mudam de posição e comportamento, permitindo uma toponímia variada para o mesmo rio que freqüentemente traz confusão tanto para a população como para quem 
pesquisa. Semelhantemente ao que ocorre com o Mampituba, outros rios do Setor Sul têm dois nomes e, por vezes, mais. Assim, o Rio Pavão também é chamado do Boi. Como seus dois canais principais, a montante da principal ponte que o atravessa, nem sempre têm fluxo subaéreo de água, aquele que estiver "sem água" é chamado de Rio Seco.

JOHNSON, em 1895, (MCGEE, 1897), criou a nomenclatura drenagem entrelaçante (interlacing drainage) para uma multidão de correntes amplas, rasas e rápidas, aproximadamente paralelas, constantemente bifurcando-se e reunindo-se, de tal maneira que originam numerosas ilhas que são invadidas e varridas do local, de tempo em tempo, pelas águas. Já no século passado, de acordo com MIALL (1982), os três termos braided, anastomosing e meandering eram usados, embora não bem definidos. DAVIS, em 1898, identificou o tipo braided, tomando como padrão o Rio Platte, classificação que se mantém até hoje. No entanto, este rio já havia sido considerado anteriormente como anastomosado (anastomosing stream). Usa-se portanto, aqui a nomenclatura entrelaçado como tradução do braided.

Alguns elementos geomórficos das sub-bacias pertencentes à Bacia do Rio Mampituba podem ser visualizados nas Figuras 30 e 31.

Essas curvas hipsométricas mostram que entre as sub-bacias analisadas e mesmo para o trecho da Bacia do Rio Mampituba, da sua nascente até a situação de Praia Grande, são as sub-bacias dos rios Josafaz, Pavão e Faxinalzinho as que drenam maior área de rochas. Este fato torna-se óbvio com os trabalhos de campo e mesmo mediante fotos aéreas, pois os rios Pavão e Faxinalzinho drenam extensa área no planalto e na escarpa, ao passo que os demais, como os rios Leão, Cachoeira, Três Irmãos, Malacara e Molha Coco apenas drenam a escarpa, e vários deles têm longos trechos em altitudes abaixo de $20 \mathrm{~m}$ e sobre sedimentos. Os rios Pavão, Faxinalzinho, Josafaz e Rio Roça da Estância (RS) são afluentes do trecho do Rio Mampituba, a montante da cidade de Praia Grande. O Rio Roça da Estância(RS) tem uma curva hipsométrica distinta das dos outros três, demonstrando a forte dissecação do planalto a leste do Mampituba, isto é, na margem direita do seu vale. 


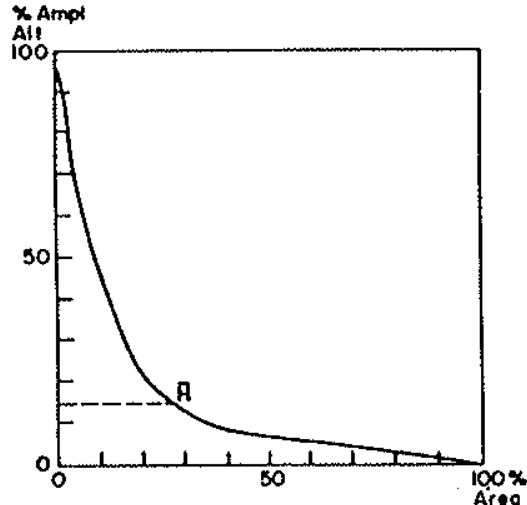

Rio Leōo

Ároo: $95,41 \mathrm{~km} 2$

Alturo Módio: $168,75 \mathrm{~m}$

Coef. Mossividade : $0,150\left(\alpha=\theta^{*} 31^{\prime} 50^{\prime \prime}\right)$

Coel. Orográfico $: 25,31$

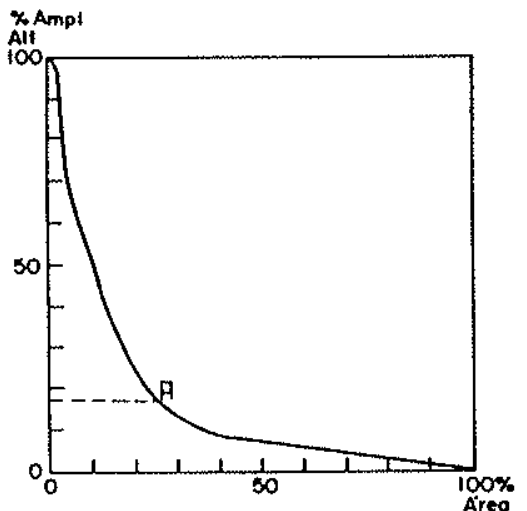

Rio Cochoeiro

Area: $35,12 \mathrm{~km} 2$

Alturo Média: 173,09 m

Coef. Mossividade: $0,1701 \alpha=9^{\circ} 39^{\prime} 33^{\prime \prime}$

Coef. Orogrófico : 29,46

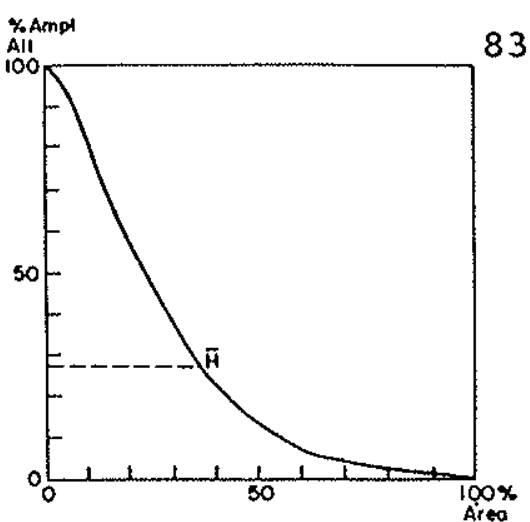

Rio Très Irmöos

Área: $22,88 \mathrm{~km} 2$

Alfuro Medio: $294,68 \mathrm{~m}$

Coef. Massividode: $0,27 \theta\left(\alpha=15^{\circ} 33^{\prime} 45^{\prime \prime}\right)$

Coel. Orográlico: 81,92

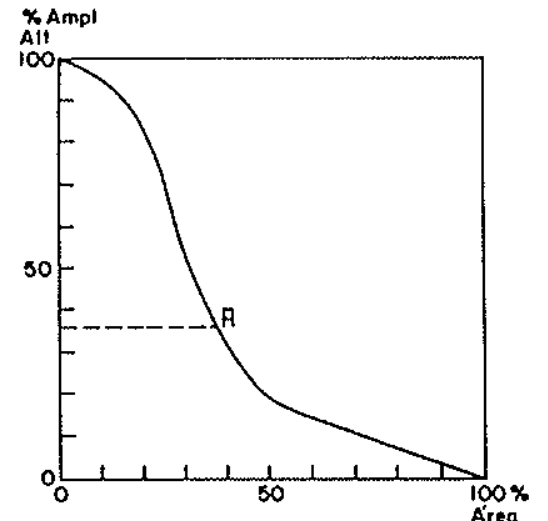

Rio Malacora ou Mococo Áreo: $37,73 \mathrm{~km} 2$

Altura Media: $391,28 \mathrm{~m}$

Coef. Massividade: $0,365\left(\alpha=20^{\circ} 03^{\prime} 07^{\prime \prime}\right)$

Coef. Orográfico: 142,82

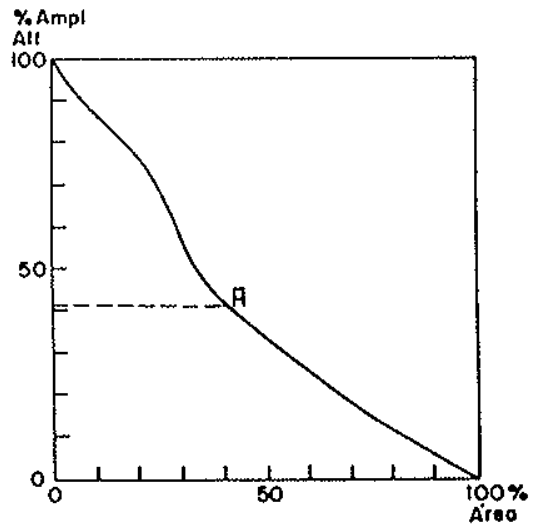

Rio Molho Coco

Area: 19,05 km2

Alfuro Média: $407,30 \mathrm{~m}$

Coef. Massividade : $0,411\left(a=22^{\circ} 20^{\prime} 51^{\prime \prime}\right)$

Coel. Orográlico: 167,40

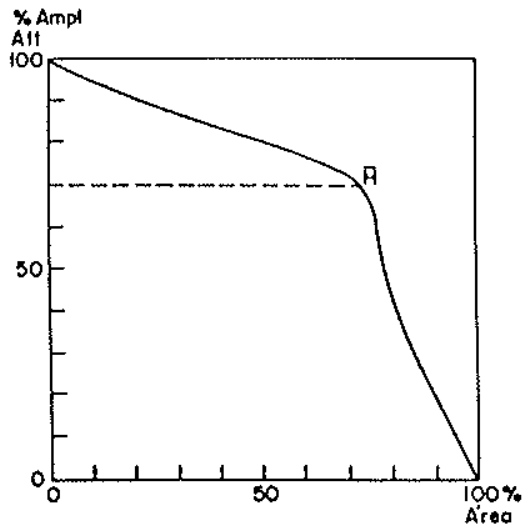

Rio Povão

Área: $101,17 \mathrm{km2}$

Alturo Médio: $716,67 \mathrm{~m}$

Coef. Massividade : $0,704\left(\alpha=35^{\circ} 09^{\prime} 25^{\prime \prime}\right)$ Coef. Orogrófico : 504,53

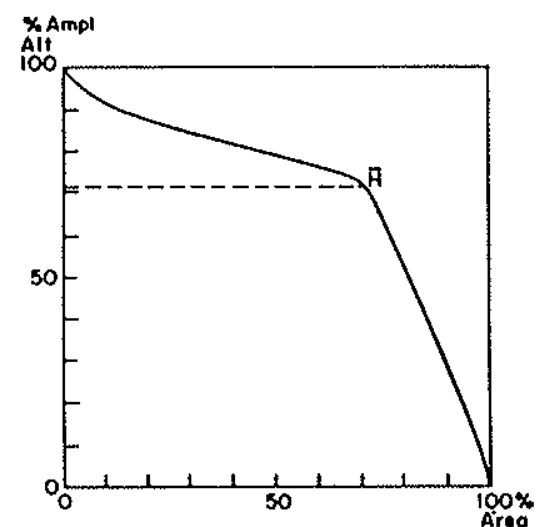

Rio Josaloz

Áreo: B1,97 km2

Alturo Médio: $630,19 \mathrm{~m}$

Coel. Mossividode: $0,691\left(\alpha=34^{\circ} 39^{\prime} 49^{\prime \prime}\right)$ Coel. Oroqrófico: 435,46

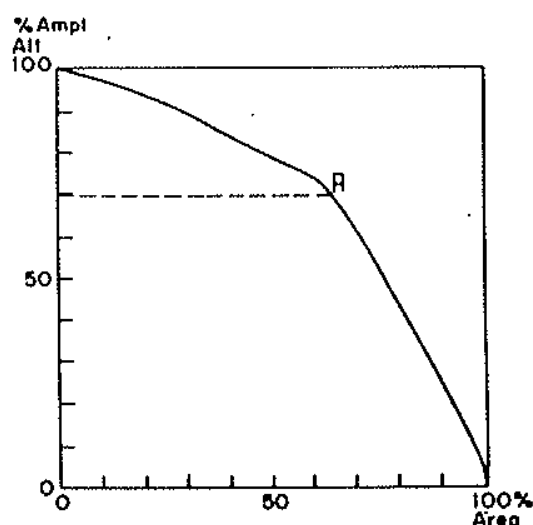

Rio Foxinalzinho

Áreo: $56,57 \mathrm{~km} 2$

Altura Média: $652,90 \mathrm{~m}$

Coef. Massividade: $0,712\left\{\alpha=35^{\circ} 27^{\prime} 16^{\prime \prime}\right\}$ Coef. Orográfico : 464,86

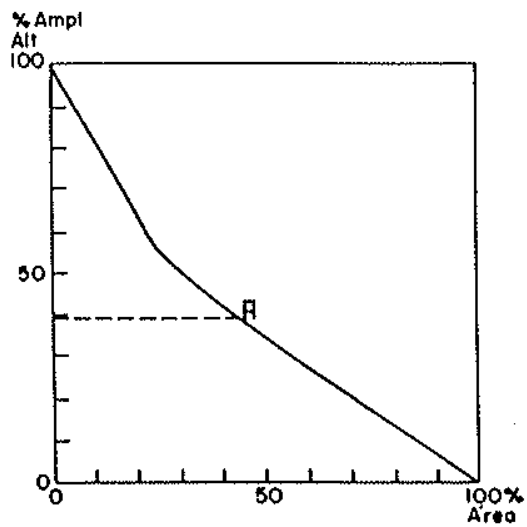

Rio Rcco do Esióncio (RS)

Áreo: $35,34 \mathrm{~km} 2$

Alturo Médio: $403,94 \mathrm{~m}$ Coef. Mossividade: $0,391\left(\alpha=21^{\circ} 21^{\prime} 19^{\prime \prime}\right)$ Coef. Orográfico: 157,94

Fig. 30 -Curvas - Dados Mipsomíficos da Baclo do Rio Mamplituba. 
$\%$ Ampl

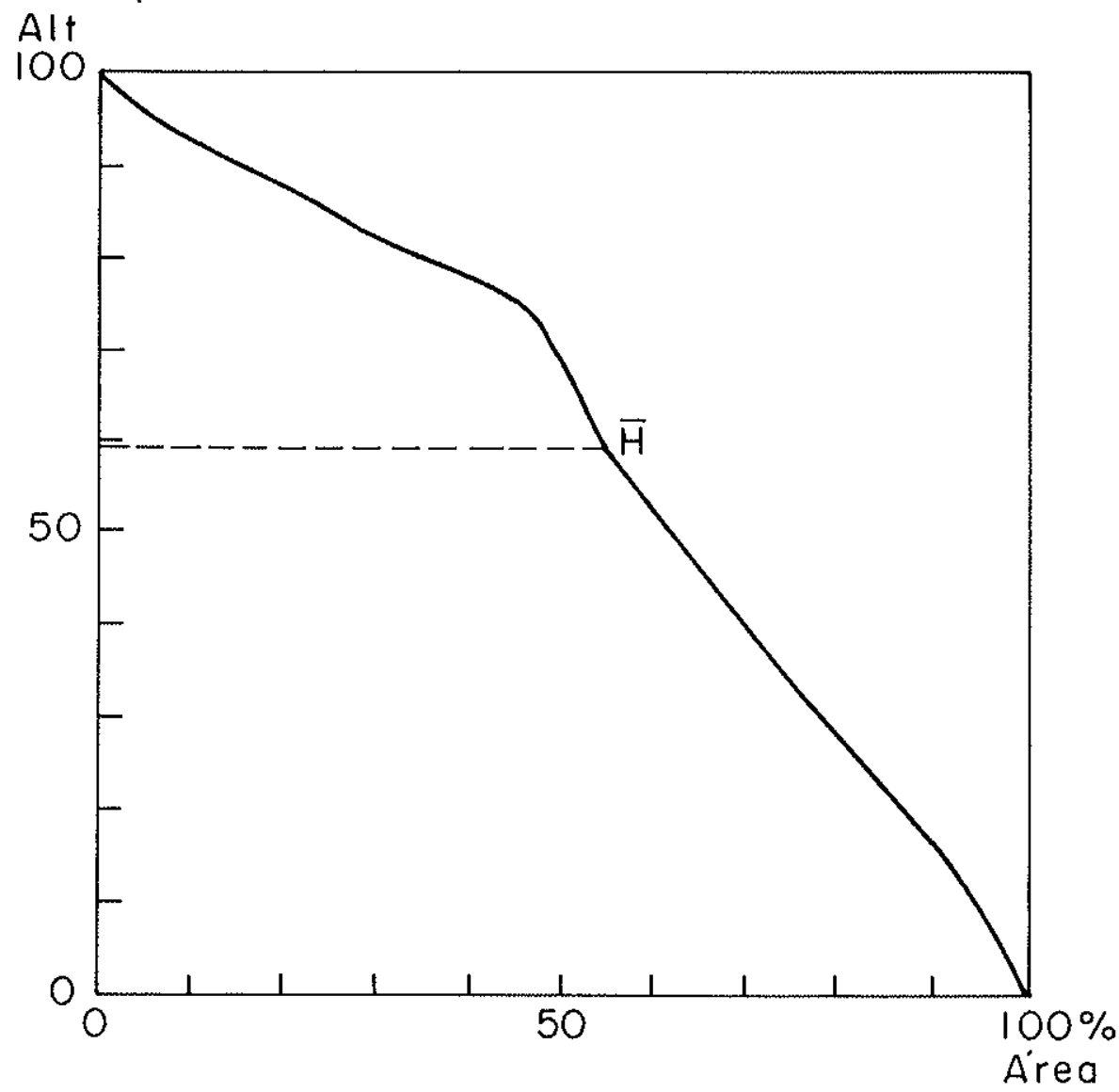

Rio Mampituba (Alto Curso)

Área: $216,69 \mathrm{~km} 2$

Altura Média: $614,47 \mathrm{~m}$

Coef. Massividade: $0,596\left(\alpha=30^{\circ} 47^{\prime} 41^{\prime \prime}\right)$

Coef. Orográfico : 366,22

Fig. 31 - Curva e Dados Hipsométricos da Bacia do Rio Mampituba. 
As sub-bacias dos rios Josafaz, Faxinalzinho e Pavão, e o conjunto reunido na Figura 31 mostram as maiores alturas médias, as mais altas declividades e os maiores potenciais erosivos, pois o primeiro é o principal formador do Mampituba e os outros dois têm suas nascentes e trechos de seus cursos no planalto.

As curvas hipsométricas e os seus dados numéricos correlacionados, para as sub-bacias dos rios Leão, Cachoeira e Três Irmãos, podem ser usadas comparativamente, porém elas não refletem as verdadeiras condições de erodibilidade e capacidade de transporte destes rios na escarpa ou mesmo da massa rochosa existente ou do potencial erosivo. A sub-bacia do Rio Leão tem uma área muito maior que aquelas dos rios Cachoeira, Três Irmãos, Malacara e Molha Coco, porém grande parte desta área situa-se abaixo da cota de $20 \mathrm{~m}$, o que reduz a altitude e a declividade médias que estão relacionadas ao coeficiente de massividade e ao coeficiente orográfico, isto é, o potencial de erosão. Dessa maneira, inúmeros dados quantitativos de redes de drenagem obtidos a partir de cartas topográficas, sem os trabalhos de campo, são muito parciais. Dependendo do relevo da área estudada, as sub-bacias não podem ser sempre a referência básica para análise quantitativa a partir de folhas topográficas.

Pouco mais a norte de Passo de Torres está a localidade de Barra Velha, nome pelo qual ainda é conhecida a área da antiga foz do Rio Mampituba. A ação da alta energia das ondas, com a subseqüente origem de um cordão arenoso, obrigava o rio a migrar paralelamente a este cordão e à linha de água marinha, até desaguar mais a norte (Foto 5). Frequentemente a desembocadura fluvial era totalmente obstruida, represando a água e inundando as suas margens durante as cheias.

A construção de molhes para manter as laterais da foz do Rio Mampituba, deixou abandonado o trecho final do rio, hoje conhecido como "Braço Morto", disposto paralelamente à linha da costa. Ele está sendo gradualmente colmatado por matéria orgânica e areia de atividade eólica e se transformando numa zona plana, baixa e úmida, de natureza paludial, situada entre cordões arenosos. 


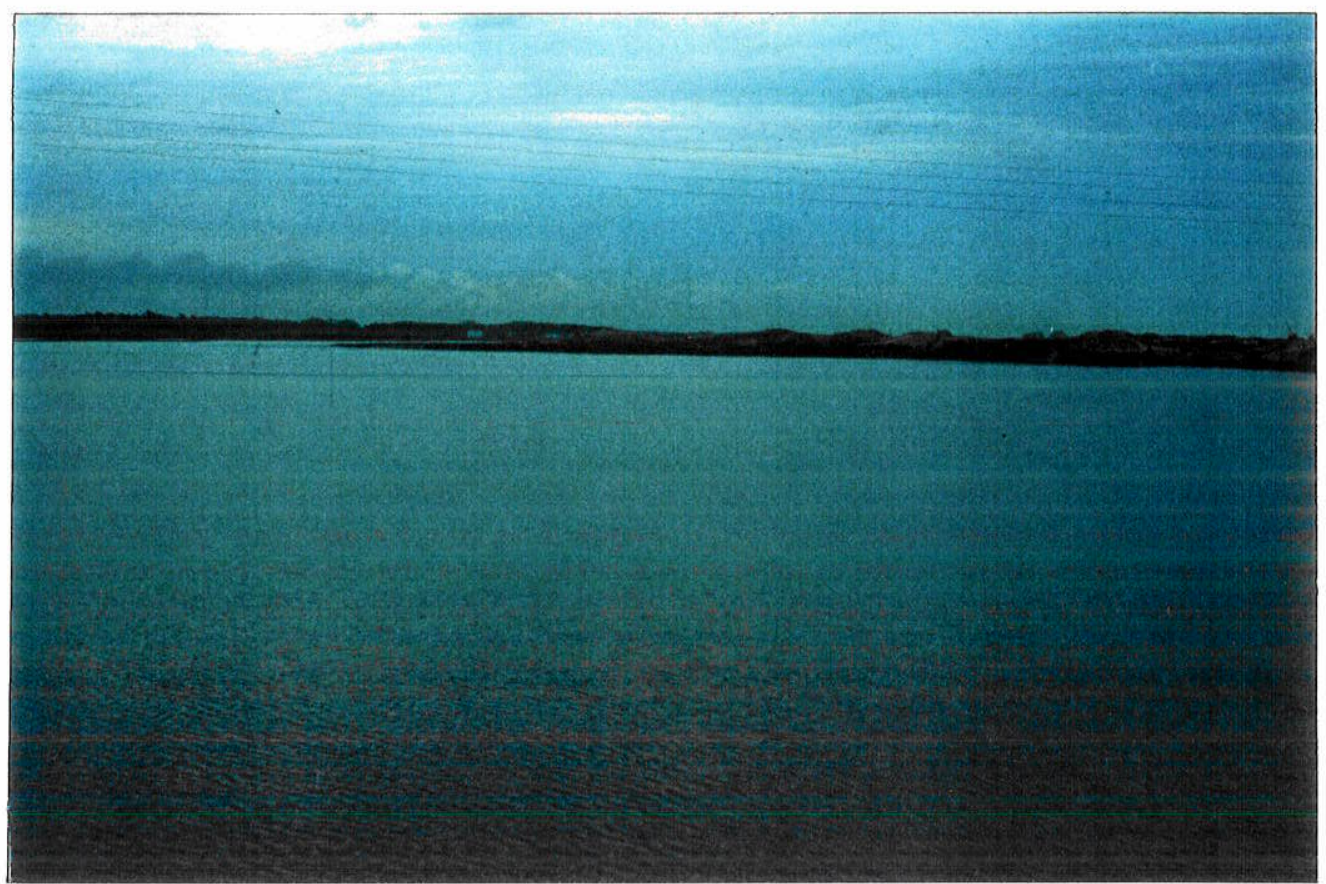

Foto 5 - Área da antiga foz do Rio Mampituba que migrava para o norte, semelhante a do Rio Araranguá, como um largo corpo estuarino, paralelo à linha do oceano. Este corpo de água foi cortado ao sul por um molhe aprisionando-o.

Esta situação é observada também em outras desembocaduras fluviais, no Estado de Santa Catarina, como nos rios Araranguá e Urussanga. O desagüe no oceano se faz pelo alargamento do curso, com conseqüente diminuição da profundidade na foz.

O processo de barramento das águas fluviais por cordão arenoso, produto da ação de ondas de alta energia, e a conseqüente migração da foz para o Norte parecem ter ocorrido em vários momentos do Holoceno, fazendo parte do processo de progradação costeira.

No baixo curso o Rio Mampituba apresenta regime estuarino, de tal modo que a variação das marés é observada a muitos quilômetros para oeste, inclusive subindo o canal do Rio Sertão, até a cidade de São João do Sul. Medidas efetuadas ao longo do canal, em cinco estações fluviométricas, podem ser visualizadas na Figura 32. 


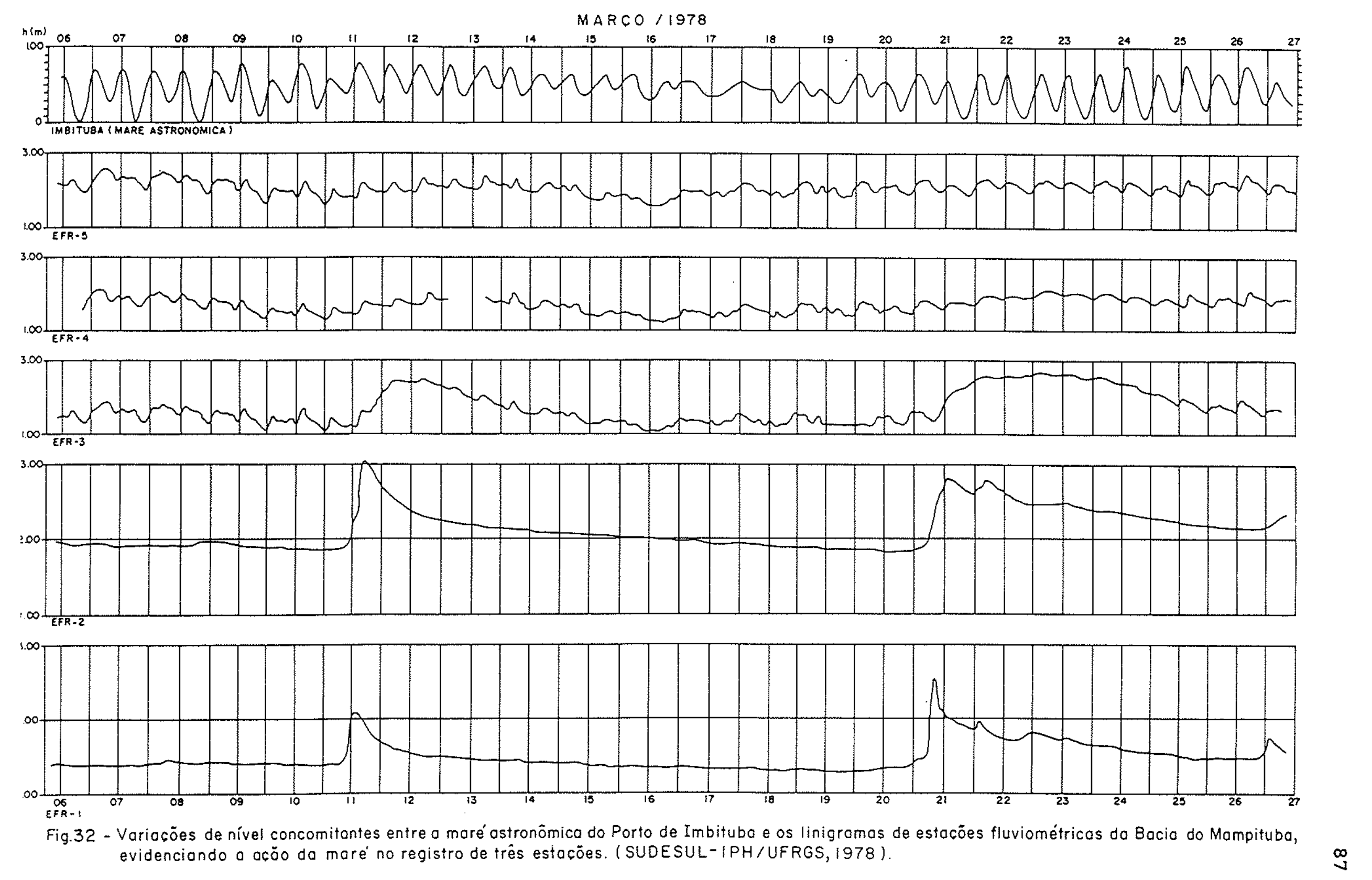




\section{OS DEPÓSITOS SEDIMENTARES}

\subsection{A MORFOLOGIA DOS DEPÓSITOS}

Os depósitos que ocorrem nos dois setores da área estudada são continentais, de leques aluviais, lacustres e eólicos. Ocorrem, também, em diferentes altitudes, depósitos transicionais (ambientes mistos), tais como estuarinos e lagunares, além dos praiais de várias idades.

No Setor Norte cobrem maior superfície os depósitos de leques aluviais, seguidos pelos depósitos de ambientes mistos praiais, lagunares e estuarinos, porém também chamam a atenção os depósitos eólicos pleistocênicos (Figura 33 no encarte).

No Setor Sul os depósitos de ambientes mistos ou transicionais são os que ocupam maior área, principalmente os paleopraiais. Os depósitos de leques aluviais e os de origem lacustre também são importantes em área, sem considerar-se os mais de $50 \mathrm{~km}^{2}$ da Lagoa do Sombrio (Figura 34 no encarte).

Depósitos marinhos com dezenas de metros de espessura, podem ocorrer em subsuperfície a leste das lagoas do Sombrio e Caverá, pois ali o embasamento está até a pouco mais de $100 \mathrm{~m}$ de profundidade.

As formas dos vários tipos de depósitos aflorantes na área foram ou estão sendo geradas tanto por processos deposicionais como por processos erosivos. 
Os diques marginais são formas de depósitos fluviais, com a menor expressão areal nos dois setores. Constituem elevações assimétricas, alongadas e descontínuas ao longo de trechos dos rios Canoas, Sertão, Itoupava, Araranguá e do baixo Mãe Luzia, sobressaindo-se altimetricamente dos terrenos da planície mais interna. Situamse entre esta e o canal fluvial. Seu perfil topográfico transversal é assimétrico, sendo mais abrupto junto ao rio e com declividade muito menor para dentro da planície de inundação (Figuras 5 e 6 no encarte).

Áreas com morfologia plana e inundáveis existem nas laterais dos baixos cursos dos rios Mampituba e Araranguá, porém não devem ser consideradas planícies de inundação, uma vez que não se originaram pela deposição fluvial, mas constituem-se de depósitos estuarinos. Os depósitos lagunares, estuarinos e lacustres têm seus topos com forma plana ou muito levemente côncava para cima.

Os depósitos de cristas praiais mais antigos ainda apresentam suas características de sucessão de arcos praiais, com topografia de cristas e depressões, ou calhas, paralelas ou subparalelas, morfologia esta gerada ao tempo da deposicão. Acham-se modificados em alguns trechos pela ação erosiva fluvial, seja de grandes rios seja de pequenos cursos de águas cujas nascentes estão sobre os próprios depósitos praiais. Situações de distintos níveis de mar colaboraram na dissecação dessas cristas (Figuras 33 e 34 no encarte).

As cristas praiais a leste das lagoas apresentam, como as anteriores, seqüências de cristas e depressões justapostas, porém, em trechos, acham-se remobilizadas por ação eólica ou mesmo cobertas por depósitos eólicos.

Cristas praiais também são observadas ao longo dos maiores corpos de água, possivelmente geradas por ondas dos corpos lacustres.

O arco praial atual, muito regular, apresenta apenas uma interrupção devida à foz do Rio Araranguá. Entretanto, este arco recebe variados nomes ao longo do seu comprimento, em razão dos pequenos aglomerados de pescadores ou de loteamentos vicinais. 
A atividade eólica na área gerou e gera formas devidas à sua dinâmica de deposição e erosão. As formas antigas dos depósitos eólicos, possivelmente de várias idades, são mantidas pela vegetação e são as mais altas no leste dos dois setores. Os depósitos eólicos atuais situam-se numa faixa paralela e imediata à linha de costa atual.

\subsubsection{LEQUES ALUVIAIS}

Leque aluvial é um depósito fluvial cuja feição topográfica é de um leque, mais ou menos desdobrado, que se desenvolve a partir do sopé de uma elevação montanhosa, irradiando-se a partir de um ponto onde o rio deixa a área montanhosa, espalhando-se para jusante. Ele faz parte de um sistema de erosão-deposição (BULL, 1968), isto é, há uma área fonte de sedimentos onde estes são reunidos pelas águas da chuva ou de derretimento de neve nos vários tributários e levados para um canal que os transfere para uma zona mais baixa, onde vai ocorrer a sedimentação. Há, portanto, uma zona onde predomina a erosão, outra onde predomina o transporte e aquela onde predomina a deposição.

De acordo com BULL (1968), McGEE, em 1891, declarou que o uso da expressão leque aluvial, neste sentido, foi feito pela primeira vez por HAAST, em 1864. Após este, também DREW (1873) a aplicou na bacia do Indus. GILBERT a usou em 1882, quando tratou do Lago Bonneville, e ECKIS, em 1928, quando estudou leques aluviais na Califórnia Meridional. Desde então outros a utilizaram, e desde o século passado a expressão tem sido aplicada à mesma forma e depósito construído sob condições climáticas diferentes.

Autores também o tem referido com a forma de um cone (VEYERET, 1941; DESIO, 1949; BULL, 1968; BEAUMONT, 1972; BLISSENBACH, 1954), de segmento de cone (BULL, 1964, 1968), de cone chato (DREW, 1873), de $1 / 4$ de cone baixo (BEATY, 1970), ou conóide (DESIO, 1949). Estes autores não estabelecem nenhuma diferença entre cone e leque aluvial. 
$\mathrm{Na}$ área estudada este tipo de depósito ocorre nos dois setores onde uma série de leques irradiam-se do sopé da escarpa da Serra Geral para o leste, coalescendo lateralmente. No Setor Norte cobrem mais de $700 \mathrm{~km}^{2}$ estando unidos os leques dos rios Manoel Alves e Jundiá, do Amola Faca que reúne o Molha Coco, o Rocinha e o Figueira, do Pinheirinho, do da Pedra e Itoupava. Mais para leste e proveniente do norte, de fora da área estudada, há depósitos relacionados aos leques dos rios do Cedro, Mãe Luzia e Sangão. E no Setor Sul estes depósitos cobrem cerca de $150 \mathrm{~km}^{2}$, distribuídos nos leques dos rios Bonito e Leão, Sanga da Ripa, Cachoeira, Três Irmãos, Malacara ou Macaco, Molha Côco, Pavão e Mampituba (Figuras 33 e 34 no encarte).

Os leques são divididos em três faixas ou zonas que se sucedem a partir do seu ápice até os depósitos mais distantes da fonte. Elas constituem a zona proximal à qual pertencem o ponto de irradiação do depósito chamado de ápice do leque e a cabeça do leque, a zona mediana e a zona distal.

No extremo sul de Santa Catarina, os leques têm parte da zona proximal ou cabeça do leque estendida e confinada dentro dos vales, isto é, constituem o que foi denominado de fan-bay por W.M. DAVIS, em 1938 (apud BLISSENBACH, 1954). Esta situação é melhor observada em todos os leques do Setor Norte, onde os alargamentos dos vales são maiores que no Setor Sul. Dominam nos dois setores os depósitos proximais e medianos dos leques aluviais. Há pouca representação dos depósitos distais. Os leques coalescem na parte que está sendo considerada como sua zona mediana.

Os raios dos leques aluviais do extremo sul catarinense variam de $7.250 \mathrm{~m}$, no leque do Rio Malacara ou Macaco, no Setor Sul, a 34.000 m, no do Rio da Pedra, no Setor Norte. Na literatura são citados raios de poucas centenas de metros (BEAUMONT, 1972), de uma milha, no leque do Tigar, na índia (DREW, 1873); de três a $30 \mathrm{~km}$ (BOOTHROYD \& NUMEDAL, 1982), até $48.270 \mathrm{~km}$ (DAVIS Jr.,1983). BLISSENBACH (1954) afirma que os raios de um leque aluvial podem ter de $152 \mathrm{~m}$ nos leques das Black Hills, Arizona, a $6,5 \mathrm{~km}$ nas Montanhas Catalina, também no Arizona, podendo, entretanto, alcançar mais de $60 \mathrm{~km}$. 
Os perfis longitudinais dos leques aluviais da área mostram-se levemente côncavos para cima, porém também poder-se-ia dizer que se constituem de vários segmentos retilineos. Cada raio que se medir nas várias direções do leque não terá os mesmos comprimentos dos segmentos dos outros. Ora mostrará maior concavidade ora menor. Este fato salienta-se no exame das curvas de nivel, em folhas topográficas em escala de 1:10.000.

Suas larguras ainda nos trechos considerados proximais variam de $4 \mathrm{~km}$ a $7 \mathrm{~km}$ no Setor Norte, e $1,5 \mathrm{~km}$ a $3 \mathrm{~km}$ nos leques do Setor Sul. Os depósitos das zonas medianas dos leques estão coalescidos, atingindo uma largura de norte a sul, de $15 \mathrm{~km}$ no Setor Sul, e cerca de $42,5 \mathrm{~km}$ no Setor Norte, de nordeste a sudoeste. Medidas transversais dos leques têm sido citadas com valores de $3 \mathrm{~km}$, em leques coalescidos na margem esquerda do Indus, na índia (DREW, 1873); de $4 \mathrm{~km}$ nos leques de Minel Creek, White Mountains, EUA, (BEATY, 1970); e de 19 a $30 \mathrm{~km}$, em leques coalescentes do oeste de Fresno County, na Califórnia (BULL, 1962, 1964).

As espessuras conhecidas nos leques dos setores Norte e Sul são variáveis. No Setor Sul as medidas até o embasamento são mais numerosas devidos aos estudos realizados pela SUDESUL. Ali o que se conhece evidencia que na zona proximal dos leques a espessura pode variar de $0 \mathrm{~m}$ a $30 \mathrm{~m}$. Na área de Costão Novo, a oeste da localidade de Cachoeira, município de Praia Grande, no leque do Rio Cachoeira, verifica-se lado a lado, tanto formas lobadas de leques aluviais quanto formas convexas sobre o Arenito Botucatu, com desniveis de 6 a $8 \mathrm{~m}$ e altitudes em torno de 80 a $90 \mathrm{~m}$. Entretanto, pouco mais ao norte, no eixo projetado da barragem do Rio Leão, os depósitos de leque apresentam-se com espessuras de $12 \mathrm{~m}$ e na do Rio Bonito, de até $18 \mathrm{~m}$. Para o sul, na área do fan-bay do leque do Rio Mampituba, as espessuras chegam a $30 \mathrm{~m}$.

Valores de espessura de leques de várias regiōes têm sido apresentados : cerca de $165 \mathrm{~m}$ no leque de Tigar, na Índia (DREW, 1873); $275 \mathrm{~m}$ no leque do Rio Jaj, no Irã (BEAUMONT, 1972), $338 \mathrm{~m}$ no leque de Minel Creek, na Califórnia, EUA, (BEATY, 1970), $30 \mathrm{~m}$ no leque de Umberumberka, em New South Wales, na Austrália e BLISSENBACH 
(1954), citando ECKIS, diz que os leques aluviais podem ter mais de $300 \mathrm{~m}$ de espessura, sendo as maiores espessuras no ápice. Entretanto, também afirma que, sob certas condições, um depósito de leque aluvial pode ser mais espesso na sua área distal do que no ápice, como é o caso do leque das Montanhas Santa Catalina, no Arizona. Nele as espessuras crescem de 0 a $30 \mathrm{~m}$, no ápice para 60 a $90 \mathrm{~m}$ na área distal.

O leque pode perder a individualização de sua forma pela coalescência lateral de dois ou mais leques. BLISSENBACH (1964) chama esta forma de leque aluvial composto e diz que é equivalente à encosta aluvial de piedmonte e à bajada. BULL (1968) também lembra que leques menores podem ter sua forma descaracterizada ou restringida por leques adjacentes maiores. Porém, para este autor, quando não se define mais a forma de um ou vários leques coalescentes, a forma constitui-se então em um avental aluvial (alluvial apron) ou encosta aluvial (alluvial slope).

GARY et al. (1972) apresentam, para a forma gerada pela coalescência lateral de uma série de leques aluviais individuais, mas confluentes, o nome de bajada, que é sinônimo de avental de leque (fan apron). Trata-se de uma ampla encosta aluvial (alluvial slope) contínua, ou superfície de detritos, inclinada suavemente para dentro e em torno de uma bacia, tendo um caráter ondulante devido às convexidades dos leques componentes.

Estes autores esclarecem, ainda, as diferenças entre pedimento e bajada. Esta é uma superfície gerada por deposição, ao passo que o pedimento é uma superfície de erosão que se assemelha à bajada na forma da mesma. Apresentam como sinônimo de bajada as seguintes palavras ou expressões: bahada, apron, alluvial apron, debris apron; fan apron, mountain apron, compound alluvial fan, aluvial plain, waste plain, piedmont plain, piedmont slope, gravel piedmont e alluvial bench. Vê-se que faltam muitas discussões para se homogenizar referências. Para os leques aluviais em questão, talvez seja melhor falar-se apenas em leques coalescidos ou mesmo avental de leque, até a nomenclatura tornar-se mais precisa.

Salienta-se que bajada ou bahada é terminologia relativa a ambiente desértico. 
Acredita-se que a área de um leque pode ser influenciada por vários fatores, porém vêem-se leques com apenas alguns decímetros, obtidos inclusive em laboratório, até com extensões cuja forma não é abrangida com apenas uma visada, e que, portanto, poderão ser delimitados apenas mediante fotografias aéreas.

BULL (1968) apresenta como variáveis mais importantes que afetam a área do leque a litologia da bacia de drenagem, o clima, a história tectônica e o espaço disponível da bacia receptora dos sedimentos.

Este autor afirma que na Califórnia os leques que têm argilitos nas áreas-fonte são duas vezes maiores que os derivados de arenitos e também são os mais espessos, considerando-se o mesmo tempo para a produção dos sedimentos. $\mathrm{O}$ autor atribui este fato à maior erodibilidade dos argilitos e folhelhos. A superficie dos leques derivados de áreas-fonte constituídas de argilitos apresentam, em geral, o dobro do tamanho de suas áreas-fonte, ao passo que áreas-fonte constituídas de quartzito geram leques com $1 / 5$ do tamanho das mesmas.

O clima, como outro fator coadjuvante das conformações dos leque, é discutido por BLISSENBACH (1954) que considera que leques mais achatados e com gradientes moderados ocorrem em ambientes úmidos, com abundância de água corrente, mais do que nos ambientes áridos. Nestes, para este autor, os leques aluviais são mais conspícuos, porque as condições áridas e semi-áridas são mais favoráveis ao seu desenvolvimento.

Essas explicações são muito sucintas, necessitando de maiores detalhes. Como já foi mencionado anteriormente, leques são encontrados em vários tipos de clima, e sob condições úmidas são gerados ao longo dos Alpes, dos Himalaias, no Japão e no Canadá, bem como nas regiões Árticas da Escandinávia e do Canadá, entre outras condições climáticas. Os registros pluviométricos, em muitas áreas do globo são precários, porém na Califórnia Meridional, ECKIS (apud BLISSENBACH, 1954) registrou precipitação pluviométrica anual de $431 \mathrm{~mm}$, e no Arizona esta varia de $254 \mathrm{~mm}$ a $482 \mathrm{~mm}$. No chamado Distrito de Sonora (McGEE, 1986 apud Blissenbach, 1954), ela pode alcançar $381 \mathrm{~mm}$ a $508 \mathrm{~mm}$, na Sierra Madre, nos sopés raramente 
chega a $254 \mathrm{~mm}$, ao passo que no interior a média cai abaixo de $127 \mathrm{~mm}$ e pode não ser superiores a $50 \mathrm{~mm}$ ou $76 \mathrm{~mm}$. Esses dados são elementos de comparação e também podem sugerir condições de sedimentação e geração de formas em climas semi-áridos. Porém, são ainda insuficientes pois não esclarecem sobre o regime dessas precipitações. Não se está levando em conta, ainda, a maior ou menor infiltração ou, a maior ou menor evaporação e quais as condições para que estas ocorram. As descrições de McGEE (1897), no próprio Distrito de Sonora e sopés da Sierra Madre, mostram que chuvas rápidas e concentradas promovem principalmente cheias em lençol (sheetflood) de areias finas que cobrem áreas relativamente extensas e com declividade perto da horizontal.

Por outro lado, as superfícies dos leques aluviais têm sido evidenciadas em fotos de muitas dessas formas e corpos. O que se observa é o que também tem sido afirmado por BLISSENBACH (1954) nos seus estudos sobre leques de áreas de clima semi-árido e árido, isto é, estas superfícies mostram sistemas de canais distributários que irradiam a partir do canal principal ou canal tronco, no ápice do leque. Esses canais se entrelaçam ao longo de todo o leque e não apenas na parte basal ou na área da bajada. São eles os distributários num sistema entrelaçado (braided). Segundo este autor, eles são rasos ou muito pouco encaixados na superfície do leque, quando em fase de deposição. Canais mais estreitos e profundos tendem a se formar em situações de degradação do leque ou de menor oferta de carga, porém com fluxo de água maior ou mais freqüente. Mas a natureza permeável do leque leva à diminuição da água corrente e, portanto, ao mais lento preenchimento do canal, ou mesmo a chegada de material entulhando o canal-tronco, na área do ápice, leva também ao retorno das condições de entrelaçamento dos distributários.

$\dot{E}$, portanto, uma forma dominantemente deposicional, com baixa inclinação, que se irradia a partir de um ponto no sopé de terreno escarpado, abrindo-se lateralmente, como um leque. Este ponto vai constituir o ápice do leque e o ponto mais alto da forma deposicional, ao mesmo tempo que é o mais baixo de uma área fornecedora de detritos que também é radiada para cima pela ação erosiva dos tributários. 
O leque nada mais é, então, do que uma feição de um sistema duplo erosivo-deposicional. Esta se configura por uma bacia hidrográfica cujas nascentes e parte de sua rede situam-se em áreas elevadas que constituem o substrato sob erosão. Estes cursos de água reúnem-se em um tronco ou leito comum, ainda em declive acentuado, mas já próximo ao sopé da elevação. Neste local, onde ocorre a mudança de gradiente, acontece a deposição por perda de competência das correntes ou fluxos. Trata-se de área significativamente mais baixa em relação às montanhas, e de baixo gradiente topográfico. Após a passagem por este leito comum, as águas e os sedimentos se espalham, pois não há mais o confinamento às paredes rochosas, formando então o leque. Esta dispersão vai permitir o desenvolvimento do padrão de canal braided.

Leques aluviais do Cenozóico, ainda com sua forma exposta subaereamente, são observados e têm sido estudados em vários Estados dos Estados Unidos como no Texas, Califórnia, Arizona, Novo México, Nevada, Wyoming, Alasca, lowa; em Estados do Canadá como Alberta e Colúmbia Britânica; e em outros países como na Índia, Austrália, Espanha, Argentina, Israel, Península do Sinai, Vale do Arava entre Israel e Jordânia, Irã, Afeganistão, Suécia, Nova Zelândia, Tasmânia, Papua, Nigéria, muitos deles ainda em desenvolvimento.

Leques ativos nas Américas, são referidos desde o Canadá Ártico até o sul da Argentina, incluindo o Brasil, com a referência feita no Rio Grande do Sul, relacionados a vários tipos de clima, como já se pode notar pelas ocorrências em muitos países citados no parágrafo anterior.

Leques aluviais têm sido registrados no Brasil, na grande maioria dos Estados, por literatura especializada nos campos de conhecimento da Geologia e Geomorfologia, no intervalo de tempo entre o Proterozóico e o Cenozóico. Os trabalhos geológicos apresentados até agora no Brasil visam principalmente a caracterização dos sedimentos, não havendo descrições de formas. A forma é apenas sugerida pelo nome leque, cone de dejeção ou em desenhos estilizados. 
Os trabalhos mais antigos com enfoque geomorfológico parecem ser os de MARTONNE (1944) e de RUELLAN (1944).

Em Santa Catarina, leques ativos são citados rapidamente, sem nenhuma descrição geológica ou geomorfológica nos trabalhos da Bacia do Paraná-Borda Leste (GUAZELLI \& FEIJÓ, 1970).

Os depósitos e formas correspondentes aos leques aluviais situam-se no sopé da escarpa da Serra Geral, aproximadamente entre menos de $20 \mathrm{~m}$ até $200 \mathrm{~m}$. Cobrem uma superfície contínua de aproximadamente $800 \mathrm{~km}^{2}$ no Setor Norte e cerca de $160 \mathrm{~km}^{2}$ no Setor Sul, em Santa Catarina (Fotos 6 a 8).

\subsubsection{Morfologia dos Leques Aluviais no Setor Norte}

Os leques do Setor Norte são diferenciados dos do setor Sul pelo tamanho bem maior que aqueles, pois têm largura e raios bem maiores, a coalescência já ocorrendo em altitudes entre 100 e $200 \mathrm{~m}$, como é o caso dos leques formados pelos rios Rocinha, Amola Faca e Molha Coco; as áreas de coalescência em cotas mais baixas são também muito maiores que nos leques do Setor Sul. A área mediana constitui um avental de leque entre 20 e $40 \mathrm{~m}$, sendo larga e contínua, havendo a coalescência de todos os leques do Setor. Esta morfologia se estende em cotas abaixo de $20 \mathrm{~m}$ e com superfície maior que a do Setor Sul (Figuras 33, 34 e 35, no encarte).

O controle do nível do oceano, nivel de base da erosão, sobre as morfologias e os sedimentos aflorantes dos leques é evidenciado pelas distâncias entre a cota de 20 $m$ nestes depósitos e o oceano, que são comparáveis nos dois setores. O Setor Norte, mais amplo e onde os depósitos de leques aluviais cobrem maior área, tem então sua cota de $20 \mathrm{~m}$ à mesma distância do oceano que a equivalente no Setor Sul.

Este fato sugere que os leques ou são muito antigos e originados sob quaisquer condições no passado, ou são ainda ativos. Se são leques do passado, o nível marinho maior ou menor possibilitou a situação eqüidistante desses leques dos dois setores. No 
segundo caso, o agente formador dos leques, isto é, os fluxos de água reunidos nas escarpas e também no planalto, continuam a agir e são controlados pelo nível marinho.

Assim se explicaria porque as formas de parte de áreas distais dos leques estão em cotas abaixo de $20 \mathrm{~m}$, ao passo que bem mais a leste há depósitos arenosos praiais e eólicos acima desta cota. Estas últimas não foram erodidas ou rebaixadas totalmente porque, ou são formas mais novas, ou dentro de sua área relativamente baixa não se originam fluxos de água competentes para rebaixá-las. Assim, estas puderam ou podem ser erodidas de maneira mais efetiva, por agentes que ajam lateralmente e não sobre elas, a partir dos seus topos. Esses agentes poderiam ser marinhos, em nível mais baixo que as mesmas e bem mais alto que o atual, ou fluvial também controlado por nível marinho mais alto que o atual.

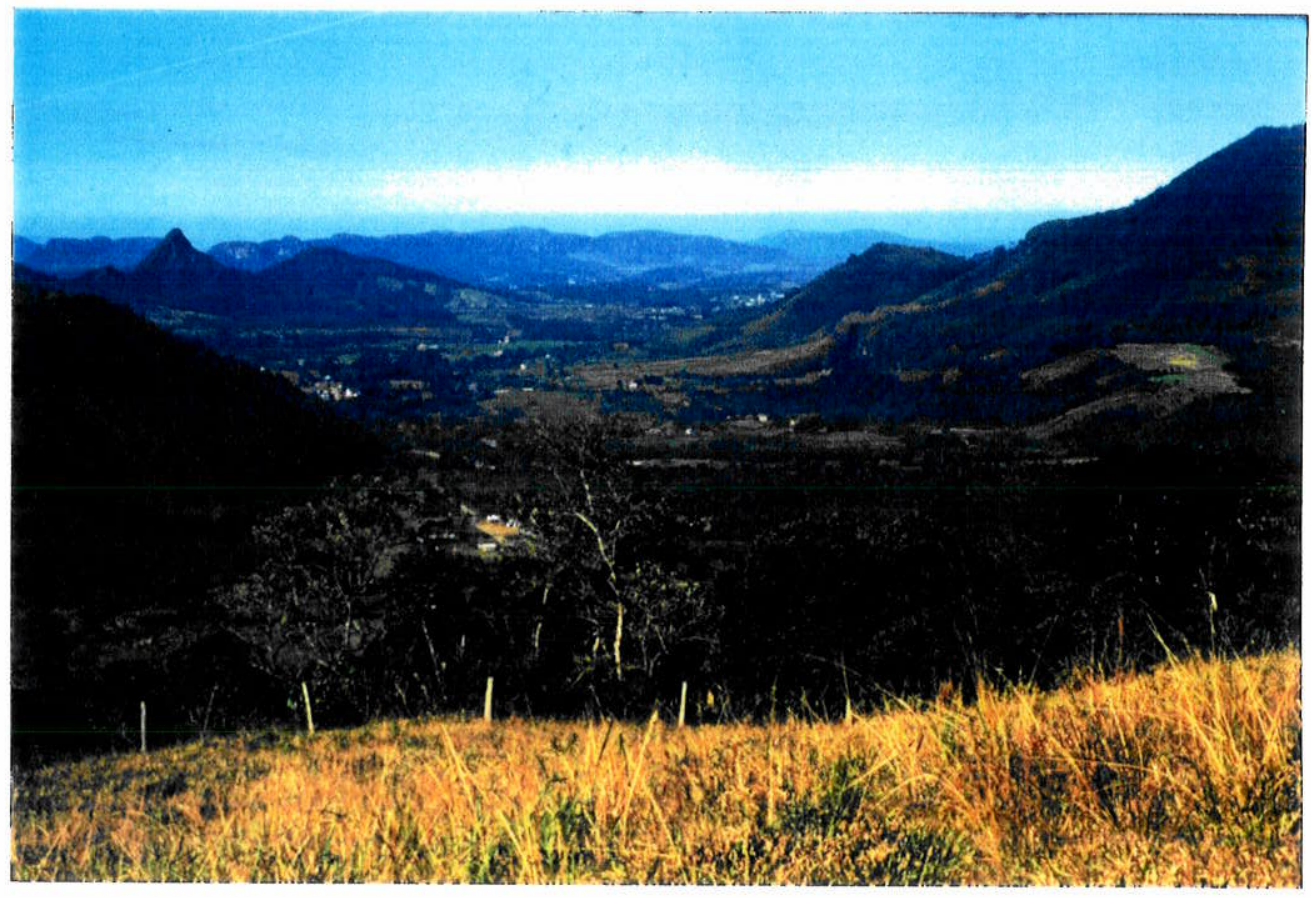

Foto 6 - Visada da Serra da Rocinha (Serra Geral) para E/SE, vendo-se as elevações laterais ao fan-bay do Rio Rocinha, um dos que formarão o leque composto dos rios Rocinha/Molha Coco/Amola Faca. Notam-se as localidades de Rocinha, Belmira e parte de Timbé sobre a morfologia mais baixa que corresponde aos depósitos rudáceos do ápice ou cabeça do leque. 


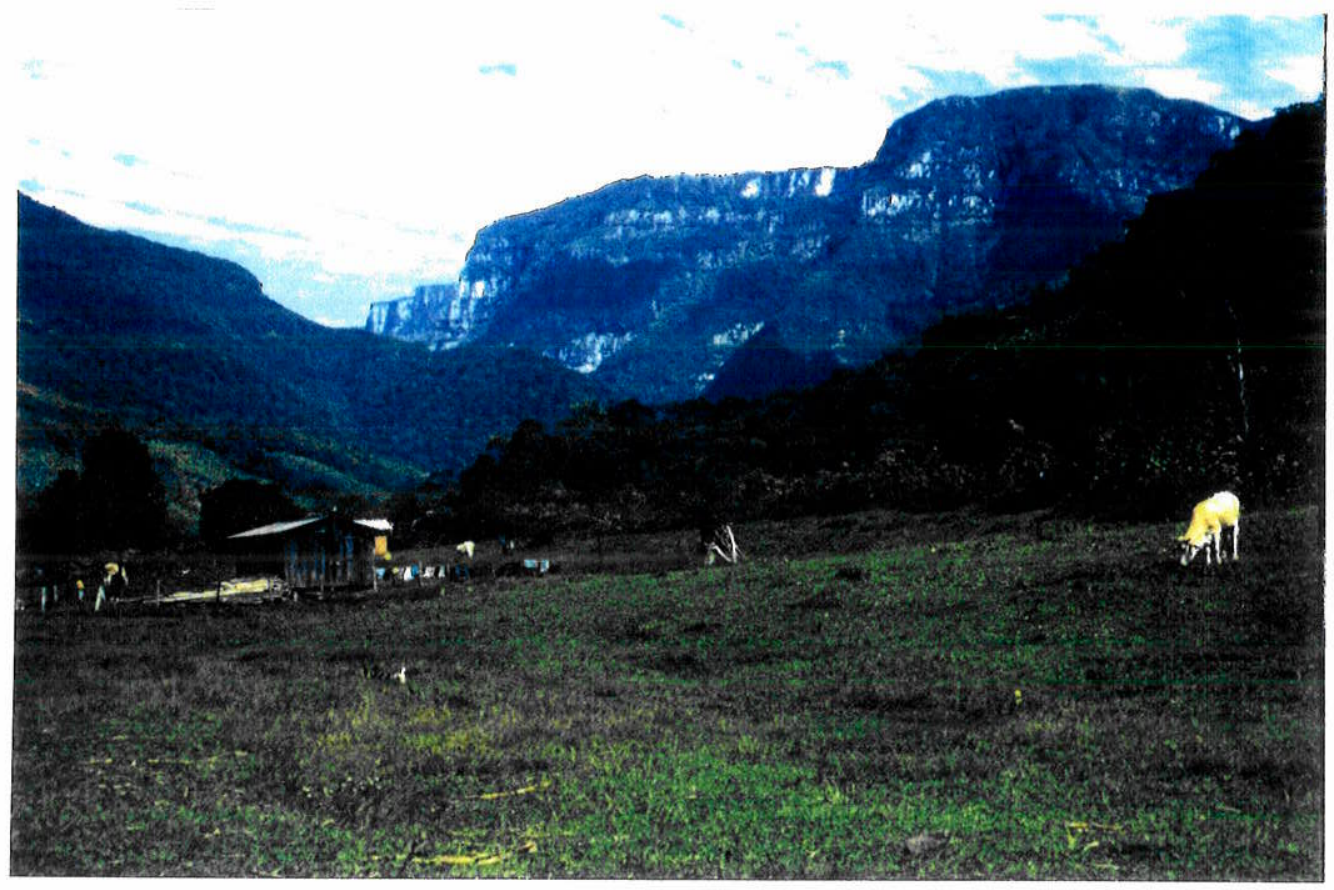

Foto 7 - Vista da escarpa da Serra Geral e das formas inclinadas do sopé, no leque do Rio da Pedra. Raras vezes percebe-se a inclinação como neste caso. Foto batida para a "Serra" a oeste da Escola Isolada Tigre Preto, Município de Jacinto Machado.

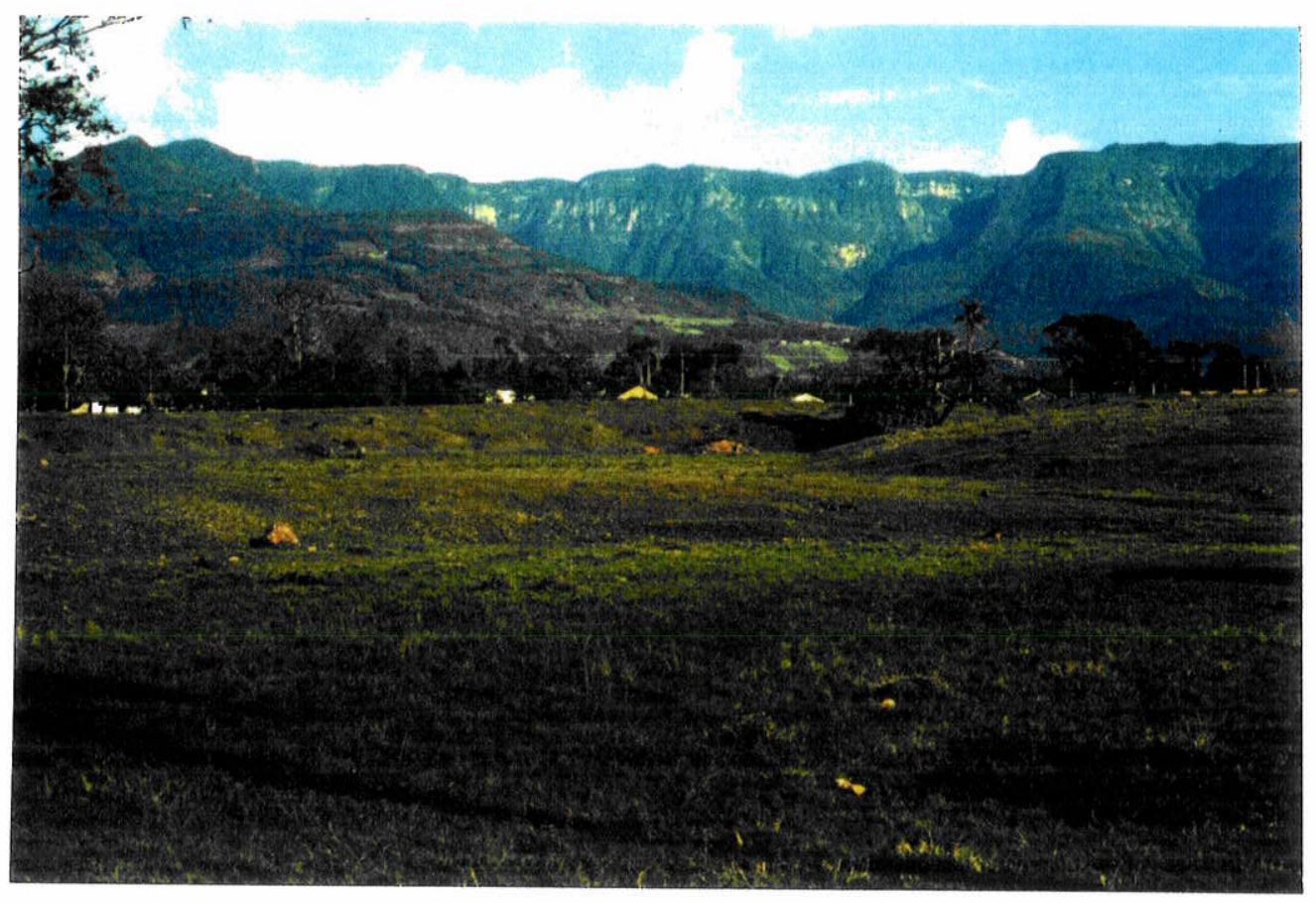

Foto 8 - Vista mais ampla da escarpa da Serra Geral, e, na metade inferior da foto, as formas convexas e lobadas de leque mediano. Visada para oeste pouco a norte e Praia Grande. 
Notam-se depósitos mais finos nas extremidades inferiores do leque, que se encontram dissecados, perdendo sua continuidade e constituindo formas isoladas. As formas maiores ainda apresentam os topos planos como continuidade da forma do leque, sendo característica herdada, e as formas menores têm topos convexos (Foto 9). Encontram-se em cotas abaixo de $20 \mathrm{~m}$ apenas na margem esquerda do Rio Araranguá e do Itoupava. Nesta margem eles são encontrados na área do baixo curso do Rio Jundiá, afluente do Itoupava, e para leste até junto à cidade de Araranguá. Na sua extremidade oeste eles podem estar interdigitados com os depósitos rudáceos e mesmo recobrindo-os.

O leque mais ao sul no Setor Norte está ligado ao Rio da Pedra que nasce no planalto e tem a primeira parte do seu vale na escarpa até $200 \mathrm{~m}$ de altitude, com forte orientação estrutural, com direção SW-NE. Esta direção geral é seguida pelo canal principal da bacia.

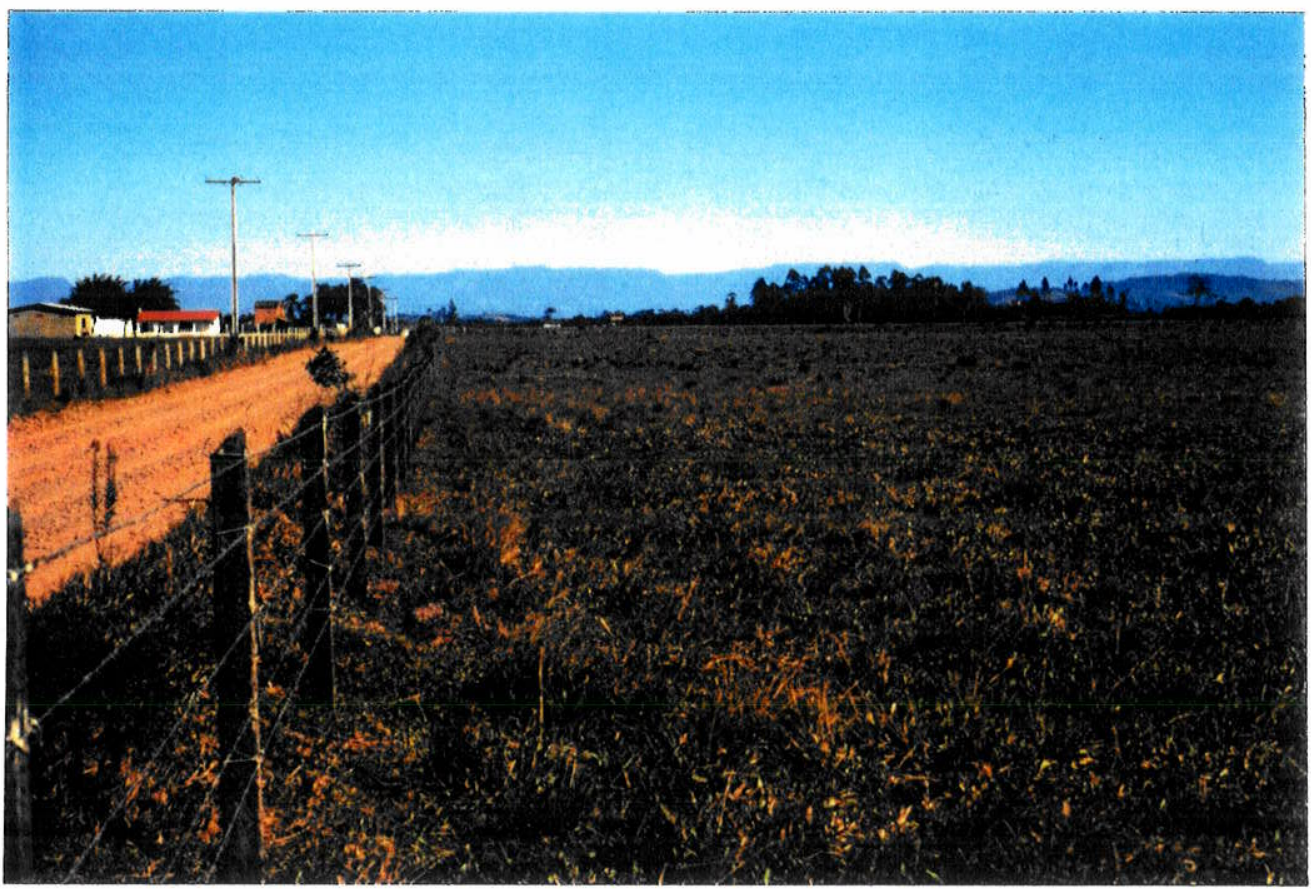

Foto 9 - Forma plana do topo dos depósitos de leque distal, ao sul de Sapiranga, entre esta cidade e o Rio Itoupava/Araranguá, a oeste do Rio Jundiá e perto da sua foz. 
Este leque é mais estreito e confinado que os que se situam a norte. As rochas-fonte principais são o basalto e o Arenito Botucatu. Por outro lado, os seus tributários nascem não apenas na escarpa, no quadrante $W$, mas também no sul, na área do esporão-interflúvio. Entre os mais significativos tributários tem-se o Rio Engenho-Velho e seus afluentes e o Rio Dois Irmãos. A contribuição sedimentar deste último é feita principalmente com areias do Arenito Botucatu. A declividade do leque do Rio da Pedra é inferior a $1^{\circ}$ entre $140 \mathrm{~m}$ e $20 \mathrm{~m}$ de altitude, diminuindo para $30^{\prime}$ entre 50 $\mathrm{m}$ e $20 \mathrm{~m}$. A área deste leque, incluindo o trecho até ltoupava, é de cerca de $140 \mathrm{~km}^{2}$.

Após este leque há o do Rio Pinheirinho e seus tributários, os rios de Dentro, Honório, do Cedro, de Fátima, que geram depósitos que coalescem entre $40 \mathrm{~m}$ e 60m de altitude. As águas e os sedimentos vão se dispersar no sopé, formando-se múltiplos canais distributários que, entre $40 \mathrm{~m}$ e $20 \mathrm{~m}$, vão se juntar com os do Rio da Pedra.

A inclinação do leque do Rio Pinheirinho é semelhante à do Rio da Pedra, considerando-se o seu desenvolvimento entre $120 \mathrm{~m}$ e $14 \mathrm{~m}$ de altitude, numa área de aproximadamente $60 \mathrm{~km}^{2}$. Para norte coalesce com o sistema do Rio Amola Faca.

O sistema do Rio Amola Faca constitui um leque bem maior. Seus tributários principais geram depósitos que coalescem entre $200 \mathrm{~m}$ e $100 \mathrm{~m}$ de altitude. Funcionam como fan-bays individuais (Foto 6) que reúnem águas e depósitos de uma ampla área da escarpa. Esta área de tributários tem uma disposição radiada na escarpa, uma vez que há nascentes de SW até $\mathrm{N}$.

Pelas condições de contribuição fazem-se referência aos rios Figueira, Serra Velha I e II /Rocinha e ao Molha Coco/Amola Faca. Os seus depósitos vão sendo reunidos a jusante, numa faixa de cerca de $7 \mathrm{~km}$ de largura, que começa a se ampliar da cota de $60 \mathrm{~m}$ para baixo. Neste trecho o entrelaçamento do Amola Faca é acompanhado paralelamente, tanto a nordeste como a sudoeste, por outros canais que vão terminar por se reunir primeiramente a outros ou no canal do Rio da Pedra/ltoupava. Entre as cotas de $40 \mathrm{~m} \mathrm{e}$ 20 m, o Rio Amola Faca amplia a área de seu entrelaçamento, que após dividir-se em três canais, vai desaguar no Rio da Pedra/ltoupava, a oeste de Ermo. O ângulo de junção ou 
desagüe é relativamente baixo, o que lembra a continuação do entrelaçamento da rede de cursos de água.

A inclinação dos leques na área dos fan-bays, entre $225 \mathrm{~m}$ e $130 \mathrm{~m}$ de altitude é de $1^{\circ}$ apenas, diminuindo em trechos de cotas mais baixas, principalmente abaixo de $45 \mathrm{~m}$.

Geologicamente este leque não é tão complexo quanto geomorfologicamente. Trata-se, portanto, de um leque com três fan-bays, isto é, três ápices de leque dentro de vales distintos, que se reúnem, ainda numa área confinada de vale, em altitude acima de $100 \mathrm{~m}$. Nesta altitude o vale é bastante largo e contém depósitos de fácies proximal. A forma se alarga pouco no leque mediano, abrindo-se a partir da cota de $60 \mathrm{~m}$. Coalesce com outros laterais aproximadamente em 40 m de altitude. Sua área aproximada é de 176 $\mathrm{km}^{2}$.

A nordeste do anterior e paralelamente a ele, há uma situação semelhante, porém, em altitudes mais baixas. Novamente três fan-bays cujos fluxos maiores de drenagem subaérea constituem os rios Jundiá, Manoel Alves e Morto.

Os fan-bays do Jundiá e do Manoel Alves coalescem já entre $140 \mathrm{~m}$ e $100 \mathrm{~m}$ de altitude, sendo separados a jusante pela elevação do Morro Grande. Coalescem novamente a partir de $60 \mathrm{~m}$ para baixo, onde também se juntam os sedimentos do leque do Rio Morto. Este último irá desaguar no Rio Manoel Alves, ao passo que o Rio Jundiá é tributário direto do Itoupava/Araranguá, recortando os sedimentos de leque até junto a sua foz. A inclinação deste leque é semelhante à verificada nos anteriores, isto é, menos de $1^{\circ}$. Sua área aproximada é de $212 \mathrm{~km}^{2}$.

Estes canais com os outros mais importantes do Setor Norte reúnem muitos outros com nascentes tanto nas elevações como na área aluvial, seja na área proximal seja na área de coalescência dos leques. Nomes como Rio do Meio, Rio Seco, Rio Turvo, Rio Morto e Sanga Perdida lembram a situação de bifurcações, mudança de curso, entulhamento, diminuição do fluxo da água, enfim entrelaçamentos típicos de leques.

$\mathrm{Na}$ seqüência para o norte, acompanhando a disposição dos leques em anfiteatro, situa-se, após estes nomeados, a área drenada pelo Rio do Cedro e pelo Mãe Luzia. Aquele é afluente deste. 
O limite Norte de $28^{\circ} 45^{\prime}$ LS, considerado para a área de estudo, trunca os leques aluviais designados por esta toponímia, fazendo com que nesta se situem apenas as partes distais com cotas dominantemente abaixo de $40 \mathrm{~m}$, com uma multidão de canais que acabam se reunindo no Mãe Luzia, até junto a sua confluência com o Rio Itoupava, para formar o Araranguá. É a área do avental do leque, onde ocorre, a coalescência com os demais.

Embora as cotas entre $20 \mathrm{~m}$ e $40 \mathrm{~m}$, e mais baixas, se caracterizem pela coalescência de todos os leques do Setor Norte, a área entre os rios Manoel Alves e Mãe Luzia é a mais ampla, tanto em largura quanto em raio, e compreende cerca de $176 \mathrm{~km}^{2}$.

\subsubsection{Morfologia dos Leques Aluviais no Setor Sul}

O mapa geomorfológico deste Setor mostra a área e a disposição dos leques aluviais (Figura 34, no encarte).

Dos rios do Setor Sul anteriormente citados, os que geram leques são o Rio Pavão; os rios Molha Coco e o Malacara ou Macaco que constituem um outro leque coalescendo com aquele onde flui o Rio Três Irmãos; o Rio Cachoeira e afluentes formam um outro, e, mais para o norte, há a área do leque da Sanga Molha Rabo e Rio Leão. A área do Rio Bonito, embora apresente depósitos rudáceos, não apresentava morfologia de leque e hoje situa-se sob um lago criado pela barragem desse rio. Mais para o norte, afluentes do Rio Bonito e outros cursos de água como o Sanga da Areia e do Barro Preto, provenientes da área do esporão-interflúvio, não apresentam leques como a oeste. Este divisor de águas é relativamente baixo e com superfície restrita, não favorecendo as condições hidráulicas para erosão e acúmulo de material sob a forma de leque.

O leque do Rio Pavão é bastante individualizado, pois não tem condições para coalescer lateralmente (Figura 36, no encarte), ao passo que os que se situam mais ao norte coalescem nas altitudes entre 40 e $60 \mathrm{~m}$, e aqueles entre a localidade de São Brás e Rio Leão já se unem a partir dos $80 \mathrm{~m}$ de altitude. Eles coalescem lateralmente, 
a partir dessas altitudes até a cota de $10 \mathrm{~m}$ ou menos. A coalescência dos leques, neste Setor Sul, principalmente na área abaixo da cota de $40 \mathrm{~m}$, constitui, do ponto de vista morfológico, avental de leque.

Em razão da dinâmica de deposição e erosão que caracterizam os leques aluviais, visualiza-se em campo como nas fotografias aéreas o padrão entrelaçado, tanto porque são freqüentemente canais múltiplos como também porque há a migração de canais. Existem canais ou trechos de canais cobertos com gramíneas, portanto, sem fluxo freqüente de água ou, então, com trechos de águas quase estagnadas, que funcionam como leitos em momentos de cheias. São considerados como constituindo um padrão entrelaçado secundário e é morfologia característica relacionada aos leques. Este padrão secundário, no Setor Sul, é bem desenvolvido ao longo das margens do Rio Mampituba até a localidade de Passo Magno, e ao longo do Rio Canoas até pouco à jusante da Costa do Rio Canoas, áreas estas onde os depósitos do leito atual são cascalhos, e as margens são caracterizadas por depósitos rudáceos, mais ou menos coesos, que estão sendo erodidos.

O conjunto de leques do Setor Sul sobressai topográfica e morfologicamente, principalmente entre as cotas de $200 \mathrm{~m}$ e $20 \mathrm{~m}$. Esta faixa estreita-se para norte, nos domínios dos rios Leão e Bonito, que se situam próximos ao esporão-interflúvio, e tem como seu limite a leste a área do Banhado do Sombrio.

O Rio Mampituba, que corre de sudoeste para nordeste, tem seu leque iniciando-se dentro do vale e, assim, nesta situação, é um fan-bay que vai se espraiar na altura da localidade de Praia Grande, quando, então, tem seus depósitos mais espalhados no espaço alargado também para leste e sudeste.

Ainda na situação de fan-bay, recebe toda a carga de detritos e águas da bacia do Rio Pavão, afluente da margem esquerda, já referido. A área dominada por este rio com canais múltiplos, situada entre a base da escarpa da Serra Geral, saindo do cânion do Itaimbezinho, até o Rio Mampituba, constitui-se num leque aluvial com disposição transversal ao fan-bay do Rio Mampituba. O leque do Rio Pavão, que é o mais individualizado entre todos, se espraia sobre o fan-bay do Mampituba. Dessa maneira seus 
sedimentos vão se misturar aos do Mampituba, gerando uma morfologia na extremidade distal do leque com desvio para nordeste, acompanhando o sentido do Mampituba.

O leque do Rio Pavão cobre aproximadamente $10 \mathrm{~km}^{2}$, enquanto o do Rio Mampituba, sem este contribuinte, tem cerca de $44 \mathrm{~km}^{2}$. As declividades de ambos explicam a morfologia geral assumida pelo leque do Rio Pavão. Enquanto o Rio Mampituba, na área do fan-bay, possui menos de $1^{\circ}$ de inclinação entre as altitude de $90 \mathrm{~m}$ e $70 \mathrm{~m}$ e apenas 30' de inclinação entre $90 \mathrm{~m}$ e $50 \mathrm{~m}$ de altitude, o Rio Pavão tem mais de $3^{\circ}$ de inclinação. Esta inclinação foi tomada entre as cotas de $190 \mathrm{~m}$ e $70 \mathrm{~m}$, isto é, ao longo de uma distância muito maior que a usada para medir a declividade ao longo do Mampituba.

BLISSENBACH (1954) apresenta valores de inclinação de leques aluviais estudados por ele e outros autores. As medidas do ângulo de inclinação das superfícies dos leques variaram de $5^{\circ}$ a $9^{\circ}$, e normalmente os ângulos maiores que $5^{\circ}$ são considerados como característicos da metade superior de leques pequenos, isto é, leques com extensão de poucas dezenas de metros, entre o ápice e seu extremo distal, ou, nos $1 / 20$ superiores de grandes leques como aqueles com extensão radial de até 7 $\mathrm{km}$. Os valores apresentados por outros autores levam à afirmação de que este ângulo raramente ultrapassa $10^{\circ} \mathrm{e}$, mesmo para alguns deles, não há ângulos maiores que $5^{\circ}$ ou $6^{\circ}$ na inclinação superficial dos leques.

Para BLISSENBACH (1954), ângulos acima de $5^{\circ}$ são raros e são chamados altos; os situados entre $2^{\circ}$ e $5^{\circ}$ são chamados baixos ou moderados, e aqueles abaixo de $2^{\circ}$ são leques achatados. Este autor verificou esses valores em trechos diferentes dos leques aluviais maiores, aqueles das montanhas Santa Catalina, no Arizona. Nos $300 \mathrm{~m}$ superiores a inclinação medida foi acima de $5^{\circ}$, nos $1.200 \mathrm{~m}$ seguintes os ângulos ficam entre $2^{\circ}$ e $5^{\circ}$, e nos restantes $5.000 \mathrm{~m}$, os ângulos estão abaixo de $2^{\circ}$.

De acordo com esses dados, a cabeça do leque do Mampituba, situada dentro do vale encaixado e, portanto, um fan-bay é já um leque achatado, quase horizontal, ao passo que o do Pavão é um leque com inclinação baixa ou moderada, o que é bastante comum. 
O leque do Malacara/Molha Coco, com aproximadamente $18 \mathrm{~km}^{2}$ de área, abrange inclusive o sítio da cidade de Praia Grande. Sua inclinação abaixo da cota de $80 \mathrm{~m}$, isto é, do leque mediano para a base ou parte distal do mesmo, varia tanto ao longo dos seus raios como também entre distintos trechos desses raios, isto é, entre as diferentes cotas altimétricas ao longo dos canais. Porém, estas variações situam-se muito próximas e todas abaixo de $1^{\circ}$. Este trecho do leque corresponde a quase $15 \mathrm{~km}^{2}$ (Foto 8 ).

Nos últimos 60 anos, de acordo com a informação dos habitantes dessas áreas, estes rios têm mudado tanto de curso como também de vazão, sugerindo que os leques são ativos ainda hoje.

Coalescente ao leque do Malacara ou Molha Coco há o do Três Irmãos, com cerca de $16 \mathrm{~km}^{2}$, que também coalesce com o leque seguinte para o norte, entre Três Irmãos e Cachoeira. Este último abrange $26 \mathrm{~km}^{2}$, dos quais $22 \mathrm{~km}^{2}$ situam-se a leste da estrada que liga estas duas localidades e entre as cotas $35 \mathrm{~m}$ e $8 \mathrm{~m}$, até junto ao Rio Canoas. Neste trecho a declividade é bem baixa, menor que 30'.

Segue-se a área da Sanga da Ripa e Sanga Molha Rabo com abrangência de $6 \mathrm{~km}^{2}$ sendo $10,5 \mathrm{~km}^{2}$ entre as cotas de $40 \mathrm{~m}$ e $10 \mathrm{~m}$ de altitude. A inclinação situa-se em torno de 30 ' ou menor que $1 \%$.

O leque seguinte é o da área dos rios Leão e Bonito com aproximadamente 12 $\mathrm{km}^{2}$, sendo $9,25 \mathrm{~km}^{2}$ entre as cotas $40 \mathrm{~m}$ e $10 \mathrm{~m}$. A inclinação é menor que $1^{\circ}(1,37 \%)$ mas, entre $40 \mathrm{~m}$ e $20 \mathrm{~m}$ de altitude é o dobro daquela entre $20 \mathrm{~m}$ e $10 \mathrm{~m}$.

\subsection{CARACTERIZAÇÃO SEDIMENTOLÓGICA}

\subsubsection{DEPÓSITOS DE LEQUES ALUVIAIS E A ATIVIDADE FLUVIAL}

Os depósitos de leques aluviais são constituídos, na área estudada, por três tipos de materiais : rudáceos, arenosos e pelíticos. Entre os rudáceos diferenciam-se os sem matriz, com matriz arenosa e com matriz argilosa. Há depósitos mais finos, areno-argilosos ou argilo-arenosos, intercalados nos rudáceos, com espessuras medidas entre 0,15 m a 
$1,10 \mathrm{~m}$. Por outro lado, freqüentemente estes depósitos rudáceos apresentam uma cobertura pedogenizada, exibindo horizontes de solo que varia de espessura, chegando a até $4 \mathrm{~m}$, onde dominam sedimentos arenosos e pelíticos, porém com pequenos geodos e fragmentos destes, de vários tamanhos ( $2 \mathrm{~mm}$ a 2,5cm), dispersos (Fotos 10 e 11). Tanto esta cobertura como seu perfil de solo são concordantes com as formas lobadas e convexas destes depósitos.

\subsubsection{Depósitos das Áreas Proximais e Medianas}

Nas áreas proximal e mediana dos leques foram medidos 63 cortes em sua espessura e comprimento e foram descritos quanto ao material constituinte, distribuição, coloração, características pedogenéticas, tendo sido amostrados 39 cortes representados nos perfis da Figura 37 e Fotos 10 a 24.

Os perfis dos afloramentos reunidos sob o título da Figura 37 são de cortes que correspondem a uma medida transversal das formas lobadas, cujos comprimentos variaram de $10 \mathrm{~m}$ a $205 \mathrm{~m}$. Entretanto, $43 \%$ dos mesmos têm entre 50 e $100 \mathrm{~m}$ e $97 \%$ abaixo de $130 \mathrm{~m}$ de comprimento. Estes afloramentos medidos têm até $4 \mathrm{~m}$ de espessura, porém, outros maiores existem em condições de acesso difícil, como as margens côncavas dos canais fluviais.

$\mathrm{Na}$ área proximal e mediana, onde dominam os depósitos rudáceos, a cobertura de materiais mais finos deve ser, em grande parte, um efeito da alteração supérgena dos rudáceos. Esta sugestão tem as seguintes razões : há afloramentos em que as cores do solo acima continuam entre seixos alterados, estes com cores distintas e variadas; em outros locais ve-se nitidamente que houve a migração das argilas de topo, penetrando no meio dos fragmentos situados abaixo; este materrial de cobertura apresenta horizontes de solo, bem desenvolvidos, definidos e estruturados, estando o horizonte-B sempre presente, - que dá uma idéia de idade relativa e sugere serem solos pleistocênicos. Um outro aspecto que colabora com a idéia de antigüidade é a possibilidade de sedimentos rudáceos terem sido completamente obliterados pela pedogênese, isto é, os depósitos de material 
rudáceo teriam sido alterados tão intensamente, que os seixos deixaram de existir. Os fragmentos maiores, alcançando até mais de $0,40 \mathrm{~m}$, mostram-se com forte decomposição, bastando apenas a limpeza dos cortes com a enxada para seccioná-los (Fotos 16 a 21). Raramente apresentam núcleo de rocha fresca. Os fragmentos são de basaltos, com exceção de alguns seixos de rochas sedimentares, encontrados em três afloramentos. Além destes fatos vê-se, muitas vezes, que estes solos acompanham o perfil convexo das formas lobadas

$\mathrm{Na}$ maioria dos afloramentos, o tamanho dos eixos maiores dos fragmentos medidos, nos depósitos rudáceos, variou de $3 \mathrm{~mm}$ a $42 \mathrm{~cm}$, porém o tamanho preponderante situou-se entre 5 a $15 \mathrm{~cm}$. Outras medidas feitas em alguns afloramentos estão nas Tabelas 1 a 10 . Elas foram realizadas medindo-se o comprimento maior de cada seixo imbricado e a perpendicular deste comprimento. Estes valores podem ser comparados com as mesmas medidas entre afloramentos distintos, ao longo dos raios dos leques. As tabelas 1 a 6 reproduzem as medidas de três afloramentos em área de fanbay do leque do Amola Faca. Entre os afloramentos há variação nos tamanhos médios dos dois eixos, no grau de seleção e nos valores de concentração dos tamanhos. 0 afloramento (Tabelas 1 e 2) a montante dos outros dois mostra-se com menor seleção, porém com maior concentração de seixos cujos tamanhos são menores que a moda (64 a $128 \mathrm{~mm}$ ) e com tamanho médio menor (88 $\mathrm{mm}$ ) que o afloramento seguinte, a jusante $(123 \mathrm{~mm}$ ) (Tabelas 3 e 4). Este segundo afloramento é um corte natural, produto da erosão fluvial, no lado norte de uma barra antiga. A média das duas medidas realizadas sobre os seixos é mais alta que a dos outros dois afloramentos situados a montante e a jusante deste. A maior parte dos seus seixos tem o tamanho acima da moda. O terceiro afloramento, cujas medidas estão nas tabelas 5 e 6 , demonstra maior seleção, pois $97 \%$ dos fragmentos concentram-se em dois tamanhos. Este depósito tem seus seixos com a menor média e a menor moda entre as medidas efetuadas nos afloramentos do fan-bay do leque do Rio Amola Faca. Dois outros afloramentos medidos (Tabelas 7 a 10), situam-se no leque do Rio da Pedra/ltoupava; um na área do fan-bay e outro na parte mediana do leque. O número de classes de tamanho é o mesmo entre os dois cortes, porém nota-se que há diminuição dos 
valores para jusante, tanto da média dos dois eixos como do tamanho modal das medidas. Há, no segundo afloramento, uma concentração de $89 \%$ dos fragmentos em duas classes de tamanho.

No Setor Norte o tamanho médio dos clastos é freqüentemente maior que no Setor Sul. Entretanto, no Setor Sul há um afloramento de área proximal de um leque, ao norte da localidade de Vila Rosa e no domínio do Rio Macaco ou Malacara, em que há predominância de matacões.

Paleocorrentes estão representadas nas Figuras 38 a 47, cujas resultantes estão assinaladas nas Figuras 5 e 6 , no encarte. As resultantes das medidas no Setor Norte (Figura 5) demonstram um movimento fluvial semelhante ao atual. A divergência pode ser explicada pela drenagem entrelaçada. No Setor Sul, algumas resultantes evidenciam movimentos perpendiculares aos atuais que podem ser explicados pela interferência das elevações isoladas e pelo padrão de drenagem entrelaçada dos leques aluviais.

No domínio das áreas proximais e medianas, no Setor Sul, são notadas, entre as formas lobadas, áreas planas, com inclinação muito baixa, isto é, menor que a inclinação geral dos leques. Estes planos apresentam na sua base material rudáceo com matacões, porém no topo os sedimentos são bem mais finos que quando secos, apresentam coloração esbranquiçada (Foto 22 a 24).

Os sedimentos representados nas figuras 48 a 50 são os mais finos, tanto os da cobertura como os intercalados entre os rudáceos e a matriz desses depósitos. Eles são polimodais, com 2 a 5 modas, tendo $43 \%$ das amostras 3 modas e $32 \% 4$ modas. A primeira moda em geral é em tamanho argila (58\% das amostras), ou areia fina (34\% das amostras). Outros tamanhos que aparecem como primeira moda são silte, areia muito fina e seixo. A segunda moda é dominada por frações da areia ( $47 \%$ das amostras), seguida da argila e do silte (14\% das amostras). Muitas amostras apresentam quantidades semelhantes de areia, argila e silte. A fração areia situa-se principalmente entre areia média e fina, tendendo para muito fina (Figuras 48 e 50). 


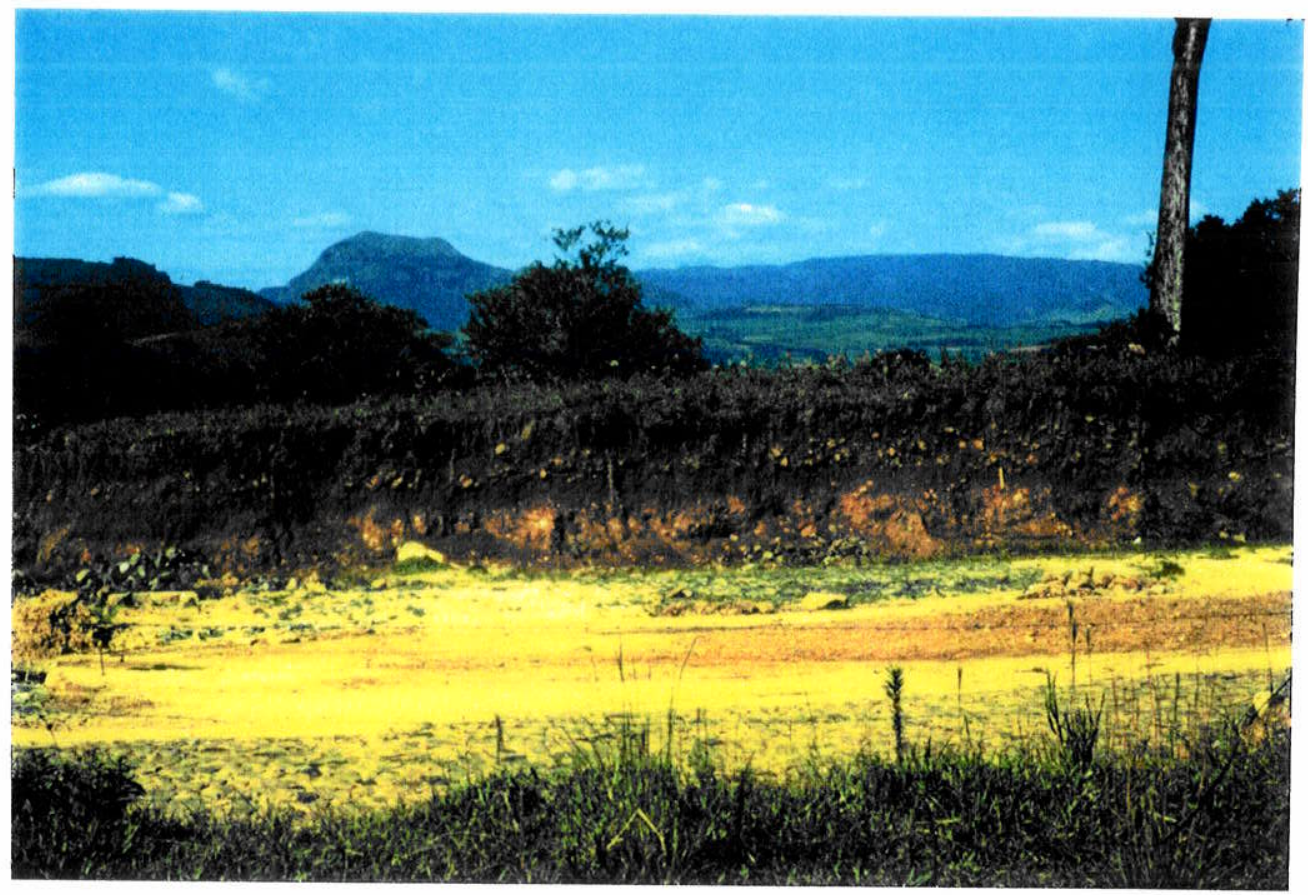

Foto 10 - Afloramento na Avenida José Inácio, em Praia Grande. Na base há depósito rudáceo muito consistente e com pouca matriz, coberto com cerca de $0,40 \mathrm{~m}$ de sedimentos mais finos. Para o topo segue-se outra camada de rudáceos, com mais matriz, também recoberta com material mais fino. A foto mostra que a forma é convexa, ampla e de pequeno desnível. Logo após as primeiras árvores situa-se o Rio Mampituba, localmente também chamado de Rio Praia Grande e que corre para leste, à esquerda da foto. Da metade da foto para cima vêem-se elevações no Rio Grande do Sul. 


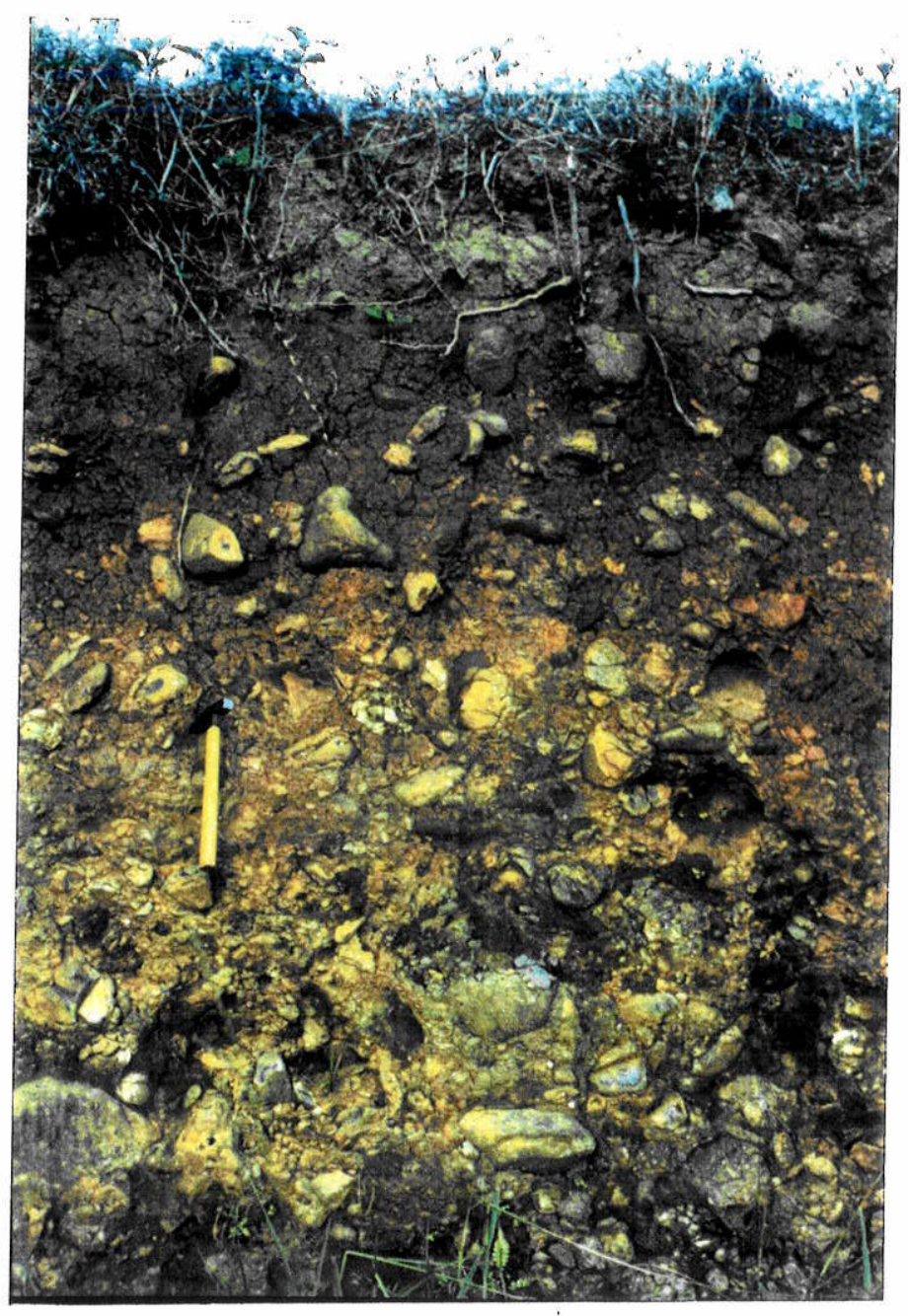

Foto 11 - Afloramento na Avenida José Inácio, em Praia Grande. O corte é perpendicular à Avenida e próximo ao da foto 10, numa outra forma lobada. Este floramento é bem mais espesso que aquele. Depósito de material rudáceo sem intercalação de camada de material mais fino. Lateralmente, para a direita, em direção à calha atual, apresenta-se com fragmentos menores que os da foto. Acima do martelo percebe-se a modificação das cores do depósito pela ação da pedogênese. 


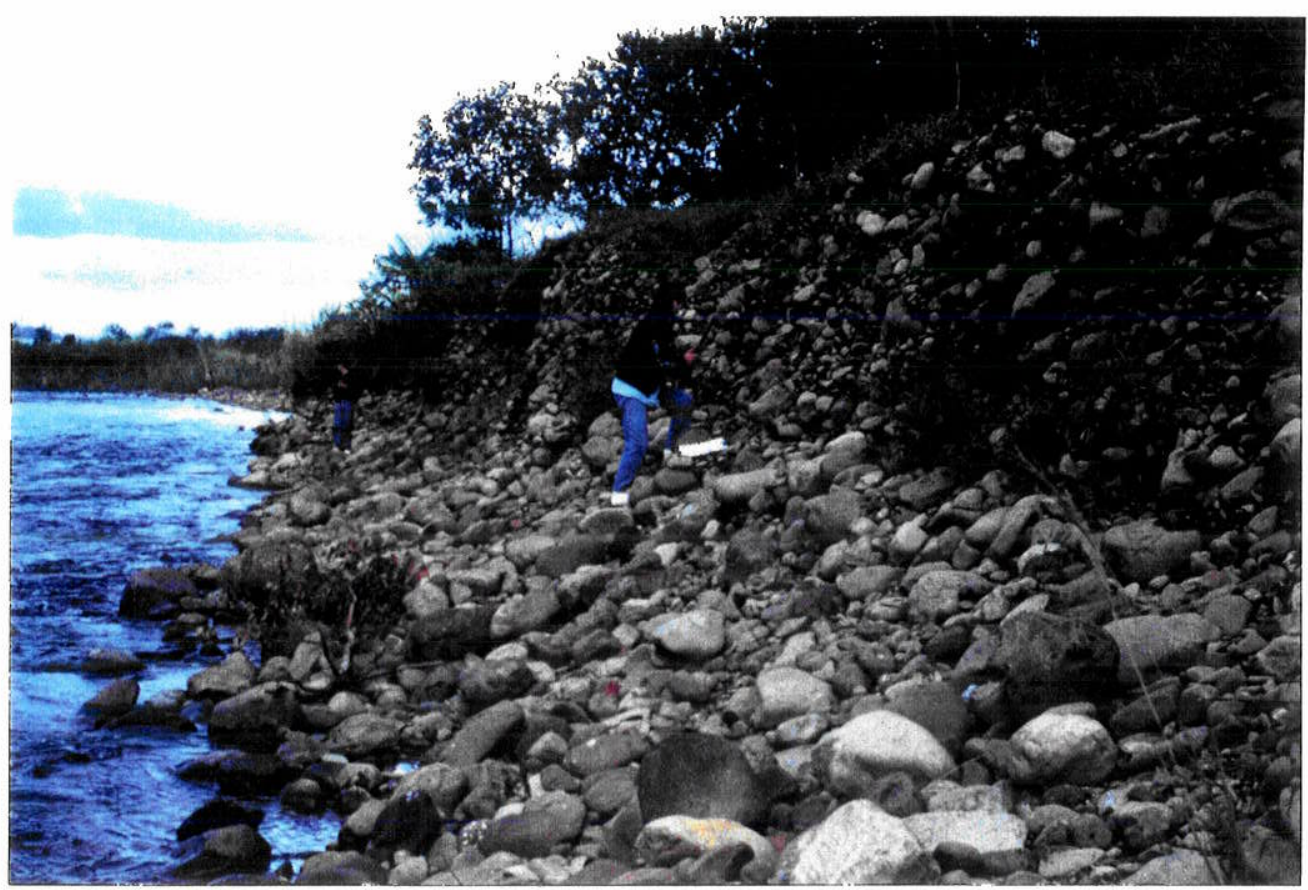

Foto 12 - Depósito de barra/ilha, em erosão rápida, na margem de um dos canais do Rio Rocinha, em Timbé do Sul. Nota-se uma concentração dos matacões na base do corte, lembrando que houve a deposição desse material na antiga barra/ilha e que está havendo uma seleção pelo transporte, porém, em águas altas eles também serão carreados.

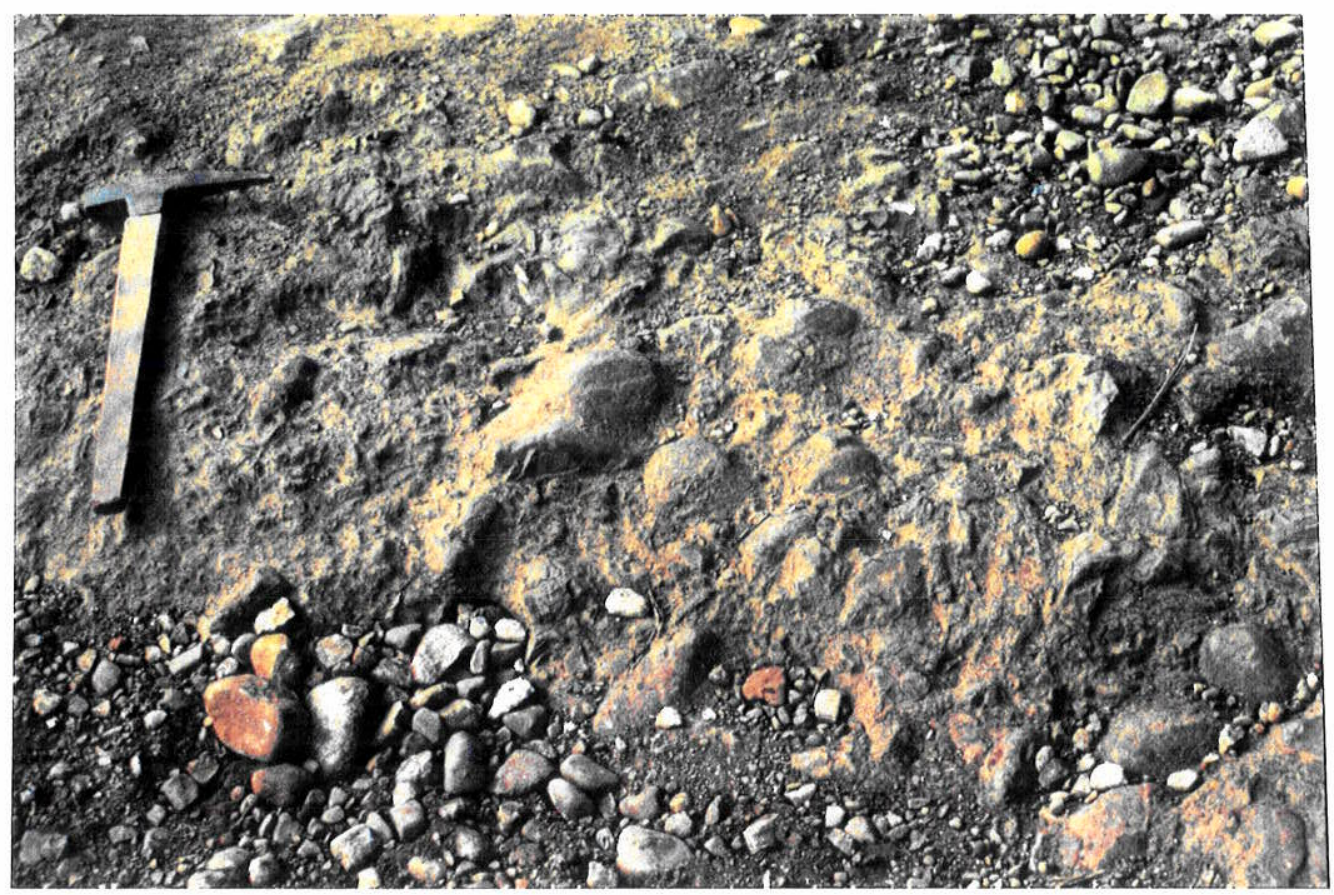

Foto 13 - Afloramento de depósito rudáceo litificado, na localidade de Barra do Pinheirinho, nordeste da cidade de Jacinto Machado, no Município homônimo. 


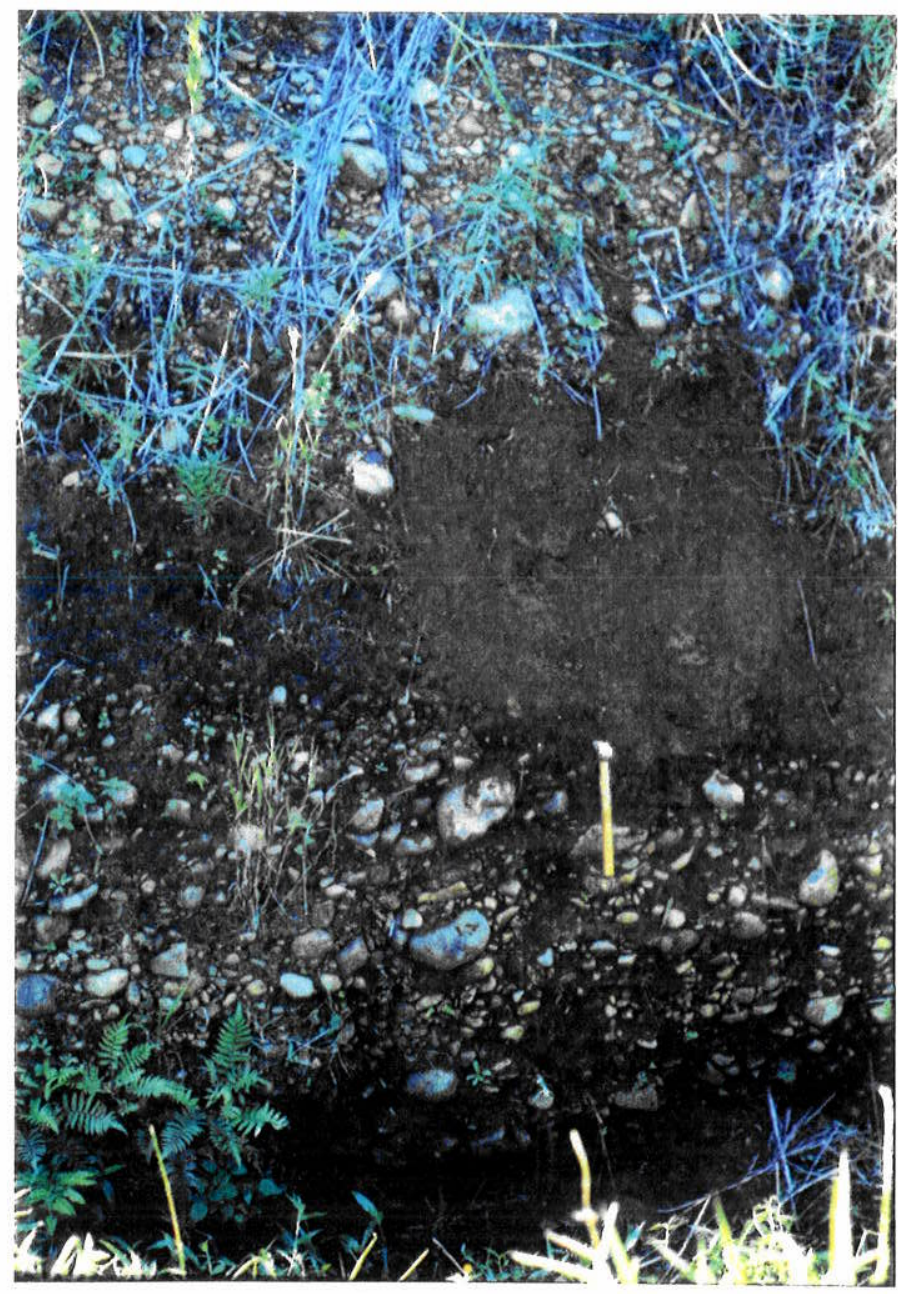

Foto 14 - Afloramento mostrando camadas rudáceas, intercaladas com sedimentos mais finos, a oeste de Vila Progresso, Município de Turvo, Setor Norte. 


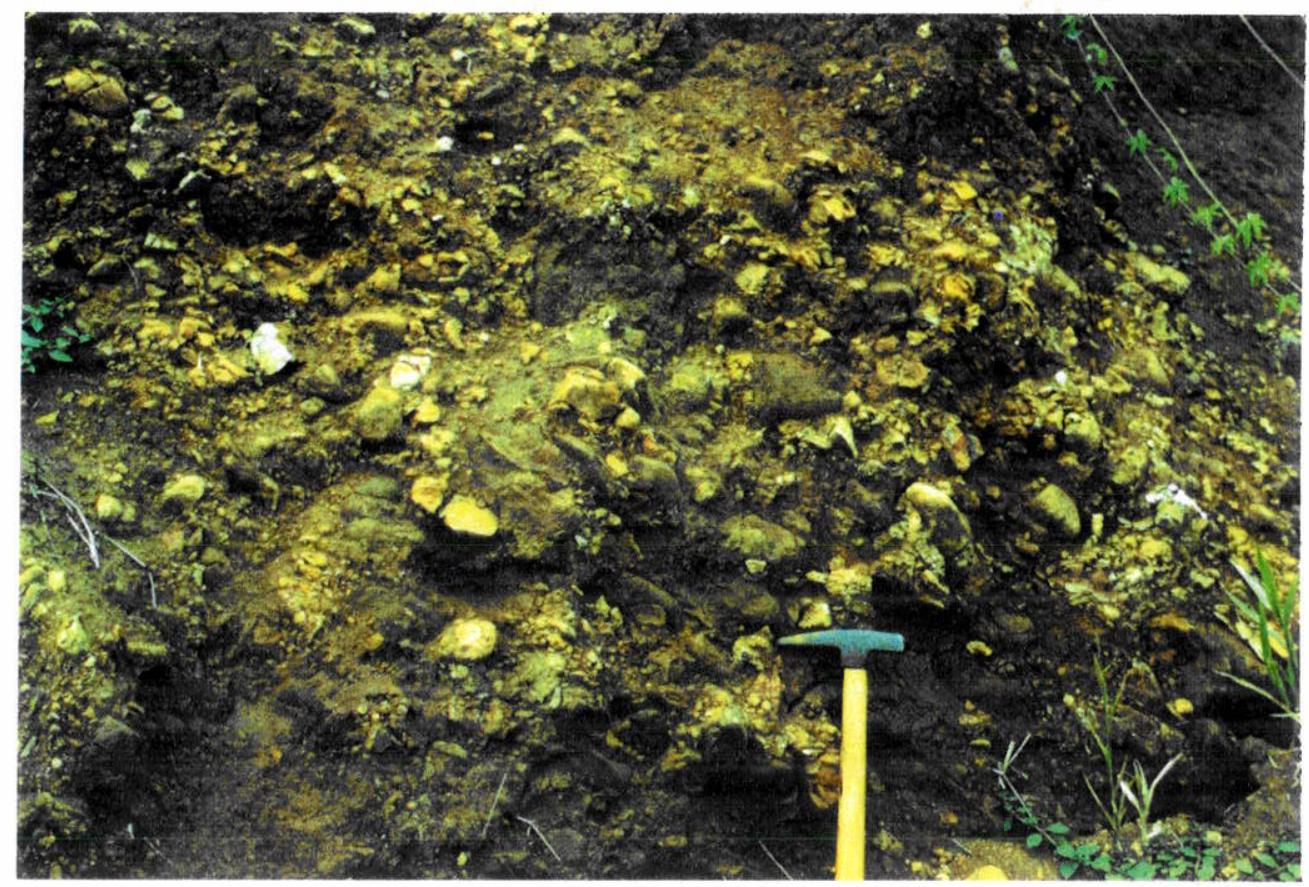

Foto 15 - Depósito de leque mediano aflorando a sul da localidade de Cachoeira, Município de Praia Grande, Setor Sul.

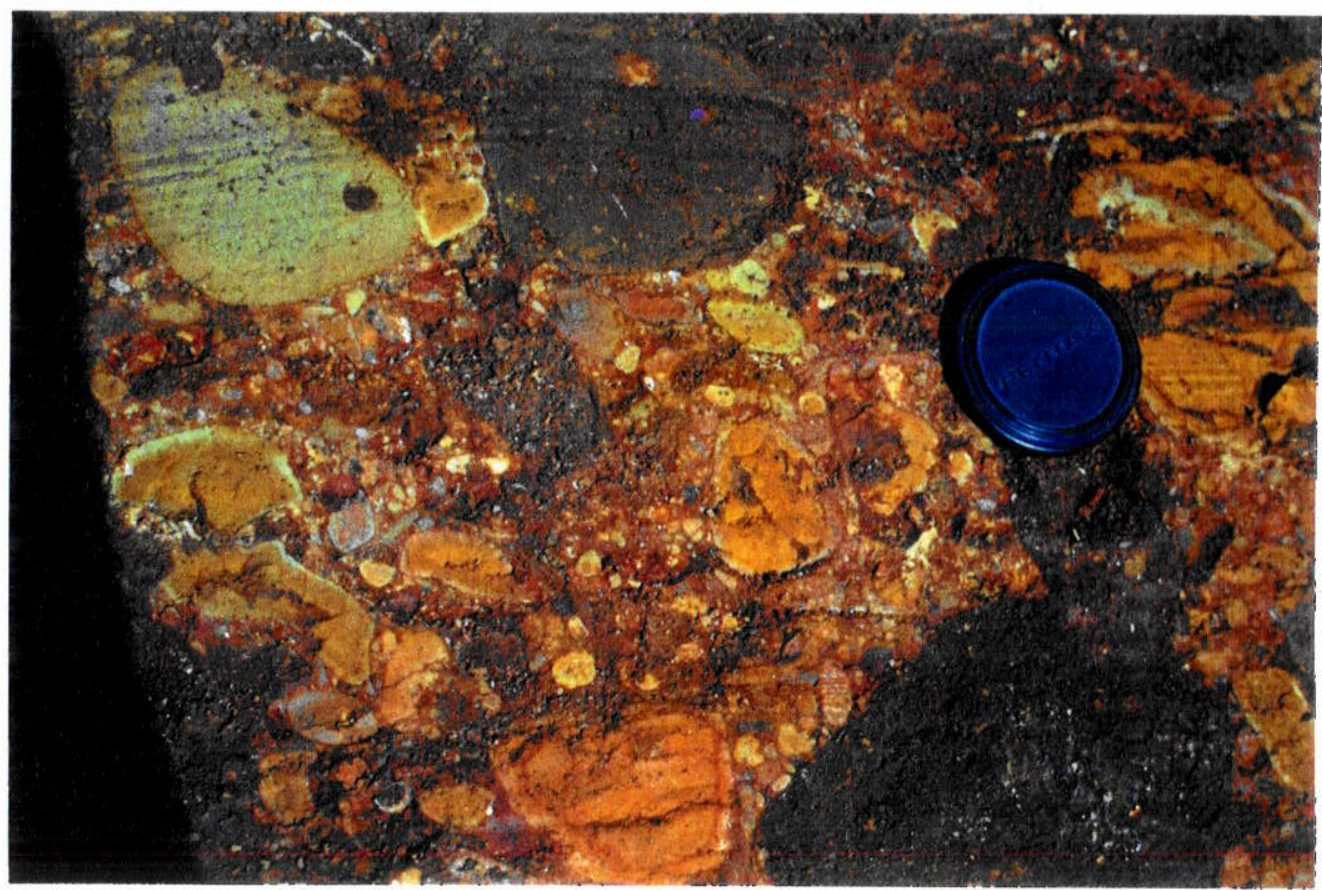

Foto 16 - Afloramento de depósito rudáceo $\mathrm{em}$ Timbé do Sul, com fragmentos alterados. Grande variedade de tamanhos e pouca matriz arenosa. Área a mais de $100 \mathrm{~m}$ de altitude onde começa a haver coalescência de depósitos proximais ainda confinados em fan-bays. É evidente que mesmo no leque proximal ou ápice pode haver depósitos com grande variedade de tamanho dos fragmentos. Estes são de basalto. 


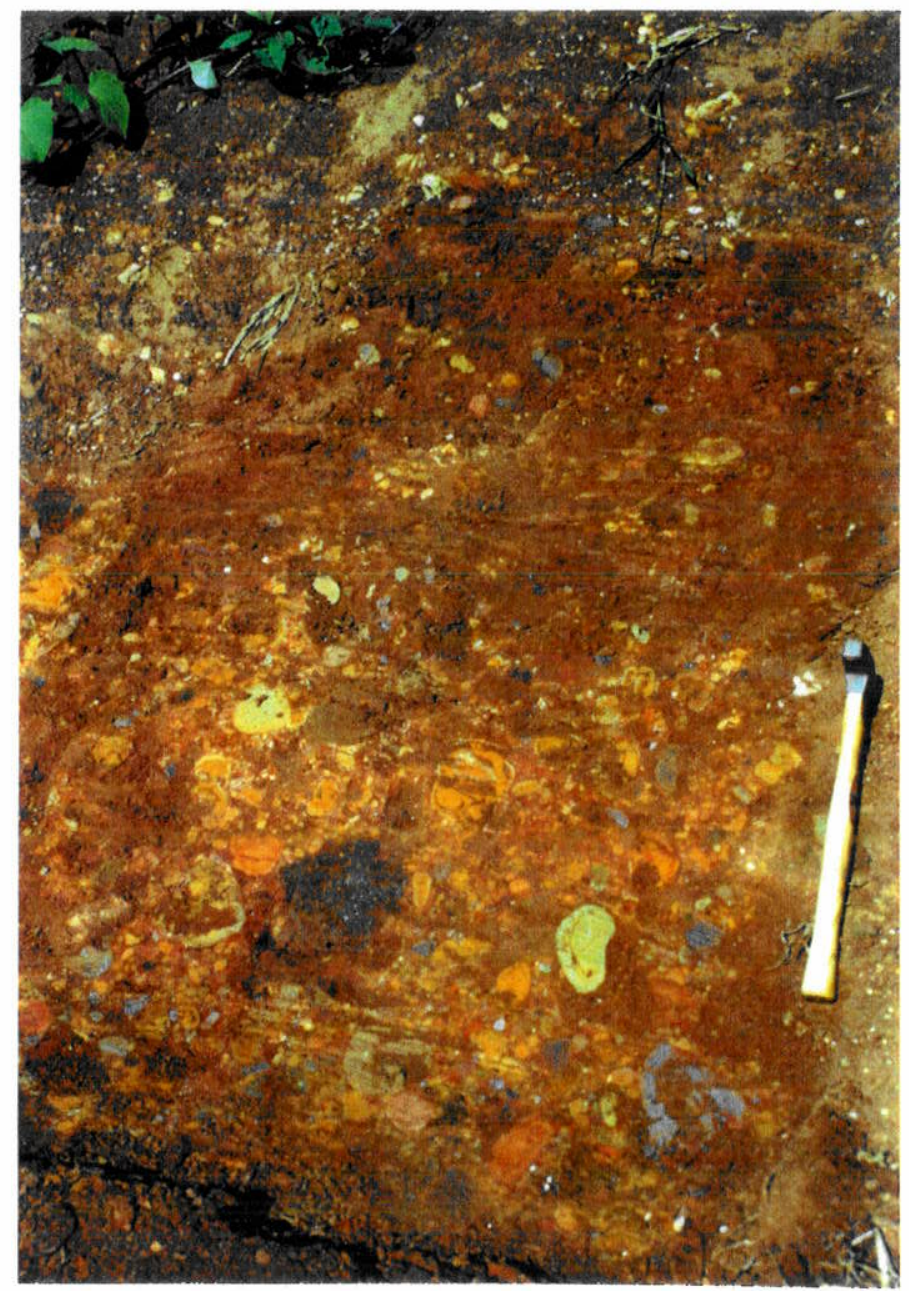

Foto 17 - Afloramento de depósitos rudáceos mostrando a alteração intempérica. As características apresentadas pela parte superior do corte, como em muitos outros locais, sugerem a possibilidade de os solos serem formados a partir desses depósitos, obliterando os antigos fragmentos. A oeste da localidade de Itoupava, Setor Norte. 


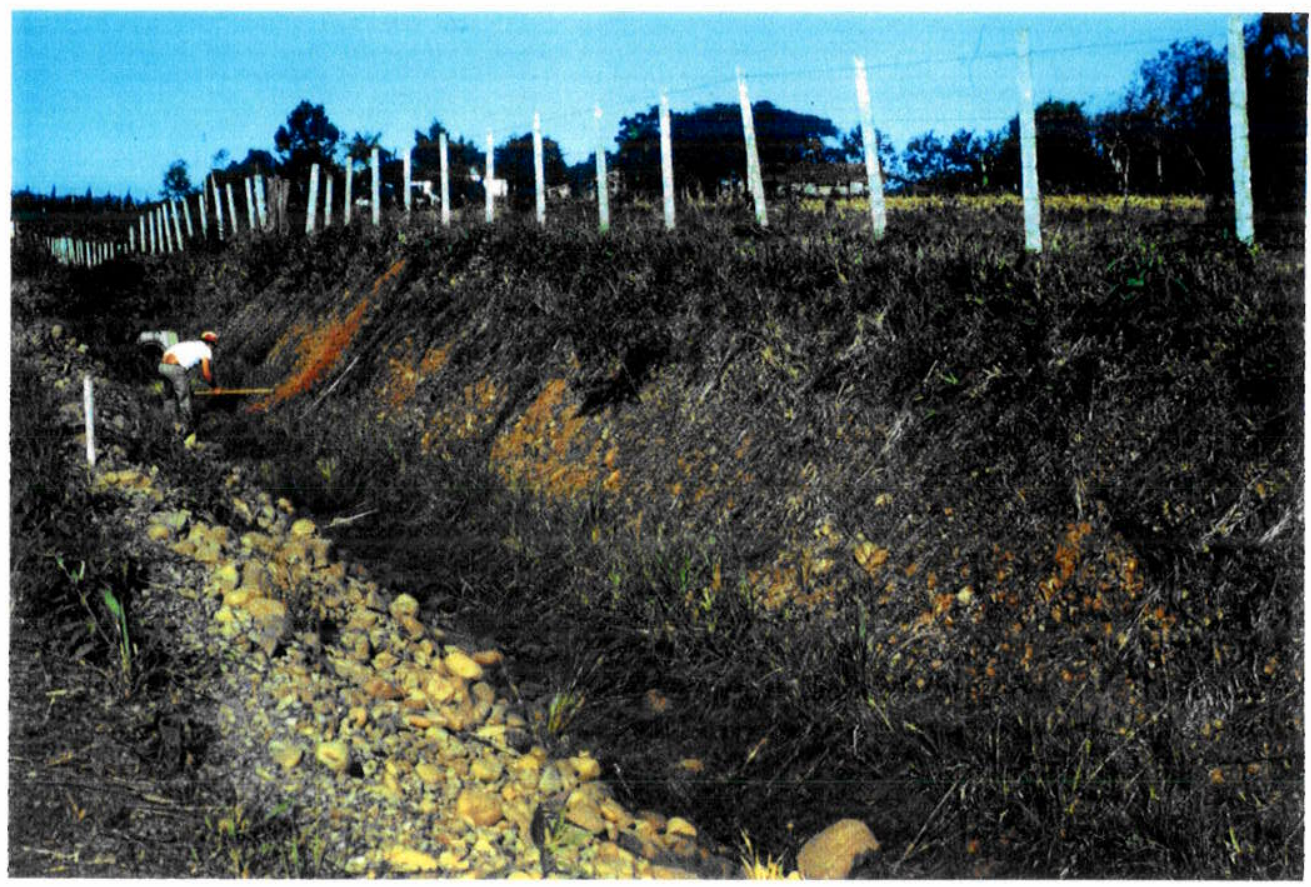

Foto 18 - Forma convexa, ampla, dos depósitos de leque mediano, na área do avental do leque do Rio Amola Faca, a noroeste da cidade de Turvo, no designado limite urbano.

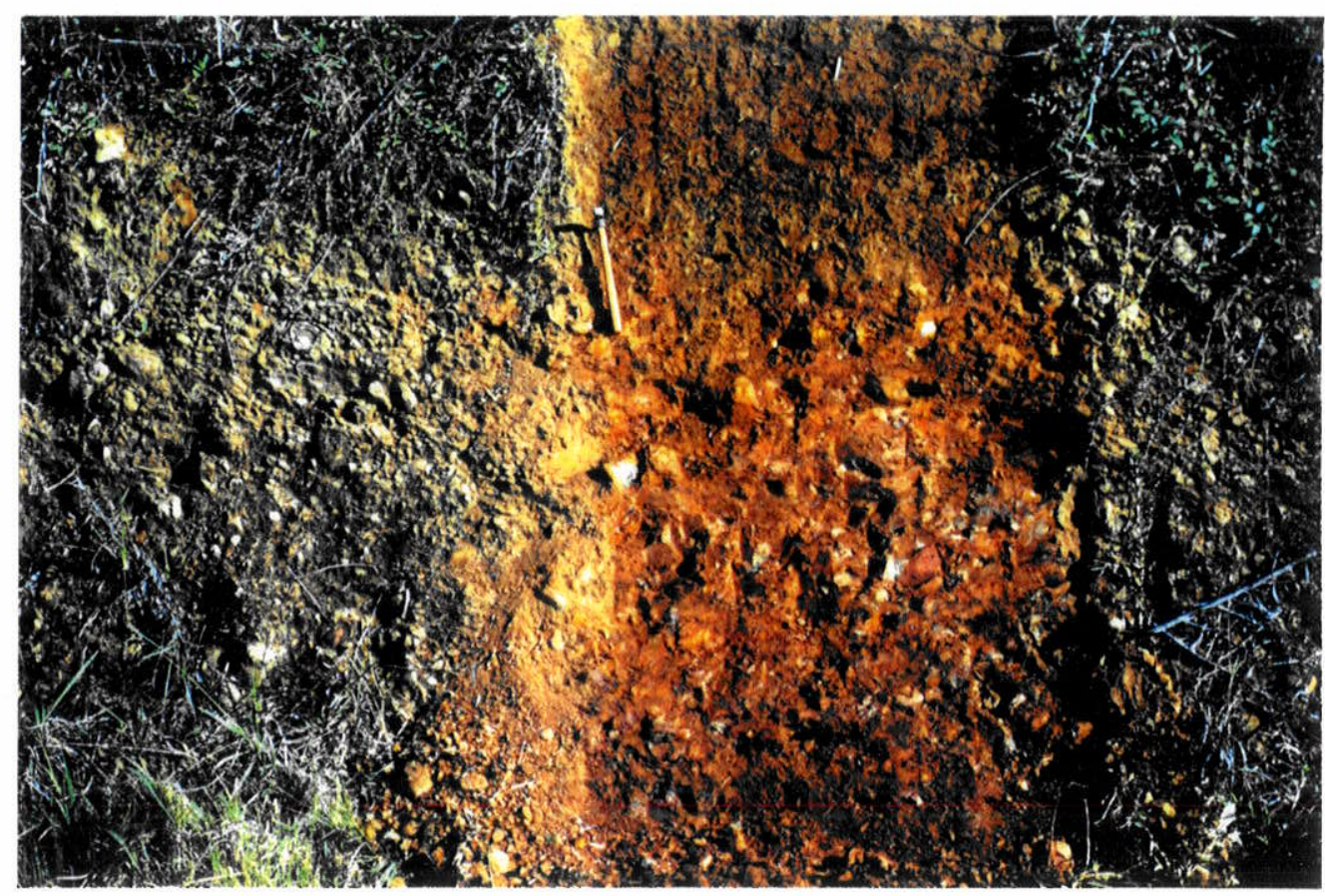

Foto 19 - Detalhe do afloramento da foto 18, notando-se o material rudáceo, tendo solo na parte superior . 


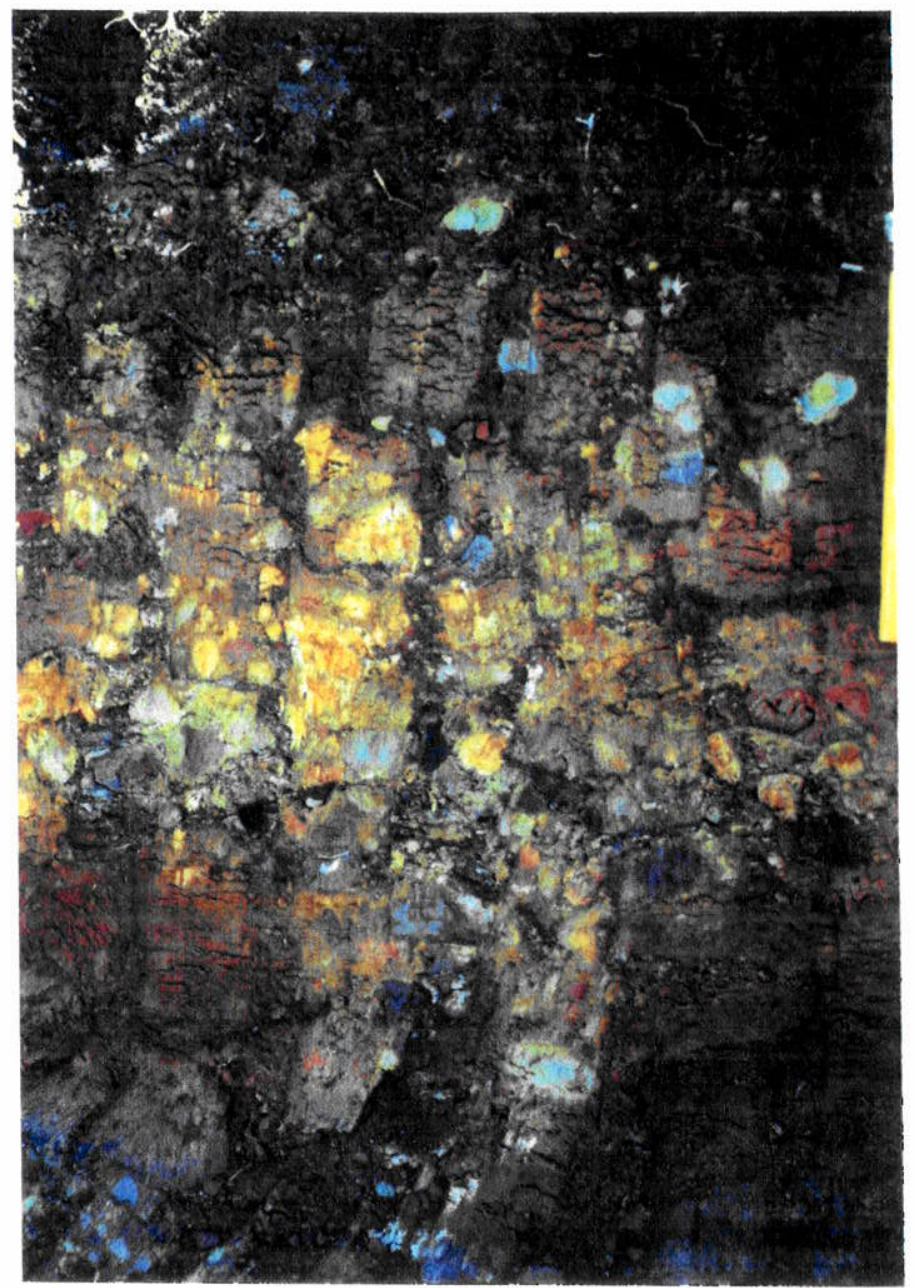

Foto 20 - Afloramento de depósito rudáceo com forte alteração, permitindo que todos os seixos sejam seccionados com o raspar da enxada. Nota-se o papel da pedogênese com migração vertical de argilas vermelhas. Localidade de Itoupava-Setor Norte. 


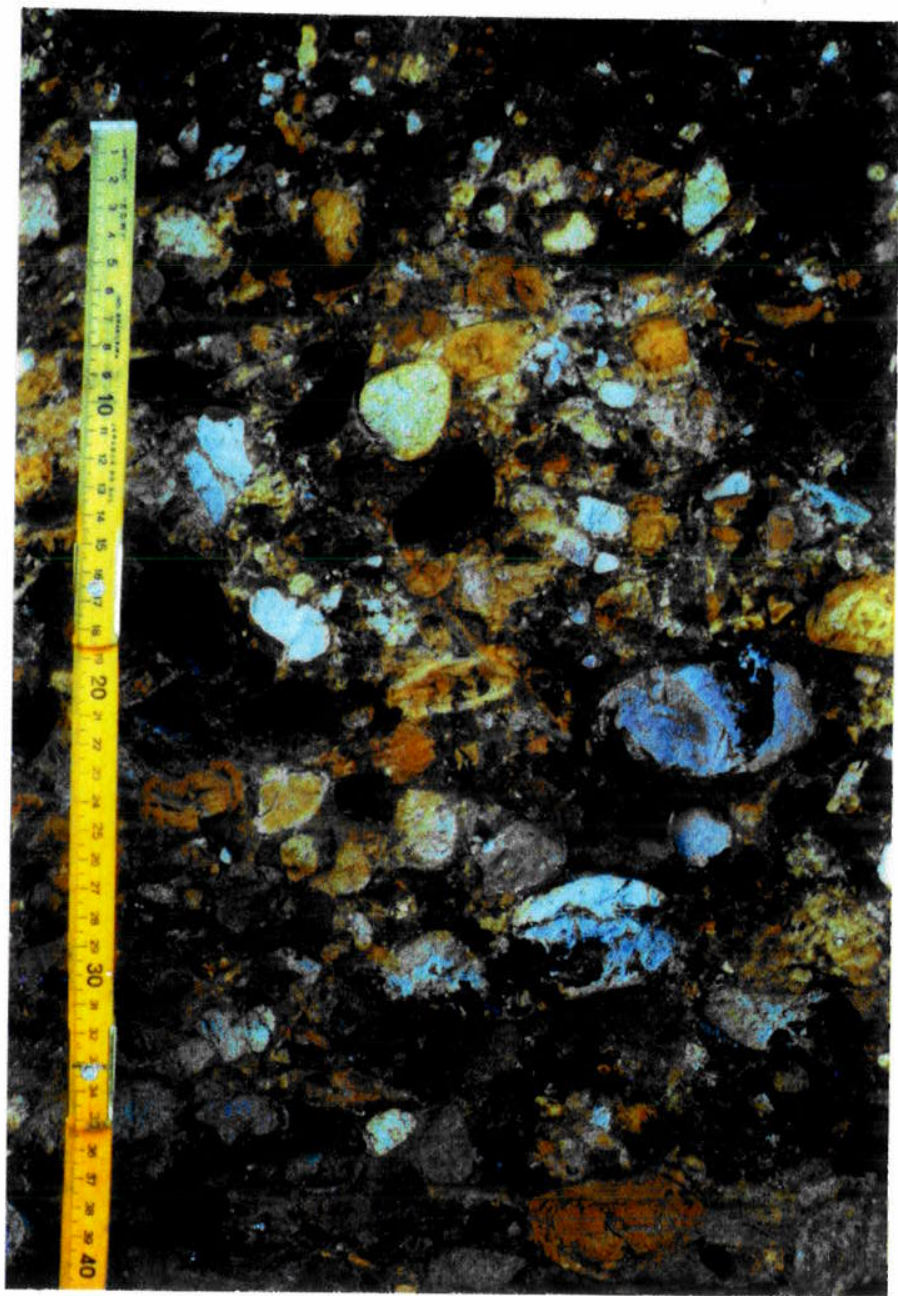

Foto 21 - Afloramento de depósito rudáceo clasto suportado, a oeste da localidade de Ermo, área do leque mediano. Fragmentos de basalto relativamente pequenos, pois são menores que $7 \mathrm{~cm}$ e com muita pouca matriz. 


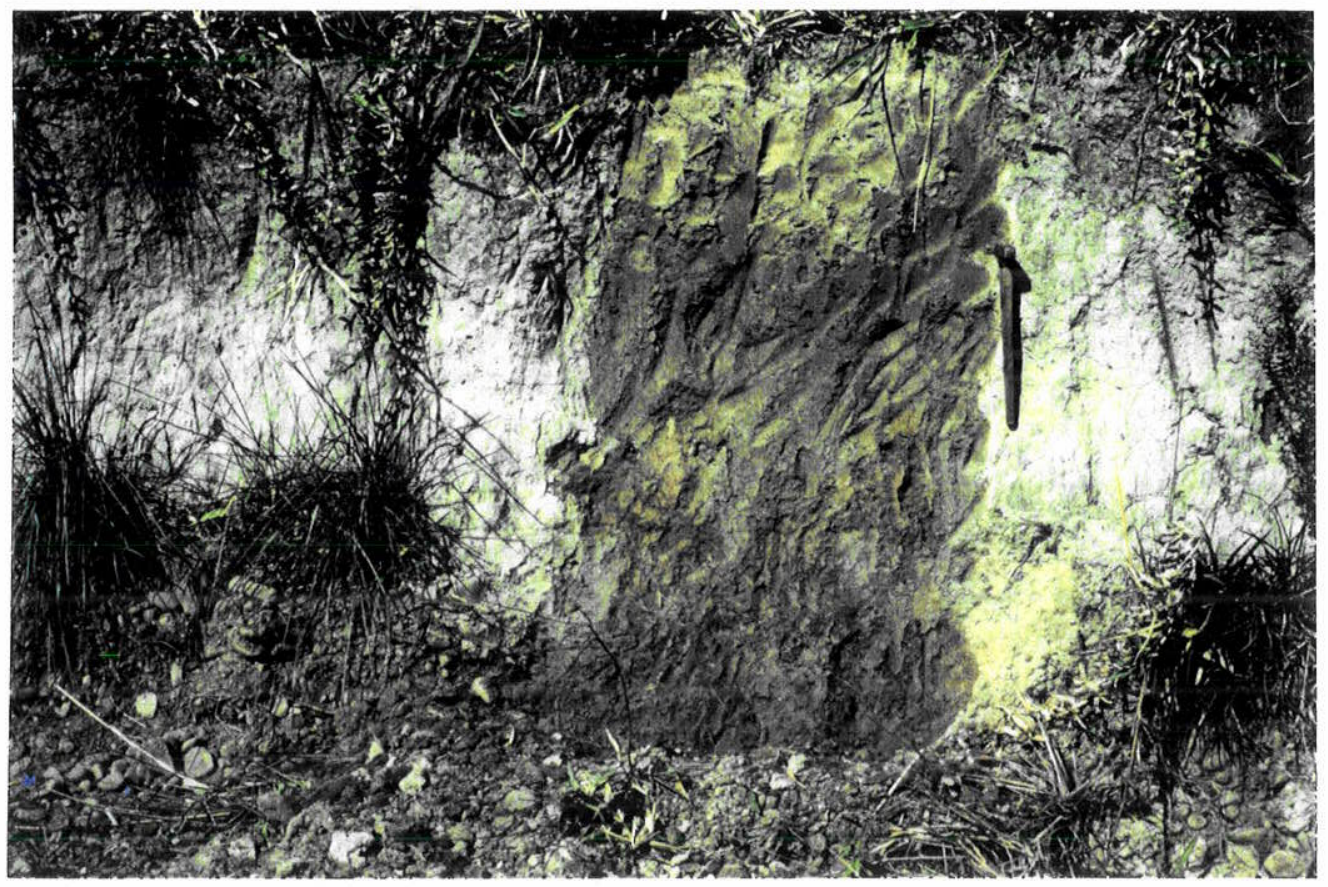

Foto 22 - Sedimentos mais finos que constituem o topo de áreas entre as formas lobadas dos leques medianos, no Setor Sul. Quando secos, estes sedimentos aparecem com cor cinza esbranquiçada. Constituem os solos Várzea da Areia ou Poço da Lontra. Afloramento na área de Três Irmãos, Município de Praia Grande.

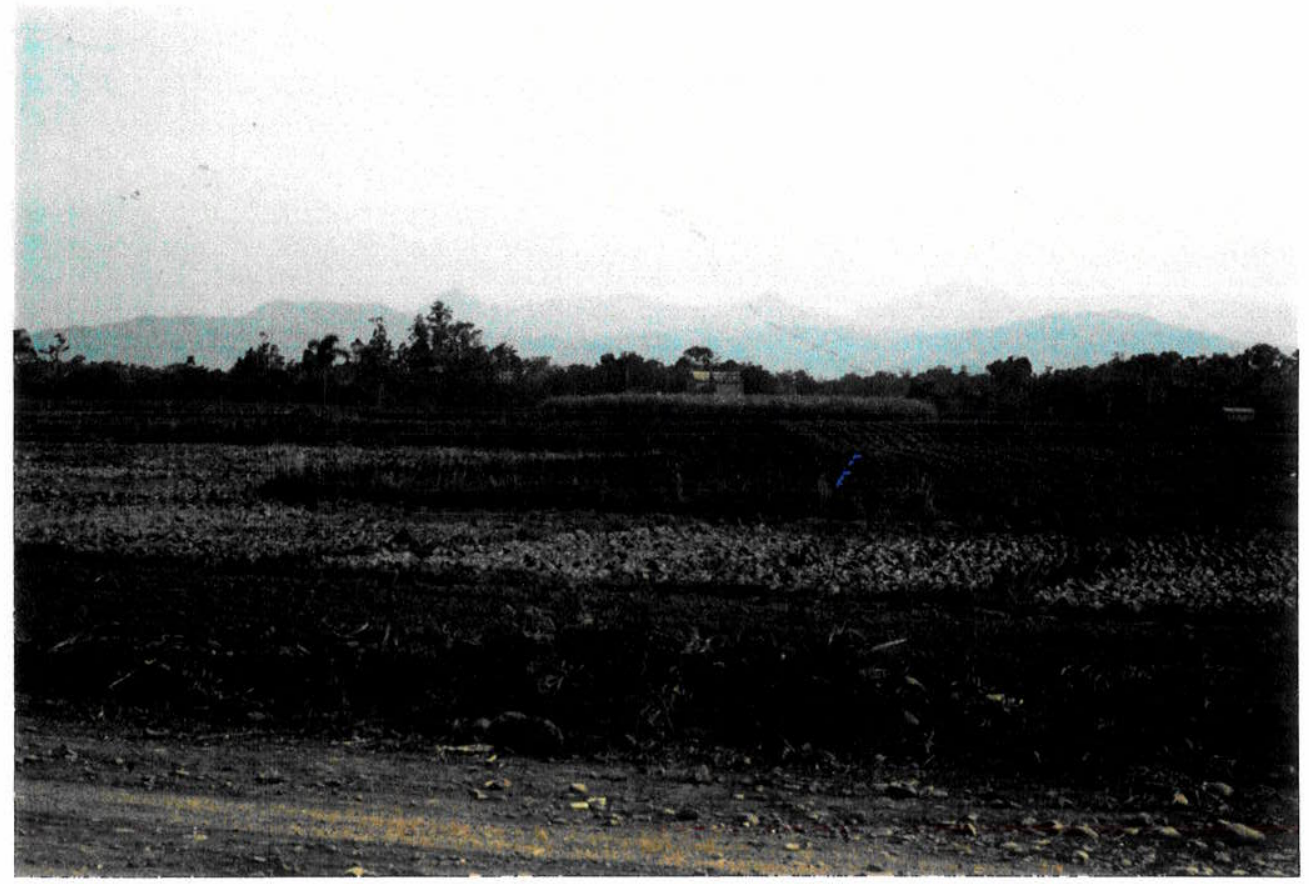

Foto 23 - Feições da área mediana dos leques no Setor Sul, entre as localidades de Favela e Costa do Rio Canoas. As formas convexas lobadas estão intercaladas com formas planas cujo material tem coloração esbranquiçada. 


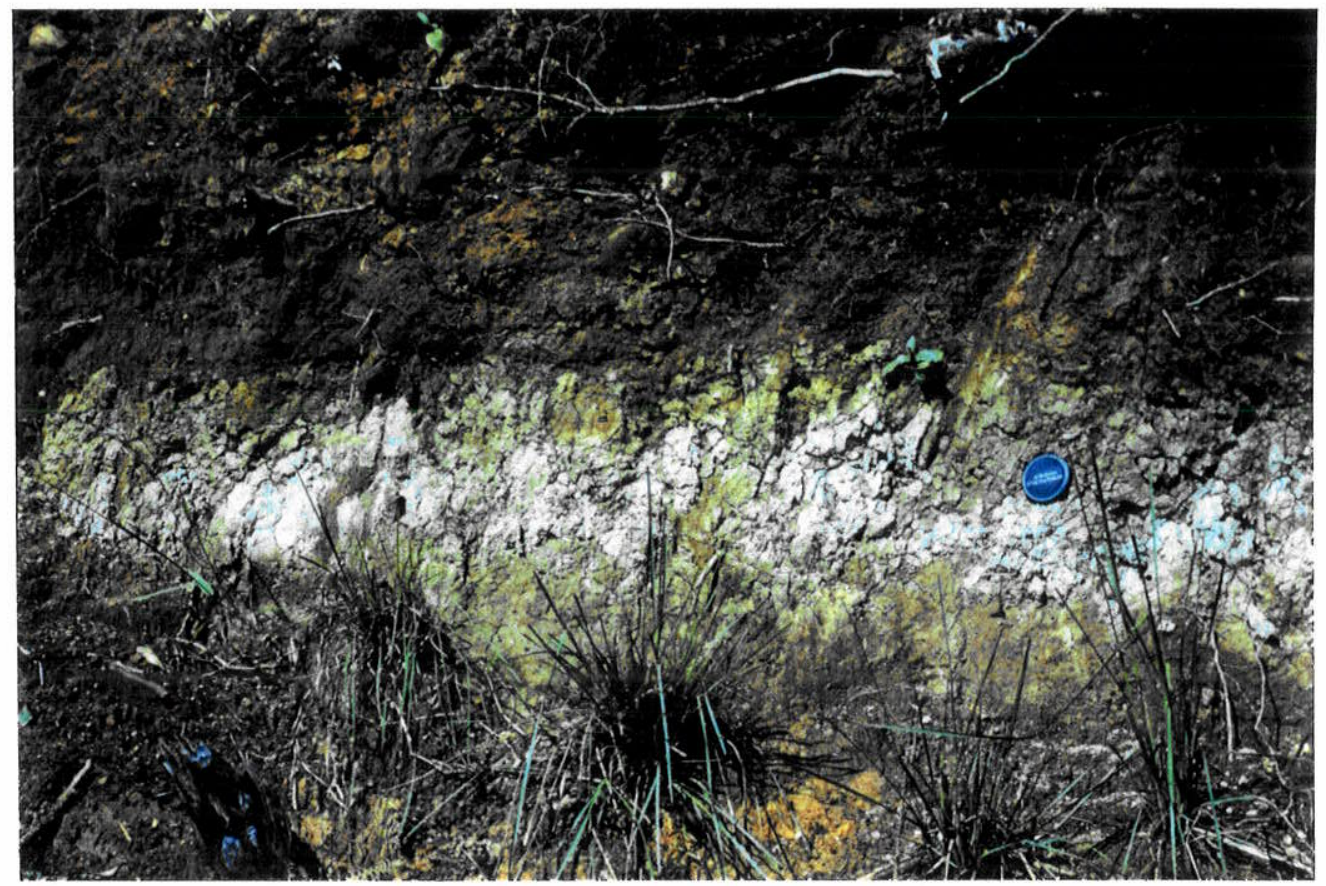

Foto 24 - Afloramento na margem direita da Sanga Molha Rabo, perto da estrada que une as localidades de Cachoeira e Tenente. A base constitui-se de material rudáceo amarelado e avermelhado, coberto com sedimentos mais finos, esbranquiçados, recobertos por sedimentos rudáceos de cor vermelha. 
O diâmetro médio deste material mais fino que cobre e intercala os depósitos rudáceos ou da matriz destes, situa-se principalmente, entre $4 \phi(0,062 \mathrm{~mm})$ e 8,9 $\phi$ $(0,0021 \mathrm{~mm})$, havendo para o lado dos grossos apenas três amostras. $89 \%$ das amostras têm o diâmetro médio nos tamanhos silte (Tabela 11).

Os tamanhos maiores, grânulo e seixo, estão também presentes. O primeiro em quase todas as amostras.

Os dados acima mencionados evidenciam que são amostras muito mal selecionadas, tendo boa representação em todas as classes da escala verbal de assimetria de FOLK \& WARD (1957), e quanto à curtose são dominantemente muito platicúrticas a platicúrticas (Tabela 11 e Figuras 51 a 54). As figuras 51 a 54 demonstram a relação entre os parâmetros estatísticos. Verifica-se que entre as amostras há tanto assimetrias positivas como negativas; não há muita variação da curtose que apresenta valores baixos, e o desvio padrão é variado. O alinhamento mostrado na Figura 53 evidencia que as assimetrias de maior negatividade ocorrem em amostras com maiores valores de $\phi$, isto é, com a diminuição dos diâmetros médios para silte e argila. $\mathrm{Na}$ Figura 52 nota-se que as amostras com valores positivos mais altos de assimetria, tendem a ter valores de curtose também mais altos, e o conjunto, neste diagrama, mostra uma leve tendência para o helicóide.

O diagrama de PASSEGA et al. (1969) (Figura 49) mostra uma relação C-M de espalhamento, com uma concentração dentro dos tipos VII e VIII, seguidos pelos campos III e IX. De acordo com PASSEGA et al. (1969), os sedimentos dos tipos VII e VIII são sedimentos de suspensão que podem ter grãos rolados menores que $1 \mathrm{~mm}$. Como os últimos podem ser levados por longas distâncias, antes de serem rolados, eles são considerados de suspensão. Mas, o tipo VIII é considerado por PASSEGA et al. (1969) como os depósitos das suspensões uniformes mais finas e de suspensões pelágicas. Como aqui não se aplica essa dedução, atribui-se a origem desta característica granulométrica à alteração intempérica. Os de tipos III e IX, que têm valor de $\mathrm{C}$ mais altos que $1 \mathrm{~mm}$, têm grãos rolados significando uma deposição perto da fonte ou transportados através de ambientes onde a suspensão era rara. Estes elementos aplicam-se mais para 
as camadas intercaladas entre os rudáceos, uma vez que outros materiais semelhantes podem ser devidos à alteração. Por outro lado, há que se referir à proximidade da fonte.

Essas amostras foram recalculadas, considerando-se como $100 \%$ as classes de areia, ou de tamanhos maiores, dentro desses depósitos mais finos (Tabela 12), com o intuito de criar condições para comparar essas areias com aquelas dos depósitos arenosos praiais e eólicos situados no leste da área. A Figura 55 demonstra que essas areias são muito similares àquelas, quanto a sua granulometria. As figuras 56 a 59 explicitam as relações entre os parâmetros estatísticos, apenas para a fração areia. Nota-se que na relação diâmetro médio, assimetria e desvio padrão (Figura 57), há um comportamento mais organizado do que para a amostra total (Figura 51) e que há um aumento do desvio padrão paralelamente com a maior negatividade da assimetria, sugerindo uma leve curva ascendente. A Figura 58 demonstra que o diâmetro médio situa-se principalmente entre 2 e $3 \phi$, portanto com desvio padrão também menor que para a amostra total. Os valores de assimetria são dominantemente negativos ( $80 \%$ das amostras), variando dentro da escala nominal, de assimetria muito negativa a assimetria muito positiva, não havendo aquela tendência para a assimetria negativa, com a diminuição do diâmetro médio, como ocorre na amostra total. Na Figura 59 visualiza-se que há agrupamentos de amostras e não uma distribuição contínua dos valores de KG'.

Algumas amostras (9) tiveram todas as classes de tamanhos examinados quanto ao índice de arredondamento de KRUMBBEIN (1941), da esfericidade de RITTENHOUSE (1943) e textura superficial. O arredondamento medido em todas as classes areia fina a areia grossa é dominantemente 0,5 , decrescendo nas areias muito finas para 0,3 . São abundantes grãos arredondados $(0,7)$ em tamanho areia grossa. $O$ índice mais freqüente de esfericidade dos grãos, na maioria das amostras, é 0,7 seguido da esfericidade 0,9 no tamanho areia grossa. Entretanto, todos os intervalos de classes das amostras da matriz do material rudáceo basal, em afloramentos de Praia Grande, mostraram-se dominantemente com grãos subangulosos $(0,3)$. São areias principalmente de grãos sacaróides polidos e subordinadamente mamelonados, polidos e foscos. Há representação de sacaróides foscos. A representação de grãos lisos é muito pequena e ocorre nas areias 
médias e grossas. Estas características lembram uma origem comum para este material de distintos afloramentos dos dois setores, havendo uma mistura de grãos texturalmente maturos com outros sem esta maturidade. A contribuição provável é de quartzo fragmentado de geodos do basalto e dos arenitos.

\subsubsection{Depósitos Distais}

Os depósitos distais aqui considerados para o conjunto dos leques, afloram apenas no Setor Norte, numa pequena área, na margem esquerda do Rio ltoupava-Araranguá, entre a localidade de Itoupava e a cidade de Araranguá. (Aqui não se vai levar em conta as características do leque do Rio Pavão, Setor Sul). Esses depósitos que originalmente teriam sido um corpo único, como uma planície aluvial no sopé do leque, hoje apresentamse em vários afloramentos, constituindo formas separadas devido a sua dissecação. $A$ maior superfície exposta desses depósitos, situada entre os rios Jundiá e o Itoupava, tem o topo plano, e as formas menores são convexas. Sua altitude varia, em geral, de 5 a $9 \mathrm{~m}$, atingindo $11 \mathrm{~m}$ em um local. Seus afloramentos (Foto 25) estão descritos nos perfís da Figura 60.

O diagrama de SHEPARD (1954) para este tipo de depósito, na Figura 61, qualifica a granulometria das amostras. Nota-se que são sedimentos arenosos, arenosiltosos e uma mistura de areia, argila e silte, com menor tendência para este último tamanho. Estes sedimentos são, em parte, distintos daqueles mais finos dos leques proximais e medianos. Na comparação com estes, os depósitos distais têm menor proporção de pelitos, uma vez que $33 \%$ das amostras têm diâmetro médio no tamanho areia. Este varia de 1,82 ф a 9,03 $\phi(0,286 \mathrm{~mm}$ a 0,0019 $\mathrm{mm})$, com $60 \%$ das amostras tendo diâmetro médio nas classes de silte (Tabela 13, Figuras 59 e 60). A diferença entre os sedimentos distais e os mais finos das áreas proximais e medianas dos leques aluviais talvez seja devida ao transporte mais fácil das areias para as áreas distais e, a contribuição posterior de finos pela alteração intempérica de outros fragmentos nas outras duas. Outras características granulométricas destes depósitos podem ser 


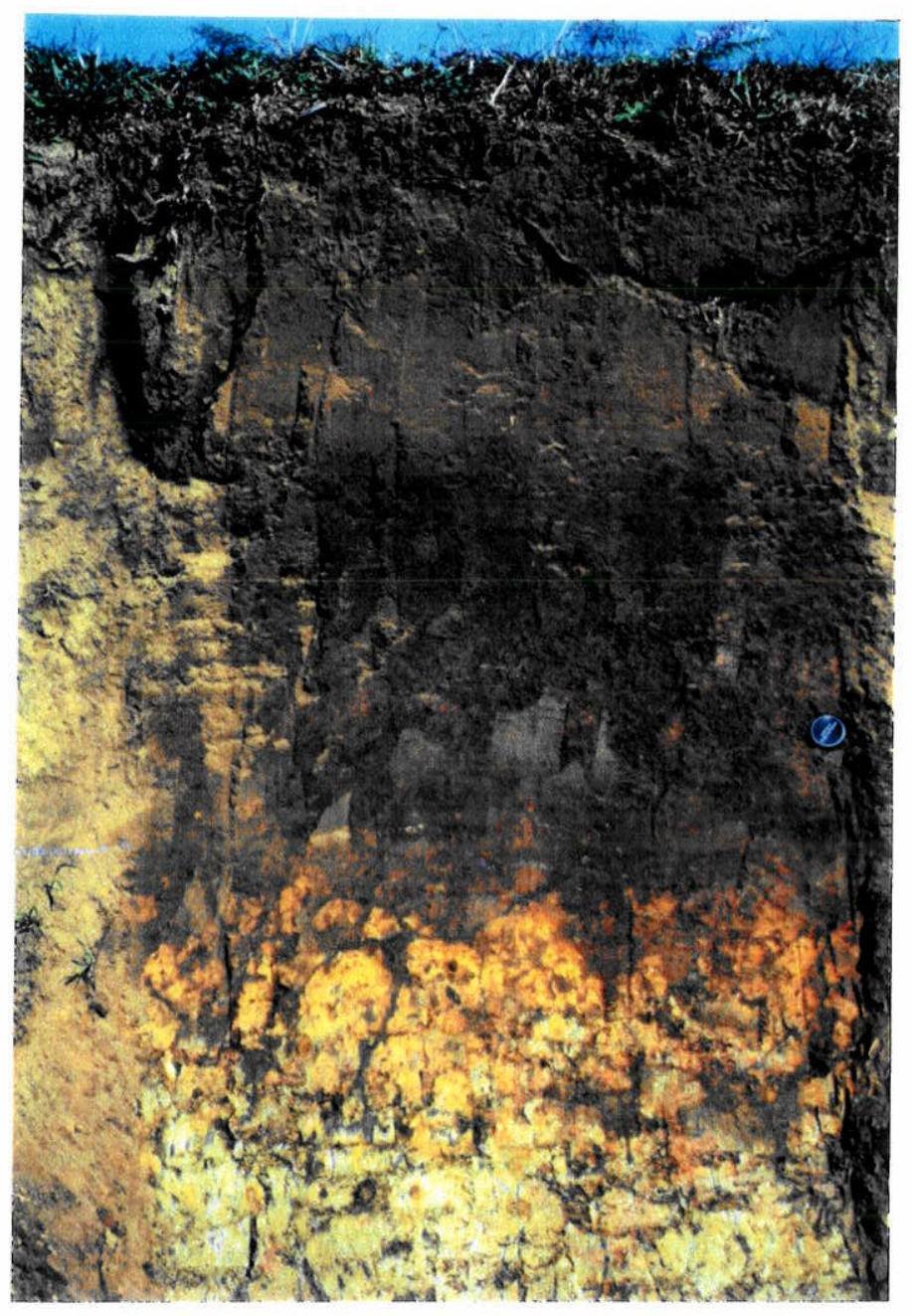

Foto 25 - Foto mostrando um dos aspectos como se encontram os sedimentos distais dos leques que afloram no Setor Norte. Corte a oeste da BR -101, distante cerca de um quilômetro, a norte de Araranguá. Notam-se o resultado da pedogênese e a presença de um Horizonte-B bem marcado, lembrando a antiqüidade desses solos. 
visualizados nos histogramas da Figura 62 que evidenciam serem sedimentos polimodais, com uma excessão, dominando 2 a 4 modas, tendo $42 \%$ das amostras 3 modas.

Estas características corroboram com os dados de seleção que as classificam como muito mal selecionadas (75\%) e mal selecionadas (20\%) (Tabela 13).

No que concerne à assimetria $76 \%$ das amostras apresentam assimetria muito positiva e o restante se distribui em todas as categorias descritivas de assimetria de FOLK \& WARD (1957). O alto percentual dos valores positivos salientam a não-normalidade das distribuições dessas amostras (Tabela 13).

Quanto à curtose há igualmente amostras classificadas em todas as categorias nominais (FOLK \& WARD, 1957) deste parâmetro, com domínio dos dois extremos: muito platicúrtica (33\%) e extremamente leptocúrtica (25\%) (Tabela 13). As amostras dentro da categoria extremamente leptocúrticas são aquelas de alguns afloramentos ao norte do Rio Araranguá e leste do Rio Mãe Luzia que apresentam maior percentagem de areias. A maioria das amostras dos depósitos de leque distal têm suas classificações dentro deste parâmetro, concordantes com as medidas de seleção e mostrando o grau de não normalidade da distribuição granulométrica.

O material destes depósitos distais no diagrama C-M de PASSEGA et al. (1969) (Figura 63) mostra também um espalhamento, como acontece para aquele das áreas proximais e medianas dos leques., As amostras porém, têm uma outra disposição dentro deste diagrama e apresentam, ainda um arranjo paralelo à linha C-M 1.000-100. Há amostras em todas as classes e aquelas designadas como $\mathrm{V}, \mathrm{V}$ e $\mathrm{VI}$ dentro das quais estão muitas amostras, não tinham esta representação dentro dos leques proximais e medianos.

O segmento QR que reúne os sedimentos transportados como suspensão graduada, está bem representado nestas amostras. Ele tem continuidade no segmento RS, que representa a suspensão uniforme. Os sedimentos nas classes $I V, V, V I$ e VII são considerados por PASSEGA (1964) e PASSEGA et al. (1969) como aqueles depositados a partir de suspensão, podendo conter grãos rolados menores que $1 \mathrm{~mm}$, mas este 
rolamento teria acontecido depois de serem transportados por longas distâncias em suspensão. A classe $V$ seria um sedimento de suspensão graduada com moderada turbulência; o tipo VII seria integrado por sedimentos de suspensão uniforme enquanto a classe VI pertenceriam àqueles de suspensão graduada com baixa turbulência.

Muitas amostras estão na classe VIII que é considerada por PASSEGA et al. (1969), como aquela onde se situam os depósitos da suspensão uniforme mais fina, aquele tipo exemplificado pela suspensão pelágica, o que não seria aqui o caso. E' aceitável que na parte distal de um leque ocorram sedimentos que tenham sido transportados por fortes correntes que se espraiam e perdem a energia, deixando então de fluir e levando a deposição da carga sólida. A associação dos segmentos QR e SR seria o resultado desta ação (PASSEGA et al. 1969). Esta possibilidade se firma também nas descrições de JOHNSON (1897).

\subsubsection{Depósitos Fluviais de Canais Atuais}

Relacionados aos leques estão também os depósitos situados nos canais ativos. Neles foram medidos os três eixos de seixos de barras laterais e longitudinais, em vários canais e ao longo deles. Seus tamanhos médios dão uma idéia da competência das correntes atuais, e a possibilidade de compará-las àquelas responsáveis pelos depósitos mais antigos. As medidas dos três eixos possibilitam além do tamanho médio, outros índices como achatamento, esfericidade e forma do seixo. Estes elementos estão relacionados às características das rochas-fonte, ao relevo, às características hidrológicas e hidráulicas destes canais na área. As águas e os sedimentos recolhidos no planalto e na escarpa escoam com grande poder erosivo e grande possibilidade de movimento. Entretanto, no sopé da escarpa, a mudança de pendente retarda o fluxo. A carga sólida tem menor mobilidade e executa outros papéis, isto é, ela tanto pode entulhar os canais, levantando o perfil longitudinal dos mesmos em certos trechos e aumentando a velocidade das águas pelos desníveis gerados, como também possibilita a "perda" de água da superfície pela infiltração. Sob a ação de chuvas fortes, mas não prolongadas, a água 
desce a escarpa sem muita carga sólida e chega ao sopé com grande velocidade, remobilizando o material já depositado. A diminuição das chuvas traduz-se por migração subterrânea da água em muitos trechos dos canais, e este fluxo retira os fragmentos menores dos interstícios entre os seixos bem como ali os deposita.

A rocha fonte principal dos seixos é o basalto. Praticamente estão ausentes destes depósitos os seixos de rochas sedimentares. Talvez deva-se este fato à alteração intempérica e às estruturas destas rochas que não as tornem boa fonte de clastos, ou também deva-se ao mais fácil desgaste que teriam ao serem transportadas.

Os cascalhos das barras fluviais atuais (Fotos 26 a 37) apresentam tamanhos entre $4 \mathrm{~mm}$ e maiores que $256 \mathrm{~mm}$, isto é, de seixo a matacão. Mas, é raro encontrar-se seixos pequenos nos depósitos, visto que freqüentemente, o intervalo entre $16 \mathrm{~mm}$ e $32 \mathrm{~mm}$ apresenta valores percentuais muito baixos, isto é, menores que 10\%, e praticamente inexistindo os menores. São sedimentos unimodais, e a moda nunca alcança $50 \%$ dos clastos medidos, embora a maioria das amostragens apresente mais de $40 \%$ dos clastos dentro da moda.

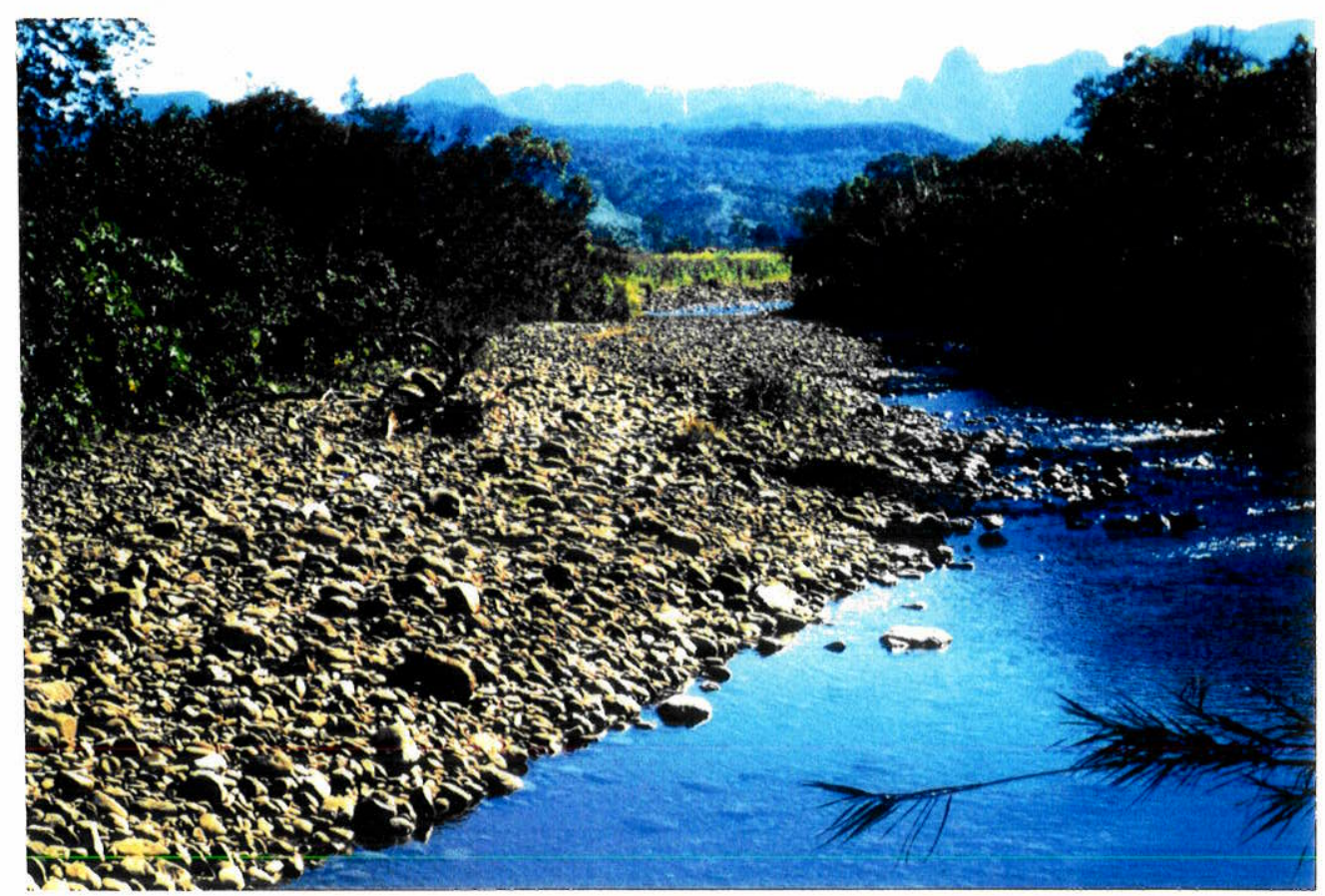

Foto 26 - Barra lateral no Rio Amola Faca, perto de Amola Faca e Capela São Miguel, Município de Timbé do Sul, Setor Norte. Percebe-se a imbricação dos seixos. As formas, na parte superior da foto, são do Arenito Botucatu. 


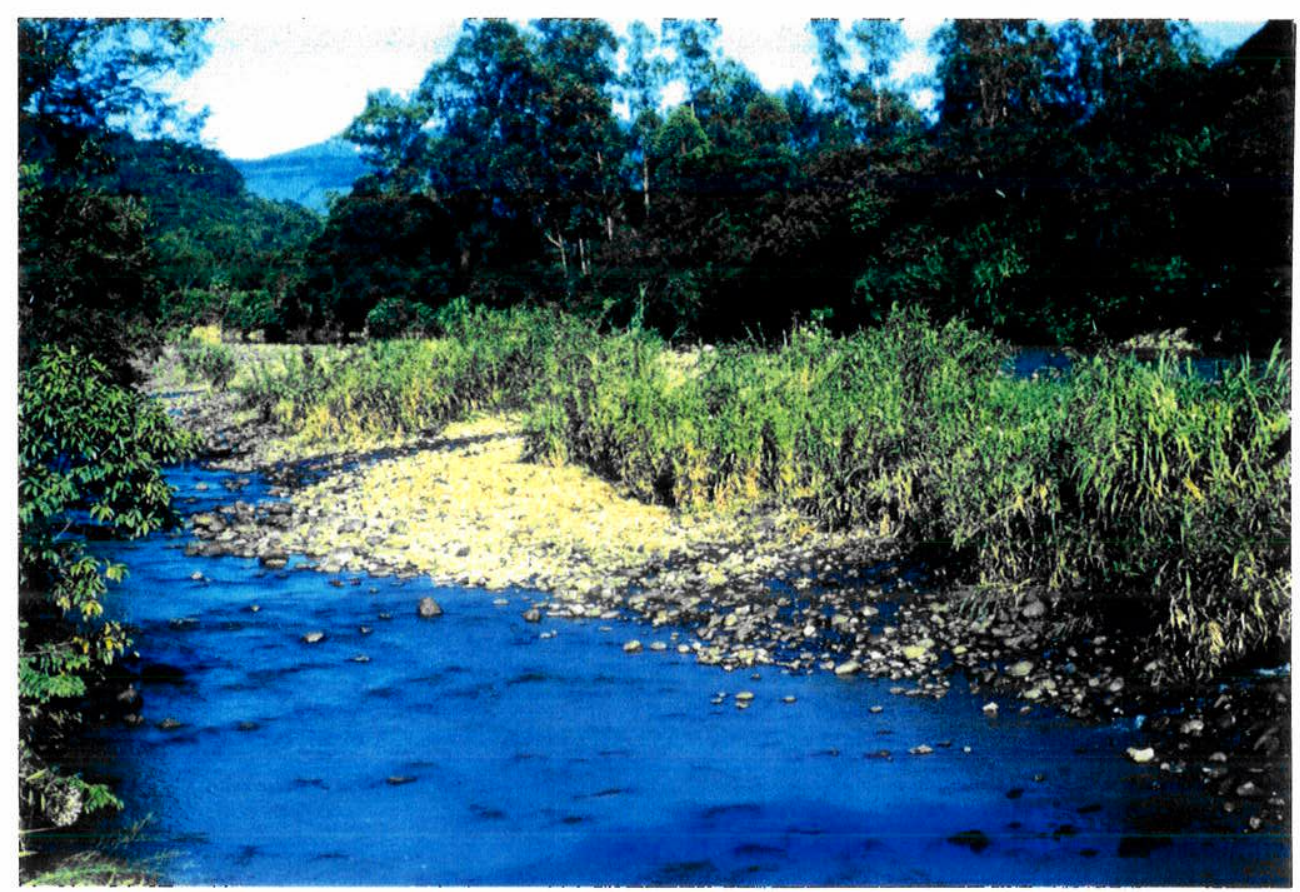

Foto 27 - Barra longitudinal no leito do Rio Pedra, na localidade de São Pedro, Município de Jacinto Machado. Vê-se água correndo em dois níveis: no canal esquerdo (à direita na foto), em posição mais alta e emitindo fluxos perpendiculares ao fluxo geral e à barra, para o nível mais baixo, na base da foto que é o canal da direita. Estas características, que se repetem na foto 31 , são comuns nos leques proximais e, por vezes, nos medianos.

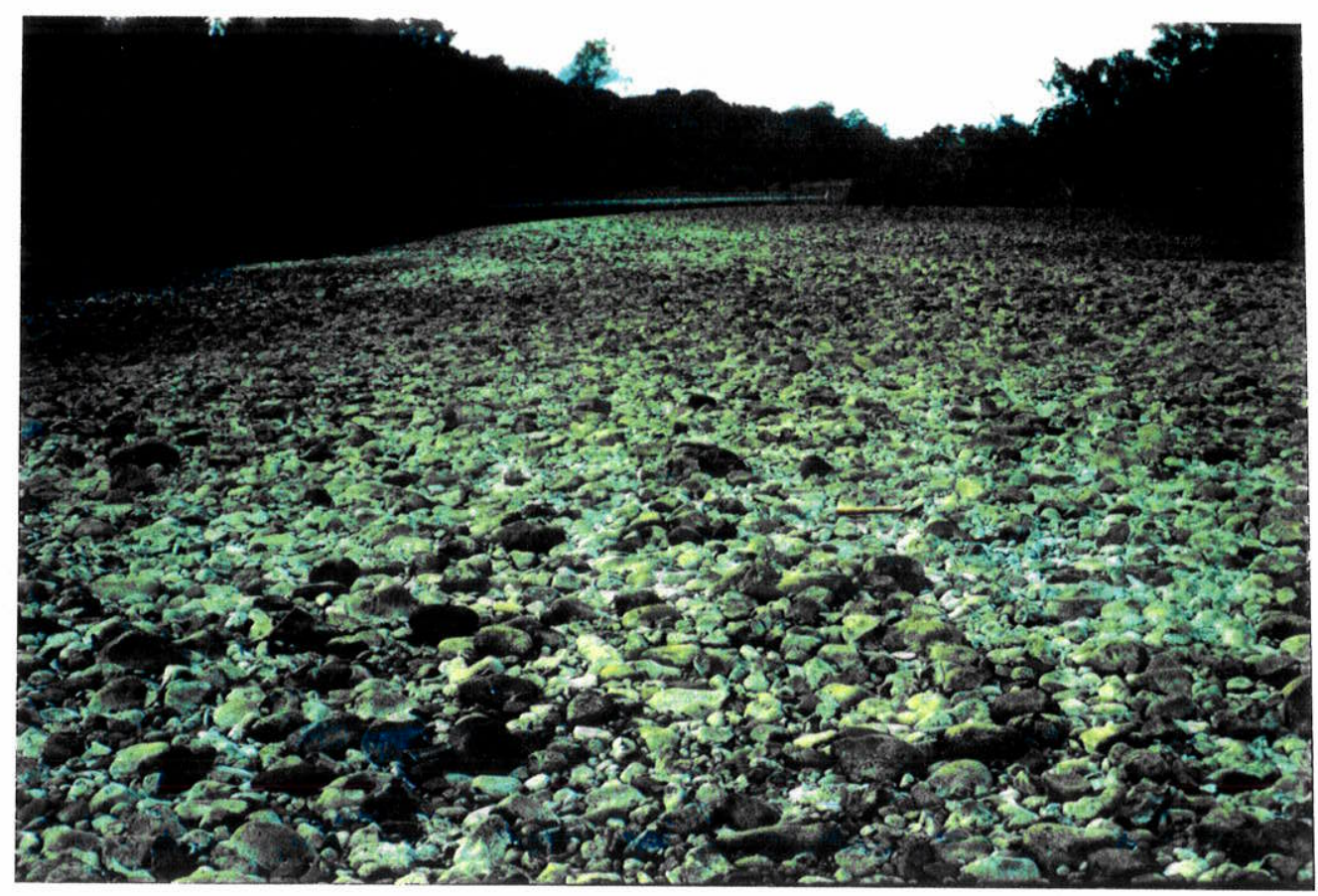

Foto 28 - Leito do Rio Itoupava, defronte à Igreja do Morro do Ermo, Município de Turvo. A água flui à esquerda. Os seixos não constituem propriamente uma barra e sim um assoalho, cujos fragmentos "bem assentados" não se deslocam com o peso de uma pessoa. A visada é para oeste. 


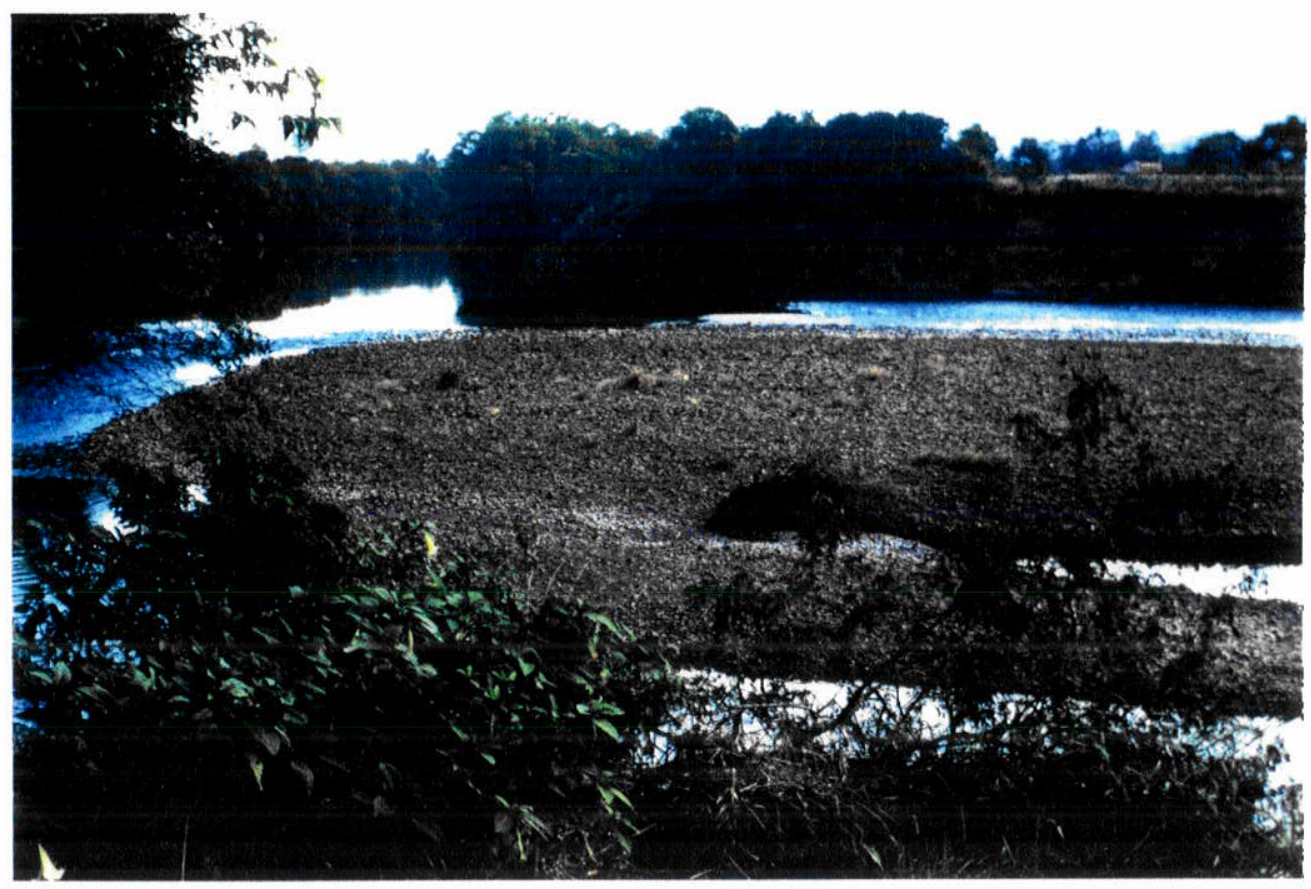

Foto 29 - Barra de cascalho bifurcada a jusante, significando um dos momentos da evolução desta barra, no Rio Itoupava, alguns quilômetros a leste da localidade de Ermo, Município de Turvo. Notase a margem esquerda (lado direito da foto), íngreme e erodida. A margem direita é também verticalizada, com vegetação cobrindo a maior parte da mesma. Ambas apresentam-se constituídas com material rudáceo. A margem esquerda tem uma cobertura arenosa sobre os rudáceos de aproximadamente $2 \mathrm{~m}$.

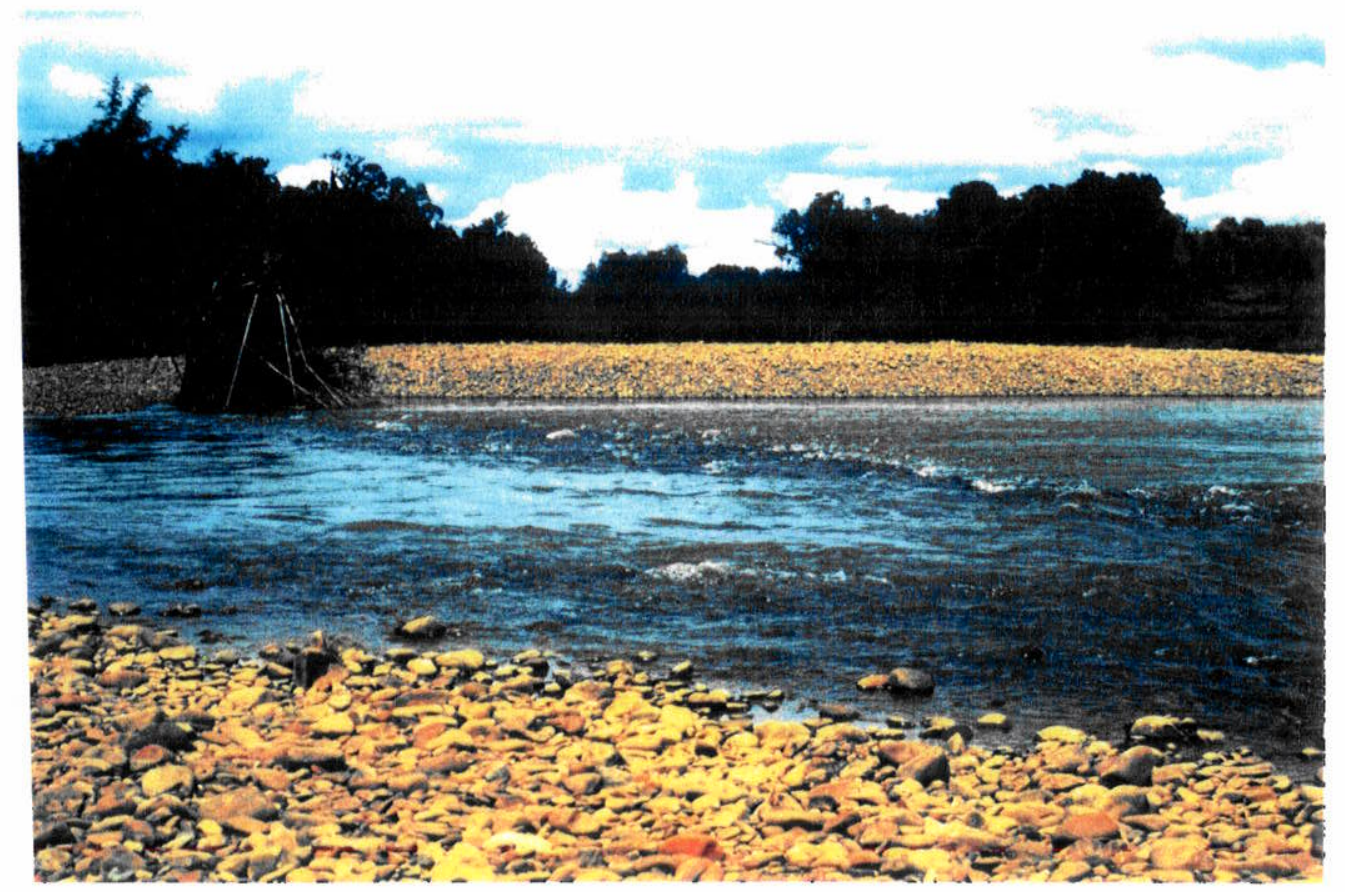

Foto 30 - Aspecto da barra de cascalho da foto 29 , visando-a ao nível das águas do Rio ltoupava, num outro momento e num outro ângulo. O rio, neste trecho, corre de oeste para leste, do fundo da foto para onde está sendo batida a mesma. O barramento faz com que desvie suas águas em dois fluxos: um que atinge a margem esquerda (lado direito da foto) e a erosiona por ser de material rudáceo e arenoso, friável; o outro pela direita, rodeando a barra. A margem direita é alta e constituída por depósito rudáceo fortemente coeso. 


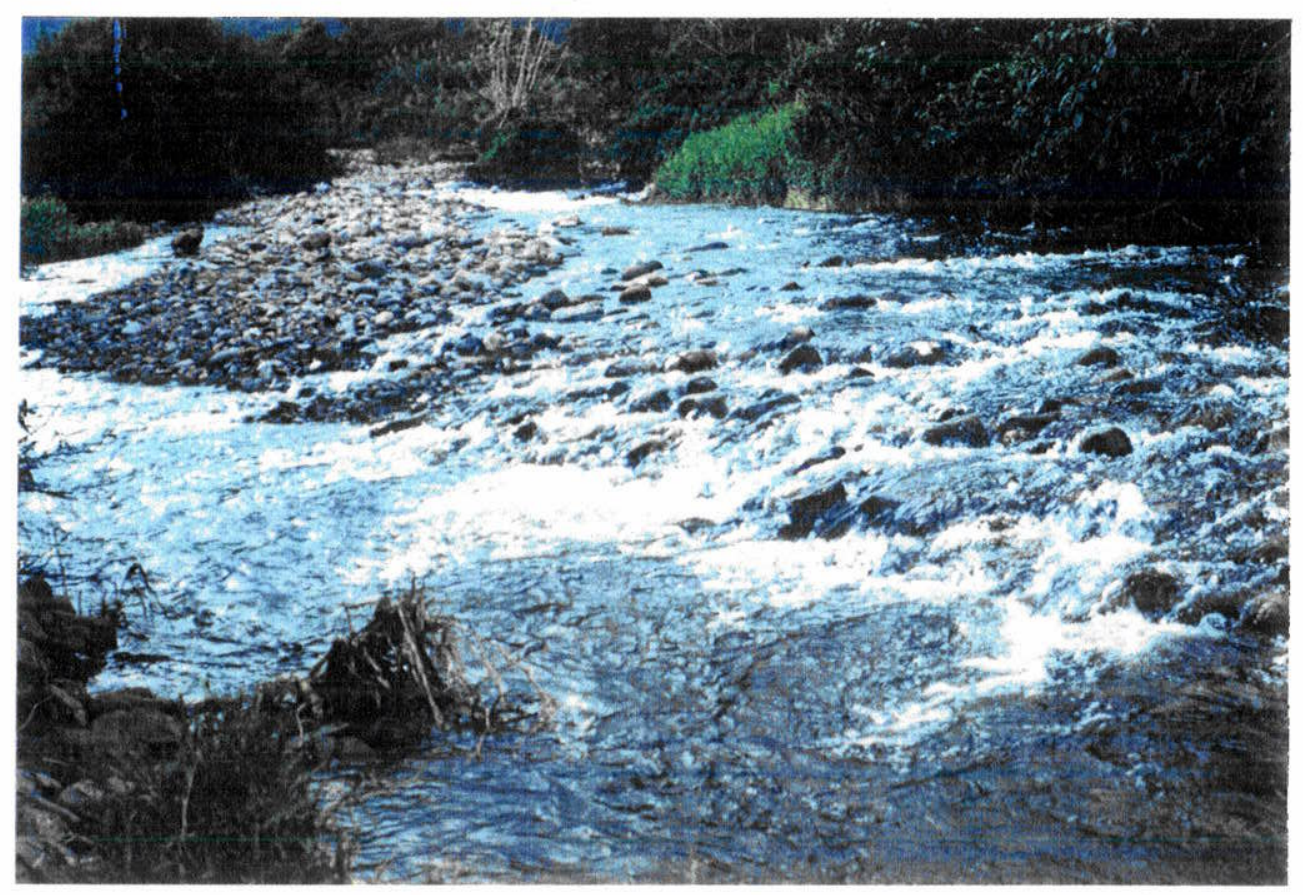

Foto 31 - Braço do Rio Pavão, Município de Praia Grande, Setor Sul. A foto mostra uma barra longilínea que faz com que as águas fluam em dois niveis e a partir de um certo ponto corram transversalmente, do nivel mais alto para o mais baixo. Trata-se de uma situação comum em muitos rios dos setores Norte e Sul, e em vários locais dos canais dos leques, nas áreas proximal e mediana, evidenciando também transições entre tipos de barras.

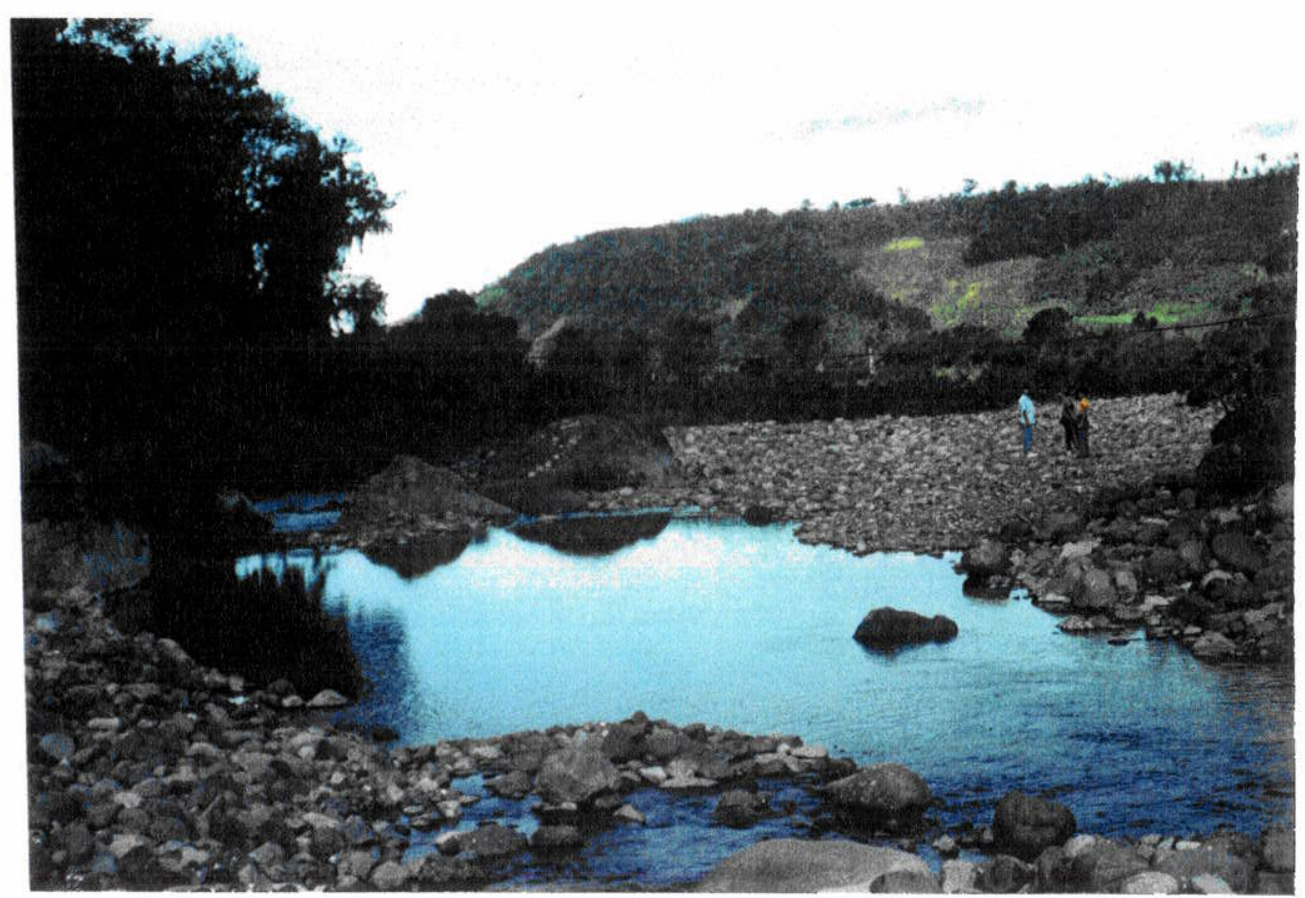

Foto 32 - Situação quase de ápice do leque do Rio Pavão, numa visada para leste. A foto foi batida também com intenção de mostrar o desnível entre o leito "seco", entulhado, da direita, onde estão as pessoas, e aquele da esquerda, por onde a água flui subaereamente. O canal seco tem seu assoalho a uma altura de mais de $2 \mathrm{~m}$ em relação ao nível da água. Por ele a água flui subterraneamente. Os blocos no centro esquerdo da foto são de basalto. São depósitos acerca de $200 \mathrm{~m}$ de altitude. Para oeste, às costas do fotógrafo, situa-se o cânion do Itaimbézinho. 


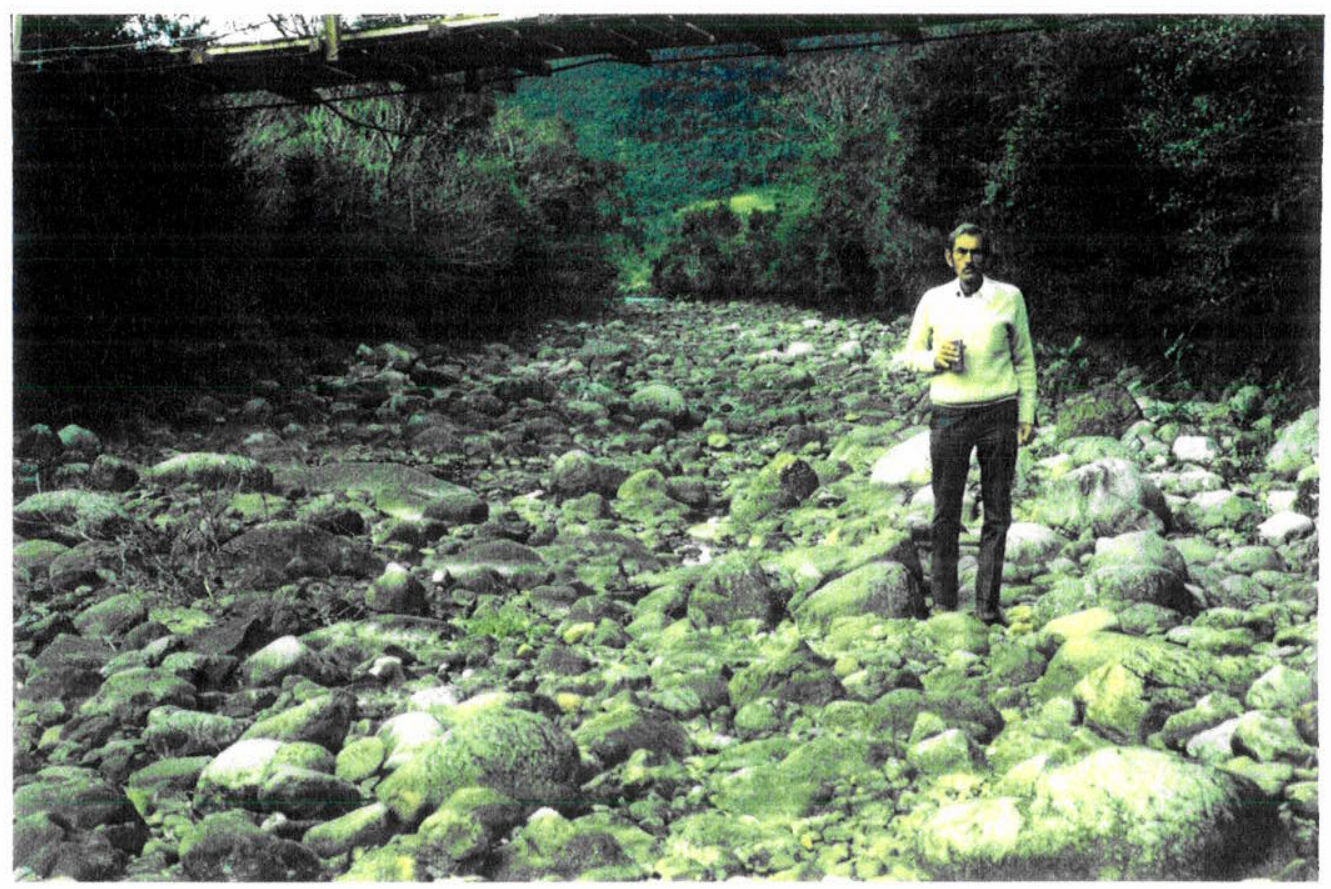

Foto 33 - Canal seco (Rio Seco) no Rio Pavão, bem a jusante das fotos 31, 32, 36 e 37. Bem no fundo, na parte alta da foto, vê-se água migrando no leito. Como está em nível baixo, ela percola subterrânemente em muitos trechos. Este canal seco é devido ao barramento mostrado na foto 32. Em épocas de chuva a água corre sobre este leito, mesmo sem ultrapassar aquele barramento.

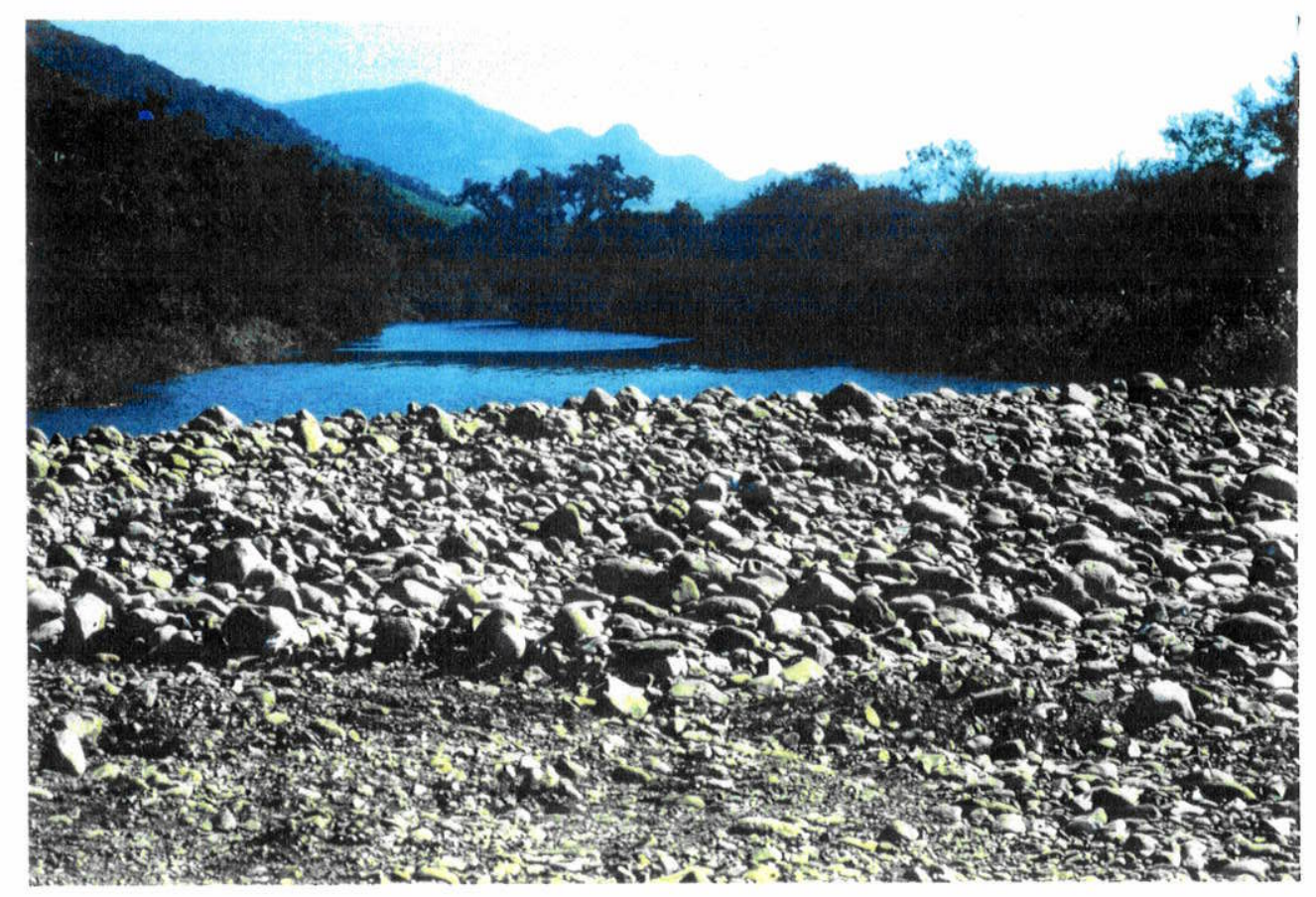

Foto 34 - Seixos imbricados de corrente que vem de oeste, à direita da foto. Trata-se do extremo distal do leque aluvial do Rio Pavão, invadindo o leito do Rio Mampituba, cujas águas migram do sul (fundo da foto) para o norte, passando pelo seu canal estreitado, no lado esquerdo da foto. A margem direita do Rio Mampituba, neste local, do lado esquerdo da foto, constitui-se de uma parede íngreme de rocha básica que também assoalha um pequeno trecho do leito deste rio. 


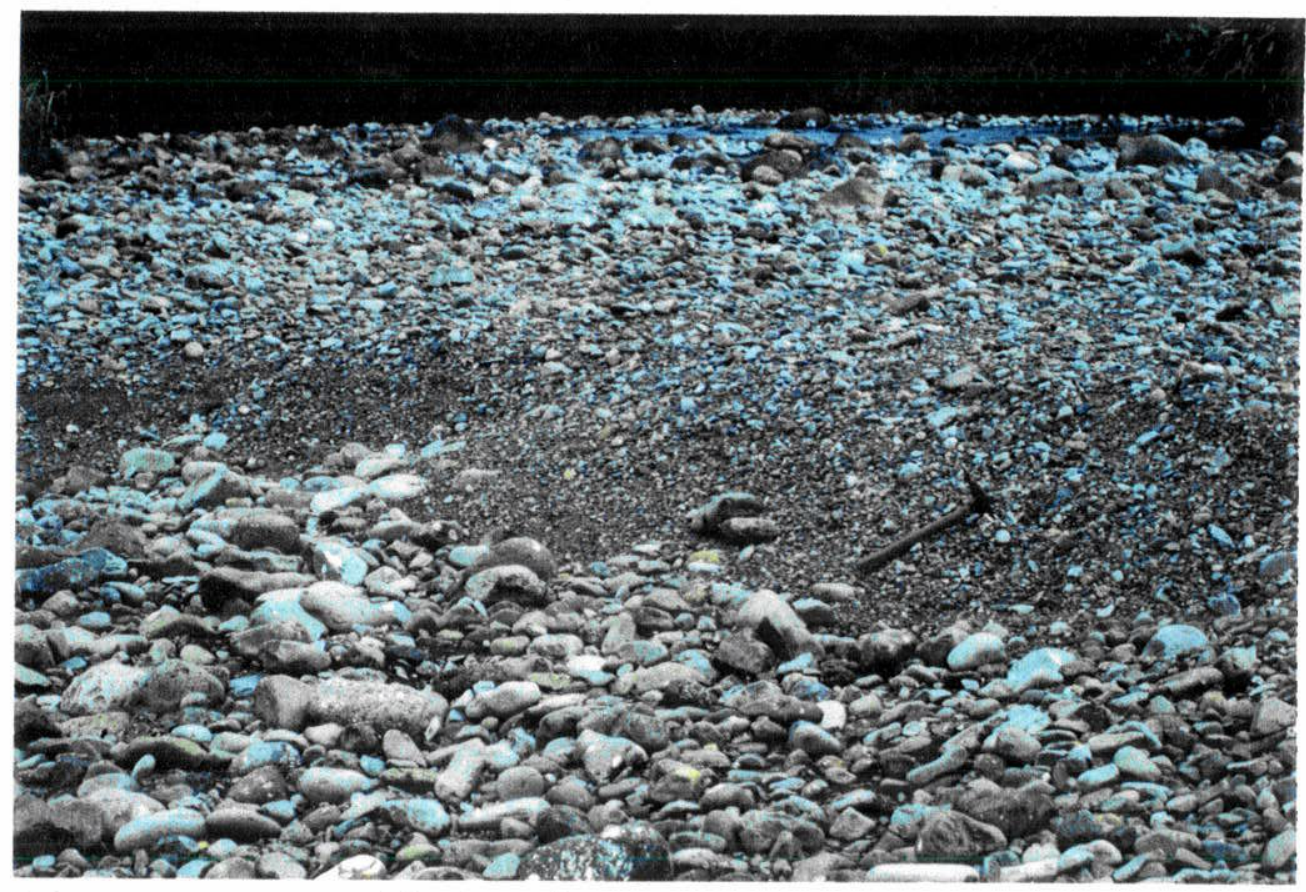

Foto 35 - A foto mostra superposição de sedimentos e a parte a jusante de uma barra de cascalho, no mesmo local da Foto 34, no extremo distal do leque aluvial do Rio Pavão, sobre o Rio Mampituba. Nota-se a forma mais ingreme da parte terminal da barra, com a concentração de fragmentos menores. A água que corre no topo da foto é do Rio Pavão. Este trecho está todo sobre o canal do Rio Mampituba, e as águas do Rio Pavão correm mais altas e perpendiculares àquelas do primeiro. Visada para o sul.

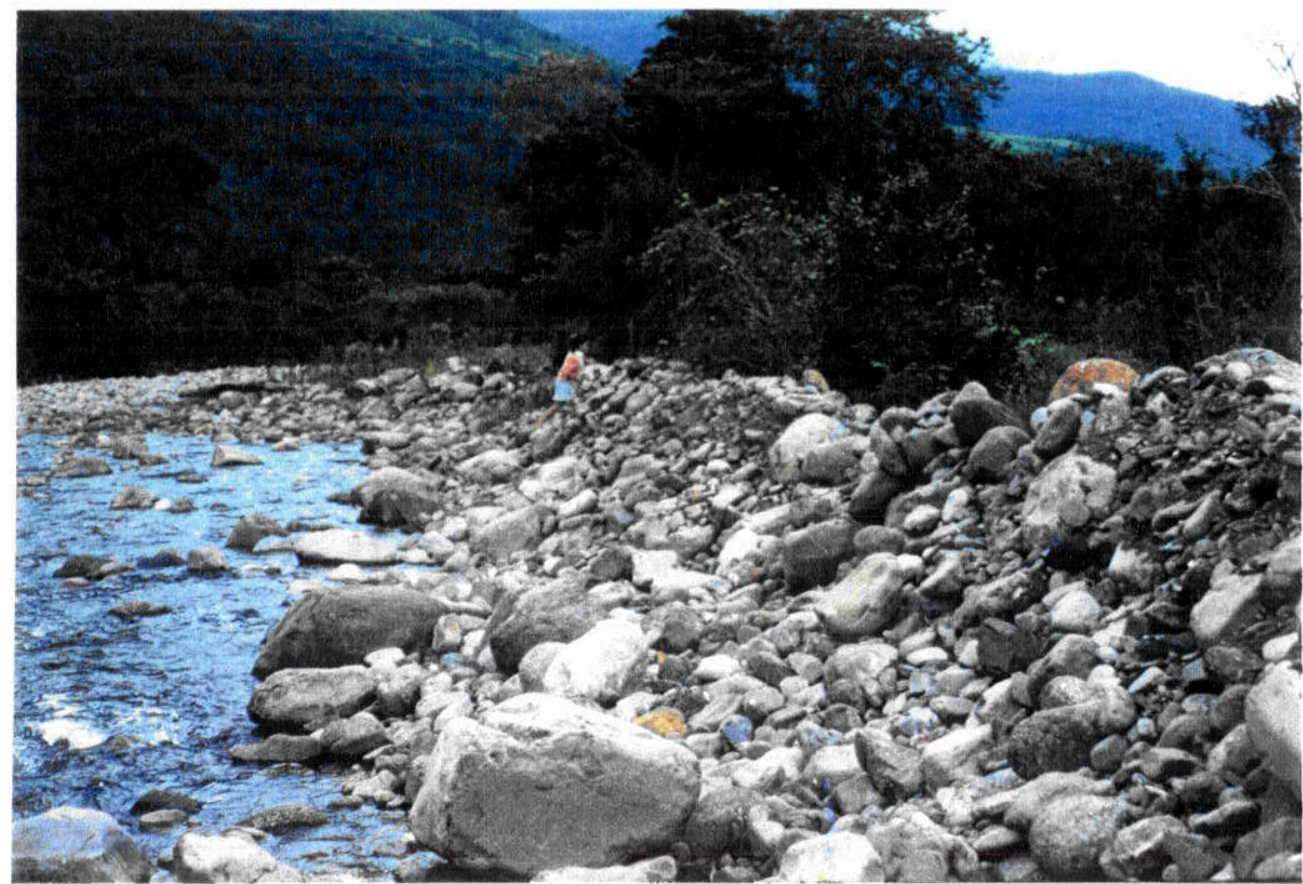

Foto 36 - Margem direita de um dos canais do Rio Pavão. Materiais e forma da margem gerados pelas águas de uma cheia. Notam-se os matacões e a altura que alcançaram. A nova forma, como uma crista, avançou sobre a margem anterior com vegetação. O alargamento do canal durante a cheia gerou esta forma que poderá ser bastante modificada na cheia seguinte. Localidade de Fundo do Rio do Boi, Município de Praia Grande. Local das Foto 37, paralelo ao local e canal da Foto 31, a jusante do local da Foto 32 e a montante do da Foto 33. 


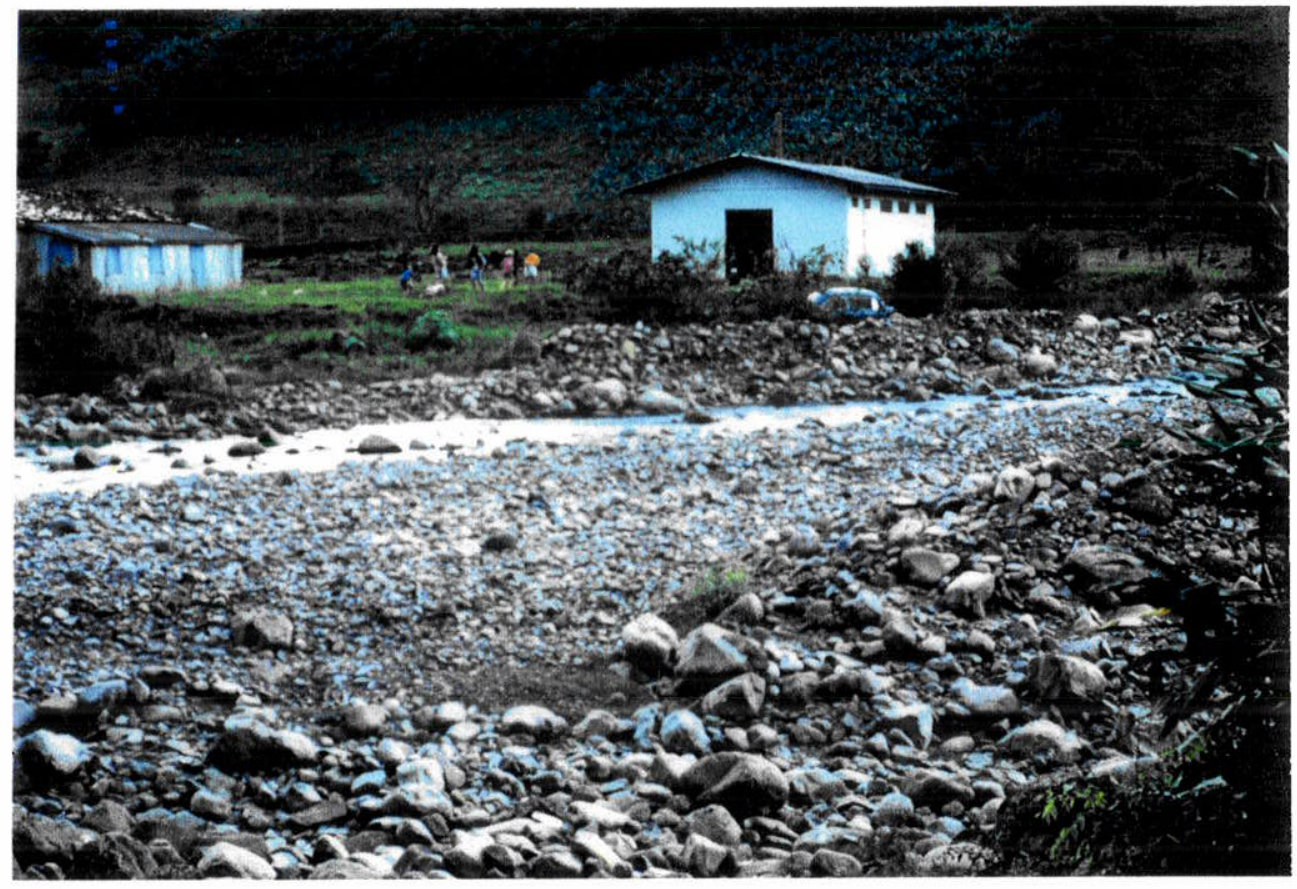

Foto 37 - Mesmo local da Foto 36, visando a margem direita do canal e do vale. A foto mostra a amplitude do canal e os sedimentos soerguidos pela cheia criando uma margem em crista. O carro serve de escala para demonstrar a altura do depósito. As formas ao lado e atrás da edificação são de sedimentos mais antigos do leque proximal. Foto a partir de uma barra/ilha. Há, portanto, paralelamente, outros canais originados pela divisão do canal-tronco que drena o fundo do cânion do Itaimbézinho. 
As medidas dos seixos ao longo dos canais dos leques do Rio Pavão, no Setor Sul, e dos rios da Pedra/ltoupava e Rocinha, no Setor Norte (Tabelas 14 a 53), evidenciam que há uma diminuição proporcional dos tamanhos dos seixos no sentido da foz e, portanto, um transporte não essencialmente seletivo. Aceita-se aqui o raciocínio de MACKIN (1970).

Na parte proximal do leque do Rio Pavão verifica-se que, considerando-se os tamanhos em classes de $1 \phi$, a classe modal situa-se no tamanho de 64-128 mm, e, para jusante, vai se transferindo para a classe de $32-64 \mathrm{~mm}$. Os valores percentuais dos tamanhos entre 64 e $128 \mathrm{~mm}$ são $48 \%$ na situação proximal e terminam em 10\% na área distal, enquanto as taxas dos tamanhos de 32 a $128 \mathrm{~mm}$ caem de $76 \%$ para $55 \%$, havendo, ao contrário, um aumento percentual dos tamanhos de 16 a $64 \mathrm{~mm}$, de $32 \%$ para $75 \%$.

As barras dos canais atuais no leque do Rio da Pedra/ Itoupava têm valores modais que variam da área proximal para a mediana. De montante para jusante, inicia-se com a classe modal de 64-128 mm, porém logo no segundo local medido, duas classes têm a mesma taxa, isto é, tanto a de 64-128 mm como a de $32-64 \mathrm{~mm}$ que passa a dominar ao longo dos canais deste leque. Verifica-se que os seixos são, em média, menores que no leque do Rio Pavão. O tamanho $64-128 \mathrm{~mm}$ inicia como moda com $36 \%$ dos clastos, e a taxa deste tamanho diminui no fim do trecho medido, para $8 \%$. Considerando-se a soma de dois tamanhos de $1 \phi$, isto é, o intervalo entre 32 e $128 \mathrm{~mm}$, suas taxas variaram para mais e para menos ao longo do percurso, iniciando com $67 \%$ e terminando com $64 \%$, porém, atingiu $81 \%$ em um local e $43 \%$ em outro. As taxas dos tamanhos entre 16 e 64 $\mathrm{mm}$ é que evidenciam a diminuição proporcional destes seixos, uma vez que na área proximal do leque começam com $48 \%$ e terminam no leque mediano com $87 \%$, havendo uma variação progressiva.

A variação de tamanho ao longo dos canais deve ser mais por atrito do que por seleção, uma vez que se encontram tamanhos os mais diversos, de grânulo a matacão, em um mesmo local, seja na parte proximal ou mediana dos leques, ou, no caso do leque 
do Rio Pavão, também na sua área distal, onde ocorrem fragmentos menores de $1 \mathrm{~cm}$ ao lado de matacões com mais de 0,50 m (Tabelas 14 a 53).

Todos os tamanhos de fragmentos, inclusive matacões de $1 \mathrm{~m}$, são movimentados pelas águas. Não apenas as medições atestam este fato como também as observações em campo. Para auxiliar esta observação, os seixos foram pintados com vários tipos de tintas, com sinais diferentes e com técnicas diferentes, como foi referido na metodologia. Em todas as ocasiões e situações, após uma chuva dentro dos padrões normais, isto é, com intensidade não excepcional, todos os fragmentos foram transportados. Um outro tipo de observação indireta pode ser feita em locais onde há pavimentação dos leitos dos rios com cimento e placas de Arenito Botucatu, para facilitar a travessia de carros e carroças. Este tipo de pavimentação de alguns centímetros de espessura é chamado de "barragem", embora ele não seja um anteparo para as águas. Nestes locais podem ser notadas modificações nos tamanhos e quantidade de fragmentos a montante e jusante destas barragens, antes e depois de cheias, bem como marcas longilíneas, em baixo relevo, deixadas pelo arraste de seixos e matacões sobre o pavimento das mesmas.

No leque do Rio Pavão, dirigindo-se de jusante para a parte proximal do leque, há defronte à primeira Escola Isolada uma destas "barragens". Junto a esta e a jusante da mesma, há um depósito de peneiramento que freqüentemente se amplia vertical e longitudinalmente pelo acréscimo de seixos. A concentração tanto de matacões como de seixos varia grandemente, demonstrando o transporte dos mesmos. Alguns matacões da tabela 40 , medidos a jusante, foram registrados anteriormente a uma cheia, a montante daquela "barragem".

Os depósitos de peneiramento são mais freqüentes no Setor Sul, isto é, no leque do Rio Pavão, reafirmando a tendência ali, para sedimentos mais grossos, nos canais atuais, do que no leque do Rio da Pedra/ltoupava, pois estes depósitos de peneiramento compreendem apenas matacões. Há possivelmente uma relação com a declividade deste leque que é maior entre todos da área.

Os depósitos de peneiramento (sieve deposits, designação de HOOKE, 1967, apud BULL, 1968) se formariam quando pouco material fino é fornecido ao leque (BULL, 1968). 
Assim, os depósitos se tornam permeáveis e permitem à água se infiltrar inteiramente, antes de alcançar a base do leque. A água passa através do depósito e não sobre o mesmo, o que permite a retenção do material grosso. O cascalho que atapeta o leito dos rios, formando barras ou não, constitui-se quase sempre neste tipo de depósito, que é também conhecido como depósito residual (lag deposits).

Estão sendo considerados aqui como depósitos de peneiramento, apenas as concentrações de matacões que as vezes retém seixos e outras estão livres dos mesmos, devido às condições de transporte. Se fosse aplicado o conceito de BULL (1968), todo o material que assoalha os canais em ambos os setores, das cabeças dos leques até a parte terminal dos mesmos seria considerado como depósito de peneiramento.

Freqüentemente, entre uma cainada e outra de seixos, nota-se a presença de areia grossa e grânulos como que trapeados pelo ajuste das formas dos clastos maiores. Eles distribuem-se descontinuamente e podem ter sido depositados sindeposicionalmente aos seixos maiores como posteriormente. Estes fragmentos menores são inseridos e retirados pelas águas. É flagrante esta migração em períodos de águas baixas, quando em muitos trechos estas correm subterraneamente. Um local que permite boa visualização deste transporte é a área distal do leque do Rio Pavão, onde este avança sobre o leito do Rio Mampituba que está num nivel mais baixo. Observa-se ali que as águas do Rio Pavão, fluindo subterraneamente, penetram nas águas do Rio Mampituba perpendicularmente ao fluxo deste. Muitas vezes elas carregam consigo estas areias e grânulos que são colocados no leito do Rio Mampituba. Isto não ocorre apenas junto à superfície das águas; muitas vezes a entrada acontece a decímetros abaixo como pequenas surgências que jogam água e sedimentos não apenas para frente mas também para cima. Este fluxo de água subterrânea tem capacidade de transporte de grânulos e areia grossa o que dá uma idéia da energia que as águas adquirem quando fluem mesmo em pequenas cheias de $0,50 \mathrm{~m}$ ou $1 \mathrm{~m}$ acima do leito.

As Tabelas 14 a 53 evidenciam que em alguns locais o eixo maior dos seixos é quase o dobro do seu eixo médio, ou pelo menos a diferença é bastante significativa. Em outros também os seixos têm o eixo médio bem maior que o eixo menor. Poder-se-ía 
pensar que este fato traria diferenças significativas sobre as formas, ou salientando uma forma original das partículas, porém estes elementos não são salientes, isto é, tanto em conjuntos medidos apresentando grandes diferenças entre os eixos, como naqueles em que isto não acontece, as diferentes formas ocorrem em taxas semelhantes. Há uma diferença deste comportamento nos depósitos de peneiramento onde os tamanhos dos clastos são predominantemente maiores (Tabelas 16, 40, 46, 52).

As medidas de cascalhos no Rio Rocinha, a montante da ponte em Timbé, são muito semelhantes àquelas realizadas à montante da ponte de concreto do Rio Pavão, quanto à variação no tamanho dos eixos, à amplitude de variação no tamanho dos eixos, à amplitude de variação dos diferentes eixos, no comportamento das formas no intervalo modal (64-128 mm) e nas proporções dos quartís. Talvez o estrangulamento gerado pela posição das extremidades das pontes bem como as pilastras durante as cheias, gere condições hidráulicas possibilitando essas semelhanças.

As tabelas 14 a 53 e as Figuras 64 a 95 mostram, além das variações de tamanho médio, as de achatamento, esfericidade e forma.

\subsection{Formas dos Clastos}

As formas (Tabelas 14 a 53) obtidas a partir das razões dos eixos B/A e C/B, segundo as categorias sugeridas por ZINGG (1935), para as barras fluviais amostradas ao longo do leque do Rio da Pedra/ltoupava, mostram uma distribuição em que dominam as formas discoidais, seguidas pelas esféricas, cilíndricas e laminares. Não seguem este padrão as medidas dos seixos em Taquarussu (Tabela 33) onde os seixos cilíndricos e os laminares apresentam taxas mais altas que os esféricos. $\mathrm{Na}$ seqüência de medidas ao longo do leque do Rio Pavão, as primeiras barras no leque proximal têm o mesmo padrão de distribuição de formas do leque acima referido, porém, em direção a jusante não há o comportamento regular observado naquele leque; uma vez que os seixos esféricos em algumas barras, é que aparecem com as taxas mais altas, e os cilíndricos são mais freqüentes que no leque do Rio da Pedra/ltoupava. Comparando-se as taxas médias das 
formas em cada conjunto de medidas, nos dois leques, nota-se que no do Rio Pavão elas são melhor distribuidas entre as quatro formas, pois, enquanto neste leque as taxas mais altas dificilmente ultrapassam os $40 \%$, no leque do Rio da Pedra a freqüência dos seixos discóides estão, em geral, acima deste valor. Quando essas formas são tratadas por classe de tamanho, vê-se que no leque do Rio da Pedra/ltoupava as formas na maioria dos diferentes tamanhos acompanham o comportamento das taxas médias, havendo uma variação no tamanho modal, $32-64 \mathrm{~mm}$, onde freqüentemente as taxas dos seixos laminares são um pouco mais altas que a dos cilíndricos.

As freqüências mais altas de seixos discóides e esféricos nas barras dos dois leques, parecem sugerir uma seleção pela forma, sendo os discoidais favorecidos pela baixa velocidade necessária para a sua deposição, enquanto os esféricos rolam mais facilmente tendo uma baixa resistência a serem transportados. Os seixos laminares, por sua vez, são transportados mais lentamente que todos os outros. Entretanto, as características estruturais do basalto, rocha fonte primordial dos seixos, devem ser as responsáveis pela forma inicial dos fragmentos, contribuindo ainda o intemperismo químico e a ação física durante o transporte, como a friç̧ão, o impacto entre as partículas e a compressão.

Nos depósitos de peneiramento, medidos em três locais ao longo do leque do Rio Pavão, os seixos esféricos são os mais freqüentes; seguem-se os cilíndricos ou alinham-se em taxas semelhantes, os discóides e os laminares. A presença de matacões principalmente com a forma esférica talvez seja um reflexo da mais baixa resistência ao transporte de fragmentos com essa forma, aliada a ação anterior do intemperismo sobre os basaltos. As formas cilíndricas teriam também relação com as características estruturais do basalto.

\subsection{Achatamento e Esfericidade}

Nos depósitos proximais do leque do Rio Pavão, verifica-se que os tamanhos entre 64 e $256 \mathrm{~mm}$ (Tabelas 34 a 39) apresentam achatamento maior que os tamanhos menores 
e maiores que estes. Por outro lado, os clastos entre 64 e $256 \mathrm{~mm}$ têm índices de esfericidade mais baixos, enquanto os menores que esta faixa apresentam-se levemente mais esféricos. Para jusante nem sempre estas características se repetem. É possível que a maior esfericidade de fragmentos menores tenha relação não apenas com o atrito, mas com a alteração do basalto in situ.

Em cada amostragem a esfericidade é que apresenta o menor coeficiente de variação e o tamanho médio o maior, não havendo regularidade de aumento ou diminuição dos seus valores, ou do achatamento, do ápice para a base. Portanto, as dinâmicas de transporte e deposição são muito mais complexas do que apenas progressão de abrasão ou de seleção.

\subsection{Relações entre Parâmetros}

As figuras 64 a 72 expõem as relações entre tamanho médio, forma e achatamento de cascalhos fluviais do Setor Norte, e as figuras 73 a 79 , as mesmas relações destes sedimentos no Setor Sul. As figuras de números 80 a 95 representam as relações entre tamanho médio, forma e esfericidade dos clastos das barras fluviais de ambos os setores.

As figuras 64 a 95 mostram que os tamanhos médios dos fragmentos independem das suas formas. Conclui-se por outro lado, que são raros os fragmentos com esfericidade inferior a 0,3 , que as maiores variações de esfericidade são verificadas entre os fragmentos classificados como discoidais e que os fragmentos laminares obviamente exibem as menores esfericidades.

Em poucos locais dos leitos fluviais, nos trechos relacionados às áreas proximais e medianas dos leques, nota-se o acúmulo de sedimentos com tamanhos em torno de $4 \mathrm{~mm}$ sob a forma de bolsões. Dois locais foram amostrados, um no Rio Pavão, a jusante da ponte de alvenaria, e outro no Rio Itoupava defronte à Santana. Neste segundo caso havia extração de material do canal em época muito seca, o que permitia acesso ao leito sobre praticamente toda a largura do rio. São sedimentos bimodais, mal selecionados, e o seu diâmetro médio mostrou uma variação de $-2,19$ a $-0,63 \phi(4,56 \mathrm{~mm}$ a 1,55 mm). A seleção 
é maior na amostra do Rio Pavão. Os valores granulométricos absolutos vão de $16 \mathrm{~mm}$ até $0,062 \mathrm{~mm}$ (Figuras 96, 97; Tabela 54).

Onde as águas tornam-se mais regularmente profundas, os sedimentos de leitos fluviais são mais finos, como os testemunhados no leito do Rio Araranguá, à época da construção da BR-101, em 1957. Sob uma lâmina de aproximadamente $8 \mathrm{~m}$ de água há cerca de $3 \mathrm{~m}$ de argila orgânica arenosa, com areia média, sobre $0,50 \mathrm{~m}$ de argila arenosa (areia fina), sobre 0,50 $\mathrm{m}$ de grânulos e seixos pequenos.

\subsubsection{Margens dos Canais Atuais - Diques Marginais}

Onde as margens dos canais são constituídas por depósitos rudáceos, houve a possibilidade de se ter acesso, em muitos locais, ao material do leito, em épocas normais, sem chuvas, porém quando essas margens estão constituídas de sedimentos argiloarenosos, o acesso ao leito tornava-se bastante difícil, devido a presença de vegetação densa, a verticalidade das paredes e a profundidade da lâmina de água.

As margens verticalizadas dos canais atuais apresentam principalmente seixos nos trechos proximais e medianos dos leques. Nos últimos, também ocorrem, embora raramente, camadas arenosas, argilo-siltosas ou silto-argilosas (Fotos 38 a 41). Os teores de areia têm seu valor variando de menos de $20 \%$ até mais de $90 \%$. São sedimentos muito mal selecionados a mal selecionados. Entretanto, domina a assimetria positiva, enfatizando a presença dos finos. Os diâmetros médios entre $1,8 \phi$ a quase $8 \phi(0,28 \mathrm{~mm}$ a $0,004 \mathrm{~mm})$ evidenciam a grande dispersão dos tamanhos das partículas, corroborando com os dados apresentados acima. Os sedimentos são polimodais, com 2 a 4 modas, predominando 3 modas uma das quais no tamanho areia, principalmente dentro da areia fina.

Em vários locais foram encontrados pedaços de madeira (caules ou galhos de árvores), folhas e matéria orgânica indistinta, intercalados nos depósitos inorgânicos, expostos nas margens verticalizadas dos canais fluviais. Foram coletadas amostras dos três tipos de matéria orgânica das quais apenas os troncos de árvores foram utilizados para datação pelo $\mathrm{C}^{14}$. 


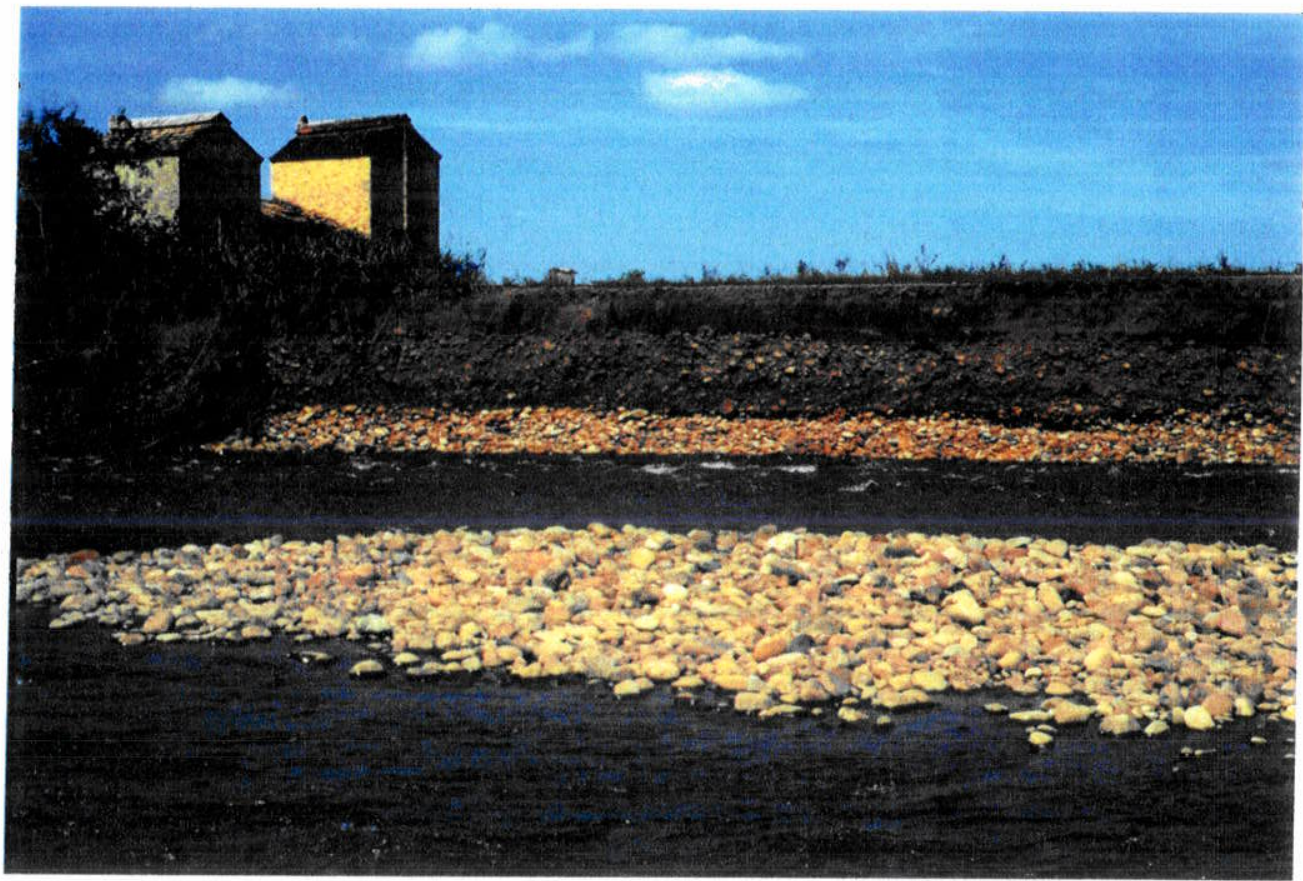

Foto 38 - Depósito de cascalho em barra longitudinal e depósito de canal aflorando na margem direita do Rio Canoas, capeado por camada areno-argilosa. Esta margem está sendo erodida. Um único seixo de rocha sedimentar foi encontrado neste afloramento. O restante dos seixos é de basalto. O local que a foto mostra situa-se a jusante da ponte, na estrada SC-450, em Praia Grande.

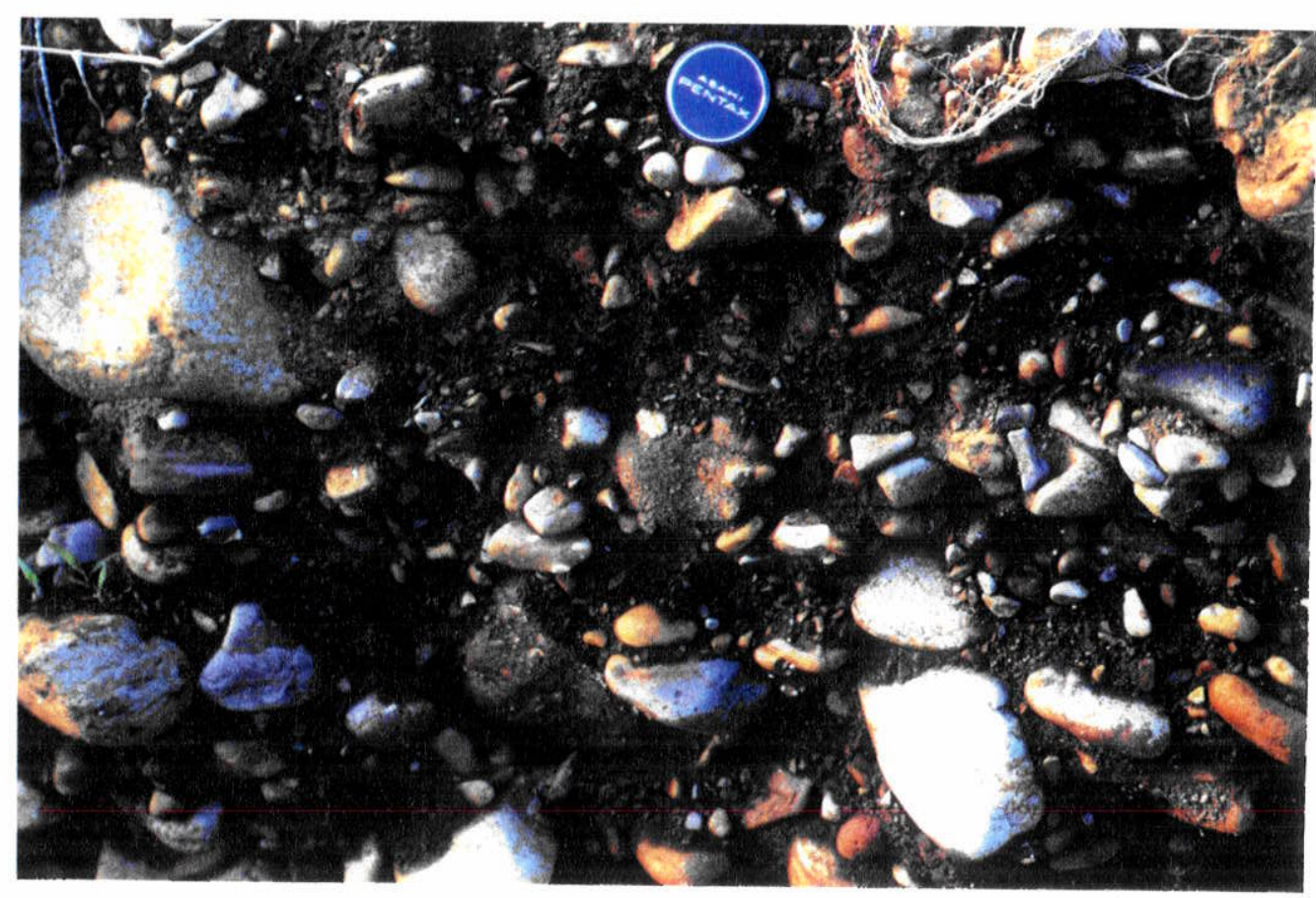

Foto 39 - Detalhe da Foto 38, do barranco da margem direita do Rio Canoas. Notam-se: imbricação, a grande variedade de tamanhos, a pouca matriz, arenosa e a estratificação que sofre interferência dos seixos maiores. 


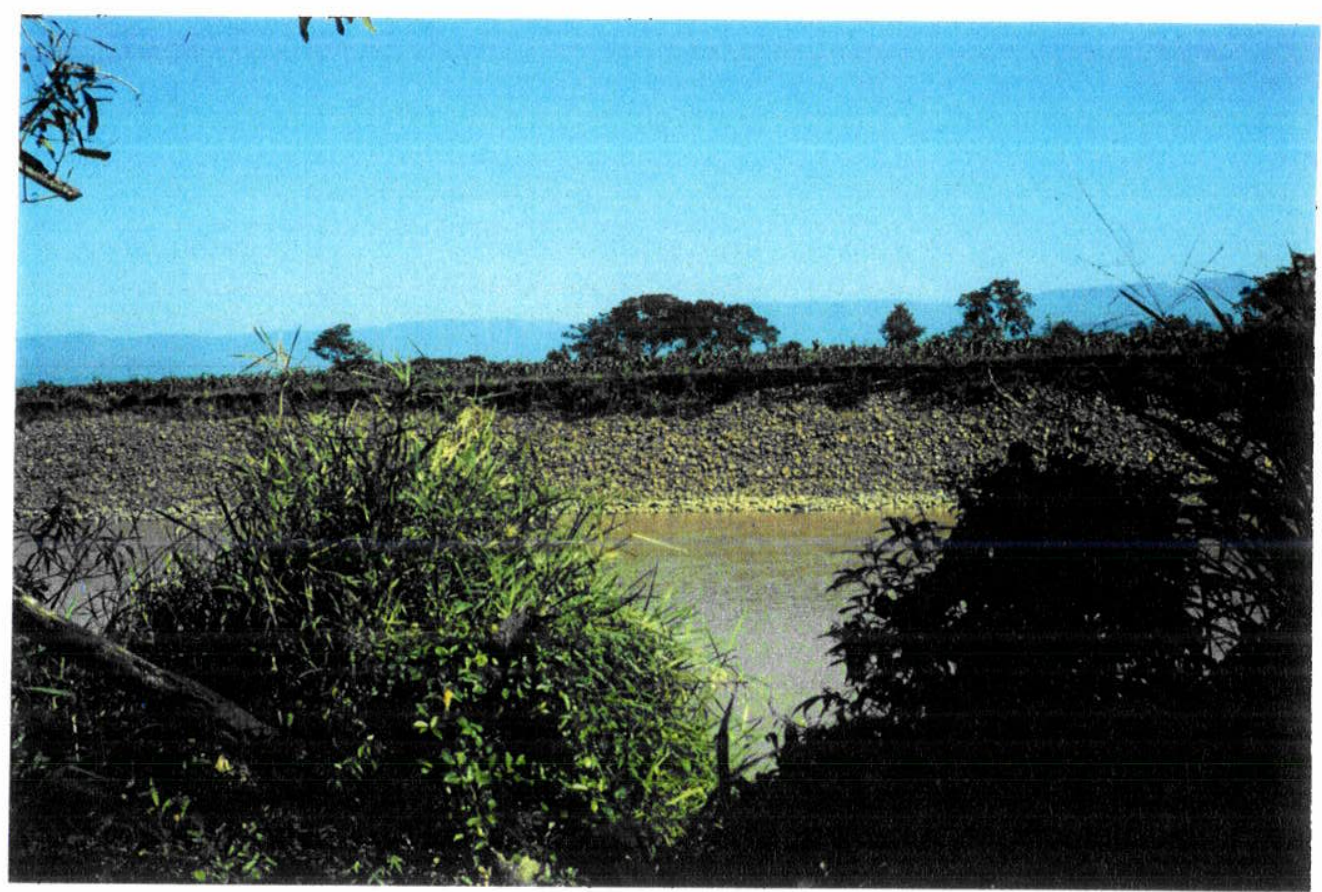

Foto 40 - Depósito rudáceo de canal, em erosão, na margem esquerda do Rio Itoupava. Note-se que a cobertura de sedimentos mais finos é bem pouco espessa, em relação à camada de seixos. Situação de leque mediano. A cerca e os pés de milho adulto poderiam servir de parâmetro para determinar-se a altura desta margem.

Uma coleta foi realizada na margem esquerda do Rio Cachoeira, $2 \mathrm{~km}$ a leste da localidade homônima. O corte da margem do canal apresenta material rudáceo, argila esverdeada e matéria orgânica constituída por folhas carbonificadas e pedaços de madeira. O afloramento com 1,30 m de espessura apresenta a matéria orgânica disposta em arco, no fundo de um paleocanal com até $3 \mathrm{~m}$ de largura no corte. Esta matéria orgânica está sobreposta a material rudáceo e recoberta com material argilo-arenoso marrom, com 0,95 m de espessura. O material rudáceo se prolonga e se espessa para montante. Para jusante dispõe-se uma camada de argila esverdeada, com cerca de $15 \mathrm{~m}$ de comprimento. A matéria orgânica foi coletada a 1,20 m de profundidade e a datação de um pedaço de madeira apresentou a idade de $560 \pm 150$ anos B.P., com $\delta^{13} \mathrm{C}-27,32 \%$ (Amostra Bah-1664).

No Município de Sombrio, na margem esquerda de um canal retificando o Córrego da Peroba, afluente do Rio da Laje, foi coletada outra amostra de madeira. No corte com 2,05 m de espessura dispõem-se quatro camadas : a basal com 0,55 m de espessura de 
Foto 41 - Seqüência que mostra a margem do Rio ltoupava, no local das fotos 29 e 30 . A base é de material rudáceo apresentando estratificação de barras, sotoposto a areias estratificadas também de barras, cobertas por sedimentos areno-argilosos maciços. A ausência de estruturas no topo da seqüência, talvez, seja devida à pedogênese. 

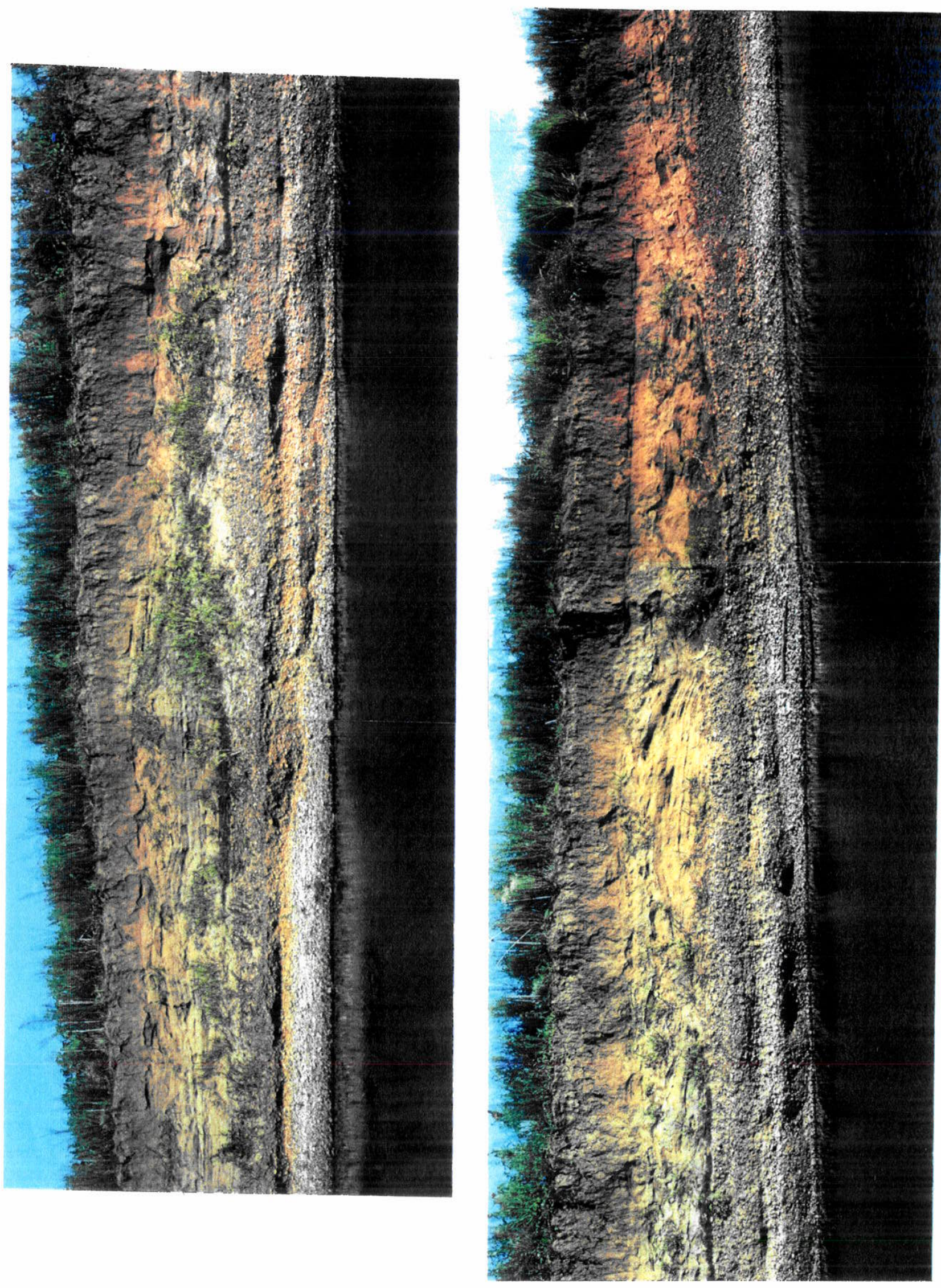
argila arenosa de cor cinza-verde, com manchas avermelhadas ao longo de gretas de contração das argilas; a segunda camada, acima desta, com $0,40 \mathrm{~m}$ de espessura, constitui-se de uma mistura de areia, argila e matéria orgânica decomposta, madeira e folhas. Esta camada é areno-argilosa na base, onde há também maior concentração de folhas; para o topo concentram-se argila, matéria orgânica decomposta e pedaços de madeira (caules). Sobreposta a estas está a terceira camada com 0,90 m de espessura, arenosa, com lentes irregulares de argila, de cor cinza clara, muito manchada de amarelo da limonita. No topo há camada de $0,20 \mathrm{~m}$ de espessura, areno-argilosa, de cor castanha. A madeira coletada a $1,10 \mathrm{~m}$ de profundidade situava-se no limite entre a segunda e terceira camadas. A amostra Bah-1663 tem a idade atual com $\delta^{13} \mathrm{C}$ de $-27,59 \%$.

Na margem esquerda do Rio Itoupava, no corte da foto 41 , poucos metros a jusante e $3 \mathrm{~km}$ a leste da localidade de Ermo, foi coletada a terceira amostra de madeira para datação. O corte com 5,30 m de altura é margem verticalizada que está sendo erodida pelo rio. Sobre uma camada basal de cascalho há localmente uma seqüência de sedimentos dispostos de forma arqueada, provavelmente dentro de um paleocanal. $\mathrm{Na}$ base deste ocorre uma camada de folhas e pedaços de madeira entremeados com cascalho fino com matriz arenosa. Neste cascalho há níveis avermelhados e amarelados onde ocorre mais matriz, que em geral, é muito escassa. Sobre esta camada há outra apenas de matéria orgânica, constiruída de galhos, troncos e folhas. Sobrepostas a esta seguem-se uma sucessão de camadas finas argilosas e arenosas. Este conjunto apresenta-se com 3,70 m de espessura. A partir daí o depósito deixa de apresentar vestígio de canal, ocorrendo, então, uma camada arenosa, castanho-avermelhada, com estratificação plano-paralela, estendendo-se para montante e jusante. Esta camada ora é incoerente, ora seu material mostra-se coeso, um tanto cimentado com colóides de ferro. No topo distribui-se areia argilosa marrom.

A idade do fragmento lenhoso coletado a $4,80 \mathrm{~m}$ de profundidade é de $1.510 \pm 50$ anos B.P. (Amostra Beta - 56860). Se a idade estiver correta, ela evidenciará uma ação continuada dos processos dos leques aluviais com os depósitos arenosos e síltico- 
argilosos indicando as posições distais da atividade fluvial no leque aluvial, mais significativas dos tempos modernos.

Os depósitos de diques marginais (Foto 42) têm morfologia de cordão assimétrico. O lado do dique voltado para o canal fluvial é curto e abrupto, acompanhando a alta declividade da margem do rio, enquanto o lado inclinado para a planície é longo, apresentando uma declividade bastante baixa. Os diques marginais são raros quando ainda ocorrem os depósitos medianos dos leques, porém, tornam-se freqüentes para jusante. No baixo curso do Rio Araranguá encontram-se também depósitos de dique marginal sobre os depósitos estuarinos. No Setor Sul eles são observados onde o Rio Canoas é mais sinuoso e na continuação deste, no trecho chamado Rio do Sertão, a montante da cidade de São João do Sul.

O diagrama de SHEPARD (1954) (Figura 98) apresenta a distribuição das amostras, classificando-as como arenosas e principalmente areno-siltosas. Os histogramas (Figura 99) mostram que são sedimentos polimodais, com $60 \%$ das amostras apresentando três modas. Seus sedimentos são muito mal selecionados a mal selecionados, com diâmetro médio entre $2,7 \phi$ e quase $6 \phi(0,24 \mathrm{~mm}$ a 0,016 $\mathrm{mm}$ ) (Tabela 55). A assimetria em geral é muito positiva, e os valores de curtose são variáveis, dominando, entretanto, as muito leptocúrticas seguidas de meso e leptocúrticas (Tabela 55). A principal moda ocorre no tamanho areia fina, e as outras, dominantemente no tamanho argila, porém, são negligiveis, pois apenas com uma exceção, elas têm menos de $10 \%$ da amostra. Outras características podem ser obtidas dos perfis da Figura 100.

No diagrama C-M (Figura 101) as amostras estão principalmente na classe V, classificando-as como depositadas a partir de correntes com suspensão graduada e de moderada turbulência.

\subsubsection{Mineralogia dos Depósitos de Leques Aluviais}

A mineralogia dos depósitos de leques aluviais está sendo apresentada sobre 8.049 indivíduos identificados através da microscopia da fração $0,088 \mathrm{~mm}$ a $0,105 \mathrm{~mm}$. Estão 


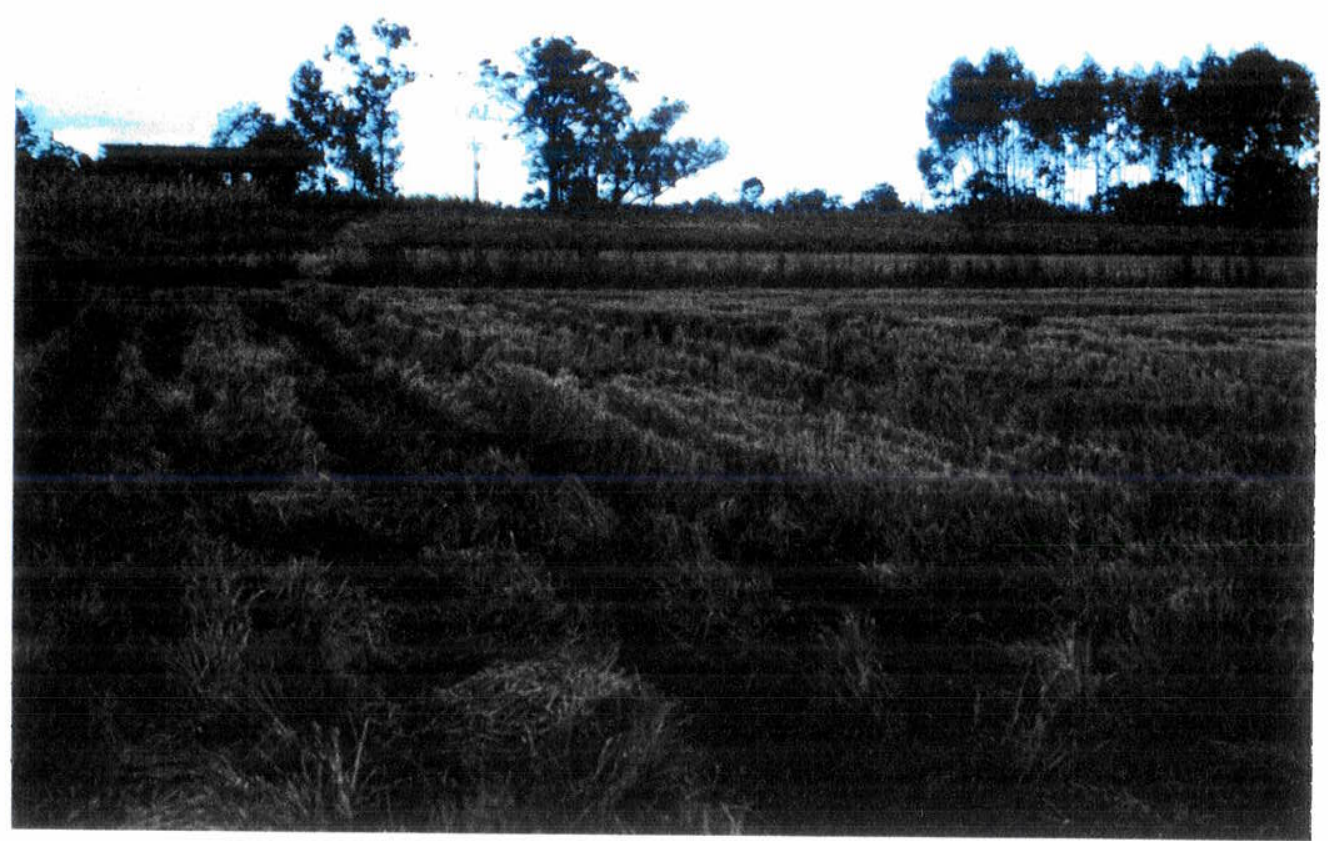

Foto 42 - Forma e desnivel do dique marginal na margem esquerda do Rio Itoupava, próximo à foz do Rio Jundiá. Pode-se ter uma idéia da altura do dique pela casa construída sobre ele e pelo plano cultivado. Visada para o sul, transversal ao canal do rio que corre para o leste, à esquerda da foto e situa-se logo após às arvores. Elas marcam a margem do mesmo. A montante deste local há depósito de transbordamento, com rompimento de dique, único na área estudada.

representados sedimentos localizados em várias partes dos leques, isto é, proximal, mediana, distal, e nos canais atuais.

Entre os minerais mais densos, os opacos predominam, como se poderia esperar pela presença do basalto na área fonte. Os minerais demonstram, a contribuição de rochas diferentes, tanto ígneas quanto metamórficas, entretanto, neste tipo de depósito, estes minerais são provenientes dos basaltos e das rochas sedimentares da Bacia do Paraná, notadamente dos arenitos das formações Botucațu e Rio do Rasto. Nas lâminas dos minerais leves tem-se os minerais quartzo mono e policristalino, calcedônia, ortoclásio, microclínio e plagioclásios. Foram registrados também fragmentos de rochas, alteritos e vidro vulcânico. 


\subsubsection{1 Área Proximal e Mediana}

Nas partes proximais e medianas dos leques os minerais leves predominantes são: quartzo monocristalino, plagioclásio não zonado paralelamente a quartzo policristalino. Há, ainda, a presença de ortoclásio, calcedônia e plagioclásio zonado. São registrados junto a estes, fragmentos de basalto e alteritos.

O quartzo monocristalino é subangular, com extinção normal ou ondulante. Apresenta inclusões globulares dispersas ou alinhadas, ou sólidas de apatita e de rutilo, sob forma de acículas. O quartzo policristalino provavelmente é proveniente das rochas sedimentares, uma vez que na área não há rochas metamórficas (Tabela 56).

Os plagioclásios não zonados apresentam-se de subangulosos e arredondados. Raros grãos têm faces cristalinas. Os zonados são principalmente subangulosos e com faces cristalinas bem freqüentes. Estes são derivados de rochas vulcânicas básicas ou de vulcânicas intermediárias.

Os fragmentos de basalto são subangulosos ou subarredondados. Estão constituídos por cristais de plagioclásio e piroxênio. Em alguns indivíduos estes dois minerais estão unidos a vidro vulcânico, constituindo fragmentos de rocha.

A quantidade de minerais pesados nas amostras destas áreas dos leques para a fração usada, variou de 0,3 a $80 \%$. Os minerais pesados mais abundantes são zircão e turmalina castanha, respectivamente 30 e $28 \%$ do total correspondente às 18 espécies minerais transparentes presentes. Segue-se a turmalina verde $(9,6 \%)$, a hornblenda castanha $(9,3 \%)$, a turmalina azul $(6,4 \%)$, turmalina schorlita $(5,5 \%)$, turmalina vermelha $(5 \%)$, estaurolita $(2,4 \%)$, hornblenda verde $(1,6 \%)$. As outras espécies estão representadas por quantidades menores (Tabela 57).

Os zircões e turmalinas prismáticos ocorrem junto com bem arredondados, evidenciando origens diferentes. 


\subsubsection{2 Área Distal}

Nos depósitos distais dos leques aluviais estão presentes 14 espécies de minerais pesados transparentes (Tabela 58). A participação do zircão com pouco mais de $37 \%$ é seguida pela da augita, com mais de $18 \%$. Seguem-se a turmalina castanha $(9 \%)$ e a hornblenda castanha $(7 \%)$. Os três outros minerais com quase $4 \%$ de representação são a turmalina schorlita, a titanoaugita e olivina/iddingsita. Com mais de $2 \%$ do total aparecem cianita, turmalina verde e estaurolita. As restantes espécies minerais identificadas apresentam percentagens abaixo de $2 \%$.

Entre os minerais leves, o quartzo monocristalino é o mais abundante, variando de 54 a $77 \%$. Seguem-se o quartzo policristalino (11-16\%) e o plagioclásio zonado (3 a 10\%). Estão presentes, ainda, o ortoclásio e a calcedônia. Microclínio, ortoclásio pertítico e plagioclásio não zonado aparecem como traços (Tabela 59).

O quartzo monocristalino abundante nos depósitos distais dos leques aluviais é do tipo subangular, com inclusões gasosas ou sólidas, provavelmente de origem ígnea. Porém, ocorrem ainda grãos angulosos devidos a crescimentos sintaxiais ou secundários, originários possivelmente do Arenito Botucatu. Como ocorre nas outras partes dos leques, este tipo de quartzo contém inclusões globulares dispersas e inclusões sólidas raras, de acículas de rutilo. A extinção desse tipo de grão é normal ou pouco ondulante.

O quartzo policristalino, cuja origem primária é o embasamento pré-cambriano deformado, está presente nesses sedimentos pelo retrabalhamento das rochas sedimentares.

Os plagioclásios zonados subangulosos, ou aqueles menos freqüentes subarredondados, apresentam macla albita e são provavelmente, provenientes das rochas vulcânicas.

Os ortoclásios em grãos angulosos até arredondados apresentam diferentes graus de alteração para produtos argilosos. A angulosidade deve-se à fragmentação ao longo de planos de clivagem durante o transporte aquoso. 
Como já foi referido, nas lâminas de minerais leves, foram observados fragmentos de rochas básicas e ácidas, além de alteritos. Os fragmentos de rochas básicas e os alteritos são mais freqüentes nas áreas proximais e medianas, mas, proporcionalmente, há nas proximais mais fragmentos de rochas ácidas. Essa contribuição seria proveniente de rochas vulcânicas intermediárias a ácidas, pós-basaltos, que ocorrem no planalto drenado pelos altos cursos de rios que pertencem às bacias da área estudada, ou fazem parte da constituição das outras rochas da área.

Quanto aos minerais pesados nas amostras examinadas, nota-se que os depósitos distais em relação às áreas proximais e medianas, têm diferenças devidas à elevada presença de zircões e ao número de espécies minerais presentes. Há uma concentração muito alta de augita e um número bem maior de titanoaugita, hiperstênio e olivina; epidotos são mais freqüentes; há um aumento de estaurolita e presença de sillimanita. Talvez a explicação para a taxa e presença de alguns, principalmente os de origem metamórfica, seja a constituição das rochas sedimentares. Nestas eles já poderiam ser encontrados em tamanhos tão pequenos que teriam sido removidos destas áreas fontes da maneira mais direta possível, e levados para áreas distais dos leques, onde se concentrariam mais facilmente. Mineralogicamente estes depósitos parecem reunir dois grupos de afloramentos, um dos quais apresenta minerais instáveis no conceito de PETTIJOHN et al. (1973), sugerindo idades diferentes para os afloramentos chamados de subtotal 1 e subtotal 2. Os testes de correlação aplicados - coeficiente de correlação de Spearman, $\mathbf{t}$ Student - mostram que a correlação é alta entre a associação mineralógica dos leques proximais e medianos com o subtotal 1 dos leques distais, com a possibilidade de aleatoriedade de 1\%. A correlação daquelas áreas com o subtotal 2 é boa, porém, com taxa de erro de $5 \%$. A correlação entre os dois conjuntos de afloramentos dos depósitos distais se faz também dentro da possibilidade de erro de $5 \%$.

Minerais de canais fluviais atuais - Nas lâminas de minerais pesados destes depósitos apenas 6 espécies de minerais transparentes foram encontradas (Tabela 60). O número de amostras analisadas pode ter sido pequeno, mas a situação dinâmica de erosão/deposição desses sedimentos, talvez, seja a sua explicação. 


\subsubsection{Processos Geradores dos Depósitos}

No que se relaciona aos leques, BULL (1968) afirma que a deposição dos sedimentos, geradora do leque aluvial, não é causada pelo decréscimo abrupto no gradiente do canal do rio, pois a declividade do ápice da maioria dos leques seria quase a mesma do canal imediatamente a montante, e, a mudança da declividade nas superfícies dos leques é gradual. Para este autor, a deposição seria causada por mudanças na geometria hidráulica do fluxo, após o rio deixar a área confinada do canal-tronco, uma vez que a descarga do rio é igual ao produto da largura média pela profundidade média e pela velocidade do fluxo. Quando um rio ou o fluxo de detritos (debris flow) alcança o final do canal-tronco, na cabeça do leque, ele se espalha. O aumento da largura é acompanhado pelo decréscimo da profundidade e da velocidade, o que causa a deposição do material. $A$ descarga também diminui quando o fluxo se faz sobre depósitos permeáveis, levando à perda de água por infiltração e ao conseqüente aumento da concentração causando a deposição.

A afirmação acima é aceitável, uma vez que há de fato modificação da geometria hidráulica pelo aumento de espaço que as águas e os sedimentos podem ocupar. Há a passagem de fluxo de canal único para múltiplos canais.

A escarpa na área estudada e os canais sobre ela contribuem para a reunião de águas e sedimentos de uma grande área ingreme, permitindo desenvolver tanto a grande velocidade das águas como a movimentação de sedimentos dos mais variados tamanhos.

É óbvio que a chegada dos sedimentos ao piemonte, em espaços de baixa declividade, determinará uma ação gravitacional menor, levando à deposição dos fragmentos. A água, por sua vez, se for abundante, não tem sua velocidade diminuida tão abruptamente, podendo ser muito alta até longas distâncias, alcançando o leque mediano e mesmo a área distal ou além dela. Este fato dependerá da dissecação mais ou menos profunda dos canais nos leques aluviais. Se os canais forem muito rasos, a água se espalhará em área maior já no leque proximal, perdendo velocidade e alcance. Por outro lado, depósitos mais densos podem movimentar-se durante muitos quilômetros mesmo em declividades baixas 
como foi referido por SHARP et al. (1953), em Wrightwood, Califórnia. O derretimento de neve nas montanhas, adicionando 25 a $30 \%$ de água aos sedimentos e tornando-os uma massa uma densidade de 2,4, fluiu por mais de $24 \mathrm{~km}$, inicialmente em uma declividade de $9^{\circ}$ e depois em declividade de $1^{\circ} 21^{\prime}$, com velocidade máxima de $4,6 \mathrm{~m} / \mathrm{s}$. A água, entretanto, fluiu por mais $14,5 \mathrm{~km}$. O fluxo confinou-se entre 6 e $46 \mathrm{~m}$ de largura. A vegetação da área, uma floresta de coníferas, teve suas árvores na área fonte carregadas. Nas áreas de declividades baixas, os depósitos rodearam casas, quase soterrando-as, bem como as árvores, sem as deslocar. Outro caso relacionado a uma tempestade, em 1969, é relatado para a área de leques aluviais, urbanizada, no sopé das Montanhas São Gabriel, que alcançam $800 \mathrm{~m}$ de altitude, em Glendora, Califórnia (SCOTT,1971). Este autor declara que os fluxos de detritos (debris-flow), se constituíram principalmente, por matacões e menos de $10 \%$ de argila e silte, tendo alcançado distâncias de até $1 \mathrm{~km}$. A maioria dos fluxos iniciaram-se a menos de $500 \mathrm{~m}$ de altitude, sobre rochas graníticas. Mas, um dos principais componentes dos debris flows foi o material dos canais que estavam vegetados com carvalhos, tendo estes um grande papel na manutenção destes depósitos. Fica claro então que podem ocorrer fluxos densos em áreas vegetadas, migrando por entre as árvores.

Quando a água se espalha sobre o leque aluvial, sua velocidade decresce, pois o fluxo é distribuído lateralmente, em múltiplos canais, mais rasos que aqueles sobre a escarpa, além de haver a infiltração de parte da água.

Os leques aluviais de ambos os setores da área de estudo, evidenciam essa infiltração, tanto pelos tipos dos sedimentos presentes como pelos substratos rochosos constituídos de rochas sedimentares, principalmente no Setor Sul, onde o embasamento é, em grande parte, de Arenito Botucatu. Esta infiltração é evidenciada pelo desaparecimento de águas correntes superficiais, gerando toponímias como: Rio Seco, Morto, Sanga Escondida. Essa situação foi observada durante os trabalhos de campo, seja em períodos mais úmidos, seja nos mais secos. O fenômeno deixa de acontecer em épocas de chuvas abundantes que geram cheias. 
Os mecanismos deposicionais são, de acordo com BLISSENBACH (1954), as cheias em lençol (sheetfloods), as cheias em canal (streamfloods) e as correntes ou rios. As primeiras são verdadeiras cheias imediatamente espraiadas. Estas cheias em lençol acontecem quando uma carga excessiva de água e detritos das rochas emerge de um vale encaixado de montanha, ou cânion. O fluxo agindo como um meio viscoso, tende a se espalhar na forma de um lençol cobrindo o leque ou partes do mesmo. Para este autor, que trabalhou em zonas semi-áridas e áridas, esses fluxos duram de segundos a minutos.

As cheias em canal (streamfloods) estão confinadas a canais definidos nos leques aluviais. Formam-se, segundo o mesmo autor, quando uma grande quantidade de material e detritos emerge do canal-tronco da montanha e a passagem deste para o leque é contínua, isto é, o canal no ápice do leque pode estar suficientemente aprofundado para impedir a cheia em lençol. O seu tempo de duração é de minutos a horas. BLISSENBACH (1954) sugere a expressão streamfloods porque elas não são contínuas e sim espasmódicas para não confundir com fluxos perenes da maioria dos rios.

$\mathrm{O}$ terceiro tipo de agente são os rios, em que tanto a quantidade de água como de detritos são menores que nos dois tipos anteriores. O que deve ser mantida é a recarga de água e não a abundância de suprimento. O fluxo dura horas ou mesmo dias, no caso dos climas semi-áridos ou áridos. Essa ação não é tão significativa nas áreas com esses tipos de climas, contudo, em regiões úmidas dos Alpes e Himalaia, os depósitos fluviais são consideráveis (BLISSENBACH, 1954).

Os depósitos que ocorrem na área são principalmente depósitos de canais, considerando que são depósitos rudáceos dominantemente clastos suportado, e pelo tamanho e forma dos seixos. Há depósitos de debris flow e depósitos pouco espessos de materiais mais finos lembrando corridas de lama, porém, são os menos freqüentes.

Tanto no Setor Sul como no Setor Norte da área estudada, os dois últimos mecanismos são nitidamente atuantes, e não se pode descartar a ação do primeiro tipo de mecanismo, principalmente em épocas de grande concentração de chuvas no planalto e na área da escarpa. As cheias de canal nos trechos proximais dos leques, muitas vezes chegam como uma onda avassaladora de tal modo que atividades ribeirinhas como a 
lavação de roupas podem ser um risco. As lavadeiras se afastam dos rios quando escutam trovejar no "costão da serra", caso contrário chegam a perder seu material. Após a passagem da onda e seu barulho típico, um outro barulho continua devido ao transporte, com choques, dos seixos. Este chocalhar de seixos tem sugerido a toponímia de Malha Coco, para rios nos dois setores. Quando a água é suficiente ela se espraia fora do canal. Quando șão grandes cheias, isto é, do tipo que estravasa do canal, a população nas áreas medianas dos leques relata a chegada inicial de grande onda de água, com forte ruído, enchendo rapidamente toda a planície. Com este tipo de cheia há a deposição de um pouco de lama ou areia na planície, e depósitos de até $5 \mathrm{~m}$ de espessura, de seixos, nos canais. Quando há a retirada destes depósitos pelas prefeituras ou outros, em certas situações o depósito é refeito na próxima cheia, ou então o local passa a ser erodido. O rio então alarga o canal e pessoas perdem parte da sua propriedade.

BULL (1968) chama atenção para os tipos de materiais transportados e a relação entre eles. Ele afirma que o fluxo nos leques aluviais varia de água limpa até lama viscosa, e os depósitos resultantes variam de areias bem selecionadas depositadas por água até detritos pobremente selecionados que podem incluir matacões de muitas toneladas. Explica como se originam e quais os fatores causadores do fluxo de detritos (debris flow) e fluxo de lama ( $m u d$ flow), das barras de cascalho e de areia, os de peneiramento.

Para BULL (1968), com a mudança da geometria hidráulica, os canais ao chegarem na área de espalhamento ou área deposicional, tornam-se descontínuos e entrelaçados (braided). Eles migram lateralmente devido ao preenchimento dos canais em momentos de maior fluxo. Desta atividade resultam depósitos que consistem de barras rasas de cascalho mal estratificado ou de areias com estratificação cruzada. Geralmente esses depósitos são de granulometria maior do que os de tipo em lençol.

De acordo com BULL (1968) os fluxos de detritos (debris flow) ou de lama (mud flow), incorporam muito sedimento. A diferença consiste em que, sendo a corrida ou fluxo de lama ( $m u d$ flow) um fluxo de detritos, constitui-se principalmente de sedimento tamanho areia, silte e argila. Os fluxos de detritos (debris flow) têm alta densidade e viscosidade e podem depositar seletivamente apenas a parte mais grossa de sua carga, sendo, portanto, 
mal selecionados. Apresentam-se em forma de línguas lobadas, com margens abruptas bem definidas, sendo capazes de transportar matacões de toneladas.

SHARP et al. (1953) já haviam discutido os termos debris flow e mudflow, considerando este último processo e seu correspondente depósito, como uma variedade do primeiro, em que a lama sem ser necessariamente predominante dota a massa de propriedades e comportamentos especiais. Estas corridas de lama por eles descritas compreendem matacões de até $1,80 \mathrm{~m}$, ficando os maiores na zona montanhosa. Clastos com cerca de $0,60 \mathrm{~m}$ foram depositados em áreas já com $2^{\circ}$ de declividade.

SCOTT (1971) apresenta seus dados considerando estes tipos de depósitos como sendo distintos, e POSTMA (1986) apresenta uma classificação para os depósitos de sedimentos de fluxos gravitacionais, considerando dois tipos de depósitos de debris flow segundo o caráter de fluxo durante a deposição : ambos laminares, de alta concentração, sendo um sem coesão e o outro coesivo.

Para BULL (1968), as causas do fluxo de detritos seriam: água abundante em períodos curtos de intervalos irregulares, além de uma fonte de material que proporcione uma matriz de lama e encostas íngremes com cobertura de vegetação insuficiente para prevenir a erosão rápida. Esclarece, porém, que, para ocorrer esse fluxo de detritos, não há necessidade de todas essas condições. O trabalho de SHARP et al. (1953), entre outros, deixa claro que ele pode ocorrer em áreas com cobertura arbórea de grande porte.

Numa área fonte que proporcione fragmentos de vários tamanhos, desde argila até matacões e que apresente fortes declives, como é o caso da escarpa da Serra Geral, quando o material, relativamente abundante, é colocado em movimento, a vegetação mesmo arbórea não o segurará, e inclusive fará parte do material em deslocamento, que se espalhará mais ou menos.

Basta presenciar a queda livre de matacões junto com material de vários tamanhos, na área do médio curso do Rio Pavão mesmo em dias sem chuva, ou verificar, atualmente, em locais escarpados, a cicatriz de material deslocado e seu acúmulo no sopé, encobrindo a vegetação, ou ainda presenciar o início de uma cheia em períodos chuvosos ou mesmo 
uma cheia resultante de chuvas caídas apenas no planalto, ou mesmo na área das escarpas, e verificar a movimentação dos seixos e matacões.

Tanto os depósitos de fluxo de detritos (debris flow), compostos de sedimentos mais grossos com matriz, como os de fluxos de lama, constituídos de sedimentos mais finos, ocorrem na área, além dos depósitos de peneiramento (sieve deposits).

É comum, em períodos sem chuva, verificar-se a água sumir e reaparecer adiante em locais embaciados, com o fluxo tão lento que parece água parada; em outros locais reaparece com movimento nítido e em outrosainda, o fluxo continua subterraneamente. $\mathrm{Na}$ parte distal do leque do Rio Pavão, avançando sobre o leito do Rio Mampituba, é comum ver-se a migração da água do primeiro como se houvesse pequenas ressurgências dentro do leito do Mampituba. Notam-se, também pequenos lobos de centímetros, de fragmentos de rochas tamanho grânulo e areia grossa que não são percebidos no arranjo imbricado dos seixos, ou sobre esses. A água infiltrada pode eliminar os fragmentos menores nos espaços entre os seixos, ficando retido só o material mais grosso.

A relação entre a precipitação pluviométrica anual e a percentagem da contribuição dos depósitos de corrida de lama, na constituição dos leques aluviais, também foi examinada por BLISSENBACH (1954). Para ele corridas de lama são depósitos formados por cheias em lençol (sheetfloods) e cheias de canal (streamfloods) violentas. Exemplifica com leques de Black Hills, no Arizona (EUA), onde a precipitação média de chuvas é de menos de $500 \mathrm{~mm}$ por ano, e as corridas de lama constituem cerca de 5 a $10 \%$ dos depósitos, enquanto na área de Tucson (EUA), a precipitação anual média é menor que $300 \mathrm{~mm}$, e os depósitos de corridas de lama constituem de 20 a $40 \%$ dos leques. Os outros sedimentos que ocorrem nas duas áreas são depositados por correntes fluviais e por moderadas cheias de canal (streamfloods).

Nota-se, também, que há, entre BULL e BLISSENBACH, uma dissonância. Enquanto BULL. (1968) considera a corrida de lama como um tipo de fluxo de detritos com granulometria tamanho areia ou mais fina, e que se apresenta em forma lobada, refletindo a geometria de fluxos individuais tanto de sedimentos depositados por água como fluxos de detritos que são depositados como línguas longas e estreitas. Para BLISSENBACH (1954), 
elas podem ser longilíneas, quando são depósitos de cheias violentas de canal, mas são também depósitos de cheias em lençol ou corridas em lençol (sheetfloods).

Sobre as corridas ou cheias em lençol (sheetfloods) há o artigo de McGEE (1897). Esse autor apresenta a ação dessas corridas, seu caráter, pré-requisitos e trabalho erosivo, no Distrito de Sonora e em outros. Ele deixa claro que o nome sheetfloods já era usado no século passado, em notas e na conversação, mas parece ser ele o primeiro autor a descrever o fenômeno e atribuir-lhe um conceito. Para ele, sheetflood e correntes (rios) são dois corpos distintos de águas moventes. Ele considera que as águas correntes, além de se reunirem e construírem canais, podem também, excepcionalmente, se espalhar em lençóis de largura limitada ou ilimitada. E quando a água flui sobre uma superfície resistente, ela não se move como uma película uniforme, pois o lençol diferencia-se em correntes paralelas, de maior profundidade e fluxo relativamente rápido, separadas por faixas mais rasas de fluxo relativamente vagaroso, e, ao mesmo tempo, tanto as correntes como as faixas intercaladas diferenciam-se numa série de ondas transversais que se movem mais rapidamente que o corpo diferenciado do lençol. A eficiência das corridas em lençol na deposição, é subordinada.

Essas idéias e descrições são importantes, porque vários destes autores trabalharam em climas semi-árido e árido, e deixam claro que sedimentos granulometricamente finos são comuns nesses climas, e, por outro lado, o papel das águas sob forma de rios ou correntes é muito importante nos leques.

\subsubsection{DEPÓSITOS PRAIAIS ANTIGOS E ATUAIS}

Os depósitos praiais antigos apresentam seus topos em várias altitudes, de aproximadamente $25 \mathrm{~m}$ até 1 ou $2 \mathrm{~m}$ acima do nivel médio atual dos oceanos.

As praias atuais constituem-se da faixa arenosa, cujo nivel superior está limitado pelo alcance das águas das marés altas.

As praias de lagoas serão abordadas no item 5.2.4. 


\subsubsection{Depósitos Praiais Pleistocênicos Anteriores a 123.000 Anos}

Os depósitos praiais pleistocênicos mais antigos e mais altos situam-se em ambos os setores, formando três grandes conjuntos: o situado a norte do Rio Araranguá e da cidade homônima, será referido como cristas praiais de Maracajá - Barro Vermelho; o situado ao sul do Rio Araranguá que se estende numa direção geral NE-SW, de Araranguá até Sombrio, com uma projeção para leste da cidade de Araranguá, e o terceiro conjunto situa-se no Setor Sul, a oeste da Lagoa do Sombrio, até Vila Santa Catarina. Como este último conjunto de cristas praiais apresenta-se com uma disposição espacial em duas direções, além de ter sido submetido à erosão fluvial ao longo do Rio Sertão, será referido como conjunto Mampituba We Mampituba E (Figuras 5 e 6, 33 e 34, no encarte).

As cristas praiais situadas a norte do Rio Araranguá apresentam-se subdivididas. Uma sucessão de cristas curvas desenvolve-se de leste para oeste e depois para sudoeste, apoiando-se em elevações chamadas Morro do Barro Vermelho (Espigão do Tigre) e Morro de Maracajá. A área pertence ao município de Maracajá. Sua parte frontal apresenta-se, em trechos, fortemente erodida, com cristas truncadas. O lado noroeste deste depósito foi erodido pela ação fluvial do Rio Mãe Luzia. A cota de 10 m é importante na delimitação deste depósito, porque em cotas mais baixas os depósitos encontrados são os fluviais de leques aluviais. Entretanto, em alguns locais a erosão laminar rebaixou esses sedimentos, podendo, então, apresentar altitudes inferiores, de até $5 \mathrm{~m}$. Este conjunto de cristas praiais cobre uma área de cerca de $24 \mathrm{~km}^{2}$, com altitudes de até $16 \mathrm{~m}$ e cristas com largura de $125 \mathrm{~m}$. A outra área dispõe-se no norte do Município de Araranguá, entre a Lagoa Mãe Luzia e o Rio dos Porcos. Compreende a área entre as localidades de Campo Mãe Luzia e Hercílio Luz. A parte norte pertence ao Município de lçara.

O depósito situado ao sul do Rio Araranguá se estende a sudoeste, sul e leste da cidade do mesmo nome, pertencendo aos municípios de Araranguá e Sombrio. É um corpo longilíneo que se apoia a nordeste, sudoeste e noroeste, em pequenas elevações residuais do Grupo Passa Dois. Este conjunto de cristas praiais apresenta área de mais de $54 \mathrm{~km}^{2}$, acima de $20 \mathrm{~m}$ de altitude, dos quais aproximadamente $20 \mathrm{~km}^{2}$ estão acima da 
cota de $25 \mathrm{~m}$, com três pequenas áreas de até $32 \mathrm{~m}$ que perfazem aproximadamente 0,74 $\mathrm{km}^{2}$. Com essas altitudes, esses sedimentos estendem-se de Araranguá até a localidade de Guarita, extremos esses marcados pelas elevações de rochas do Grupo Passa Dois. Ao sul e a oeste da localidade de Guarita até a cidade de Sombrio, esse corpo apresenta morfologia de cristas praiais, com altitudes de até pouco mais de $16 \mathrm{~m}$. Para leste e para oeste estas altitudes decrescem.

As áreas acima dos $30 \mathrm{~m}$ devem ser acúmulos eólicos, e mesmo parte daquelas acima dos $25 \mathrm{~m}$ podem ter essa origem. Não há estruturas primárias para sua confirmação, pois toda a superfície deste depósito encontra-se profundamente pedogenizada, em pelo menos $5 \mathrm{~m}$ de espessura.

A noroeste de Guarita e ao sul do Morro do Soares, apoiada num morrote, há uma crista isolada do conjunto, com aproximadamente $150 \mathrm{~m}$ de largura e altitude em torno de $15 \mathrm{~m}$. É um depósito arenoso, em forma de arco, voltado para leste que foi erodido no seu extremo sul.

As cristas praiais do Setor Sul são divididas em dois conjuntos : o mais interno, situado a oeste do Rio do Sertão, apresentando cristas curvas, numa disposição quase N-S e voltadas de maneira côncava para o leste, e o conjunto mais a leste que se dispõe em cordöes arenosos curvos, de nordeste para sudoeste, a partir das elevações junto à cidade de Santa Rosa do Sul, estendendo-se até a paleolagoa de Piritu. Esses sedimentos continuam para sul, porém com as feições de cristas obliteradas pelos processos erosivos posteriores que agiram sobre esses depósitos. O primeiro conjunto mais a oeste é o mais fortemente dissecado pela atividade erosiva, possivelmente de vários agentes como correntes fluviais, ação marinha de ondas e correntes de maré, de niveis de mar subseqüentes mais baixos. Nas folhas topográficas Praia Grande e Sombrio, do IBGE, pequenas áreas desses sedimentos alcançam mais de $20 \mathrm{~m}$. Uma no extremo oeste da ocorrência desses depósito, a norte de Vila de Santa Catarina e outra área maior ocorre a norte da paleolagoa de Piritu, a oeste da localidade de Três Coqueiros. Entretanto, medidas realizadas para os projetos da SUDESUL e as que se efetuaram neste estudo evidenciam que esses depósitos estão com as maiores altitudes entre 14 e $16 \mathrm{~m}$. 
A classificação pedogenética destes depósitos, segundo KLAMT et al. $(1978,1980)$, é solo Podzólico Vermelho Amarelo da Unidade Araranguá, com horizonte B textural, com substrato de sedimentos arenosos do Quaternário. São solos profundos, com todos os horizontes. $O$ horizonte $A$ arenoso pode alcançar $1,20 \mathrm{~m}$ de espessura, apresenta estrutura em blocos subangulares fracamente desenvolvida, muito friável. O horizonte $B$ é um pouco mais argiloso e, quando molhado, a consistência é ligeiramente plástica e pegajosa. Ocorrem perfis em que o horizonte B é mais escuro que em outros, ou "mosqueado" e de coloração mais amarelada. Estes autores situam este solo sobre a Formação Chuí, pleistocênica.

Entre uma crista e outra, na situação da cava, a má drenagem favorece o acúmulo de matéria orgânica, originando o solo glei húmico, classificado como Tapera, com seqüência de horizontes em perfis profundos.

Todos os depósitos encontram-se fortemente pedogenizados, com cores acastanhadas, apresentando Horizonte-B textural que chega a ter $5 \mathrm{~m}$ de espessura (Fotos 43 e 44). Neste horizonte notam-se estreitas faixas onduladas que os pedólogos chamam de lamelas, tendo até $5 \mathrm{~cm}$ de espessura, com maior conteúdo de argila e tonalidades mais escuras do que os materiais intercalados entre elas. Essas lamelas seriam produzidas em processo de podzolização.

SUGUIO et al. (1976) estudaram estas estruturas em solos da Formação Bauru, chamando-as de estruturas de "bandas onduladas", considerando-as de origem pedogenética.

QUEIROZ NETO (1975) faz um estudo sobre perfis de solo com bandas onduladas, no Estado de São Paulo, demonstrando que estas estruturas ocorrem em solos de vários continentes, sob vários tipos de clima. Considera que as bandas onduladas, em solos daquele Estado, têm origem tanto em processo de coluvionamento como pedogenético.

BIGARELLA (1975) denomina feições similares de estruturas de dissipação. Ele não considera que a migração e o enriquecimento com argila que ocorre nestas estruturas estejam relacionados com o processo pedogenético e, sim, são devidas a episódios de enxurradas, dissipando as areias e carregando material coloidal a partir dos colúvios das 
elevações próximas. Os processos complexos de escorregamento das areias e argilas gerariam as estruturas de dissipação.

Estruturas com as características referidas acima são observadas em qualquer afloramento destas cristas praiais, de norte a sul. Salienta-se que nos topos horizontalizados, devido à largura relativamente grande das cristas, estas estruturas dispõem-se paralelamente a eles. Esse fato levanta uma interrogação quanto ao processo de dissipação. Não se trata aqui de elevações com encostas íngremes e nem de campo de dunas elevadas (Foto 44).

Pelas suas altitudes, disposição geográfica e situação geológica na área, a sua pedogênese alcançando espessuras elevadas e gerando espesso Horizonte-B, e a correlação com outros depósitos, pode-se afirmar que estes sedimentos são pleistocênicos. A sua relação com depósitos de leques aluviais ou paludiais lagunares e lacustres, em altitudes entre 6 e $14 \mathrm{~m}$, no seu lado oeste, e a existência de cristas praiais a leste das lagoas do Sombrio e de Caverá, com 8 a $9 \mathrm{~m}$, também pleistocênicas, permitem situar estes depósitos dentro do Pleistoceno Médio e correlativo à Barreira II de VILLWOCK et al. (1984) e que MARTIN et al. (1993) apresentam como depósitos de nível marinho mais alto, anterior a 123.000 anos A.P.. MARTIN et al. (1988) identificam estes depósitos entre Araranguá e São João do Sul como terraços marinhos arenosos, pleistocênicos, de 120.000 anos A.P., nos quais se distinguem os alinhamentos de antigas cristas praiais. Entretanto, afirmam que os terraços com esta idade têm altitudes que chegam a 9,5 m: Os depósitos na área citada são muito mais altos, sendo, portanto, mais antigos. (Figura 102, no encarte) não havendo evidência de tectônica quaternária na área. Estes depósitos constituem em Santa Catarina, as melhores exposições de terraços arenosos pleistocênicos anteriores a 123.000 anos A.P., com a morfologia de sucessão de cristas praiais. A área abrangida por este mar pleistocênico poderia ser o sugerido nas Figuras 103 e 104.

Estes corpos desenvolveram-se sobre plataforma rasa, com profundidades menores que $35 \mathrm{~m}$, atestados pelo embasamento dos depósitos arenosos aí situados e registrados nos perfis de poços para carvão. O poço 5-AT-01-SC em Sanga da Toca, Município de 


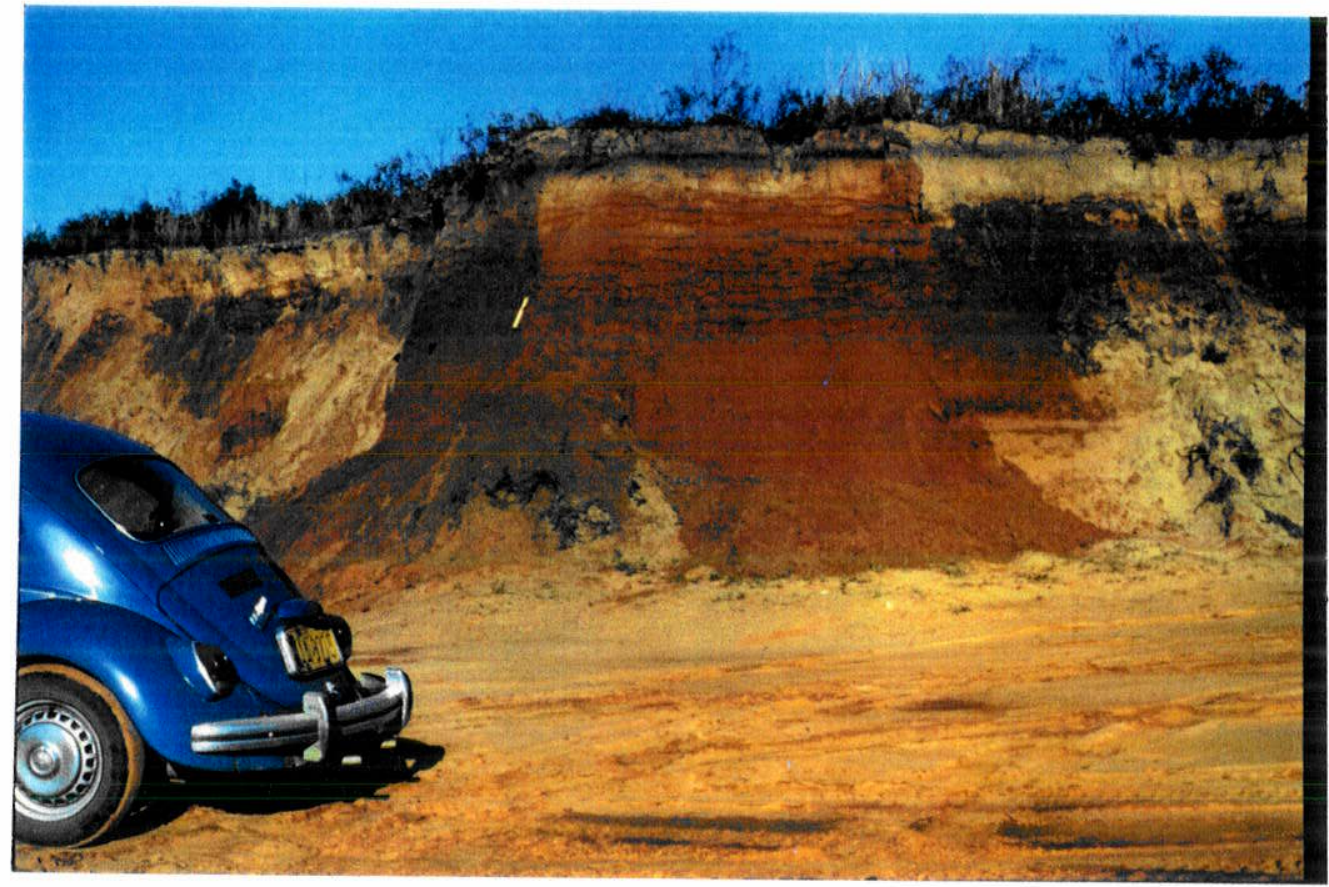

Foto 43 - Corte numa área de topo do depósito arenoso pleistocênico, situado entre Araranguá e Sombrio. Os sedimentos são praiais de ilha barreira neste afloramento. A foto mostra um corte com mais de $4 \mathrm{~m}$ de espessura. Vê-se a mudança de cores ao longo do perfil de solo, as estruturas onduladas horizontalizadas, o topo lixiviado e a grande espessura destes solos que é uma evidência de antigüidade. A camada cinza escura próxima ao topo é provavelmente um sítio arqueológico TupiGuarani, pela grande quantidade de cacos de cerâmica encontrados. Pertence a Mato Alto e situase a uns 5 quilômetros a sudoeste de Araranguá, numa altitude acima de $20 \mathrm{~m}$.

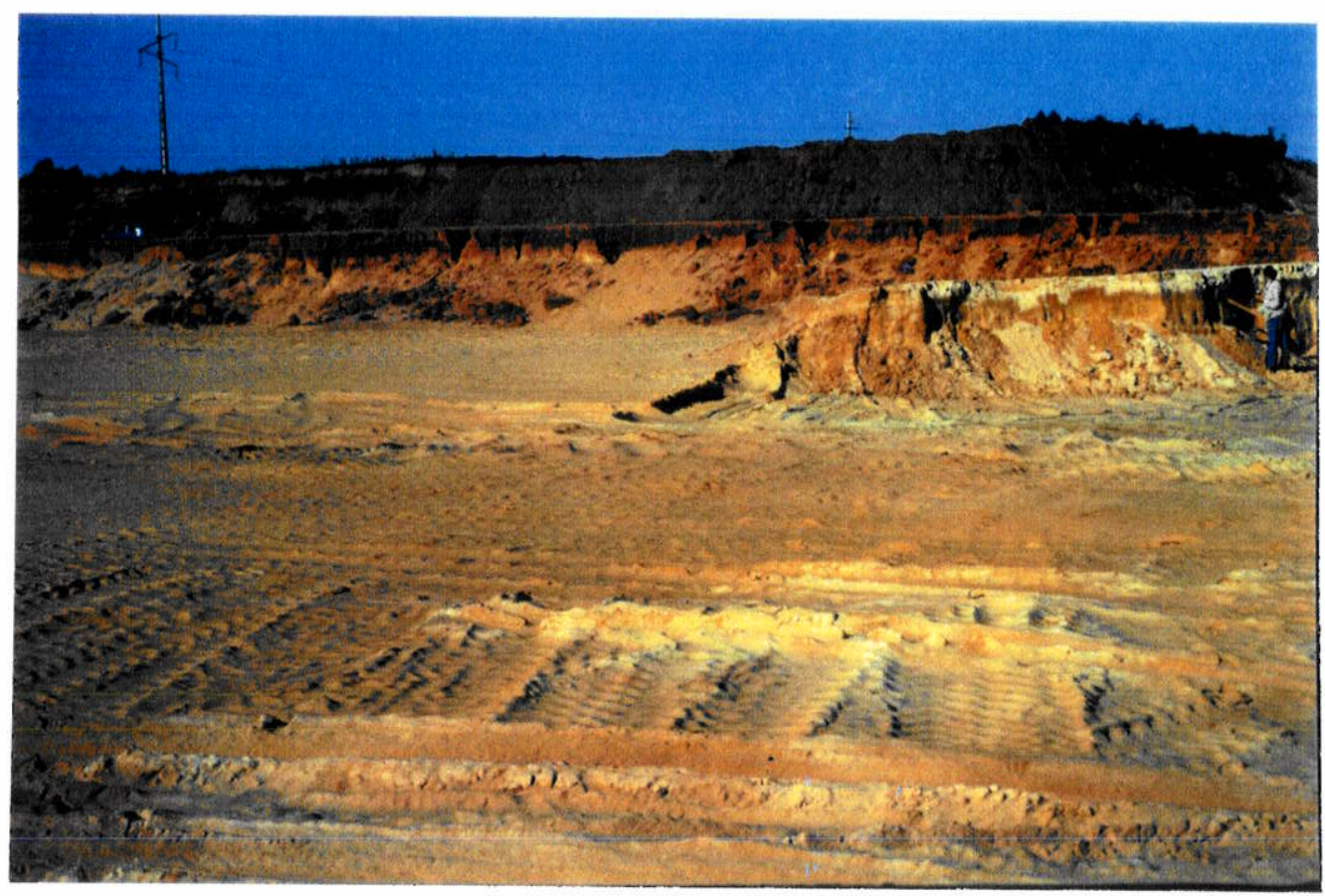

Foto 44 - Vista parcial e ampla, da seqüência dos sedimentos em Mato Alto, sudoeste de Araranguá. Vê-se a espessura pedogenizada até pouco abaixo do carro, sob a qual vê-se uma série de níveis de bioturbação, superpostos, alternando-se níveis de coloração branca, amarela e avermelhada. 
Araranguá, cerca de $6 \mathrm{~km}$ ao norte de Guarita, atravessou $24 \mathrm{~m}$ destas areias e $18 \mathrm{~m}$ de material rudáceo dos leques aluviais. Em Maracajá estes depósitos têm cerca de $16 \mathrm{~m}$ de espessura sobre $18 \mathrm{~m}$ de depósitos dos leques.

O depósito a sul do Rio Araranguá, no Setor Norte, no trecho entre Araranguá e Guarita, desenvolveu-se como ilha-barreira. A ilha-barreira é uma forma de depósito que fecha áreas mais baixas, lagunares, lacustres ou apenas pantanosas à retaguarda, em direção ao continente. $O$ nome diz que se trata de uma ilha cuja definição dada por vários autores é de ilha arenosa, longa, baixa. Os mecanismos que a originam e levam ao seu desenvolvimento vêm sendo discutidos há mais de cem anos (FISHER, 1982).

McCUBBIN (1982) define barreiras (barriers) como ilhas ou penínsulas alongadas arenosas, paralelas à costa e dela separadas por lagunas ou pântanos. Elas são um tipo transicional para as planícies de cordões arenosos.

Para HAILS (1982), barreiras são acumulações de areias ou cascalhos ao longo das costas, que ficam permanentemente acima do nível da maré alta. Elas podem ser praiasbarreira, flechas-barreira ou ithas-barreira. A evolução das ilhas-barreira pode se dar em submergências ou em emergências da costa ou, ainda, em nível estável do mar, desde que haja um suprimento adequado de material e que haja um baixo gradiente na zona offshore.

FISHER (1982) apresenta as discussões sobre vários aspectos relacionados às ilhas-barreira, como terminologia até mecanismos de origem e desenvolvimento. Para ele, ilha-barreira é uma das sete feições morfológicas tipo barreira. É uma barreira complexa com múltiplas cristas praiais, dunas, pântanos. Resume as teorias de origem em : barras de offshore emergentes, em nível estável de mar; bancos emergentes, em nível de mar baixando; bancos emergentes, em nivel de mar subindo; barras submergentes, em nível de mar subindo; cristas de dunas, em nível de mar subindo; flechas complexas, em nível de mar subindo; bancos emergentes, em nivel de mar subindo; migração sobre a costa em nivel de mar subindo, ou uma combinação destas. As ilhas-barreira diferem entre si no tamanho, morfologia e estratigrafia. Về-se que há preferência para explicações com nível de mar subindo. 
Ihas-barreira podem então originar-se em muitas situações e com nível de mar estabilizado, ou subindo e baixando relativamente. Entretanto, KRAFT (1982) afirma que mais de $50 \%$ das costas de ilhas-barreira do mundo, são transgressivas.

A referência à origem do depósito como ilha-barreira deve-se a sua posição geográfica, a sua relação geológica tanto lateral quanto vertical, a sua forma em planta e expressão topográfica, e à espessura. Na sondagem para carvão, poço AT-01-SC, em Sanga da Toca, local com cota de $21,50 \mathrm{~m}$ de altitude, foram perfurados $24 \mathrm{~m}$ de areias que se sobrepõem a depósito rudáceo dos leques aluviais. A sucessão é transgressiva e a espessura das areias evidencia Dois outros elementos importantes a considerar são a intensa bioturbação e a presença de estratificação cruzada tipo hummocky. A bioturbação, nesses depósitos, foi em grande parte provavelmente, gerada por crustáceos tipo Callichirus (Fotos 46 a 51). A bioturbação apresenta-se em camadas superpostas, significando que o mar estava em ascensão, e o nicho desses animais acompanhava esse movimento do nivel marinho. Por outro lado, as condições para a vida desses animais eram semelhantes no lado interno (oeste) e externo (leste) do depósito arenoso, pois os bancos bioturbados inclinam para os dois lados (Fotos 45 a 51). Além desses fatos, no lado interno, a oeste destes depósitos, há outros, típicos de corpos de água, como lagunas e lagoas com até $14 \mathrm{~m}$ de altitude, onde há superposição de camadas argilosas e arenosas, freqüentemente com muitos restos orgânicos (Fotos 52 e 53).

Os sedimentos arenosos entre a localidade de Guarita e a cidade de Sombrio se desenvolveram no período regressivo, adquirindo a forma de uma seqüência de cristas praiais. Essas bloquearam, pelo extremo sul deste conjunto, o corpo de água que ocupou a área à retaguarda.

Todo o conjunto, como também os demais, foi posteriormente dissecado, na sucessão de eventos de variação relativa do nivel marinho. Hoje ele é nascente de pequenos rios que migram a partir de seu lado noroeste e mesmo do seu extremo nordeste para o Rio Araranguá. Há outros que correm para sudeste, sul e sudoeste para desaguar nas lagoas de Caverá e Sombrio. Também migram para áreas de banhados e turfeiras entre essas lagoas, até a Lagoa da Serra. Esses pequenos rios ajudam na dissecação 
vertical e criam formas que, em planta, assemelham-se a pequenos "vales". Porém, a dissecação mais efetiva foi a lateral, efetuada por niveis de mar mais altos que os atuais e mais baixos que aquele que construiu este extenso depósito.

\subsection{Características Sedimentológicas}

Foram examinados e amostrados 84 perfis e poços escavados com 1,5 a $2 \mathrm{~m}^{2}$ de boca e com profundidade variável (Figura 105).

Os sedimentos desses depósitos são arenosos, entretanto o topo pedogenizado apresenta pelitos, por vezes em proporção muito alta, especialmente nas estruturas onduladas. Os finos também são máis abundantes nas áreas de cavados. As bandas onduladas chegam a ter pouco mais de $78 \%$ de finos e entre esses a argila domina. Nos cavados os finos podem representar de $48 \%$ a mais de $54 \%$. O tamanho de grãos das areias variam de areia grossa para tamanhos menores.

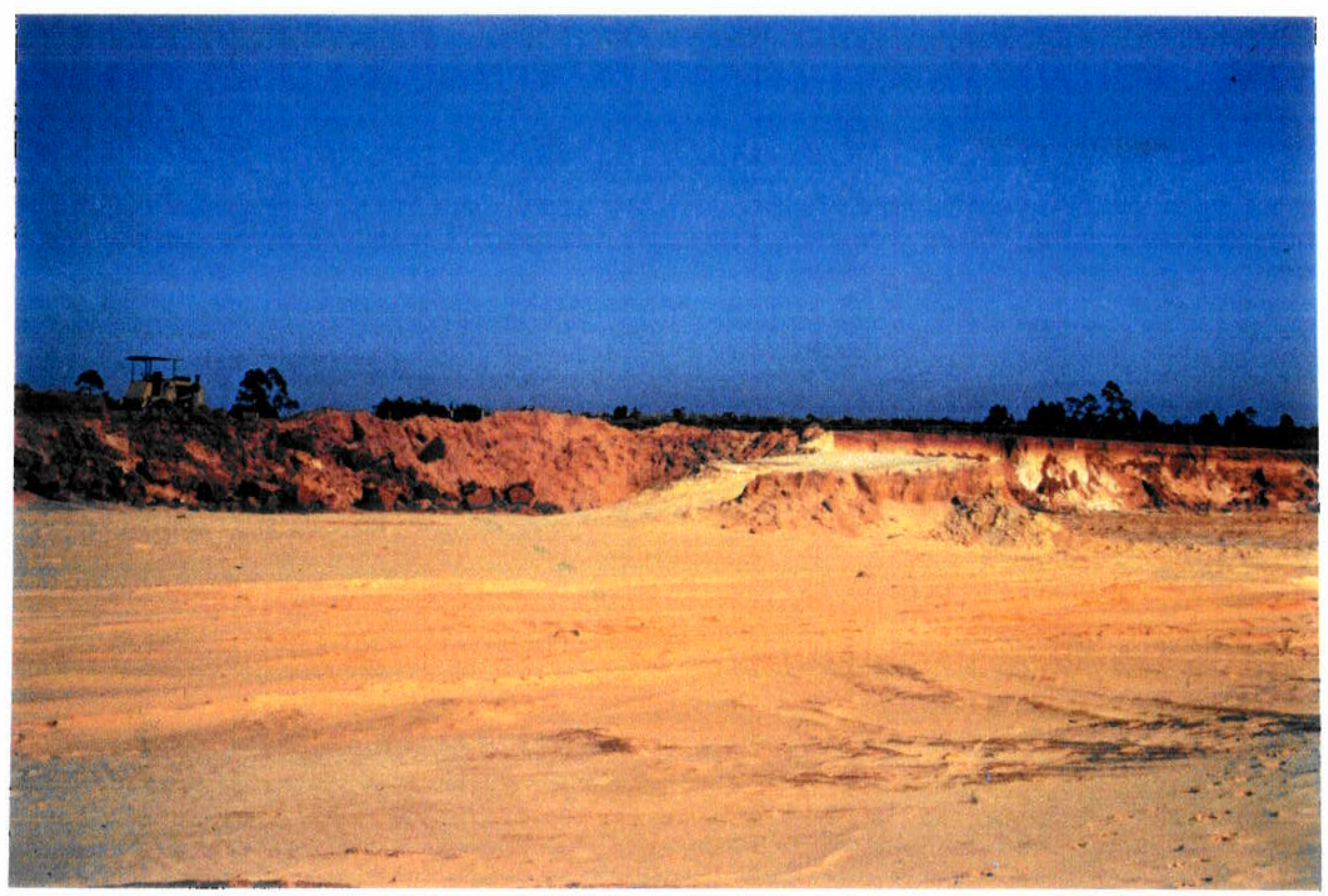

Foto 45 - Continuação da vista da mineração de areia em Mato Alto, observando-se a inclinação da forma para oeste. Os níveis bioturbados também inclinam nesta direção. 


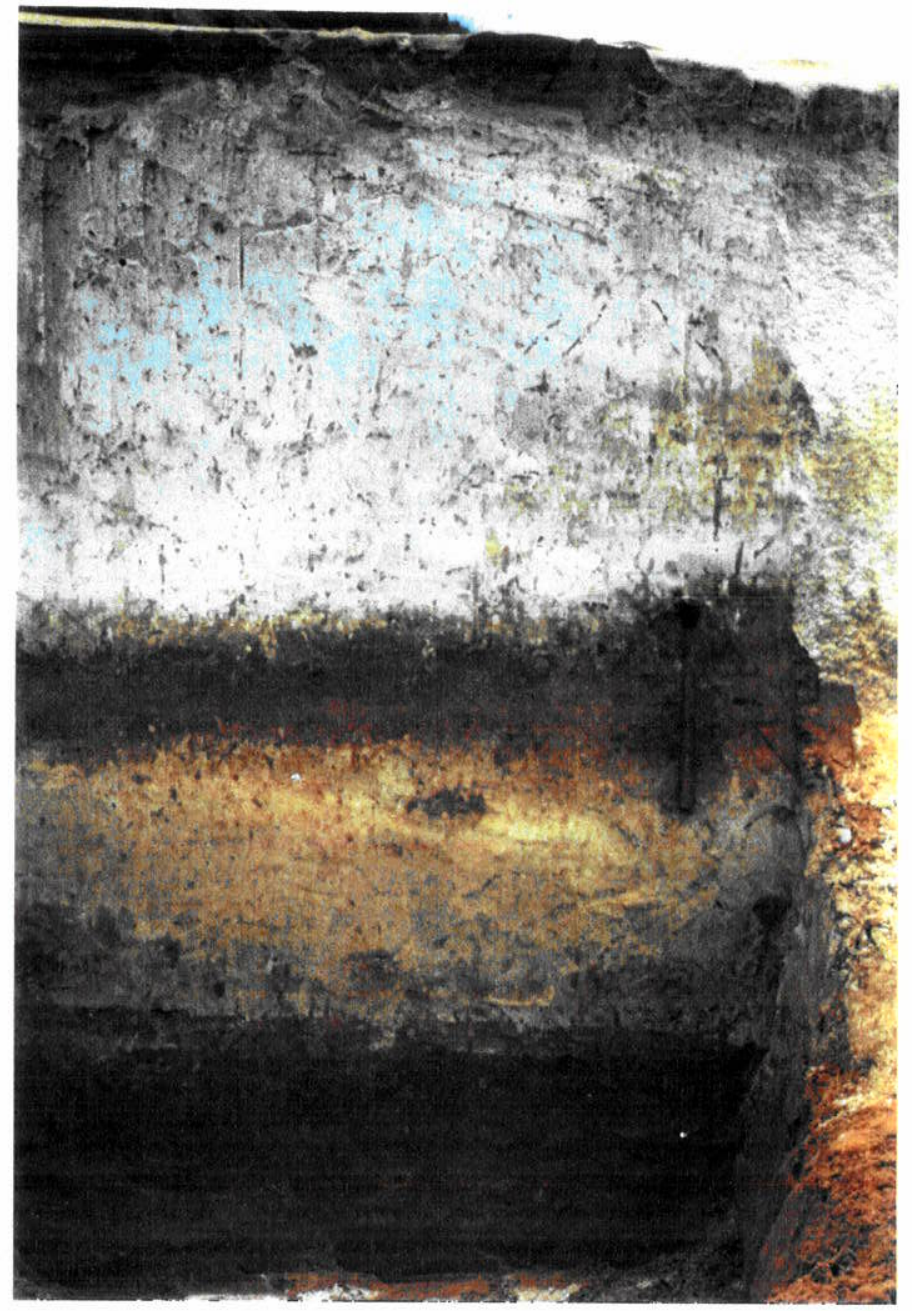

Foto 46 - Detalhe da bioturbação e da seqüência de níveis mais intensamente bioturbados com outros menos e mais claros. Mesmo local das fotos 43, 44 e 45. 


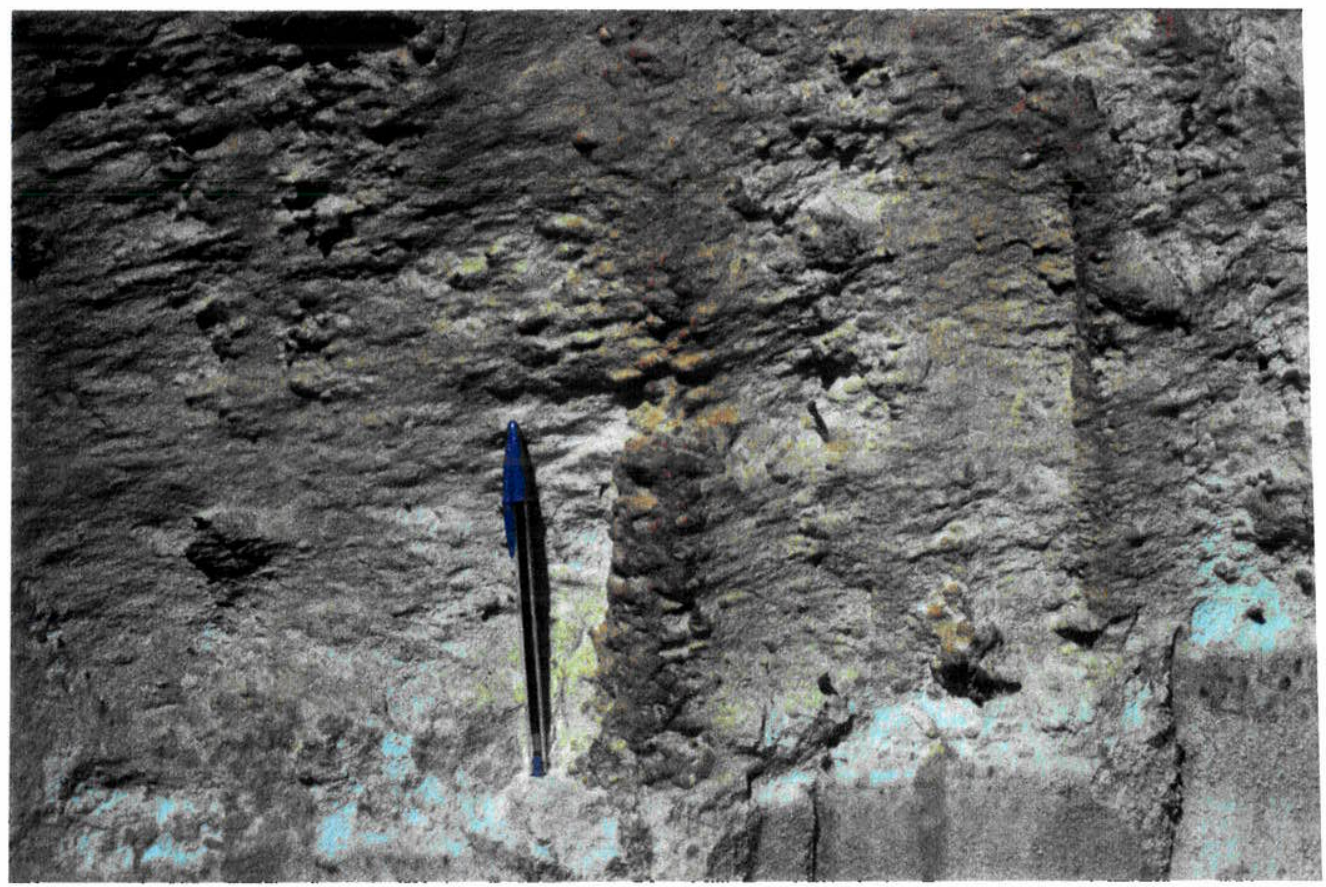

Foto 47 - Em Mato Alto, detalhe das estruturas cuja parte externa é corrugada, criada pelos crustáceos do gênero Callichirus provavelmente Callichirus major, pois as galerias não são muito ramificadas. 


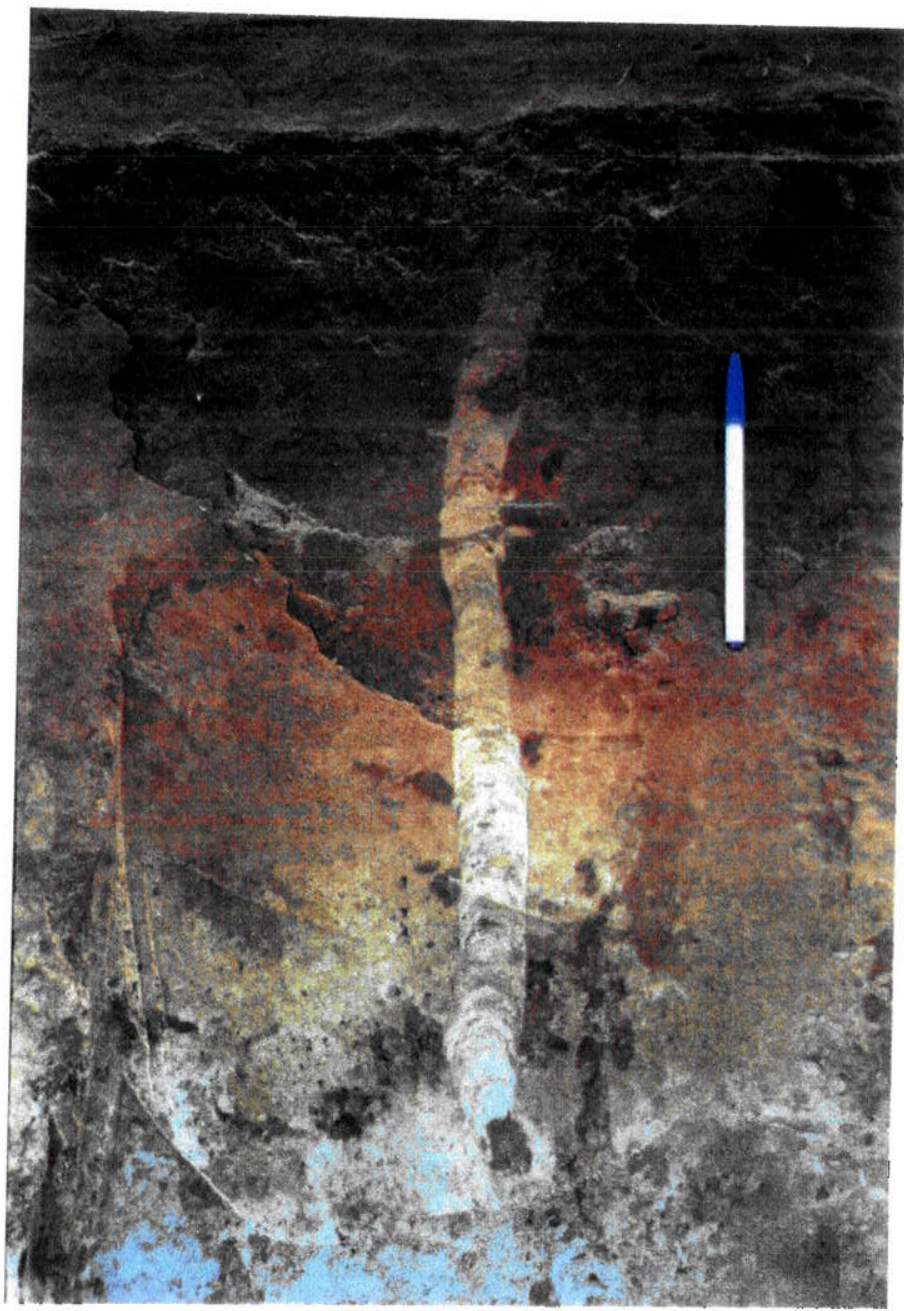

Foto 48 - Detalhe do afloramento de Mato Alto, Araranguá, mostrando evidências da bioturbação. Aspecto do preenchimento do tubo. 


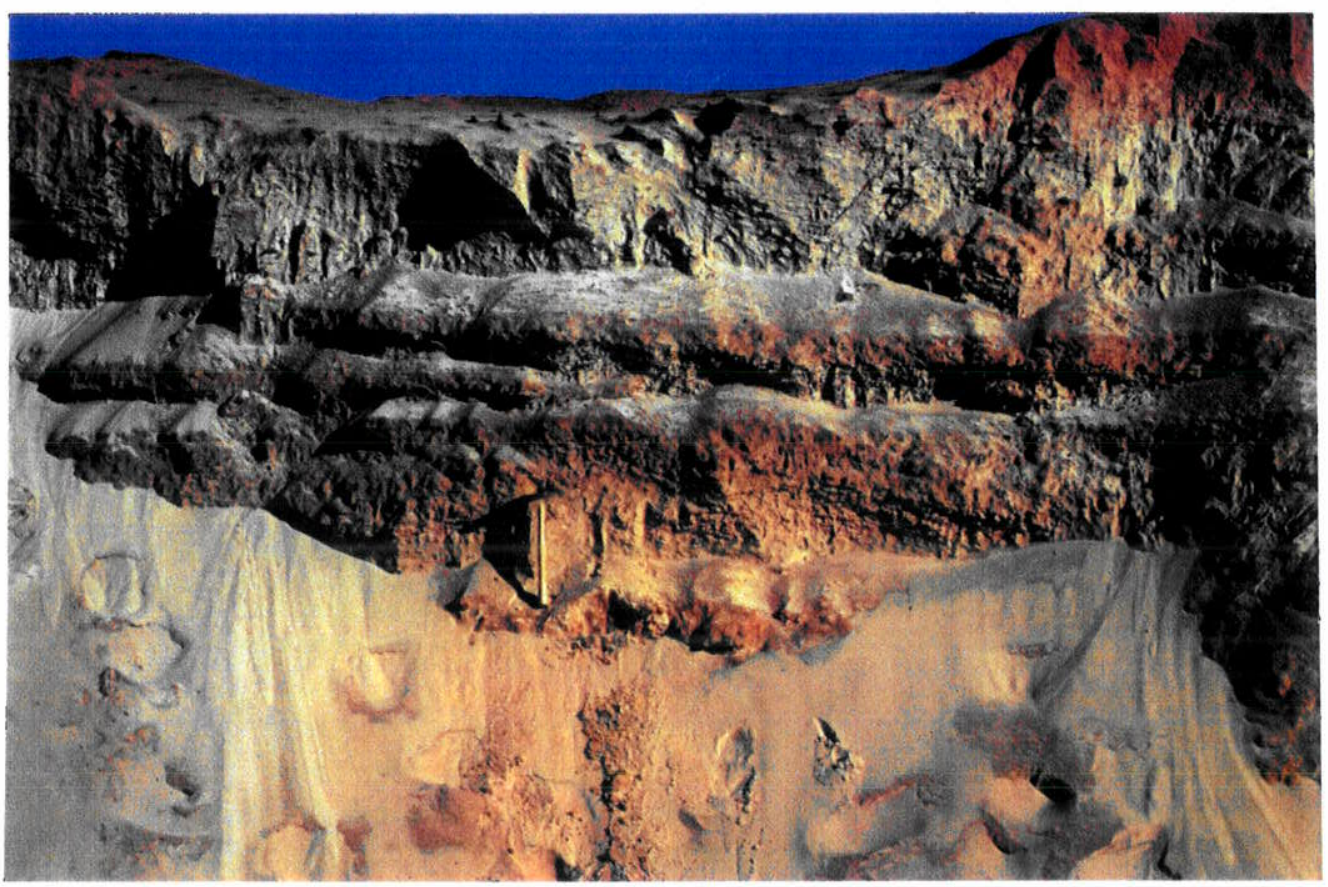

Foto 49 - Detalhe do afloramento de Mato Alto, notando-se o comportamento erosional, distinto no topo dos níveis bioturbados, quando as areias secam, acompanhando a paleomorfologia dos sedimentos intermarés.

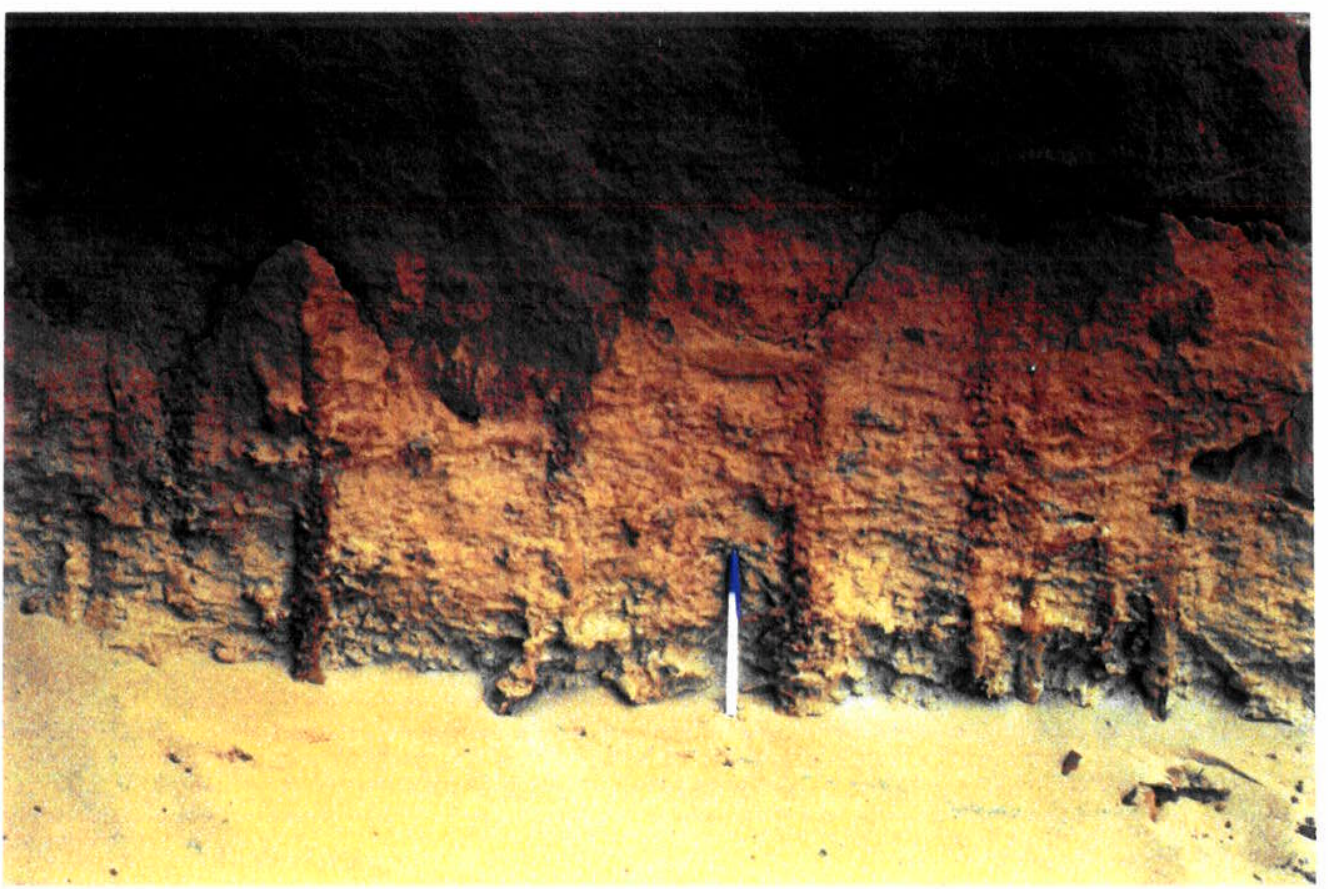

Foto 50 - Detalhe do afloramento em Mato Alto, na faixa de contato com a parte pedogeneizada. Tubos provavelmente de Callichirus major. 


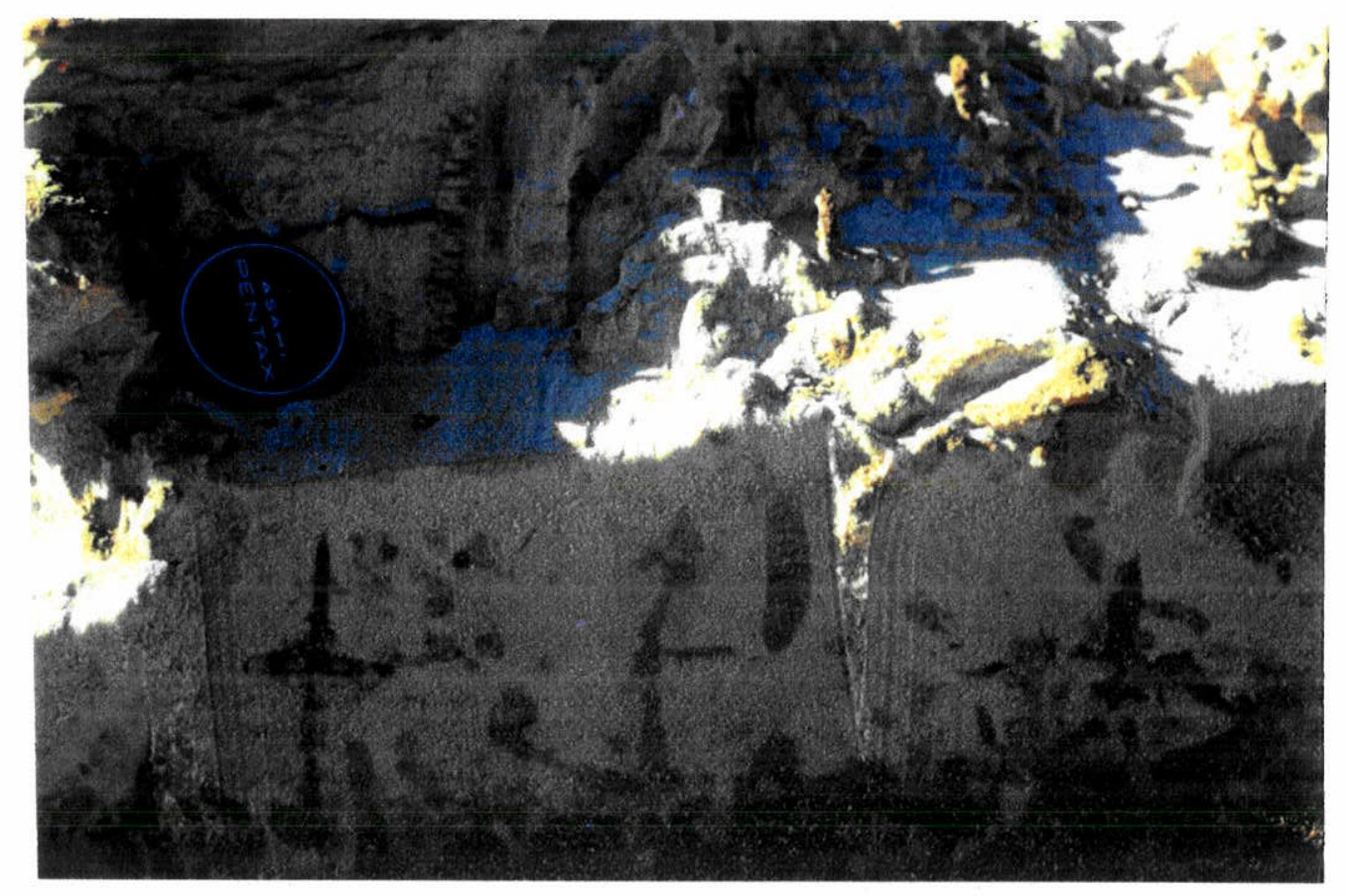

Foto 51 - Detalhe do afloramento em Mato Alto, Araranguá, mostrando as evidências numerosas de bioturbação. Certas evidências, como o aspecto externo das galerias, só é possível visualizarse quando as areias estão secas e onde a pedogênese ainda não homogeneizou as cores. Evidências de bioturbação são encontradas em todos os depósitos de cristas praiais, porém a profundidade e área dos cortes não possibilitam as inferências dadas por este afloramento.

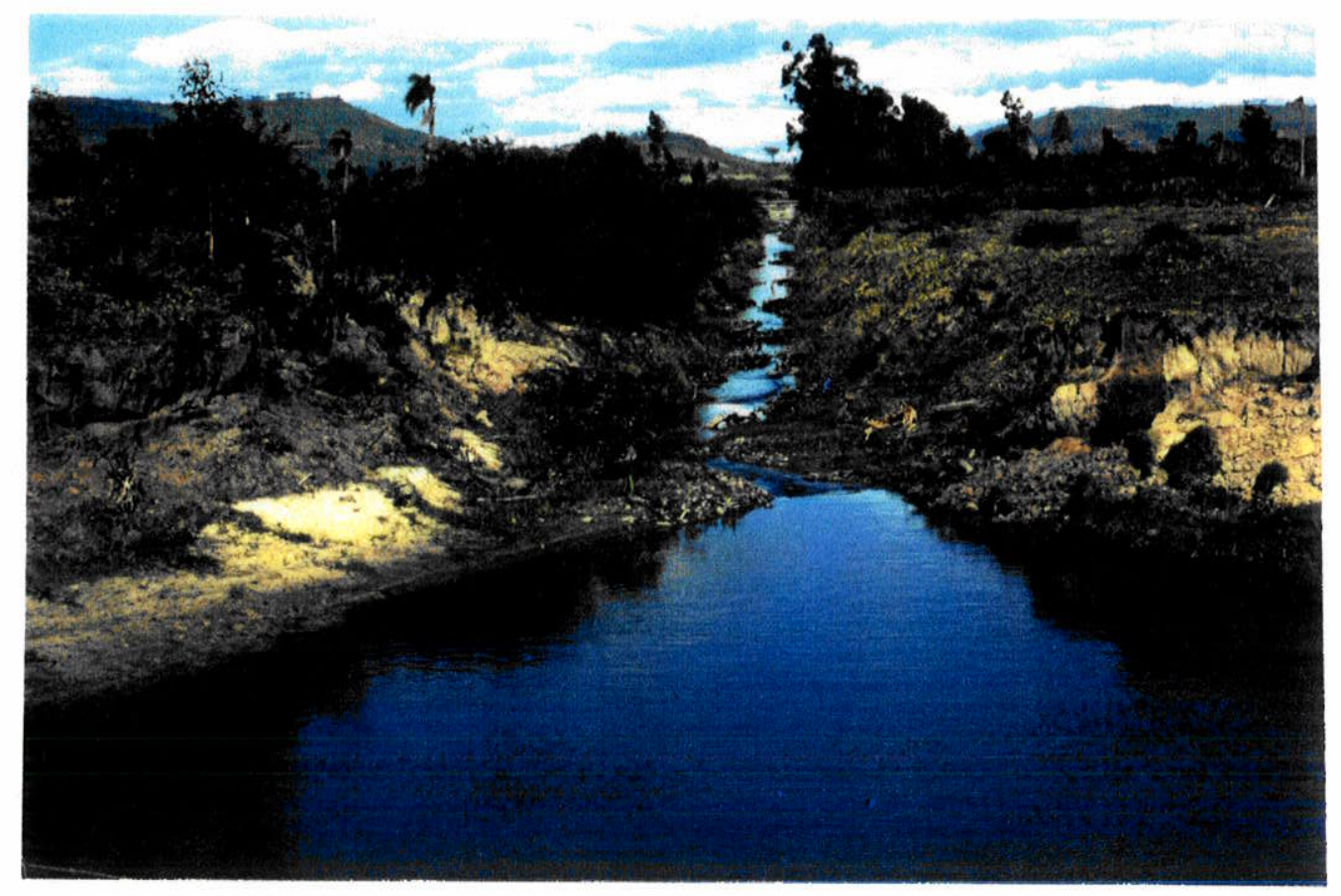

Foto 52 - Área de paleolaguna a oeste dos depósitos de ilha-barreira e cristas praiais entre Araranguá e Sombrio. Este trecho situa-se a oeste da localidade de Sanga Negra e a noroeste de Sombrio. Drenagem do Canal do Rio da Laje. Altitude de topo acima de $10 \mathrm{~m}$. 


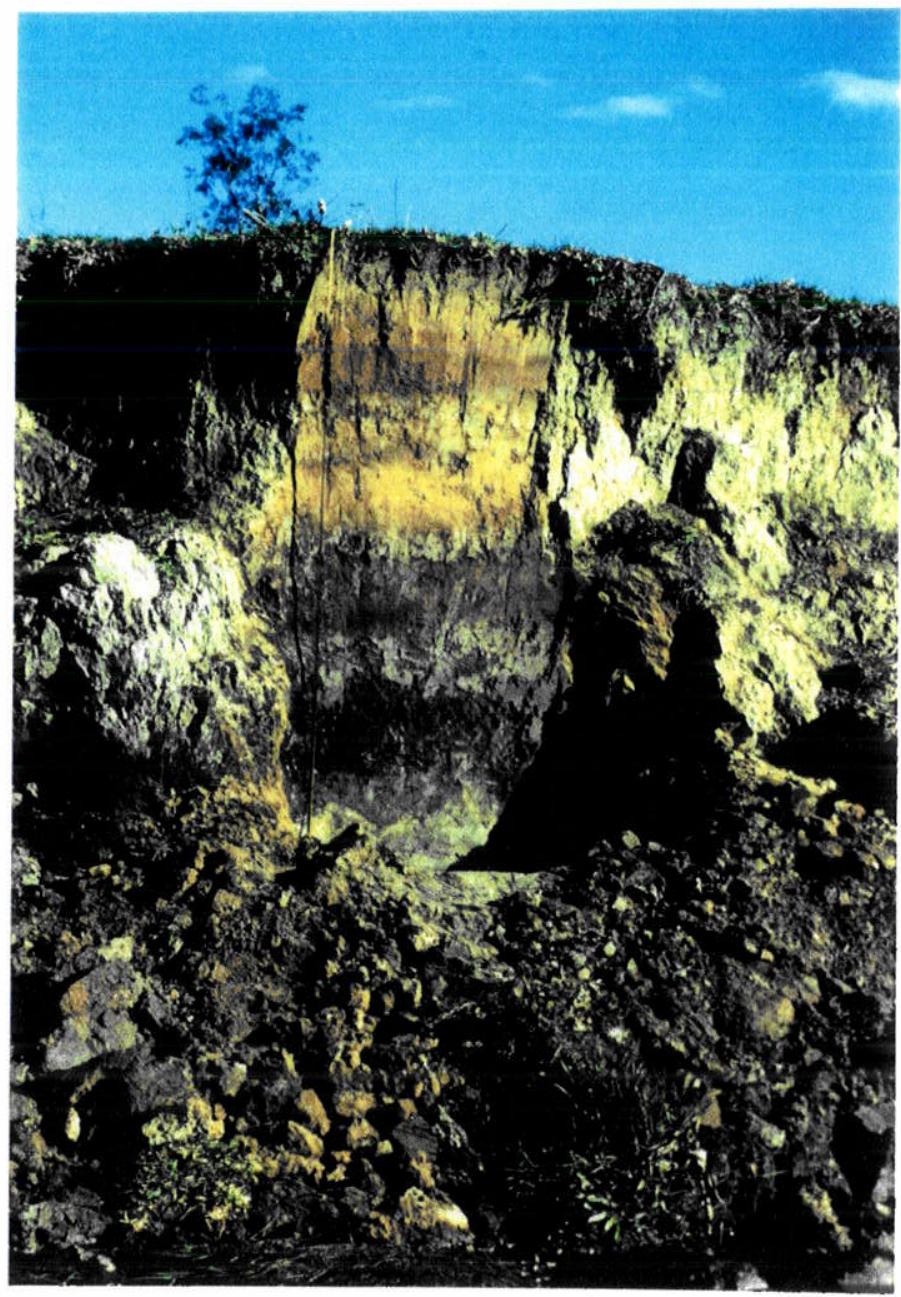

Foto 53 - Afloramento na margem do Canal do Rio da Laje, detalhe da foto 52, a oeste de Sanga Negra, Município de Sombrio, mostrando alternância de camadas argilosas, orgânicas, arenosas e mistas, na área de paleolaguna.

A) Cristas Praiais de Maracajá - Barro Vermelho - Nas cristas de Maracajá - Barro Vermelho, a norte do Rio Araranguá ( $A N$ ), essa situação é comprovada. Os sedimentos arenosos dominantes variam de 80 a 100\% de areias que são de grossas a muito finas (Figuras 106 a 108). Raros casos apresentam areia muito grossa. Nota-se a presença de pequenas concreções ferruginosas nas estruturas onduladas ou lamelas.

São sedimentos polimodais, pois apenas $5 \%$ das amostras são unimodais. O número de modas varia de 1 a 4 ф. Os tamanhos silte e argila apresentam, na maioria das amostras, uma ou duas modas. Nos siltes domina uma moda ao passo que nas argilas dominam duas modas. A primeira moda é, na grande maioria, no tamanho areia fina, principalmente nas frações de 0,177 mm e 0,149 mm. A segunda, terceira e quarta modas 
situam-se em geral nas argilas e siltes. Em resumo, ocorrem modas nos tamanhos silte e argila, mas não são tão significativas quanto na da areia fina. $64 \%$ das amostras têm tamanho médio entre 2 e $3 \phi(0,25 \mathrm{~mm}$ e 0,125 mm), mas há representação de tamanhos médios de 2 a $8 \phi(0,25 \mathrm{~mm}$ a $0,004 \mathrm{~mm})$.

A presença dos finos permite a classificação desses sedimentos como mal selecionados, chegando a extremamente mal selecionados. Como a tendência é para sedimentos mais finos, $86 \%$ das amostras apresentam assimetria muito positiva. Quanto à curtose, a dominância de areias finas faz com que $72 \%$ das amostras sejam classificadas como extremamente leptocúrticas evidenciando a seleção em torno da moda (Tabela 61).

A figura 109 apresenta a distribuição destes sedimentos segundo os mecanismos de transporte, de acordo com PASSEGA (1964). As amostras situam-se dominantemente dentro da classe $V$, isto é, teriam sido depositadas a partir de uma suspensão graduada de turbulência moderada.

B) Cristas Praiais entre Araranguá e Sombrio - O depósito ao sul do Rio Araranguá (AS) é semelhante ao situado a norte, porém, como se teve acesso a perfis mais profundos, as amostras sem argila são mais freqüentes no universo amostrado (Figuras 108,110 e 111). As maiores percentagens de finos nesse depósito ficam por conta das amostras da crista isolada ao sul do Morro do Soares e, daquelas coletadas em altitudes em torno de $20 \mathrm{~m}$, em uma depressão circular (Figura 102 no encarte), com grande quantidade de matéria orgânica.

Os sedimentos deste depósito têm de 1 a 4 modas (classes de $1 \phi$ ), sendo $33 \%$ unimodais, porém, mesmo havendo mais de uma moda, cerca de $70 \%$ das amostras têm mais de $90 \%$ de areias, e $66 \%$ das amostras têm de 70 a $92 \%$ apenas de areias finas. Como não podia deixar de ser, a quase totalidade tem a primeira moda na classe areia fina e $93 \%$ das amostras têm essa moda no intervalo 0,149 $\mathrm{mm}$. Uma ou duas nos tamanhos silte e argila. Pelas razões citadas e com cerca de $40 \%$ das amostras sem argilas, deve-se esperar um conjunto mostrando mais seleção que o de Maracajá - Barro Vermelho.

Correspondendo ao já descrito, $80 \%$ das amostras têm tamanhos médios entre 2 a 
$3 \phi(0,25 \mathrm{~mm}$ a $0,125 \mathrm{~mm})$. Entretanto, quanto ao grau de seleção, há amostras cujos materiais são muito bem selecionados e outras nas quais são extremamente mal selecionados. $35 \%$ das amostras são mal selecionadas. A polimodalidade já indica a possibilidade dessa variação da seleção. Essa classificação é explicada pela presença dos finos gerados pela pedogênese. A quantidade de finos nas amostras coletadas na depressão circular, talvez seja devida a processos pedogenéticos com formação de solo orgânico, e aquela nas amostras da crista praial isolada, possivelmente seja devida à contribuição das elevações próximas de rochas do Grupo Passa Dois.

$\mathrm{Na}$ assimetria a maioria das amostras se concentra nas classes de assimetria negativa $(-0,30$ a $-0,10)$ e de assimetria muito positiva $(+0,30$ a $+1,00)$. O restante das amostras apresentam todos os demais tipos de assimetria da escala descritiva própria. Há, entretanto, domínio das assimetrias positivas, devido à tendência para sedimentos mais finos (Tabela 61).

As curvas para essas amostras podem ser classificadas como mesocúrticas a extremamente leptocúrticas, sendo esta última a classe com maior concentração (44\%).

Os mecanismos de transporte destes sedimentos situados ao sul do Rio Araranguá, estão referidos na Figura 112, similar ao das cristas ao norte do Rio Araranguá.

C) Cristas Praiais a Leste de Araranguá - As amostras coletadas a leste da cidade de Araranguá ( $\mathrm{AE}$ ) fazem parte do depósito situado ao sul do Rio Araranguá e a partir do sopé das elevações de rochas do Grupo Passa Dois que ocorrem naquele sítio urbano. Algumas de suas características sedimentológicas podem ser visualizadas nas figuras 102 e 107 a 109.

Mostram-se com seleção menor do que o restante da área para o sul e com tamanhos médios entre 2 e $4 \phi \quad(0,25 \mathrm{~mm}$ e 0,062 $\mathrm{mm})$ seguidos por tamanhos entre 5 e 6 $\phi(0,031 \mathrm{~mm}$ e $0,0156 \mathrm{~mm}) .84 \%$ das amostras têm assimetria muito positiva e curtose de muito a extremamente leptocúrticas. As amostras coletadas apresentam de 1 a 4 modas (classes de $1 \phi$ ) (Tabela 61). Todas as amostras apresentam a moda mais importante na areia fina, principalmente dentro da fração $0,149 \mathrm{~mm}$. 
D) Cristas Praiais no Setor Sul - Os depósitos dos sedimentos praiais pleistocênicos no Setor Sul serão considerados, como já foi referido, como a seqüência de cristas do lado oeste do Rio do Sertão (MW) e aquela a leste desse rio (ME).

Embora as diferenças com os depósitos já descritos sejam pequenas, elas existem. Um dos exemplos é que apenas com duas exceções, todas as amostras têm mais de 10\% de silte e argila. A percentagem dessas partículas varia, então de 10 a $39 \%$. Nota-se que em muitos perfis a percentagem de argila aumenta com a profundidade, indicando a presença do Horizonte-B. Algumas amostras apresentam areia muito grossa, mas a grande maioria contém de areia grossa a argila (Figuras 108, 116 a 119).

Outras diferenças notadas ocorrem por exemplo, nas modas. Também são sedimentos polimodais com modas ( 2 a 4 ) nas areias, siltes e argila. Apenas $2 \%$ das amostras são unimodais. A primeira moda apresenta uma novidade, pois, além de ser constituída por areias finas, há também uma boa representação das areias muito finas. No primeiro caso, a moda constitui-se principalmente de grãos na fração $0,149 \mathrm{~mm}$, e no segundo caso, na fração de $0,105 \mathrm{~mm}$.

O diâmetro médio constitui outra diferença, uma vez que nos outros depósitos predominava o diâmetro de 2 a $3 \phi(0,25 \mathrm{~mm}$ a $0,125 \mathrm{~mm})$; neste caso predomina o tamanho de 3 a $4 \phi(0,125 \mathrm{~mm}$ a $0,062 \mathrm{~mm})$, havendo também alguma representação das classes 2 a $3 \phi(0,25 \mathrm{~mm}$ a 0,125 mm) e de 4 a $5 \phi(0,062 \mathrm{~mm}$ a $0,031 \mathrm{~mm})$.

Os sedimentos são mal selecionados a muito mal selecionados. Há coerência com a polimodalidade e o espalhamento dos finos.

Como conseqüência a assimetria é muito positiva em $98 \%$ das amostras que se classificam como muito leptocúrticas a extremamente leptocúrticas pela concentração dos tamanhos areia fina e muito fina (Tabela 61).

Os sedimentos a leste do Rio Sertão (ME) têm maiores semelhanças com os do depósito entre Araranguá e Sombrio (AS), pois $85 \%$ das amostras têm diâmetro médio entre 2 e $3 \phi(0,25 \mathrm{~mm}$ a $0,125 \mathrm{~mm})$, a seleção dos sedimentos tem representação em quase todas as classes deste parâmetro, segundo FOLK \& WARD (1957), isto é, são muito bem selecionados a mal selecionados, a assimetria varia de negativa a muito positiva, 
dominando essa última, seguida da assimetria positiva. Na curtose é que essas amostras são mais parecidas com as do oeste (MW), pois predominam as extremamente leptocúrticas seguidas das muito leptocúrticas (Tabela 61).

No que se relaciona às modas em amostra total, os sedimentos têm características similares aos anteriores, havendo um aumento da unimodalidade para $13 \%$, mas $87 \%$ são polimodais. As amostras que têm modas em silte e argila têm comportamento similar às do oeste, isto é, ocorrem nos siltes dominantemente 1 moda e nas argilas 1 a 2 modas em proporções equivalentes.

As figuras 120 e 121 evidenciam as características deposicionais, segundo PASSEGA et al. (1969). As amostras das cristas praiais MW e ME mostram que são principalmente sedimentos do tipo $V$, depositados em suspensão com moderada turbulência.

A relação entre parâmetros estatísticos das amostras praiais pleistocênicas até aqui descritas, pode ser vista nas figuras 122 e 123 para amostra total. As Figuras 124 e 125 mostram essa relação nas amostras recalculadas sem os finos, isto é, foram refeitas todas as curvas e cálculos para estas amostras de cristas praiais para se verificar o comportamento das areias sem o efeito da pedogênese. Os parâmetros estatísticos das amostras recalculadas encontram-se na tabela 62.

E) Mineralogia dos Depósitos - A mineralogia de pesados desses sedimentos constituise de 16 espécies minerais, com dominância dos minerais opacos. Entre os minerais transparentes seguem-se, em ordem de importância: zircão $(24,3 \%)$, hornblenda castanha $(13,9 \%)$, turmalina castanha $(13,4 \%)$, estaurolita, cianita, turmalina schorlita, epidoto (pistacita), turmalina verde, hornblenda verde, sillimanita, rutilo e epidoto clinozoisita. Com exceção dos três últimos, os outros têm 112 a 746 grãos contados nas amostras desses depósitos. Seguemse com relativa importância turmalina azul e turmalina vermelha (Tabelas 63).

Nota-se que há diferença qualitativa e quantitativa entre essa assembléia e a que ocorre nos leques aluviais.

Quanto aos minerais leves, estão presentes primordialmente quartzo monocristalino e policristalino, seguindo-se ortoclásio, plagioclásio não zonado, microclínio e plagioclásio zonado. Estes depósitos apresentam maior freqüência de ortoclásio do que de 
plagioclásios que os leques aluviais. Nas lâminas diminui também a freqüência de fragmentos de rochas e de alteritos, embora ainda sejam comuns os fragmentos de basalto, possivelmente pela grande área exposta da sua fonte (Tabela 64).

\subsubsection{A Área a Leste das Maiores Lagoas}

A leste do depósito arenoso, entre Araranguá e Sombrio e daqueles descritos no Setor Sul, ocorrem quatro lagoas maiores e uma série de pequenas lagoas em cordão, alongadas na direção NE-SW. Entre as maiores, de nordeste para sudoeste, estão as lagoas dos Bichos, da Serra, de Caverá e do Sombrio. Outras são conhecidas como lagoinhas de Fora, da Bezerra.

As lagoas da Serra, Caverá e Sombrio, e possivelmente também a dos Bichos constituíram um corpo de água contínuo, inicialmente lagunar e posteriormente lacustre, que, pela colmatação parcial, separou-se, gerando as atuais lagoas. Essas lagoas encontram-se separadas por terrenos muito baixos, planos e úmidos, parcialmente ocupados por turfas que serão tratados posteriormente.

Para o leste, após estas lagoas, turfeiras e áreas palustres, ocorrem seqüências de cristas praiais recobertas mais ou menos intensamente por depósitos eólicos.

A faixa sobretudo arenosa, a leste das lagoas, é mais larga ao sul que ao norte, onde a largura reduz-se à metade já na altura do paralelo da cidade de Arroio do Silva, terminando junto ao Morro dos Conventos. Daí para o norte, após o Rio Araranguá, ocorrem depósitos pleistocênicos praiais e eólicos. Ali situam-se também as lagoas Mãe Luzia, dos Esteves, do Faxinal, Urussanga Velha e depósitos holocênicos.

\subsection{Depósitos Praiais Pleistocênicos de Nive/ de Mar de 123.000 Anos}

No extremo oeste desta faixa acima descrita há uma seqüência de cristas praiais bem formadas, sem retrabalhamento eólico significativo. Essas cristas tem 8 a $9 \mathrm{~m}$ de altitude (Fotos 54 e 55) e as depressões alongadas intercordões ou cavados estão 


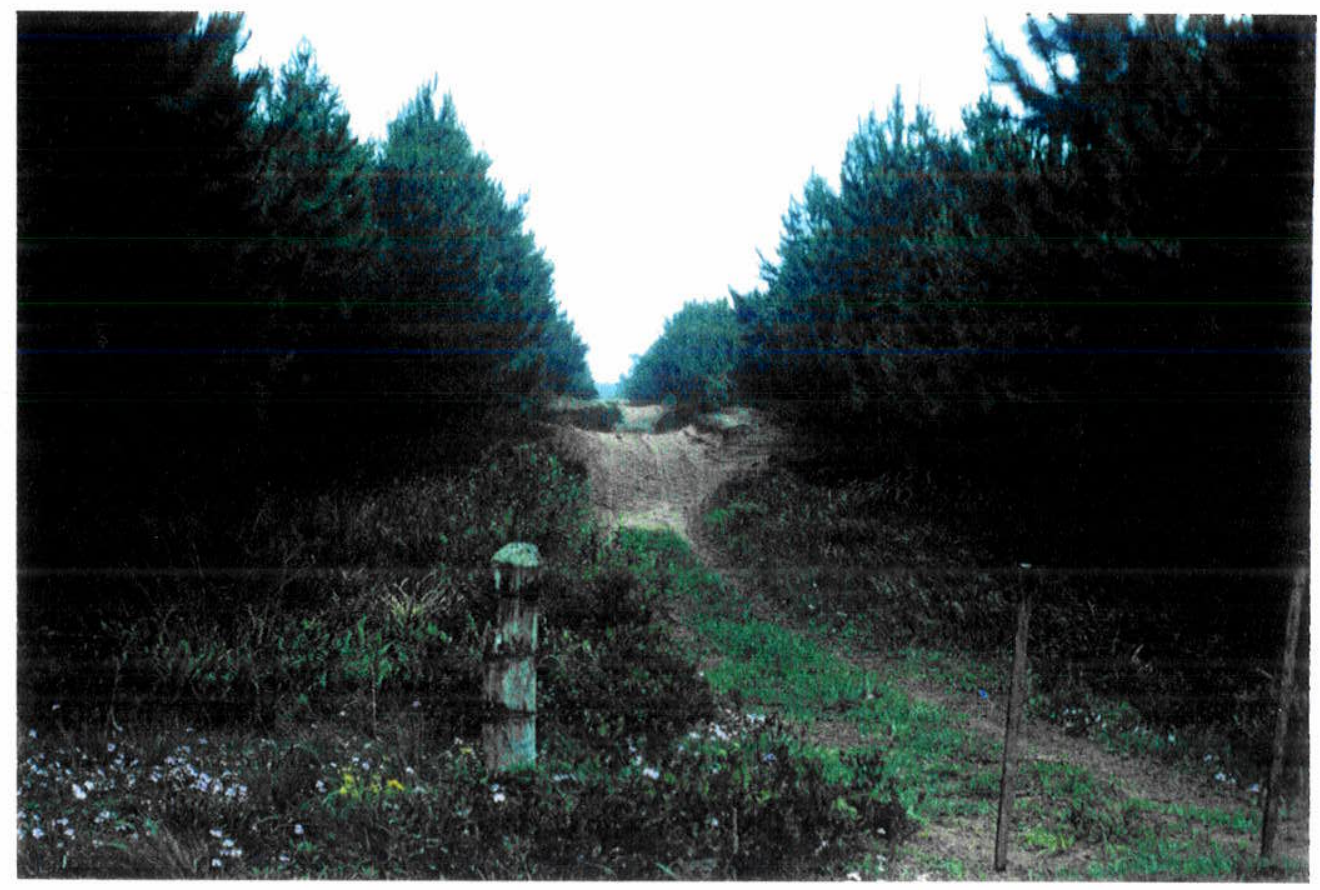

Foto 54 - Seqüência de cristais praiais pleistocênicas a sudeste da Lagoa de Sombrio, a leste da Sanga dos Rodrigues. Elas têm altitudes entre 8 e $9 \mathrm{~m}$ e desnível entre o topo e o cavado de $3 \mathrm{~m}$. São feições muito regulares e paralelas nesta área. Em outras acham-se um pouco remobilizadas por atividade eólica.

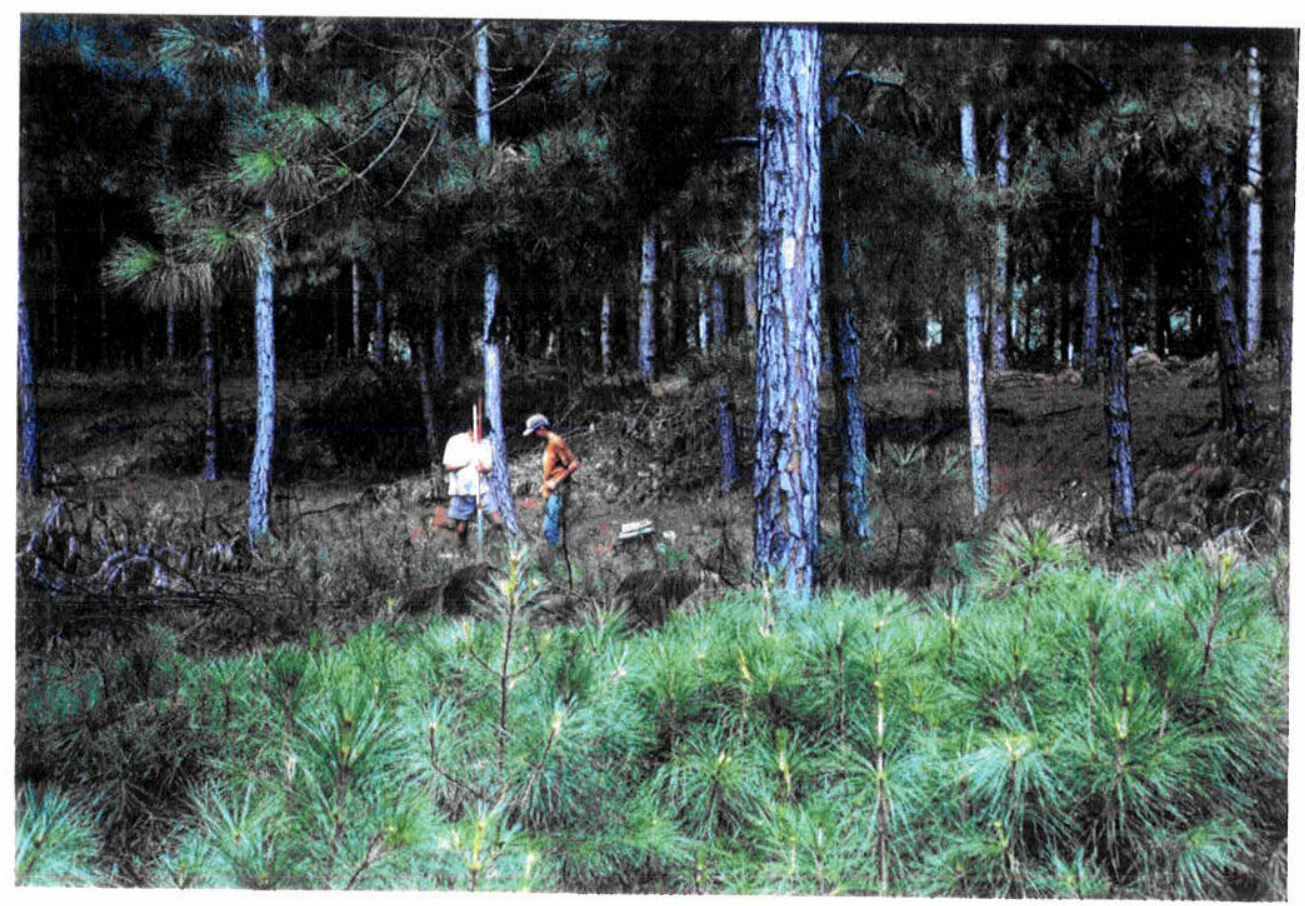

Foto 55 - Crista praial, pleistocênica, na parte central da foto, no reflorestamento da Olvebra (Foto 54). A foto foi batida para nordeste, obliquamente à direção das cristas. Os homens estão no cavado sobre cerca de $1 \mathrm{~m}$ de turfa, e o topo da crista está bem mais alto que eles. A área de turfa é favorável ao desenvolvimento espontâneo do Pinus. É o caso para as mudas na base da foto. 
preenchidas por turfas de cerca de $1 \mathrm{~m}$ de espessura. Essas cristas situam-se a leste da Sanga do Rodrigues e são cortadas pela estrada que, de Curralinhos leva à praia Rosa do Mar. Elas apresentam um desnível de $3 \mathrm{~m}$ entre o topo da crista e o fundo do cavado. Esta constitui apenas uma das razões da afirmação de que a atividade eólica foi inexpressiva, caso contrário não teria sido mantido esse desnivel. Outra razão é que as cristas se apresentam muito regulares e retilíneas.

Pelas suas altitudes e graus de pedogênese, essas cristas são consideradas pleistocênicas, mais recentes que as situadas a oeste das lagoas (Figura 126) e correspondentes à Formação Cananéia ou Transgressão Cananéia de SUGUIO et al. (1978) e Barreira III de VILLWOCK et al. (1984). Estes depósitos foram considerados como holocênicos (Qbc4) ou depósitos da Barreira IV por VILLWOCK et al. (1984) e HORN Fo (1987) e areias marinhas litorâneas bem selecionadas do Holoceno por MARTIN et al. (1988).

Para o norte, até defronte a Lagoa do Caverá, em muitos trechos, as cristas praiais foram remobilizadas pela atividade eólica. Perderam parte de suas morfologia e continuidade. Para o norte e para o leste estão substituídas por conjuntos de cristas praiais e dunas mais recentes, holocênicas.

Essas cristas, no extremo sul, com 8 a $9 \mathrm{~m}$ de altitude, largura variando de $30 \mathrm{~m}$ a $60 \mathrm{~m}$ e desnivel entre seu topo e seu cavado, de $3 \mathrm{~m}$, granulometricamente têm as seguintes características: apresentam finos abaixo de $5 \%$, areias médias a muito finas de 99 a $100 \%$, com moda na areia fina $(0,149 \mathrm{~mm})$, unimodais. Para o norte elas se tornam bimodais, com a segunda moda com percentuais muito baixos. Há algumas amostras polimodais (Figuras 127 e 128, Fotos 56 e 57).

Trata-se de sedimentos cujo diâmetro médio situa-se entre 2 e $3 \phi(0,25 \mathrm{~mm}$ e $0,125 \mathrm{~mm}$ ), muito bem selecionados, com assimetria variando de negativa a muito positiva, e com a maior percentagem das amostras com assimetria positiva. Todos os tipos de curtose estão representados, concentrando, entretanto, entre platicúrtica a leptocúrtica. Essa variação pode ser explicada, talvez, pelo comportamento das modas, pois algumas amostras são polimodais, mostrando o espalhamento da distribuição (Tabela 65). 
O diagrama C-M (Figura 129) sugere que os mecanismos de transporte destes sedimentos foram os mesmos dos outros depósitos praiais mais antigos.

A) Mineralogia - A mineralogia desses sedimentos mostra-se bastante distinta da de cristas praiais pleistocênicas a oeste das lagoas, pois, além dos opacos, são o epidoto (pistacita) e a hornblenda castanha os mais abundantes. Estão presentes 24 espécies minerais transparentes. Além dos citados, aparecem, em ordem decrescente de freqüência: turmalina castanha, hornblenda verde, cianita, epidoto clinozoisita, estaurolita, augita, turmalina schorlita, zircão e sillimanita com a mesma taxa, epidoto zoisita, tremolita/actinolita, hiperstênio, seguindo-se os outros menos freqüentes (Tabela 66).

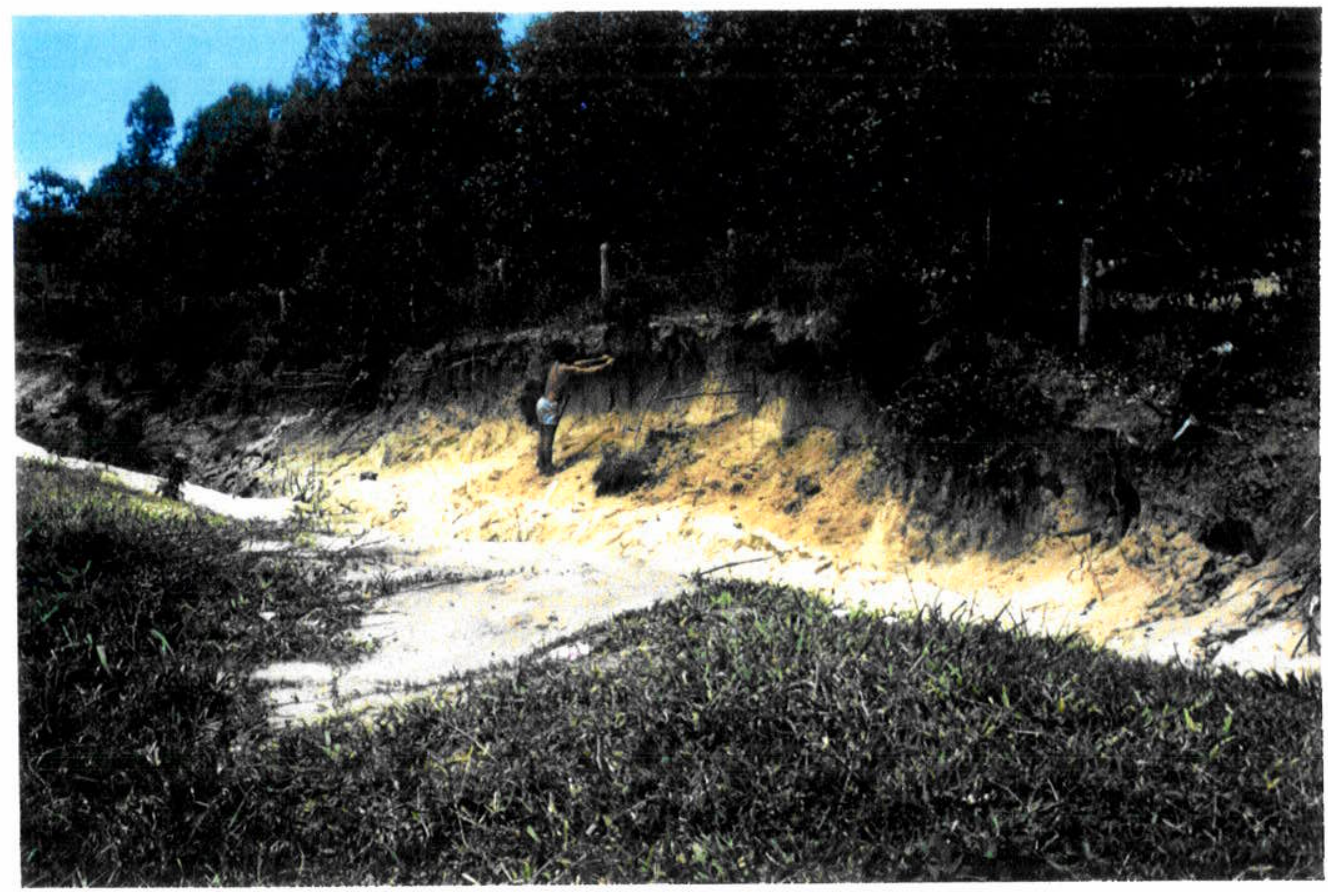

Foto 56 - Formas e sedimentos da área de cristas pleistocênicas remobilizadas por ação éolica, a leste de Sombrio. Nota-se a formação de solo acompanhando a parte alta da forma que é convexa e longilínea. 


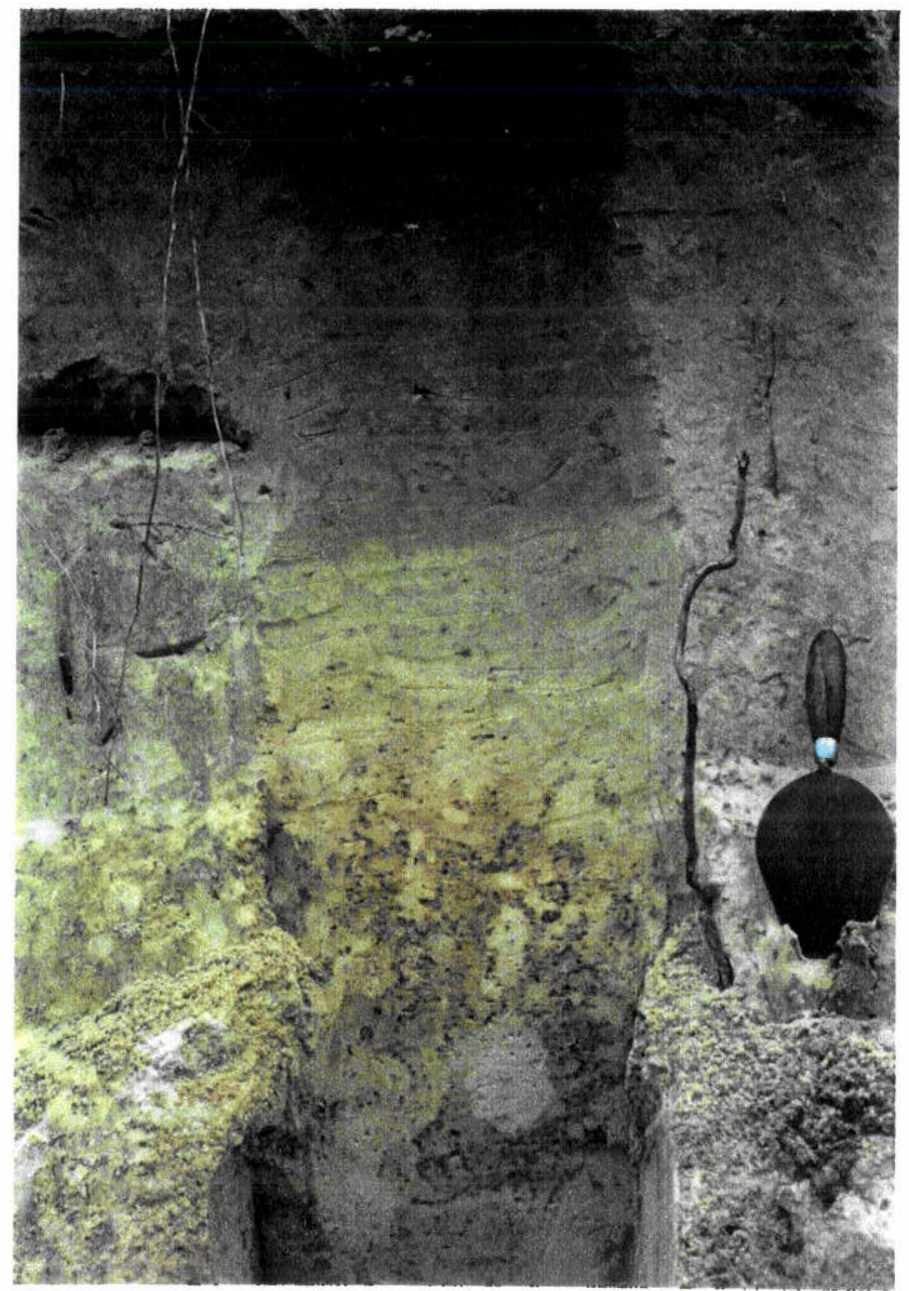

Foto 57 - Aspecto dos sedimentos a leste da Lagoa de Sombrio, na localidade de Anita Garibaldi. Corte lateral à vala de drenagem aberta pelo DNOS. Evidência de pedogênese e bioturbação. 
Entre os minerais leves, o quartzo monocristalino é o mais abundante, sem comparação com qualquer outro, e semelhante às cristas do lado oeste das lagoas. Seguese com taxas muito menores, o quartzo policristalino e o ortoclásio. Estas taxas são bem menores que nos depósitos praiais mais antigos. Os plagioclásios, tanto os não zonados como os zonados, e particularmente esses, aparecem com taxas bem mais altas que o ortoclásio e o microclínio, e também que os plagioclásios dos depósitos mais antigos. A presença de fragmentos de rochas básicas nas lâminas, em taxas mais altas que os ortoclásios e similares as do quartzo policristalino, talvez se explique pela proximidade da fonte (Tabela 67).

\subsection{Depósitos Praiais Holocênicos}

Os depósitos praiais holocênicos estão situados no extremo leste da faixa de sedimentos arenosos compreendida entre as grandes lagoas e o oceano. Eles estão sob forte ação eólica que os retrabalha. Apesar desta atividade eles exibem parâmetros granulométricos e minerológicos similares aos depósitos praiais pleistocênicos contíguos (Figura 130 a 133 e Tabela 68).

Em alguns trechos vê-se a morfologia paralela e longilínea das cristas praiais em meio aos mantos aspergidos de areia, pela atividade eólica. Sobre estas cristas e sobre pequenas dunas ou encobertos por dunas maiores encontram-se sítios arqueológicos tipo sambaqui. Estes sítios têm constituintes similares, de gêneros e espécies da malacofauna, com uma exceção.

Foram coletadas amostras para classificação e datação, em quatro sambaquis. Um situa-se ao norte do Rio Araranguá, na localidade de Barra Velha, Município de lçara. Trata-se de um sítio cujo material foi usado para fábrico de cal e para a estrada que o corta, sendo portanto atualmente muito baixo, tendo cerca de $50 \mathrm{~m}$ de comprimento paralelos a um corpo de água alongado, praticamente colmatado.

Constitui-se de Olivancillaria vesica, Donax hanleyanus, Anomalocardia brasiliana, Ostrea equestris, Macoma constricta. Foram coletadas a $0,60 \mathrm{~m}$ de profundidade, dentro 
da areia, grandes valvas de Ostrea $s p$, alcançando $30 \mathrm{~cm}$ de tamanho. A datação destas valvas de Ostrea deu a idade de $1.880 \pm 170$ anos A.P. com $\delta^{13} \mathrm{C}$ de $-1,93 \%$ o. (PDB).

Ao sul do Rio Araranguá e a oeste da cidade de Arroio do Silva havia um sambaqui, intacto à época do trabalho, hoje completamente destruido, constituído principalmente de Mesodesma mactroides e em segundo lugar por Donax hanleyanus. Situava-se sobre dunas de areia de cor cinza. A idade deste sítio é de $1.740 \pm$ A.P. com $\delta^{13} \mathrm{C}$ de $-1,48 \%$ (PDB). Próximo a este há um sambaqui constituído com Anomalocardia brasiliana.

Doze quilômetros ao sul do Balneário Arroio do Silva, defronte à Praia do Arpoador um outro sambaqui foi datado. A malacofauna consiste de Donax hanleyanus, Mesodesma mactroides, Olivancillaria vesica e Buccinanops duartei, todas comestiveis e a idade é de $1.330 \pm 160$ anos com $\delta^{13} \mathrm{C}$ de $-1,63 \%$ (PDB). A altitude dos depósitos arenosos é menor que $2 \mathrm{~m}$.

Ao sul deste, no Balneário da Lagoinha, está o sambaqui da Lagoinha instalado sobre uma duna pequena, sob um marco geodésico marcando $11 \mathrm{~m}$ de altitude e a cerca de $350 \mathrm{~m}$ da praia. Sua malacofauna reúne Donax hanleyanus, Mesodesma mactroides, Olivancillaria vesica e Strophocheilus sp. (terrícula). Sua idade é $1.420 \pm$ A.P. $\delta^{13} \mathrm{C}$ de $1,92 \%$ (PDB).

A) Mineralogia - A mineralogia das cristas holocênicas é similar a das cristas praiais pleistocênicas do leste das lagoas. Entre os minerais pesados, a hornblenda castanha, o epidoto (pistacita), a hornblenda verde e a augita são os mais freqüentes, acima mesmo dos opacos. Nas últimas cristas praiais, o mineral mais freqüente é o epídoto (pistacita), que também é mais numeroso que os opacos. Além dos quatro primeiros citados, seguem, por ordem decrescente, opacos, turmalina schorlita, turmalina castanha, zircão, cianita, hiperstênio, estaurolita, epidoto clinozoisita, turmalina verde e mais onze minerais em menor proporção (Tabela 70). Os minerais leves estão indicados na tabela 71.

Os alteritos estão presentes em quantidade ínfima quando comparados com o número que ocorre nas cristas praiais pleistocênicas mais antigas, a oeste das lagoas, o que lembra também a pedogênese sobre elas. Nas cristas praiais a leste das lagoas, os 
alteritos ocorrem em número quase quatro vezes maior que nas praias, porém também em pequeno número, quando comparados aos das praias mais antigas.

B) Praias Atuais - Conforme referência em páginas anteriores as praias atuais constituem um arco com cerca de $70 \mathrm{~km}$ de comprimento na área estudada, interrompido pela foz do Rio Araranguá. São praias largas e pouco inclinadas onde o estirâncio é seguido por pró-dunas, por vezes cortadas em pequenas escarpas (cliffs). A amostragem foi pouco numerosa e os locais de coleta separados por grandes distâncias.

São sedimentos compostos predominantemente por areias finas, com menos de $1 \%$ de areia média e valores um pouco mais expressivos de areia muito fina. Algum fundo de finos aparece nas amostras coletadas junto às desembocaduras do Mampituba e Araranguá (Figuras 134, 135).

O diâmetro médio situa-se entre 2 e $3 \phi(0,25 \mathrm{~mm}$ e 0,125 $\mathrm{mm})$ e as amostras são muito bem selecionadas. A assimetria é sobretudo positiva nas poucas amostras analisadas, mas há representação também de assimetria negativa. As curvas são especialmente mesocúrticas, mas também leptocúrticas e platicúrticas (Tabela 69). Isso se explica, pois, embora bem selecionados, esses sedimentos apresentam 1 e 2 modas. Quando são unimodais, o tamanho dos grãos na moda é areia fina, concentrando-se na fração 0,149 $\mathrm{mm}$. Quando são bimodais, este tamanho constitui a primeira ou segunda moda. A outra moda cai em areia muito fina.

C) Moluscos - Amostras de conchas das praias foram coletadas e classificadas para comparação com os gêneros e espécies coletados em bancos naturais de associação morta e em sambaquis.

Constituem comunidade de praia arenosa de mar aberto a Mesodesma mactroides, Donax hanleyanus, Raeta plicatella, Olivancillaria vesica. Outras devem ter sido trazidas de costões pela deriva litorânea, uma vez que são de fundo rochoso. Na praia de Bela Torres, a norte do Rio Mampituba e com sua influência, ocorre Tagelus plebeius. Na praia do Morro dos Conventos são encontradas Olivancillaria urceus e Anomalocardia brasiliana, além das já citadas inicialmente. 


\subsubsection{DEPÓSITOS EÓLICOS ANTIGOS E ATUAIS}

\subsubsection{Depósitos Eólicos Pleistocênicos}

Os sedimentos eólicos mais antigos da área estudada situam-se no nordeste da mesma entre o Rio dos Porcos e as lagoas dos Esteves e do Faxinal (Figuras 5 e 33, no encarte). Constituem um corpo alongado NE-SW, com cerca de $48 \mathrm{~km}^{2}$ acima de $25 \mathrm{~m}$ de altitude, dos quais aproximadamente $13 \mathrm{~km}^{2}$ acima de $50 \mathrm{~m}$ de altitude, alcançando em alguns pontos $100 \mathrm{~m}$. Tratamse de depósito bastante complexo, evidenciado no corte em anfiteatro, com $15 \mathrm{~m}$ de altura, aberto para a exploração do mesmo. Este corte está em altitude aproximada de $70 \mathrm{~m}$. As cores das areias variam de vermelha escura a cinza clara, passando pelo marrom (Figura 136). Os sedimentos eólicos estão atravessados por crosta ferruginosa contínua, bastante irregular. Essa crosta separa duas seqüências, a basal que mergulha para sudoeste ou sul e a de topo que mergulha para leste. A seqüência basal tem três camadas, havendo uma superfície de erosão entre a segunda e terceira, de baixo para cima. A seqüência de topo constitui-se de quatro camadas. Aquela logo acima da crosta ferruginosa separa-se da que the está sobreposta por uma superfície de erosão muito longa no corte, atravessando-o. Estas camadas e superficies evidenciam estágios e superposição de material em altitudes relativamente elevadas (Fotos 58 a 62).

Pelo seu porte - extensão e altitude - suas cores, pedogênese profunda, situação geológica e geográfica, e espessura, pode se afirmar que é um depósito pleistocênico tão antigo quanto ou mais antigo que as cristas praiais pleistocênicas mais antigas do extremo sul do Estado. Corresponde possivelmente à unidade 1 de GIANNINI (1993) ou mais antigo.

Cerca de 20 sondagens para carvão, tanto do Sub-projeto Araranguá como do Projeto Carvão Bonito Gaseificável perfuraram este depósito eólico. De acordo com os perfis destas testemunhagens, estas areias têm espessuras de 50 a $132 \mathrm{~m}$, e todo o corpo arenoso está sobre a Formação Palermo. No caso do furo 5BG-109-SC que demonstra terem estes sedimentos $132 \mathrm{~m}$ de espessura, a boca do poço estava a $88,76 \mathrm{~m}$ de altitude, 
significando que os depósitos continuam $43,24 \mathrm{~m}$ abaixo do nível atual do mar. É provável que estes sejam sedimentos também de origem marinha. Vários perfis demonstram, entretanto, que a Formação Palermo está quase ao nível do zero hidrográfico atual em vários locais sob este corpo arenoso.

Próximas a esta duna situam-se outras com mais de $20 \mathrm{~m}$ de altitude que se dispõem descontinuamente do lado leste das lagoas do Faxinal, dos Esteves e da Mãe Luzia (Fotos 63 e 64).

Ao sul do Rio Araranguá, entre a cidade homônima e a localidade de Morro dos Conventos, há uma série de dunas que chegam a ter pouco mais de $40 \mathrm{~m}$ e que também se dispõem numa direção NE-SW, a norte da Lagoa da Serra. Cordões descontínuos de dunas com mais de $20 \mathrm{~m}$ de altitude situam-se próximos e a leste das lagoas de Caverá e do Sombrio. Elas se tornam mais contínuas a sudeste da Lagoa do Sombrio, quando constituem um cordão de dunas cujas maiores altitudes estão entre 25 e $30 \mathrm{~m}$. No último trecho sul, a 2,5 km a norte do Rio Mampituba, elas cobrem uma soleira de rocha básica. $\mathrm{O}$ mesmo acontece a leste da cidade de Sombrio, onde as areias eólicas quase recobrem uma soleira de diabásio de $56 \mathrm{~m}$ de altitude. Ao longo da margem leste da Lagoa do Sombrio há também cordões de dunas fixas, com menos de $20 \mathrm{~m}$ de altitude.

Nessas dunas eólicas a leste e paralelas às grandes lagoas, notam-se vários horizontes $\mathbf{A}$ de solo, soterrados que poderiam representar paleossolos recobertos por. reativações eólicas, ou são devidos a processos repetidos de podzolização. Ambas as hipóteses fazem sugestões sobre a idade e a dinâmica deste tipo de ambiente costeiro. Em topos de dunas, a sudeste da Lagoa do Sombrio, vê-se cerca de 0,60 m de espessura de matéria orgânica, constituindo o Horizonte A. São todas dunas fixas, e as que apresentam este perfil de solo devem estar mantendo a vegetação por tempo suficientemente longo para haver esta concentração da matéria orgânica que não é observada nas dunas fixas holocênicas. Pedólogos da Universidade Federal do Rio Grande do Sul em informação oral, atestaram que nunca verificaram tal condição nas dunas do 


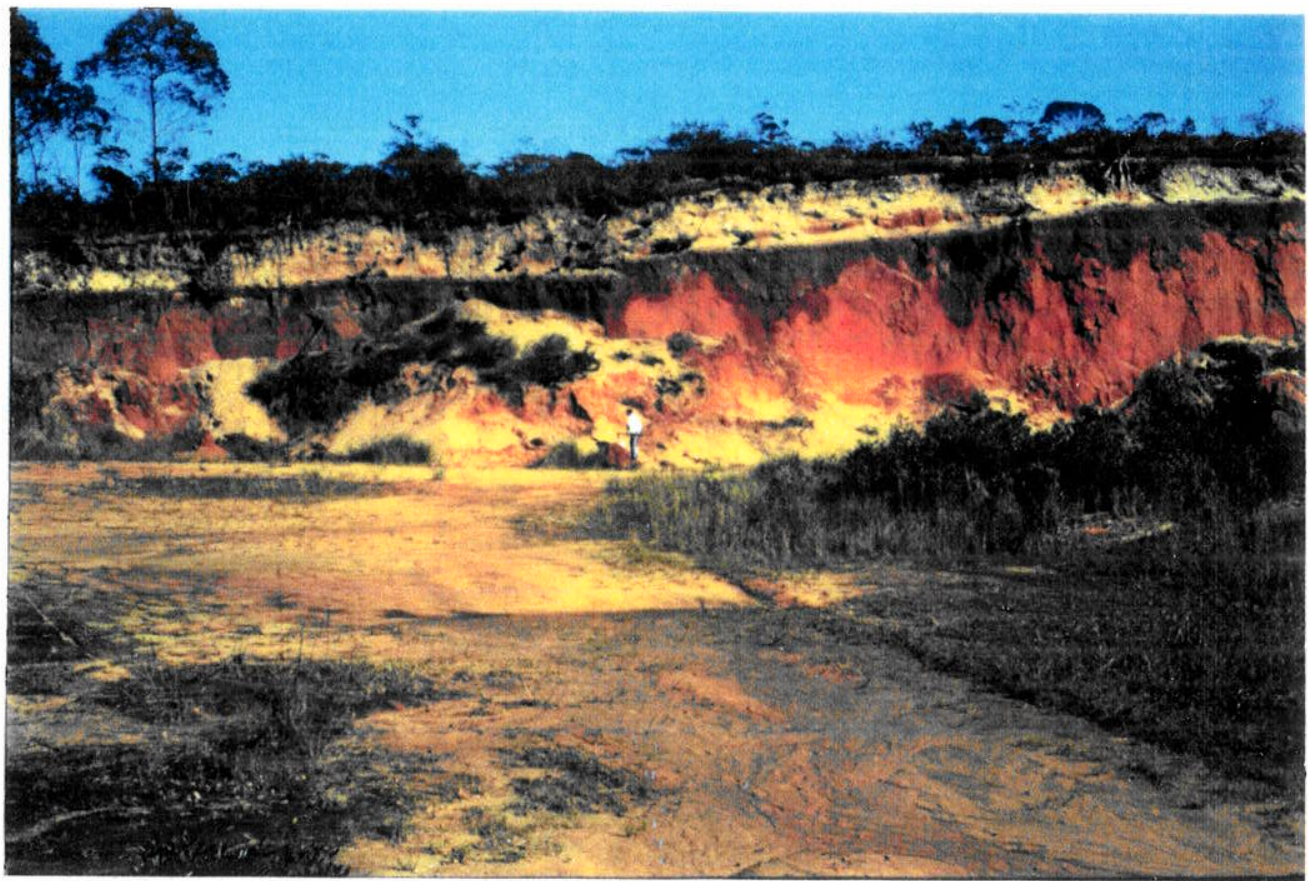

Foto 58 - Vista ampla, parcial, do afloramento no topo de duna pleistocênica que chega a $100 \mathrm{~m}$ de altitude, a nordeste da área estudada e a noroeste da Lagoa dos Esteves. Notam-se paleosuperfícies de erosão, a coloração variada e distinta, o vermelho forte de algumas camadas e o topo lixiviado. O corte expõe cerca de $15 \mathrm{~m}$ de espessura do material de topo desta formação eólica, no sul do Município de Içara.

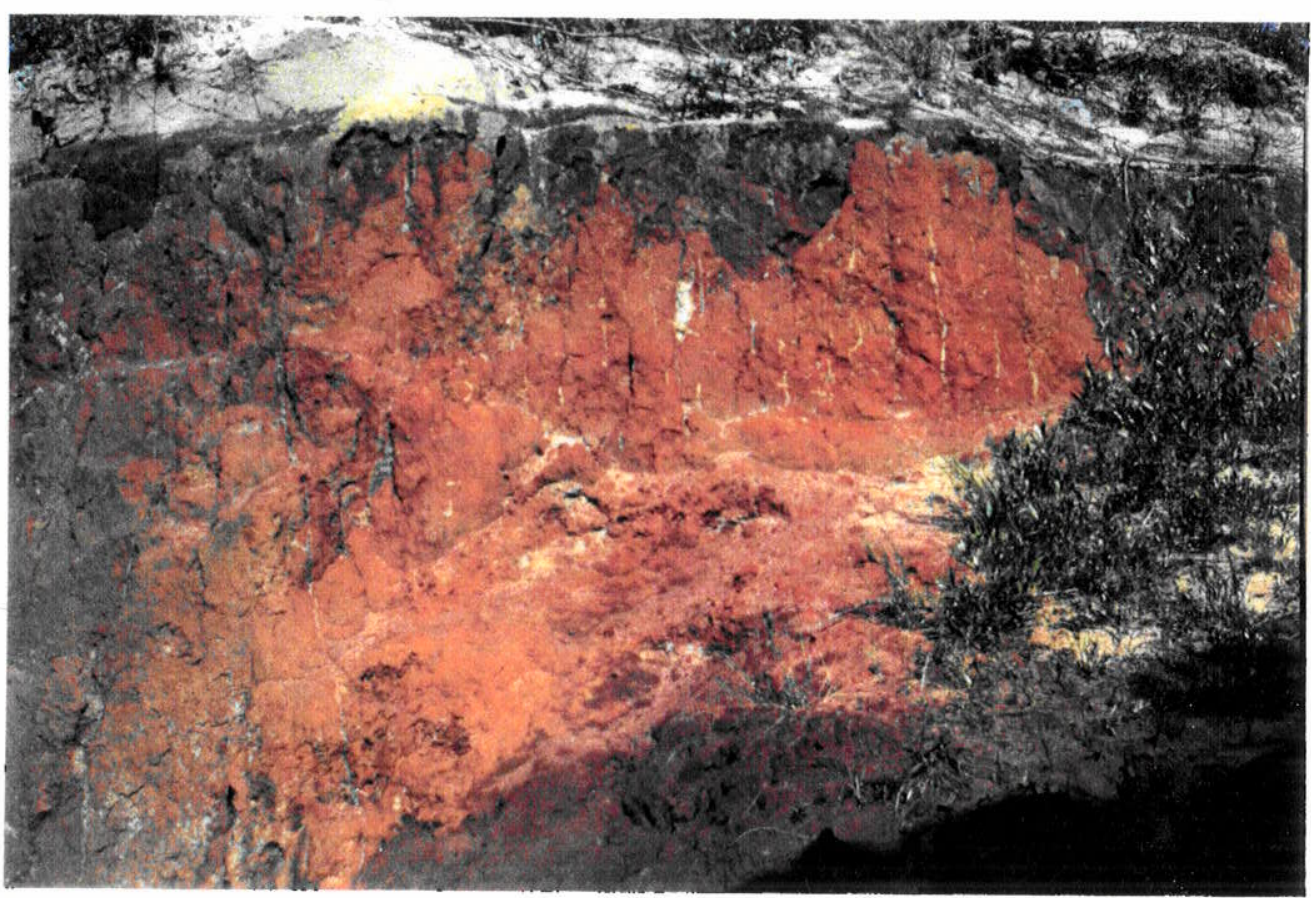

Foto 59 - Detalhe da duna pleistocênica da Foto 58, com manchas brancas verticalizadas, geradas no processo pedogenético por raízes. Vê-se o truncamento da seqüência gerando uma superfície que separa os sedimentos vermelho-escuros de outros mais claros. 


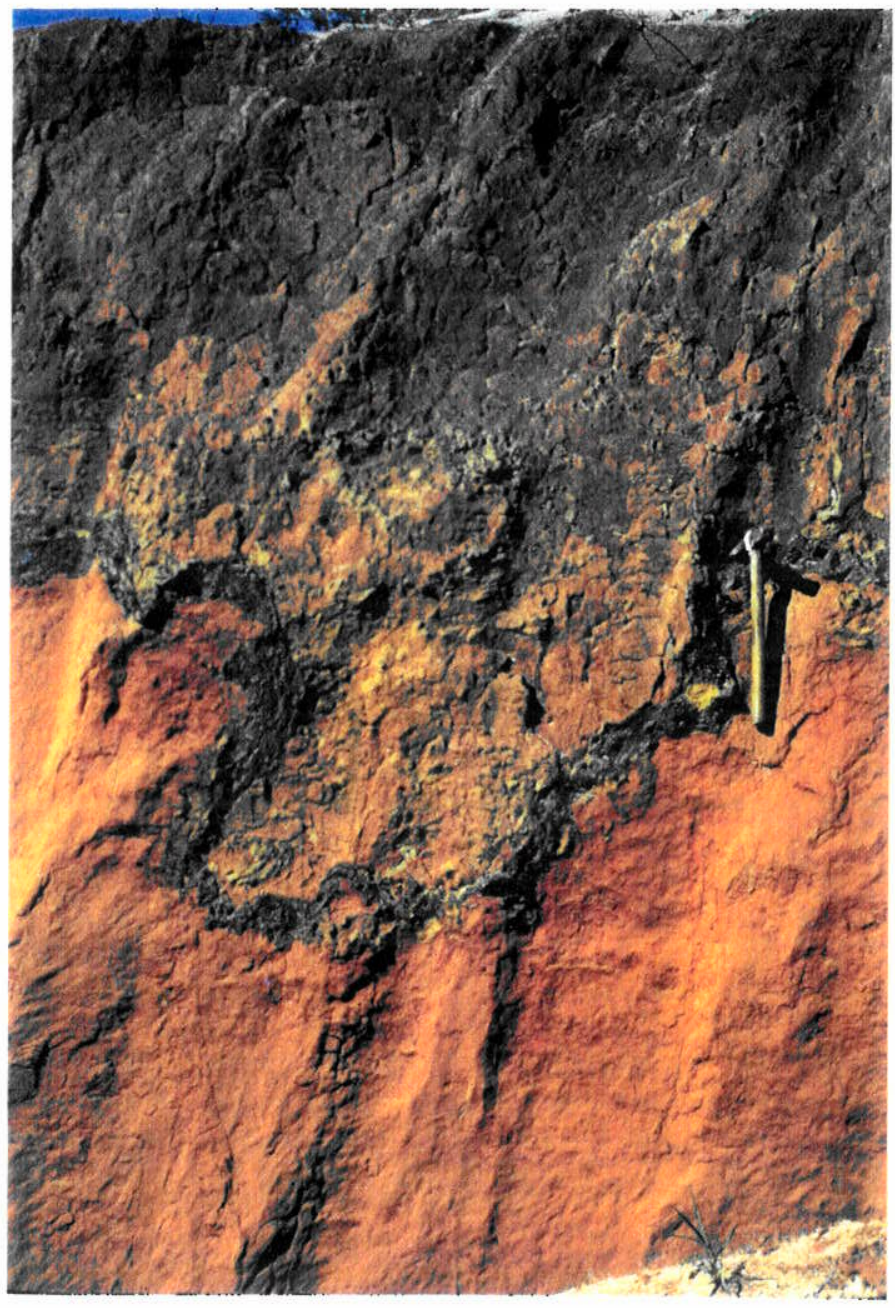

Foto 60 - Detalhe do afloramento da Foto 58, com crosta ferruginosa espessa, irregular e contínua em grande parte do afloramento. A crosta sugere condições paleohidrológicas e pedogenéticas distintas das atuais. Nota-se a diferença de textura acima e abaixo da crosta. 


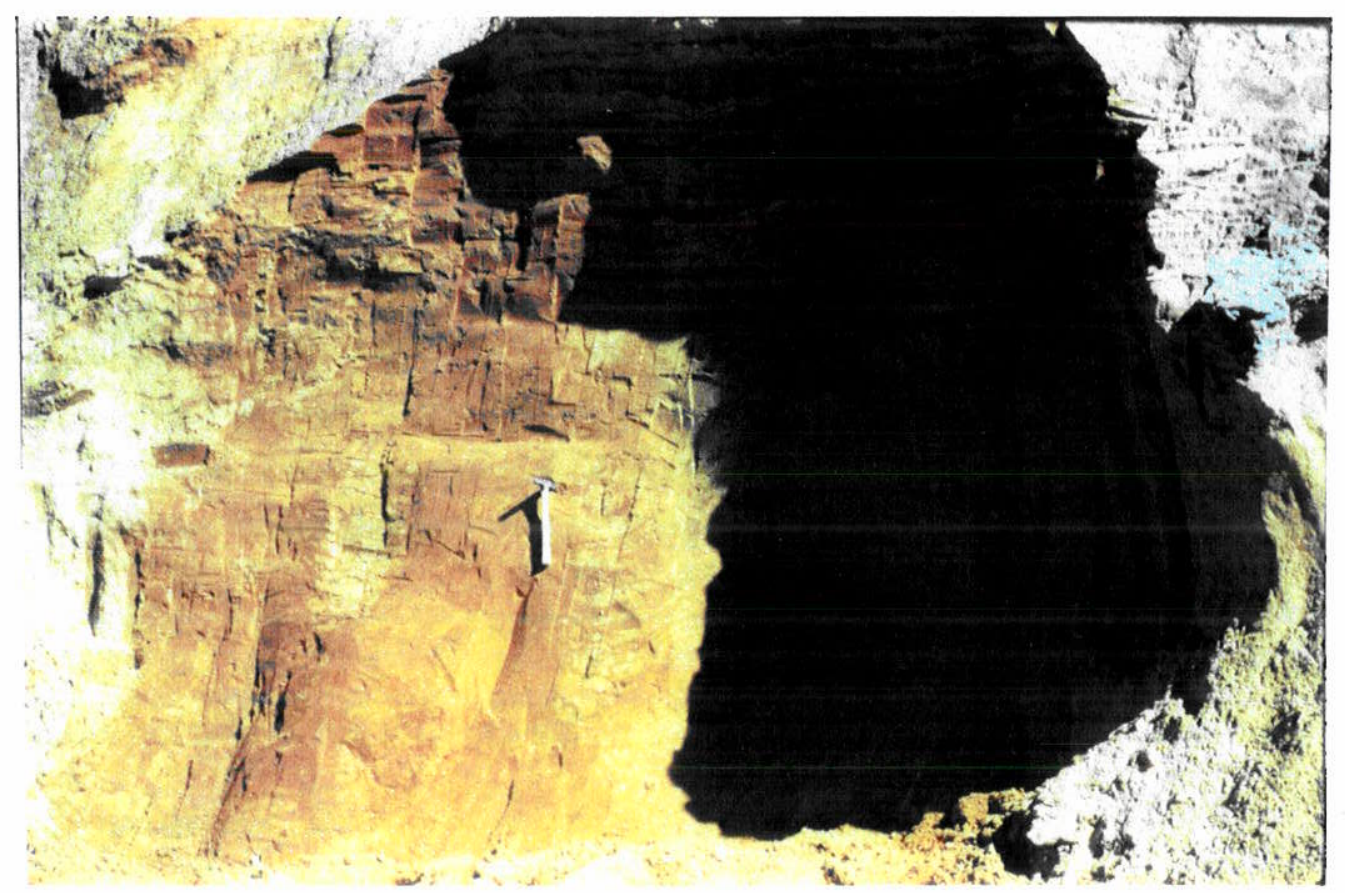

Foto 61 - Detalhe do afloramento da Foto 58 , mostrando pequeno trecho localizado quase na base do extremo leste do corte, com coloração castanho-avermelhada e estruturas onduladas melhor visualizadas na área sombreada da foto.

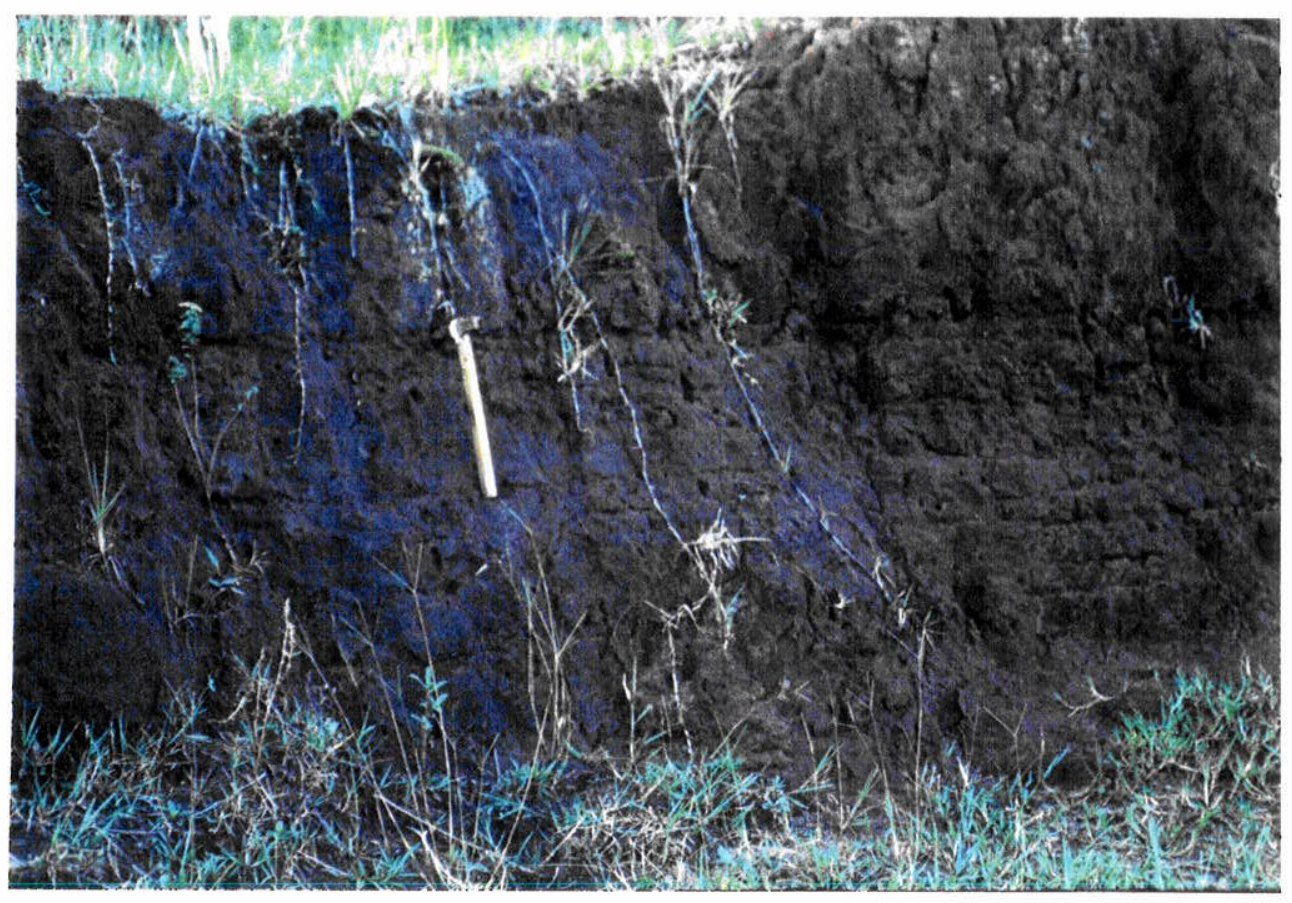

Foto 62 - Corte no extremo sul da duna pleistocênica, ao sul do afloramento das fotos 58 a 61 e em altitude menor. Ve-se estratificação que mergulha $5^{\circ}$ para leste. A cor vermelha escura está um tanto obscurecida pelos fungos, musgos e líquens. 


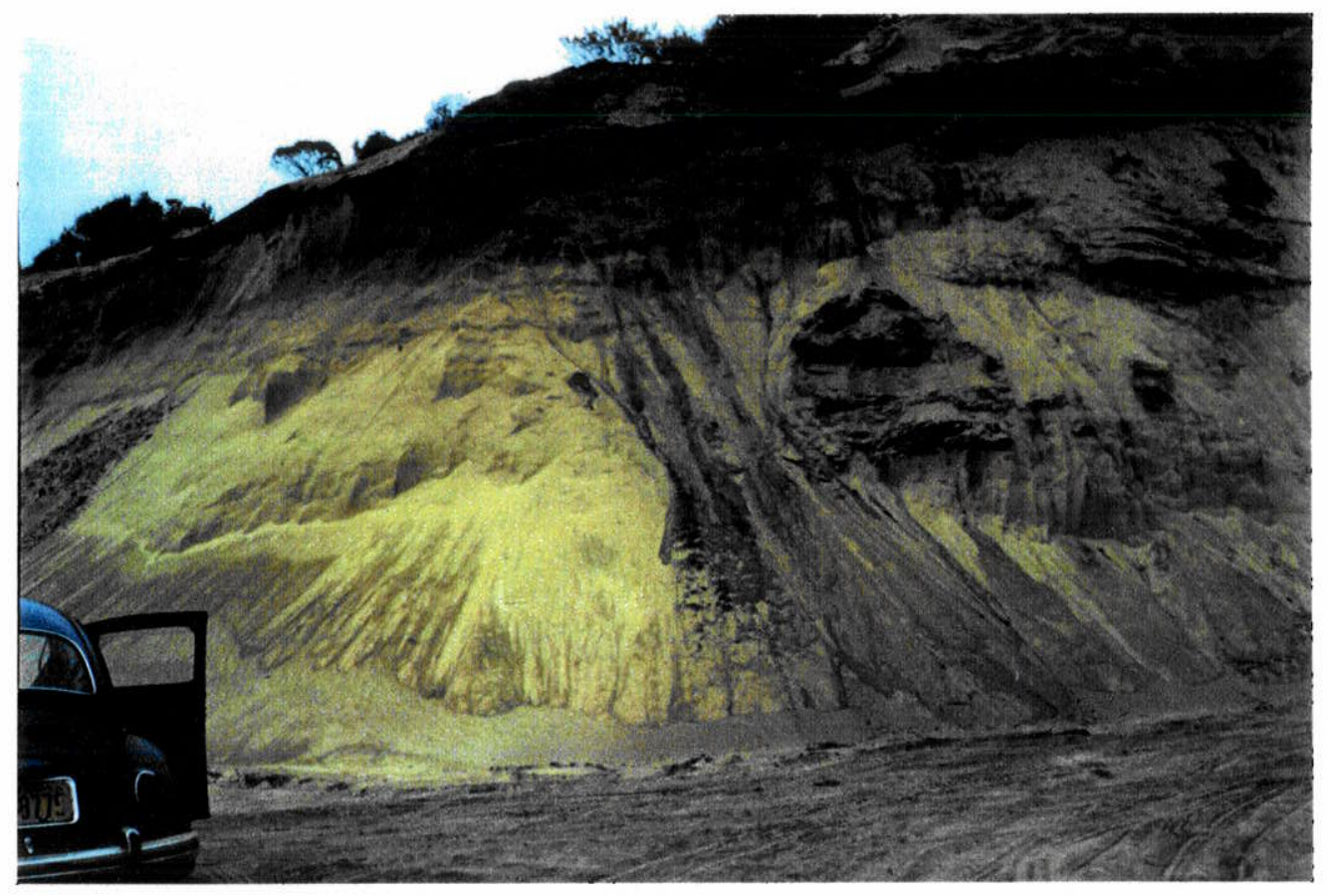

Foto 63 - Depósito eólico pleistocênico com profundo perfil de solo. Situa-se do lado leste e pouco ao sul da Lagoa Mãe Luzia, Município de Araranguá. Pertence a um conjunto mais novo do que os das fotos 58 a 62, situado a leste das maiores lagoas. Está sendo minerado clandestinamente. 


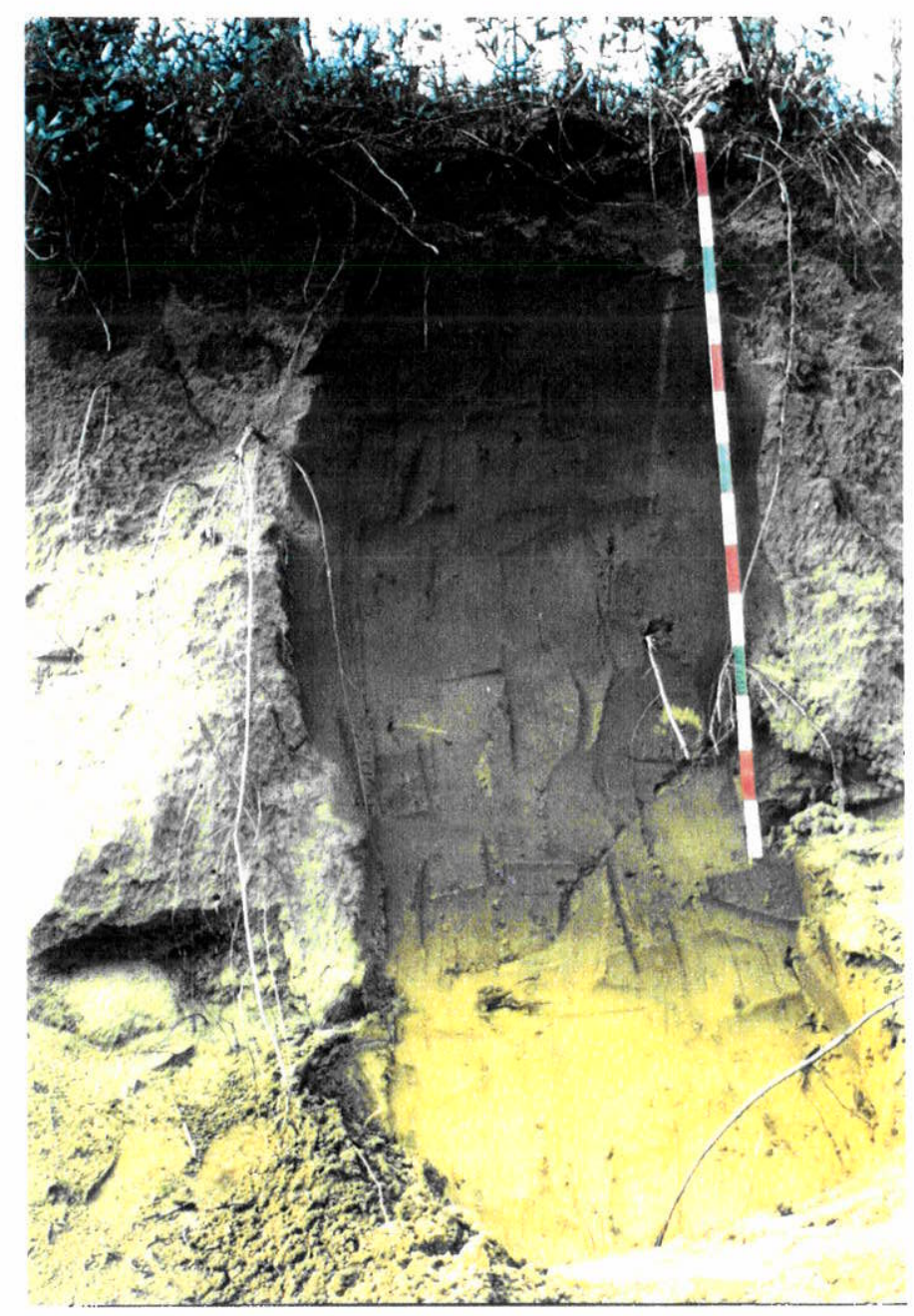

Foto 64 - Exposição em corte de estrada, dos sedimentos de cordão de dunas fixas pleistocênicas a sudeste da Lagoa de Sombrio. O corte tem direção E-WW, perpendicular ao cordão, e situa-se na base do flanco leste da duna. Notam-se as cores dadas pela pedogênese profunda que alcança mais de $2 \mathrm{~m}$. 
Estado vizinho. No caso em pauta trata-se de um horizonte espesso na superfície da duna que sugere também um longo período para sua formação.

Entre os extremos norte e sul da área verifica-se que a atividade eólica aconteceu em várias épocas, porém não tão intensa nem tão orientada (direção geral NE-SW), como esta que originou as dunas até agora referidas, em que o sentido do vento deveria ter sido de nordeste. Pelas suas características pedogenéticas e de situação geográfica e geológica, estas dunas também são pleistocênicas, porém mais novas que a primeira citada.

A leste destas há evidências de atividades eólicas modificando as cristas praiais pleistocênicas e holocênicas. Paralela à Lagoa de Caverá, da sua metade para o norte, há uma área de alguns quilômetros quadrados cuja base é de areia cinza média a escura. Sobre ela há vestígios de dunas parabólicas baixas e irregulares, com as laterais bem afastadas, e o nariz apontando para a lagoa. Isso indicaria uma época em que o vento que movimentou essas areias provinha de sudeste. A migração das areias parece ter se dado sobre zona úmida e baixa com muita matéria orgânica. Daí para o norte a área vai se estreitando e deixa de apresentar as características observadas ao sul, e as dunas fixas mais recentes são bem mais baixas (Figura 5 e 6 , no encarte).

\subsection{Características Sedimentológicas}

A) A duna pleistocênica mais antiga no extremo nordeste da área apresenta uma variação de percentagem de areia de $45 \%$ a $99 \%$, o que significa que contém camadas com até $55 \%$ de finos (Figuras 136 a 138). Uma explicação para esta quantidade de finos seria a fonte dos fragmentos, talvez as rochas sedimentares a norte ou nordeste, e a intensa e profunda pedogênese alterando minerais e fragmentos de rochas. Um depósito com a forma, altitude e espessura deste não tem outra explicação de sua origem que a eólica. Orientações de algumas camadas medidas, em estruturas planares, mostram mergulho de aproximadamente $5^{\circ}$ para leste e outras com cerca de $20^{\circ}$ para oeste. 
Estes sedimentos são polimodais. A primeira moda situa-se no tamanho areia média, com uma exceção em que esta ocorre no tamanho argila. Há uma grande concentração do material nos tamanhos areia média e fina (Figura 138). A Figura 136 apresenta alguns perfis de afloramentos de depósitos eólicos, salientando as cores dos horizontes dos solos.

O diâmetro médio varia de $1,86 \phi$ a $6,03 \phi(0,27 \mathrm{~mm}$ a 0,015 $\mathrm{mm})$, havendo um maior número de amostras com diấmetro médio entre 1 e $2 \phi(0,50 \mathrm{~mm}$ e $0,25 \mathrm{~mm})$ e 4 e 5 $\phi(0,062 \mathrm{~mm}$ e 0,031 mm). Esta variação corrobora com a da seleção das amostras que são de mal a extremamente mal selecionadas. A assimetria muito positiva da maioria das amostras se explica pela presença importante dos finos. Concordantemente com a sua seleção e polimodalidade, as amostras têm uma distribuição que as classifica dentro da curtose como muito platicúrticas a platicúrticas (Tabela 72, amostras D-12).

B) Outras dunas fixas mesmo que tenham características de idade elevada, apresentam-se muito bem selecionadas, embora haja amostra mal selecionada. O diâmetro médio fica entre 2 e $3 \phi(0,25 \mathrm{~mm}$ e 0,125 mm). Entretanto, são amostras que em geral apresentam finos de origem pedogenética e granulometricamente vão até areia média. Em algumas delas há também areia grossa. Ocorrem menos de $5 \%$ de finos nas amostras, com duas exceções, e há menos de $5 \%$ de areias médias em $80 \%$ das amostras. Vê-se que quanto à curtose há representação desde platicúrticas até extremamente leptocúrticas. No que concerne à assimetria, na escala verbal de FOLK \& WARD (1957), estas amostras têm desde assimetria muito negativa até assimetria muito positiva, com domínio da assimetria positiva.

Esses sedimentos são principalmente unimodais nas classes de tamanho areia fina de WENTWORTH (1922). Como algumas amostras têm até 4 modas, estas estão tanto nas areias como nos siltes e argilas, porém estes dois últimos constituem moda em apenas $10 \%$ das amostras e com taxas despreziveis.

Os sedimentos eólicos pleistocênicos distribuem-se nos tipos IV e $\mathrm{V}$ do diagrama de PASSEGA et al. (1969) (Figura 139). São sedimentos transportados em suspensão, podendo conter também grãos rolados, depositados sob turbulência alta e moderada. 
C) Mineralogia - A quantidade de minerais pesados na fração utilizada das amostras selecionadas variou de 8 a $16 \%$. Estes sedimentos eólicos apresentam valores relativamente altos de minerais opacos e zircão, porém, após os opacos, a hornblenda castanha é o mineral mais freqüente, seguidos por zircão, epidoto (pistacita), estaurolita, hornblenda verde, cianita, turmalina castanha, turmalina schorlita, rutilo, epidoto clinozoisita, turmalina verde, augita e hiperstênio. Ao todo são 17 espécies e variedades minerais além dos opacos (Tabela 73).

Entre os minerais leves dominam o quartzo monocristalino e o plagioclásio não zonado, seguidos pelo plagioclásio zonado, quartzo policristalino e ortoclásio. Nas lâminas também é importante a presença de fragmentos de basalto (Tabela 74).

\subsubsection{Dunas ativas}

As dunas ativas cobrem uma faixa relativamente larga, cerca de $1,5 \mathrm{~km}$ paralela à praia atual, de nordeste a sudoeste. Esse campo de dunas é importante do ponto de vista da superfície coberta. A atividade eólica atual não forma dunas altas como as primeiras mencionadas e nem tem a mesma componente de ventos, porém interfere muito nas cristas praiais recobrindo-as com seus depósitos. Geram formas eólicas complexas num campo amplo, devido provavelmente à ação de mais de uma direção eólica, entre as quais a de sudeste também é importante. A ação eólica de sudesteleste "empurra" as areias da praia para o interior e a componente nordeste modela as areias em formas menores.

O diagrama de SHEPARD (1954) modificado, permite comparar os sedimentos de dunas ativas e a fração arenosa dos depósitos de dunas fixas. Vê-se que dominam as areias finas, com uma tendência para areias mais finas e para areias médias (Figura 140).

As dunas ativas diferem das anteriores em alguns aspectos: nenhuma amostra apresenta qualquer valor de finos, a classe areia média ocorre em quantidades menores que $2 \%$, as areias finas constituem de 83 a $98 \%$ das amostras (Figuras 138, 140 e 141). Apresentam portanto, um tamanho médio entre 2,5 e $3 \phi(0,177 \mathrm{~mm} \mathrm{e} \mathrm{0,125} \mathrm{mm),} \mathrm{são}$ 
todas muito bem selecionadas, na assimetria quase todas as classes estão representadas, desde assimetria muito negativa à assimetria positiva. Quanto à curtose são principalmente mesocúrticas a muito leptocúrticas (Tabela 72, amostras DA-).

Estas características possivelmente são explicadas pelas areias muito finas. A primeira moda está sempre dentro do tamanho areia fina na fração 0,149 mm (Figura 141).

Os mecanismos de transporte dos sedimentos eólicos estão delineados na Figura 135, de acordo com PASSEGA et al. (1969). Os valores C-M das amostras dos sedimentos eólicos atuais concentram-se no tipo $\mathrm{V}$, correspondendo a sedimentos transportados em suspensã̃o, podendo conter grãos rolados menores que $1 \mathrm{~mm}$. Estes também podem ter sido transportados em suspensão por longos trechos.

A freqüência dos diferentes minerais pesados nos dois tipos de dunas, isto é, ativas $e$ inativas, é semelhante. Nestes sedimentos a quantidade de minerais pesados nas amostras escolhidas variou de 9 a $24 \%$.

Além dos minerais opacos, ocorrem em ordem decrescente: hornblenda castanha, epidoto (pistacita), zircão, hornblenda verde, augita, turmalina schorlita, turmalina castanha, cianita, estaurolita, hiperstênio, hornblenda basáltica, turmalina verde, granada, epidoto clinozoisita (Tabela 73).

Os testes de correlação aplicados sobre a associação de minerais pesados e a quantidade absoluta de cada mineral demonstram a alta correlação entre os sedimentos das dunas ativas, das dunas fixas e das praias atuais, sugerindo a manutenção das mesmas fontes.

Comparando-se as composiçōes dos minerais leves, entre dunas ativas e aquelas fixas, percebe-se que o quartzo monocristalino é o mineral predominante, tendo diminuído bastante a presença de plagioclásio não zonado e aumentado o número de plagioclásio zonado. Diminui o número de quartzo policristalino e de ortoclásio. Aumenta o número de fragmentos de rochas básicas (Tabela 74). 


\subsubsection{DEPÓSITOS DE LAGUNAS, ESTUÁRIOS E LAGOAS PRETÉRITAS E ATUAIS}

Foram examinados os depósitos desses paleoambientes e das margens das lagoas atuais através dos seus afloramentos em paredes de valas de drenagem, em pequenos poços abertos com pás e através de amostras obtidas com os amostradores já citados.

A delimitação desses depósitos nas condições de poucos dados é muito difícil, uma vez que as lagunas e estuários podem ser morfologicamente semelhantes, e uma laguna pode apresentar um regime estuarino em que marés e a contribuição de águas doces e salgadas tornam difícil separar paleoambientes, se não forem minuciosamente estudados.

A tentativa de se obter indicadores paleoambientais através de diatomáceas e outros microorganismos como ostracodes e foraminiferos, não deu resultados muito satisfatórios. As 13 amostras analisadas para microorganismos calcários (ostracodes e foraminíferos), eram todas estéreis. No caso das diatomáceas foram analisadas 9 amostras do substrato de turfas. Três amostras eram estéreis e as associações de outras 4 evidenciam que o ambiente era de águas doces. Há uma que indica águas salobras e outra que tem indivíduos de água doce e salobra.

É mais fácil delimitar as paleolagoas da área, pois em geral apresentam turfeiras. Mas, sob o ambiente lacustre, ocorrem depósitos lagunares. Por outro lado, sob depósitos lacustres também podem estar depósitos estuarinos. Uma evidência de depósitos lagunares sob os lacustres deve-se à ocorrência de conchas de água salgada, encontradas em várias sondagens.

Estão sendo considerados como depósitos lagunares os que se situam em áreas que foram barradas por depósitos praiais e aquelas que apresentaram um estreitamento grande no seu contato com águas oceânicas, marcadas atualmente pela morfologia. Os depósitos que não mostram evidência desse paleoestreitamento são considerados lagunares/estuarinos.

A presença de rios importantes como o Mampituba e o Araranguá, e a sua evolução com condições hidráulicas e hidrológicas acentuadas pelas escarpas, contribuem para as 
dúvidas, pois a presença das águas doces ocorreria em qualquer dos dois ambientes de maneira significativa.

Ocorrem depósitos de paleolagunas sobrepostos por depósitos lacustres na área do Banhado do Sombrio, Banhado Piritu, Canal do Rio da Laje e Canal Itoupava, Córrego Corrupiá, Córrego da Peroba e nos espaços interlagoas. Depósitos lagunares ocorrem aflorando ao sul do Banhado Piritu e Lagoa do Sombrio. Depósitos de paleolagunas e paleoestuários ocorrem na área do Rio Araranguá, também na área do seu afluente Rio dos Porcos. Ao longo do Rio Araranguá, principalmente na área da sua margem esquerda, esses depósitos ocorrem até a montante da cidade de mesmo nome. Junto a esta cidade, em perfurações na margem esquerda para a implantação da BR-101, ocorrem cerca de $11,5 \mathrm{~m}$ de argila orgânica arenosa, argila arenosa, areia fina, areia média e pedregulho. Algumas destas argilas orgânicas são muito plásticas e freqüentemente apresentam conchas.

No sul da área entre a Lagoa de Sombrio e o Rio Mampituba foi perfurado o poço AT-06, com boca em $5 \mathrm{~m}$ de altitude. O perfil do mesmo apresenta $33 \mathrm{~m}$ de areias, argilas e conchas sobre basalto. A sudeste deste foi perfurado o poço AT-08 mais próximo à sede do Município Passo de Torres. Este poço iniciado em altitude de $8,60 \mathrm{~m}$ atravessou $90 \mathrm{~m}$ de areias, intercaladas com argila preta plástica, sobre Arenito Botucatu.

Alguns afloramento estão descritos nos perfis da Figura 142.

\subsubsection{Características Sedimentológicas}

A granulometria desses depósitos se caracteriza por areia média a argila, com uma grande percentagem de finos, mas também ocorrem areias grossas até seixos, embora com teores relativamente baixos e apenas em algumas amostras (Figura 143 e 144). Isso evidencia a contribuição de vários agentes, variação de energia e fonte similar a dos outros tipos de depósitos com influência marinha.

A percentagem de areias varia de 3 a 100\%. As amostras com maior percentagem de areias foram coletadas na área do Banhado do Piritu, que se encontra rodeado de 
depósitos arenosos das cristas praiais pleistocênicas. Entretanto, $50 \%$ das amostras têm menos que $50 \%$ de areia. $\mathrm{Na}$ área do Rio da Laje nenhuma amostra apresenta tamanho maior que areia média. Isso talvez seja devido à presença do Arenito Botucatu em extensa exposição na área que no Pleistoceno teria a feição de falésia, considerando-se suas paredes verticalizadas.

São sedimentos principalmente polimodais com até 4 modas, sendo apenas $11 \%$ das amostras unimodais. Os siltes e argilas apresentam 1 a 2 modas ou nenhuma.

O diâmetro médio é então muito variável, desde $1 \phi$ até $8 \phi(0,50 \mathrm{~mm}$ até $0,004 \mathrm{~mm})$. As amostras são de mal a extremamente mal selecionadas. A assimetria varia desde muito negativa a muito positiva, e são as assimetrias positiva e muito positiva as dominantes pela grande presença dos finos. Quanto à curtose, as distribuições granulométricas vão desde muito platicúrticas a extremamente leptocúrticas, sem concentração em um ou em outro tipo (Tabela 75).

No que concerne aos agentes transportadores destes sedimentos, a figura 145 dá uma indicação.

A mineralogia de pesados desses sedimentos é também caracterizada pela grande freqüência de zircão, após a dos minerais opacos, seguidos em ordem crescente pela turmalina castanha, hornblenda castanha e a estaurolita. Seguem a turmalina schorlita, epidoto (pistacita), turmalina verde e turmalina azul, cianita, epidoto clinozoisita, hornblenda verde, sillimanita e outros dez minerais em menor proporção (Tabela 76).

Quanto aos minerais leves, o quartzo monocristalino apresenta-se em taxas elevadas, as maiores entre todos os ambientes até aqui descritos, seguidos pelos policristalinos. Segue o ortoclásio. É muito baixo o número de plagioclásios e microclínio (Tabela 77).

Como fragmentos de rochas ocorrem apenas os de rochas ácidas. 


\subsubsection{Tanatocenoses de Moluscos}

Em vários desses depósitos foram coletadas amostras de conchas que foram classificadas e datadas.

Ao sul do Banhado Piritu foram coletadas amostras em dois locais. Um se situa junto à primeira ponte, na estrada SC-450, indo do leste para oeste. Trata-se de um banco natural cuja associação compreende: Codakia constata, Trachycardium muricatum, Anomalocardia brasiliana, Ostrea equestris, Lucina pectinata, Tellina lineata, Crepidula protea, Cerithium atratum, Bulla striata, Bititium varium, Tagelus plebeius e um gênero de gastrópode da família Rizóide. No mesmo depósito, bem mais ao sul, ao lado da BR-101, não foram encontradas as duas primeiras, Bititium varium e Crepidula protea, mas ocorrem ainda Crepidula aculeatea e Laevicardium laevigatum. A datação dessas conchas deu uma idade de $5.670 \pm 220$ anos A.P. com $\delta^{13} \mathrm{C}$ de $+1,53 \%$ (Amostra Bah - 1667).

O outro depósito situa-se mais a leste e ao sul da Lagoa do Sombrio, constitui-se de Ostrea equestris, Anomalocardia brasiliana, Lucina pectinata, Bititium varium e o gastrópode da família Rizóide. Este ocorre em grande quantidade bem como Anomalocardia brasiliana. Além desses há, ainda, Codakia constata, Corbula caribea, Bulla striata, Tagelus plebeius e Tellina lineata. A idade desse material é de $5.900 \pm 230$ anos A.P. com $\delta^{13} \mathrm{C}$ de $+1,87 \%$.

Outro banco natural de conchas amostrado foi o do Rio dos Porcos. A constituição é de Ostrea equestris, Anomalocardia brasiliana, Lucina pectinata, Bititium varium, Semele proficua, Prototharca antiqua, Macoma constricta, Tellina lineata, Tagelus plebeius, Mactra fragilis, Cerithium atratum, Crepidula protea, Bulla striata, Chione paphia, e o gastrópode da família Rissoidae, Corbula caribea, Neritina virginea, Nassirius vibex, Trachycardium muricatum. A amostra Bah - 1738 apresentou a idade de $6.490 \pm 240$ anos A.P. com $\delta^{13} \mathrm{C}$ de $+1,18 \%$ o.

Estes depósitos com conchas apresentam altitudes entre 1 e $3 \mathrm{~m}$ e demonstram pelas suas idades, que correspondem ao episódio da primeira transgressão holocênica, antes de alcançar o seu pico positivo (MARTIN et al. 1988, 1993). 
Pelos valores do $\delta^{13} \mathrm{C}$ são todos depósitos marinhos e pela associação faunística são comunidades de ambiente areno-lodoso até lodoso, em águas calmas de baías ou mesmo lagunas com boa circulação de água salgada.

Em um depósito de paleolagoa, no município de Turvo, próximo e a oeste da foz do Rio Jundiá, ocorre um banco natural de conchas de um só tipo: Erodoma mactroides cujo ambiente de vida é de lagoas salobras até quase doces, de fundo lodoso. Raros Strophocheilus sp, um gastrópode terrícola, foram encontrados no depósito.

A idade obtida por intermédio da Erodoma mactroides na amostra Bah-1737, foi de $7.390 \pm 270$ anos A.P. e na amostra Beta-60729 foi de $6.020 \pm 90$ anos A.P. com um $\delta^{13} \mathrm{C}$ de $-6.0 \%$. A idade corrigida pelo $\delta^{13} \mathrm{C}$ fica em $6.330 \pm 90$ anos A.P. O $\delta^{13} \mathrm{C}$ evidencia ser um molusco de água doce. Esta área com 4 a $5 \mathrm{~m}$ de altitude, situada a $22,5 \mathrm{~km}$ distante do mar em linha reta, não foi alcançada pela primeira transgressão holocênica.

\subsubsection{Margens das Lagoas Atuais}

Nas margens das lagoas atuais do Sombrio e de Caverá, ocorrem terraços onde se notam cristas praiais, duas ou três no lado oeste e uma no lado leste das lagoas. A Lagoa da Serra apresenta pequena praia nas suas margens noroeste e sul. Esses sedimentos foram amostrados através de poços rasos. Mostram uma estratigrafia semelhante a dos anteriores (Fotos 65 e 66), sendo formados por camadas distintas apresentando níveis de matéria orgânica carbonosa e de conchas intercaladas em sedimentos inorgânicos (Figura 146).

São sedimentos em que predominam areias médias até siltes. São poucas as amostras que apresentam argilas, e, quando ocorrem, a freqüência varia de 4 a $22 \%$. Há numerosas amostras com areias grossas, embora com baixọs teores. Há, então, camadas essencialmente arenosas e aquelas em que os finos chegam a mais de $60 \%$. A maior parte (85\%) das amostras é unimodal, mas também existem amostras polimodais. Poucas amostras apresentam modas em silte e argilas, e, quando acontece, têm 1 a 2 modas. (Figuras 147 e 148). Seus diâmetros médios situam-se entre 1 e $4 \phi \quad(0,50 \mathrm{~mm}$ a 
$0,062 \mathrm{~mm})$, porém a maioria tem de 2 a $3 \phi(0,25 \mathrm{~mm}$ a 0,125 $\mathrm{mm})$. Há amostras de muito bem a muito mal selecionadas, mas a maioria se classifica como muito bem selecionada (Tabela 78). Esse fato é uma característica das condições de separação dos tamanhos dentro dos corpos de água.

Quanto aos graus de assimetria, ocorrem amostras com assimetria muito negativa até muito positiva. No que se refere à curtose, há uma freqüência maior de curvas mesocúrticas e leptocúrticas.

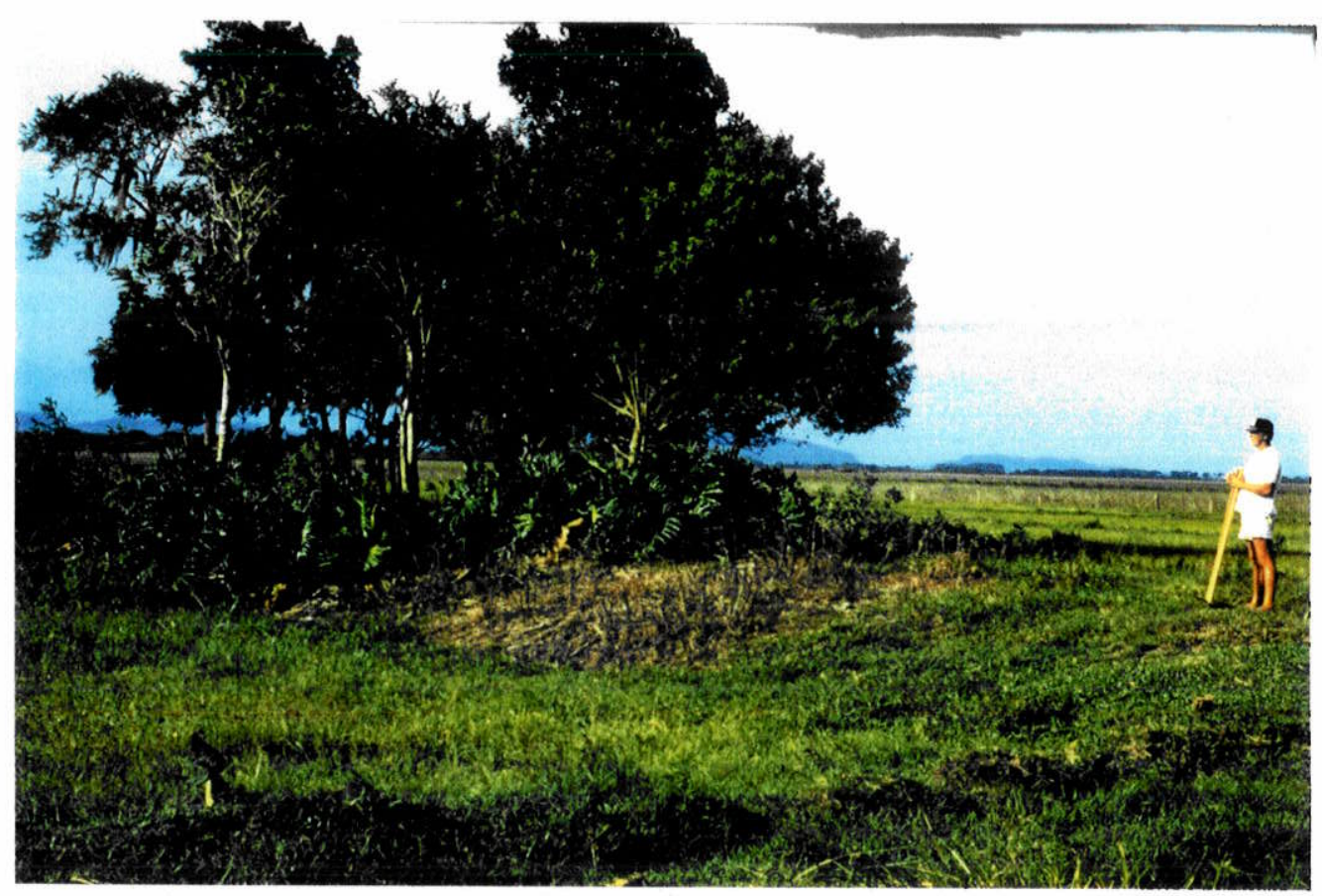

Foto 65 - Aspecto das margens das lagoas maiores. Há uma crista praial onde estão o operário e as árvores. A visada é para nordeste vendo-se logo após a crista, o plano do terraço lacustre da margem oeste da Lagoa de Sombrio, na sua parte sul, junto à BR-101. 


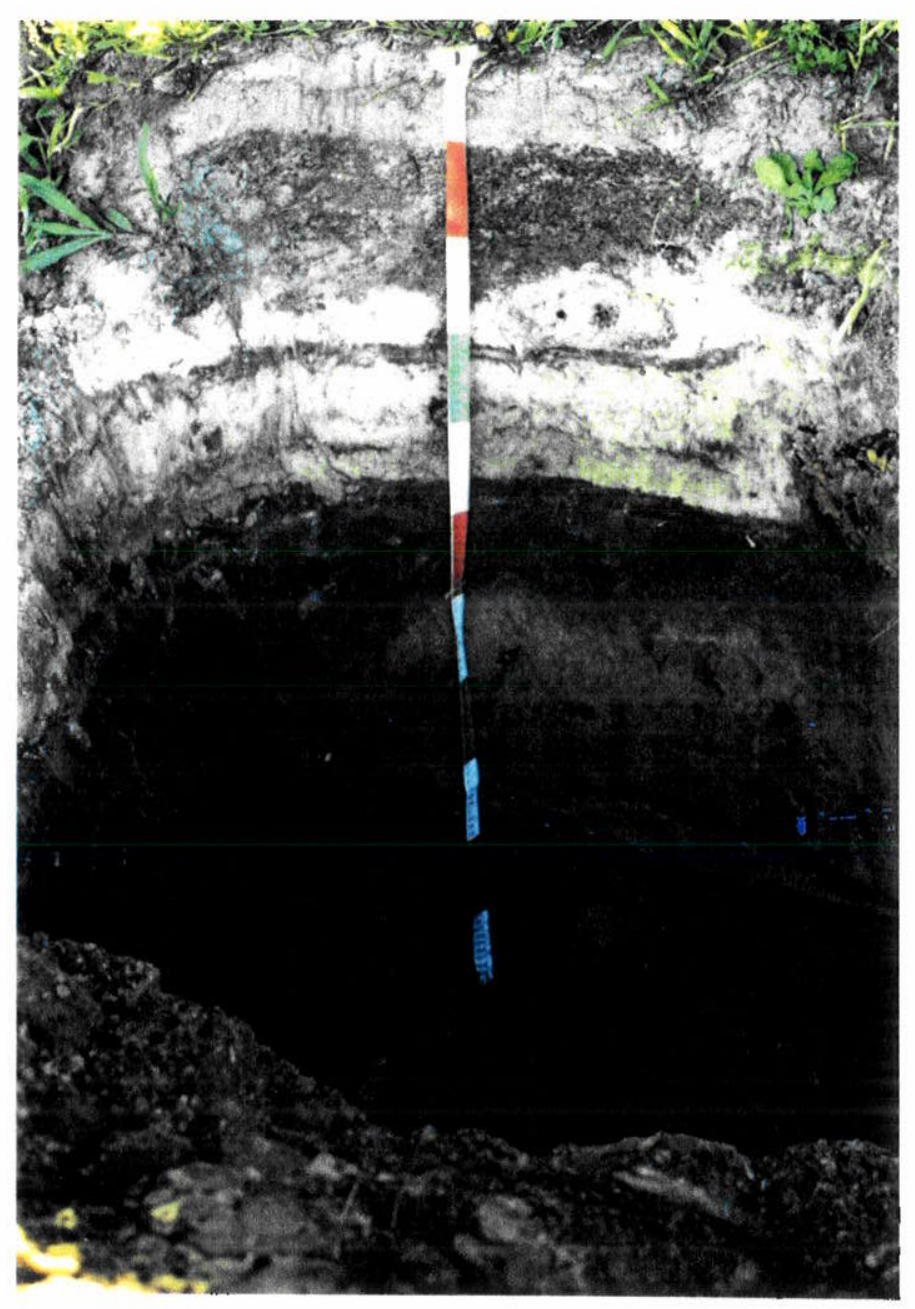

Foto 66 - Parede de poço escavado na extremidade leste da Ponta Grossa, feição da margem oeste da Lagoa de Sombrio, em crista praial lacustre. Notam-se as distintas camadas, alternando-se carnadas inorgânicas e mistas. A 1,70 m de profundidade foram coletadas conchas cuja idade é de $5.790 \pm 220$ anos A.P. (Amostra Bah - 1668).

A Figura 149, de acordo com PASSEGA et al. (1969), evidencia que os agentes transportadores dos sedimentos foram correntes trativas.

\subsection{Mineralogia}

No que concerne à mineralogia de pesados, estes sedimentos constituem-se de grande percentagem de minerais opacos. Seguem em ordem decrescente, a hornblenda castanha, o epidoto (pistacita) e a turmalina castanha. Depois aparecem zircão, cianita, estaurolita, turmalina schorlita, epidoto clinozoisita, hornblenda verde, augita, turmalina 
verde e tremolita actinolita. Estas são as mais comuns entre as espécies minerais e suas variedades ocorrentes (Tabelas 79).

Entre os minerais leves, o quartzo monocristalino é menos abundante que nos sedimentos similares mais antigos. Além do quartzo policristalino, em ordem decrescente, aparecem ortoclásio, plagioclásio não zonado e microclínio (Tabela 80).

Estão presentes tanto fragmentos de rochas básicas quanto ácidas.

\subsection{Tanatocenoses de Moluscos}

Nesses sedimentos foram coletadas conchas em vários locais, na margem oeste da lagoa do Sombrio, em subsuperfície, bem como um material turfoso. Foram datadas uma amostra de conchas e a turfa.

Na zona mediana da lagoa do Sombrio há um estreitamento deste corpo de água promovido pela forma chamada Ponta Grossa. Esta ponta apresenta no seu extremo leste, um afloramento de rocha básica que serviu de apoio à sedimentação. Em um poço escavado em crista baixa desta área, foram coletadas a $1,70 \mathrm{~m}$ de profundidade conchas dos seguintes moluscos: Tellina lineata, Ostrea equestris, Littorina flava, Tagelus plebeius, Crepidula aculeatea, Bulla striata, Anomalocardia brasiliana, Bionphalaria sp. Pamacea sp, e gastrópode da família Rissoidae. Três deles não foram encontrados em outros depósitos. A idade desta camada de conchas é de $5.790 \pm 220$ anos A.P. com $\delta^{13} \mathrm{C}$ de $+1,24 \%$. (Amostra Bah - 1668).

Trata-se do mesmo evento lagunar que construiu o depósito ao sul da Lagoa do Sombrio e para oeste até o Banhado Piritu e que corresponde à primeira transgressão holocênica.

Ao norte da localidade de Barrinha, na margem sudoeste da Lagoa do Sombrio, foram coletadas conchas em calhas situadas entre cristas praiais da margem desta lagoa. Entre a segunda e a terceira cristas, mais afastadas do corpo de água, foram coletadas conchas de: Divaricella quadrisulcata, Lucina pectinata, Ostrea equestris, Tellina lineata, Bulla striata, Anomalocardia brasiliana, Tagelus plebeius e gastrópode da família Rissoidae. 
Mais ao norte, entre a primeira e a terceira cristas, uma vez que não ocorre a segunda crista, foram coletadas conchas dos moluscos: Tellina lineata, Donax hanleyanus, Bulla striata, Anomalocardia brasiliana, Olivancillaria vesica.

No lado interno após a terceira crista, foram coletadas as conchas de: Ostrea equestris, Anomalocardia brasiliana, Tellina lineata, Tagelus plebeius, Bulla striata, Pomacea sp e gastrópode da família Rissoidae.

As três últimas amostras não foram datadas, mas, pela associação faunística e natureza dos sedimentos, devem ser da mesma época dos sedimentos da Ponta Grossa e do terraço ao sul da Lagoa do Sombrio.

Ao norte destas cristas mencionadas, sob uma outra que parece ser a única naquele local, um poço foi escavado sobre a crista. A 1,40 m de profundidade foi coletado material turfoso. A datação da amostra Bah-1665 indicou uma idade de $1.770 \pm 180$ anos A.P. com um $\delta^{13} \mathrm{C}$ de $-25,29 \%$. Outra amostra (Beta-55.383) forneceu uma idade de $1.200 \pm 60$ anos A.P. O $\delta^{13} \mathrm{C}$ de $-25,29$ sugere que os sedimentos mais superficiais da lagoa do Sombrio foram depositados em condições de água doce. O extremo sul entre a lagoa do Sombrio e o Rio Mampituba estava preenchido com sedimentos lagunares, circundando a lagoa.

\subsubsection{Depósitos Organógenos Carbonosos}

Vários antigos corpos de águas apresentam-se hoje colmatados. A parte superior dos seus depósitos consiste em turfas.

As turfas são restos vegetais mais ou menos decompostos e acumulado em áreas paludiais, apresentando-se, então, saturadas de água. O grande teor de água é que possibilita a decomposição, principalmente anaeróbia, com participação de microorganismos.

As turfeiras são ecossistemas formadores de turfa em que estão acumulados pelo menos 0,30 m desse material (SHOTYK, 1988), caso contrário são chamados solos orgânicos. 
Existem tipologias de turfas e turfeiras estudadas em vários países da Europa e da América do Norte, baseadas em vários critérios como : a origem da água das turfeiras, as condições geográficas, a natureza dos vegetais formadores, características físicas, químicas, físico-químicas, conteúdo de água, capacidade de retenção de água, textura estrutura, cor e componentes minerais, orgânicos e elementares. Nota-se, na literatura específica, que a nomenclatura não é usada homogeneamente, de tal modo que o seu uso é dificultado. As tabelas 81 e 82 demonstram o sistema de VON POST.

\begin{tabular}{|c|c|c|c|c|c|}
\hline \multicolumn{6}{|c|}{$\begin{array}{l}\text { TABELA } 81 \text { - Sugestões de identificação para graus de decomposição (humificação) de } \\
\text { turfas, escala de VON POST (HENDERSON \& DOIRON, 1982, apud } \\
\text { SHOTYK,1988). }\end{array}$} \\
\hline $\begin{array}{l}\text { GRAU DE } \\
\text { HUMIFICACÃO }\end{array}$ & ÁGUA INICIAL & TEXTURA & RESTOS DE PLANTAS & $\begin{array}{l}\text { TESTES DE COMPRESSĂO } \\
\text { ESMAGAMENTO }\end{array}$ & OBSERVAÇÕES \\
\hline$H 1$ & Clara & Áspera & Plantas Vivas & Muito Esponjosa & H1 Vivendo \\
\hline $\mathrm{H} 2$ & $\begin{array}{l}\text { Clara a levemen- } \\
\text { te amarela }\end{array}$ & Aspera & Estruturas Inteiras & $\begin{array}{l}\text { Esponjosa - retornará ao nor- } \\
\text { mal após pressáa }\end{array}$ & $\begin{array}{l}\text { H2 Mesmo que } \\
\text { H1 exceto náo } \\
\text { está vivendo }\end{array}$ \\
\hline H3 & $\begin{array}{l}\text { Amarela levemen- } \\
\text { te túrbida }\end{array}$ & - Áspera & $\begin{array}{l}\text { Quebra em pedaços, } \\
\text { mas pedaços estáo intac- } \\
\text { tos }\end{array}$ & $\begin{array}{l}\text { Levemente esponjosa, mantêm } \\
\text { uma forma bem definida da } \\
\text { impressáo da máo }\end{array}$ & \\
\hline$H 4$ & $\begin{array}{l}\text { Levemente mar- } \\
\text { rom, türbida }\end{array}$ & $\begin{array}{l}\text { Muito leve- } \\
\text { mente escor- } \\
\text { regadia }\end{array}$ & $\begin{array}{l}\text { Pedaços dispersando-se } \\
\text { em componentes individu- } \\
\text { ais, i. é, folhas, talos, etc. }\end{array}$ & $\begin{array}{l}\text { Năo esponjosa, forma uma ré } \\
\text { plica distinta da impressáo da } \\
\text { Máo- nenhuma turfa escapa } \\
\text { entre os dedos }\end{array}$ & $\begin{array}{l}\text { H4 "grandes } \\
\text { articulaçбes } \\
\text { (H3 é arredon- } \\
\text { dada enquanto } \\
\text { H4 é angulosa) }\end{array}$ \\
\hline $\mathrm{H} 5$ & $\begin{array}{l}\text { Marrom - mistu- } \\
\text { ra de restos de } \\
\text { plantas, materi- } \\
\text { al amorfo e água }\end{array}$ & $\begin{array}{l}\text { Levemente } \\
\text { escorregadia }\end{array}$ & $\begin{array}{l}\text { Componentes individuais } \\
\text { desintegrando-se de tal } \\
\text { modo que algum material } \\
\text { amorfo está presente }\end{array}$ & $\begin{array}{l}\text { Uma pequena quantidade de } \\
\text { turfa escapa entre os dedos }\end{array}$ & \\
\hline$H 6$ & $\begin{array}{l}\text { Soluçáo marrom } \\
\text { escura }\end{array}$ & Escorregadia & $\begin{array}{l}\text { Estruturas de plantas evi- } \\
\text { dentes em exame cuida- } \\
\text { doso. Aproximadamente } \\
\text { metade da amostra em } \\
\text { estado amorfo }\end{array}$ & $\begin{array}{l}\text { Um terço da amostra escapa } \\
\text { por entre os dedos }\end{array}$ & \\
\hline $\mathrm{H7}$ & $\begin{array}{l}\text { Marrom muito } \\
\text { escura em muito } \\
\text { pequena quanti- } \\
\text { dade }\end{array}$ & $\begin{array}{l}\text { Um tanto pas- } \\
\text { tosa }\end{array}$ & Estruturas năo muito dis- & $\begin{array}{l}\text { Mais da metade do material es- } \\
\text { capa das máos como pasta }\end{array}$ & \\
\hline H8 & Nenhuma & Pastosa & $\begin{array}{l}\text { Apenas raizes e fibras } \\
\text { distingalveis - homoge- } \\
\text { neas }\end{array}$ & $\begin{array}{l}\text { Acima de } 2 / 3 \text { escapam das } \\
\text { măos }\end{array}$ & \\
\hline H9 & Nenhuma & Como pudim & Restos náo distingâlveis & Quase toda escapa das máos & \\
\hline H10 & Nenhuma & & Nâo distingalveis & Tudo escapa das máos & $\begin{array}{l}\text { H10 Raro em } \\
\text { turfas sedimen- } \\
\text { tares }\end{array}$ \\
\hline
\end{tabular}




\begin{tabular}{|c|c|c|}
\hline \multicolumn{3}{|c|}{ 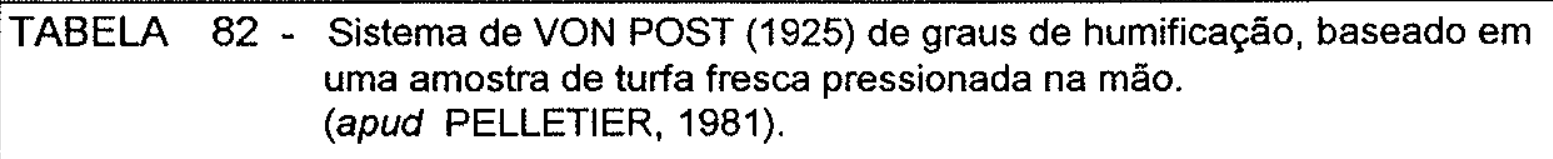 } \\
\hline Graus de Humificação & $\begin{array}{l}\text { Qualidade da água que escorre } \\
\text { da mão }\end{array}$ & $\begin{array}{l}\text { Natureza do resíduo } \\
\text { deixado na mão }\end{array}$ \\
\hline $\mathrm{H} 1$ & Água clara, incolor & $\begin{array}{l}\text { Estruturas características } \\
\text { das plantas }\end{array}$ \\
\hline $\mathrm{H} 2$ & Água amarelo-marrom & $\begin{array}{l}\text { Residuos identificáveis de } \\
\text { plantas }\end{array}$ \\
\hline H3 & Água marrom turva & $\begin{array}{l}\text { Resíduos de plantas, mas } \\
\text { nenhuma lama }\end{array}$ \\
\hline H4 & Água marrom, muito turva & Partes lamosas visíveis \\
\hline H 5 & $\begin{array}{l}\text { Água marrom, muito turva, } \\
\text { com alguns sólidos de } \\
\text { turfa mais grossos }\end{array}$ & $\begin{array}{l}\text { Lamosa, resíduos de } \\
\text { plantas ainda identificá- } \\
\text { veis }\end{array}$ \\
\hline H6 & $\begin{array}{l}1 / 3 \text { da turfa se perde na } \\
\text { água }\end{array}$ & $\begin{array}{l}\text { Muito lamosa, resíduos de } \\
\text { plantas ainda identificá- } \\
\text { veis }\end{array}$ \\
\hline$H 7$ & $\begin{array}{l}3 / 2 \text { da turfa se perde na } \\
\text { água }\end{array}$ & $\begin{array}{l}\text { Muito lamosa, residuos } \\
\text { plantas ainda identificá- } \\
\text { veis }\end{array}$ \\
\hline H 8 & $\begin{array}{l}2 / 3 \text { da turfa se perdem } \\
\text { na água }\end{array}$ & $\begin{array}{l}\text { Apenas raizes, madeira, } \\
\text { fibras grossas }\end{array}$ \\
\hline H9 & $\begin{array}{l}\text { 9/10 da turfa são perdidos } \\
\text { na água }\end{array}$ & $\begin{array}{l}\text { Apenas um pouco de } \\
\text { resíduos de plantas iso- } \\
\text { lados }\end{array}$ \\
\hline H 10 & $\begin{array}{l}\text { A massa inteira escorre- } \\
\text { ga através dos dedos }\end{array}$ & Nenhum resíduo \\
\hline
\end{tabular}


Até bem pouco tempo atrás, o pensamento dominante era de que a turfa seria um material específico de climas temperados e frios. A matéria orgânica acumula-se porque as condições de oxigenação ficam reprimidas. Nos trópicos, com altas temperaturas, nã̉o haveria condições necessárias ao acúmulo desse material. Entretanto, desde o início deste século há citações ou estudos de turfeiras no Brasil (ULE, 1900; PASSOS,1936). Porém, os especialistas dos países da Europa e América do Norte passaram a aceitar melhor a idëia da ocorrência de turfa tropical com as descobertas feitas na Malásia e outros países do oriente.

No Brasil, sabe-se atualmente da existência de vários tipos de turfas e turfeiras em todos os estados. Em Santa Catarina há turfas e turfeiras, tanto na zona costeira como no planalto. Na área estudada, ocorrem várias turfeiras em que a turfa está aflorando ou mesmo está soterrada sob depósitos inorgânicos.

As depressões onde houve o acúmulo de turfa são de várias origens: lagunar ou lacustre atrás de ilhas-barreiras, depressões em planície de inundação fluvial e depressões sobre depósitos estuarinos; depressões ou cavas entre cristas praiais.

São pelo menos 16 locais com turfa (Figura 150). A espessura varia de 0,60 m a $4,50 \mathrm{~m}$. A grande maioria das turfeiras tem mais de $1 \mathrm{~m}$ de espessura. Seis desses locais foram perfurados e amostrados.

A importância desses depósitos vem do grande número de usos que se pode fazer desse material e pelo interesse que órgãos governamentais vêm demonstrando sobre a turfa, considerando-a uma alternativa energética.

\subsection{Localização dos Depósitos e Acesso}

No sul de Santa Catarina, na área estudada, as três turfeiras mais importantes são: Turfeira Banhado do Sombrio, Turfeira Banhado de Piritu e Turfeira Caverá. Existe uma série de turfeiras menores tanto em área como em espessura, e, portanto, em volume. Em geral são turfas sem capeamento, porém, há também turfas soterradas. 
A turfeira mais afastada da atual linha de costa é conhecida como Banhado do Sombrio, pertencendo hoje ao Município de Santa Rosa do Sul e com pequeno trecho sul no Município de São João do Sul e outro no Município de Jacinto Machado. Está situada aproximadamente, entre as latitudes $29^{\circ} 05^{\prime}$ e $29^{\circ} 09^{\prime} \mathrm{S}$ e longitudes $49^{\circ} 47^{\prime}$ e $49^{\circ} 49^{\prime} \mathrm{W}$. Está delimitada por acidentes geográficos, formados pelo Rio Bonito e Rio Leão a oeste e pela área do sopé do esporão-divisor ao norte, pelos rios Canoas e Sertão a sul, e a leste pela área de influência dos rios Sanga D'Anta e Sanga da Areia (Figuras 151).

Estradas sem pavimentação dão acesso à área, sendo o acesso à turfeira possível a pé a partir das estradas. Entretanto, a SUDESUL, na época da implementação do "Subprojeto Sombrio", instalou um posto no Morro do Bino, de tal maneira que o acesso pelo norte foi facilitado nos últimos anos.

A Turfeira do Banhado do Piritu situa-se no Município de São João do Sul, a leste da cidade homônima, a oeste da localidade de Vila Conceição e a sudoeste da localidade de Três Coqueiros. Acha-se rodeada por estradas sem pavimentação, mas no seu limite sul há uma estrada asfaltada (SC-450) que liga a BR-101 às cidades de São João do Sul e Praia Grande. $O$ acesso à turfeira também se dá mediante trilhas (Figuras 152).

A Turfeira Caverá pertence ao Municipio de Araranguá e situa-se entre a Lagoa de Caverá a sul, e a Lagoa da Serra ao norte. No seu extremo norte é cortada pela estrada asfaltada que liga Araranguá a Rincão. Ao sul é também cortada por outra estrada que liga a BR-101, da localidade de Sanga da Areia à praia da Caçamba (Figuras 153).

No Município de Araranguá há, ainda, a Turfeira Barro Vermelho, entre a localidade homônima e o Rio Araranguá. Mais para leste há a Turfeira Rio dos Porcos, situada parcialmente no Município de Araranguá e no de lçara (Figura 150).

O acesso é possibilitado por estrada sem pavimentação que é transitável só em períodos secos e, na maior parte, pode ser feito a pé.

No município de Turvo há a Turfeira Corrupiá que se estende do sopé do Morro do Soares para o norte. É cortada no sul pela estrada asfaltada SC-448 que liga a BR-101, na localidade de Sanga da Toca, à localidade de Ermo (Figuras 150, 154). 
No município de Sombrio há a Turfeira Canal Itoupava/Rio da Laje. Ela é constituida por dois corpos alongados, separados por uma crista praial, situada entre Garapuvu do Sul a oeste e Campo d'Água a leste, sendo drenada pelos canais ltoupava e do Rio da Lage, ao sul do Morro do Soares (Figura 150). Ambos os corpos são rodeados por estradas não pavimentadas, sendo difícil o acesso à turfeira do Canal Itoupava que está a oeste da crista praial. A ocupação desta crista possibilitou o acesso à turfeira do Rio da Laje.

Ainda no mesmo município, há a Turfeira Sanga Negra situada a oeste da BR-101. (Figura 150).

Entre a Lagoa do Sombrio e a Lagoa de Caverá, também ocorre turfa de pequena espessura.

No município de Sombrio há, ainda, corpos longilíneos de turfa a oeste das Lagoas do Sombrio e de Caverá, entre as cristas praias, com pelo menos $60 \mathrm{~cm}$ de espessura.

Nos limites dos municípios de Santa Rosa do Sul e São João do Sul há a Turfeira Três Coqueiros, situada entre esta localidade ao sul e a de São Cristóvão ao norte. Ela inicia-se junto à BR-101, e a sua drenagem é feita para a Lagoa do Sombrio (Figuras 150).

No município de São João do Sul, há, ainda, a Turfeira Rio do Sertão, a Turfeira Sanga dos Rodrigues, a Turfeira Olvebra, a Turfeira Sul da Lagoa do Sombrio e turfas soterradas (Figuras 152).

A Turfeira Rio do Sertão desenvolve-se descontinuamente, ao longo desse rio, ao sul da Turfeira Banhado do Sombrio. Não é contínua, pois se constitui de vários corpos. O acesso é difícil (Figuras 6 no encarte e 150).

A Turfeira Sul da Lagoa do Sombrio situamse ao sul dessa Lagoa e ao sul de uma elevação constituída por uma soleira de diabásio. A estrada sem pavimentação que liga a BR-101 à localidade de Curralinhos e ao Balneário Rosa do Mar é o acesso melhor e mais próximo (Figuras 6 no encarte e 150).

A Turfeira Sanga dos Rodrigues é drenada pelo rio homônimo que vai desaguar no Rio Mampituba e desenvolve-se paralelamente e a leste dos cordões de dunas fixas que orlam o lado leste da Lagoa do Sombrio. É cortada pela estrada citada acima, que liga a BR-101 ao Balneário Rosa do Mar (Figura 150). 
A leste desta turfeira, dispõe-se uma série de cristas praiais, cujas zonas intercordões estão preenchidas de turfa. Essas depressões cheias de turfa formam corpos paralelos e longos, chamados de Turfeira Olvebra. Esses corpos acham-se cortados pela mesma estrada citada nos dois parágrafos anteriores (Figura 150).

\subsection{Turfeira Banhado do Sombrio}

A área desta turfeira foi a principal razão do Sub-Projeto Banhado do Sombrio, da SUDESUL, dentro do Projeto de Desenvolvimento do Litoral Sul de Santa Catarina, uma vez que foi considerada área ótima para a agricultura (Fotos 67 e 68).

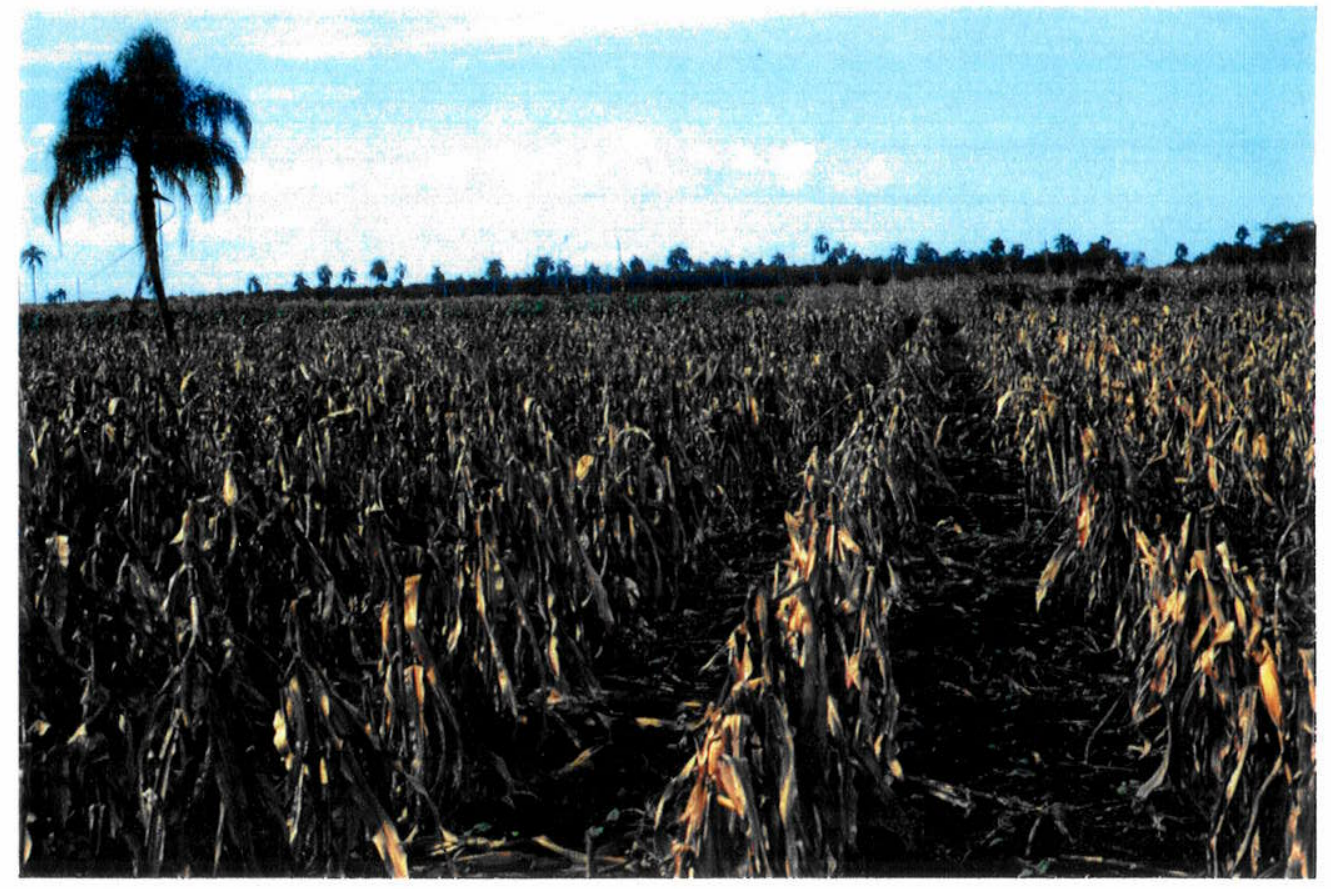

Foto 67 - Área de Turfeira Banhado do Sombrio, loteada pela SUDESUL, plantada com milho e feijão. Da mata original há algum vestígio na parte superior da foto, com preponderância de coqueiros. Visada para o sul. 


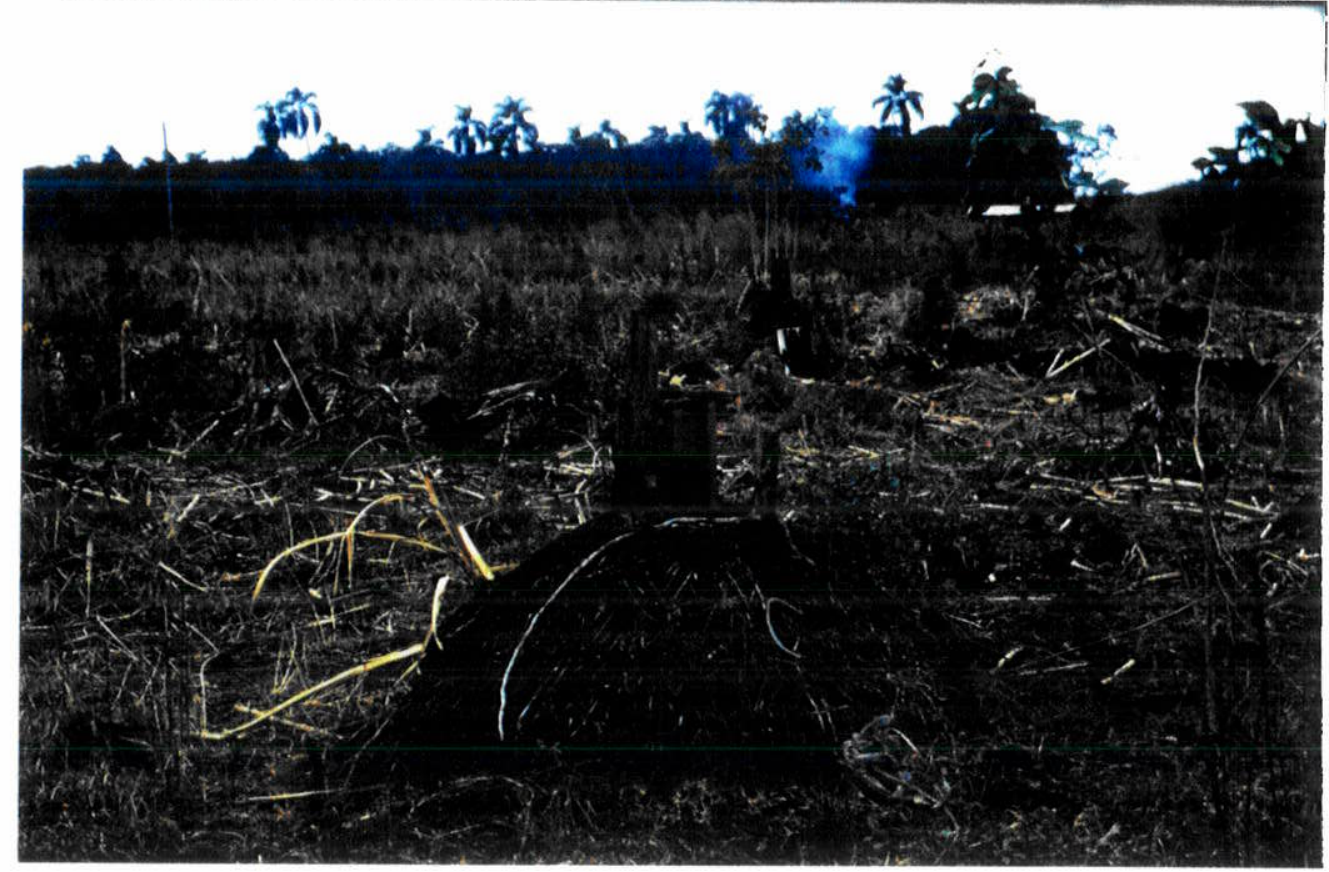

Foto 68 - Área desmatada da Turfeira Banhado de Sombrio, vendo-se troncos queimados. O fogo e a má regulação da drenagem fizeram rebaixar mais de $80 \mathrm{~cm}$ de turfa em poucos anos. Isto é visualizado pelas raízes expostas do que resta das árvores, como do coqueiro em primeiro plano. O martelo que está junto ao tronco e a fita métrica branca servem para sinalizar a exposição das raízes.

A maior parte da superfície da turfeira tem entre 6 e $10 \mathrm{~m}$ de altitude, e parte ao sul está entre 4 e 6 m (Figuras 6 no encarte e 151).

Uma elevação com 46,59 m, denominada Morro do Bino, constituída de rochas do Grupo Passa Dois sobressai-se no norie.

A área da turfeira acha-se delimitada por elevações ao norte e a oeste. Ao norte são formas residuais que constituem o esporão interflúvio entre as bacias do Mampituba e do Araranguá. No lado oeste a escarpa da Serra Geral, ao lado do Banhado, apresenta altitudes em torno de $1000 \mathrm{~m}$. No sopé da borda do planalto, há depósitos conglomeráticos e areno-argilosos. Depósitos areno-argilosos também são encontrados no lado sul da turfeira. No lado leste-sudeste ocorrem cristas praiais arenosas, pleistocênicas, com altitudes de 6 a $16 \mathrm{~m}$. A geologia e altimetria dos terrenos circundantes têm importância na caracterização da turfeira e contribuem para explicar o tipo de depósito. As águas que percolam as rochas podem tornar-se enriquecidas com elementos químicos que serão 
depositados na turfeira ou entrarão em reações químicas com os ácidos húmicos e fúlvicos que se formam na turfa.

Esta turfeira, portanto, esteve e está em condições de receber águas através das chuvas, através do lençol freático e por intermédio de cheias. Sedimentos também podem ser nela depositados pela ação de cheias dos rios. Estas possibilidades de alimentação química deste ambiente são devidas à sua situação geográfico-geológica.

A turfeira tem cerca de 1.564 ha, sem recobrimento de material terrígeno, podendo ter pequenas espessuras recobertas nos seus limites com os rios Leão e Canoas, isto é, a sudoeste e sul, por depósitos devidos às cheias fluviais.

Foram realizadas 6 testemunhagens nesta turfeira, distribuídas entre o Morro do Bino e a Fazenda Matiola (Figura 151). Quatro testemunhos foram retirados com amostrador a pistão e descritos em campo. Outros dois foram obtidos com amostrador a percussão e tubos de PVC que foram levados para laboratório para outras descrições e medidas. O local de cada testemunhagem foi limpo, e retirada a parte superior com pá em função da desidratação da turfa.

\section{A) Descrição da Turfa em Campo}

Primeira amostragem a sudeste do Morro do Bino:

Inicialmente foi aberto um poço com pá, de $0,65 \mathrm{~m}$ de profundidade, porque a turfa estava muito seca, seguindo-se a testemunhagem.

- Os primeiros 0,65 m é turfa seca, desidratada devido ao rebaixamento do nível da água através de canais de drenagem para favorecer o plantio.

Constataram-se vidências de queima, através de troncos e turfa carbonizados.

$1^{\circ} \mathrm{m}$ - Este primeiro metro amostrado compreende mais de $0,50 \mathrm{~m}$ de turfa e quase $0,50 \mathrm{~m}$ de um misto de material orgânico e argila. Na base da turfa há folhas e fragmentos de caules finos, e as primeiras são de cor marrom ainda com nervuras visíveis. Corresponde ao $\mathrm{H}-4$ de VON POST. 
- Na argila há fragmentos de partes lenhosas até $5 \times 6 \mathrm{~cm}$, de cor avermelhada que logo torna-se preta na parte externa. Este fato ocorreu várias vezes na extração da turfa. Assim que ela era depositada na superfície, progressiva e rapidamente tornava-se mais escura, dificultando a tomada de cores.

- A cor da argila é cinza média para cinza escura com leve tom de verde. No topo a argila se torna amarronzada, com furos finos de raízes e manchas de cor avermelhada-vinho para marrom até preta em torno dos furos.

Total $-1,65 m$

Segunda amostragem mais a leste que a anterior :

Foi aberto um poço com pá, com cerca de $0,30 \mathrm{~m}$ de profundidade, prosseguindo a partir daí a sondagem, com o amostrador a pistão.

- Retirados os primeiros $0,30 \mathrm{~m}$ de turfa seca com o topo carbonizado.

$1^{\circ} \mathrm{m}$ - Neste primeiro metro, a iurfa apresenta fragmentos lenhosos, de cor amarela-esverdeada a avermelhada, logo ficando com cor cinza-amarelada e cinza clara. Fragmentos de material lenhoso, raízes e gramíneas são perceptíveis. Correspondente ao $\mathrm{H}-4$.

$2^{\circ} \mathrm{m}$ - É este metro de turfa semelhante ao anterior no que concerne à presença de fragmentos de partes lenhosas que mudam de cor rapidamente, de vermelha-alaranjada para cinza e depois preta. Na base o material corresponde ao $\mathrm{H}-8$ de VON POST.

- A parte superior deste segundo metro, tem muita argila misturada com a turfa.

$3^{\circ} \mathrm{m}$ - Na parte superior deste terceiro metro $0,60 \mathrm{~m}$ são de turfa e 0,35 $\mathrm{m}$ são de argila, o que falta é devido à compactação. A turfa parece ter características de $\mathrm{H}-9$, porém pode ser devido à argila. A argila na base é de cor cinza, mas, para o topo, dos seus 0,35 m de espessura apresenta muita matéria orgânica ainda distinguível uma vez que apresenta fragmentos lenhosos, embora muito finos. 
Total de turfa $-2,90 \mathrm{~m}$; total da amostragem $3,30 \mathrm{~m}$.

Terceira amostragem mais ao sul que as duas anteriores, perto da mata da Reserva Ecológica do Banhado do Sombrio:

Foi aberto um poço de $0,40 \mathrm{~m}$ de profundidade. Próximo havia o resto de um coqueiro com as raizes expostas, evidenciando que houve o rebaixamento da turfa em cerca de $0,80 \mathrm{~m}$.

- Retirados os primeiros $0,40 \mathrm{~m}$ de turfa seca, desidratada, carbonificada na parte superior desta medida.

$1^{\circ} \mathrm{m}$ - Inicia com turfa que passa para turfa com argila. O topo deste metro é de cor cinza escura e para a base, a cor é cinza esverdeada.

- Continua, para baixo, como turfa de cor preta, com fragmentos lenhosos finos e fragmento cilíndrico de vegetal, com conduto interno vazio.

A última turfa corresponde ao $\mathrm{H}-7$ a $\mathrm{H}-8$ de VON POST.

$2^{\circ} \mathrm{m}$ - Neste metro foram obtidos $0,70 \mathrm{~m}$ de turfa de cor marrom escura, sem água, pastosa, escapando quase tudo da mão, há poucas fibras, correspondendo ao $\mathrm{H}-8$.

- Quando se parte o testemunho em pedaços perpendiculares ao seu comprimento, vê-se pequenas folhas pretas com nervuras, paralelas ao possivel acamamento, sugerindo condições de águas calmas à época da deposição.

- Os restantes 0,30 m são de argila arenosa cinza.

$3^{\circ} \mathrm{m}$ - No topo deste metro há um fragmento grande de vegetal, lenhoso, de cor amarela-bege para alaranjada. O restante é argila arenosa cinza escura passando para argila, isto é, nos últimos $0,50 \mathrm{~m}$ o material é mais argiloso. Há furos finos verticais, de raizes.

Total da amostragem $-3,40 m$, sendo cerca de 2,10 m de turfa. Há intercalações de sedimentos inorgânicos e o terceiro metro amostrado também é deste material. 
A quarta amostragem foi realizada na Fazenda Matiola, junto ao Rio Sanga da Areia, no lado leste desta Turfeira. Foi aberto um pequeno poço de $0,30 \mathrm{~m}$ onde aparecem troncos em decomposição.

- Nos 0,30 m iniciais predominam troncos em decomposição com pouca matéria orgânica já decomposta.

$1^{\circ} \mathrm{m}$ - Nos seguintes $0,50 \mathrm{~m}$, a água que sai quando a turfa é esmagada é de cor marrom, e o material praticamente não escapa da mão. Há presença de folhas, raízes e outras fibras. Corresponde ao $\mathrm{H}-4$.

- A turfa da parte inferior deste metro corresponde ao $\mathrm{H}-5$ e $\mathrm{H}-6$, apresentando grandes pedaços de material lenhoso, de cor amarelada.

$2^{\circ} \mathrm{m}$ - Nos primeiros $0,55 \mathrm{~m}$ deste segundo metro amostrado, notam-se fibras e material semelhante a pequenos caules com até $3 \mathrm{~mm}$ de diâmetro. Corresponde ao $\mathrm{H}-6$.

- Para a base a turfa é marrom escura. A parte superior desta metade parece argilosa, como um pudim com fibras finas. O comportamento do material com características de plasticidade pode ser resultado do material orgânico intensamente decomposto. Corresponde ao $\mathrm{H}-6$ a H-7.

$3^{\circ} \mathrm{m}$ - Constitui-se de argila arenosa cinza. Trata-se de argila mais arenosa que nos outros furos descritos desta turfeira. No extremo superior é mais mole. É mais arenosa no topo deste terceiro metro que na sua base, cuja parte terminal presenta-se liqüefeita. Na base não liqüefeita há manchas de cor marrom.

Total $-3,30 \mathrm{~m}$ amostrados, sendo $2,30 \mathrm{~m}$ de turfa podendo ter argila agregada.

B) Descrição dos Testemunhos em Laboratório

Testemunho retirado perto da Reserva Ecológica ao sul do Morro do Bino. Sondagem de $3 \mathrm{~m}$, recuperação de 1,60 m devido ao adensamento. 
$0-11 \mathrm{~cm}$ - turfa fibrosa com fragmentos de caule, de até $1 \mathrm{~cm}$ de diâmetro, semente de coqueiro jerivá. Aplicando-se o teste de VON POST, nota-se água preta, muito densa, dada a presença de micropartículas, e nenhum outro material sai da mão. Cor 5 YR 2,5/1(preta). Densidade aparente: 0,20.

$11-37 \mathrm{~cm}$ - turfa com fragmentos lenhosos de até $1 \mathrm{~cm}$ de diâmetro. Ao espremer o material, sai água marrom e quase nada do restante. Cor 5 YR 3/1 (cinza muito escura). Densidade aparente: 0,19.

$37-42 \mathrm{~cm}$ - turfa mais clara e mais fina, sem água ao ser espremida cerca de 1/3 do material escorrega da mão. Cor 5 YR 3/1 (cinza muito escura).

42 - 50,5 cm - turfa fibrosa,ao ser espremida, não emite água, mas escorregam mais de 2/3 do material na mão. Cor 10 YR 2/2(marrom muito escura).

$50,5-56,5 \mathrm{~cm}$ - parece argilosa, com fragmentos lenhosos de até $1,3 \mathrm{~cm}$ de diâmetro. Cor 10 YR 2/1 (preta).

56,5 - $94 . \mathrm{cm}$ - turfa fibrosa fina, bem mais escura, que a anterior,com fragmentos lenhosos de até $1 \mathrm{~cm}$ de diâmetro, sem água, não sobra quase nada na mão, parece até argilosa. Cor 10 YR 3/2(marrom acinzentada, muito escura). Densidade aparente: 0,13 .

$94-160 \mathrm{~cm}$ - camada argilosa com alguns fragmentos fibrosos achatados, de vegetais, bem resistentes, e fragmentos de material lenhoso de até $2,7 \mathrm{~cm}$ de diâmetro. Cor 10 YR 3/1 (cinza muito escura).

Depois de alguns dias do testemunho aberto, tanto a turfa quanto a argila encolheram bastante. A metade superior do testemunho apresenta cor marrom cinza, com mais fibras e mais troncos. A metade inferior também tem fragmentos de caules finos. É preta e parece conter, a partir da terceira camada, material orgânico-argiloso. A base de argila cinza apresenta fraturas de ressecamento, horizontais e verticais, pela perda da água depois do testemunho aberto.

Segundo testemunho coletado a uns $300 \mathrm{~m}$ a leste do anterior. Sondagem de $3 \mathrm{~m}$, recuperação de $1,03 \mathrm{~m}$. 
$0-17 \mathrm{~cm} \quad$ - turfa um tanto seca, com fragmentos lenhosos de até $2 \mathrm{~cm}$.

Cor 5 YR 2,5/1 (preta). Densidade aparente: 0,15.

17 - 36cm - turfa mais úmida, fibrosa com fragmentos lenhosos. Cor 10 YR 2/2 (marrom muito escura). Densidade aparente: 0,11.

36 - $40 \mathrm{~cm}$ - parece argila com fragmento lenhoso de até $2 \mathrm{~cm}$. Este fragmento apresenta seus constituintes de forma radiada, e sua cor é 2,5 Y 4/4(cinza escura). A cor do material é 10 YR entre $3 / 1$ e 3/2(cinza muito escura e marrom acinzentada muito escura).

$40-77,5 \mathrm{~cm}$ - material orgânico argiloso, muito fino, com fibras finas com fragmentos lenhosos de até $1,5 \mathrm{~cm}$. Sob o teste de VON POST não emite água e todo o material escapa da mão. Cor 10 YR 2/1(preta). Densidade aparente:0,13. $77,5-101,5 \mathrm{~cm}$-turfa fibrosa que ao ser espremida sai nenhum material da mão, além da água que é marrom com material em suspensão, porém é quase transparente. Cor 10 YR 2/2(marrom muito escura). Densidade aparente: 0,07. $101,5-103 \mathrm{~cm}$ - material orgânico-argiloso de cor 2,5 Y 2/0(preta).

Muitos fragmentos lenhosos ocorrem ao longo do testemunho. A turfa da base é semelhante a do testemunho anterior, quando examinados depois de dias de exposição no laboratório, porém sua cor é mais para a preta-azulada, ao passo que no anterior é de cor preta cinza. $O$ material da base chega a ser até amarelado quando seco, o que parece ser devido às antigas raízes. O topo é mais coeso e mais amarronzado do que a parte superior do testemunho anterior. Este testemunho não alcançou a base inorgânica.

Deve-se salientar que os tubos de PVC tinham $3 \mathrm{~m}$ de comprimento e, embora penetrassem com facilidade, o material era adensado. Comprovou-se este adensamento uma vez que antes da retirada de cada tubo, media-se o espaço interno vazio do mesmo. Esta medida mostrava que em $3 \mathrm{~m}$ de tubo enterrado e ainda in situ, o material no interior preenchia, por vezes, menos da metade do comprimento do mesmo. 


\subsection{Turfeira Banhado do Piritu}

Esta turfeira constitui um corpo alongado na direção N-S, bastante complexo quanto à composição da turfa.

Apresenta-se limitada por terrenos arenosos pleistocênicos, com exceção no seu limite sul, onde, por cerca de $300 \mathrm{~m}$, não ocorrem esses sedimentos.

Pelas características morfológicas e situação geológica, a depressão da turfeira deve ter sido formada pela ação erosiva de marés, em épocas de níveis de mar mais altos, ainda no Pleistoceno.

Os depósitos arenosos pleistocênicos apresentam-se mais altos a norte e oeste da turfeira, onde a curva de nível de $10 \mathrm{~m}$ situa-se junto e paralela à turfeira, e o depósito arenoso chega a alcançar $17 \mathrm{~m}$ a oeste e $20 \mathrm{~m}$ a norte, enquanto no lado leste o depósito pleistocênico chega a altitudes entre 4 e $9 \mathrm{~m}$. Para o sul, ocorrem sedimentos arenosos e argilosos, com conchas marinhas, com altitude de até $5 \mathrm{~m}$, sendo semelhante à da superficie da turfeira.

Esta turfeira é alimentada por águas das chuvas e pelo lençol freático, que não devem ser ricas em nutrientes, pois os corpos arenosos que rodeiam a turfeira são dominantemente quartzosos. Este fato reflete-se possivelmente na vegetação da turfeira, pois ela apresenta grandes tufos de Sphagnum na sua metade norte.

\section{A) Descrição da Turfa em Campo}

Amostragem no lado oeste desta turfeira, no seu extremo norte, com testemunhador a pistão.

$1^{\circ} \mathrm{m} \quad$ - Não veio nenhum material no testemunhador devido, provavelmente, a grande quantidade de água.

$2^{\circ} \mathrm{m} \quad$ - Não veio nenhum material no amostrador. 
$3^{\circ} \mathrm{m} \quad$ - No teste de VON POST a água que sai da turfa é marrom escura, túrbida. A turfa constitui-se de fibras finas e escorrega rapidamente da mão permanecendo apenas $1 / 3$ do material. $H-8$.

$4^{\circ} \mathrm{m} \quad$ - Turfa muito liqüefeita, semelhante a anterior, e começando a aparecer material orgânico cinza. $\mathrm{H}-8 / \mathrm{H}-10$.

$4^{\circ} \mathrm{m}$ - Outra tentativa no $4^{\circ} \mathrm{m}$. O pouco material que veio no amostrador escorregou rapidamente para fora do mesmo. Havia pequeno fragmento lenhoso de $8 \mathrm{~cm}$, amassado. $O$ resto estava liqüefeito.

$5^{\circ} \mathrm{m}$ - Areia com pelitos, de cor esverdeada tendendo para cinza. Havia parte liqüefeita, marrom, com alguns fragmentos vegetais.

Total - Cerca de 4,0 m de turfa, embora bastante liqüefeita, em sondagem de $5,0 \mathrm{~m}$.

Segunda amostragem no lado oeste da Turfeira Banhado Piritu, algumas dezenas de metros mais ao sul que a anterior.

$1^{\circ} \mathrm{m} \quad-O$ teste de VON POST neste primeiro metro mostra que a água que sai da turfa é marrom escura, densa, com fibras e na mão só restou $1 / 3$ do material.

$2^{\circ} \mathrm{m}$ - Nos primeiros $0,50 \mathrm{~m}$, a turfa é avermelhada, com fragmentos lenhosos. $\mathrm{H}-4 / \mathrm{H}-5$.

- Nos últimos 0,50 m deste segundo metro a turfa é de cor marrom. $\mathrm{H}-5 / \mathrm{H}-6$.

$3^{\circ} \mathrm{m}$ - Neste terceiro metro o sedimento é argila cinza.

Total $-2,0 \mathrm{~m}$ de turfa e testemunhagem de $3,0 \mathrm{~m}$.

B) Descrição dos Testemunhos em Laboratório

Testemunho obtido no lado oeste da turfeira. Sondagem de $3,0 \mathrm{~m}$, recuperação de $1,38 \mathrm{~m}$ : 
$0-17 \mathrm{~cm}$ - turfa muito fibrosa, com vários fragmentos lenhosos de até $1 \mathrm{~cm}$ de diâmetro, "heterogênea", sem consistência. Cor 5 YR 2,5/1(preta). Densidade aparente: 0,11.

$17-43,5 \mathrm{~cm}$ - turfa mais densa, fibrosa, mais fina que a descrita acima, com raizes na base. Cor 5 YR 2,5/1 (preta). Densidade aparente: 0,08.

43,5 - $68 \mathrm{~cm}$ - turfa fibrosa, mais densa que a da camada anterior. No teste de VON POST a água que sai da turfa é marrom bem mais escura que a das camadas abaixo; não sai turfa da mão e nela ficam as marcas dos dedos.

Cor 5 YR 2,5/2 (marrom-avermelhada escura). Densidade aparente: 0,09.

68 - $84,5 \mathrm{~cm}$ - turfa fibrosa, mais fina entre todas deste testemunho, com manchas avermelhadas, isto é, tem material avermelhado disperso, sugerindo ser um tipo de vegetação o responsável por esta cor. No teste de VON POST a água que sai da turfa é marrom, pouco mais escura que a da camada abaixo, ficando bem marcados os dedos na massa de restos que permanece na mão, custa a sair algum material entre os dedos.

Cor 2,5 YR 2,5/4 (marrom-avermelhada escura). Densidade aparente: 0,08. 84,5-89,5 cm - turfa de transição, dá a impressão de estar estratificada; a água da turfa é de cor marrom média, sai material por entre os dedos.

Cor 5 YR 2,5/1(preta).

$89,5-138 \mathrm{~cm}$ - argila fina, gelatinosa. Cor 2,5 Y $3 / 0$ ou 5 Y $3 / 1$ (cinza muito escura).

O testemunho aberto, após alguns dias de exposição no laboratório, mostrou diminuição de volume mais acentuada na argila que na turfa. A turfa é avermelhada na parte inferior do testemunho, logo em seguida, para cima, apresenta cor preta e mais para o topo é uma mistura que tende para cinza. A base do testemunho é argilo-arenosa.

Segundo testemunho a percussão nesta turfeira. Sondagem no lado leste, de $3 \mathrm{~m}$, com recuperação de $1,70 \mathrm{~m}$ : 
$0-3,5 \mathrm{~cm}$ - turfa homogênea, densa, cor marrom mais escura, muito seca, não escapa nada da mão.

$3,5-7,0 \mathrm{~cm}$ - turfa densa, homogênea, mais clara que a acima. Pouca água sai da turfa no teste de VON POST, de cor marrom média, e o material não escorrega da mão. Cor 10 YR 2/2(marrom muito escura).

7,0 - $12,5 \mathrm{~cm}$ - turfa fibrosa fina, mais escura que a da camada acima, sem água, escapa muito pouco material da mão. Cor 10 YR 2/2(marrom muito escura).

12,5 - $28 \mathrm{~cm}$ - turfa fibrosa, mais grossa, avermelhada. Água marrom sai da turfa espremida, mas não escapa material da mão. Cor 5 YR 2,5/1 (preta). Densidade aparente: 0,09.

$28-50 \mathrm{~cm}$ - turfa fibrosa, de fibras maiores que as das camadas superiores, mais solta, com fragmentos de raízes de até $4 \mathrm{~mm}$ de diâmetro, água marrom, não escapa turfa da mão. Cor 5 YR 2,5/2(marrom-avermelhada escura). Densidade aparente: 0,09.

$50-65 \mathrm{~cm}$ - turfa fibrosa, mais fina que as superiores, estratificada, com manchas horizontais mais para o topo, isto é, há tonalidades diferentes, com pequenos fragmentos lenhosos de até $7 \mathrm{~mm}$ de diâmetro, água marrom clara, sem muita turbidez, material não escapa da mão. Cor do material do topo 7,5 YR 3/4(marrom escura); cor na base 10 YR 2/1(preta).

Densidade aparente: 0,07.

65 - $91 \mathrm{~cm}$ - turfa fibrosa fina, com um fragmento lenhoso no meio de material de aspecto homogêneo e distinto da turfa fibrosa em torno. A turfa no teste de VON POST mostrou-se sem água; é escorregadia, escapando quase toda da mão. Cor 5 YR 2,5/1(preta). Densidade aparente: 0,08.

$91-97 \mathrm{~cm}$ - turfa argilosa fina. Cor 10 YR 2/1 (preta).

$97-13,5 \mathrm{~cm}$ - areia fina de cor marrom média a clara, com manchas irregulares, ora mais circulares ora mais alongadas, horizontais, de cor bege; marcas de raízes. Cor 10 YR 4/1 (cinza escura). 
$113,5-141 \mathrm{~cm}$ - areia de cor bege para cinza, com manchas marrons, difusas, alongadas, ora mais largas ora mais estreitas, de raizes, também manchas de cinza, pouco mais grossa que as anteriores. Cor 2,5 YR 5/2(vermelha fraca).

141 - $170 \mathrm{~cm}$ - areia cinza esverdeada, mais finaque a descrita acima, com manchas marrom de raízes, com minerais pesados. Cor 5 Y $5 / 1$ (cinza).

Depois de alguns dias do testemunho estar aberto, a turfa, na parte inferior mostrava-se ser mais densa que a superior e de cor preta, ficando amarronzada para o topo.

\subsection{Turfeira Caverá}

Esta turfeira tem como limite sul as águas da Lagoa de Caverá e estende-se na direção NE-SW, desde a Lagoa da Serra, pouco abaixo do paralelo da cidade de Araranguá e localidade de Morro dos Conventos, até, pelo menos, a Lagoa de Caverá. É bem maior que a Turfeira Piritu, porém, de modo semelhante a ela, acha-se rodeada por terrenos arenosos. Tem contorno irregular e está limitada do lado noroeste pelos terrenos arenosos pleistocênicos, com até $30 \mathrm{~m}$. A sudeste os terrenos arenosos são eólicos e praiais do Holoceno, com altitudes dominantes de 5 a $6 \mathrm{~m}$, porém com dunas de até $22 \mathrm{~m}$. Ao norte ocorrem também depósitos arenosos praiais e eólicos, provavelmente pleistocênicos, na maior parte, com 13 a $16 \mathrm{~m}$, porém as dunas chegam a $35 \mathrm{~m}$.

Um afloramento pequeno, com $28 \mathrm{~m}$ de altitude, de rochas do Grupo Passa Dois, ocorre no norte desta turfeira, pouco an sul da Lagoa da Serra.

A alimentação da turfeira é semelhante à de Piritu, considerando-se, entretanto, que é bem mais ampla e mais próxima do mar do que aquela, apresentando sedimentos mais recentes a leste e com um corpo de água no seu limite sul. 
A superfície da turfeira situa-se, em geral, entre 4 e $6 \mathrm{~m}$ de altitude, porém ao norte os mapas mostram altitudes de até $9 \mathrm{~m}$. É a única turfeira da área cujo material está sendo minerado para uso como combustivel (Foto 69 e Figura 153).

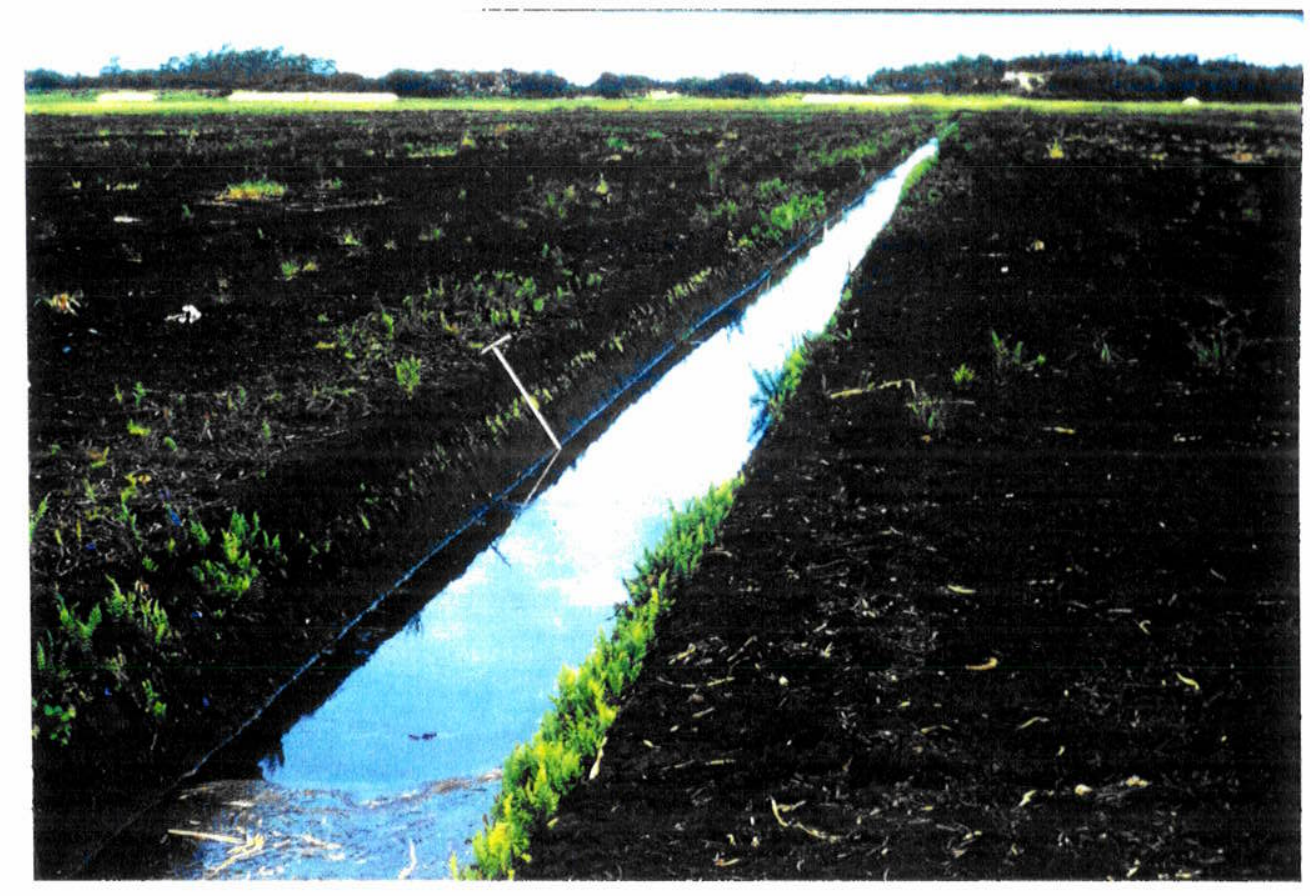

Foto 69 - Turfeira Caverá, Município de Araranguá. Um dos canais de drenagem, na parte $\mathrm{N}$ da área minerada, aberto para a secagem inicial da turfa, numa preparação para a extrudagem da mesma. A haste tem $1 \mathrm{~m}$ de comprimento. Na parte superior da foto, área de limite da turfeira exposta, estão lonas que cobrem o material já extrudado, colhido e deixado para secar em campo. 


\section{A) Descrição da Turfa em Campo}

Primeira amostragem realizada no sudeste da turfeira :

$1^{\circ} \mathrm{m}$ - Teste de VON POST nos 0,20 m inferiores : água amarelo-marrom, turva. Turfa "esponjosa", com fragmentos lenhosos semelhantes a pequenos galhos de até $1 \mathrm{~cm}$ e raízes. Corresponde ao $\mathrm{H}-3$ de VON POST.

$2^{\circ} \mathrm{m}$ - Entre 0,45 e $0,60 \mathrm{~m}$, a turfa é mais seca, ficando a massa fibrosa com a marca da mão. $\mathrm{H}-3$.

- O teste de VON POST nos últimos $0,15 \mathrm{~m}$ deste segundo metro de profundidade monstra que a turfa não espele água e quebra em pedaços. Há fragmentos lenhosos amarelados, e raízes de cor marrom. $\mathrm{H}-3 / \mathrm{H}-4$.

Total $-1,90 \mathrm{~m}$ de turfa em $2,0 \mathrm{~m}$ de perfuração.

Segunda amostragem em local próximo da perfuração anterior : Perfuração a partir do fundo de uma vala com $1,0 \mathrm{~m}$ de profundidade, portanto, a partir do $2^{\circ} \mathrm{m}$ de espessura da turfa.

$2^{\circ} \mathrm{m}$ - Teste entre $0,25 \mathrm{~m}$ e $0,30 \mathrm{~m}$ deste segundo metro. A turfa apresenta poucos restos de material fibroso, fino. Quando espremida, a turfa mostrase escorregadia e a água que sai é de cor marrom escura. H-5/H-6.

- Entre 0,85 e 0,95 o material é fibroso, friável, de cor alaranjada escura. H-5.

$3^{\circ} \mathrm{m}$ - Teste entre $0,75 \mathrm{~m}$ e $0,85 \mathrm{~m}$ neste terceiro metro. A água que sai da turfa espremida é marrom e o material escorregadio; 1/3 escapa da mão. Há material lenhoso, friável, alaranjado. $\mathrm{H}-6$.

$4^{\circ} \mathrm{m}$ - Teste entre 0,60 e 0,75 $\mathrm{m}$ - sem água, quase tudo escapa das mãos.

Havia estrutura vegetal semelhante a um caule amassado, lisa no lado de fora e, internamente, fibrosa, de cor laranja. 
- Os 0,20 m da base deste quarto metro são de argila arenosa, cor cinza escura, levemente esverdeada. O restante para o topo é turfa.

Total $-4,0 \mathrm{~m}$ de testemunho e $3,80 \mathrm{~m}$ de turfa.

Terceira amostragem efetuada no norte da área minerada, na Turfeira Caverá :

$1^{\circ} \mathrm{m}$ - Os testes feitos neste metro mostraram um material sem água, que não escapa da mão, fibroso, com folhas achatadas, mantém a forma dos dedos impressos, de cor marrom escura. Tem características tanto de $\mathrm{H}-4$ como de $\mathrm{H}-8$, talvez pelo efeito da drenagem.

$2^{\circ} \mathrm{m}$ - $\mathrm{O}$ teste realizado nos primeiros $0,40 \mathrm{~m}$ deste segundo metro mostra que a turfa apresenta água marrom escura, com fibras, escapando da mão cerca de $1 / 3$ do material, de cor avermelhada. $\mathrm{H}-5$ e $\mathrm{H}-6$.

- Em 0,45 m havia uma semente pequena, cheia de reentrâncias como meias-esferas.

- Entre 0,40 m e 0,70 m há argila cinza, com manchas de cor marrom-vinho, em torno de tubos de raízes. Em $0,65 \mathrm{~m}$ havia outra semente.

- Em 0,70 m inicia-se areia fina, branca, com manchas de cor cinza escura.

Total $-2,0 \mathrm{~m}$ de testemunho e $1,40 \mathrm{~m}$ de turfa.

Quarta amostragem realizada mais ao norte, ainda na área minerada :

$1 \circ \mathrm{m}$ - numa vala de drenagem com $1 \mathrm{~m}$ de profundidade.

$2^{\circ} \mathrm{m}$ - teste entre $0,60 \mathrm{~m}$ e 0,90 $\mathrm{m}$ neste segundo metro. Da turfa espremida sai muita água marrom, e o material escorregadio escapa parcialmente entre os dedos. A turfa é fibrosa, avermelhada e apresenta estruturas de plantas.

$3^{\circ} \mathrm{m} \quad$ - argila que tem na base pequenas manchas milimétricas de areia branca. Para o topo há furos de raízes.

Total $-3,0 \mathrm{~m}$ de testemunho e $2,90 \mathrm{~m}$ de turfa. 
B) Descrição dos Testemunhos em Laboratório

Testemunho obtido no sudeste da turfeira. Sondagem de $3,0 \mathrm{~m}$, recuperação de $1,0 \mathrm{~m}$ :

$0-7,5 \mathrm{~cm}$ - turfa mais fina, terrosa, mais escura que a inferior. Cor $10 \mathrm{YR} 2 / 1$ (preta). $7,5-12,5 \mathrm{~cm}$ - turfa fibrosa, com fragmentos lenhosos, mais clara que a situada acima, pouca água com muitos colóides, não sai nada do material através dos dedos. Cor 10 YR 2/2(marrom muito escura).

12,5-17,5 cm-material muito fino, parecendo argiloso, com fragmentos lenhosos.

$17,5-27,5 \mathrm{~cm}$ - turfa com muitos fragmentos lenhosos de $4 \mathrm{~mm}$ a até $2 \mathrm{~cm}$ de diâmetro, muito fibrosa, pouco decomposta, quando espremida na mão, sai água com muitos colóides, "densa", isto é, há muitas partículas orgânicas em suspensão, mas a turfa não sai da mão. Cor 7,5 YR 3/2(marrom escura). Densidade aparente: 0,11 .

27 - $54 \mathrm{~cm}$ - turfa muito mais escura que as amostras acima, mais fina. No teste de Von POST a turfa mostra-se quase sem água, cor marrom escura, muito densa, saindo mais de $2 / 3$ do material através dos dedos.

Cor 10 YR 2/1 (preta). Densidade aparente: 0,09.

$54-71 \mathrm{~cm}$ - turfa de cor semelhante à anterior, porém mais fibrosa, mais "solta", as fibras são mais grossas, água turva com muitos colóides, sai menos de 1/3 entre os dedos. Cor 10 YR 2/1(preta). Densidade aparente: 0,08.

71 - 90,5 cm - turfa mais fina que a anterior, porém no restante é semelhante, água limpa com colóides dispersos, não sai nada da mão. Cor 10 YR 2/1 (preta).

Densidade aparente: 0,07 .

90,5-99,5 cm - turfa manchada, com cores marrom bege para marrom mais escura e preta, parecendo estratificação. Cor 10 YR 2/1 (preta). As manchas que aparecem ficam dentro deste índice de cor, porém são ora mais claras e ora mais escuras. A Carta Münsell não oferece índice para esta variação de tonalidade. 
Depois de alguns dias, o material exposto em laboratório permitiu visualizar que a base era de material mais denso e de cor preta, passando para o topo, para cor amarronzada e depois à cinza.

Segundo testemunho, obtido junto à ponte sobre o Rio Sangrador, na margem esquerda deste. Sondagem de $3 \mathrm{~m}$. Recuperação de $1,08 \mathrm{~cm}$ :

0 - 45,5 cm - turfa muito compactada, talvez devido a água da turfeira estar sendo drenada pela mineradora. Não foi possivel cortar o testemunho com o nylon e sim apenas com a faca. É turfa estratificada. Pouca água e muito pouco material saem da mão quando a turfa é espremida.

Cor 2,5 YR 2,5/4(marrom avermelhada escura). Densidade aparente: 0,14. 45,5 - $50 \mathrm{~cm}$ - Há transição para material argiloso, é bem mais escura que a anterior, com muitas folhas impressas, brilhantes, lembrando deposição de folhas em águas calmas. Cor 5 YR 2,5/1(preta). Densidade aparente: 0,22.

50 - $88 \mathrm{~cm}$ - argila preta, plástica, brilhante no corte com faca. Da metade para baixo aparecem pequenas manchas circulares de areia branca. Há também intervalos de areia argilosa, com argila plástica.

88 - $95 \mathrm{~cm}$ - intercalações de argila preta e lentes de areia, tipo flaser; a areia é cinza clara.

95 - $99 \mathrm{~cm}$ - areia cinza, com finas camadas argilosas pretas e pequenos fragmentos de conchas.

99-108 cm - areia cinza com manchas pretas, pequenas e difusas.

Depois de seco, por exposição em laboratório, o material todo contraiu-se, diminuindo de volume, mesmo aquele da base, arenoso e argilo-arenoso. A turfa tende mais para a cor preta e cinza, com manchas avermelhadas. Esta cor está dispersa na turfa, sugerindo que algum vegetal contribui para esta cor. 
Terceiro testemunho retirado no lado oeste da turfeira, na margem direita do Rio Sangrador, afastado do rio. Sondagem de $3 \mathrm{~m}$; recuperação de $1,36 \mathrm{~m}$ :

0 - $5 \mathrm{~cm}$ - turfa com pequenos fragmentos lenhosos, grumosa, e com raizes finas atuais, não sai água, nem material da mão no teste de VỌN POST. Cor 10 YR 2/1 (preta).

5 - $51 \mathrm{~cm}$ - turfa fibrosa, com pequenos fragmentos lenhosos com até $1 \mathrm{~cm}$ de diâmetro, parecem ser pequenos caules cilíndricos, água de cor marrom média, pouco densa, isto é, há material disperso nela. Cor 10 YR 2/2(marrom muito escura). Densidade aparente: 0,10.

51 - 55,5.cm - turfa fibrosa, mais fina que a anterior, mais clara, água marrom avermelhada densa. O material que sai da mão é menos de $1 / 3$.

Cor 10 YR 2/2 (marrom muito escura).

55,5 - $61 \mathrm{~cm}$ - turfa fibrosa fina, mais clara entre todas, água com colóides amarelados, sai pouco material da mão e ficam as marcas dos dedos no que sobra.

Cor 10 YR $3 / 3$ e 2/2(marrom escura e marrom muito escura).

Densidade aparente: 0,10.

$61-74 \mathrm{~cm}$ - No topo da camada, turfa com fibras longas, perpendiculares ao furo, como acamamento, parece uma touceira fibrosa deitada, pois conecta-se com a raiz, o resto é fibrosa, mais fina. Água pouco mais clara do que a turfa que está sotoposta. Menos de 1/3 do material escapa da mão.em Cor 10 YR 2/1 (preta). Densidade aparente: 0,10.

$74-80 \mathrm{~cm}$ - turfa muito fina, parece ter argila, água marrom muito escura, muito densa. Cerca de $1 / 3$ do material é perdido da mão. O que fica detém a marca dos dedos. Cor 10 YR $2 / 1$ (preta).

$80-95 \mathrm{~cm}$ - argilosa de cor cinza escura, esverdeada, com manchas curtas de cor marrom. Cor 5 Y $3 / 1$ (cinza muito escura).

$95-108 \mathrm{~cm}$ - argila arenosa, com as outras características da anterior. Cor 5 Y 5/2(cinza oliva).

$108-114 \mathrm{~cm}$ - argila arenosa com corpos pequenos, arredondados, de areia branca. 
$114-117,5 \mathrm{~cm}$ - areia argilosa com manchas verticais, alongadas, largas constituidas apenas de areias.

$117,5-130,5 \mathrm{~cm}$ - areia com manchas alongadas, verticalizadas, de argila preta.

$130,5-136 \mathrm{~cm}$ - areia com muitos fragmentos e conchas inteiras de 2 a $5 \mathrm{~mm}$.

Quando o material ao ser espremido sai pouco da mão, naquele que sobra, fica a marca dos dedos.

Com o testemunho bem seco, vê-se que a argila arenosa encolheu-se bastante. Para o topo, a turfa, logo após o sedimento inorgânico, é preta com fragmentos avermelhados. Torna-se avermelhada para o topo, muito fibrosa. Dentro desta, parece que o tom mais vermelho (acaju-ferrugem) é dado por raízes ou pequenos troncos, isto é, material lenhoso.

\subsection{Turfeira Olvebra}

Corresponde a alguns corpos sucessivos e paralelos de turfa, situados nas depressões entre cristas praiais, com altimetria entre 8 e $9 \mathrm{~m}$.

A superfície da turfa está, aproximadamente, a $2 \mathrm{~m}$ abaixo daquela das cristas, logo, com 6 a $7 \mathrm{~m}$ de altitude.

Os depósitos que ladeiam estes corpos são arenosos e quartzosos, sugerindo pouca oferta de nutrientes emitidos para a turfeira.

A) Descrição da Turfa em Campo

Amostragem na área do reflorestamento da empresa Olvebra :

1,15 m - Aberto poço de 1,15 $\mathrm{m}$ - sendo $1,05 \mathrm{~m}$ de turfa, $0,05 \mathrm{~m}$ de argila cinza escura e $0,05 \mathrm{~m}$ de areia castanha.

- Nos 0,25 m superiores, há turfa com raízes, mais seca e de cor preta amarronzada. 
- Entre 0,25 e 0,65 m, aplicando-se o teste de VON POST, não sai água, porém, sobra na mão apenas cerca de $1 / 3$ do material. A turfa tem cor tendendo para preta.

- Entre 0,65 e 0,95 m - sai água marrom escura, mas a turfa fica inteiramente na mão. É de cor amarronzada.

B) Descrição do Testemunho em Laboratório

Testemunho coletado na mesma área da amostragem anterior. Sondagem de $2,0 \mathrm{~m}$, recuperação de $1,12 \mathrm{~m}$.

$0-4,5 \mathrm{~cm}$ - turfa mais escura, com blocos duros, úmidos, parece que tem argila pela coesão do material. Cor 2,5 YR 2,5/0(preta).

4,5 - 29,5cm - turfa fibrosa, fibras mais finas, compacta com furos finos, sem água, o material sai quase todo da mão. Cor 5 YR 2,5/1(preta). Densidade aparente: 0,07 .

29,5 - $70 \mathrm{~cm}$ - turfa fibro-esponjosa, com "raízes" ou fibras longas e finas, sai pouca água, densa, parece floculação, e metade do material escapa da mão, o que fica detém a marca dos dedos. Cor 10 YR 2/1 (preta). Densidade aparente: 0,09.

$70-75,5 \mathrm{~cm}$ - turfa macia, plástica, porém plasticidade de matéria orgânica.

Cor 10 YR 2/1 (preta).

75,5 - $86 \mathrm{~cm}$ - material semelhante a da primeira camada, na aparência de cor, isto é, tende para a cor preta, porém é mais fino, plástico, com plasticidade de matéria orgânica, macio. A cor na Carta Münsell é 10 YR 2/1(preta), porém é mais escura do que a camada acima, que tem o mesmo índice.

$86-95 \mathrm{~cm}$ - areia de cor bege escura, com muitas manchas de raízes.

$95-112 \mathrm{~cm}$ - areia de cor bege clara, com manchas geradas por raizes finas de cor marrom, que poderiam ter sido das primeiras plantas com raizes que colonizaram o local. 


\subsection{Turfeira Sanga dos Rodrigues}

Sanga dos Rodrigues é um pequeno afluente da margem esquerda do Rio Mampituba, que nasce e percorre área a leste da Lagoa do Sombrio, drenando longitudinalmente a área com turfa e os depósitos arenosos que ladeiam a turfeira.

A turfeira tem sua superfície com altitudes aproximadas de 3 a $6 \mathrm{~m}$. Trata-se de um corpò alongado entre a Lagoa do Sombrio e a Turfeira Olvebra, e paralelo a ambas.

Os terrenos arenosos laterais são de origem eólica e praial.

\section{A) Descrição da Turfa em Campo}

Amostragem realizada a algumas dezenas de metros ao norte da estrada que atravessa a turfeira:

Foi escavado um poço de $0,30 \mathrm{~m}$ de profundidade e a turfa rejeitada.

$1^{\circ} \mathrm{m}-0,65 \mathrm{~m}$ de turfa e $0,35 \mathrm{~m}$ de argila.

- Teste na turfa mostrou água de cor preta, o material de fibras finas ficou quase todo na mão.

Total $-0,90 \mathrm{~m}$ de turfa em $1,30 \mathrm{~m}$ perfurados.

\subsection{Turfeira Córrego Corrupiá}

Trata-se de turfeira pequena e alongada, situada no sopé do Morro do Soares, constituido de rochas sedimentares do Grupo Passa Dois. Localiza-se entre esta elevação de $53 \mathrm{~m}$ de altitude e um depósito arenoso pleistocênico com altitude de quase $30 \mathrm{~m}$, sendo o mesmo depósito arenoso citado na descrição da Turfeira Caverá.

Sua superfície situa-se entre 10 e $20 \mathrm{~m}$ de altitude.

O Córrego Corrupiá é pequeno afluente do Rjo Itoupava/Araranguá, que deságua a leste da localidade de Ermo. 


\section{A) Descrição do Testemunho em Laboratório}

Testemunho coletado a nordeste do Morro do Soares. Sondagem de $2,0 \mathrm{~m}$, recuperação de $0,66 \mathrm{~m}$.

0 - 11,5 cm - material orgânico argiloso, em blocos e incoerente.

11,5 -26 cm - argila orgânica plástica, com aspecto colunar, mais seca que a camada superior. Cor 5 YR 2,5/1(preta). Densidade aparente: 0,91

$26-62,5 \mathrm{~cm}$ - material brilhante ao corte do fio de nylon, argiloso, com fragmentos percebiveis de vegetação (gramíneas). Cor 10 YR $3 / 1$ (cinza muito escura).

$62,5-65,5 \mathrm{~cm}$ - areia argilosa, fina e brilhante.

\subsection{Turfeira Rio do Sertão}

Trata-se de uma área ao longo do Rio do Sertão, ao sul do Banhado do Sombrio, que apresenta em grande parte turfa soterrada sob camada de sedimentos inorgânicos, de espessura variada, que nas sondagens indicou ser de 0,0 a 0,70 m. A espessura da turfa também varia de 0,50 a 0,60 m. O recobrimento é principalmente com argila cinza escura, muito plástica, produto das cheias do rio, por situar-se a turfa na área da planície de inundação atual do referido rio.

\subsection{Outras Turfas Soterradas}

Uma camada de cerca de 0,30 m de material turfoso e denso está intercalada nos sedimentos da margem oeste da Lagoa do Sombrio, sob depósitos de cristas praiais desta lagoa .

Devem existir outras áreas de turfas soterradas, como acontece com áreas intercristas praiais, a leste das lagoas recobertas com material eólico, ou mesmo nas margens da Turfeira Caverá. 
Testemunho obtido em uma crista praial da Lagoa do Sombrio, na margem oeste. Sondagem de $2,0 \mathrm{~m}$, recuperação $0,73 \mathrm{~m}$ :

0 - $6 \mathrm{~cm}$ - areia com raízes. Cor 7,5 YR 5/2(marrom).

6 - $17 \mathrm{~cm}$ - areia com manchas arredondadas de cor marrom. Cor 10 YR 5/3 (marrom).

$17-22 \mathrm{~cm} \quad$ - areia de cor marrom, com algumas manchas bege, de tons variados e preta.

$22-35 \mathrm{~cm} \quad$ - areia com cor 5 YR 2,5/1(preta).

$35-40 \mathrm{~cm}$ - areia marrom clara, com manchas bege, é uma camada de transição entre a anterior e a que segue.

$40-51 \mathrm{~cm}$ - areia bege-marrom, com manchas difusas. Cor 7,5 YR 4/2(entre marrom escura e marrom).

$51-63 \mathrm{~cm}$ - areia de cor bege clara, com estratificação na base constituída de intercalações desta areia com material de cor preta e marrom. Cor 10 YR 6/3(marrom pálido).

$63-67 \mathrm{~cm}$ - material orgânico, argiloso. Cor 5 YR 2,5/1 (preta em tom mais escuro). O adensamento transformou o material com $0,30 \mathrm{a0}, 40 \mathrm{~m}$ de espessura em apenas $0,04 \mathrm{~m}$.

$67-73 \mathrm{~cm}$ - areia fina, estratificada, com camadas milimétricas, mais escura para a base, manchada com hidróxido de $\mathrm{Fe}$. A estratificação é dada pelas camadas de tons de cor marrom.

\subsubsection{Solos das Turfeiras}

As turfeiras em Santa Catarina, do ponto de vista pedológico, são classificadas na categoria de solos orgânicos, com o nome regional ou unidade de mapeamento chamada Gravatal, por ter o perfil referência sido analisado na área entre Tubarão $e$ Gravatal. 
De acordo com LEMOS et al., (1973), estes solos são classificados como "Histosol Dystric Histosol", que

"São solos orgânicos, formados pela sucessão de gerações vegetais depositadas nos pântanos e banhados. (...)

O perfil de um solo orgânico, portanto, é caracterizado por camadas diferentes que, com o tempo poderão tornar-se horizontes de solo.

Normalmente, apresentam uma seqüência de duas camadas, até atingir o lençol freático.

Quimicamente, são fortemente ácidos, com teores bastante elevados de alumínio trocável. A saturação de bases é baixa e os teores de matéria orgânica são superiores a $20 \%$ (condição para que um solo seja considerado orgânico).

A primeira camada apresenta-se mais decomposta que a inferior (...)

Segundo os autores supracitados, estes solos ocupam uma área de 29.500 ha no Estado de Santa Catarina, correspondendo 0,3\% do território total.

Trabalhos mais recentes, especialmente sobre a área da Bacia do Rio Mampituba e a oeste da Lagoa do Sombrio, foram efetuados por KLAMT et al. $(1978,1980)$.

KLAMT et al. (1978) classificam os solos da área segundo o sistema em uso no "Centro Nacional de Levantamento e Conservação do Solo" da EMBRAPA, relacionando-os com o Sistema Compreensivo Americano - Soil Taxonomy, EUA, de 1975.

Turfa e solos com turfa foram enquadrados por estes autores, nas categorias de Ordem, Subordem, Grande Grupo, Subgrupo, Família e Fase.

$\mathrm{Na}$ categoria de Ordem os solos orgânicos são todos enquadrados como "solos pouco desenvolvidos", e as unidades principais de mapeamento são: Gravatal, Rio do Sertão e Juncal.

O solo Gravatal apresenta a seguinte identificação e classificação :

Subordem: Hidromórfico/Argila de Atividade Alta.

Grande Grupo: Orgânico

Subgrupo: Distrófico

Família: Turfosa 
Fases - Relevo: plano

- Substrato: sedimentos orgânicos.

Subgrupo do "Soil Taxonomy": "Hydric medihemist"

Esta classificação é modificada por KLAMT et al. (1980b) para:

Ordem: solos orgânicos

Subordem: hidromórficos

Grande Grupo: -

Subgrupo: eutrófico

Família: turfoso

Fases - Relevo: plano

- Substrato: sedimentos orgânicos

Subgrupo da "Soil Taxonomy" : "Typic Medisaprist"

É bom realçar que estes solos, no nível de Ordem, foram enquadrados em ordem própria. A posição anterior como "solos pouco desenvolvidos" era uma subordinação à classificação usada para solos inorgânicos. Os técnicos não faziam diferença.

O seguinte solo mais importante com turfa é o da unidade de mapeamento Rio do Sertão. Havia sido classificado por KLAMT et al. (1978), como:

Subordem: Hidromórfico/argila de atividade baixa

Grande Grupo: Gley pouco húmico

Subgrupo: eutrófico

Família: argilosa

Fases - Relevo: plano

- Substrato: sedimentos argilosos e orgânicos

Subgrupo da "Soil Taxonomy": "Thapto-Histic fluvaquent"

Mas, na classificação de KLAMT et al. (1980b), esta unidade é identificada até a categoria das fases, na qual item relevo é o mesmo do solo Gravatal, e o item substrato do 
solo Rio do Sertão corresponde a sedimentos argilosos e arenosos. Na aplicação da "Soil Taxonomy" do Sistema Americano, a unidade Rio Sertão está situada como Fluvaquentic Medisaprist.

De acordo com RUFAS (1986), o solo Gravatal ocupa, na bacia do Rio Mampituba, incluindo a parte no Estado do Rio Grande do Sul, uma área de 3.521 ha. Associado com os solos Rio Sertão, aumenta mais 1.461 ha.

O solo Gravatal, no extremo sul de Santa Catarina, apenas dentro do Sub-Projeto Sombrio, cobre uma área de cerca de 2.066 ha. Este é encontrado em associação com outros tipos de solo. Naquela associação em que constitui o solo Rio do Sertão, há mais 161 ha do solo Gravatal e, portanto, de turfa. Porém, há ainda outros pequenos corpos junto com outros tipos de solo (KLAMT et al. 1978).

A Unidade Gravatal, de acordo com estes autores, apresenta as seguintes características: o lençol freático na superfície ou quase na superfície, oscilando durante o ano; o Horizonte $O$ é preto ou bruno muito escuro, espesso, pois alcança até mais de $3 \mathrm{~m}$, predominantemente orgânico; as fibras vegetais são parcial ou totalmente decompostas, isto é, os perfis apresentam matéria orgânica em diferentes estágios de decomposição; a contribuição inorgânica é pequena; o Horizonte $O$, com mais de $1,50 \mathrm{~m}$, é subdividido em Oa e Oe; a cor preta no Oa passa à bruna muito escura no 0 e1 e Oe2, e à cinza muito escura no Oe3; o Horizonte Oa é sáprico e tem menos de 1/3 do volume não decomposto, e o Oe é hêmico, com menos de $2 / 3$ do material não decomposto; no Oa, há uma estrutura moderadamente desenvolvida e no Oe é maciça, fibrosa; a consistência do Oa é friável, não plástico e não pegajoso. Também o Oe1 é não plástico e não pegajoso, porém o restante do Oe é ligeiramente plástico e ligeiramente pegajoso (KLAMT et al. 1978).

Do ponto de vista da aptidão agrícola, o solo Gravatal é classificado como tendo apenas ligeira deficiência da "fertilidade natural", isto é, trata-se de um solo com boas reservas de nutrientes disponíveis às plantas. A saturação de bases é superior a $35 \%$, a saturação com Al é inferior a $50 \%$, e a soma das bases trocáveis é superior a $3 \mathrm{me} / 100 \mathrm{~g}$ de solo. A deficiência em água é nula, isto é, a disponibilidade da água não constitui limitação para o desenvolvimento das culturas, não ocorrendo época seca. 
O excesso de água é muito forte, significando que, para as plantas não adaptadas ao excesso de água, só a drenagem artificial é que possibilitará seu desenvolvimento. A suscetibilidade à erosão é também nula, pois o seu relevo é plano, com infiltração rápida e permeabilidade na horizontal, moderadamente lenta, com alta capacidade de armazenar águas e nutrientes. O impedimento à mecanização é muito forte, o que significa que esses solos não podem ser usados para a agricultura ou o serão com grande dificuldade (KLAMT et al. 1978).

A utilização desses solos e os sistemas de manejo, de acordo com os autores acima mencionados, estarão de acordo com sua aptidão que é boa para culturas de ciclo curto, porém regular, para aquelas de ciclo longo, em sistema de manejo transicional, isto é, com práticas que reflitam nível razoável de conhecimento técnico. O sistema pode ser deste para o avançado, isto é, naquele em que as práticas agrícolas estejam condicionadas a um alto nivel tecnológico, principalmente no que concerne com o controle do nível do freático.

Os mesmos autores afirmam que, quando estes solos estão adequadamente drenados, ou seja, com um sistema bem planejado que permita controlar o nível do lençol freático, para evitar a subsidência do solo e sem riscos de inundação, então eles estarão aptos para cultivo de milho, feijão, arroz, cana-de-açúcar, mandioca, cenoura, beterraba, alface, repolho, agrião, aipim, tomate, chicória, radiche, couve comum, couve-flor, mostarda, nabo, pepino, rabanete e pastagens com espécies aptas ao solo úmido. $O$ cultivo deve ser em pequenas áreas, ao passo que a exploração em grandes áreas deve ser restrita à pecuária com uso de pastagens melhoradas. Não recomendam a silvicultura ou a fruticultura. A mecanização deverá se restringir a implementos de tração animal, microtratores e mão-de-obra manual.

A Unidade Rio do Sertão, situada nas laterais do Rio do Sertão, compreende uma área de 271 ha, acrescendo-se aquela já referida em associação com o solo Gravatal, correspondendo a 161 ha.

Os solos desta unidade constituem-se de sedimentos aluviais argilosos, depositados sobre turfa. A espessura do material inorgânico é variável e também do material orgânico que se encontra com diversos graus de decomposição (KLAMT et al. 1978). 
A camada de turfa com $0,60 \mathrm{~m}$ no perfil amostrado, passa da cor preta para bruna muito escura e à bruna acinzentada muito escura. Aumenta também a decomposição com a profundidade, e a consistência passa de ligeiramente plástica e ligeiramente pegajosa para não plástica e não pegajosa. A estrutura é maciça, fibrosa. Esta camada, depois de uns $25 \mathrm{~cm}$, passa a ser mais decomposta.

KLAMT et al. (1980a), em levantamento de solos especial para o Banhado do Sombrio, repetem que o Solo Gravatal corresponde a solos orgânicos distróficos, com textura turfosa, relevo plano e substrato de material orgânico. O enquadramento no sistema americano se faz com pequena mudança, pois é classificado como "Thermic Hydric Medihemist". Ocupa uma área de 1.564 ha. A descrição é semelhante à apresentada anteriormente, esclarecendo-se que, no Horizonte Oa, o material é bem decomposto, e nos Horizontes Oe, ele está parcialmente decomposto, apresentando fibras, fragmentos de galhos e troncos pouco decompostos.

\subsubsection{A Vegetação das Turfeiras}

As duas maiores turfeiras estudadas, a do Banhado do Sombrio e a Caverá, apresentavam até há poucos anos, grandes áreas com vegetação arbórea, mas hoje encontram-se em grande parte desmatadas. O desmatamento da primeira turfeira ocorreu em função do Subprojeto Sombrio, e o da segunda turfeira deu-se pela extração da turfa pela COMINAS, para uso como combustível, em indústria cerâmica em Tubarão.

Vegetação arbórea desenvolve-se nas turfeiras do Rio do Sertão, Três Coqueiros e Banhado Piritu. Provavelmente ocorria também na área do Córrego Corrupiá. Na Turfeira do Banhado Piritu, a área com vegetação arbórea sempre foi pequena e hoje é menor, pelo desmatamento para uso da mesma como lenha.

Esta vegetação pertence à chamada Mata Tropical Atlântica ou mata pluvial. Entretanto, não é apenas este tipo de vegetação que ocorre nas turfeiras, pois nelas vive também vegetação específica de ambientes aquosos, mal drenados. 
ULE (1900) talvez tenha sido um dos primeiros a registrar turfas e turfeiras em vários estados brasileiros e a estudar os musgos deste ambiente. Este autor, como professor de escolas alemãs em São Francisco do Sul, Itajaí, Florianópolis e Tubarão, coletava este material desde antes de 1897, quando C. WARNSTORF publicava na Revista Hedwigia, material enviado por ULE.

ULE (1900) descreve que é justamente no sul de Santa Catarina, que as formações em que crescem os musgos de turfa adquirem um caráter peculiar. Espaços amplos e planos compreendem locais arenosos, lagoas e regiões pantanosas e, na passagem entre os locais alagados e os secos, ocorrem arbustos e campos turfosos. Estes eram conhecidos pela população, como "costa de campos".

Este autor relata que "os arbustos característicos aqui são: Ternstroemia brasiliensis Camh., Byrsonima lingustrifolia Juss., Myrsine rapanea Roem. et Schult., Ilex pseudobxuus, I. thelzans Mart., Ocotea pulchella Mart., Psidium cattleyanum Sabine, Gaylussacia brasiliensis Meissn. e muitos outros".

Acrescenta os musgos turfosos que se apresentam em estofos esponjosos: Sphagnum puigganii C. Müll., S. purpuratum C. Müll., S. medium Limpr. e S. recurvum var. pulchricoma (C. Müll.).

Além destes, registra a presença das gramíneas: Andropogon, Panicum, Paspalum e ciperáceas do gênero Rhynchospora; eriocauláceas: Paepalanthus, Erynegium ebracteatum Lam.; melastomatáceas: Rhynchanthera cordata DC., Polygala paludosa St. Hil., às quais se juntam, nos lugares mais esponjósos, Androtrichum polycephalum Kth., Xyris; pequenas Utricularia, Eriocaulon e Sagittaria. Afirma que aparecem freqüentemente regiões com Sphagnum; Sphagnum subtursum C. Müll., S. subbrachycladum C. Müll;; $S$. acyphyllum C. Müll.; S. brachybolax C. Müll. e S. Oxyphyllum Warnst. var. nanum (C. Müll.).

REITZ (1961) afirma que, nos seus trabalhos sobre a vegetação da zona marítima, entrou em contato com turfeiras, especialmente na zona sul do Estado. Ele a chama de vasta zona, pois a área toda estava compreendida pelo Município de Sombrio de 1961, além do distrito de Praia Grande de então. Entre 1944 e 1945 fez muitas excursões de 
estudo 'e coleta na área. Este autor classifica a vegetação das turfeiras dentro da hidrossera de água doce ou Helossera. Ele declara que as plantas hidrófitas têm um grande poder de adaptação e que elas estão mais sujeitas às vicissutudes meteorológicas, no que concerne à precipitação, devendo ser flutuantes nas épocas de cheias e fixas nos tempos de secas, o que torna difícil estabelecer sua classificação como flutuantes ou fixas. Afirma que os lagos, as margens dos rios e sangradouros da área apresentam algas de grupos distintos. As diatomáceas chegavam em certas épocas de proliferação, "a turvar a água pela sua enorme quantidade". Divide esta flora em : flora de etapa submersa, etapa flutuante, etapa das ciperáceas, etapa das turfeiras, etapa paludosa, etapa brejosa e etapas subseqüentes.

A vegetação de todas essas etapas, talvez com dúvidas para a última, contribuíram e contribuem para o acúmulo da turfa, vertical e lateralmente.

Este autor cita como exemplos vegetais da etapa das turfeiras, que são arbustos como Ternstroemia brasiliensis, Leucothöe numularia, Gaylussacia brasiliensis, Psidium littorale, Ilex pseudobuxus, Ilex theezans, Byrsonima ligustrifolia, Ocotea pulchella e Pera glabrata, no meio dos quais "se formam turfeiras bem desenvolvidas". Esses elementos parecem fazer parte das turfeiras nos espaços interdunas e intercristas praiais.

Continua o mesmo autor dizendo que o principal elemento destas formações é o musgo Sphagnum, com doze espécies, mas que, entremeadas a este musgo, crescem muitas outras plantas.

Como exemplo do papel que desempenharam ou que devem desempenhar as outras etapas, lembrava-se aquele das ciperáceas. Elas têm preferência pelas áreas relativamente rasas dos banhados. "Estes lugares, no entanto são bastante ricos em matérias orgânicas em decomposição quer de plantas mortas locais, quer de plantas arrastadas pelos rios" (REITZ, 1961). Uma das espécies que, no entender deste autor é mais ativas, causadora dé entulhamentos de margens de corpos de água maiores ou menores, é a Fuirena robusta, conhecida como "peri", que dá nome a uma pequena lagoa, hoje colmatada e drenada, que é conhecida como Piritu. Este nome é usado para a localidade e para acidentes geográficos como o Banhado do Piritu. Mas, ocorre 
também na área, Cyperus giganteus Vahl nos banhados de água funda cujo tamanho vai de 1 a $3 \mathrm{~m}$. Outros exemplos são a Lagenocarpus giganteus Pfeiffer, conhecida como tiririca, a Rhynchospora polycephala Wydl. ex-Kunth e o Scirpus giganteus Kunth. Todas contribuem e devem ter contribuido para formar as turfeiras.

Os agrônomos que fizeram o "Levantamento de Reconhecimento dos Solos do Estado de Santa Catarina" (LEMOS et al. 1973) relataram que as matas situadas nas áreas de solos orgânicos, isto é, das turfeiras, apresentam o Arescastrum rommanzoffianum, conhecido como coqueiro, os guamirins representados pelas Myrcia dichrophylla e Myrcia glabra; o Ficus organensis ou figueira-da-folha-miúda; a Tabebuia umbellata, conhecida como ipê-amarelo. Estes dois últimos é que sobressaem. Porém, esclarecem que esta formação vegetal está sendo substituída por campos de gramineas.

KLAMT et al. (1980a) afirmam que a vegetação natural sobre a turfeira no Banhado do Sombrio é predominantemente mata nativa, densa, com espécies arbóreas de porte baixo, médio e alto, representadas por mirtáceas, figueiras, ipê-amarelo, coqueiro, entre outras. Estas estão intercaladas com tucum, juncos e bromélias em grande quantidade, e formam os estratos inferiores da mata. Entretanto, está sendo intensamente desmatada para uso como lenha nas estufas de fumo. Sobre estas áreas desmatadas, há o cultivo de arroz, mitho, mandioca e pastagens ou, caso contrário, desenvolve-se vegetação arbustiva secundária, de brejo.

Segundo RUFAS (1986), no Banhado do Sombrio, "após o desmatamento, se o solo não estiver sob cultivo, surge uma vegetação secundária de grama larga, grama boiadeira, juncos, tiririca, rabo de burro, pega-pega, lambe papo, vassourinha e várias gramineas dos gêneros Paspalum e Asconopus".

A Figura 155 mostra as áreas de matas em 1979, na área da Turfeira Banhado do Sombrio, Turfeira Rio do Sertão e adjacências. Hoje o quadro é bem distinto. 


\subsubsection{Algumas Características Climatológicas}

O clima é considerado como um fator que favorece a formação das turfas e para alguns é até determinante da sua existência. Alguns elementos do clima, como a precipitação pluviométrica, a temperatura e a evapotranspiração, podem ajudar a entender as condiçōes de acúmulo e transformação da matéria orgânica.

No que se relaciona às condições da turfa, do ponto de vista agrológico, a probabilidade de déficits maiores da capacidade de armazenamento de água ocorre nos meses de novembro-dezembro-janeiro (SUDESUL, 1978). Esses déficits ou os excessos hídricos são calculados dentro de balanços hídricos que usam a evapotranspiração e a capacidade de armazenamento do solo. Mas, são cálculos muito teóricos, pois no ano de 1978, o que se sabia do solo Gravata! era muito pouco. De qualquer forma, os meses de agosto e setembro serão aqueles com menor probabilidade de déficit, isto é, com maior probabilidade de excesso, do ponto de vista agronômico.

Porém, no que se relaciona ao clima, deve-se levar em conta questões ainda não completamente explicadas, pois, como afirma TATSCH (1980), a turfa acumula-se em bacias lacustres mal drenadas, desde o Ceilão e Sumatra até as turfeiras Árticas, onde o solo é permanentemente congelado. Os produtos da decomposição acumulam-se sob condições de decomposição retardada, exigindo um nível freático alto, combinado com condições próximas da saturação, em pelo menos parte do ano. Assim, a formação da turfa é mais dependente da água do que da temperatura. Porém, os depósitos tropicais parecem estar mais permanentemente encharcados do que aqueles das regiões boreais. No nordeste da Austrália, camadas de turfa lenhosa ocorrem em ambientes deltáicos áridos, interdigitada com depósitos arenosos de canal, evaporitos e sedimentos de planície de maré.

HUNT \& HOBDAY (1984) afirmam que alguns ecossistemas de turfeiras apresentam uma forte inércia e um estado tampão, mesmo para mudanças climáticas importantes, mas, em outros casos, pequenas mudanças no clima podem causar inesperadamente grandes mudanças nestes ecossistemas. $O$ efeito do clima pode ser 
extremamente variável, além de estar de modo freqüente, inextrincavelmente ligado a fatores geológicos e edáficos.

Segundo McCABE (1984) muitas das vastas turfeiras da Sibéria e do Canadá recebem menos que $500 \mathrm{~mm}$ de precipitação por ano. Embora este autor não afirme a presença de turfa no Sudão, Nigéria, Chad ou Iraque, ele lembra que há pântanos extensos, associados com rios e lagos, em regiöes áridas ou sazonalmente secas,onde a turfa poderia ocorrer. A região Sudd, do Sudão meridional, é uma extensa área pantanosa, de gradiente muito baixo, nos trechos superiores do Nilo. Nela grandes áreas de savana são inundadas durante a estação úmida, a despeito da precipitação insignificante. Essas condições persistem para numerosos canais fluviais ao longo do ano. A própria vegetação do pântano bloqueia muitos canais. Outra área de pântanos em climas áridos ocorre em torno da confluência dos rios Tigre e Eufrates, no Iraque, e na área em torno do Lago Chad, na Nigéria e no Chad.

BRENNER et al. (1978) estudaram turfas localizadas no vale do Rio Hula, em Israel. Trata-se de uma região com bastante água, pantanosa, no vale do Jordão setentrional, dentro do rift do Jordão-Arava. A pluviosidade na área é de $600 \mathrm{~mm}$ por ano e quase exclusivamente no inverno, apresentando, portanto, condições de semi-aridez. As perfurações efetuadas na área alcançaram $300 \mathrm{~m}$ e revelaram quatro camadas de turfa. $A$ turfa ativa tem em média 4 a $6 \mathrm{~m}$ de espessura, porém, alcança até $8 / 9 \mathrm{~m}$, e uma amostra coletada a $3,9 \mathrm{~m}$ forneceu uma idade de $2.480 \pm 100$ anos A.P. São 4.000 ha de turfa, que constitui a principal fonte de nitratos para o Rio Jordão, com possíveis efeitos desastrosos na eutroficação do Lago Kineret (Mar da Galiléia). As quatro camadas de turfa sugerem condições propícias ao acúmulo de turfa, em ambiente tectonicamente ativo, pois a quarta camada está entre $281 \mathrm{~m}$ e $292 \mathrm{~m}$ de profundidade. A segunda camada foi datada por duas amostras coletadas entre $48,5 \mathrm{~m}$ e $54 \mathrm{~m}$ de profundidade que deram idades de $32.900 \pm 800$ A.P. e 35.000 anos A.P. Embora possa ter havido mudança climática, a turfa não deixou de se desenvolver até os dias atuais. 


\subsubsection{Características Físico-Químicas}

As características físico-químicas das turfas do extremo sul de Santa Catarina, devido à limitação dos laboratórios, restringem-se a poucos parâmetros.

Além dos dados de campo já apresentados, foram realizadas análises imediatas de 52 amostras e análises químicas de solo em 42 amostras. Foram calculadas a densidade aparente a seco ou DBD (dry bulk density) e a densidade aparente a úmido de 29 amostras.

As análises imediatas compreenderam as determinações dos teores de água, apresentados como umidade livre e umidade higroscópica, os teores de cinzas, o poder calorífico superior (PCS) e análises elementares. Estas últimas constituíram-se na determinação de matérias voláteis, carbono, hidrogênio, nitrogênio e enxofre, todos em base seca. O hidrogênio e o nitrogênio foram medidos apenas em 18 amostras, também em base seca. Com os dados obtidos, foram calculados os teores de oxigênio, o poder calorífico superior e o poder calorífico inferior, para efeito de comparação. Os dois primeiros foram calculados apenas para 18 amostras e o último para todas as amostras. Os teores de cinzas e o poder calorífico superior foram também medidos em base seca.

As análises químicas de solo serão apresentadas em outro sub-título.

O conjunto dos resultados das "análises imediatas" são apresentados na Tabela 83.

\subsection{Turfeira Banhado do Sombrio}

Considerando-se o tamanho desta turfeira, suas características geológicas e seu uso planejado pela SUDESUL, nela foi coletado o maior número de amostras para análises imediatas, isto é, 17 amostras.

Os dados dispostos na Tabela 84 como amostras TBS, demonstram que a umidade livre varia de $69,9 \%$ a $92,90 \%$. A maior variação e os valores mais baixos são observados no conjunto de amostras coletadas em março. A variação é menor no conjunto coletado em julho. 
244

TABELA 83 - Resultados das Análises Imediatas, PCS, PCS calculado, PCi sobre Umidade Higroscópica e Livre, Cor da turfa moída.

Amostra Prof UL UH CZ MV $\mathrm{C} \quad \mathrm{H} \quad \mathrm{N}$ Stot $O$ PCS PCScalc PCIUL PCIUH CORdoPo C/N

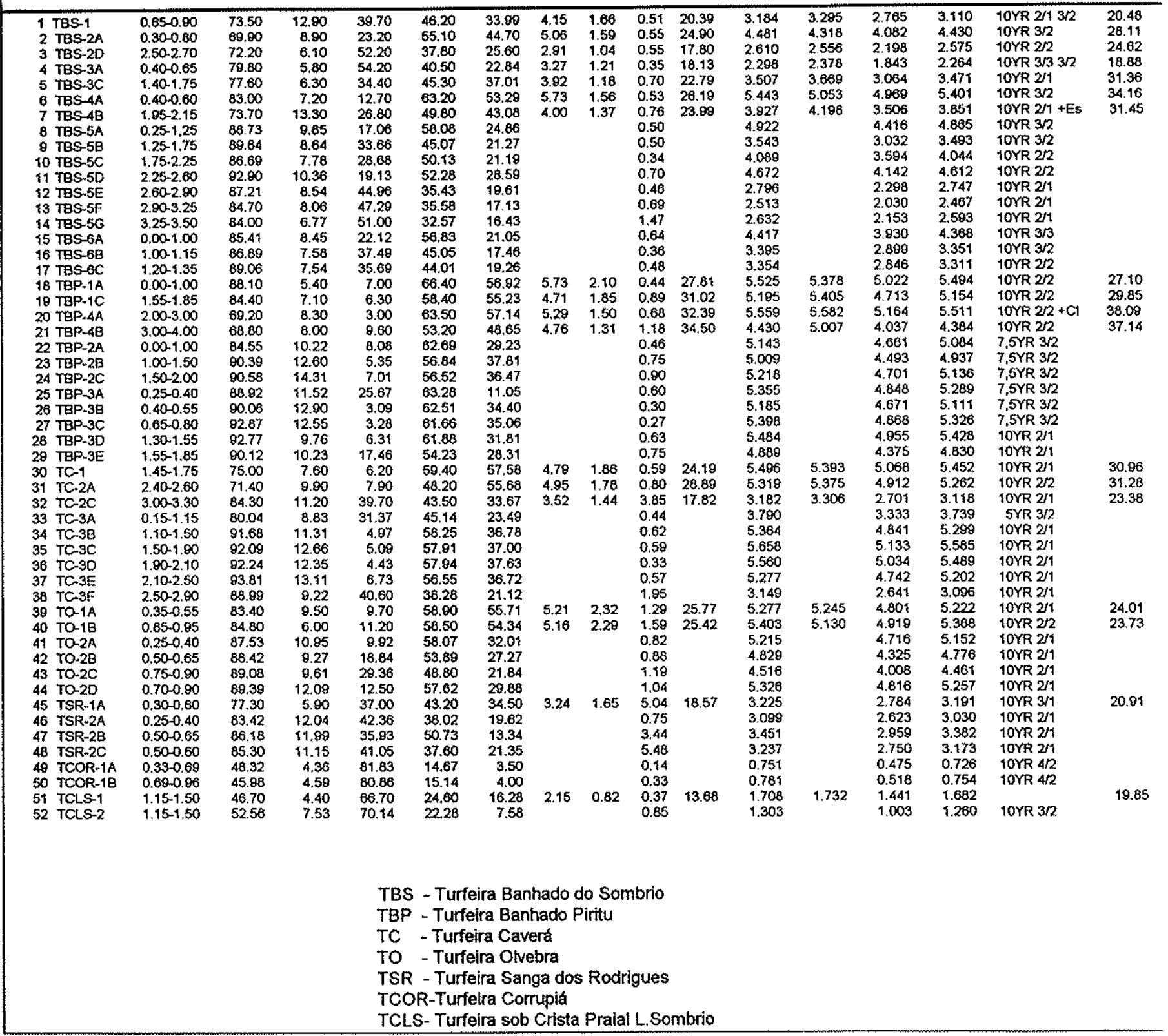




\begin{tabular}{|c|c|c|c|c|c|c|c|c|c|c|c|c|}
\hline \multirow{2}{*}{$\begin{array}{l}\text { TABELA } 84 \\
\text { Amostra }\end{array}$} & \multicolumn{12}{|c|}{$\begin{array}{l}\text { - Resultados das Análises Imediatas PCS, PCS calculado, PCi sobre umidade } \\
\text { livre de amostras de turfa da Turfeira Banhado do Sombrio. }\end{array}$} \\
\hline & Umiliv & UmiHig & Clnzas & MV & Cbs & $\mathrm{Hbs}$ & Nbs & Sbs & 0 & PCS & PCScalc & $\mathrm{PCl}$ \\
\hline $1 \mathrm{MBi}-\mathrm{N}-1$ & 73.5 & 12.9 & 39.7 & 46.2 & 33.6 & 4.2 & 1.7 & 0.5 & 20.4 & 3.184 & 3.295 & 2.614 \\
\hline $2 M B i-N+E-3$ & 69.9 & 8.9 & 23.2 & 55.1 & 44.7 & 5.1 & 1.6 & 0.6 & 24.9 & 4.481 & 4.318 & 3.911 \\
\hline $3 \mathrm{MBi}-\mathrm{N}+\mathrm{E}-6$ & 72.2 & 6.1 & 52.1 & 37.8 & 25.6 & 2.9 & 1.0 & 0.6 & 17.8 & 2.610 & 2.556 & 2.040 \\
\hline $4 M B i-N+S-1$ & 79.8 & 5.8 & 54.2 & 40.5 & 22.8 & 3.3 & 1.2 & 0.4 & 18.1 & 2.298 & 2.378 & 1.728 \\
\hline $5 \mathrm{MBI}-\mathrm{N}+\mathrm{S}-3$ & 77.6 & 6.3 & 34.4 & 45.3 & 37.0 & 3.9 & 1.2 & 0.7 & 22.8 & 3.507 & 3.660 & 2.937 \\
\hline 6 BIE-1m & 88.7 & 9.9 & 17.1 & 58.1 & 24.9 & & & 0.5 & & 4.922 & & 4.352 \\
\hline 7 BIE-2m-To & 89.6 & 8.6 & 33.7 & 45.1 & 21.3 & & & 0.5 & & 3.543 & & 2.973 \\
\hline 8 BIE-2m-Ba & 86.7 & 7.8 & 28.7 & 50.1 & 21.2 & & & 0.3 & & 4.089 & & 3.519 \\
\hline $9 \mathrm{BIE} 3 \mathrm{~m}-\mathrm{TO}$ & 92.9 & 10.4 & 19.1 & 52.3 & 28.6 & & & 0.7 & & 4.672 & & 4.102 \\
\hline $10 \mathrm{BIE}-3 \mathrm{~m}-\mathrm{Me}$ & 87.2 & 8.5 & 45.0 & 35.4 & 19.6 & & & 0.5 & & 2.796 & & 2.226 \\
\hline $11 \mathrm{BIE}-3 \mathrm{~m}-\mathrm{Ba}$ & 84.7 & 8.1 & 47.3 & 35.6 & 17.1 & & & 0.7 & & 2.513 & & 1.943 \\
\hline 12 BIE-4m-To & 84.0 & 6.8 & 51.0 & 32.6 & 16.4 & & & 1.5 & & 2.632 & & 2.052 \\
\hline $13 \mathrm{MBI}-\mathrm{SE}-1 \mathrm{~m}$ & 85.4 & 8.5 & 22.1 & 56.8 & 21.1 & & & 0.6 & & 4.417 & & 3.847 \\
\hline $14 \mathrm{MBI}-\mathrm{SE} 2 \mathrm{mT}$ & 86.9 & 7.6 & 37.5 & 45.1 & 17.5 & & & 0.4 & & 3.395 & & 2.825 \\
\hline $15 \mathrm{MBI}-\mathrm{SE} 2 \mathrm{mM}$ & 89.1 & 7.5 & 35.7 & 44.0 & 19.3 & & & 0.5 & & 3.354 & & 2.784 \\
\hline 16 Matio-1 & 83.0 & 7.2 & 12.7 & 63.2 & 53.3 & 5.7 & 1.6 & 0.5 & 26.2 & 5.443 & 5.053 & 4.873 \\
\hline 17 Matio-4 & 73.7 & 13.3 & 26.8 & 49.8 & 43.1 & 4.0 & 1.4 & 0.8 & 24.0 & 3.927 & 4.198 & 3.357 \\
\hline
\end{tabular}

Os valores de cinzas situam-se entre $12,7 \%$ a $54,2 \%$ e são mais baixos nas amostras do segundo conjunto, mas o poder calorífico superior tem uma variação similar em ambos. O PCS variou de $2.298 \mathrm{kcal} / \mathrm{kg}$ a $5.443 \mathrm{kcal} / \mathrm{kg}$. Os valores de PCS calculado mostrou que não são muito diferentes daqueles do PCS medido. Alguns dos valores calculados estão abaixo e outros acima daqueles medidos.

$O$ diagrama $X-Y$ de dispersão dos valores de cinzas versus poder calorífico superior evidencia um arranjo linear. A regressão linear aplicada (Figura 156) demonstra que estes dois parâmetros têm um elevado coeficiente de correlação negativa, isto é, $r=-0,99$ constituindo-se em $97,37 \%$ de correlação.

MORAES (1982) apresenta dados de 872 amostras de turfas do Triângulo Mineiro que evidenciam por meio de um diagrama, esta mesma correlação, porém os valores de cinzas são iguais ou mais altos que os encontrados nas turfas do sul do Estado, e apenas 
um valor do poder calorífico superior fica acima das $5.000 \mathrm{kcal} / \mathrm{kg}$, como é o caso também da turfa do Banhado do Sombrio. ROCHA \& GONÇALVES (1982) apresentam a correlação entre estes dois parâmetros por um diagrama, baseados em 30 amostras de turfas da Bahia. LIMA et al. (1982) também apresentam dados da correlação desses mesmos parâmetros, em turfas da costa da Bahia, porém sem os seus valores numéricos.

A quantidade de cinzas é um inibidor às aplicações energéticas da turfa, pois as matérias inorgânicas nela contidas não são combustíveis e são prejudiciais na coqueificação desse material.

O diagrama múltiplo (Figura 157), com base no PCS medido, mostra que o enxofre, com valores de $0,34 \%$ a $1,47 \%$ não afetou significantemente os limites do PCS, porém, a pequena variação verificada, foi maior em valores de PCS mais baixos.

Os valores de enxofre obtidos são coerentes com o tipo de turfeira low-moor ou turfeira baixa, segundo alguns autores.

O carbono tem uma correlação positiva com o PCS, mas com alta variação de seu teor (Figura 157). Seu conteúdo varia de 16,43\% a 53,29\%. Os melhores combustíveis devem ser ricos em carbono e pobres em oxigênio.

As matérias voláteis também apresentam uma correlação positiva, e os seus teores variam de $32,57 \%$ a $63,2 \%$ (Tabela 84 e Figuras 157 e 158).

A umidade higroscópica apresentada pelas amostras tem pequena variação, o que não acontece com a umidade livre.

O diagrama tridimensional (Figura 159) com as variáveis PCS, umidade livre e cinzas demonstra uma pequena concentração de amostras com umidade livre entre $81 \%$ a $89 \%$, e cinzas de $20 \%$ a $40 \%$, porém com grandes variações do PCS.

\subsection{Turfeira Banhado Piritu}

Foram determinados os valores das análises imediatas para 12 amostras (Tabela 85). 


\begin{tabular}{|c|c|c|c|c|c|c|c|c|c|c|c|c|}
\hline TABELA 85 & $\begin{array}{c}\text { - Resu } \\
\text { livre }\end{array}$ & $\begin{array}{l}\text { ultados } \\
\text { de ams }\end{array}$ & $\begin{array}{l}\text { das A } \\
\text { ostras }\end{array}$ & $\begin{array}{l}\text { Inális } \\
\text { de to }\end{array}$ & $\begin{array}{l}\text { es Im } \\
\text { rfa d }\end{array}$ & $\begin{array}{l}\text { ediat } \\
\text { a Tur }\end{array}$ & $\begin{array}{l}\text { as, P } \\
\text { feira }\end{array}$ & $\begin{array}{l}\text { CS, } \\
\text { Ban }\end{array}$ & $\begin{array}{l}\text { CS ca } \\
\text { ado } P\end{array}$ & $\begin{array}{l}\text { culado, } \\
\text { ritu. }\end{array}$ & PCis & bre umidade \\
\hline Amostra & Umiliv & UmiHtg & Cinzas & MV & Cbs & Hos & Nbs & Sbs & PCS & PCScalc & 0 & $\mathrm{PCl}$ \\
\hline 1 DAE-1m-1 & 88.1 & 5.4 & 7.0 & 66.4 & 56.9 & 5.7 & 2.1 & 0.4 & 5.525 & 5.378 & 27.8 & 4.955 \\
\hline 2 DAE- $2 m-3$ & 84.4 & 7.1 & 6.3 & 58.4 & 55.2 & 4.7 & 1.9 & 0.9 & 5.195 & 5.405 & 31.0 & 4.625 \\
\hline 3 Pir $3 m$ & $œ .2$ & 8.3 & 3.0 & 63.5 & 57.1 & 5.3 & 1.5 & 0.7 & 5.550 & 5.582 & 32.4 & 4.969 \\
\hline $4 \mathrm{Pir}-4 \mathrm{~m}$ & $\wp 8.8$ & 8.0 & 9.6 & 53.2 & 48.7 & 4.8 & 1.3 & 1.2 & 4.430 & 5.007 & 34.5 & 3.860 \\
\hline $52 D A E-1 \mathrm{~m}$ & 84.6 & 10.2 & 8.1 & 62.7 & 29.2 & & & 0.5 & 5.143 & & & 4.573 \\
\hline 6 DAE-2m-To & 90.4 & 12.6 & 5.4 & 56.8 & 37.8 & & & 0.8 & 5.000 & & & 4.439 \\
\hline $7 \mathrm{DAE}-2 \mathrm{~m}-\mathrm{Ba}$ & 90.6 & 14.3 & 7.0 & 56.5 & 36.5 & & & 0.9 & 5.218 & & & 4.648 \\
\hline 8 DOR-PO-1 & 88.9 & 11.5 & 25.7 & 63.3 & 11.1 & & & 0.6 & 5.355 & & & 4.785 \\
\hline 9 DOR-Po-2 & 90.1 & 12.9 & 3.1 & 62.5 & 34.4 & & & 0.3 & 5.185 & & & 4.615 \\
\hline 10 DOR-PO-3 & 92.9 & 12.6 & 3.3 & 61.7 & 35.1 & & & 0.3 & 5.398 & & & 4.828 \\
\hline 11 2DOR-2mTo & 92.8 & 9.8 & 6.3 & 61.9 & 31.8 & & & 0.6 & 5.484 & & & 4.914 \\
\hline 12 DOR-2mMe & 90.1 & 10.2 & 17.5 & 54.2 & 28.3 & & & 0.8 & 4.889 & & & 4.832 \\
\hline
\end{tabular}

Estas apresentam percentuais mais altos de umidade livre do que as do Banhado do Sombrio e, também, mais díspares nas amostras coletadas em março do que em julho. As condições de encharcamento, de fato, eram maiores neste último mês. A variação da umidade livre foi de $68,8 \%$ a $92,87 \%$.

Os teores de cinzas são de $3,0 \%$ a $25,67 \%$; Apenas duas amostras apresentaram valores acima de $10 \%$. São baixíssimos quando comparados com os teores das amostras do Banhado do Sombrio.

Com exceção de duas amostras, as restantes têm poder calorifico entre 5.009 $\mathrm{kcal} / \mathrm{kg}$ e $5.559 \mathrm{kcal} / \mathrm{kg}$.

Parece que esta turfeira é mais homogênea quanto a estes parâmetros, que a Turfeira Banhado do Sombrio. Deve-se salientar que a Turfeira Banhado Piritu apresentase cerca de $90 \%$ rodeada por depósitos arenosos, quartzosos, pleistocênicos. No seu lado sul-sudeste situam-se materiais mais variados e mais recentes. São depósitos lagunares em que se alternam areias e argilas orgânicas com conchas.

O diagrama da Figura 160 mostra uma dispersão das amostras no que se relaciona ao confronto do PCS com os teores de cinzas. A correlação é também negativa, como a 
citada para as turfeiras anteriores, porém muito baixa, $r=-0,19$, isto é, apenas $3,6 \%$ das amostras teriam uma correlação linear entre essas duas variáveis.

O diagrama múltiplo de relações de distintas variáveis com os PCS medidos (Figura 161), demonstra que o enxofre tem um comportamento similar ao das amostras das outras turfeiras, embora um pouco mais homogêneo quanto ao seu comportamento, em relação ao PCS. Seus valores variam de $0,27 \%$ a $1,18 \%$.

A relação com o carbono é altamente variada.

As matérias voláteis apresentam-se com pequena correlação positiva com o PCS.

Os valores da umidade higroscópica evidenciam uma pequena variação, enquanto que os da umidade livre são bem maiores. Esta é devida principalmente a duas amostras de valores mais baixos $(68,8 \%$ e $69,2 \%)$ coletadas entre 2 e $4 \mathrm{~m}$ de profundidade, representando as coletas mais profundas nesta turfeira. Uma delas apresenta o valor extremo de enxofre(Tabela 84).

O diagrama tridimensional (Figura 162) deixa claro que a maioria das amostras tem teores de cinzas até $15 \%$ e umidade livre acima de $83 \%$, com PCS alto, mas variável. A amostra que tem o maior PCS é a que tem o mais baixo valor de umidade livre e de cinzas, porém há uma exceção, pois, embora tenha valores baixos de cinza e umidade, tem o PCS mais baixo desta turfeira $(4.430 \mathrm{kcal} / \mathrm{kg})$.

\subsection{Turfeira Caverá}

Cerca de 700 ha da Turfeira Caverá estão sendo minerados para uso como combustível. A extração é feita a céu aberto, através do processo de extrudagem e secagem no campo de produção. No cálculo da empresa Cominas S.A., a turfa tem $90-92 \%$ de umidade que é reduzida para 38 a $41 \%$ na própria área de lavra. Há drenagem superficial primária, ligada a um sistema superficial secundário e ao sistema de bombeamento. 
A abertura de trincheiras secundárias compreende escavações de $500 \mathrm{~m}$ de comprimento, separada, em espaços de $20 \mathrm{~m}$, perpendiculares ao sistema principal, sendo a profundidade das mesmas de $1,00 \mathrm{~m}$.

A extração é realizada em cada campo separado pelas trincheiras, e a secagem do material é natural, através da evaporação ao ar livre, auxiliada pelo revolvimento que é efetuado várias vezes. Após a secagem, a turfa é transportada e estocada. É levada em caminhões para Tubarão, onde é usada em fornos para queima de cerâmica.

Foram realizadas nove análises imediatas de amostras desta turfeira (Tabela 86).

\begin{tabular}{|c|c|c|c|c|c|c|c|c|c|c|c|c|}
\hline \multirow{2}{*}{$\begin{array}{r}\text { TABELA } 86 \\
\text { Amostra }\end{array}$} & \multicolumn{12}{|c|}{$\begin{array}{l}\text { - Resultados das Análises Imediatas, PCS, PCS calculado, PCi sobre umidade } \\
\text { livre de amostras de turfa da Turfeira Caverá. }\end{array}$} \\
\hline & UmiLiv & UmiHig & Cinzas & MV & Cbs & Hbs & Nbs & Sbs & PCS & PCScalc & 0 & $\mathrm{PCl}$ \\
\hline 1 Cave+N-1 & 75.0 & 7.6 & 6.2 & 59.4 & 57.6 & 4.8 & 1.9 & 0.6 & 5.496 & 5.393 & 24.2 & 4.926 \\
\hline 2 Cave-S- 2 & 71.4 & 9.9 & 7.9 & 48.3 & 55.7 & 5.0 & 1.8 & 0.8 & 5.319 & 5.375 & 28.9 & 4.749 \\
\hline 3 Cave-5 3 & 84.3 & 11.2 & 39.7 & 43.5 & 33.7 & 3.5 & 1.4 & 3.9 & 3.182 & 3.306 & 17.8 & 2.612 \\
\hline 4 Cav-1m & 80.0 & 8.8 & 31.4 & 45.1 & 23.5 & & & 0.4 & 3.790 & & & 3.220 \\
\hline 52 Cav-2mTo & 91.7 & 11.3 & 5.0 & 58.3 & 36.8 & & & 0.6 & 5.364 & & & 4.794 \\
\hline $62 \mathrm{Cav}-2 \mathrm{mMe}$ & 92.1 & 12.7 & 5.1 & 57.9 & 37.0 & & & 0.6 & 5.658 & & & 5.088 \\
\hline $72 \mathrm{Cav}-2 \mathrm{mBa}$ & 92.2 & 12.4 & 4.4 & 57.9 & 37.6 & & & 0.3 & 5.560 & & & 4.990 \\
\hline $82 \mathrm{Cav}-3 \mathrm{mTo}$ & 93.8 & 13.1 & 6.7 & 56.6 & 36.7 & & & 0.6 & 5.277 & & & 4.707 \\
\hline $92 \mathrm{Cav}-3 \mathrm{mMe}$ & 89.0 & 9.2 & 40.6 & 38.3 & 21.1 & & & 2,0 & 3.149 & & & 2.579 \\
\hline
\end{tabular}

A umidade livre variou de $71,4 \%$ a $93,81 \%$ e o teor de cinzas de $4,43 \%$ a $40,6 \%$. Os teores mais altos de cinzas corresponderam às amostras mais profundas que $2,50 \mathrm{~m}$. Um outro valor também alto é da superfície, os restantes são semelhantes àqueles das turfas do Banhado Piritu. Este fato é coerente com a sua situação geológica, uma vez que está dominantemente limitada por terrenos arenosos quartzosos. No lado noroeste estão os depósitos pleistocênicos, e no lado sudeste estão os depósitos, em grande parte, holocênicos. 
Os PCS também foram semelhantes àqueles do Banhado Piritu, com exceção das três amostras com altos teores de cinza. Este índice variou de $3.128 \mathrm{kcal} / \mathrm{kg}$ a 5.658 $\mathrm{kcal} / \mathrm{kg}$.

O diagrama $X-Y$ (Figura 163) evidencia o que foi dito anteriormente, pois representa uma relação do PCS com o teor de cinza das amostras. A correlação é negativa, com um valor alto, $r=-0,996$, equivalendo a $99,3 \%$ de correlação.

No diagrama múltiplo de PCS contra as outras variáveis, vê-se que as amostras com mais enxofre são aquelas com os menores valores de PCS (Figura 164).

Os valores de carbono são variados, mas têm uma correlação positiva com os do PCS. O mesmo se dá para os teores de matérias voláteis, porém com variação menor.

Os teores de cinzas, como já foi comentado, têm uma forte correlação linear negativa.

A umidade higroscópica é quase linear e, portanto, sem grande variação, o que não acontece com a umidade livre.

O diagrama tridimensional (Figura 165) evidencia que amostras, tanto com os mais altos como com os mais baixos teores de umidade livre medidos, têm os mesmos valores baixos de cinza e se equivalem quanto ao PCS. As amostras de mais baixo poder calorífico superior são amostras com os mais altos índices de cinzas e valores também altos de umidade.

\subsection{Turfeira Olvebra}

Foram analisadas apenas seis amostras (Tabela 87) que apresentam homogeneamente valores entre $83,4 \%$ e $89,39 \%$ de umidade livre, valores de cinzas relativamente altos, entre $9,7 \%$ e $29,36 \%$, uma vez que se trata de turfas entre cristas praiais, depósitos arenosos quartzosos, sem proporcionar contribuição de argila ou outros componentes inorgânicos. A explicação poderia ser dada, talvez, pelo tipo de vegetação. 


\begin{tabular}{|c|c|c|c|c|c|c|c|c|c|c|c|c|}
\hline TABELA 87 & $\begin{array}{l}\text { - Resul } \\
\text { de am }\end{array}$ & $\begin{array}{l}\text { ados d } \\
\text { stras d }\end{array}$ & $\begin{array}{l}\text { s Análi } \\
\text { turfa }\end{array}$ & $\begin{array}{l}\text { es Ime } \\
\text { Turfe }\end{array}$ & $\begin{array}{l}\text { atas, } \\
\text { Olve }\end{array}$ & $\begin{array}{l}\text { S, PC } \\
\text { a. }\end{array}$ & cal & lado, & Ci sol & re umid & de liv & \\
\hline Amostra & UmiLiv & UmIHig & Cinzas & MV & Cbs & $\mathrm{Hbs}$ & Nbs & Sbs & PCS & PCScalc & 0 & $\mathrm{PCi}$ \\
\hline 1 Cri-E-So1 & 83.40 & 9.50 & 9.70 & 58.90 & 55.71 & 5.21 & 2.32 & 1.29 & 5.277 & 5.245 & 25.77 & 4.707 \\
\hline $2 \mathrm{Cri}-\mathrm{E}-\mathrm{So} 2$ & 84.80 & 6.00 & 11.20 & 58.50 & 54.34 & 5.16 & 2.29 & 1.59 & 5.403 & 5.130 & 25.42 & 4.833 \\
\hline 3 Olv-1 & 87.53 & 10.95 & 9.92 & 58.07 & 32.01 & & & 0.82 & 5.215 & & & 4.645 \\
\hline 4 Olv-2 & 88.42 & 9.27 & 18.84 & 53.89 & 27.27 & & & 0.88 & 4.829 & & & 4.259 \\
\hline 5 Olv 3 & 89.08 & 9.61 & 29.36 & 48.80 & 21.84 & & & 1.19 & 4.516 & & & 3.946 \\
\hline 6 Olv-4 & 89.39 & 12.00 & 12.50 & 57.62 & 29.88 & & & 1.04 & 5.326 & & & 4.756 \\
\hline
\end{tabular}

Os valores de enxofre são também os mais altos, em média, porém o PCS é alto, apesar desses aspectos. Os valores vão de $4,516 \mathrm{kcal} / \mathrm{kg}$ a $5.403 \mathrm{kcal} / \mathrm{kg}$.

O diagrama da Figura 166 mostra uma certa dispersão devido ao pequeno número de amostras, porém a correlação linear é também negativa e alta entre o PCS e as cinzas. O valor de ré $-0,95$, isto é, corresponde a $90,20 \%$ de correlação negativa entre estas duas variáveis.

O diagrama da Figura 167 mostra que os teores de enxofre são muito homogêneos, isto é, não apresentam variação para os diferentes valores de PCS.

Há uma grande variação do carbono fixo e uma correlação positiva com o PCS.

As matérias voláteis também crescem com o PCS ou vice-versa, mas a variação dos teores é pequena.

A umidade livre, bastante alta, não apresenta a variação encontrada nas turfeiras anteriores.

Na Figura 168 em que as três variáveis PCS, umidade livre e cinzas são plotadas, verifica-se o que já foi dito acima. 


\subsection{Turfeira Sanga dos Rodrigues}

Apenas quatro amostras de turfa foram analisadas (Tabela 88), constituindo-se em número estatisticamente muito pequeno para análise. Entretanto foram feitos os mesmos diagramas para as turfeiras já discutidas (Figuras 169 e 170).

\begin{tabular}{|cccccccccccccc}
\hline TABELA & 88 & - \\
\multicolumn{1}{c}{ - Resultados das Análises Imediatas, PCS, PCS calculado, PCi sobre umidade } \\
livre de amostras de turfa da Turfeira Sanga dos Rodrigues.
\end{tabular}

Os índices de umidade livre são semelhantes aos da Turfeira Olvebra, porém os valores de cinza são muito mais altos. Os valores altos de cinza, entre $35,93 \%$ a 42,93\% talvez sejam explicados pela origem da turfeira, pois, embora se situe paralela à da Olvebra e entre terrenos arenosos, o que é hoje a Turfeira Sanga dos Rodrigues foi uma laguna muito longa que parece ter relação com o canal do Rio Mampituba, no trecho da sua antiga foz paralela à linha de costa, de modo semelhante ao que acontece atualmente com vários rios da costa catarinense. Desta maneira, ela pode ter recebido deste rio, influxo das águas com muito sedimento durante o desenvolvimento da turfa. As espessuras medidas também são muito pequenas.

Embora no diagrama de correlação as quatro amostras apresentem-se dispersas, elas mostram uma correlação negativa significativa entre o PCS e as cinzas, de $r=-0,81$, isto é, 65,7\% das amostras apresentam correlação dessas duas variáveis (Figuras 169).

A Figura 170 mostra que os teores de enxofre apresentam uma variação bem maior que nas outras turfeiras. 


\subsection{Turfeira Corrupiá}

Duas amostras apenas foram analisadas (Tabela 89) e dão valores altos de correlação entre PCS e cinzas, mas os resultados podem não ser representativos pelo número exíguo de amostras.

\begin{tabular}{|c|c|c|c|c|c|c|c|c|c|c|}
\hline TABELA & $89-$ R & $\begin{array}{l}\text { Resultac } \\
\text { livre de }\end{array}$ & $\begin{array}{l}\text { dos das } \\
\text { amostr }\end{array}$ & $\begin{array}{l}\text { nálise } \\
\text { de tur }\end{array}$ & Imec & $\begin{array}{l}\text { atas, } \\
\text { arfeir }\end{array}$ & $\begin{array}{l}\text { CS, } \\
\text { Córr }\end{array}$ & $\begin{array}{l}\text { CS c } \\
\text { go C }\end{array}$ & $\begin{array}{l}\text { alculad } \\
\text { orrupiá }\end{array}$ & $\begin{array}{l}\text { do, PCi sobre umidade } \\
\text { á. }\end{array}$ \\
\hline Amostra & UmiLlv & UmiHig & Cinzas & MV & Cbs & Hbs & Nbs & Sbs & PCS & $\mathrm{PCl}$ \\
\hline 1 Corr-1 & 48.32 & 4.36 & 81.83 & 14.67 & 3.5 & & & 0.14 & 753 & 181 \\
\hline 2 Corr-2 & 45.98 & 4.59 & 80.86 & 15.14 & 4.0 & & & 0.33 & 781 & 211 \\
\hline
\end{tabular}

Os dados dessas duas amostras, entretanto, dão uma pista da sua situação geológica, pois apresentam as menores umidades livres $(45,98 \%$ a $48,32 \%)$, os maiores teores de cinzas $(81,83 \%)$, os menores índices de matérias voláteis, $(14,67 \%$ e $24,6 \%$ ) os mais baixos teores em carbono e os mais baixos PCS, isto é, de 751 a $781 \mathrm{kcal} / \mathrm{kg}$.

Trata-se de uma turfeira, com muita argila, desenvolvida no topo de sedimentos lagunares, atrás de uma itha-barreira, recebendo influxo de argilas de rochas do Grupo Passa Dois, em elevações próximas.

\subsection{Turfeira sob Crista Praial da Lagoa do Sombrio}

Foram analisadas somente duas amostras (Tabela 90).

\begin{tabular}{|ccccccccccccc}
\hline TABELA & 90 & - Resultados das Análises Imediatas, PCS, PCS calculado, PCi sobre umidade livre \\
de amostras de turfa da Turfeira soterrada sob crista praial da Lagoa do Sombrio.
\end{tabular}


A umidade livre, as matérias voláteis, o carbono e o enxofre têm valores mais altos que os das amostras da Turfeira Corrupiá. O mesmo acontece com o PCS, ao passo que o teor de cinzas diminui.

\subsection{Total das Amostras Analisadas}

Analisando-se a totalidade das amostras das turfas do sul do Estado de Santa Catarina, estudadas, através da Tabela 83, verifica-se que o poder calorífico superior apresentado pelas verdadeiras turfas da área, isto é, as das turfeiras Banhado do Sombrio, Banhado Piritu, Caverá, Olvebra e mesmo Sanga dos Rodrigues, é similar ao apresentado pelos carvões energéticos brasileiros, segundo os valores apresentados por NAHUYS \& PIATNICKI (1983), e ainda por coques provenientes de misturas do carvão catarinense com carvões norte-americanos, segundo os dados apresentados por LIMA (1974).

Os resultados do conjunto das amostras analisadas repete a correlação negativa alta, já comentada, entre os índices do PCS e o teor de cinzas. A correlação linear é de $r=$ - 0,98, significando que $95,80 \%$ dos valores do PCS são dependentes dos teores de cinzas das amostras, isto é, quanto mais alto o teor de cinzas, mais baixo o PCS (Figuras 171).

Entre o PCS e as matérias voláteis há uma alta correlação positiva, pois, o PCS cresce com o aumento de matérias voláteis. O coeficiente de correlação é $r=0,96$, isto é, o PCS é dependente $92,15 \%$ dos índices de matérias voláteis (Figuras 172).

A correlação entre matérias voláteis e cinzas é, portanto, negativa $(-0,95)$, e o coeficiente de correlação é alto, $\mathrm{R}^{2}=87,74 \%$ (Figura 173).

O coeficiente de correlação entre o carbono fixo e o PCS é relativamente baixo, pois 'está no limite de aceitação estatística. A correlação é positiva com $r=0,71$ e taxa de correlação de $50,12 \%$.

Com os índices de hidrogênio, a correlação com os valores do PCS é mais alta e positiva. O coeficiente de correlação é $r=0,94$, isto é, são interdependentes em $89,07 \%$, para 18 amostras. 
Os valores de nitrogênio mostram uma correlação com o PCS numa taxa mais alta que aquela do carbono. Entretanto, são consideradas aqui apenas 18 amostras, enquanto que para o carbono foram 52 amostras, o que permite mais "espalhamento".

O coeficiente de correlação nitrogênio versus PCS é $r=0,77$ ou, apenas $58,58 \%$ dos valores do PCS são dependentes do nitrogênio. É uma correlação relativamente baixa.

Os índices de PCS quando relacionados com os teores de umidade higroscópica e umidade livre são desprezíveis. O mesmo acontece com os teores de enxofre total.

Os diagramas triangulares das figuras 174 a 176 , salientam as correlações lineares, mesmo quando são relacionadas três variáveis.

A maioria das amostras situa-se na área marcada com índices de cinza de zero a $40 \%$ e valores de umidade livre entre $75 \%$ e $95 \%$, apresentando seus PCS altos e variáveis. Estes são semelhantes para as amostras com teores de umidade livre entre $65 \%$ e $75 \%$, o que confirma a falta de correlação entre o teor de umidade e o PCS das amostras.

Embora o poder energético dessas turfas seja elevado, qualquer uso deverá ser bem analisado, uma vez que as turfas de Santa Catarina e do Brasil ainda são mal conhecidas, além de que deve se levar em conta a sua multitude de usos possíveis.

\subsubsection{Características Agronômicas}

No que se relaciona ao uso agronômico das turfas, em Santa Catarina há apenas o cultivo empírico, a criação de gado e o reflorestamento com eucalipto.

As análises seguem a visão e a rotina de solos mormente inorgânicos.

Para o presente estudo foram feitas análises de rotina ou de fertilidade e determinações do carbono orgânico (Tabela 91).

A análise química de solos compreende a determinação do $\mathrm{pH}$, do índice SMP (de SHOEMAKER, MCLEAN \& PRATT), adaptado por KUSSOV, de fósforo extraível ou disponível, do potássio trocável, da matéria orgânica, do cálcio, magnésio e alumínio trocáveis. Esta análise é acompanhada por uma determinação do teor de argila por 
intermédio de densímetro, usada na identificação da classe do solo. A classe a que pertence o solo é determinada por este teor de argila, relacionado às Unidades de Mapeamento do Solo que já são conhecidas em Santa Catarina e no Rio Grande do Sul. A partir daí tem-se os parâmetros para a interpretação dos teores de fósforo do solo, e as necessidades deste solo em fósforo.

É talvez nesta determinação de argilas que reside o principal ponto fraco destas análises aplicadas a turfas.

TABELA 91 - Resultado de Análises Agronômicas sobre as amostras de turfas.

Turfeira Prof Pppm Kppm Al CaMg H MO Carborg IndSMP pH AcidTroc Text Classe

\begin{tabular}{|c|c|c|c|c|c|c|c|c|c|c|c|c|c|}
\hline 1 TBS $-5 a$ & $0.20-1.20$ & 4.4 & 93 & 0.8 & 6.0 & 5.48 & $œ .87$ & 41.1 & 4.7 & 4.4 & 6.28 & 17 & 4 \\
\hline 2 TBS-5b & $1.20-1.70$ & 6.7 & 145 & 0.7 & 10.0 & 3.14 & 58.99 & 34.7 & 5.2 & 4.7 & 3.84 & 11 & 4 \\
\hline 3 TBS $-5 c$ & $1.70-2.20$ & 15.5 & 109 & 0.7 & 10.0 & 2.46 & 61.54 & 36.2 & 5.4 & 4.7 & 3.16 & & 5 \\
\hline 4 TBS $-5 d$ & $2.20-2.80$ & 8.8 & 75 & 0.5 & 9.8 & 1.63 & 58.31 & 34.3 & 5.8 & 4.9 & 2.13 & 5 & 5 \\
\hline 5 TBS-5e & $2.80-3.20$ & 7.4 & 67 & 0.4 & 10.0 & 2.46 & 43.18 & 25.4 & 5.5 & 4.9 & 2.86 & 11 & 4 \\
\hline 6 TBS $5 \mathrm{f}$ & $3.20-3.35$ & 3.3 & 109 & 0.4 & 10.0 & 4.28 & 22.27 & 13.1 & 5.0 & 4.7 & 4.86 & 17 & 4 \\
\hline 7 TBS-6a & $0.00-1.00$ & 2.0 & 67 & 0.4 & 10.0 & 3.84 & 61.37 & 36.1 & 5.1 & 4.5 & 4.24 & 26 & 3 \\
\hline $8 \mathrm{TBS}-6 / \mathrm{c}$ & $1.00-2.00$ & 2.7 & 67 & 0.9 & 8.3 & 3.78 & 52.53 & 30.9 & 5.0 & 4.4 & 4.68 & 8 & 5 \\
\hline 9 TBS-3b & $0.65-1.10$ & 4.5 & 105 & 1.0 & 8.9 & & & & & & & & \\
\hline $10 \mathrm{TBS}-3 \mathrm{~d}$ & $1.75-2.10$ & 3.8 & 54 & 2.0 & 6.6 & 11.76 & 10.00 & & 3.9 & 3.7 & & 27 & \\
\hline 11 TBS-2b & $0.80-1.30$ & 8.4 & 93 & 0.7 & 9.7 & & 10.00 & & & & & 20 & \\
\hline 12 TBS-2C & $1.30-2.30$ & 2.6 & 84 & 0.6 & 10.0 & & 10.00 & & & & & & \\
\hline 13 TBS-2e & 2.70 .2 .90 & 3.8 & 83 & 9.4 & 2.6 & & 10.00 & & & & & & \\
\hline 14 TBS $-4 \mathrm{C}$ & $1.60-1.85$ & 3.4 & 79 & & 10.0 & & 10.00 & & & & & & \\
\hline 15 TBP-2a & $0.00-1.00$ & 11.5 & 89 & 1.7 & 10.0 & 12.06 & $\$ .36$ & 40.8 & 3.9 & 3.6 & 13.76 & 28 & 3 \\
\hline 16 TBP-2b & $1.00-1.50$ & 4.4 & 93 & 0.5 & 10.0 & 6.42 & 62.39 & 36.7 & 4.6 & 4.7 & 6.92 & 25 & 4 \\
\hline 17 ТВP-3a & $0.25-0.40$ & 5.7 & 37 & 1.1 & 9.7 & 8.19 & 70.89 & 41.7 & 4.3 & 4.1 & 9.29 & 27 & 3 \\
\hline 18 TBP-36 & $0.40-0.55$ & 2.0 & 31 & 0.9 & 9.6 & 6.74 & 78.54 & 46.2 & 4.5 & 4.4 & 7.64 & 22 & 4 \\
\hline 19 TBP-3c & $0.65-0.80$ & 2.3 & 49 & 0.8 & 8.5 & 4.36 & 74.97 & 44.1 & 4.9 & 4.2 & 5.16 & 21 & 4 \\
\hline 20 TBP-3d & $1.00-1.35$ & 0.6 & 43 & 0.6 & 10.0 & 5.68 & 84.49 & 49.7 & 4.7 & 4.6 & 6.28 & 24 & 4 \\
\hline 21 TBP 3 & $1,35-1.40$ & 28.0 & 69 & & 4.8 & 0.97 & 2.00 & & 6.6 & 5.5 & 0.97 & 16 & 4 \\
\hline 22 TBP-1b & $1.36-1.45$ & 3.8 & 96 & & 10.0 & & 10.00 & & & & & & \\
\hline 23 TBP-1d & $1.85-1.95$ & 1.1 & 84 & & 10.0 & & 10.00 & & & & & & \\
\hline 24 TCA-3a & $0.00-1.00$ & 6.1 & 51 & 0.9 & 6.3 & 6.74 & 57.12 & 33.6 & 4.5 & 4.1 & 7.64 & 33 & \\
\hline 25 TCA-3b & $1.10-1.35$ & 1.6 & 40 & 0.6 & 10.0 & 5.68 & 74.46 & 43.8 & 4.7 & 4.4 & 6.28 & 22 & \\
\hline 26 TCA-3c & $1.35-1.55$ & 1.0 & 31 & 0.7 & 10.0 & 1.23 & 73.95 & 43.5 & 5.9 & 4.6 & 1.93 & 13 & \\
\hline 27 TCA-1 & $2.90-3.00$ & 2.6 & 97 & & 10.0 & & 10.00 & & & & & & \\
\hline 28 TCA-2C & $3.30-3.60$ & 7.2 & 150 & & & & 10.00 & & & & & & \\
\hline 29 TOL-2a & $0.25-0.40$ & 3.7 & 45 & 1.7 & 10.0 & 13.48 & 73.95 & 43.5 & 3.8 & 3.8 & 15.18 & 25 & 4 \\
\hline 30 TOL-2b & 0.500 .65 & 1.0 & 27 & 1.1 & 8.8 & 7.33 & 59.84 & 35.2 & 4.4 & 4.0 & 8.43 & 16 & 4 \\
\hline 31 TOL-2C & $0.75-0.90$ & 1.0 & 33 & 1.0 & 10.0 & 5.92 & 62.05 & 36.5 & 4.6 & 4.2 & 6.92 & 19 & 4 \\
\hline 32 TOL-2d & $0.70-0.90$ & 5.7 & 35 & 0.7 & 10.0 & 3.98 & 74.46 & 43.8 & 5.0 & 4.3 & 4.68 & 14 & 4 \\
\hline 33 TOL-1a & 0.350 .55 & 1.1 & 18 & 0.9 & 10.0 & & 10.00 & & & & & & \\
\hline 34 TOL-1b & $0.85-0.95$ & 1.1 & 18 & 0.4 & 10.0 & & 10.00 & & & & & & \\
\hline 35 TSR-2a & $0.25-0.40$ & 3.7 & 45 & & 10.0 & 2.86 & 37.23 & 21.9 & 5.5 & 5.4 & 2.86 & 25 & 4 \\
\hline 36 TSR-2b & $0.50-0.65$ & 3.3 & 43 & & 10.0 & 3.16 & 45.22 & 26.6 & 5.4 & 5.0 & 3.16 & 16 & 4 \\
\hline 37 TSR-2c & $0.50-0.60$ & 3.0 & 67 & & 10.0 & 3.16 & 48.96 & 28.8 & 5.4 & 4.8 & 3.16 & 16 & 3 \\
\hline 38 TSR-1b & $0.60-0.90$ & 2.6 & 83 & 3.0 & 10.0 & 4.64 & 10.00 & & 4.5 & 3.8 & & 12 & \\
\hline 30 TCor-1a & $0.45-0.60$ & 50.0 & 18 & 7.6 & 3.0 & $1 . \infty$ & 31.79 & 18.7 & 4.3 & 4.2 & 9.29 & 20 & 4 \\
\hline 40 TCor-1b & $0.70-0.85$ & 27.3 & 17 & 8.1 & 2.9 & 2.15 & 25.67 & 15.1 & 4.2 & 4.4 & 10.25 & 20 & 4 \\
\hline 41 TCLS-2 & $1.15-1.50$ & 12.5 & 96 & 8.8 & 3.1 & 6.38 & 24.14 & 14.2 & 3.8 & 3.7 & 15.18 & 22 & 4 \\
\hline 42 TCLS-1 & $1.15-1.50$ & 11.0 & 75 & 2.2 & 10.0 & & 10.00 & & & & & & \\
\hline
\end{tabular}


$\mathrm{O}$ índice de acidez $\mathrm{pH}$ fornece valores até abaixo de 4, sendo, em geral, o esperado para este tipo de ambiente e material, evidenciando uma tendência para acidez excessiva.

A Turfeira Sanga dos Rodrigues é a que apresenta em média os índices mais altos. As turfeiras Olvebra, Caverá e Piritu têm valores semelhantes e mais baixos que os da Turfeira Banhado do Sombrio, lembrando sua posição geológica e a entrada de bases neste último caso. A Turfeira Corrupiá desmente um pouco essa idéia, porém deve-se lembrar que os teores de $\mathrm{Al}$, neste última, são os mais altos das turfeiras ativas. Nota-se que há uma certa tendência para o aumento do $\mathrm{pH}$ com a profundidade.

KIEHL (1985) afirma que a turfa, quando tem pH abaixo de 5,0, é deficiente em Ca, e, suficiente neste elemento, quando c pH for maior que 5,0. É interessante, então, notar esses valores pouco acima de 5,0 para a Turfeira Sanga dos Rodrigues, embora os dados disponiveis sejam poucos. Mas esta correlação de KIEHL deve ser melhor analisada.

Aceitando-se a classificação de turfas de LUCAS, RIECKE \& FARNHAM (s/d apud KIEHL, 1985) de acordo com o pH, a maioria das turfas analisadas sieriam consideradas

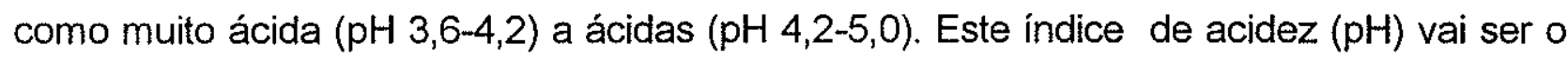
regulador das soluções tampão aos ácidos prejudiciais à nutrição das plantas. Ele dará a resposta à calagem orientada pelo índice SMP.

Os teores de matéria orgânica que caracteriza esses são bastante altos, apresentando-se com os maiores teores as turfeiras Banhado Piritu, Caverá e Olvebra. A Turfeira Banhado do Sombrio também apresenta níveis com teores elevados, porém são em média mais baixos que das três mencionadas. As outras três turfeiras, Sanga dos Rodrigues, Corrupiá e a sob a crista praial da lagoa do Sombrio, apresentam teores bem mais baixos. Porém, a da Sanga dos Rodrigues mostra que seus teores em matéria orgânica são semelhantes a muitas turfas paulistas.

Muitas turfas do Rio Grande do Sul têm teores de matéria orgânica ainda mais altos que as aqui analisadas (vide KAMPF \& SCHNEIDER, 1989). Lá os conteúdos variam, nas turfeiras estudadas por estes autores, de 23 a $97 \%$ e com média de $71,9 \%$. Eles lembram que há decréscimos pronunciados com a profundidade, em perfis mais rasos e que em 
alguns há descontinuidade no conteúdo da matéria orgânica indicando períodos de adição de matéria mineral.

Estes fatos são notados nas turfeiras de Santa Catarina, mas o segundo item se aplica mais à Turfeira Banhado do Sombrio.

KAMPF \& SCHNEIDER (1989) relatam que o conteúdo de matéria orgânica é em média, mais elevado nos horizontes fíbricos e nos hêmicos do que nos horizontes sápricos. Nestes também são observadas as maiores amplitudes deste conteúdo.

O teor de matéria orgânica afeta a densidade do solo, que varia nas turfeiras do Rio Grande do Sul, de 0,03 a 0,38 $\mathrm{g} / \mathrm{cm}^{3}$, sendo os valores maiores encontrados nas camadas superficiais de solos drenados e cultivados (KAMPF \& SCHNEIDER, 1989). No sul de Santa Catarina, as turfeiras drenadas e cultivadas ou mineradas, Corrupiá, Banhado do Sombrio e Caverá são também as que apresentam valores mais altos de densidade aparente (DBD). Na Turfeira Caverá, as amostras coletadas perto das trincheiras de drenagem mais profundas e onde há cultivo de eucalipto apresentam os valores mais altos de densidade aparente (DBD). Com exceção da Turfeira Olvebra, as turfeiras em que os valores de densidade aparente (DBD) foram medidos, também evidenciam que a camada superficial apresenta valores mais altos (Tabela 92).

O conteúdo de água, como já foi referido, tem relação com o conteúdo de matéria orgânica e, portanto, também com a densidade do solo. Na Tabela 92 nota-se que a densidade do material úmido em relação ao material seco (DBD) é a redução que o material seco alcançou em volume e em peso.

KAMPF \& SCHNEIDER (1989) propõem, em função das relações constatadas entre teor de matéria orgânica, densidade do solo e conteúdo de água, que sejam considerados solos orgânicos aqueles que apresentem teor de matéria orgânica igual ou superior a $20 \%$ e densidade de solo igual ou inferior a $0,5 \mathrm{~g} / \mathrm{cm}^{3}$, com camada de $60 \mathrm{~cm}$ de espessura, quando o solo não é drenado, e com $0,40 \mathrm{~m}$, quando for drenado. Os horizontes superficiais submetidos à drenagem prolongada e sob uso pastoril poderão apresentar densidade superior a $0,5 \mathrm{~g} / \mathrm{cm}^{3}$. 


\begin{tabular}{|c|c|c|c|c|c|c|c|}
\hline \multirow{2}{*}{$\begin{array}{c}\text { TABELA } 92 \\
\text { Amostras }\end{array}$} & \multicolumn{7}{|c|}{$\begin{array}{l}\text { - Valores de Densidade Aparente (DBD, HDB), Reduçåo em Peso e em Volume da Turfa, } \\
\text { Índice de Cor da Turfa e da Água. }\end{array}$} \\
\hline & Prof & DBD & $\mathrm{HBD}$ & ReduVol & ReduPeso & CorTurfa & Cor da Água Tur. Seca \\
\hline $\begin{array}{l}1 \text { TBS-t1A } \\
2 \text { TBS-t1B } \\
3 \text { TBS-t1C } \\
4 \text { TBS-t2A } \\
5 \text { TBS-t2B } \\
6 \text { TBS-t2C } \\
7 \text { TBS-t2D } \\
8 \text { TBP-t1A } \\
9 \text { TBP-t1B } \\
10 \text { TBP-t1C } \\
11 \text { TBP-t1D } \\
12 \text { TBP-t2A } \\
13 \text { TBP-t2B } \\
14 \text { TBP-t2C } \\
15 \text { TBP-t2D } \\
16 \text { TCA-t1A } \\
17 \text { TCA-t1B } \\
18 \text { TCA-t1C } \\
19 \text { TCA-t1D } \\
20 \text { TCA-t1E } \\
21 \text { TCA-t2A } \\
22 \text { TCA-t2B } \\
23 \text { TCA-t3A } \\
24 \text { TCA-t3B } \\
25 \text { TCA-t3C } \\
26 \text { TOL-t1A } \\
27 \text { TOL-t1B } \\
28 \text { TOL-t2B } \\
29 \text { TCOR-t1A }\end{array}$ & $\begin{array}{c}0.0-11 \mathrm{~cm} \\
11-37 \mathrm{~cm} \\
56.5-94 \mathrm{~cm} \\
0.0-17 \mathrm{~cm} \\
17.36 \mathrm{~cm} \\
40-75 \mathrm{~cm} \\
75-101.5 \mathrm{~cm} \\
0.0-17 \mathrm{~cm} \\
17-43.5 \mathrm{~cm} \\
43.5-68 \mathrm{~cm} \\
68-84.5 \mathrm{~cm} \\
12.5-28 \mathrm{~cm} \\
28.50 \mathrm{~cm} \\
50-65 \mathrm{~cm} \\
65-91 \mathrm{~cm} \\
17.5-27.5 \mathrm{~cm} \\
27-54 \mathrm{~cm} \\
54-71 \mathrm{~cm} \\
71-90.5 \mathrm{~cm} \\
90.5-99.5 \mathrm{~cm} \\
0.0-45.5 \mathrm{~cm} \\
45.5-50 \mathrm{~cm} \\
551 \mathrm{~cm} \\
55.5-61 \mathrm{~cm} \\
61.74 \mathrm{~cm} \\
4.5-29.5 \mathrm{~cm} \\
29.5-70 \mathrm{~cm} \\
25-50 \mathrm{~cm} \\
25-60 \mathrm{~cm} \\
\end{array}$ & $\begin{array}{l}0.20 \\
0.19 \\
0.13 \\
0.15 \\
0.11 \\
0.13 \\
0.07 \\
0.11 \\
0.08 \\
0.09 \\
0.08 \\
0.09 \\
0.09 \\
0.07 \\
0.08 \\
0.11 \\
0.09 \\
0.08 \\
0.07 \\
0.08 \\
0.14 \\
0.22 \\
0.10 \\
0.10 \\
0.10 \\
0.07 \\
0.09 \\
0.11 \\
0.91 \\
\end{array}$ & $\begin{array}{l}0.85 \\
1.01 \\
0.95 \\
0.82 \\
0.87 \\
0.96 \\
0.81 \\
0.87 \\
0.97 \\
0.93 \\
0.94 \\
0.89 \\
0.81 \\
0.80 \\
0.90 \\
0.79 \\
0.90 \\
0.81 \\
0.84 \\
0.64 \\
0.99 \\
1.19 \\
0.83 \\
0.82 \\
0.84 \\
0.75 \\
0.91 \\
0.90 \\
1.41 \\
\end{array}$ & $\begin{array}{l}77.77 \\
51.11 \\
34.42 \\
56.56 \\
80.01 \\
34.42 \\
44.06 \\
79.19 \\
52.67 \\
39.83 \\
45.15 \\
55.56 \\
66.68 \\
77.77 \\
26.96 \\
72.57 \\
25.61 \\
23.04 \\
23.63 \\
18.20 \\
50.79 \\
48.91 \\
78.37 \\
30.12 \\
87.07 \\
21.89 \\
16.00 \\
28.44 \\
84.13 \\
\end{array}$ & $\begin{array}{r}23.95 \\
18.34 \\
13.90 \\
17.87 \\
12.81 \\
13.74 \\
8.93 \\
12.73 \\
8.21 \\
9.24 \\
8.34 \\
9.75 \\
10.79 \\
9.21 \\
8.81 \\
13.44 \\
9.52 \\
10.25 \\
8.93 \\
12.72 \\
14.16 \\
22.08 \\
12.39 \\
9.85 \\
11.45 \\
0.34 \\
0.35 \\
0.40 \\
1.08 \\
\end{array}$ & $\begin{array}{l}\text { 5YR } 2.5 / 1 \\
\text { 5YR } 3 / 1 \\
\text { 1OYR } 3 / 2 \\
\text { 5YR } 2.5 / 1 \\
\text { 1OYR } 2 / 2 \\
\text { 1OYR } 2 / 1 \\
\text { 1OYR } 2 / 2 \\
\text { 5YR } 2.5 / 1 \\
\text { 5YR } 2.5 / 1 \\
\text { 5YR } 2.5 / 2 \\
2.5 Y R 2.5 / 4 \\
\text { 5YR } 2.5 / 1 \\
\text { 5YR } 2.5 / 2 \\
\text { 7.5YR } 3 / 4 \\
\text { 5YR } 2.5 / 1 \\
\text { 7.5YR } 3 / 2 \\
\text { 1OYR } 2 / 1+\text { Escura } \\
\text { 1OYR } 2 / 1 \text { B+Escura } \\
\text { 1OYR } 2 / 1 \\
\text { 10YR } 2 / 1 \\
\text { 2.5YR } 2.5 / 4 \\
\text { 5YR } 2.5 / 1 \\
\text { 10YR } 2 / 2 \\
\text { 1OYR } 3 / 3 \\
\text { 1OYR } 2 / 1 \\
\text { 5YR } 2.5 / 1 \\
\text { 1OYR } 2 / 1 \\
\text { 1OYR } 2 / 1 \\
\text { 5YR } 25 / 1 \\
\end{array}$ & $\begin{array}{l}\text { AMARELA M.ESCURA } \\
\text { AMARELA CLARA } \\
\text { INCOLOR } \\
\text { AMARELA ESCURA } \\
\text { INCOLOR } \\
\text { INCOLOR } \\
\text { INCOLOR } \\
\text { AMARELA ESCURA } \\
\text { AMARELA CLARA } \\
\text { AMARELA MED.FORTE } \\
\text { AMARELA MED.FORTE } \\
\text { AMARELA MEDIA } \\
\text { AMARELA MEDIA } \\
\text { AMARELA ESCANCOL } \\
\text { AMARELA CLARA } \\
\text { AMARELA CLARA } \\
\text { AMARELA ESCURA } \\
\text { INC/AMARELA CLARA } \\
\text { INCOLOR } \\
\text { AMAR.MED.OLEOSA } \\
\text { AMARELA CLARA } \\
\text { INCOLOR } \\
\text { VERMELHA AMAR.MED } \\
\text { AMARELA } \\
\text { AMARELA MEDIA } \\
\text { AMARELA CLARA } \\
\text { INCOLOR } \\
\text { INCOLORA AMAR.CL. } \\
\text { INCOLOR }\end{array}$ \\
\hline & $\begin{array}{l}\text { TBS - Turfeira } \\
\text { TBP - Turfeira } \\
\text { TCA - Turfeira } \\
\text { TOL - Turfeira } \\
\text { TCOR-Turfeira } 0\end{array}$ & $\begin{array}{l}\text { hado P } \\
\text { rerá } \\
\text { ebra } \\
\text { ruplá }\end{array}$ & u & & & & \\
\hline
\end{tabular}

KAMPF \& SCHNEIDER (1989) lembram, ainda, que estes solos são chamados de orto-orgânicos, quando apresentam teor de matéria orgânica igual ou superior a $65 \%$, com densidade de solo igual ou menor que $0,15 \mathrm{~g} / \mathrm{cm}^{3}$ e, quando saturados, podem conter mais de $500 \%$ de água. Estes têm severas restrições ao uso agrícola. Os solos para-orgânicos têm teor de matéria orgânica de 20 a $65 \%$, com densidade do solo entre 0,15 e $0,5 \mathrm{~g} / \mathrm{cm}^{3}$ e podem conter de 150 a $500 \%$ de água. Estes correspondem aos mucks dos Estados Unidos. Os mesmos autores afirmam que nestes a aptidão ao uso é melhor quanto menor for o teor de matéria orgânica.

Em algumas das turfeiras estudadas, o teor de matéria orgânica corresponde ao dos solos para-orgânicos, a densidade é variável e algumas amostras enquadram-se nesta 
classificação. Estas características sugerem afluxo de argila durante o desenvolvimento da turfeira, pois a densidade é tanto mais alta quanto maior for a quantidade de material inorgânico, como se verifica na Turfeira Corrupiá.

O índice SMP indicará a calagem necessária conforme o tipo de cultura. Por outro lado, a correção da acidez natural da turfa, de acordo com KIEHL (1985), deve ser feita com material que não provoque a floculação dos colóides, como ocorre quando se aplica calcário. Para este autor, a neutralização ideal é feita com amoníaco ou solução de potassa-caústica que, além de dispersar a turfa gerando hidrossóis, leva ao produto os nutrientes nitrogênio e potássio.

Os nutrientes são absorvidos pelas plantas através das soluções do solo. O fluxo de nutrientes para as raízes é controlado por vários processos, sendo o mais importante o processo de difusão, particularmente para $\mathrm{P}$ e K. A taxa de difusão dos nutrientes rumo às raízes das plantas depende de vários fatores como a concentração na solução, o poder tampão e o coeficiente de difusão, isto é, a velocidade com que o íon se movimenta no solo (SIQUEIRA et al., 1989).

Os nutrientes $\mathrm{P}, \mathrm{K}, \mathrm{Ca}, \mathrm{Mg}, \mathrm{S}, \mathrm{N}$, além do $\mathrm{Al}$ serão analisados a seguir, de acordo com os dados obtidos para cada turfeira.

\subsection{Turfeira Banhado do Sombrio}

O fósforo, se aceitarmos as classes 4 e 5 de acordo com o parâmetro de textura, apresenta valores considerados de limitante a baixo. Se considerarmos que esta turfa ou solo orgânico tem a classe 6 , isto é, dos solos alagados, estes mesmos teores são considerados limitantes a suficientes para cultivo de arroz, por exemplo.

Os valores de potássio são considerados médios a suficientes, uma amostra tem teor alto, para as classes referidas. Os teores adotados por LEMOS et al., (1981) como médios englobariam quase todas as amostras, com exceção de uma em que o teor é considerado alto. Na turfeira analisada por esses autores, os teores de potássio foram todos baixos. 
Os teores de cálcio e magnésio são considerados altos, passando em várias amostras além do limite exigido.

O nitrogênio e o enxofre não foram determinados pelo Laboratório de solos, porém são valores existentes na Tabela 83.

Os teores de nitrogênio nesta turfeira são bem mais altos que nas turfas paulistas. $O$ conteúdo deste elemento é fundamental na consideração da propriedade fertilizante da turfa (KIEHL, 1985).

O teor de alumínio, que é considerado bastante tóxico para as plantas, é de médio a baixo, segundo a tabela adotada por LEMOS et al. (1981).

A foto 68 registra o efeito do mau uso agrícola a que está submetida esta turfeira.

\subsection{Turfeira Banhado Piritu}

As nove amostras provenientes desta turfeira demonstram (Tabela 91) que as turfas têm, para as classes indicadas de 3 a 4, valores de fósforo que variam de limitantes a altos, de acordo com os parâmetros de SIQUEIRA et al., (1989). Porém, se forem usados como solos alagados, isto é, pertencentes à classe 6 , estes valores são considerados de suficientes a muito baixos.

Os teores de potássio são considerados de muito baixos a suficientes, para as classes 3 e 4.

A maioria das amostras tem alumínio em teores médios a baixos, com uma exceção em que o valor é alto $(1,7 \mathrm{me} \%)$.

Os índices de $\mathrm{Ca}$ e $\mathrm{Mg}$ são altos, com apenas uma exceção. Este fato levanta a questão quanto à entrada desses elementos na turfeira. As águas subterrâneas seriam uma explicação e talvez também os depósitos lagunares com conchas, no sul, poderiam ser uma fonte.

O conteúdo de matéria orgânica é elevado, quase o dobro de muitas turfas paulistas, e semelhante ao que é indicado em Minas Gerais e no Rio Grande do Sul. 
A densidade (DBD), é bem menor que a das amostras da Turfeira Banhado do Sombrio, e os valores de pH também são menores (Tabela 91 e 92).

\subsection{Turfeira Caverá}

Foram analisadas apenas cinco amostras que pelo pequeno número dificultam a interpretação, pois trata-se de um material muito heterogêneo e teriam pouca representatividade.

Os valores de fósforo são limitantes a baixos para culturas, dentro das classes de solo 3 e 4 em que talvez se enquadrem.

Os teores de potássio variam de muito baixos para as culturas, até muito altos, isto é, além das necessidades das plantas.

O Al aparece em teores semelhantes aos do Banhado Piritu. Os teores podem variar de praticamente zero a altos $(1,7 \mathrm{me} \%)$, de acordo com a classificação adotada por LEMOS et al. (1981).

Os teores de cálcio e magnésio são semelhantes aos do Banhado Piritu, isto é, dominantemente altos, extrapolando os limites necessários.

Os teores de matéria orgânica também são altos e a densidade (DBD) aparente é mais alta que os valores achados no Banhado Piritu, principalmente para as amostras coletadas junto e a oeste do Rio Sangrador. São valores intermediários entre os da Turfeira Banhado do Sombrio e Turfeira Banhado Piritu.

\subsection{Turfeira Olvebra}

Os índices de fósforo são muito baixos, variando de valor limitante até valores médios.

Os teores de potássio são principalmente baixos a muito baixos, mas há amostras com teores considerado limitantes. 
Os valores de alumínio são mais altos que os da Turfeira Caverá e semelhantes aos das turfeiras Banhado do Sombrio e Banhado Piritu.

Os teores de matéria orgânica, cálcio e magnésio são altos ou suficientes para culturas dentro dos parâmetros da classe 4.

A densidade aparente a seco (DBD) apresenta valores similares aos da Turfeira Banhado Piritu.

\subsection{Turfeira Sanga dos Rodrigues}

Foram analisadas apenas quatro amostras que apresentam teores de fósforo de limitantes a muito baixos. Se a classe considerada fosse seis em lugar de quatro, esses valores seriam classificados como médios a baixos.

Os teores de potássio também são baixos bem como os da matéria orgânica. Neste caso são semelhantes às das turfeiras paulistas.

O alumínio mostrou-se ausente de três amostras, porém em uma ele foi o mais alto valor de quaisquer das turfeiras já descritas e mais baixo do que as duas que seguirão.

Os teores de cálcio e magnésio são altos, além dos valores considerados necessários.

\subsection{Turfeira Corrupiá}

Apenas duas amostras foram analisadas e os valores de fósforo para ambas foram altos, sendo os maiores de qualquer das turfeiras até aqui descritas. Porém, o teor de potássio é limitante ao cultivo e os teores de matéria orgânica são muito baixos, apenas sobrepondo-se aos da turfa soterrada.

Os índices de alumínio são altíssimos, estando entre os mais elevados de todas as amostras analisadas.

Os teores de cálcio e magnésio são médios, o que sepodee estranhar uma vez que há condições geológicas para maiores entradas desses elementos. 


\subsection{Turfeira Sob Crista Prajal da Lagoa do Sombrio}

A turfa aqui analisada mostrou teores médios de fósforo. Os teores de potássio são suficientes, ao passo que os de cálcio e magnésio variam de médios a suficientes.

Os teores de aluminio variam muito entre as duas amostras analisadas e são altos. A matéria orgânica tem teores baixos.

\subsubsection{Idades, Espessuras e Taxas de Sedimentação}

Para as turfas da área estudada foram obtidas seis datações por radiocarbono. Cinco idades foram calculadas pelo Laboratório da Beta Analytic Inc., na Flórida, e uma no Laboratório de Física Nuclear Aplicada do Instituto de Física da Universidade Federal da Bahia.

A amostra mais antiga é proveniente da Turfeira Banhado do Sombrio que apresentou um resultado de $4.700 \pm 70$ anos A.P. (Beta-55381). Ela foi coletada a uma profundidade entre $3,55 \mathrm{~m}$ e $4,05 \mathrm{~m}$, onde a superfície da turfeira apresenta altitude entre 8 e $10 \mathrm{~m}$, sobre argila orgânica. Na sondagem foram recuperados na base da turfa, $0,15 \mathrm{~m}$ de argila orgânica de cor cinza, seguida de 0,10 m de argila orgânica cor esverdeada.

A amostra situava-se a uma altitude entre um mínimo de $4 \mathrm{~m}$ e um máximo de $5,5 \mathrm{~m}$.

Considerando as curvas de variação do nível médio relativo do mar durante os últimos 6.000 a 7.000 anos para o Brasil, apresentados por MARTIN et al. (1988) para Santa Catarina, o nível máximo do mar no Holoceno aconteceu há cerca de 5.100 anos A.P., alcançando cerca de $3,5 \mathrm{~m}$. Segundo estes autores, desde então os níveis de mar sempre foram mais baixos, incluindo portanto a idade de $4.700 \pm 70$ anos A.P., aqui apresentada.

Para a Bahia, SUGUIO et al. (1985) apresentam mais detalhes dizendo que, após o nivel máximo de 5.100 anos A.P., ocorreu uma regressão rápida até 4.900 anos A.P. que 
se tornou lenta até 4.200 anos A.P.. MARTIN et al. (1988) afirmam que entre 4.100 e 3.800 anos A.P., o nivel marinho estava abaixo do atual.

Com estas considerações supõe-se que o ambiente da Turfeira Banhado do Sombrio já era lacustre( água doce) à época da deposição dos materiais orgânicos.

A amostra da turfa do Banhado Piritu, situada entre $1,50 \mathrm{~m}$ e $1,90 \mathrm{~m}$ de profundidade, coletada a oeste e na parte central da turfeira, mostrou uma idade de $1.720 \pm$ 60 anos A.P. Sotoposta há argila com fragmentos de vegetais, seguida por uma argila muito plástica, de cor cinza-verde.

As altitudes da turfeira estão abaixo de $10 \mathrm{~m}$. Algumas medidas altimétricas situam-nas entre $3 \mathrm{~m}$, sul, e $7 \mathrm{~m}$ na parte central. Para o $\mathrm{N}$ não há medidas. $\mathrm{A}$ coleta foi realizada na metade norte, onde a superfície da turfeira tem, provavelmente, $7 \mathrm{~m}$ de altitude. Dessa maneira, a amostra foi retirada de uma altitude entre $5 \mathrm{~m}$ e $5,50 \mathrm{~m}$.

A esta época a curva para Itajaí-Laguna de SUGUIO et al. (1985) demonstra que o nível marinho, em regressão, estava a pouco mais de $1 \mathrm{~m}$ acima do atual. Para MARTIN et al. (1988) o último máximo, para Santa Catarina, teria acontecido por volta de 2.500 anos, alcançando $2,0 \pm 0,5 \mathrm{~m}$.

Para a Turfeira Caverá, a amostra coletada a sudeste, próximo à sua extremidade sul, em profundidade entre $2,30 \mathrm{~m}$ e $2,80 \mathrm{~m}$, indicou idade de $2.360 \pm 70$ anos A.P.

É uma amostra também basal sobre argila cinza-verde-azulada.

A altitude da turfeira no local da coleta situa-se entre $4 \mathrm{~m}$ e $5 \mathrm{~m}$. Dependendo desta amplitude de cota a amostra provém de uma altitude entre os extremos 1,20 m e 2,70 m. Se considerarmos como cota os $4 \mathrm{~m}$, a coleta foi realizada a uma profundidade correspondente à altitude de $1,20 \mathrm{~m}$ a $1,70 \mathrm{~m}$, porém, se o topo local da turfeira tinha $5 \mathrm{~m}$, então a amostra foi coletada entre $2,20 \mathrm{~m}$ a $2,70 \mathrm{~m}$ de altitude.

SUGUIO et al. (1985) e MARTIN et al. (1988) afirmam que por volta de 2.500 anos A.P., o nivel marinho estava cerca de $1 \pm 0,5 \mathrm{~m}$ acima do atual e que desta data até hoje ele esteve em abaixamento regular até a presente posição.

Esta amostra, pela altitude e idade, poderia situar-se num ambiente com influência marinha, isto é, num ambiente lagunar, porém deve-se lembrar a sua situação geológica e 
geográfica. Ao sul do local da coleta há um corpo de água, a Lagoa de Caverá, com água doce. Ao sul deste há um terraço lagunar/lacustre com sedimentos principalmente areno-argilo-orgânicos e com pequenos corpos de turfa. Neste terraço afloram rochas básicas e Arenito Botucatu. Então, sempre houve uma restrição do antigo corpo de água para sul, e ele fechou mais cedo seu contato com o mar do que a Lagoa do Sombrio. Os terraços lagunares, ao sul desta última, apresentam conchas que foram datadas em 5.900 \pm 2.300 anos A.P. (Bah - 1666) e que estão numa altitude semelhante àquela do terraço entre as duas lagoas. Logo, o fechamento deu-se numa época bem mais antiga do que a idade da Turfeira Caverá. O ambiente era então provavelmente lacustre.

Outra idade foi obtida para a Turfa da Turfeira Olvebra. Como já foi relatado, esta é constituída de corpos paralelos de turfa situados nos cavados entre as cristas praiais. Estas são regularmente espaçadas e apresentam um desnível de $3 \mathrm{~m}$ entre o topo das cristas e a base da turfa. A espessura da turfa é cerca de $1 \mathrm{~m}$ e a turfeira em cada corpo tem alguns metros de largura.

A idade obtida para a base da turfa, isto é, para a amostra coletada entre 0,70 e $1 \mathrm{~m}$ de profundidade foi de $2.360 \pm 60$ anos A.P.

As cristas tem 8 a $9 \mathrm{~m}$ de altitude, e o topo da turfeira está entre 6 e $7 \mathrm{~m}$ de altitude, portanto sua base está entre 5 e $6 \mathrm{~m}$ acima do nível médio do mar. Por conseguinte, está bem mais alta que a amostra de Caverá, porém tem a mesma idade.

A turfa soterrada sob sedimentos arenosos da crista praial da Lagoa do Sombrio foi datada pelo Laboratório de Física Nuclear Aplicada da UFBa e pela Beta Analytic Inc. A idade obtida por este último Laboratório foi de $1.200 \pm 60$ anos A.P. (Beta - 55383) e pelo primeiro foi de $1.770 \pm 180$ anos A.P., com $\delta^{13} \mathrm{C}$ de $-25.29 \%$ (Bah - 1665).

A crista tem cerca de $2 \mathrm{~m}$ de altitude e a amostra foi coletada entre $0,90 \mathrm{~m}$ e 1,35 $\mathrm{m}$ abaixo desta cota. A camada de turfa tinha $40 \mathrm{~cm}$ e sob esta há areias de cores castanha e branca, manchada de preta. Sobre o material turfoso estão camadas de areias.

A camada de turfa situa-se, então, entre cerca de $0,90 \mathrm{~m}$ e 1,35 m acima do atual nivel do mar. $\mathrm{O}$ material orgânico apresentou um $\delta^{13} \mathrm{C}$ de -25.29 , isto é, claramente de água doce ou de ambiente continental. A curva de variação do nível do mar de SUGUIO et 
al. (1985), sugere que nesta época o nível do mar estava pouco acima de $1 \mathrm{~m}$, mas provavelmente a entrada do mar na Lagoa do Sombrio estava barrada.

Alguns trabalhos sobre turfas no Brasil apenas sugerem idades, como o de MENDES \& COSTA (1981), COSTA \& MENDES (1981), MORAES (1981), RAMOS \& LIMA FILHO (1982), LEMOS et al. (1981). VILLWOCK et al. (1980) apresentam três dataçōes de $2.200 \pm 100$ anos A.P. de $2.500 \pm 100$ anos A.P. e $4.500 \pm 100$ anos A.P., lembrando que essas turfeiras estão ativas desde 5.000 anos. As datações são da Turfeira Águas Claras (RS). ROTH \& LORSCHEITTER (1989) e ROTH (1990) apresentam uma idade de 10.480 \pm 140 anos A.P., correspondente, segundo os autores, ao início da Formação da turfa e final do Pleistoceno. Esta amostra do Parque nacional dos Aparados da Serra, no planalto do Rio Grande do Sul, foi coletada a 3,30 m de profundidade.

VILLWOCK et al. (1980) estimam uma taxa de acumulação em torno de $1 \mathrm{~m}$ em cada 2.000 anos, pois a amostra mais antiga está entre 1 e $2 \mathrm{~m}$ de profundidade, e a segunda amostra mais antiga foi coletada entre 0 e $1 \mathrm{~m}$ de profundidade.

A idade de 10.480 anos A.P. para uma amostra situada a $3,30 \mathrm{~m}$ de profundidade (ROTH \& LORSCHEITTER, 1989), significa uma taxa de deposição de pouco mais de $3 \mathrm{~mm} / \mathrm{ano}$.

Nas turfeiras do litoral de Santa Catarina aqui analisadas, esta taxa é pouco variável. Usando-se a profundidade do topo das amostras e as datas obtidas, tem-se para a Turfeira Banhado do Sombrio a taxa estimada de 1,16 mm/ano; para a Turfeira Banhado do Piritu é de $1,15 \mathrm{~mm} / \mathrm{ano}$; para a Turfeira Caverá a taxa estimada é de $1,03 \mathrm{~mm} / \mathrm{ano}$; e para a Turfeira Olvebra é de $2,36 \mathrm{~mm} / \mathrm{ano}$.

Portanto, se as turfas fossem depositadas continuamente por acréscimo vertical, sem interrupções e de maneira homogênea ao longo de toda turfeira, na do Banhado do Sombrio haveria a sedimentação de cerca de $1,16 \mathrm{~m} / 1.000$ anos; na Turfeira Banhado Piritu, cerca de $1,15 \mathrm{~m} / 1.000$ anos; na Turfeira Caverá, $1,03 \mathrm{~m} / 1.000$ anos e na Turfeira Olvebra, 2,36 m/1.000 anos, o que seria o dobro da taxa de sedimentação da Turfeira Águas Claras(RS), no caso da comparação com as três primeiras. A Turfeira Olvebra tem uma taxa bem mais elevada em relação às demais, porém menor do que a da 
Turfeira dos Aparados da Serra de ROTH \& LORSCHEITTER (1989). Estas duas últimas situam-se acima do valor médio de taxa de acumulação sugerida por AYERS \& KAISER (1984).

Estas questões relativas à idade e às taxas de sedimentação são difíceis de serem interpretadas, quando se fazem análises pontuais, pois tem-se que levar em conta aquela situação apresentada no canto superior esquerdo da Figura 177, a que muitos autores se referem. Há possibilidade de turfas flutuantes serem mais antigas do que as provenientes de plantas fixas, ao fundo de um estágio posterior, ou mesmo turfas provenientes de organismos não fixos, como algas microscópicas que se acumulam no fundo e, que, no entanto, estão sotopostas à turfa flutuante na seqüência estratigráfica, mas trata-se de uma inversão cronoestratigráfica.

Em outros países há referências de taxas de acumulação variando de zero a $1 \mathrm{~m} / 1.000$ anos (SCHOPF, 1973; apud TATSCH, 1980).

Segundo STACH (1975) e STACH et al. (1982), na zona temperada a taxa anual de crescimento das turfas de pântano é estimada em $1 / 2$ a $1 \mathrm{~mm} / \mathrm{ano}$, mas as high-moor crescem de 1 a $2 \mathrm{~mm} / a n o$. Na Flórida e no delta do Mississipi, ambientes subtropicais, a taxa é de 1,3 mm/ano e $1 \mathrm{~mm} / \mathrm{ano}$, respectivamente. Muitas turfas tropicais apresentam taxas de crescimento mais altas, como é o caso de N.W. Borneo em que elas são de 3-4 mm/ano, isto é, $1 \mathrm{~m}$ em cada 300 a 400 anos, ou 3 a $4 \mathrm{~m} / 1.000$ anos.

AYERS \& KAISER (1984) apresentam taxas de acumulação para vinte e seis turfeiras (bogs, swamps) modernas, de latitudes subárticas a tropicais. Estes estudos revelam taxas baixas de 0,10 a $0,16 \mathrm{~mm} / 1.000$ anos, no delta de Yukon e altas de $4,8 \mathrm{~m} / 1.000$ anos nas turfeiras altas (raised swamps) de Borneo. Na área subtropical do delta do Mississipi eles determinaram de 4,5 a 6 m/1.000 anos. $O$ valores são diferentes daqueles apresentados por STACH (1975) e STACH et al. (1982). A taxa média de acumulação estabelecida por AYERS \& KAISER (1984) foi de 1,72 m/1.000 anos.

As turfas ativas do sul de Santa Catarina, pelas medidas efetuadas, têm espessuras variando de $1 \mathrm{~m}$ a quase $5 \mathrm{~m}$, situando-se dentro da variação apresentada pelas turfeiras no Brasil e em grande parte das turfeiras de outros países. 
Espessuras maiores são referidas por VILLWOCK et al. (1983b) para turfa da Austrália, com 8 m, e admitidas por MORAES \& CALDASSO (1982) para o Nordeste Oriental brasileiro com até $12 \mathrm{~m}$; por TATSCH (1980) para os depósitos de Nilgiri, em Madras, Índia, com $10 \mathrm{~m}$ de espessura e para áreas deltaicas tropicais, como no delta do Rio Klang, com até $15 \mathrm{~m}$. Este autor diz que, na planície costeira do Suriname e Guianas, muitos depósitos de turfa excedem a espessura de $40 \mathrm{~m}$ interdigitados localmente com depósitos arenosos de praia. McCABE (1984), referindo-se a trabalhos de outros autores, relata que num delta no Lago Sucker (Michigan), a turfa alcança até $15 \mathrm{~m}$ de espessura e no delta Rajang, do norte de Borneo, Malásia, ela tem 13,7 m de espessura. Espessura muito alta também foi registrada por STACH et al. (1982) em dolinas nas Bermudas, onde chega a $33 \mathrm{~m}$.

\subsubsection{O Embasamento dos Depósitos de Turfas}

As descrições anteriores sobre a amostragem realizada no sul de Santa Catarina, demonstra que freqüentemente o material inorgânico sotoposto à turfa é argiloso. A argila é de cor cinza que varia de escura a média, com uma tendência para cinza verde.

A espessura mínima de sedimento sotoposto argiloso foi encontrada na Turfeira Olvebra com cerca de $5 \mathrm{~cm}$.

Mas, o material nem sempre é argila pura e sim são camadas argilo-arenosas ou argilo-siltosas. Em alguns testemunhos foi possivel verificar-se a passagem gradativa da turfa para sedimentos argilosos e destes para arenosos.

Com o amostrador tipo Hiller foi possivel fazer perfurações com profundidades variando de $3,50 \mathrm{~m}$ a $7,50 \mathrm{~m}$.

Foram realizadas análises granulométricas de poucas amostras situadas mais profundamente e não daquelas em contato com as turfas, das turfeiras Banhado do Sombrio e Banhado Piritu. As onze amostras coletadas em vários níveis evidenciam a superposição de camadas distintas, pois a quantidade de argila varia de $6 \%$ a $60 \%$, a de 
areia varia de $3 \%$ a $55 \%$ e a de silte varia de $15 \%$ a $44 \%$. São todas amostras polimodais.

$\mathrm{Na}$ Turfeira Banhado Piritu há materiais que se comportam de maneira totalmente distinta que os das outras turfeiras. Em trincheiras abertas no lado leste, encontra-se um material gelatinoso ultramfino que pode tratar-se de matéria orgânica coloidal.

Conchas são encontradas na extremidade sudeste da Turfeira Piritu em nível equivalente ao da turfa. Também são encontrados fragmentos de conchas no extremo sul e sudeste da Turfeira Banhado do Sombrio, entre os limites de 2,40 m e 9,15 m de profundidade, dentro de argilas orgânicas com silte e pouca areia. Na Turfeira Caverá foram encontradas conchas à profundidade de $3 \mathrm{~m}$ no seu lado oeste, em areias cinza-esverdeadas.

As conchas encontradas a sul-sudeste da área de turfa do Banhado Piritu, estão cobrindo cerca de $0,40 \mathrm{~m}$ deste material.

Os embasamentos das turfas são constituídos, portanto, de depósitos lagunares passando para lacustres. A partir das lagoas houve condição para o acúmulo da matéria orgânica que deu origem às turfas.

A turfa soterrada sob cristas praiais da Lagoa do Sombrio foi acumulada em condições nitidamente de água doce pois o $\delta^{13} \mathrm{C}$ desta amostra é $-25,29 \%$.

A Turfeira Olvebra é outro caso que chama a atenção pela pequena largura de seus corpos alongados, com o embasamento principalmente arenoso e camada de argila sotoposta de apenas alguns centímetrus de espessura.

A Turfeira Banhado do Sombrio é, entre todas as pesquisadas, a única que apresenta intercalações argilosas, evidenciando sua posição geológica, com terrenos elevados a oeste e ao norte, dos quais pode receber materiais inorgânicos. Porém, esses sedimentos argilosos devem representar momentos de inundações maiores, evidenciando assim, também a influência fluvial sobre a turfeira, principalmente dos rios Canoas, Leão e Bonito. Esta turfeira apresenta a oeste e sudoeste recobrimento por sedimentos inorgânicos de diques marginais dos rios Canoas e Leão, em altitudes abaixo de $6 \mathrm{~m}$. 
A Turfeira Rio do Sertão está em grande parte recoberta também por sedimentos fluviais de diques marginais e de planície de inundação do rio homônimo.

A Turfeira Corrupiá é constituída de um muck ou solo para-orgânico ou mesmo um gley muito húmico, pelos teores de matéria orgânica, densidade aparente a seco (DBD) e poder calorífico.

A Turfeira Sanga dos Rodrigues exibe teores relativamente baixos de matéria orgânica, ausência de alumínio e pH mais alto entre as turfeiras analisadas.

As turfeiras aqui estudadas são semelhantes a muitas referidas desde o Rio Grande do Sul até o Nordeste brasileiro, por VILLWOCK et al. (1980), LEMOS et al. (1981), MORAES (1981), MORAES (1982), MOTA et al. (1982), MORAES \& CALDASSO (1982), ALGARTE et al. (1982), entre outros. Porém, as semelhanças não necessariamente se referem a todos os aspectos aqui mencionados.

\subsection{RELAÇÕES ESTRATIGRÁFICAS E IDADES DOS SEDIMENTOS}

As relações estratigráficas entre os depósitos de leques aluviais e os sedimentos praiais pleistocênicos, bem como entre os depósitos lagunares e lacustres, são facilmente estabelecidas pelas características sedimentológicas: granulometria, composição mineralógica; e pela situação geológica, permitindo chegar-se às suas idades relativas.

Nos depósitos holocênicos há várias datações de conchas, turfas e troncos, que permitem reconstituir à evolução geológica destes depósitos.

Os depósitos de leques aluviais, na área estudada, estão aflorando no sopé da escarpa que forma a borda do planalto meridional, estendendo-se para leste e passando lateralmente para outros tipos de depósitos. A faixa de afloramento é muito mais larga e extensa no Setor Norte que no Setor Sul. No Setor Sul, na área de afloramentos, estudos para as barragens do Rio Mampituba, a montante da cidade de Praia Grande, e as dos rios Leão e Bonito, além dos poços para carvão no Setor Norte e Sul, forneceram uma idéia de espessura desses depósitos. 
No Setor Norte, poços realizados para prospecção de carvão como o SW-01-SC, perfurado junto ao Rio Figueira, a sudoeste da cidade de Turvo, atravessou $20 \mathrm{~m}$ de depósitos de seixos sobre arenito róseo, fino, micáceo, da Formação Rio do Rasto, e o SW-02-SC, a oeste da cidade de Meleiro e pouco ao norte dos $28^{\circ} 50^{\prime} \mathrm{LS}$, perfurou $15,80 \mathrm{~m}$ de depósitos de seixos sobre siltito avermelhado, arenoso.

Mais para leste, em Maracajá, um poço para obtenção de água subterrânea, aberto pela Companhia T. Janer para a Companhia de Água e Saneamento de Santa Catarina (CASAN), registrou $3 \mathrm{~m}$ de espessura de depósitos de seixos sob $5 \mathrm{~m}$ de solo argilo-siltoso, rico em matéria orgânica e sobre folhelho síltico cinza claro. A leste deste poço, ainda no município de Maracajá, em Barro Vermelho, a sondagem para carvão IMA-13-SC apresenta $19 \mathrm{~m}$ de seixos imersos em areia fina a média, sob $12,50 \mathrm{~m}$ de areia fina a média inconsolidada.

Na mesma localidade, um pouco ao norte, a perfuração IMA-16-SC apresentou $18 \mathrm{~m}$ de seixos imersos também em matriz arenosa fina a média, sob $16 \mathrm{~m}$ de areia fina a média, argilosa, inconsolidada.

Ao sul do Rio Araranguá, sob depósitos praiais pleistocênicos, foram encontrados os materiais rudáceos dos leques aluviais em poços para carvão, para água subterrânea e em sondagens para construções de pontes e edifícios. Em Sanga da Toca, a sudoeste de Araranguá, o poço 5-AT-01-SC foi iniciado com a boca situada a $21,50 \mathrm{~m}$ de altitude, perfurando $24 \mathrm{~m}$ de areias inconsolidadas sobre conglomerado semi-consolidado com $17,90 \mathrm{~m}$ de espessura, cujos seixos possuem tamanho médio em torno de $10 \mathrm{~cm}$, por sua vez superposta à Formação Rio do Rasto. Pouco ao norte, no Bairro Mato Alto, poços para água subterrânea perfurados por diversas empresas, assinalam a presença desses sedimentos. O poço da T. Janer (Pa -1759), perfurado para a Fundação SESP ( Serviço de Saneamento Público), registrou cascalho constituído por seixos rolados de basalto entre 40 e $65 \mathrm{~m}$ de profundidade e entre 70 e $80 \mathrm{~m}$. Estas camadas são separadas entre si por argila parda com presença de matéria orgânica. A empresa Braspoços também reconheceu a ocorrência de camadas de cascalhos entre 48 e $52 \mathrm{~m}$ e entre 58 e $60 \mathrm{~m}$, separadas entre si por $6 \mathrm{~m}$ de areia quartzosa mal selecionada. Estão recobertos por 
camadas arenosas e areno-síltico-argilosas até $48 \mathrm{~m}$. Poderiam ser, ainda, apresentados os dados de mais de 20 poços para água subterrânea e sondagens para construções civis, no município de Araranguá e arredores. Todos evidenciam áreas ocupadas no passado, pelos leques aluviais bem a leste das exposições atuais, portanto, bem maiores que as aflorantes. Ocorrem também sedimentos praiais pleistocênicos sobre os depósitos de leques aluviais, bem como sedimentos rudáceos intercalados em depósitos provavelmente de paleolagunas ou paleoestuários.

No Setor Sul, as sondagens para barragens e pontes também contribuem com dados de espessuras. Nas sondagens nas cabeceiras da ponte sobre o Rio Bonito, na estrada estadual, a espessura da camada de seixos variou de 3 a 4,50 m. Nas cabeceiras da ponte do Rio Leão, na mesma estrada, variou de 1,30 a 3,10 m. A espessura de fato é pequena no local, pois no leito do rio afloram argilito e arenito do Grupo Passa Dois, provavelmente da Formação do Rio do Rasto. Junto à ponte do Rio Cachoeira as espessuras são de $4,75 \mathrm{~m}$ a $7,55 \mathrm{~m}$. Na área de ponte sobre o Rio Malacara as espessuras medidas são de 7,50 a $8,70 \mathrm{~m}$ e junto à ponte sobre o Rio Três Irmãos de $14 \mathrm{~m}$.

Os dados sobre a área da barragem projetada para o Rio Mampituba, a montante da cidade de Praia Grande, podem ser visualizados nas figuras 15 a 20 . As descrições registram $21 \mathrm{~m}$ de espessura de cascalho aluvionar no eixo proposto $A-A^{\prime}$ e $35 \mathrm{~m}$ de espessura máxima nos eixos B-B'.

No eixo da barragem do Rio Leão, as espessuras têm grande variação, chegando a até $12 \mathrm{~m}$, sobre rocha sedimentar, provavelmente do Grupo Passa Dois. Comportamento similar é apresentado no eixo da barragem do Rio Bonito, pouco ao norte.

Para o leste do Setor Sul, na área dos sedimentos pleistocênicos, a oeste da Lagoa do Sombrio, em Três Coqueiros, o poço 5-AT-03-SC para carvão registrou a presença de cascalho sob areia, acima do arenito da Formação Botucatu.

Em São João do Sul defronte à Igreja e ao lado da Praça, um poço da T. Janer, para água subterrânea, perfurou sob $15 \mathrm{~m}$ de areia, cerca de $47 \mathrm{~m}$ de cascalho grosso intercalado com areias, argilas e siltes de cores creme a avermelhadas, superposto arenito 
silicificado. Outro poço da mesma empresa, aberto em Santa Rosa do Sul, também atravessou depósito rudáceo com intercalação de areia fina e matriz silto-arenosa, entre 21 e $27 \mathrm{~m}$ de profundidade. Ambos estão sob as cristas praiais pleistocênicas.

A leste da Lagoa do Sombrio e no paralelo de Três Coqueiros, os autores da descrição do poço 5-AT-07-SC, descreveram $110 \mathrm{~m}$ de "areia e argila inconsolidada, e seixos de diabásio e basalto, provenientes do conglomerado Mampituba." Esses sedimentos estão sobre a Formação Botucatu. Outro poço mais ao sul, o 5-AT-12-SC, bem mais próximo ao mar que o anterior, e a nordeste de Torres, atravessou $54 \mathrm{~m}$ de areia esbranquiçada, muito fina, argilosa, com conchas, sobre $4 \mathrm{~m}$ de conglomerado com seixos de diabásio e basalto, sobre $31 \mathrm{~m}$ de argila cinza escura e orgânica, que estão situados sobre o Arenito Botucatu. Neste caso, os depósitos rudáceos estão provavelmente situados sobre depósitos de plataforma com lama e recobertos por areias de plataforma rasa a praiais.

\subsection{RELAÇÃO COM OS NIVEIS MARINHOS QUATERNÁRIOS}

Muitos estudiosos brasileiros e estrangeiros, como os citados por BIGARELLA et al. (1975: 246) vêm estudando as flutuações do nível de mar no Quaternário. Entretanto, a maioria desses autores relacionava essas flutuações com as variações climáticas de âmbito global, e muitos tentavam verificar o ajuste de seus dados às curvas estabelecidas em outros continentes. Foram comuns as correlações com as variações apresentadas pela chamada "Curva de FAIRBRIDGE" de 1961, mesmo após esse autor, usando datações correspondentes a situações de vários estados brasileiros, principalmente dos Estados do Paraná e Santa Catarina, ter afirmado que a curva de 1961 possuía erros devido aos dados limitados, efeitos de maré e flexura crustal (FAIRBRIDGE, 1976).

MARTIN \& SUGUIO (1975) pela primeira vez estabeleceram curvas de variação do nivel do mar para os últimos 6000 anos no litoral paulista. Esses autores, em 1976, propuzeram que o mecanismo de flexura continental diferencial poderia explicar as diferenças encontradas nos setores norte e sul do litoral de São Paulo. 
MARTIN \& SUGUIO (1976) afirmam que importantes transgressões, uma pleistocênica e outra holocênica, registradas nos sedimentos depositados em ambiente marinho raso, poderiam ser reconhecidas mediante datações de amostras de concha e madeira dos depósitos, e de sambaquis. Estabelecem a curva de variação do nível médio do mar nos últimos 6000 anos e, portanto, a seguinte história da evolução geológica neste intervalo de tempo. Em torno de 5000 anos B.P. o nível médio era provavelmente um pouco inferior ao atual. Em torno de 3200 anos B.P. o nível médio do mar passou por um segundo máximo situado cerca de $3 \mathrm{~m}$ acima do atual. Finalmente, há 1800 anos B.P. o mar voltou ao nível próximo do atual." (MARTIN \& SUGUIO, 1976: 8-9). Naquele mesmo ano, a história da evolução geológica foi detalhada por MARTIN et al. (1976).

Seguem-se uma série de trabalhos que podem ser representados pelo trabalho de SUGUIO et al. (1985). Eles expõem uma série de fatores que controlam o nível médio do mar, fatores esses que agem independentes ou concomitantemente, em trechos das zonas costeiras do globo, que também foram discutidos anteriormente por MARTIN et al. (1982). Apresentam dados da costa leste do Brasil, do Estado de Alagoas ao de Santa Catarina, com oito curvas de variação do nível médio relativo do mar para diferentes trechos desta costa, construída com base em evidências fornecidas por dados arqueológicos, geológicos e biológicos. Concluem pela apresentação da evolução geológica através de transgressões e regressões durante o Quaternário da costa do Brasil. Para Santa Catarina, especialmente, há o trabalho de MARTIN et al. (1988), já apresentado em outro capítulo.

Pesquisadores da Universidade Federal do Rio Grande do Sul têm atuado na costa do Rio Grande do Sul desde a década de 60, sobre uma zona costeira larga e com cerca de $600 \mathrm{~km}$ de comprimento. Alguns têm descrito terraços marinhos com altitudes médias de $20 \mathrm{~m}$ e $25 \mathrm{~m}$, considerados pleistocênicos, a que corresponderiam níveis de mar muito mais altos que essas altitudes (JOST \& SOLIANI, 1976).

$\mathrm{Na}$ área de estudo estão bem registrados niveis acima de $20 \mathrm{~m}$ de altitude, que se não foi afetada por atividade tectônica, esses níveis devem estar ligados a um nível relativo de mar pelo menos $25 \mathrm{~m}$ acima do atual, sendo então correlacionáveis à Barreira 2 do Estado vizinho. 
Há outros niveis com cristas praiais a leste das lagoas que pela sua altitude de 8 a 9 $\mathrm{m}$, corresponderiam a niveis mais altos de mar, também do Pleistoceno, isto é, à transgressão Cananéia (MARTIN et al. 1975; SUGUIO et al. 1985), ou 123.000 anos (MARTIN et al. 1993). Seguem-se a estas cristas outras entre o nível do mar atual e cerca de $5 \mathrm{~m}$ de altutude; são holocênicas. O nível da primeira transgressão marinha do Holoceno está bem registrado em depósitos de paleolagunas e paleoestuários cujas conchas foram datadas. As idades situam-se entre $5.670 \pm 220$ anos A.P. e $6.490 \pm 240$ anos. Os sítios arqueológicos tipo sambaqui encontrados sobre as cristas praiais holocênicas com retrabalhamento eólico, têm idades entre $1.330 \pm 160$ anos A.P. e 1.880 \pm 170 anos A.P. 


\section{CONCLUSÕES E CONSIDERAÇÕES}

A área estudada é diferente de todas as outras áreas costeiras do Estado de Santa Catarina, tanto pela natureza de seus depósitos cenozóicos e respectivas morfologias e altitudes, como pelo tipo de seu embasamento constituído por rochas paleozóicas e mesozóicas da Bacia do Paraná, que também como feição geomorfológica de maior expressão apresenta a escarpa da borda do planalto.

Esta escarpa apresenta uma direção geral N-S nas folhas Jacinto Machado e Praia Grande, porém apresenta sinuosidades devidas à erosão preferencial ao longo de linhas tectônicas com direções NW-SE e NE-SW. A primeira direção se expressa mais no Setor Sul, e a segunda, no Setor Norte, sendo a última acompanhada pelos dois principais cursos fluviais, que são os rios Mampituba e Araranguá.

A Serra Geral, toponímia aplicada à borda escarpada do Planalto Meridional, é parte de uma feição que se estende do Rio Grande do Sul ao Espírito Santo, constituindo um grande escarpamento desenvolvido sobre vários tipos de rocha, que está relacionado à separação e migração dos continentes durante a formação do Oceano Atlântico.

A formação deste oceano, no limite continental leste, determina a existência de um novo grande controlador dos processos erosivos e deposicionais continentais. Este novo 
nivel de base da erosão, então formado, gera nova dinâmica entre as massas continentais e o corpo de água criado, principalmente onde a amplitude de relevo for mais acentuada.

$\mathrm{Na}$ área estudada, o novo limite continental expresso pela borda da Bacia do Paraná, mais ou menos soerguida, passa a ter uma nova relação de causa e efeito com o oceano que se forma e se expande. O controle exercido pelo nível oceânico se expressa tanto nas formas erosivas da área, quanto nos depósitos, seus tipos, sua distribuição e algumas de suas formas. Salienta-se a ação do Oceano Atlântico erodindo e depositando na área através dos seus movimentos e variações de nível.

A escarpa da Serra Geral é morfologicamente diferenciada do resto, configurandose em área dispersora de águas e sedimentos. Deste modo, as suas rochas foram a fonte principal de detritos para os depósitos que constituem a planície do Sul de Santa Catarina.

As rochas sedimentares e ígneas da Bacia do Paraná, em morros testemunhos ou constituindo o esporão-divisor das duas bacias fluviais, evidenciam posições antigas, mesozóicas e terciárias da escarpa que estava situada mais para leste.

O esporão-divisor bem como elevações residuais, têm sua resistência marcada, em grande parte, pela presença de corpos ígneos básicos intrusivos.

Os anfiteatros formados pelas elevações contínuas dão aos dois setores a conformação de paleobaías que existiram durante fases de níveis de mar mais altos, no passado. Durante estas fases muitas das elevações residuais, nos dois setores, constituíram ilhas, e o esporão-divisor teria sido um promontório entre as duas baías. $\mathrm{O}$ ataque marinho ficou registrado na parte frontal deste, através de várias cavernas, produto da erosão marinha no Arenito Botucatu que se apresentava como falésia. A base dessas grutas situa-se a $5,50 \mathrm{~m}$ acima do nível médio do mar atual. Elas podem ter sido elaboradas por níveis de mar mais altos registrados nos depósitos da área, da transgressão pleistocênica anterior a 123.000 anos ou daquela de 123.000 anos. Embora haja condições de altitude para sua formação durante a primeira transgressão holocênica, não havia espaço na paleolaguna de Sombrio, para ondas de alta energia.

O comportamento da distribuição espacial das rochas da Bacia do Paraná, também detectado através de sondagens, permite inferir uma tectônica de direções gerais N-S e 
E-W, anterior aos depósitos cenozóicos. Esta tectônica também se salienta na orientação dos vales e canais fluviais, na área da escarpa, e deste modo, o cânion do Itaimbezinho representaria uma garganta tectônica que se adentra nesta escarpa.

A disposição das grandes lagoas permite também vislumbrar uma orientação tectônica NE - SW, subparalela à linha atual da costa, detectada através de sondagens para água e prospecção de carvão, desde 1952, já referidas por PUTZER (1953) e por LEINZ (1949), com os blocos mais orientais com abatimento maior. As diferenças de espessura dos sedimentos cenozóicos entre a situação dos terraços a oeste das lagoas do Sombrio e Caverá, e os terrenos a leste, são de mais de $100 \mathrm{~m}$. Há nitidamente um degrau a leste das lagoas do Sombrio e Caverá. Não se pode confirmar qualquer tectônica atingindo os depósitos cenozóicos da área emersa, embora haja registro de abalos sísmicos na Bacia de Pelotas (DIAS NETO, 1986).

As altitudes do embasamento recoberto com os depósitos cenozóicos variam de $100 \mathrm{~m}$ até no mínimo $-105 \mathrm{~m}$, isto é, um desnivel de $205 \mathrm{~m}$. Entretanto, no Setor Sul, a oeste da Lagoa do Sombrio, os valores vão de $100 \mathrm{~m}$ a $-30 \mathrm{~m}$, gerando, portanto, nesse espaço, desniveis de $130 \mathrm{~m}$, o que significa uma forte dissecação anterior aos depósitos cenozóicos. Este desnivel deve representar várias etapas ou situações em que o embasamento ficou sob o domínio da erosão, sem que se possa afirmar que ele estivesse em qualquer momento, totalmente desprovido de cobertura sedimentar cenozóica.

Esta situação deve ter evoluido através de sucessivas etapas de erosão e sedimentação, tanto fluviais como marinhas. A área hoje a oeste das maiores lagoas, no Pleistoceno, constituía-se em plataforma rasa atapetada com depósitos rudáceos de leques aluviais sobre os quais se depositaram seqüências de cristas praiais.

Os depósitos continentais de leques aluviais estão parcialmente sotopostos e interdigitados com os depósitos de origem marinha, e aflorando, a oeste destes, em grandes áreas dos dois setores, mas, principalmente no Setor Norte, a partir do sopé da escarpa da Serra Geral, desenvolvendo-se a partir de $200 \mathrm{~m}$ de altitude. Na primeira situação são encontrados até no extremo leste da área, como no poço AT-12, a sudeste da Lagoa do Sombrio, onde ocorrem com $4 \mathrm{~m}$ de espessura, sob $54 \mathrm{~m}$ de areias e argilas com 
conchas marinhas. Estes fatos confirmam que são, pelo menos parcialmente, depósitos muito antigos, anteriores aos depósitos praiais pleistocênicos de nivel de mar mais alto, anterior a 123.000 anos. Mas esta atividade fluvial continua até hoje. Deste modo, existem depósitos de leques aluviais de várias idades que, no estágio atual de conhecimentos, não se pode discriminar.

Muitos dos leques aluviais, principalmente os do Setor Norte, têm seus ápices dentro de vales, formando-se então fan-bays. A maioria já começa a coalecer logo a jusante desta posição e forma amplas áreas de aventais de leque, ainda com depósitos rudáceos.

Os depósitos rudáceos são dominantemente produto da deposição em canais fluviais sendo pequena a contribuição de depósitos de debris flow ou de corridas de lama. Eles acham-se recobertos por materiais pelítico-arenosos que são, em grande parte, devidos a ação pedogenética sobre os rudáceos.

Os depósitos arenosos entre Araranguá e Sombrio atingem altitudes acima de $25 \mathrm{~m}$ e passaram por uma fase inicial de transgressão marinha pleistocênica, como itha-barreira. $\mathrm{Na}$ regressão que se seguiu, outros depósitos arenosos foram acrescidos sob forma de cristas praiais, entre Sombrio e Guarita, e a leste de Araranguá, com altitudes em torno de 14 a $16 \mathrm{~m}$. Estes depósitos correspondem à Barreira II no Rio Grande do Sul e a um nivel de mar mais alto anterior a 123.000 anos. Depósitos de cristas praiais de mesma idade da etapa de regressão deste nivel marinho, são encontrados ao norte do Rio Araranguá, em Maracajá-Barro Vermelho e Campo Mãe Luzia-Hercílio Luz, e no Setor Sul.

Além desses, há no Pleistoceno uma outra seqüência de depósitos praiais regressivos, a leste das lagoas, com altitudes entre 8 e $9 \mathrm{~m}$. Eles são correspondentes à Barreira III do Rio Grande do Sul e a um nivel de mar mais alto de 123.000 anos. Seguemse os depósitos praiais e eólicos holocênicos na faixa do extremo leste, correspondentes à Barreira IV do Estado vizinho.

Ocorre, a nordeste da área, uma grande duna pleistocênica com até $100 \mathrm{~m}$ de altitude, na qual são visualizadas várias superfícies de erosão e paleossolos profundos. Mais ao sul ocorrem outras dunas pleistocênicas, porém mais jovens. Parece que os dois 
momentos de maior atividade eólica foram o do Pleistoceno que gerou a duna mais alta, e a atividade atual.

Os depósitos lagunares ou estuarinos são também de várias idades atestadas pelas suas altimetrias. Os mais antigos, a oeste das cristas praiais pleistocênicas mais antigas, têm entre 10 e $15 \mathrm{~m}$ de altitude, e os mais jovens têm altitudes principalmente entre 1 e $3 \mathrm{~m}$. Muitos deles contêm bancos de conchas e alguns foram datados através das mesmas. As idades são holocênicas, da fase transgressiva da primeira transgressão holocênica. Em muitos trechos acham-se recobertos por depósitos de paleolagoas e como parte destes ocorrem as turfas, também holocênicas.

Ãs margens das duas maiores lagoas ocorrem cristas praiais que se sucedem, marcando baixos terraços e apresentando-se de maneira assimétrica, pois são mais numerosas no lado oeste que no leste desses corpos de água.

Os depósitos paludiais organógenos são turfeiras com até $4,5 \mathrm{~m}$ de espessura, holocênicos. São de vários tipos devido às variações da contribuição vegetal e de nutrientes trazidos pelas águas dos lençóis freáticos. As turfeiras são todas do tipo low moor ou turfeiras baixas, tendo a Turfeira Piritu uma tendência para o tipo high moor ou turfeira alta, na sua metade norte, pelo desenvolvimento excepcional da vegetação de Sphagnum. 


\section{BIBLIOGRAFIA}

ALGARTE, J. P., OLIVEIRA, C. A., ABOARRAGE, A. M.. Prospecção de turfa na Bacia de Taubaté - SP. In: CONGR. BRAS. GEOL., 32., 1982, Salvador. Anais... v. 5, p. 2261-2272.

ALLEN, P. A.. Sediments and processes on a small stream-flow dominated, Devonian alluvial fan, Shetland Islands. Sedim. Geol., Amsterdam, v. 29, n. 1, p. 31-66, 1981.

ALMEIDA, F. F. M. de. Contribuição à geomorfologia da região oriental de Santa Catarina. Bol. Paulista de Geografia, São Paulo, n. 10, p. 3-32, 1952.

ALMEIDA, F. F. M. de. O planalto basáltico da Bacia do Paraná. Bol. Paulista de Geografia, São Paulo, n. 24, p. 3-34, 1956.

ALVES, C. E.. Estruturas da margem continental sul brasileira e das áreas oceânicas e continentais adjacentes. In: ASMUS, H. E., (Ed.). Estrutura e tectonismo da margem continental brasileira e suas implicações nos processos sedimentares e na avaliação do potencial de recursos minerais. Rio de Janeiro : Petrobrás, CENPES, DINTEP, 1981. p. 145-170. (Série Projeto REMAC, 9).

AMADOR, E. da S.. Estratigrafia e sedimentação da Bacia de Resende - RJ. An. Acad. Bras. Ciên., v. 47, p. 181-225, 1975. Suplemento. Apresentado no Simpósio Internacional sobre o Quaternário.

AMAJOR, L. C.. Alluvial fan facies in the Miocene-Pliocene-coastal plain sands, Niger delta, Nigeria. Sedim. Geol., Amsterdam, v. 49, n. 1/2, p. 1-20, 1986.

AMARAL, S. E. do, FUCK, G. F.. Sobre o deslizamento de lama turfosa ocorrido em Campos do Jordão, SP, em agosto de 1972. Bol. IG., São Paulo : USP, v. 4, p. 21 37, 1973. 
ANDREIS, R. R., BOSSI, G. E.. Sedimentologia del conglomerado Mampituba, RS. Brasil. Pesquisas, Porto Alegre, v. 10, p. 45-54, 1978.

ARIENTI, L. M.. Aspectos morfológicos, sedimentológicos e genéticos da Barreira das Lombas - Província Costeira do Rio Grande do Sul In: CONGR. BRAS. GEOL. SBG., 34., 1986, Goiânia. Anais... 1986. v. 1, p. 483-493.

ASMUS, E. da C.. Hipóteses sobre a origem dos sistemas de zonas de fraturas oceânicas/alinhamentos continentais que ocorrem nas regiões Sudeste e Sul do Brasil. Aspectos estruturais da margem continental Leste e Sudeste do Brasil. p. 39-73. (Projeto REMAC, 4).

ASMUS, H. E.. Relacionamento genético de feições geológicas da margem continental sudeste brasileira e da área continental emersa adjacente. In: SIMPÓSIO REGIONAL DE GEOLOGIA, 3., 1981, Curitiba. Anais... 1981. v. 1, p. 262-272. Atas.

ASMUS, H. E.. Significado geotectônico das feições estruturais das bacias marginais brasileiras e áreas adjacentes. In: CONGR. BRAS. GEOL., 32., 1982, Salvador. Anais... 1982. v. 4, p. 1547-1557.

ASMUS, H. E., PORTO, R.. Classificação das bacias sedimentares brasileiras segundo a tectônica de placas. In: CONGRESSO DA SBG, 26., 1972, Belém. Anais... 1972. v. 2 , p. $67-90$

ASMUS, H. E., GUAZELLI, W.. Descrição sumária das estruturas da Margem Continental Brasileira a das áreas oceânicas e continentais, adjacentes - hipóteses sobre o tectonismo causador, e implicações para os prognósticos do potencial de recursos minerais. In: ASMUS, $H$. E., (Ed.). Estrutura e tectonismo da Margem Continental Brasileira e suas implicações nos processos sedimentares e na avaliação do potencial de recursos minerais. Rio de Janeiro: Petrobrás, CENPES, DINTEP, 1981. p. 187-269. (Série Projeto REMAC, 9).

AYERS, W. B., KAISER, W. R.. Lacustrine-interdeltaic coal in the Fort Union Formation (Paleocene), powder Reiver basin, Wejoming and Montana, U.S.A.. In: RAHMANI, R. A., FLORES, R. M. (Eds.). Sedimentology of coal and coal-bearing sequences. Intern. Assoc. Sediment., 1984. v. 7, p. 61-84. Special Public.

BARBER, K. E.. Peat stratigraphy and climatic change. Roterdam : A. A. Balkema, 1981. $219 p$.

BARRABÉ, L., FEYS, R. Géologie du charbon et des bassins houilleurs. Masson et Cie, 1965. $229 \mathrm{p}$.

BARRY, T. A. A simple field classification of peat types in the raised type bogs (Hochmoore) of Ireland. In: INTERN. SYMP. CLASSIFICATION OF PEAT AND PEATLANDS, 1979, Finlândia. Proceedings... 1979. p. 200-211.

BEANE, J. E., TURNER, C. A., HOOPER, P. R. et al. Stratigraphy, composition and form of the Deccan Basalts, Western Ghats, India. Bull. Volcanology, v. 48, n. 1, p. 61-83, 1986. 
BEATY, C. B.. Age and estimated rate of accumulation of an alluvial fan, White Mountains, California, U.S.A. Am. Jour. Of Sci., v. 268, p. 50-77, 1970.

BEAUMONT, P.. Alluvial fans along the foothills of the Elburz Mountains, Iran. Palaeogeog., Palaeoclim., Palaeoeco., Amsterdam, v. , p. 251-273, 1972.

BIGARELLA, J. J.. Structures developed by the dissipation of sand dunes. Bol. Paranaense de Geociências, Curitiba, n. 33, p. 44-45, 1975.

BIGARELLA, J. J.. Lagoa Dune Field (State of Santa Catarina, Brazil), a model of eolian and pluvial activity. Bol. Paranaense de Geociências, Curitiba, n. 33, p. 133$167,1975$.

BIGARELLA, J. J., BECKER, R. D.. Brazilian marine reworked gravel deposits. 4. Mampituba rudaceous deposit. Bol. Paranaense de Geociências, Curitiba, n. 33, p. 262, 1975.

BIGARELLA, J. J., MOUSINHO, M. R., SILVA, J. X.. Pediplanos, pedimentos e seus depósitos correlativos no Brasil. Bol. Paranaense de Geociências, Curitiba, n. 16/17, p. 117-151, 1965.

BITTENCOURT, A. C. da S. P., DOMINGUEZ, J. M. L., MARTIN, L. et al. Dados preliminares sobre a evolução do delta do Rio São Francisco (SE/AL) durante o Quaternário. Influência das variações do nivel do mar. Rio de Janeiro, 1982. p. 49-68. Atas do IV Simpósio do Quaternário no Brasil.

BITTENCOURT, A. C. da S. P., MARTIN, L., VILAS BOAS, G. da S. et al. Quaternary marine formations of the coast of the State of Bahia (Brazil). In: 1978 INTERNATIONAL SYMPOSIUM ON COASTAL EVOLUTION IN THE QUATERNARY, 1979, São Paulo. Proceedings... 1979. p. 232-253.

BITTENCOURT, A. C. da S. P., MARTIN, L., DOMINGUEZ, J. M. L. et al. Evolução paleogeográfica quaternária da costa do Estado de Sergipe e da costa sul do Estado de Alagoas. Rev. Bras. Geociências, v. 13, n. 2, p. 93-97, 1983.

BJORNBERG, A. J. S., GANDOLFI, N., PARAGUASSU, A. B.. Ocorrência de prismas hexagonais de arenito em São Carlos, SP (Formação Botucatu). Bol. Soc. Bras. Geol., v. 13, n. 1 e 2, p. 61-66, 1964.

BLISSENBACH, E.. Geology of alluvial fans in semiarid regions. Bull. Geol. Soc. Amer., v. 65, p. 175-190, 1954.

BLUCK, B. J.. Sedimentation of an alluvial fan in Southern Nevada. Jour. Sedim. Petrol., v. 34, n. 2, p. 395-400, 1964.

BORGES, J.. Turfa no Ramal de São Paulo da estrada de ferro da Central do Brasil. Rio de Janeiro: Ministério da Agricultura, DNPM, DFPM, 1945. 25 p. Avulso 70.

BOVIS, M. J.. Late Quaternary continental deposits of the Moril area southern Spain. Z.

Geomorph. N. F., Berlin, suppl. - bd. 18, n. 4, p. 426-436, 1974. 
BRASIL. Ministério das Minas e Energia. DNPM. Secretaria de Estado em Ciência Tecnologia e Meio Ambiente. SCTME-CRM. Textos básicos de geologia e recursos minerais de Santa Catarina. Florianópolis: DNPM, SCTME-CRM, 1987. (Série Mapas e Cartas de Síntese 3, Seção Geologia n. 3). Mapa Geológico do Estado de Santa Catarina.

BREMER, H.. Fluvial geomorphology. Z. Geomorph. N. F., Berlin, suppl. - bd. 55, p. 1 $150,1985$.

BRENNER, S., IKAN, R., AGRON, N. A. et al. Hulla Valley Peat : review of chemical aspects soil. Science, v. 125, n. 4, p. 226-232, 1978.

BRYAN, K.. Erosion and sedimentation in the Papago Country, Arizona. U. S. Geol. Surv. Bull, v. 730, p. 19-90, 1922.

BULL, W. B.. Alluvial-fan deposits in Western Fresno County, California. Jour. of Geol., (Geol.Notes), v. 71, p. 243-251, 1962.

BULL, W. B.. History and causes of channel trenching in Western Fresno County, California. Am. Jour. Of Sci., v. 262, p. 249-258, 1964.

BULL, W. B.. Geomorphology of segmented alluvial fans in Western Fresno County, California. U. S. Geol. Survey Prof. Paper 352 - E., p. 89-129, 1964.

BULL, W. B.. Alluvial fans. Jour. of Geol. Educ., v. 16, n. 3, p. 101-106, 1968.

CARVALHO, J. C. de, FRANCISCONI, O'.. Análise de depocentros e suas associações com a geomorfologia e a estrutura da Margem Continental Brasileira. In: ASMUS, H. E., (Ed.). Estrutura e tectonismo da Margem Continental Brasileira e suas implicações nos processos sedimentares e na avaliação do potencial de recursos minerais. Rio de Janeiro: Petrobrás, CENPES, DINTEP, 1981. p. 171186. (Série Projeto REMAC, 9).

CATACOSINOS, P. A.. Tables for the determination of sphericity and shape of rock particles. Jour. Sedim. Petrol., v. 35, n. 2, p. 354-365, 1965.

CHANG, H. K., KOWSMANN, R. O., FIGUEIREDO, A. M. F. de. New concepts on the development of east Brazil marginal basins. Rio de Janeiro : Petrobrás, CENPES, DEPEX/SEDOC, 1988. Reg. 6796.

CHURCH, M. A., MCLEAN, D. G., WOLCOTT, J. F.. River bed gravels : sampling and analysis. In: THORNE, C.R., BATHURST, J. C., HEY, R. D. (Eds.). Sediment transport in gravel-bed rivers. New York. John Wiley \& Sons. 1987, p. 43-88.

COOKE, R. U.. Morphometric analysis of pediments and associated landforms in the Western Mojave Desert, California. Am. Jour. Sci., v. 269, n. 1, p. 26-38, 1970.

CORDANI, U. G. et al. Estudo preliminar de integração do Pré-Cambriano com os eventos tectônicos das bacias sedimentares brasileiras. Petrobrás - Ciência, 
Técnica, Petróleo, Rio de Janeiro: Petrobrás, n. 15, p. 11-70, 1984. Seção Exploração de Petróleo.

COSTA, A. C. da, MENDES, V. A.. Características ambientais dos jazimentos de turfa no Nordeste do Brasil. Recife, 1981. p. 40-47. Atas do X Simpósio Geol. do Nordeste.

COSTA, I. V. G. da, GONÇALVES, J. C. V., GUIMARÃES, J. T. et al. Turfeira Rio das Pontes - uma reserva viável de insumo energético alternativo no litoral norte da Bahia. In: CONGR. BRAS. GEOL., 33., 1984, Rio de Janeiro. Anais... 1984. v. 3, p. 1343-1354.

COULON, F. K.. Geologia e geotecnia das barragens dos rios Leão e Bonito (SC). Pesquisas, Porto Alegre, v. 15, p. 192-203, 1983.

DAITX, E. C.. Contribuição ao conhecimento geológico dos depósitos molássicos relacionados à região de dobramentos Sudeste: 1 - Bacia de Campo Alegre, SC. Rio Claro, 1979. v. 1, p. 131-146. Atas do 2. Simp. Reg. Geol.

DAUZACKER, M. V., SILVA, A. B. da. Integração Pelotas-Santos. Prospectos potenciais. Rio de Janeiro : Petrobrás, DEPEX/SEDOC, 1975. reg. 5048. Relatório Interno ก. 31.292.

DAVIS, J. C.. Statistics and data analysis in Geology. New York : John Wiley \& Sons, 1986. 646p.

DAVIS JR., J. H.. The peat deposits of Florida. Florida Geological Survey, Geol. Bull, n. 30, p. 1-247, 1946.

DAVIS, W.M.. The geographical cycle. Geographical Journal, Londres, v. 14, p. 481$504,1899$.

DELLA FÁVERA, J. C.. Análise estratigráfica do 2-RSS-1 - Bacia de Pelotas - Rio Grande do Sul. Rio de Janeiro : Petrobrás, DEPEX/SEDOC, 1974. reg. 2371. Relatório Interno DIREX, n. 1655.

DENNIS, J. G. (Ed.). International tectonic dictionary. A.A.P.G., 1967. 196 p. (Memoir, 7).

DENNY, C. S.. Alluvial fans in the Death Valley Region, California and Nevada. U. S. Geol. Survey Prof. Paper. 466, p. 1-62, 1965.

DENNY, C. S.. Fans and pediments. Am. Jour. Of Sci., v. 265, p. 81-105, 1967.

DESIO, A.. Geologia applicata all'ingegneria. Milão : Ulrico Hoepli, 1949. 851 p.

DEVEY, C. W., LIGHTFOOT, P. C.. Volcanological and tectonic control of stratigraphy and structure in the Western Deccan Traps. Bull. Volcanology, v. 48, n. 4, p. 195$207,1986$. 
DIAS NETO, C. de M. Contribuição à análise sismotectônica da Região Sudeste do Brasil. USP-IG : 1986. 121 p. Dissertação (Mestrado) - Universidade de São Paulo, 1986.

DOMINGUEZ, J. M. L., BITTENCOURT, A. C. da S. P., MARTIN, L.. Esquema evolutivo da sedimentação quaternária nas feições deltáicas dos rios São Francisco (SE/AL), Jequitinhonha (BA), Doce (ES) e Paraíba do Sul (RJ). Rev. Bras. Geociências, São Paulo, v. 11, n. 4, p. 227-237, 1981.

DREW, F.. Alluvial and lacustrine deposits and glacial records of the Upper-Indus Basin. - Part I. Alluvial Deposits. Geol. Soc. London Quart. Jour., v. 29, p. 441$471,1873$.

ENGE. Rio. Barragem do Rio Mampituba : resultados dos levantamentos eletrorresistivimétrico e eletromagnético (VLF). 1989. 58 p. Relatório Final. Cartas. (Para SUDESUL).

ENOS, P.. Flow regimes in debris flow. Sedimentology, v. 24, p. 133-142, 1977.

ESTRELLA, G. A.. O estágio "Rift" nas bacias marginais do leste brasileiro. In: CONGRESSO DA SBG, 25., 1972, Belém. Anais... 1972. v. 3, p. 29-34.

FABRÍCIO, J. A. C.. et al. Projeto carvão de Santa Catarina, relatório integrado até outubro de 1973. Porto Alegre: DNPM/CPRM, 1972.

FABRIClO, J. A. C.. Projeto carvão em Araranguá-Torres. Porto Alegre DNPM/CPRM, 1976. Relatório Final.

FABRÍClO, J. A. C., CAYE, B. R.. Projeto Araranguá. Porto Alegre : CPRM, 1978. 59 p. Relatório Final de Pesquisas. Anexos.

FABRÍCIO, J. A. C.. Projeto carvão em Araranguá-Torres, 2a. etapa. Porto Alegre : CPRM, 1979. Relatório Final.

FABRíCIO, J. A. C. et al. Projeto carvão de Santa Catarina. In: Carvão no Estado de Santa Catarina. Brasília : DNPM, 1981a. p. 13-52. (Série Geologia, 15; Seção Geologia Econômica, 2). Relatório Integrado.

FABRÍCIO, J. A. C., CAYE, B. R., SÜFFERT, T.. Projeto carvão norte de Santa Catarina. In: Carvão no Estado de Santa Catarina. Brasilia : DNPM, 1981b. p. 5987. (Série Geologia, 15; Seção Geologia Econômica, 2).

FABRÍCIO, J. A. C., FERREIRA, J. A. F., SÜFFERT, T. . Projeto carvão em Araranguá-Torres. In: Carvão no Estado de Santa Catarina. Brasília : DNPM, 1981c. p. 158-207. (Série Geologia, 15; Seção Geologia Econômica, 2).

FAIRBRIDGE, R. W. et al. Eustatic changes in sea level. In: AHRENS, L. H., (Ed.), PRESS, F., RANKAMA, K.. Physics and chemistry of the Earth-4. Pergamon Press, 1961. p. 99-185. 
FAIRBRIDGE, R. W.. Shelfish-eating preceramic Indians in coastal Brazil. Science, v. 191, p. 353-359, 1976.

FISHER, J. J.. Barrier islands. In, Schwartz, M. L. (Ed.), The encyclopedia of beaches and coastal environments. Hutchinson Ross Publ. Co., 1982. V. 15, p.124-133.

FISHER, R. V.. Features of coarse-grained, high-concentration fluids and their deposits. Jour. Sedim. Petrol., v. 41, n. 4, p. 916-927, 1971.

FLEXOR, J.-M., MARTIN, L., SUGUIO, K.. Sobre a utilização da razão isotópica $13 \mathrm{C} / 12 \mathrm{C}$ na determinação de paleoambientes marinhos e lagunares. In: CONGR. BRAS. GEOL. SBG., 30., 1978, Recife. Anais... 1978. v. 2, p. 887-896.

FLEXOR, J.-M., MARTIN, L., SUGUIO, K. et al. Gênese dos cordões litorâneos da parte central da costa brasileira. In: SIMPÓSIO SOBRE RESTINGAS BRASILEIRAS, 1984, Niterói. Anais... 1984. p. 35-45.

FOLK, R. L., WARD, W. C. Brazos river bar : a study in the significance of grain size parameters. Jour. Sedim. Petrol. , v. 27, n. 1, p. 3-26, 1957.

FONTANA, R. L.. Investigações geofísicas preliminares sobre o Cone do Rio Grande Bacia de Pelotas - Brasil. Acta Geológica Leopoldensia, n. 30, p. 161-169, 1990. Publicação especial n. 6, SGB - Núcleos RS/SC/PR. IV Simpósio Sul-Brasileiro de Geologia, Atas, 2. Porto Alegre.

FRIEDMAN, G. M., SANDERS, J. E.. Principles of sedimentology. New York : John Wiley \& Sons, 1978. 792 p.

FUCKSMAN, C. H. (Ed.). Peat and water : aspects of water retention and dewatering in peat. London : Elsevier Applied Science Publ., 1986. 373 p.

FUCKSMAN, C. H.. Chemical methods of peat analysis. In: Peat industrial chemistry and technology. New York: Academic Press, 1980. chap. 16.

FÚlfARO, V. J.. O Cenozóico da Bacia do Paraná. 1979. v. 1, p. 231-241. Atas 2. Simp. Reg. Geol., Rio Claro.

FÚlFARO, V. J., SUGUIO, K.. O Cenozóico Paulista: gênese e idade. In: CONGR. BRAS. GEOL. SBG., 28., 1974, Porto Alegre. Anais... 1974. v. 3, p. 91-101.

FÚLFARO, V. J., SUGUIO, K. Vertical Movements in continental southern Brazil during the Cenozoic, Earth Rheology, Isostasy and Eustasy. Nils-Axel Mörner, 1980. p. $419-425$.

GAPLAN-SC. Atlas de Santa Catarina. 1986.

GARY, M., MCAFEE JR., R., WOLF, C. L. (Eds.). Glossary of geology. Washington, D. C. : American Geological Institute, 1972. 805 p., A-1-52 p 
GIANNINI, P. C. F.. Sistemas deposicionais no Quaternário costeiro entre Jaguaruna e Imbituba, SC. São Paulo: USP : 1993. 2 volumes. Tese (Doutorado) Universidade de São Paulo, 1993.

GOMES JR., F. C.. Geologia do Cenozóico de Santa Catarina. In: Textos básicos de geologia e recursos minerais de Santa Catarina. Florianópolis : DNPM, SCTMECRM, 1987. p. 196-204. (Série Mapas e Cartas de Síntese, 3).

GOMES, A. M. B. Aspectos da evolução geomorfológica da escarpa oriental do Planalto Meridional durante o Quaternário. Porto Alegre : UFRGS : 1976. 98 p. e Documentação. Tese (Livre Docência) - Universidade Federal do Rio Grande do Sul, 1976.

GOMES, A. M. B., AB'SÁBER, A. N.. Uma gruta de abrasão interiorizada nos arredores de Torres. Geomorfologia, São Paulo, v. 10, p. 1-4, 1969.

GONÇALVES, A., OLIVEIRA, M. A. M. de, MOTTA, S. de O.. Geologia da Bacia de Pelotas e Plataforma de Florianópolis. Rio de Janeiro : Petrobrás, DEPEXSEDOC, 1978. reg. 5222, 56 p. Relatório Interno. Anexos.

GONÇALVES, A., OLIVEIRA, M. A. M. de, MOTTA, S. de O.. Geologia da Bacia de Pelotas e da Plataforma de Florianópolis. Bol. Téc. Petrobrás, v. 22, n. 3, p. $157-$ 174,1979

GONZAGA, T. D.. O Quaternário da área interior do Rio Pardo, RS. In: CONGR. BRAS. GEOL. SBG., 28., 1974, Porto Alegre. Anais... 1974. v. 3, p. 115-131.

GUAZELLI, W., FEIJÓ, F. J.. Geologia de semi-detalhe do Centro-Leste e Sudeste de Santa Catarina : relatório n. 396, Petrobrás. DESUL, SEGES, 1970. Ponta Grossa. Paraná. Relatório Interno, n. 3.720. 38 p. Anexos. Mapas.

HAILS, J. R.. Barrier island coasts. In, Schwartz, M. L. (Ed.), The encyclopedia of beaches and coastal environments. Hutchinson Ross Publ. Co., 1982. V. 15, p.124.

HALLAM, A.. A revolution in the Earth Sciences. Oxford University Press, 1973. 127 p.

HARVEY, A. M.. Dissected alluvial fans in southeast Spain. Catena, v. 5, p. 177-211, 1978.

HAUSMAN, A.. Comportamento do freático nas áreas basálticas do Rio Grande do Sul. Bol. Paranaense de Geografia, Curitiba, n. 18/20, p. 177-214, 1956.

HOOKE, R. LeB.. Steady-state relationships on arid-region alluvial fans in closed basins. Am. Jour. of Sci., v. 266, p. 609-629, 1968.

HORN FILHO, N. O. Geologia das Folhas de Torres, Três Cachoeiras, Arroio Teixeira e Maquiné, Nordeste do Rio Grande do Sul. Porto Alegre : UFRGS : 1987. 245 p. Dissertação (Mestrado) - Universidade Federal do Rio Grande do Sul, 1987. 
HORN FILHO, N. O. et al. Mapa geológico. Folhas Três Cachoeiras e Torres. In: Atlas geográfico da Província Costeira do Rio Grande do Sul. UFRGS : IG. CECO, 1984. não paginado.

HUNT, J. W., HOBDAY, D. K.. Petrolographic composition and sulphur content of coals associated with alluvial fans in the Permian Sydney and Gunnedah Basins, eastern Australia. In: RAHMANI, R. A., FLORES, R. M. (Eds.). Sedimentology of coal an coal-bearing sequences. Intern. Assoc. Sediment., 1984. v. 7, p. 43-60. Special Public.

JONES, J. G., VEEVERS, J. J.. A Cainozoic history of Australia's Southeast Highlands. Jour. Geol. Soc. of Australia, v. 29, n. 1/2, p. 1-12, 1982.

JOST, H.. O Quaternário da Planicie Costeira do Rio Grande do Sul. I - A Região Norte. In: CONGRESSO DA SBG, 25., 1971, São Paulo. Anais... 1971. v. 1, p. 53-62.

JOST, H., SOLIANI JR., E.. Mapeamento geológico e geomorfológico : plano integrado para o desenvolvimento do Litoral Norte do Rio Grande do Sul. Porto Alegre: Governo do Estado do Rio Grande do Sul, SUDESUL/DNOS, 1976. $121 \mathrm{p}$.

KABAILIENE, M., RAUKAS, A.. Stratigraphy of Lake and Bog deposits and climatic changes in the Late-Glacial and Holocene in the Soviet Baltic Republics : a review. Boreas, v. 16, n. 2, p. 125-131, 1987.

KAMPF, N., SCHNEIDER, P. 1989. Caracterização de solos orgânicos do Rio Grande do Sul : propriedades morfológicas e físicas como subsídios à classificação. Rev. Bras. Ci. Solos, v. 13, p. 227-236, 1989.

KIEHL, E. J.. Aproveitamento da turfa na agricultura - caracterização e influência nas propriedades do solo. CESP, 1985. 12 p. Pré-print.

KLAMT, E., GIANLUPPI, D., SCHNEIDER, P. Levantamento de reconhecimento com detalhes dos solos do Vale do Rio Manpituba. SUDESUL-UFRGS, 1980a. $177 \mathrm{p}$.

KLAMT, E., SCHNEIDER, P., GIANLUPPI, D.. Levantamento detalhado dos solos das áreas dos projetos PAP I e II. SUDESUL/Fundatec, 1980b. 93 p.

KLAMT, E., KÄMPF, N., GIANLUPPI, D. et al. Levantamento de reconhecimento detalhado dos solos na área do sub-projeto Sombrio. SUDESUL/AgronomiaUFRGS, 1978. $198 \mathrm{p}$.

KNECHT, T.. Estudo preliminar sobre as ocorrências de turfa no Vale do Ribeira de Iguape, SP. Rev. IG., São Paulo: Secr. Agric. e Abast., v. 3, n. 1, p. 5-14, 1982.

KOGBE, C. A., ME'HES, K.. Micropaleontology and biostratigraphy of the coastal basins of West Africa. Journ. of African Earth Sciences, v. 5, n. 1, p. 1-100, 1986.

KOSTER, E. H., STEEL, R. J. (Eds.). Sedimentology of gravels and conglomerates. Canadian Soc. Petrol. Geol., Canada, p. 1-441, 1984. Memoir 10. 
KOUTSOUKOS, E. A. M.. Geohistória e paleoecologia das bacias marginais de Florianópolis e Santos. In: CONGR. BRAS. GEOL., 32., 1982, Salvador. Anais... 1982. v. 5, p. 2369-2382.

KRAFT, J. C.. Barrier islands, transgressive and regressive. In, Schwartz, M. L. (Ed.), The encyclopedia of beaches and coastal environments. Hutchinson Ross Publ. Co., 1982. V. 15, p.133-134.

KREBS, A. S. J.. Projeto Arroio do Silva : nota explicativa. Porto Alegre : CPRM, 1984. 31 p. Anexos.

KRUMBEIN, W. C.. Measurement and geological significance of shape and roundness of sedimentary particles. Jour. Sedim. Petrol., v. 11, n. 2, p. 64-72, 1941.

LEINZ, V.. Contribuição à geologia dos derrames basálticos do Sul do Brasil. Bol. Geol., São Paulo : Faculdade de Filosofia, Ciências e Letras, n. 5, p. 1-61, mais fotos e sumários, 1949.

LEMOS, R. C. de, UBERTI, A. A. A., VIZZOTTO, V. J. et al. Levantamento de reconhecimento dos solos do Estado de Santa Catarina. MEC-MINTERGoverno do Estado, 1973. 2v., 494 p. Mapa.

LEMOS, V. B., SIEDLECKI, K. N., OLIVEIRA, J. M. P. et al. Considerações preliminares quanto à prospecção de áreas turfosas. In: SIMP. REG. GEOL., 3., 1981, Curitiba. Anais... 1981. v. 2, p. 243-258.

LIMA, L. da R. Elementos básicos de engenharia química. Mc Graw-Hill, 1974. 412 p.

LIMA, R. C. da C., COSTA, I. V. G. da, SILVA, J. F. da et al. Turfa na faixa costeira da Bahia - Sergipe. In: CONGR. BRAS. GEOL., 32., 1982, Salvador. Anais... 1982. v. 5, p. 2185-2197.

LOPES, R. da C., LAVINA, E. L., SIGNORELLI, N.. Fácies sedimentares e evolução paleoambiental do Supergrupo Tubarão na borda leste da Bacia do Paraná. In: CONGR. BRAS. GEOL. SBG., 34., 1986, Goiânia. Anais... 1986. v. 1, p. 206-229.

LORSCHEITTER, M. L.. Estudo polínico de sedimentos da mata paludosa do Faxinal, Torres, Rio Grande do Sul. In: CONGR. NAC. BOTÂNICA, 38., 1987, São Paulo. Anais... 1987. p. 57. Resumos.

LORSCHEITTER, M. L., LEMOS, V. B.. Estudo palinológico preliminar em turfeiras do Estado do Paraná. In: SIMP. SUL-BRAS. GEOL., 2., 1985, Florianópolis. Anais... 1985. p. 461-473.

LUCAS, R. E., DAVIS, J. F.. Relationships between $\mathrm{pH}$ values of organic soils and availabilities of 12 plant nutrients. Jour. Art. 2731, Michigan Agricultural Experiment Station, p. 177-182, [19--]. 
MACKIN, J. H.. Métodos de investigación racionales y empíricos en la geología. In: ALBRITTON,Jr., C. C., (Ed.) Filosofia de la geologia. México : Comp. Ed. Continental, S. A. , 1970. p. 173-207.

MARINI, O. J., FUCK, R. A., DANNI, J. A. M. et al. As faixas de dobramentos Brasília, Uruaçu e Paraguai-Araguaia e o Maciço Mediano de Goiás. In: SCHOBBENHAUS, C., (Coord.) et al. Geologia do Brasil. Brasilia: DNPM, DGM, 1984. p. 251-303.

MARTIN, L., BITTENCOURT, A. C. da S. P., VILAS BOAS, G. da S. et al. Mapa geológico do Quaternário costeiro do Estado da Bahia : texto explicativo. Salvador, $1980.57 \mathrm{p}$.

MARTIN, L., MÖRNER, N.-A., FLEXOR, J.-M. et al. Reconstrução de antigos níveis marinhos do Quaternário. São Paulo, 1982. 154 p. Publ. Esp. CTCQ-SBG.

MARTIN, L., SUGUIO, K. . The State of São Paulo coastal marine Quaternary geology The ancient strandlines. In: Simpósio Internacional sobre o Quaternário., 1975, Curitiba. Anais da Academia Brasileira de Ciências. (Suplemento) 1975. V. 47, p. 249-263.

MARTIN, L., SUGUIO, K.. O Quaternário marinho do litoral do Estado de São Paulo. Belo Horizonte, 1976. 25 p. Pré-Print do XXIX Congresso da SBG.

MARTIN, L., SUGUIO, K.. Ilha comprida : um exemplo de ilha-barreira ligado às flutuações do nível marinho durante o Quaternário. In: CONGR. BRAS. GEOL. SBG., 30., 1978, Recife. Anais... 1978. v. 2, p. 905-912.

MARTIN, L., SUGUIO, K.. Excursion route along the coastal plains of the States of Paraná and Santa Catarina. 1986. n. 1, p. 1-124. International Symposium on Sea Level Changes and Quaternary Shorelines. Special publication.

MARTIN, L., SUGUIO, K., FLEXOR, J.-M.. Utilisation des amas coquilliers artificiels dans les reconstructions des anciennes lignes de riváge : exemples brésiliens. Sér. Géol., Cach. O.R.S.T.O.M., v. 12, n. 2, p. 135-146, 1981/1982.

MARTIN, L., SUGUIO, K., FLEXOR, J.-M. et al. Mapa geológico do Quaternário costeiro dos Estados do Paraná e Santa Catarina. Brasilia: DNPM, 1988. p. 140. (Série Geologia, 28; Seção Geologia Básica, 18).

MARTIN, L., SUGUIO, K., FLEXOR, J-M.. As flutuações de nível de mar durante o Quaternário Superior e a evolução geológica de "deltas"brasileiros. Bol. IG-USP, São Paulo : Instituto de Geociências, 1993. p. 1-186. (Publicação Especial n. 15).

MARTINS, A. M., SILVA, A. da. Prospecção de turfas no Estado do Rio de Janeiro. Mineração e Metalurgia, Rio de Janeiro, n. 431, p. 12-16, 1981.

MARTONNE, E. de. Problemas morfológicos do Brasil Tropical Atlântico. 1. Rev. Bras. de Geografia, v. 5, n. 4, p. 69-99, 1943.

MARTONNE, E. de. Problemas morfológicos do Brasil Tropical Atlântico. II - O modelado tropical. Rev. Bras. de Geografia, v. 6, n. 2, p. 155-178, 1944. 
McGEE, W. J.. Sheetflood erosion. Bull. Geol. Soc. Amer., v. 8, p. 87-111, 1897.

MEDEIROS, R. A., SCHALLER, H., FRIEDMAN, G. M.. Fácies sedimentares. Rio de Janeiro: Petrobrás - Ciência-Técnica-Petróleo, CENPES, DIDOP, 1971. 123 p.

MEIS, M. R. M. de, AMADOR, E. da S.. Contribuição ao estudo do Neo-Cenozóico da Baixada da Guanabara : Formação Macacu. Rev. Bras. Geociências, São Paulo, v. 7, n. 2, p. 150-174, 1977.

MELO, M. S. de, CAETANO, S. L. V., COIMBRA, A. M.. Tectônica e sedimentação na área das Bacias de São Paulo e Taubaté. In: CONGR. BRAS. GEOL. SBG., 34., 1986, Goiânia. Anais... 1986. v. 1, p. 321-336.

MENDES, V. A., COSTA, A. C. da. Potencialidades de turfa no Nordeste do Brasil e suas possibilidades de emprego. Recife, 1981. p. 132-144. Atas X Simp. Geol. do Nordeste.

MIALL, A. D.. Fluvial sedimentology. Canadian Soc. Petrol. Geol., 859 p., 1982.

MIALL, A. D.. Fluvial sedimentology : an historical review. Canadian Soc. Petrol. Geol., p. 1-47, 1982.

MIALL, A. D.. Architectural-element analysis : a new method of facies analysis applied to fluvial deposits. Earth-Science Reviews, n. 22, p. 261-308, 1985.

MILLETTE, J. A., BROUGHTON, R. S.. The effect of water table depth in organic soil on subsidence and swelling. Can. Your. Soil. Sci., v. 64, p. 273-282, 1984.

MOIOLA, R. J., WISER, D.. Textural parameters : an evaluation. Jour. Sedim. Petrol., v. 38, p. $45-53,1968$.

MORAES, J. A. P. de. Avaliação preliminar dos recursos e potencial de turfa no Triângulo Mineiro. In: CONGR. BRAS. GEOL., 32., 1982, Salvador. Anais... 1982. v. 5, p. $2198-2209$.

MORAES, J. F. S. de, CALDASSO, A. L. da S.. Síntese dos conhecimentos atuais sobre turfa na Região Nordeste Oriental. In: CONGR. BRAS. GEOL., 32., 1982, Salvador. Anais... 1982. v. 5, p. 2252-2260.

MORAES, J. F. S. de. Dados preliminares sobre a geologia econômica da maior turfeira do Nordeste. Recife, 1981. p. 194-203. Atas X Simp. Geol. do Nordeste.

MOTTA, J. F. M., NAKANO, S., SHIMADA, $H$. et al. Turfa - a experiência do IPT nos campos geológicos e tecnológicos. In: CONGR. BRAS. GEOL., 32., 1982, Salvador. Anais... 1982. v. 5, p. 2238-2251.

NAHUYS, J., PIATNICKI. Carvões brasileiros - estado da arte. Comun. Serv. Geol. Portugal, Lisboa, v. 70, n. 2, p. 175-204, 1984. 
NAIR, K. K.. Geomorphological and quaternary geological studies along the coastal plain in parts of Cannanore and Kasargod Districts, Kerala. Jour. Geol. Soc. of India, v. 29, n. 4, p. 433-439, 1987.

NAIR, M. M.. Coastal geomorphology of Kerala. Jour. Geol. Soc. of India, v. 29, n. 4, p. $450-458,1987$.

OJEDA, H. A. O. Y.. Estrutura, estratigrafia e evolução das bacias marginais brasileiras. [S.I. : s.n.], 1981. näo paginado.

OJEDA, H. A. O. Y., CESERO, P. de. Bacia de Santos e Pelotas : geologia e perspectivas petrolíferas. Rio de Janeiro: DEXPRO, DIVEX, 1973. Curso de atualização em geologia de petróleo, CAGEP-1. Relatório n. 4.695.

OJEDA, H. A. O. Y., SILVA, A. B. da. Bacia de Santos, Pelotas : relatório de progresso. Rio de Janeiro: Petrobrás, DEXPRO, 1974. não paginado. Relatório n. 4.974 .

OLLIER, C. D.. The Great Escarpament of Eastern Australia : tectonic and geomorphic significance. Jour. Geol. Soc. of Australia, v. 29, n. 1/2, p. 13-23, 1982.

OLLIER, C. D.. Morphotectonics of passive continental margin : introduction. In: OLLIER, C. D., (Ed.). Morphotectonics of passive continental margins. 1985. p. 1-9. (Zeitschrift Für Geomorphologie. N. F. Suppl-Bd. 54).

OLLIER, C. D., MARKER, M. E.. The Great Escarpment of Southern Africa. Z. Geomorph. N. F., Suppl. Bd. 54, p. 37-56, 1985.

OLLIER, C. D., POWAR, K. B.. The Western Ghats and the morphotectonics of peninsular India. Z. Geomorph. N. F., suppl. Bd. 54, p. 57-69, 1985.

ONU. Report on the use of peat for energy. 1981. 48 p. United Nation. General Assembly. A/Conf. 100/PC/32. Anexo.

PAIN, C. F.. Morphotectonics of the continental margins of Australia. Z. Geomorph. N. F., suppl. Bd. 54, p. 23-35, 1985.

PASSEGA, R.. Texture as characteristic of clastic deposition. Bull. Amer. Assoc. Petrol. Geol., v. 41, n. 9, p. 1952-1984, 1957.

PASSEGA, R.. Grain size representation by $\mathrm{CM}$ patterns as a geological tool. Jour. Sedim. Petrol., v. 34, n. 4, p. 830-847, 1964.

PASSOS, N.. Turfa de Marahú (Estado da Bahia). Brasília : Ministério da Agricultura, DNPM, SFPM, 1936. 10 p. Publ. Esp.

PAUWELS, Pe. G.. A morfogênese do litoral catarinense. Rev. Bras. Geogr., v. 3, n. 4, p. $785-804,1941$. 
PELLETIER, B.. Aperçu sur l'analyse et la valorisation des tourbes. Paris, 1981. 42 p. Relatorio.

PEREIRA, L. H. M., TESCH, N. A.. Avaliação dos depósitos de turfa no município de Conde-Bahia. In: CONGR. BRAS. GEOL., 32., 1982, Salvador. Anais... 1982. v. 5 , p. 2224-2237.

PETRI, S., FÚlLARO, V. J.. Geologia da Chapada dos Parecis, Mato Grosso, Brasil. Rev. Bras. Geociências, São Paulo, v. 11, n. 4, p. 274-282, 1981.

POSTMA, G.. Classification for sediment gravity-flow deposits based on flow conditions during sedimentation. Geology, v. 14, n. 4, p. 291-294, 1986.

PONTE, F. C., ASMUS, H. E. The brazilian marginal basins : current state of knowledge. An. Acad. Bras. Ciên., v. 48, p. 215-239, 1976. Suplemento.

PUTZER, H. Diastrofismo "germanótipo" e sua relação com o vulcanismo basáltico na parte meridional de Santa Catarina. Bol. Soc. Bras. Geol., v. 2, n. 1, p. 37-74, 1953.

PUTZER, H.. Geologia da Folha de Tubarão, Estado de Santa Catarina. Bol. DNPMDFPM, Rio de Janeiro, n. 96, p. 1-94 e mapa, 1955.

PUUSTJÄRVI, V.. Classification of Virgin peat with regard to the requirements of horticultural peat use. In: INTERN. SYMP. CLASSIFICATION OF PEAT AND PEATLANDS, 1979, Finlândia. Proceedings... 1979. p. 239-242.

QUEIROZ NETO, J. P. de, Observações preliminares sobre perfis de solos com bandas onduladas do Estado de São Paulo. Sedimentologia e Pedologia, São Paulo, n. 7, p. 1-34, 1975.

RAHMANI, R. A., FLORES, R. M. (Eds.). Sedimentology of coal and coal-bearing sequences. Oxford: Blackwell Scientific Publications, 1984. 412 p. Publ. n. 7 of the Intern. Assoc. of Sedimentologists.

RAMBO, B.. Estudos botânicos em Sombrio, município de Araranguá, Santa Catarina. Anais Botânicos do Herbário "Barbosa Rodrigues", Itajaí, n. 1, p. 7-20, 1949.

RAMOS, B. V., LIMA FILHO, C. A.. Turfa : solução energética para o Nordeste?. In: CONGR. BRAS. GEOL., 32., 1982, Salvador. Anais... 1982. v. 5, p. 2178-2184.

REINECK, H. E., SINGH, I. H.. Depositional sedimentary environments. Berlin : Springer-Verlag, $1980.549 \mathrm{p}$.

REITZ, P. R.. Vegetação da zona marítima de Santa Catarina. Sellowia, n. 13, p. 17$115,1961$.

ROCHA, A. J. D., GONÇALVES, J. C. V.. Depósitos de turfa descobertos pela CPRM nos municipios de Cairú, Nilo Peçanha e Ituberá, no Estado da Bahia, Brasil. In: CONGR. BRAS. GEOL., 32., 1982, Salvador. Anais... 1982. v. 5, p. 2210-2223. 
ROTH, L., LORSCHEITTER, M. L.. Análise palinológica de uma turfeira do Parque Nacional de Aparados da Serra, Rio Grande do Sul : resultados preliminares. In: CONGR. NAC. BOTÂNICA, 38., 1987, Salvador. Anais... 1987. p. 56. Resumos.

ROTH, L. Palinologia de uma turfeira do Parque Nacional de Aparados da Serra, Planalto Leste do Rio Grande do Sul, Brasil. UFRGS : 1990. 261 p. Dissertação de Mestrado - Universidade Federal do Rio Grande do Sul,

ROTH, R., LORSCHEITTER, M. L.. Palynology of a peat in Parque Nacional de Aparados da Serra, Rio Grande do Sul, Brazil. São Paulo, 1989. p. 56-59. Inter. Symp. on Global Changes in South America During the Quaternary. Special Publ. $n$. 1.

RUELLAN, F.. A evolução geomorfológica da Baía de Guanabara e das regiões vizinhas. Rev. Bras. de Geografia, v. 6, n. 4, p. 103-199, 1944.

RUFAS, J. M.. Projeto executivo para implantação de um lote piloto de irrigação por aspersão no PAP do Banhado do Sombrio (Santa Catarina). SUDESUL/IRYDA, 1986. 67 p.

SCHOLLE, P. A., SPEARING, D.. Sandstone depositional environments. Amer. Assoc. Petrol. Geol., Tulsa, p. 1-410, 1982.

SCOTT, K. M. Origin and sedimentology of 1969 debris flows near Glendora, California. U. S. Geol. Survey Prof. Paper 750-C, p. C242-C247, 1971.

SHARP, R. P.. Early Terciary fanconglomerate, Big Horn Mountains, Wyoming. Jour. of Geol., v. 56, n. 1, p. 1-15, 1948.

SHARP, R. P., NOBLES, L. H.. Mudflow of 1941 at Wrightwood, Southern California. Bull. Geol. Soc. Amer., v. 64, p. 547-560, 1953.

SHEPARD, F. P.. Nomenclature based on sand-silt-clay ratios. Jour. Sedim. Petrol., V. 24, n. 3, p. 151-158, 1954.

SHIMADA, H., MOTTA, J. F. M., CABRAL JR., M. et al. Prospecção de turfa no Estado de São Paulo. In: SIMP. REG. GEOL., 3., 1981, Curitiba. Anais... 1981. p. 259-273.

SHOTYK, W.. The use of peatlands in geochemical exploration. Jour. of Geochemical Exploration, n. 29, p. 431, 1987.

SHOTYK, W.. Review of the inorganic geochemistry of peats and peatland waters. Earth-Science Reviews, n. 25, p. 95-176, 1988.

SILVA, J. F., LUUKKONEN, M., PEDREIRA, A. J.. Turfeira de Santo Amaro das Brotas, Sergipe : exploração e preparação para lavra experimental. In: CONGR. BRAS. GEOL., 33., 1984, Rio de Janeiro. Anais... 1984. v. 3, p. 1355-1365.

SIQUEIRA, O. J. F. de, SCHERER, E. E., TASSINARI, G. et al. Recomendações de adubação e calagem para os Estados do Rio Grande do Sul e Santa Catarina. 2. ed. EMBRAPA-CNPT, 1989. 128 p. 
SMITH, N. D.. The braided stream depositional environment : comparison of the Platte River with some Silurian clastic rocks, North-Central Appalachians. In: Sedimentary processes : hydraulic interpretation of primary sedimentary structures. 1977. p. 156176. (Soc. Econ. Paleon. Miner. Reprinted Series, 3).

SPALLETTI, L. A.. Paleoambientes sedimentarios : en secuencias silicoclasticas. Buenos Aires, 1980. p. 1-175. (Asoc. Geol. Argentina. Serie "B", Didáctica y Complementaria, 8).

SPIEGEL, M. R.. Estatística. São Paulo : McGraw-Hill, 1984. 454p.

STACH, E. Coal petrology. Berlin : Gebrüder Borntraegger, 1975. 428 p.

STACH, E., MACKOWSKY, M.-Th., TEICHMÜLLER, M. et al. Textbook of coal petrology. Gerbrüder Borntraeger, 1982. 535 p.

STUTZER, O., NOÉ, A. C.. Geology of coal. University of Chicago Press, 1940. 461 p.

SUBRAHMANYA, K. R.. Evolution of the Western Ghats, India : a simple model. Jour. Geol. Soc. of India, v. 29, n. 4, p. 446-449, 1987.

SUDESUL. Projeto Litoral Sul de Santa Catarina - Sub-Projeto Sombrio : V.Iv estudo hidrológico na área do Sub-Projeto Sombrio. IPH/UFRGS, 1978. 63 p.

SUDESUL. Projeto Litoral Sul de Santa Catarina - Sub-Projeto Sombrio : 2, estudo climatológico e zoneamento agroclimático na área do Sub-Projeto Sombrio. IPH/UFRGS, 1978. $116 \mathrm{p}$.

SUDESUL. Plano diretor de desenvolvimento da Bacia do Rio Mampituba. 1983. $278 \mathrm{p}$.

SUDESUL. Projeto Litoral Sul de Santa Catarina : Sub-Projeto Sombrio. [19--]. Magna.

SÜFFERT, T.. Projeto carvão em Araranguá - Torres : 1a. fase, relatório final. Porto Alegre: CPRM, 1976. não paginado. Convênio DNPM-CPRM.

SÜFFERT, T., CAYE, B. R., DAEMON, R. F.. Projeto carvão Bonito gaseificável. Porto Alegre : CPRM, 1977.

SÜFFERT, T. et al. Projeto carvão Bonito gaseificável. In: Carvão no Estado de Santa Catarina. Brasília : DNPM, p. 95-157. (Série Geologia, 15; Seção Geologia Econômica, 2).

SUGUIO, K.. Flutuações do nivel marinho nos últimos milênios e evolução das planícies brasileiras. Rev. do Museu Paulista, Nova Série, São Paulo, v. 24, p. 125-141, 1983/1984.

SUGUIO, K.. Annotated bibliography on quaternary shorelines and sea-level changes. 1986. 51 p. Produced with Dr. Louis Martin's (ORSTOM) participation in 
the decade 1975-1985. Special Publication n. 2, International Symposium on Sea Level Changes and Quaternary Shorelines.

SUGUIO, K., COIMBRA, A. M.. Estudo sedimentológico das "bandas onduladas" de solos da Formacão Bauru na área balisada pelas cidades de Osvaldo CruzRancharia e Tupã, Estado de São Paulo. Bol. IG. Inst. Geoc. USP., v. 7, p. 27-38, 1976.

SUGUIO, K., MARTIN, L.. Formações quaternárias marinhas do litoral paulista e sul fluminense. In: INTERNATIONAL SYMPOSIUM ON COASTAL EVOLUTION IN THE QUATERNARY, 1978. IGCPO - Project 61/IGUSP/SBG. 1978. n. 1, $54 \mathrm{p}$. Special publication.

SUGUIO, K., MARTIN, L.. Estudos sobre as oscilações do nível marinho Quaternário ao longo do litoral brasileiro. 1980. 22 p. Preprint, Simposio: Problemas Geológicos del Litoral Atlántico Bonaerense.

SUGUIO, K., MARTIN, L.. Progress in research on Quaternary sea level changes and coastal evolution in Brazil. In: INTERN. SIMP. HOLOCENE SEA LEVEL FLUCTUATIONS, MAGNITUD AND CAUSES, 1981, South Carolina. Proceedings... 1981. p. $166-181$.

SUGUIO, K., MARTIN, L., BITTENCOURT, A. C. da S. P. et al. Flutuações do nível relativo do mar durante o Quaternário superior ao longo do litoral brasileiro e sua implicações na sedimentação costeira. Rev. Bras. Geociências, São Paulo, v. 15, n. 4, p. 273-286, 1985.

SUGUIO, K., MARTIN, L., FLEXOR, J.-M.. Les variations relatives du niveau moyen de la mer au Quaternaire recent dans la region de Cananeia-Iguape (São Paulo). Bol. IG-USP, v. 7, p. 113-129, 1976.

SUGUIO, K., MARTIN, L., FLEXOR, J.-M.. Sea-level fluctuations during the past 6.000 years along the coast of the State of São Paulo, Brazil. In: MÖRNER, N.-A., (Ed.). Earth Rheology, Isostasy and Eustasy. England, 1977. p. 471-486.

SUGUIO, K., RODRIGUES, S. de A., TESSLER, M. G. et al. Tubos de Ophiomorphas e outras feições de bioturbação na Formação Cananéia, Pleistoceno da Planície Costeira Cananéia-Iguape, SP. In: SIMPÓSIO SOBRE RESTINGAS BRASILEIRAS, 1984, Niterói. Anais... 1984. p. 111-122.

SUGUIO, K., MARTIN, L.. Brazilian coastline Quaternary Formations - the State of São Paulo and Bahia Littoral zone evolutive schemes. An. Acad. Bras. Ciên., v. 48, p. 325-334, 1976. Suplemento.

SUGUIO, K., TESSLER, M. G.. Planicies de cordões litorâneos Quaternários do Brasil : origem e nomenclatura. In: SIMPÓSIO SOBRE RESTINGAS BRASILEIRAS, 1984, Niterói. Anais... 1984. p. 15-25.

TATSCH, J. H.. Coal deposits : origin, evolution, and present characteristics. Massachusetts: Tatsch Associates, 1980. 590 p. 
TIBBETTS, T. E., FRASER, J. A. The utilization of canadian peat as an alternative energy source. CIM Bull., Canadá, p. 107-110, 1978.

TINGEY, R. J.. Uplift in Antarctica. Z. Geomorph. N. F., suppl. Bd. 54, p. 85-99, 1985.

THORNE, C. R., BATHURST, J. C., HEY, R. D.. (Eds.). Sediment transport in gravel-bed rivers. New York: John Wiley \& Sons, 1987. 995 p.

ULE, E.. Die verbreitung der torfmoose und moore in Brasilien. Engler's Botanische Jahrbrücher, v. 27, p. 238-258, 1900.

VAN DER WIJK, A., EL-DAOUSKY, F., ARENDS, A. R. et al. Dating peat with U/Th disequilibrium : some geochemical considerations. Chem. Geol., v. 59, n. 4, p. 283292, 1986.

VEYRET, P.. Un centenaire : l'étude sur les torrents des Hautes-Alpes de Surell. Revue de Géogr. Alp., Paris, p. 513-524, 1941.

VILAS BOAS, G. da S., BITTENCOURT, A. C. da S. P., MARTIN, L.. Leques aluviais pleistocênicos da região costeira da Bahia : implicações paleoclimáticas. Rev. Bras. Geociências, São Paulo, v. 15, n. 3, p. 255-258, 1985.

VILLWOCK, J. A.. Geology of the coastal province of Rio Grande do Sul, Southern Brazil : a synthesis. Pesquisas, Porto Alegre, n. 16, p. 5-49, 1984.

VILLWOCK, J. A.. Os paleoambientes da provícia costeira do Rio Grande do Sul e a possivel ocorrência de antigos manguezais na Costa Sul do Brasil. In: SIMP. SOBRE ECOSSISTEMAS DA COSTA SUL E SUDESTE BRASILEIRA, 1987. Anais... 1987. v. 3, p. 132-137.

VILLWOCK, J. A., DEHNHARDT, E. A., LOSS, E. L. et al. Sugestões para o aproveitamento agroenergético das turfas do Rio Grande do Sul. Acta Geologica Leopoldensia, v. 7, n. 14, p. 55-64, 1983a.

VILLWOCK, J. A., DEHNHARDT, E. A., LOSS, E. L. et al. Turfas da Província Costeira do Rio Grande do Sul, condicionamento geológico de uma fonte energética potencial. Acta Geologica Leopoldensia, v. 7, n. 14, p. 79-92, $1983 \mathrm{~b}$.

VILLWOCK, J. A., DEHNHARDT, E. A., LOSS, E. L. et al. Turfas da Província Costeira do Rio Grande do Sul : geologia do depósito de Águas Claras. In: CONGR. BRAS. GEOL., 31., 1980, Balneário de Camboriú. Anais... 1980. v. 1, p. 500-512.

VISHER, G. S.. Grain size distributions sand depositional processes. Jour. Sedim. Petrol., v. 39, n. 3, p. 1074-1106, 1969.

VOGEL, J. C., KRONFELD, J.. A new method for dating peat South African. Jour. of Science, v. 76, p. 557-558, 1980.

WALKER, R. G. (Ed.). Facies models. 1983. 211 p. Geoscience Canada, Reprint Series $1 \mathrm{Geol}$. Assoc. Canada. 
WASSON, R. J.. Catchment processes and their evolution of alluvial fans in the lower Derwent valley, Tasmania. Z. Geomorph. N. F., Berlin, suppl.- bd. 21, p. 147-168, 1977.

WASSON, R. J.. Sedimentation history of the Mundi Mundi alluvial fans, Western New South Wales. Sedim. Geol., v. 22, p. 21-51, 1979.

WENTWORTH, C. K.. A method of measuring and plotting the shapes of pebles. Bull. Geol. Survey, v. 730c, p. 91-92, 1922.

YEVDOKIMOVA, N. V., MOSTOVYY, M. N., MALYY, Ye. J.. Subsidence and biochemical destruction of peat in the Ukrainian poles'ye. Pochvovedeniye, n. 6, p. 126-128, 1976.

ZBORIL, L.. New discovered oil - bearing structures of the African Continent in relation to the dynamics of crustal movements. Jour. Geodynamics, v. 7, n. 3/4, p. 395-424, 1987.

ZELTZER, F. Geologia e paleogeografia da restinga da Laguna do Patos - Porto Alegre : UFRGS : 1976. 118 p. Dissertação (Mestrado) - Universidade Federal do Rio Grande do Sul, 1976. 


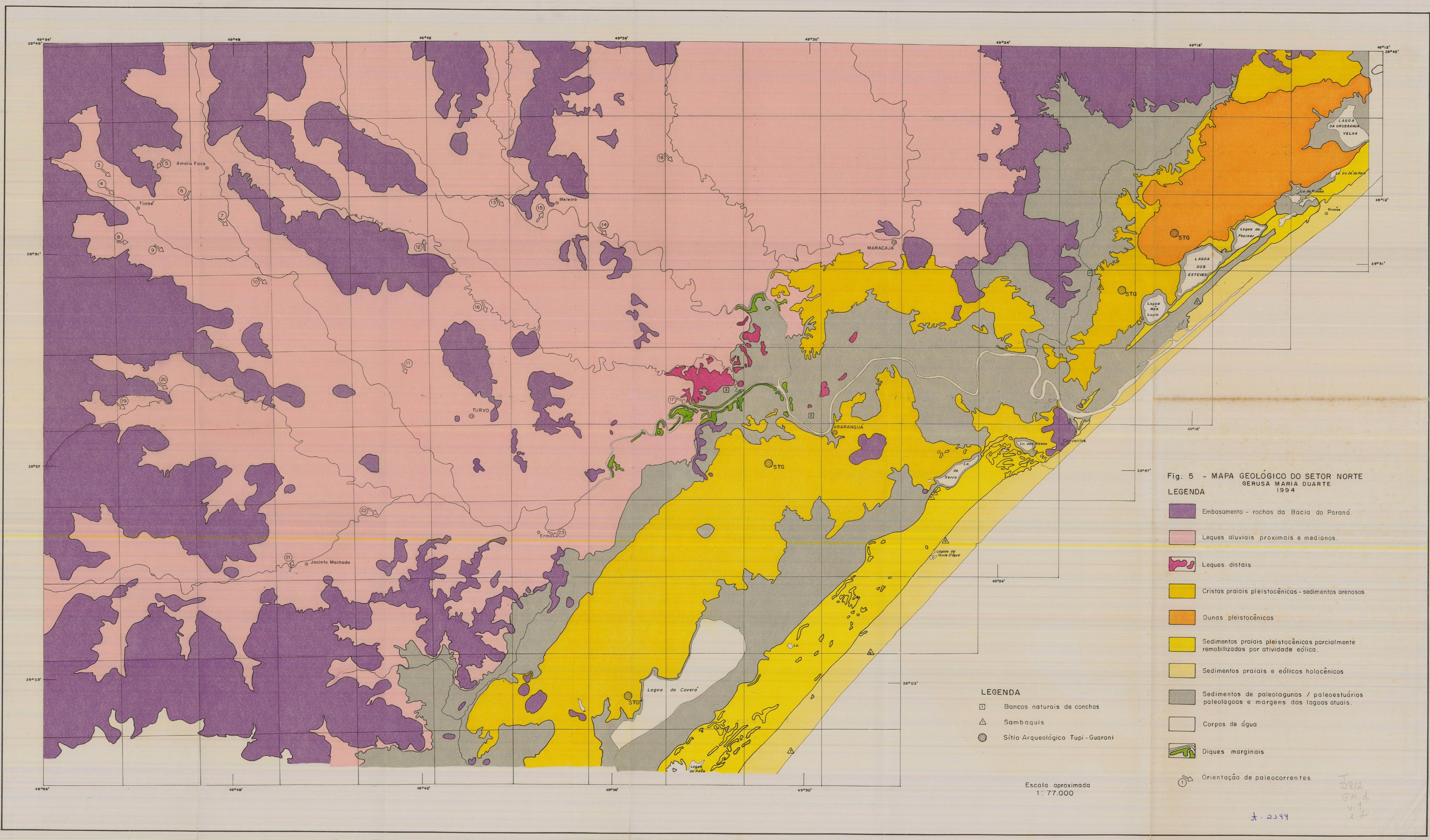




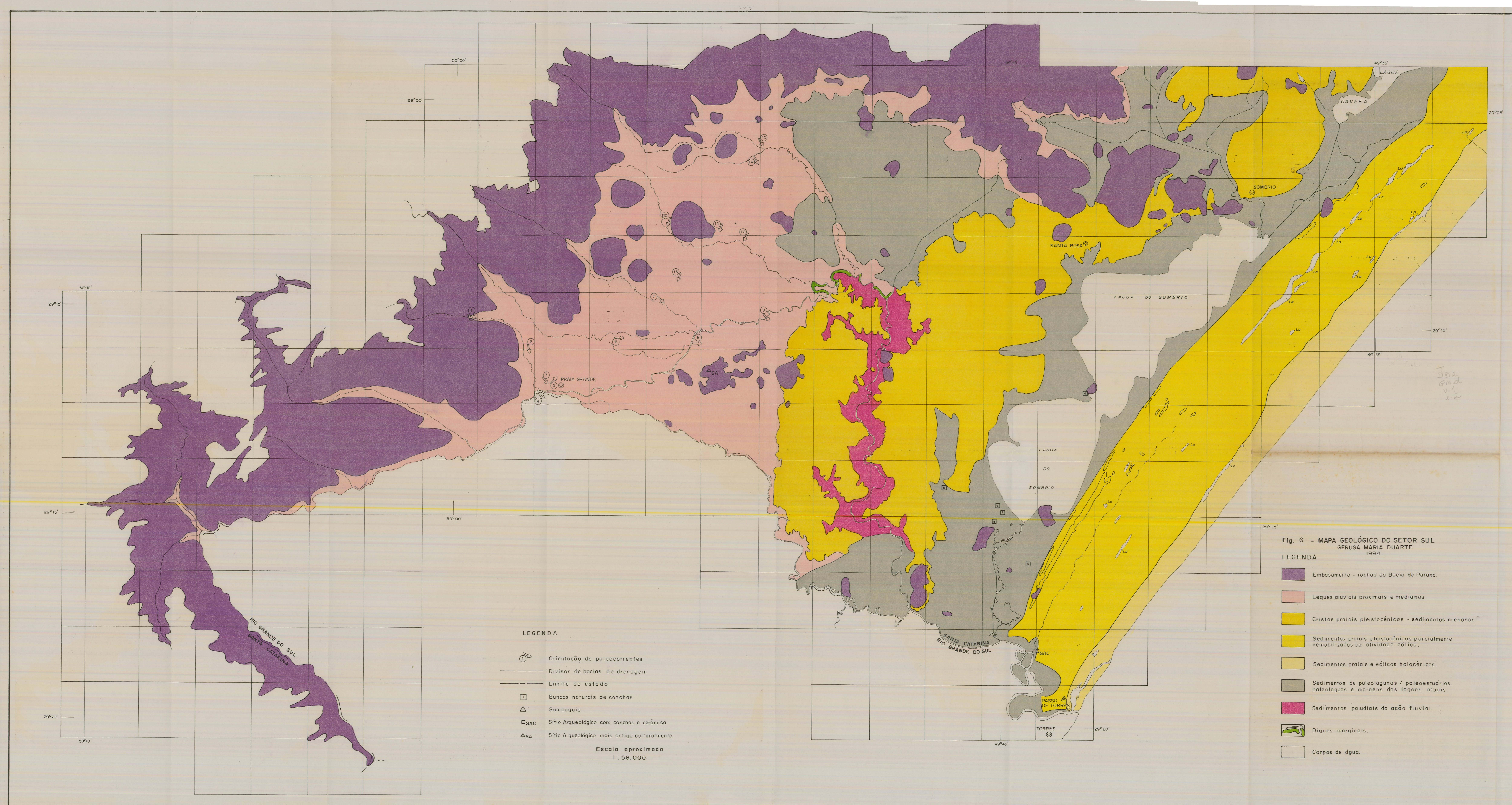




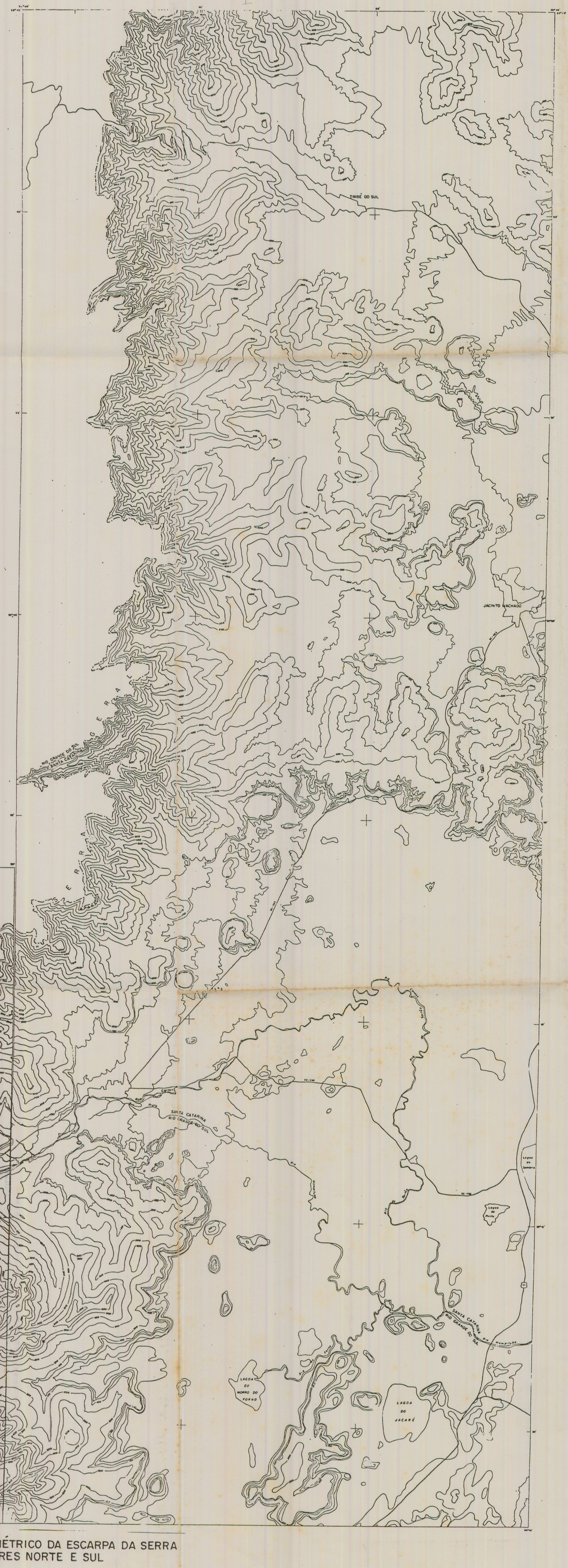




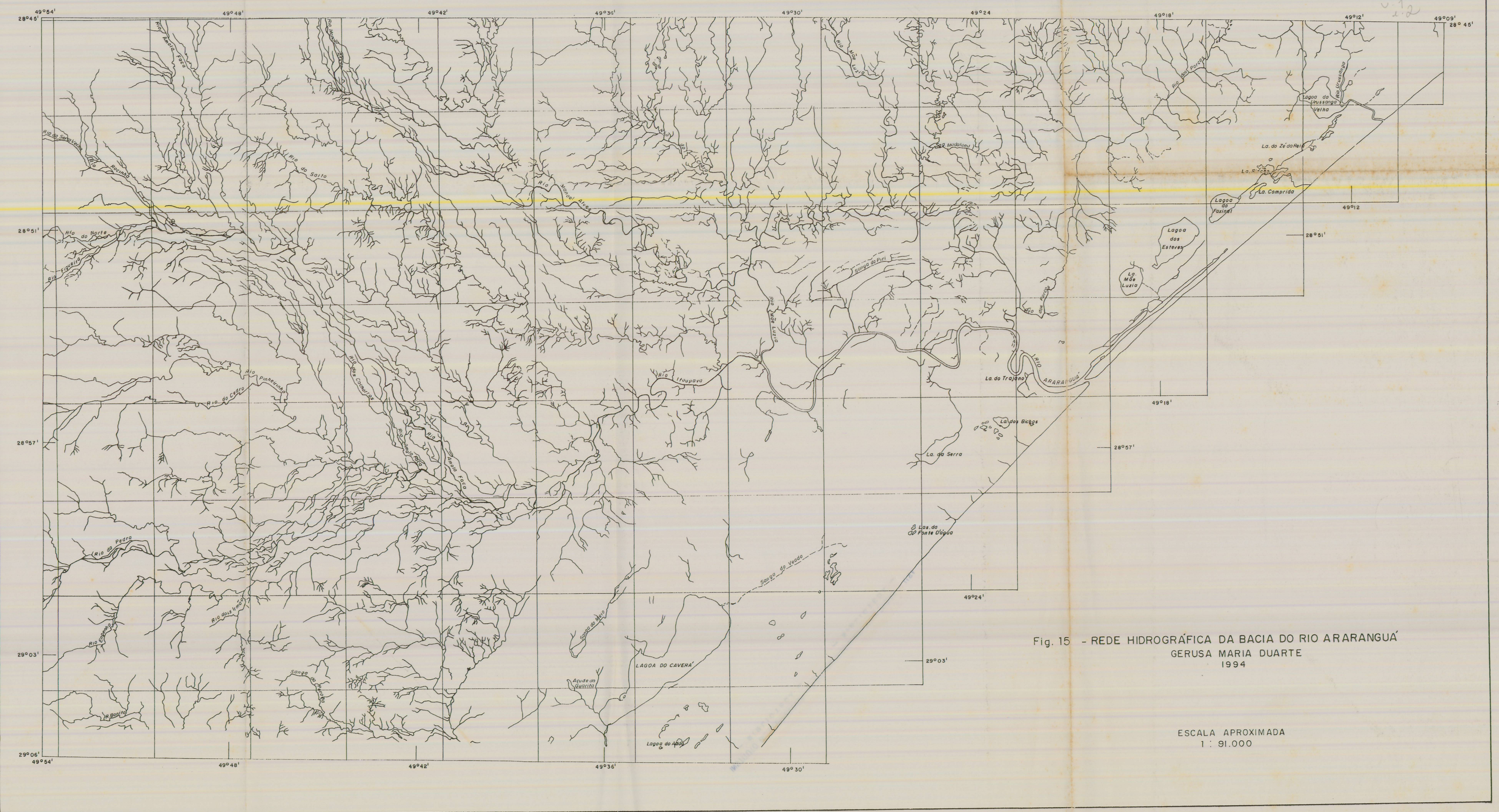




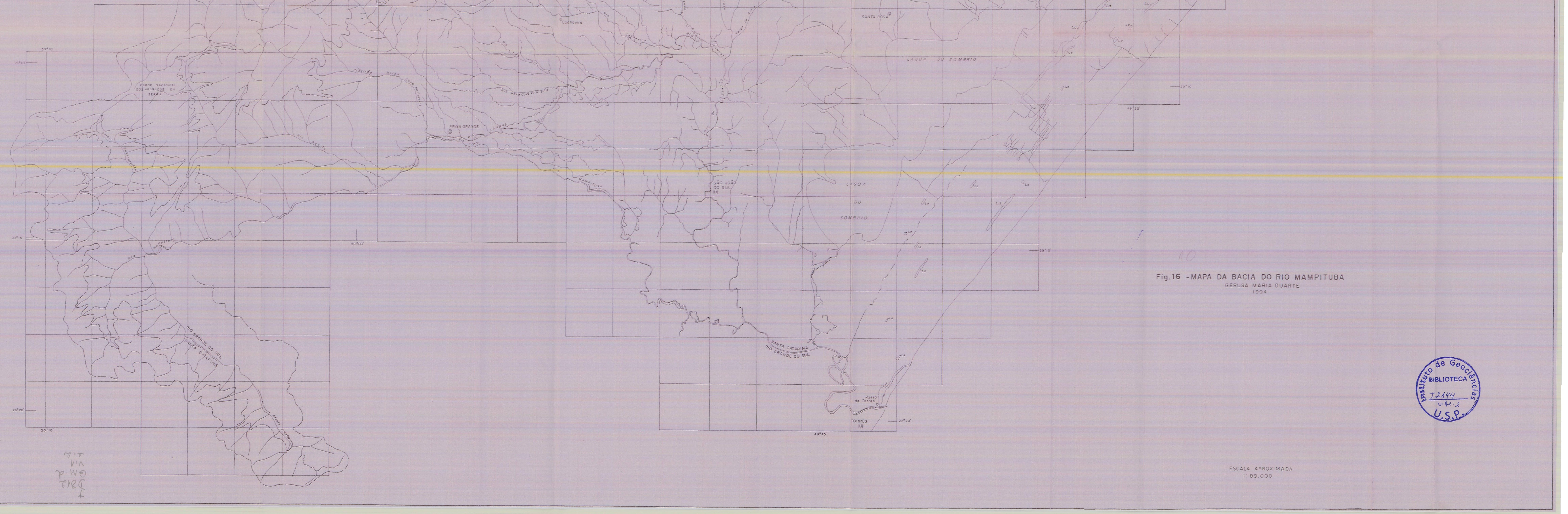

